\title{
High-Level Waste Storage Tank Farms/242-A Evaporator Standards/Requirements Identification Document (S/RID),
} Vol. 4

Date Published

April 1994

Prepared for the U.S. Department of Energy

Office of Environmental Restoration and Waste Management

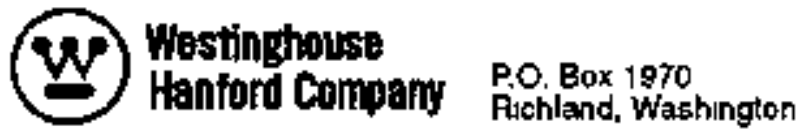

Hantord Oparabons and Endmong Contractor tor the

i $\$$ Departwent ol Energy under Contract DE-ACO6-B7PL 10930

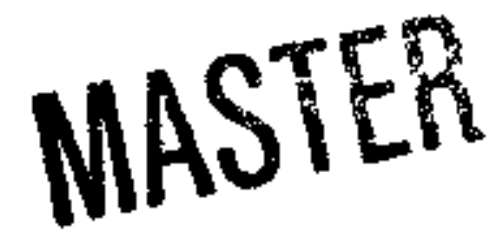

Approved for Public Release 


\section{DISCLAIMER}

This report was prepared as an account of work sponsored by an agency of the United States Government. Neither the United States Government nor any agency thereof, nor any of their employees, make any warranty, express or implied, or assumes any legal liability or responsibility for the accuracy. completeness, or usefulness of any information, apperatus, product, or process disclosed, or represents that its use would not infringe privately owned rights. Reference herein to any specific commercial product, process, or service by trade name, trademark, manufacturer, or otherwise does not necessarily constitute or Imply its endorsement, recomrnendation, or favoring by the United States Government or any agency thereof. The views and opinfons of authors expressed herein do not necessarily state or reflect those of the United States

Government or any agency thereof. 


\section{DISCLAIMER}

Portions of this document may be illegible in electronic image products. Images are produced from the best available original document. 


\section{INFORMATION RELEASE REQUEST \\ PUBLIC DOCUMENT CHANGE/REVISION \\ (Short Form No. i]}

1. Base Document tD Number: WHC-EP-0750

2. Base Document Title:

High-Level Waste 5torage Tank Farms/242-A Evaporator Standards/Requirements Identification Document (S/RIO)

3. Change/Revision Number: 1/10 of the is Functional Areas

4. Change/Revision Date: $\quad 09 / 14 / 94$

5. Unclassified Category:* UC - N/R

6. Budget \& Reporting Code** B\&R - N/R

1 verify this change/revision to the base document indicated above:

- Complies with the provisions of WHC-CM-3-4

- Contains no Linited-Use information

- Contains no classified or Appized Technology references

- Does not change the intent or meaning of the base document

- And, the base document itseff is approved for public release.

7. Responsible Manager: David L. Burt

MSIN: RI-62 Telephone Number:

$373-3091$

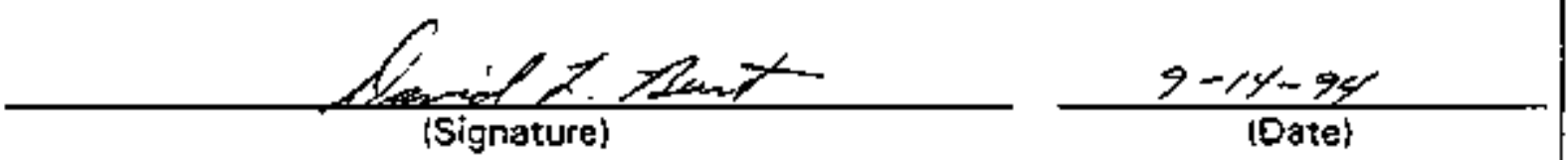

8. Information Release Administration Specialist: **

Not, Required [Signature)

\{Date\}

- Requira only for full revisions transmitted to OSTI.

- Required only for full revisions. 


\section{NOTICE}

The High-Level Waste Storage Tank Farms/242-A Evaporator Standards/Reguirements Identification Document (S/RID) is contained in muttiple binders. The content of the binders by functional area is as follows:

Volume 1

Management Systems . . . . . . . . . . . . . I

Configuration Management $\ldots \ldots \ldots \ldots \ldots \ldots$

Volume 2

Quality Assurance $\ldots \ldots \ldots \ldots \ldots \ldots \ldots$

Training and Qualificarion $\ldots \ldots \ldots \ldots \ldots \ldots$

Emergency Planning and Preparedness . . . . . . . . 1

Construction $\ldots \ldots \ldots \ldots \ldots \ldots \ldots \ldots$

Volume 3

Safeguards and Security $\ldots \ldots \ldots \ldots \ldots \ldots \ldots$

Engineering Design $\ldots \ldots \ldots \ldots \ldots \ldots \ldots \ldots$

Maintenance $\ldots \ldots \ldots \ldots \ldots \ldots \ldots$

Volume 4

Radiation Protection . . . . . . . . . . . . 0

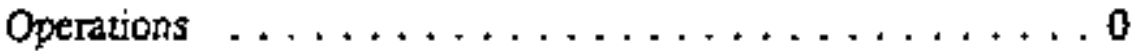

Volume 5

Fire Protection . . . . . . . . . . . . . . t

Packaging and Transportation $\ldots \ldots \ldots \ldots \ldots \ldots$

Volume 6

Environmental Restoration and Waste Management . . . . . 0

Research \& Development \& Experimental Activities .... . . 1

Nuclear Safery . . . . . . . . . . . . . . . 0

Volume 7

Occtipational Safery and Fealth $\ldots \ldots \ldots \ldots \ldots \ldots$

Environmentai Protection $\ldots \ldots \ldots \ldots \ldots \ldots$ 
(2) Fi:L

High-Levei Waste Storage Tank Farms/242-A Evaporator Standards Requirements Identification Document (\$/RID)

CHAHGE CONTROL RECOAO

\begin{tabular}{|c|c|c|c|}
\hline \multirow{2}{*}{ Rurision } & \multirow{2}{*}{ (4) Deseription of changt - keplace, Add, and Jelate Pages } & \multicolumn{2}{|c|}{ kukhorized for Releast } \\
\hline & & (5) Eog. Engr. & (6), Cog, $\mathrm{kgr}$, \\
\hline \multirow[t]{12}{*}{$1 *$} & $\begin{array}{l}\text { (7) Replace the following functional } \\
\text { areas: }\end{array}$ & $\begin{array}{l}\text { M.R.Mrbu=- } \\
\text { Witherspoon }\end{array}$ & $0.1 .80 x^{t}<9$ \\
\hline & 1.0 Management Systems & & \\
\hline & 3.0 Configuration Management & & \\
\hline & 4.0 Training and Qual ifications & & \\
\hline & 5.0 Emergency Management & & \\
\hline & 7.0 Engineering Design & & \\
\hline & 8.0 Construction & & \\
\hline & 12.0 Fire Protection & & \\
\hline & 13.0 Packaging and Transportation & & \\
\hline & $\begin{array}{c}\text { 15.0 Research \& Development and } \\
\text { Experimental Activities }\end{array}$ & & \\
\hline & 18.0 Environmental Protection & & \\
\hline & Revised in response to DOE-HO comments. & & \\
\hline \multirow[t]{3}{*}{$2 *$} & Replace the following functional area: & AR Witherspogh & OL Burt 9/19/94 \\
\hline & 13.0 packaging and Transoortation & $2 \pi / 9 / 44$ & $2 x_{-2}>\sin$ \\
\hline & *Reyfsed in response to OOE-HO comments. & & \\
\hline & & & \\
\hline & & & \\
\hline & & & \\
\hline & & & \\
\hline & & & \\
\hline & & & \\
\hline & & & \\
\hline & & & \\
\hline & & & \\
\hline & & & \\
\hline & & & \\
\hline & & & \\
\hline & $=$ & & \\
\hline & & & \\
\hline & & & \\
\hline & & & \\
\hline & 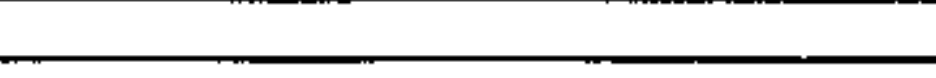 & & \\
\hline
\end{tabular}




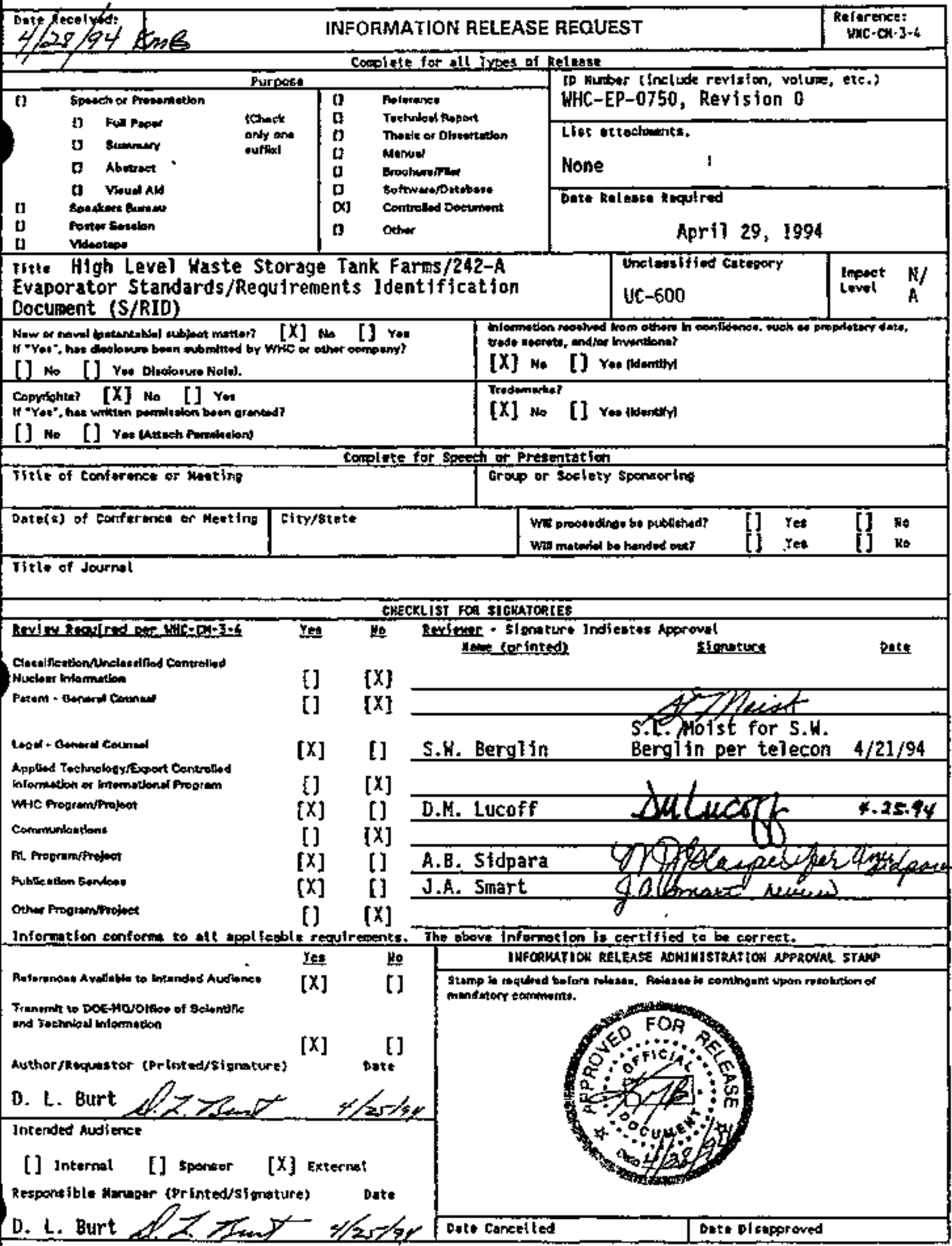




\section{WESTINGHOUSE HANFORD COMPANY}

\section{REQUIREMENTS}

\section{IDENTIFICATION}

\section{DOCUMENT}

FACRIT:

HIGH LEVEL WASTE STORAGE TANK FARMS/242-A EVAPORATOR
EMCTONALABEA:

Radlological Protection

\section{REVISION O MASTLI}




\section{REQUIREMIENTS IDENTIFICATION DOCUMENT \\ HIGH LEVEL WASTE STORAGE TANK FARMS \\ Radiological Protection \\ Rerision 0}

\section{TABLE OR CONTENTS}

11.0 RADIOLOGICAL PROTECTION

11.1

PROGRAM MANAGEMENT $\ldots \ldots \ldots \ldots \ldots \ldots \ldots \ldots \ldots$

11.1.1

11.1 .2

11.1.3

11.1 .4

11.1 .5

11.1.6

11.1 .7

11.1 .8

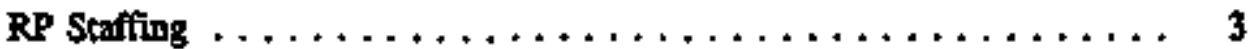

RP Selection and Qualiflcation $\ldots \ldots \ldots \ldots \ldots \ldots \ldots \ldots \ldots \ldots$

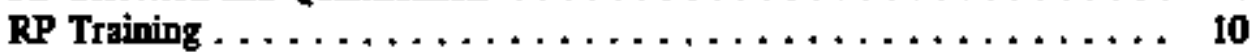

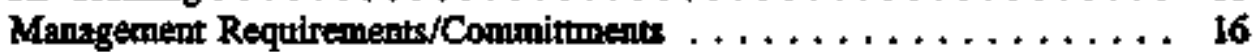

Radiological Program Performance Goals . . . . . . . . . . . 19

Program Policy and Procedures $\ldots \ldots \ldots \ldots \ldots \ldots \ldots \ldots \ldots \ldots$

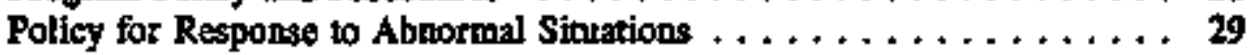

Rad Protection Program Assessments/Internal Audits . . . . . . . 31

11.2.1

11.2.2

11.2 .3

11.2 .4

Radiation Monicors and Alarms $\ldots \ldots \ldots \ldots \ldots \ldots \ldots \ldots$

Dose Rate Surveys $\ldots \ldots \ldots \ldots \ldots \ldots \ldots \ldots \ldots \ldots \ldots \ldots$

Airborne Radioactivity Monitors, Alarms and Sarvess $\ldots \ldots \ldots \ldots 43$

Contamination Montoring and Surveys . . . . . . . . . 48

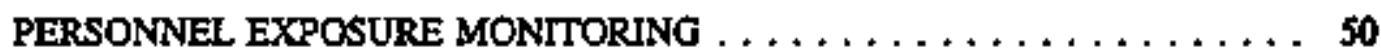

11.3.1

11.3 .2

11.3 .3

11.3.4

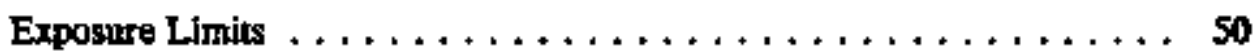

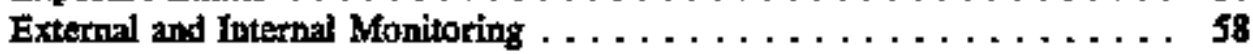

Dosimetry Program . . . . . . . . . . . . . . . . . 66

Calculation Methods Models $\ldots \ldots \ldots \ldots \ldots \ldots \ldots \ldots \ldots$

ENTRY AND EXTT CONTROL $\ldots \ldots \ldots \ldots \ldots \ldots \ldots$

11.4.1

11.4 .2

11.4 .3

Access Restrictions $\ldots \ldots \ldots \ldots \ldots \ldots \ldots \ldots \ldots \ldots \ldots$

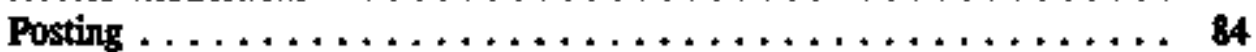

Radjation Work Permits $\ldots \ldots \ldots \ldots \ldots \ldots \ldots \ldots \ldots \ldots$

CONTAMINATION CONTROL $\ldots \ldots \ldots \ldots \ldots \ldots$

11.5.1

11.5 .2

11.5.3

11.5 .4

11.5.5

11.5 .6

11.5.7

Source Containment, Confinemett, and Ventilation Control . . . . . 101

Persomel Contamination Monitoring . . . . . . . . . . . 103

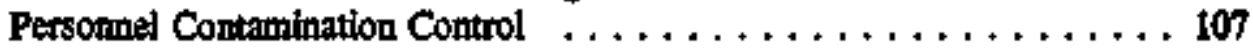

Equipment and Area Contamination Control $\ldots \ldots \ldots \ldots$. . . .

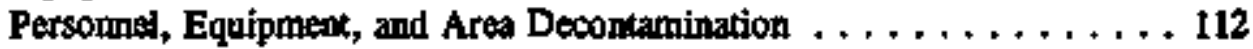

Hot Particle and Specific Nuclide Control $\ldots \ldots \ldots \ldots \ldots \ldots \ldots \ldots$

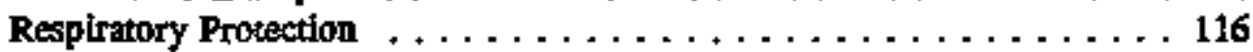




\section{REQUIREMENTS IDENTIFICATION DOCUMENT HIGH LEVEL WASTE STORAGE TANE FARMS \\ Radiological Protection \\ Rorision o}

11.6.1

11.6 .2

11.6 .3

11.6 .4

11.6 .5
Radioactive Material Handling $\ldots \ldots \ldots \ldots \ldots \ldots \ldots \ldots \ldots \ldots$

Radionctive Material Packaging and Labeling . . . . . . . . . . . 122

Radioactive Material Storage . . . . . . . . . . . . . . . . . . . 124

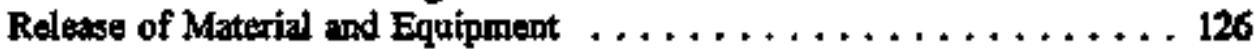

Sealed Source Managenent $\ldots \ldots \ldots \ldots \ldots \ldots \ldots \ldots \ldots \ldots \ldots \ldots$

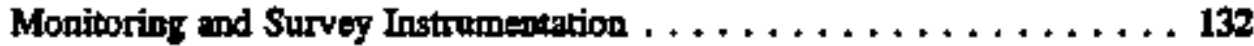

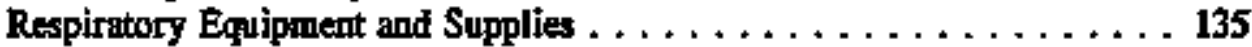

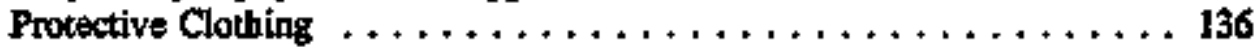

Dosimetry Equipment . . . . . . . . . . . . . . . . . . 140

Equipment Maintenance and Caljoration $\ldots \ldots \ldots \ldots \ldots \ldots \ldots$

EXPOSURE REDUCTION AND ALARA $\ldots \ldots \ldots \ldots \ldots \ldots \ldots \ldots 151$

Exposure Controls $\ldots \ldots \ldots \ldots \ldots \ldots \ldots \ldots \ldots \ldots \ldots$

Exposure Control Recuirements for Specific Wort Activities . . . . . 156

Emergency Exposure Controd Requirements $\ldots \ldots \ldots \ldots \ldots \ldots$. . . . 160

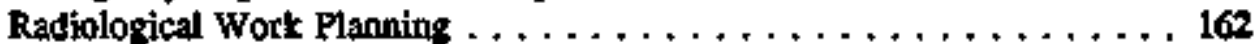

ALARA Reviews $\ldots \ldots \ldots \ldots \ldots \ldots \ldots \ldots \ldots \ldots \ldots$

ALARA Dose Goals . . . . . . . . . . . . . . . . . . . . 168

ALARA Performance and Training Requirements . . . . . . . . . . . 169

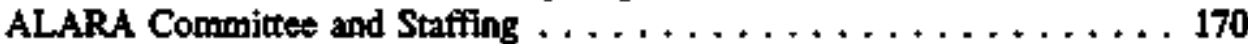

Dose Tracking and Trending $\ldots \ldots \ldots \ldots \ldots \ldots \ldots \ldots$

ALARA Design Requiroments $\ldots \ldots \ldots \ldots \ldots \ldots \ldots \ldots$

Cost-Benefit Analysis $\ldots \ldots \ldots \ldots \ldots \ldots \ldots \ldots \ldots \ldots \ldots \ldots \ldots$

ALARA Audits $\ldots \ldots \ldots \ldots \ldots \ldots \ldots \ldots \ldots \ldots \ldots$

OCCURRENCES AND INVESTIGATIONS $\ldots \ldots \ldots \ldots \ldots \ldots \ldots, 176$

Occurrences/Events $\ldots \ldots \ldots \ldots \ldots \ldots \ldots \ldots \ldots \ldots \ldots$

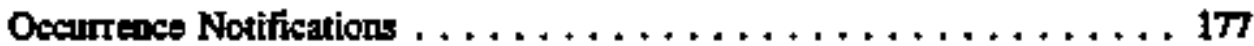

Occurrence Investigations and Critiques $\ldots \ldots \ldots \ldots \ldots \ldots \ldots \ldots$

Occurtence Reports $\ldots \ldots \ldots \ldots \ldots \ldots \ldots \ldots$

OCCURRENCE REPORTS $\ldots \ldots \ldots \ldots \ldots \ldots \ldots \ldots \ldots \ldots \ldots \ldots, 178$

Personned Exposure Records $\ldots \ldots \ldots \ldots \ldots \ldots \ldots \ldots$

Personnel Previous Exposure Records . . . . . . . . . . . . . 186

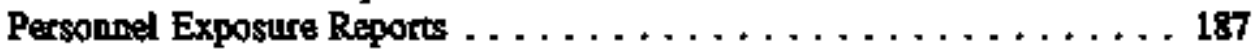

Visitor Exposure Records asd Reports $\ldots \ldots \ldots \ldots \ldots \ldots \ldots \ldots \ldots$

Reports of Personnel Exposure Events $\ldots \ldots \ldots \ldots \ldots \ldots \ldots$

Survey Records/Radiological Work Control Records . . . . . . . . . . 190

Material and Equipment Release Records . . . . . . . . . . . . . . . 193

ALARA Review/Program Records . . . . . . . . . . . . . . 193 


\section{REQUIREMENTS IDENTIFCATION DOCUMENT HIGH LEVEL WASTE STORAGE TANK FARMS \\ Radiological Protection \\ Rerision o}

11.11 .9

11.11.10

11.11.11

11.12

11.12.1

11.12.2

11.12 .3

11.12.4

11.12 .5

11.12 .6

11.12 .7

11.12 .8

11.12 .9

$11.12,10$

11.12 .11

11.12 .12
Radiation Protection Equipment Records . . . . . . . . . 194

Training and Qualification Records . . . . . . . . . . 195

Misc. Radiation Protection Records . . . . . . . . . . . . 197

Key Intefaces $\ldots \ldots \ldots \ldots \ldots \ldots \ldots \ldots$

Mangement Systems . . . . . . . . . . . . . . . . 199

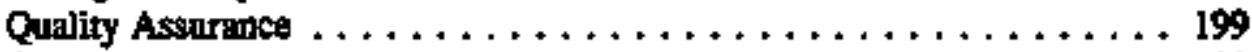

Configuration Mandigement $\ldots \ldots \ldots \ldots \ldots \ldots \ldots \ldots$

Training and Qualifications $\ldots \ldots \ldots \ldots \ldots \ldots$

Emergency Ptaming $\ldots \ldots \ldots \ldots \ldots \ldots \ldots \ldots \ldots \ldots \ldots \ldots$

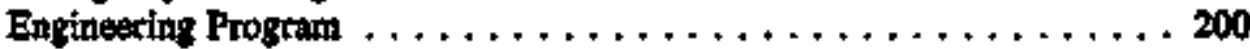

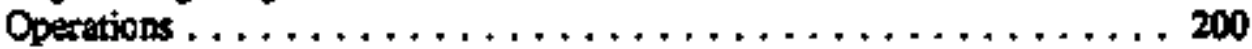

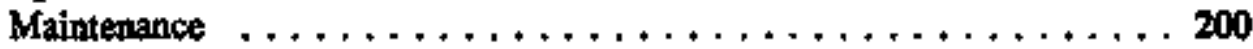

Packaging and Transportation $\ldots \ldots \ldots \ldots \ldots$. . . . . . . .

Research and Development and Experimental Activities . . . . . . 200

Nuclear Safety . . . . . . . . . . . . . . . . . . . 200

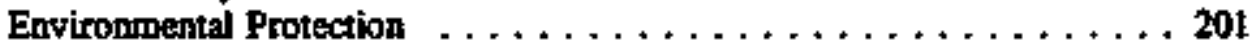




\title{
REQUIREMENTS DENTIFICATION DOCUMENT \\ MGH LEVEL WASTE STORAGE TANK FARMS \\ Radiological Protection \\ Rerision 0
}

11.0 RADIOLOGICAL PROTECTION

\author{
INTRODUCTION
}

\section{SCOPE}

The Radiological Protection (RP) Functional Area Requirements Identification Document includes both regulatory requirements and industry recommendations/ good practices which define the elements of a complete and proper RP Program.

Radiation protection of personnel and the public is accomplished by establishing a well defined Radiation Protection Organization to ensure that appropriate controls on radioactive materials and radiation sources are implemented and documented. The Radiation Protection Organization operates via both clearly defined procedures and by ensuning the personnel are properfy trained to apply good radiation protection practices and appropriate limits for all work activities performed at the facility. Verification of the effectiveness of these controls, procedures and limits is established through a retwork of monitoring and sampling of personted, the worlylace, and the adjacent environment. Recond management and controls are required to demponstrate compliance with regulations, to establish personnel exposure trends and histories, and to respond to reporting requirements.

This RID applies to the activities, personnel, structures, systems, components, and programs involved in executing the mission of the Tank Farms. The physical boundaries within which the requirements of this RID apply are the Single Shell Tank Farms, Double Shell Tank Farms, 242-A Evaporator-Crystallizer, 242-S,T Evaporators, Liquiđ Effluent Retention Factlity (LERF), Purgewater Storage Facility (PWSF), and all interconnecting piping, valves, instrumentation, and controls. Also included is all piping, valves, instrumentation, and controls up to and including the most remote valve under Tank Farms control at any other Hanford Facility having an interconnection with Tank Farms. The boundary of the structures, systems, components, and programs to which this RID applies, is defined by those that are dedicated to and/or tinder the control of the Tank Farms Operations Department and are specifically implemented at the Tank Farms.

The Nuclear Safety functional area describes when nuclear accident dosimetry must be used and thus interfaces with the Radiation Protection functional area. Radiation Protection personned will assure that the nuclear accident dosimetry is acceptable under the dosimetry program which they administer. The Radiation Protection (RP) functional area interfaces with all other functional areas in the sense the personnel must interface with the Radiation Protection Organization in order to perform work and must also adhere to the requirements established the Radiation Protection Personnel to ensure protection of plant workers and the public.

Additionally, RP has numbrous direct interfaces with other functional areas including training, Quality Assurance and Management Systems. 


\section{REQUIREMENTS IDENTIFICATION DOCUMENT HIGH LEVEL WASTE STORAGE TANK FARMS \\ Radiological Protection \\ Revision 0}

$\mathbf{1 1 . 1}$

PROGRAM MANAGEMENT

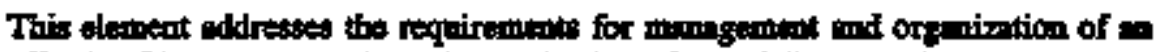
affectivo RP Program. Formal orgenization of w RP Progrem is nectostry to

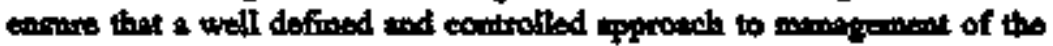
prograin and exestion of the prognm is echioved. Estublishment of a formel

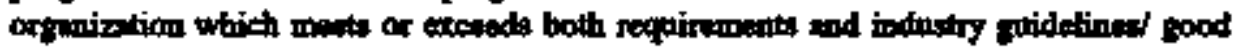
Frectices enhances the pocentint for echtioving 2 quality progetsm and for attaining optimum levels of safery performance and efficiency. This element deseribes the extent of the formil RP Propram orgentization structurs

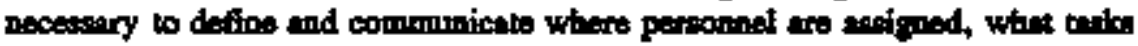
thy aro expected to scoontolish, methods for weromplithment, and miningement's expectutions for perforwence. Expectatious for performenpes include requirements celated to establishing and tracking goals specific to Radiation Protection.

This eiemeat also deflines specific merngement requirements and committonts intuted specifically to Rudiation Protection programs and tho policy for respone to abnormal rediologicil sibuatione.

The Management and Organization element for Radiation Protection inchudes requirsements which are sposific to Rediation Protection and likely do not

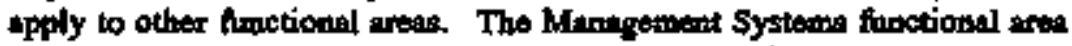
interfaces with Radiation Protection Functional Aron by providin: requiremedts which aro essentiol to the condect of Rediation Protection, but which aleo are esential to the conduct of oporations within other functional arese

\section{SITE REQUIREBENE SOURCE: DOE-N5480.6 Section 141.1}

"Contractor Rediological Control Organization

Radiological Control Organization

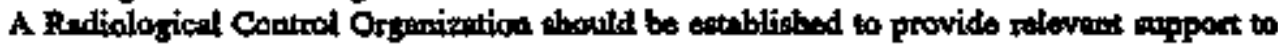
line managess and workess. To effectively function, tbe Rediologinal Control

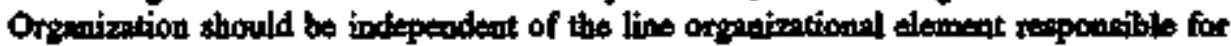
prodaction, operetion or resenrch ectivitios end should buve an equivileat riportiog lowel. A single, dediented Radiological Control Orgmaization for the sito should bo sufficiont. At

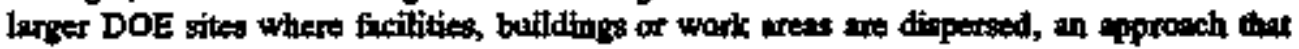

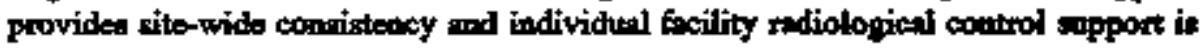
recommended. The sesicer line menager responsibte for opentions at in filty should have areigued radiological control persomel deticuted to the factity. Consistency of

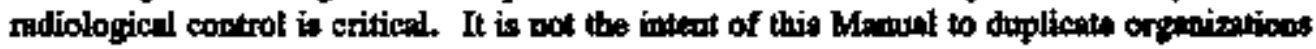
bet to use personot in a more effective unamer in workplace siturions."

\section{SITE REQUIREMENT SOURCE: DOFNS480.6 Sectlon 141.2}

"Radiologicai control personnal sball enaure adherence to the Sito-Specific Radiological Control Manual and be svailablo to the facility line manager for radiological support to the wark force. To effectively fimction in this copacity, they should receive

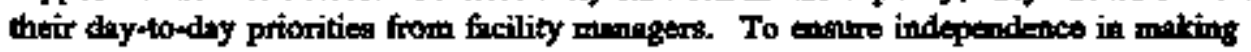




\section{REQUIREMENTS IDENTIFICATION DOCUMENT HIGH LEVEL WASTE STORAGE TANK FARMS \\ Radiological Protection \\ Rorision 0}

cornect radiological decisiom, the Rediological Costrol Oryenization should be ecounteble to the Radiological Coatrol Managex:"

\section{STTE REQUIREMITNT SOURCE: DOE-N\$40.6 Section 141.3}

The Radiological Cootrol Memager hoods the Rediological Coetrol Orgenization and is respousible for ad shoold ostublist a high quality Rediolopical Control Program -

\section{SITE REQUIREAMENT SOURCE: DOE-N5430.6 Section 141.4}

The Radiolopical Control Manger shall bave necess to tho senior site srecutive for ratiologied control mattera."

\section{SIIE REQUREMIENT SOURCE: DOE/ERH0135 RP.1.2}

2. Organizational repousibilitite for radiological protection are well defined and mederstood."

\section{SITE REQUIREMIENT SOURCE: DOE/EFH0135 RP.1.5}

'Responsibilities and authorities for tent rediological protection technicisn position on the sitelfuetility are clenrly defined ind sufficient to control wort sctivities to protect employess."

\section{SITE REQUIREMIFNT SOURCE; DOERHO135 RP.1.6}

Personel clearly understand their authority, responsibilities, mocountabilitien, and interfaces with ntpporting groups."

\section{SITE REQURREMINT SOURCE: DOE/EH0135 RP.1.S}

The miliation protection manser has direct eccess to the operations minnors and hes sofficient nothority to perform his dutios offectively."

11.1.1 RP Staming

This element includes requirementr related to ensuring adequrto shefing for Radietion

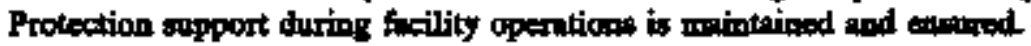

\section{SITE REQUIRTHIENT SOURCE: DOE/MATO135 RP.13}

3. Staffing ind resolures are sufficient to wcomplish tseipoed tastos."

SIIE REQUIREMENT SOURCE: NUREG-1761 Section 3.h(3)

The minimum oteffing by stite, for each componere in the radiation protection organizstion, specifying the numbers in terms of professionals, forement, scerior and juatior

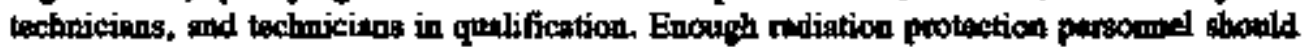




\section{REQUIREMENTS IDENTTICATION DOCUMEANT FIGH LEVEL WASTE STORAGE TANK FARMS \\ Radiological Protection \\ Revision}

be present at the station to ensure that all routine rudintion protection functions cen be completed in a timely manner and that all radiation protection fequitements con be net during normal operations, anticipated opecational ocourrences, unanticipmed rediological

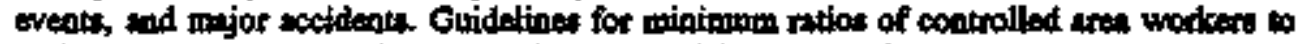

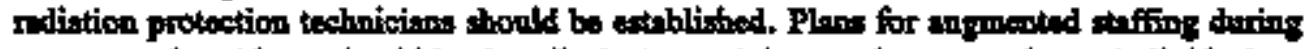
outages and socidents stould be described. As 4 minimum, there mest be an indiviturel

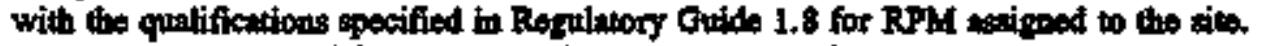
There should be a quelified aubatitute for the RPM available to the site when the RPM it not aveilablo for extended periods doe to illeces, trevel, or vecotion. For short-term absences, a substitute qualified to carry out the RPM's energensy duties should bs

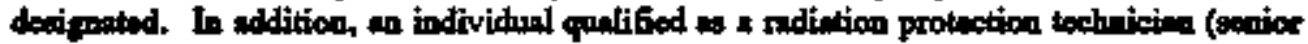

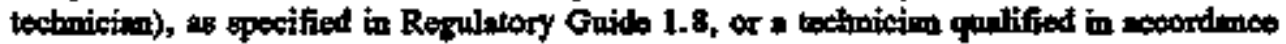
with 1 qualification program specified in technical specificaticns shall be oneito when there is fuel ongite after initial operation. The nitio of supervisors/foremen to techaicient should be established and described."

BP Selection and Ounalificention

This element inchades requirementy for the apropriate celection and qualification of personocal to perform specific RP rolnted joba.

\section{SIIE REQUIREMENT SOURCE: DOE-N5480.6 Section 142.1}

"Radiological Control Mrenger Qualifications

The Radiological Control Marager stonld be an experienced professional in radiologtent control and be fautiliar with the design feanuses and operations of the facility that affece the poteatial for exposures of persons to rediation."

\section{SITE REQUIREMENT SOURCE; DOE-N5480.6 Section 142.2}

The Rudiological Coutrol Minnager should have the technical competence and experience to eetriblish radiolopical control programs and the supervisory capability to direct the implemestation and maintenance of radiological control programa."

\section{STTE REOUIREMRENT SOURCE: DOE-N3480.6 Seetion 142.3}

The Radiojogical Control Mansger should have a minimam of a bachalor's deapres or the equivaleat in science or enginerring, including esmo formal trining in rediological control. Advanced acadenic degrees can count as experience where course wodt rointed

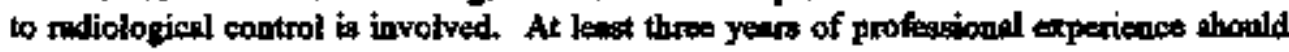
be in applied radiological cosntrol work. Cortificetion by the Americen Boend of Flealth Physies provides equivaleacy to the above."

\section{SIIE REQUIREMENT SOURCE: DOE-N5480.6 Section 142.4}

"In sitution where the most effective utankyer for this position does not satisfy the chove quelifications, special arrangements should be made. In these situations, the assigmment of - deputy with the requisite expertise and qualifications can satisfy the requirement." 


\section{REQUIREMENTS IDENTIFICATION DOCUMENT \\ HIGH LEVEL WASTE STORAGE TANK FARMS \\ Radiological Protection \\ Revision 0}

\section{SITE REQUIREMENY SOURCE: DOE-N5480.6 Section 142.5}

"Menagement should provide persom assigned to or being considesed for the Radiological Control Minager * strwenured projrom kesting to certification by the Admerion Boent of Health Physion."

\section{STIE REQUREMENT SOURCE; DOE-N5480.6 Seetion 183.1}

"Radiological Control Organization Functions and Staffing

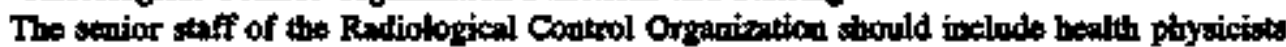
and other profescionens with four-year degros in science of enginocting. A comtinumg trinting piogrem shall be extablished. Pursit of certification by the Americm Bourd of Health Physies for senior and professionl staft members is encounged."

\section{STTE REQUIREMENT SOURCE: DOE-NS480.6 Section 143.2}

"Rediological sppport personnel provido bealth physics and radiological eagineering, dosimetry, bioassay, independent oversight, instrumentation and celtibration fluctions. These persontol shosild have vechnical qualifientions pertinent to their ascigned duties."

\section{SITE REQUIREMINT SOURCE: DOE-N\$480.6 Seetion 144.1}

Relatioutip Betwen Radiological Contral Technicions and Worken Ratiolorical Control Techniciens and their supervisors perform the fonctions of asisting and guiding workers in the rediological aspects of the job. Rutiological woxters should be sufficiently quatified to recogaize the symptoms of deleriorating radiological conditions and seek wvice from Rediologieal Control Techniciens and their stpervisors."

\section{SITE REQURREMENT SOURCE; DOE-N5490.6 Section I46.3}

Radilogical Ansessor

This position shoald be staffed by a professional who is adept at dontifying techrical wod menagement problems. This person shoruld participate in contusuning training to develop profestional and madarement sills."

\section{STIZ RTQUTREMENT SOURCE: DOE-N5480.6 Section 614.1}

"Qualification Standerids for Radiological Costrol Tectunicians Qunlification Standanda define the requirements for demoustrating completion of traizing. Signatures on the forma in Quetification Stenderds shall document setisfactory proficiency."

SITE REQUIREMENT SOURCE: DOE-NS490.6 Section 614.2

"Qunlification Smadarde frow the standaritized core course shall be used."

\section{SITE IEOUIREMINT SOURCE: DOR-N3480.6 Section 614.3}

"The qualification Standards from the standardized core cokres shat be supplemented to include site-specific elements." 


\section{REQUIREMENTS IDENTICATION DOCUMENT HIGH LEVEL WASTE STORAGE TANK FARMS \\ Radiological Protection \\ Rerision}

\section{STTE REQUIREMENT SOURCE: DOE-N5480.6 Section 614.4}

"Qualification Stundards for the Radiological Control Technicien porition thall inslodo can-tho-job tratining to provide hands-ce experienco ditactly applicable to the job."

\section{SITE REQUIREMANT SOURCE: DOE-N5480.6 Section 614.5}

"On-tho-job traines shall be rader the control of qualified perownel. Betore performing - job finctien withoat direct anpervision, a traines with purtially completed qualifications shell bive completed the quelifications for that tust."

\section{SITE REQUIRENENT SOURCE: DOE-N5480.6 Section 615.1}

Oral Examination Boards

An Oral Examination Board shall determine the qualification of cendidates for Radiological Control Technician and Supervisor positions."

\section{SITE REQUIREMENT SOURCE: DOE-N\$480.6 Section 615.2}

"Tho Radiological Control Mansper shell designate the Bound members and appoint Canifarson.

\section{SITE REQUIREMENT SOURCE: DOE-N5480.6 Section 615.3}

The Board constituted to eraluate Radiologicel Control Technician qualification shoold be composed of at lenst thes persons to include a Radiolocical Control Tectimicim Supervisor, Radiological Coatrol staff, sad libe management operations department supervisors and steff personned, applicable. Rediologicel Control Technicisn Instructors may porticipate a nouroting mombers."

\section{STIE REQUIREMAENT SOURCE: DOE-N5480.6 Section 615.4}

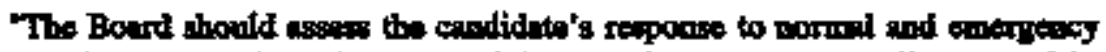

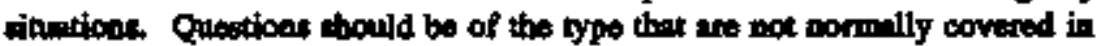
4 written examination."

\section{STrE REQUIREAEANT SOURCE: DOE-N\$490.6 Section 615.5}

The Boerd contstituted to eveluate Redtolopical Coatrol Technicien Supervisor qualification should not incilude peers of suboctinotes as voting members."

\section{STIE REQUTREMENT SOURCE: DOE-N5480.6 Section 641}

\footnotetext{
-Radiological Control Texbnician Qualificatina Requirenents

Training and qualification of Radiological Control Technisinns and their inmediate

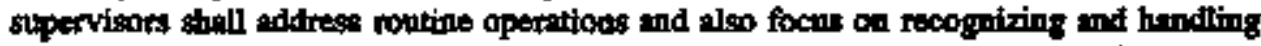
situations in both normal and changing tadiological conditions. Newhy qualified tochenicinns and those still in training should be given the opportumity to wort with quelified, experienced technicinas to foster devesopmeat."
} 


\section{REQUIREMENTS IDENTHICATION DOCUMENT HIGH LEVEL WASTE STORAGE TANK FARMS \\ Radiological Protection \\ Rerision 0}

\section{REIATED REFERENCES}

1. DOE/EHO2S6T Articlo 641

\section{STIE REQUIREMENT SOURCE; DOENS480.6 Section 642.1}

Rodiological Cootrol Tectmicien

Rediological Contral Tecturicien qualification tonsids of tho dandardized core courso training material, on-the-job trining pes the Qunlification Stonderde, and pasting both a finl tomprehensive written exturination and final Onl Exnmimation Boud."

\section{RELATED RETLRENCES}

\section{DOEEH0256T Aticle 642}

\section{STTE REQUIREMINT SOURCE: DOE-N5490.6 Section 642.4}

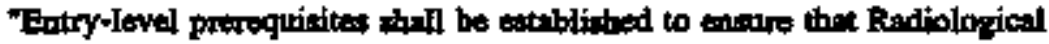

Control Techricins mest stenderds for physicel condition and education. At a minimem, these standend should include the following:

a. High school educetion of equivalency;

b. Fublamentals of mathematics, physics, chemistry and sciences

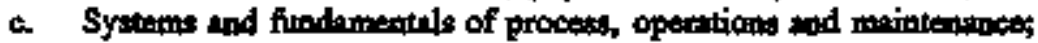

d Resding and comprebension level sufficied to follow procedures, write permits, prepure sarvoy maps, writo ceports and preparo shipping and tronsfer permits;

a. Ability to work in a sapport rolo, tneluding commumicating verbal instructions to othere;

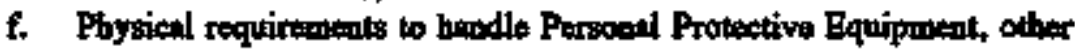

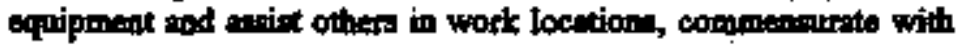
arrignment."

\section{REILATED REFERENCES}

\section{DOEJEHOSOT Articlo 642}

\section{STE REQUIREMINT SOURCE: DOE-N5400.6 Section 642.5}

"Rediological Control Tectinicians are ancouraged to porste retistrition by the National Registry of Radietion Protection Technologita (NRRPT)."

\section{RRLATED REFERENCES}

\section{DOE/EHO2S6T Articlo 642}

SITE REQUIREMENT SOURCE: DOE-N5\$80.6 Section 642.6

"Sites ne encounged to give credit wowrd completion of standarilized cone training requirements for NRRPT registration." 


\section{REQUIREMENTS IDENTIFICATION DOCUMENT HIGH LEVEL WASTE STORAGE TANK FARMS Radiological Protection \\ Rerision 0}

\section{RELATED REFERENCES}

1. DOE/EHO2S6T Articlo 642

\section{STIE REQGIREMENT SOURCE: DOE-N5480.6 Section 644.1}

"Radiological Control Technician Supervisors

Radiologicat Control Technicien Supervisors shall have qualified as Rediological Contral Technicians and should participate in continuins adiolotical trining proyenma."

\section{RELATED REFERENCES}

\section{DOE/AH0256T Axticle 644}

\section{SITE REOUIREMIENT SOURCE: DOE-N5480.6 Section 644.2}

"Rudialoficel Control Technicten Supervisars should have supervisory and leaderahip copabilities to direct the work of technicians; effoctively internet with enfts, lins supervisors, professional stuff and other managers

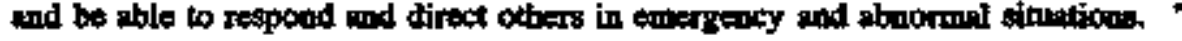

\section{REILATED REFERENCES}

\section{DOE/EH02S6T Article 644}

SIIE REQUIREMENT SOURCE: DOE-NS480.6 Section 644.3

'Radiological Control Technitian Supervisors shall be requalified overy 2 years through eouprehensive Oral Examiantion Boerds it acoondnce with Articte 615."

\section{RELATEU REFERENCES}

1. DOE/EHO256T Article 644

\section{SITE REOUIREMENT SOURCE: DOE-N3490.6 Section 644.4}

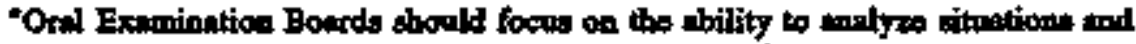
supervise subontinatea. Tho Radiological Control Téchnician Supervisor's depth of bowledge should exesed that expected of a Rediolopical Control Technicino.*

\section{REIATENO REGERENCES}

1. DOE/EHO256T Articlo 644

SITE REQUIREMENT SOURCE; DOE-N5480.6 Section 645.1

* Subcontracted Radiological Cortrol Techusiciens

Subcantrected Radiological Contral Techniciens should bave the samo knowledge 


\section{REQUIREMENTS TEENTIFICATION DOCUMENT FIGH LEVEL WASTE STORAGE TANK FARMS Radiological Protection Revision 0}

and qualificstions reguired of facility technicitns performing the same dutisa. At a minimmm, the triming and qualification prognim ahould inclade the following:

2. Review of teames to ideatify tectericions with experience in jobs indiker to those for which they will be enployed;

b. Written examinntion and oral evaluation to verify appropriato knowledge level;

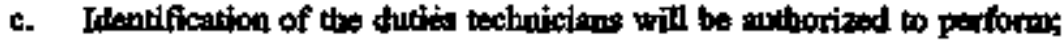

d. Training in facility procedures and equipment aseocinted with the nuthorized duties;

- Truinipg on recent operating experiesco:

f. Obdervation of on-lbo-job performences by the Radiological Coutrol Technicion Supervisor."

\section{RELATED REFERENCES}

\section{DOE/EHO256T Article 645}

\section{STIE REQUIREMENT SOURCE: DOE-N5480.6 Section 645.2}

"Subcontracted technicinns who wotr at the facility for axtended time periods (more than 6 months) should receive continuing training commensurate with their assipod duties. This sumuld include anowesul completion of an onl examination.

\section{RELATED REFERENCES}

\section{DOE/EH02S6T Article 645}

\section{SIIE REQUIREMINT SOURCE: DOE-N5489.6 Section 645.3}

Radiological Coatrol Technical Supervisora stall be requalified every 2 yeurs

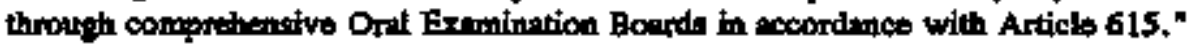

\section{RELATED REFERENCES}

\section{DOEJEHO2S6T Artide 645}

\section{STIE REQUIREMENT SOURCE: DOE-N5480.6 Section 654.1}

Radiological Coniroi Porsonnel

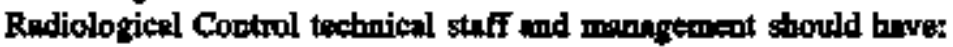

2 A combintion of echucation and experience commensentite with their job responsibilities;

b. Continuing training based on an avessment of job respomsibilities to mointrin and enharece proficiency;

c. Continuing training to remain cogaizant of changes to the facility, openting experience, procedurea regulations and quality asurance requirempots." 


\section{REQUIREMENTS IDENTIFICATION DOCUMENT HIGH LEVEL WASTE STORAGE TANK FARMS \\ Radiological Protection \\ Revision 0}

\section{STTE REQULREMENT SOURCE: DOE-N5480.6 Section 654.2}

"Rodiologienl support pursomed include but tre not limited to: dosimatry

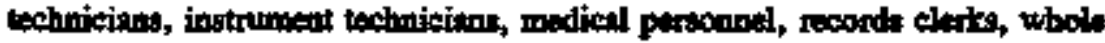
body ootuter technicitans and habonstory persombel."

\section{SITE REQUIREMRNT SOURCE: DOEN5480.6 Section 654.S}

"Certification and involvement with professional industry organizations thonld bo mootunged."

\subsubsection{BPTraining}

This element inctudes roputinements relatiog to the establishment of trining propnens for RP persongel and the curricthim which wetet be included es part of that program to coestro RP personed ere eppropriately quelified to provide Radiation Prosection support.

\section{SITE REQUIREMENT SOURCE: DOEAN3480.6 Setion 121.10}

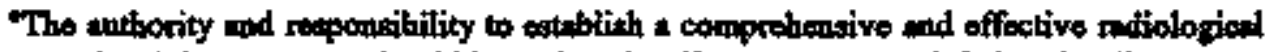
control training program should be assigoed to lino manngers and their subondinates. Training, in most ceses, should be provided by a dedicuted training orpanizetion, bet the

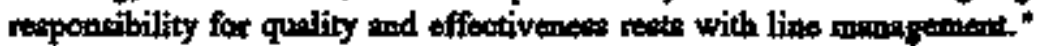

\section{RFIATED REKERENCES}

\section{DOEJEH0256T Articie 121, Parngraph 9}

\section{SIIE REQUIREMENT SOURCE: DOE-N5480.6 Section 122.2}

"Improving the attitude of the wotk force should be supported by the training progrant.

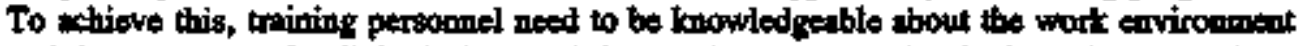
and thos apecte of sutiological cootrol that and importint to doveloping a better wortster attitude and perspective."

\section{STIE REQUREMANT SOURCE; DOE-N54\$0.6 Section 124.1}

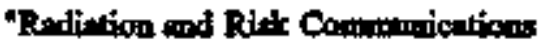

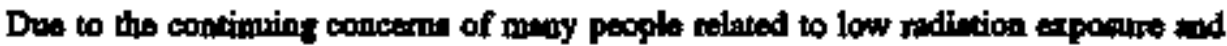

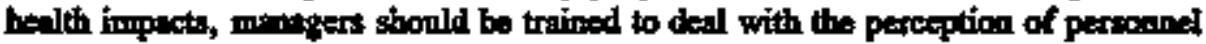

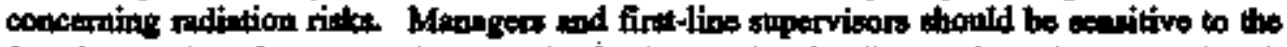

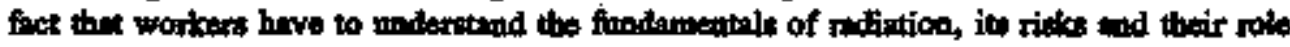
in mimimixing expostre. It is not sufficient to rely soldy an regtlatory limite for estublisting or defining wotptoble work protices nod work environments. Appropriete

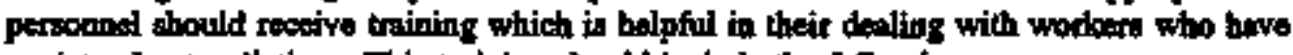
maxiety shout rediation. This training should indude the following

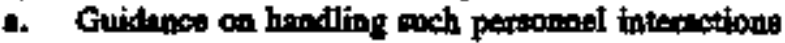
b. Emphasis on being fictured
c. Fundementals of sommoniceting ristos

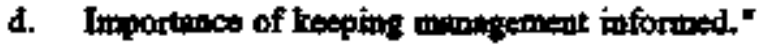




\title{
REQUTREMENTS DENTHFCATION DOCUMENT FIGH LEVEL WASTE STORAGE TANK FARMS \\ Radiological Protection
}

Revision 0

\section{STI REQUREMENT SOURCE: DOE-N5480.6 Section 126}

Improving Wotter Awaroness of Radiological Conditions

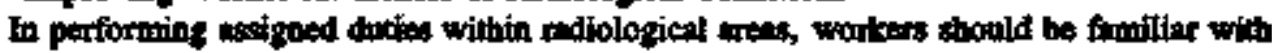

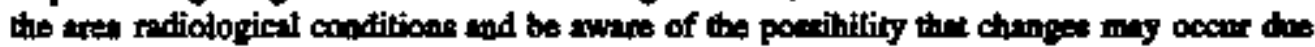

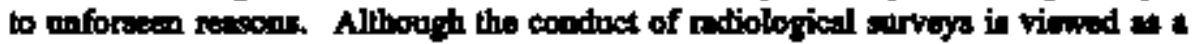

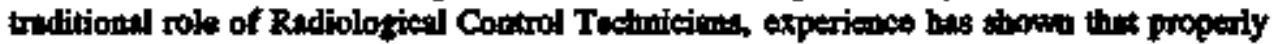
cratned and quallified workers are capeble of performins sopplemental prifological aurvey in the course of work. This process results in exposurs savings and improved contamination control.

Specific examples of surveys that may be effoctively performed by wotres and realt in ALARA exposuro reduetions inchude self-monitoring of does rated during Hagh Radintion Ares entries and the monitoring of tools and ecpupment for contaminntion as a quatitative

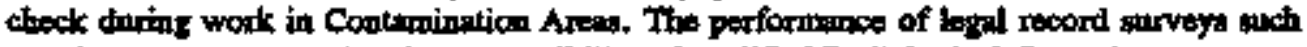
at relatse surveys rentatiss the responsibiltity of qualified Radiolotical Control Tochnicians."

\section{SITE REQUIREMENT SOURCE: DOENS480,6 Section 612}

\begin{abstract}
"Stonderdizanion
Stonderdized core courste and training meterials shall be ued to whievo convintency Deportment-wide. In establishing local training gnogrnus, the standurdized eore courses shall be presented and sito-specific toformation shall be adted. Fot example, training at

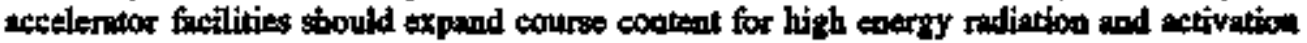
products. Trizing at pilutoutum facitties should axpend the course content for alpha control. In all cases, tho standattized cono course weaterials should be filly implemented. Stendurdized core sourse trining material developed and meintuined by DOE Elemdquarters (EH) consiats of lessom plans, viowgraphs, studert handbanks, quatification staodards, question banks and wallet-efized training cortificates. The standandized core courses training motorials wero besed on ASTM E 1168 87, "Strnderd Guids for Rudiological Protection Trining for Nucienr Fucility Workers," ad wero doveloped neing the principles of performincobesed training per DOE 54\$0.20. The trondartized cone course for the Rediologicen Contrel Techniciens partially fulfills DOE training

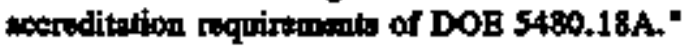

\section{SYTE REQULREMTNT SOURCE: DOE-NB480.6 Sution 612,1}

"Stondendized core courses training materiel thell bo used for Genesel Employee Radiological Tratning, Rodiological Worker I and II training and Radialogical Control Tochnicien trining."

\section{SITE REQUIREMENT SOURCE: DOE-N5480.6 Section 612.2}

"Wallet-sized training certificalses that identify oursent training atatas bould be provided."

\section{STE REQULEMINT SOURCE: DOE-N5480.6 Section 6123}

"Successful completion of the stenderdized courses for General Employec 


\section{REQUIREMENTS IDENTIFICATION DOCUMIENT \\ HIGH LEVEL, WASTE STORAGE TANK FARMS \\ Radiological Protection \\ Rerision 0}

Rediological Training, Ratiological Worker I and II and Radiological Coatrol Technician

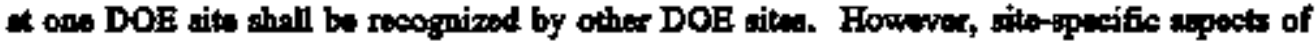

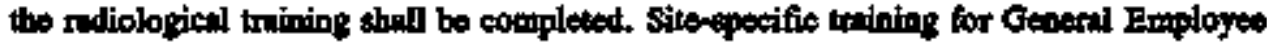
Rediological Training and Radiological Wortor I and If trining may be inchoded with other tito orientation trining."

\section{STIE REQUIREMENT SOURCE: DOR-NS480.6 Section 612.4}

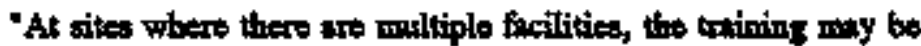

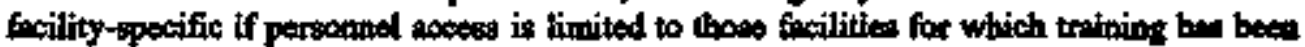
comploted."

\section{STTE REQUREMMENT SOURCE: DOE-NS480.6 Section 612.5}

The tito Retiologicat Control Mineger of a desipres shall ocnetr is site-pencented andiologited training materini."

\section{SITE REQUIREMIENT SOURCE: DOE-NS480.6 Section 613.2}

Training shoold addree both normal and haormol tituntiond in rafiological control.*

\section{STIE REQUIREMENT SOURCE: DOE-N5480.6 Sectiod 613.5}

"Site-spectific training and refrenher training shnll inchude chonges in

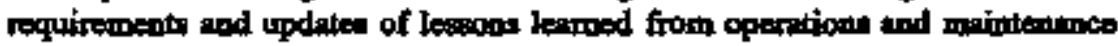
experience ard oceurrance neportiog, for the wite and actose the DOE complex."

\section{STIE REQUREMIENT SOURCS: DOE-N5480.6 Section 613.6}

"Verification of the effectivenest of radiological control training should be aceormplished by survejing a limited subse of former studento in the workplece. This venfificetion is in udition to performence evaluattons routinely performed by trotining deportriente. This

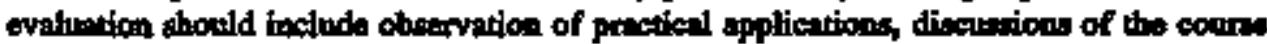
materinl, and mey inchado writien exnminations. The sarvey should be performad by

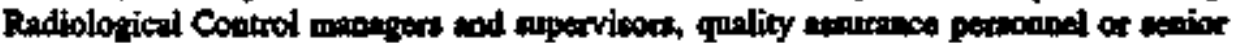
instructors after the formes avdent hes hod the opportenity to perform wort for avveral monthe. The residts ahorld be doctemented."

\section{STIE REQUIREMENT SOURCE; DOENN5490.6 Section 642.2}

Redtological Control Technicion trining shalf uso the standerdized core course unining materials and in adwition should emphasiza sito-specific information."

\section{RETLATED REFERENCES}

1. DOEJEHO2S6T Artick 642 


\section{REQUIREMENTS IDENTIFICATION DOCUMENT HIGH LEVEL WASTE STORAGE TANK FARMS \\ Radiological Protection \\ Rerision 0}

STE REQTIRYMIENT SOURCE: DOEN5480.6 Setiod 642.3

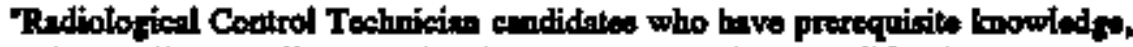
wath to collopo credit, operational axporience or reluted qualifications, why atiofy individual esction of the standartized core coures training requiroments by pasting comprebeneivo chollenge trominetions."

\section{REILATED REFERINCES}

1. DOEJH02SGT Artalo 642

SITE REQULEMENT SOURCE: DOEN5480.6 Section 643.1

"Contimuing Training

Following sucessfil conpletion of standintized core course requireinents including proctical training, the Rudiologioal Control Tochnician ahall pues

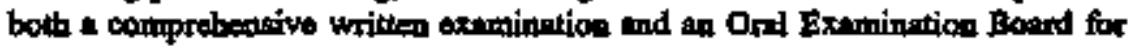
final qualification."

\section{RFIATED RGEERENCES}

1. DOEREH0256T Article 643

SITE REQUIREMENT SOURCE: DOE-N5480.6 Section 643.2

"Following Oral Exantination Boord qualifictition, the Rutiological Control Toctiniciem ahould begin a 2-yeer cycle of contimuing training required for requalification. Every requalificetion requires completion of practical treining, a comprebeasive written extuminatioa and a final Oral Exnmination Boord:

\section{REYLATEO REFIRINCES}

\section{DOE/EHO256T Anticls 643}

\section{SIIE REQUIREMIDNT SOURCE; DOENS480.6 Saction 643.3}

"Continuing training should provide continued improvernent in tho howledge and stills of the Radiologitel Conatrol Techarcim."

\section{RFTATED REFERENCES}

\section{DOEJEH0256T Article 643}

\section{SITE REQUIREMENT SOURCE: DOE-N5490.6 Section 643.4}

"Contiruing training should include site-specific and DOE-wide changes in requiremeats and updates of lessons kerped from operating experienco and industry ovents." 


\section{REQUIREMENTS IDENTIFICATION DOCUMENT \\ HIGH LEVEL WASTE STORAGE TANK FARMS \\ Radiological Protection \\ Rerision 9}

\section{REAATEO REFERJACES}

1. DOERTHO2S6T Articlo 643

\section{SIE REQUEREMANT SOURCE: DOE-NS480.6 Section 644.1}

Retiologicel Control Techmiatin Supervisors

Rediological Control Teckniction Supervisors sketl have qualified as Rediologienl Contol Technicirns and bould purticipets in continuing madiolotical tratioins protans."

\section{RELATID REFERENCES}

1. DOEJEH0256T Articls 644

\section{SITE REQUIREMENT SOURCE: DOE-NS480.6 Section 651}

"Other Radiological Trúning

Mandigent Trining

Line Managers (DOE and contractors) who montge, mupervite or provide overaight of Rodiclogienl Control Progrtims stall be trained in the principles of thin Mantal. Such trining should be besed on DOE stendartized cort course utrining meteriall aupplemented by sito-apecific procedturses and be completed by pow personnel prior to formally sunmin; Itint superviston and menagement responsibilities. Incumbents should portictipat in continuing training. The continuing troining should emphesizs self-aseseament and axternsl evaluations including performance indieatons, root causes and boson lourned besed on operational experience."

\section{SITE REQUREMIENT SOURCE: DOE-N\$480.6 Section 654.3}

Rediological support perscones should heves:

- Training an stondentized core course topics from Radiological Worter I and II and Radialogical Control Technicien trining and adtitional job-specific topics, ss applicablez

b. Trnining appropriate to the terse to be performed;

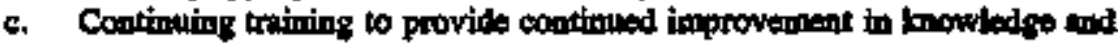
skille.

\section{SIIE REQUTREMENT 5OURCE: DOENS490.6 Section 656.5}

Trining should molke it cleor thet lifeerving he prionity over rodiologion controls."

SITE REQUTREMENT SOURCE: DOENS490.6 Sectian 656.6

"Records of this training shoxid be maintrined." 


\title{
REQUIREMENTS IDENTIFICATION DOCUMENT \\ HIGH LEVEL WASTE STORAGE TANK FARMS \\ Radiological Protection \\ Rerision 0
}

\section{SITE REQUIREMENT SOURCE: DOEN5480.6 Section 6 B3}

\author{
Tritium Facilitiea \\ The following topits should be considerod in edflition to stendardized core \\ conining requirements * trithum ficitities: \\ Properties of tritiom \\ Sources of trition \\ Exposins pathnays and forms of tritinm \\ Expoware control \\ Tritivem contrininest

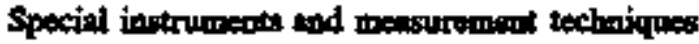 \\ Personned protection \\ trventary control and accoumtability \\ Airborne tritiug measaremeilt \\ Airtoras tritivm controls \\ Effluent tocovery systeins \\ Tritium released \\ Bioussey prognm \\ Biological effects.
}

\section{SITE REQURBMENT SOURCE: DOES480.11 Sectlon 9.o(3)}

"Radiaxion Protection Technicin. Rudietion protection technicinn training and retraining projrams stall be established and conducted at a sufficient frecuency, not to exceed every 2 yets, to familiarize technicians with the findamontais of radintion protection ind the proper procedurea for mainmining exposares ALARA. This program shall inclade both classtom and applied tetining and steall precede of be concurrest with escionment as 2 mdiation protection tochnicien while under the expervision of a trained individuel. The

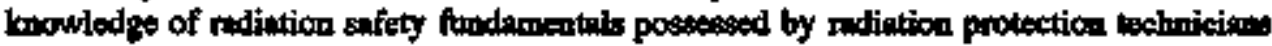
should be certified by oxamination prior to an nanupervised wotk andignment. The

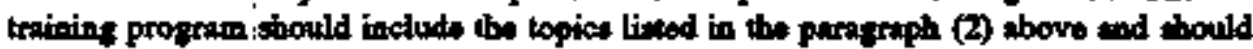

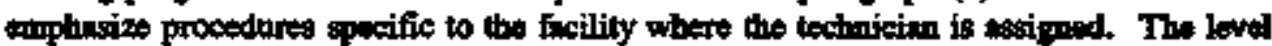

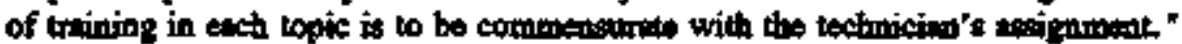
STIE REQUIREMENT SOURCE: INPO-88-010 Chapter If, Section C.2, Paraguaph 1

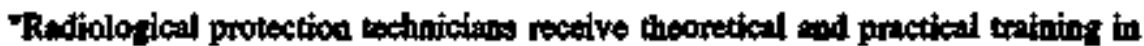
ratiological probction. This training incluxtes besic mechemetica, physical seience, plant

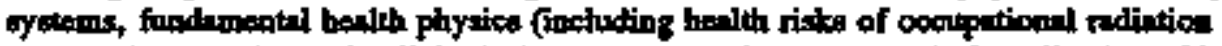
enposare), operations of ndiological protection equipureat, praction applicetion of healdh physice methode, and use of radiological protection procedurts. The most importint training for andiological peotoction tochnicions and their immedian oupervieors is in

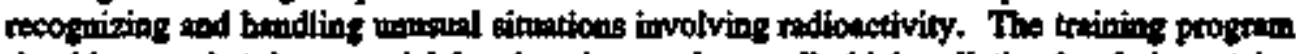
chould strest thet the potential for chenging or aboormelly high redietion levels in ortoin plant aress or systems could impact wott in progress. Written, onl, and preatical

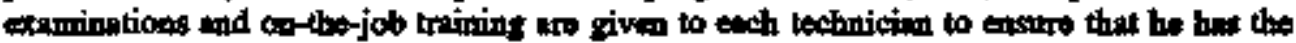
loowledge and alialls needed to perform his job. Each nuclear station's rmotiological probaction technticien trining program is aceredited." 


\section{REQUIREMENTS IDENTLHCATION DOCUMENT \\ HIGH LEVEL WASTE STORAGE TANK FARMS \\ Radiological Protection \\ Revision $\theta$}

Managenent Requirements/Commiltments

This element addresses requirements for Radiation Protoction Minngement to ensiro

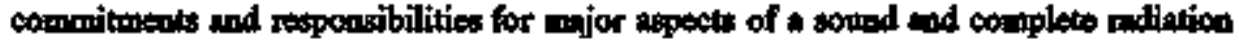

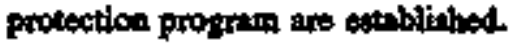

\section{STrE REQUIREMRNT SOURC: BOE-N5490,6 Section 121.1}

"Senior Manngement Commitment

Seaior manspers should establish high standads for tho peformence of nodiological control. These stendards and manegement expectations ebonld be frequenty

comminiceted to the work force."

\section{RELATED REFERENCAS}

1. DOEEH0256T Article 121, Paragraph 9

STTE REQUREMAENT SOURCE: DOE-N5480.6 Section 121.I1

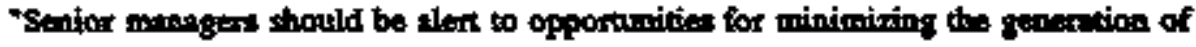
radiological waste and discherges to the envircament, coatrolling

contamination at its source md reducing rediation exposure to workers and the pulatio."

\section{RELATED REFERENCES}

I. DOE/EH0256T Article 121, Reragraph 9

STE REQUIREMENT SOURCE: DOE-NS480.6 Section 121.12

Reporting a problem to a superior (coetractor or DOE) does not abeolve the meninger from promptly fixing or miliguting a sinusion."

\section{REILATID REFERENCES}

1. DOE/EHO2S6T Article 121, Purageph 9

STTE REQUIREMIONT SOURCE: DOENS430.6 Section 121.3

"Senior menagers stould stuts in writtog their firm commitumeat to a

Radiological Control Program of the highest quality. Mrengroment com mitment and support ero demonstratod by allocating sufficient resources imeloding perboumel and providing for traigint to weare wortere are qualified for their arigad dutios."

\section{RELAED RFFERENES}

1. DOE/EH0250T Articls 121, Perrgraph 9 


\section{REQUIREMENTS IDENTIFICATION DOCUMENT HIGH LEVEL WASTE STORAGE TANK FARMS \\ Radiological Protection \\ Rerision 1}

STIE REQUIREMENT SOURCE: DOE-N\$480.6 Section 121.3

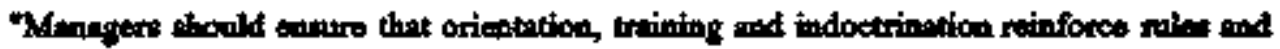
guldelines for eech worker to minimizes radiation exposire and control sudioentivity."

\section{RELATED REFEIRENCES}

t. DOE/EFO056T Articlo 121, Paragraph 9

SUE REQUIREMENT SOURCE: DOENS480.6 Section 121.4

"Mandits thould bold workers end their superviooss mosountable for radiolorical coatrol performence. Relevert knowledse nud performuce should be assesed as a specific part of persod's performance ovaluation. This wesenent shovid not be limited to those who puform radicactive work, since meny otber workers have an infact on the Radiological Control Program."

\section{RELATW REFERENCES}

1. DOE/EHO2S6T Article 121, Parngraph 9

\section{STTE REQUTREMENT SOCRCE: DOE-NS480.6 Section 121.5}

"Sentior mangers shomld solicit foedbeck from their ratiologicel control profaspionals, line management and workers on radiological coatrol performence."

\section{RELATED REFERINCES}

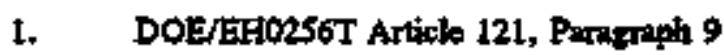

\section{SITE REQUIREMEENT SOURCE: DOE-N5480.6 Section 121.6}

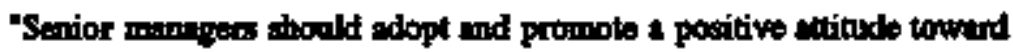

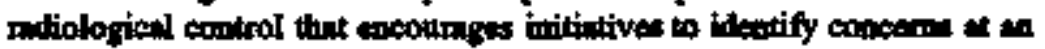
esrly stape, to provent probleme from detertorating end to promote doing the ripht job correctly the first time."

\section{RELATED REFERENCES}

1. DOE/EHO256T Articlo 121, Paragreph 9

\section{STIE REQUIREMENT SOURCE: DOE-N54\$0.6 Seetion 121.7}

"Provention of the aproad of redionetivity is lese coodly then romediation.

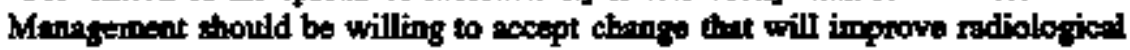
controd and should forter this mindset throughout the orgamization." 


\section{REQUIREMENTS IDENTIFICATION DOCUMENT HIGH LEVEL WASTE STORAGE TANK FARMS \\ Radiological Protection \\ Revition}

RFHLATD REFERENCES

1. DOPJEHOZS6T Article 121, Parajmiph 9

STE REQUIREMINT SOURCE: DOE-N5490.6 Section 125.2

"Managers at all levele are expected to bo imvolved in the planning, echeduling and

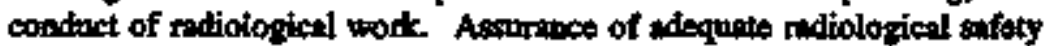
should not be compremised to echieve prodnction, remedietion or raceirch objectives."

\section{STTE REQUREEMINT SOURCE: DOR-N5480.6 Section 125.3}

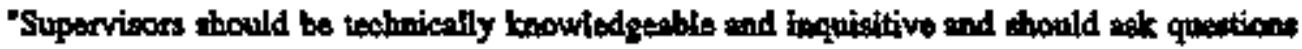
of the work force coocerning rediological work details to engure and demonetrate worker understanding nand comprebension."

\section{SIIE REQUIREMENT SOURCE: DOE-N\$480.6 Section 125.4}

"Line menugers stould periodieally monitor work sreat to observe persomel at work and to identify radiolopical deficioncies and concersos. Frequent incpections and walk-throughs, incloding off-hours and weekeods (whone appropriate), the extentinl to reinfore mangemente expections to the work force.

\section{SITE REQUIRBMENT SOURCE: DOEN5480.6 Section 125.5}

Thongent, wapervisors and wotkers should be involved in the developmeat of accurate, clear, written procedures for perfortuing radiological work. If during the use of procectures a written requirement ceanot be reaponsibly followed, the work should be stopped and guidace obtuided."

\section{SIIE REQUIREMENT SOURCE: DOE-N5480.6 Section 125.6}

"Supervisors and memagers should meonarse the work force to identify

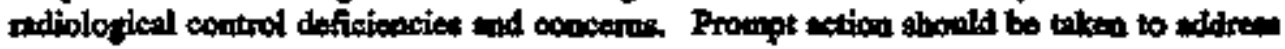
and eliminate identified istres enil prevent reourrence.

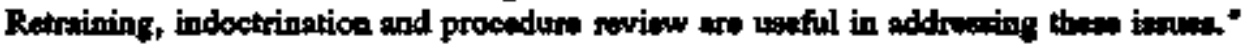

\section{SIIE REQUIREMENT SOURCE: DOE-N\$490.6 Section 125.7}

"Menigers and supervisars should establish working condititong the encoutuge improved nadiological control. This includes temperenos, bumidity and lightiog as well as the mose difficult considerations of mocessibility. Wort conditions stoctld bo considered in platring work."

\section{SHTE REQUIREMENT SOURCE: DOE-NS480.6 Section 125.8}

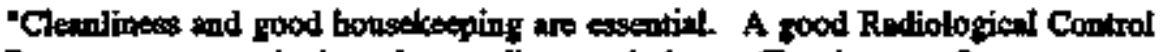

Program cennot exist in a sloppy, dinty workplace. Cleaning up after 


\section{REQUIREMENTS IDENTIFICATION DOCUMENT HIGH LEVEL WASTE STORAGE TANK FARMS Radiological Protection \\ Reristion 0}

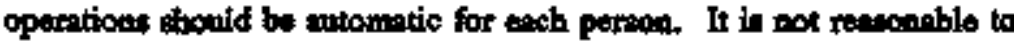
axpet radiologienl control to be separeded from the work envircinment; they go torether."

\section{SIIE REQUREMIEN SOURCE: DOE/FH0135 RP.1}

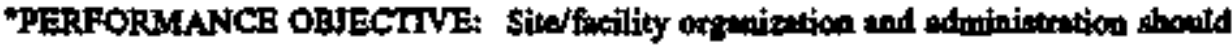
ensure effoctive implementation and control of radiological protection etivities on the situ/focitity."

\section{STIE REOUIREMIENT SOURCE: DOE/EHOT33 RP,1.4}

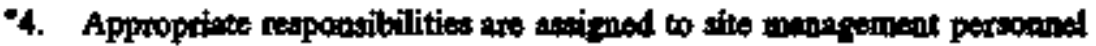
for such matters an:

- minimizing personed rafiatioe exposures

- minimizing the contermination of arews, equipment, and personnel; ind

- roducing solid radionctive whste volumes."

SITE REQULRENENT SOURCE: DOE/EH0135 RP.1.7

"Rediotogical protection requirimeats are getivedy administered by "ite/facility manngement mid supervirion and adpered to by pertonnel."

\section{SITE RIQUIREMIENT SOURCE: DOE/EH0135 RP.1.9}

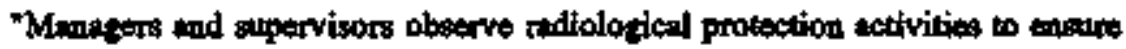
whersece to totablished policies and procectures and to identify and correct problems."

\section{SUE REQUTRWMENT SOURCE; DOE/EH0135 RP.2 ACCIDRNTSINCIDENTS.S}

-3. Manageneat respence to prevention and/or cerrection of incidents is positive. There it adequab follow-np, inctuding additionel training of workers, to kepp all employeed tinformed of the types of incidents thit

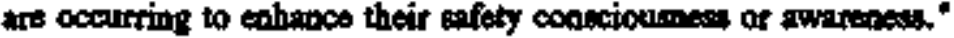

\section{SITE REQUIREMIDNT SOURCE: DOEJEH0135 RP.2 INIERNAL AUDITS.6}

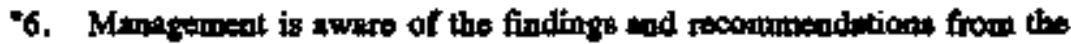
intermal eudit and usoures appropiate follow-ip ection."

\section{Badiolorical Program Perionmance Gouls}

This eleanent includes those requiremente related to the estublishment of Radivition Protection performance goals, the traclding of performince verstis pouls and tho Ifpropriato use of and reepenses to performince reporte. 


\section{REQUIREMENTS IDENITICATION DOCUMENT HIGH LEVEL WASTE STORAGE TANK FARMS Radiological Protection \\ Revision 9}

SUIE REQUIREMENT SOURCE: DOE-N5480.6 Section 121.8

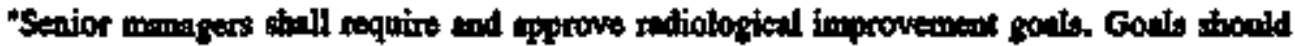

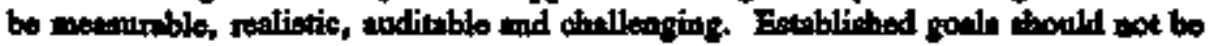
chmged without teahtical justification and senior momagement epprovil. Senior

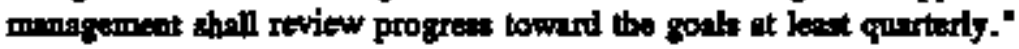

\section{RELATED REFERENCES}

\section{DOE/EH0256T Article 121, Paratrath 9}

SIrE REQUIREMIDT SOURCE; DOE-NS480.6 Section 121.9

A performence inticitor program for mensuring and treading the effectiveness of tho Rediological Control Program againat predetermined goals thould be established and mintininst."

\section{REILATED REFERENCES}

\section{DOE/EHE256T Article 121, Paragraph 9}

\section{SITE REQUIREMIENT SOURCE: DOE-NS490,6 Section 131.1}

\section{Tmproving Radiological Performance}

Rediological Performence Go:ls

Gonls are inteoded as a mearare of and a motivation for tenprovement, not an ood in

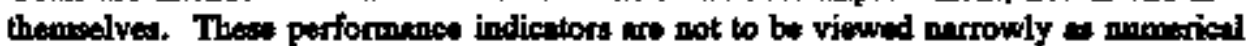

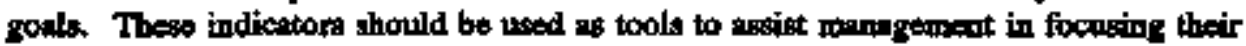
priarities and attentico. The following are examples of goals that aray be appropriater Person-Rem of Collective Exposure: This goal sbould be bused upon planiond activitios

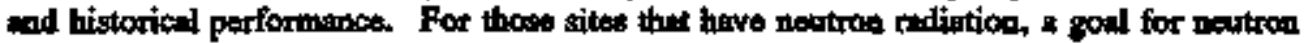
person-rem should also be established."

\section{RELATED REFERENCES}

\section{DOEERO256T Articlo 131}

\section{SIIE REQUIREMENT SOURCE: DOE-NS480.6 Section 131.2}

Numbers of Skin and Persomal Clothing Contamination Ocenrrences: Perconned contaminations min indicate a breakdown of controla intended to prevent the sproed of contamination."

\section{RELATED REFERENCES}

1. DOE/EH025ST Article 131 
SITE REQULREMENT SOURCE: DOE-NS489.6 Section 131.3

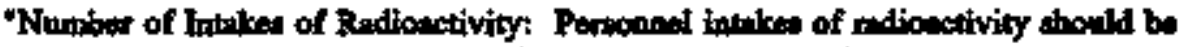
minimized and munagtoment should focur ettention on any failure of the costrols that renilts in intakes."

\section{RETLAED REHERINCES}

\section{DOH/EHO2SGT Article 131}

\section{SITE REQUIREMTNT SOURCE: DOE-N5490.6 Section 131.4}

"Square Feat of Coatininoted Aree (within bulldintes): Operating with a

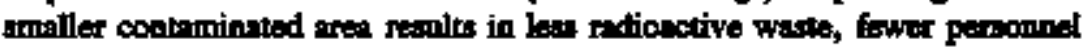
contmininations and improved productivity. The reduction of existing contaminated erees needs to bo balareed by the recopnitice that this gederates rediosective wasto. Goals for both stould be conrelated."

\section{RFLATWD REFERENCES}

\section{DOE/EH02S6T Article 131}

\section{STIE REQUIREMTRT SOURCR: DOE-N5480.6 Section 131.3}

-Culte Feet of Rationctive Wagte: Miniminging the generation of rectioective waste reduces the envirenmentol impact of DOE operation, helps redoce personnel exposere and redeces costs ussocirted with houdling, pectuging and disposal."

\section{RELATED REFERENCES}

\section{DOE/EFOZ250T Article 131}

\section{STIE REQUIREMENT SOJRCE: DOE-N5490.6 Section 131.6}

"Ourites of Liquid and Airborms Radionctivity Relened: Mininiring eflibants reduces the environmeatul impect of DOE operations ond reducew the eodu associnted with remedietion."

\section{RELATEO REFERENCES}

\section{DOEJEHO256T Articlo 131}

\section{SITE REQUREDMENT SOURCR: DOE-N\$480.6 Section 132.1}

-Mapageanent of Radiological Performance Gouls

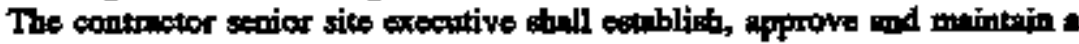
nutiolopital performance goats proprite." 


\section{REQUIREMENTS IDENTIFICATION DOCUMENT HIGH LEVEL WASTE STORAGE TANK TARMS \\ Radiological Protection \\ Rerision}

\section{RELATEED REFERENCKS}

\section{DOE/EETO2S6T Articlo 132}

\section{SITE REQUIREMIXNT SOURCE: DOEN5480.6 Section 132.2}

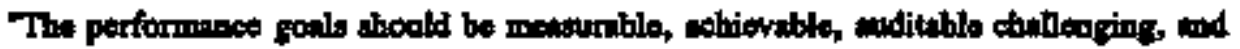
meningfol in promoting improvement."

\section{REHATID RGFERENCES}

\section{DOE/EHTO256T Articlo 132}

\section{SIIE REQUIREMENT SOURCE: DOE-N5480,6 Section 132,3}

"Gonts need to be developed primarily by thowe tesponsible for performing the work. Forming a Radtological Awartess Committes that includes the ective participution of the wort force is encouraged."

\section{REILATED REFERENCES}

1. DOERH0256T Article 132

\section{STTE REQUTREMENT SOURCE: DOE-N\$480.6 Sectlon 132.4}

"Radiological performance gools shonli be reviewed at least anmulily md revised as eppropriate. Normally, more stringert gonls should be set ar.muily to reflect to improved radiological performence it the tacility.

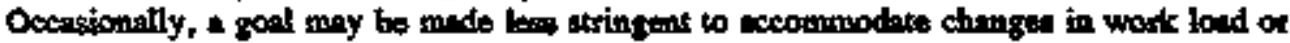
mission."

\section{RETATED REFERENCES}

\section{DOE/EH0250T Anticlo 132}

\section{SIIE REQUIREMIDNT SOURCT: DOE-NS4\$0.6 Section 133.1}

\section{Totiological Performence Reports}

The Radiolopical Control Manaiger should provide a periodic strmmiry teport to the

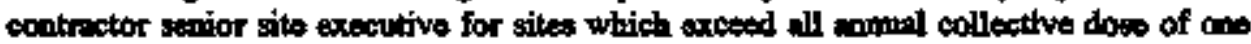
person-rew. This teport is sucpested to bo monthly but should not bo tee frequent then quarterily. This report should ieclude at leaet the retiological performince goels eatablished in accordance with Article 131. Eximples of indicalors thet provids a more detriled andysis of performente are identified in Table 1-1. Indteotors thould be coatsined in the report for the mosth as well an tracking and treeding for the prior twelve month period."

\section{RFLATED RAFERJNCES}

\section{DOE/EH02S6T Article 133}




\section{REQUIREMENTS IDENTIFICATION DOCUMENT HIGH LEVEL, WASTE STORAGE TANK FARMS \\ Radiological Protection \\ Revision 4}

SIIE REQUIREMINT SOURCE4 DOE-NS480.6 Section 133.2

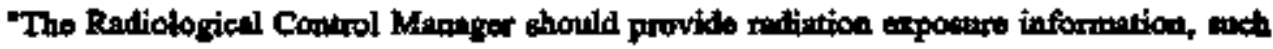

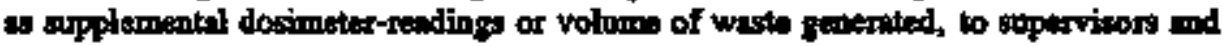

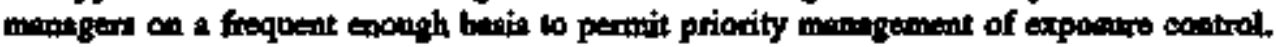
The frequeacy should be consintent with the monure of the worktoed and the natiation exposine poteatial."

\section{REH,ATED REFEIRENCES}

\section{DOE/EHO236T Artiok 133}

\section{STIE REQUIREMENT SOURCE: DOE-NS480.6 Section 133.3}

"To promote worker awareness of their radistion exposure status, selected indicatory reinted to their work group shauld be posted in tho woxtplect."

\section{RELATTED REHFRENCES}

\section{DOE/EHO256T Asticle 133}

\section{SITE REQUIREMENT SOURCE: DOE/EHO135 RP.1.13}

11. Site/facility manegers are awre of treods with regard to occupational radiation exposares, quantity and quality of solid and liquid rodioactive waste, contamination and radiation levele and the number and locution of radiation and contaminated aress within the gite/faclity."

\section{SIIE REQUTREMENT SOURCE: DOE/AHOL35 RP.1.14}

"14. Radiological protection personnel are astively encournged to develop improved methods of meeting radiation protection objectives and gosls."

\section{SIIE REQUIREMIENT SOURCE: DOE/EF0133 RP,1.15}

-15. Indicatos of radiological protection pesformanse are octablisted and periodically assessed to enhence radiological protection effectivenes:"

\section{SITE REQUIREMENT SOURCE: DOEVEH013S RP.2}

'PERFORMANCE OBJECTIVE: The internal axdit progmm for both routirs optrition: and unusul natiological occurrences shorld provide adequate performance assessinsents."

\section{Proseram Polliar and Proceilures}

This element indudes polieis which bave been estiblished as requirements for the facility and which must be adhered to in all aspects of radiation protection at the tacility. It also defines policies and recuiremeats to be followed when astablishing additional ficitity specific policies and procedures. 


\title{
REQUIREMENTS IDENTIFICATION DOCUMENT \\ HIGH LEVEL WASTE STORAGE TANK FARMS \\ Radiological Protection \\ Rerixion 0
}

\section{STE REQUIREMRNT SOURCE: DOE-N5480.6 Section 111}

\author{
Rotiological Control Policy \\ A bey element of the Rodintion Protection Guidence to the Federal Agencies for

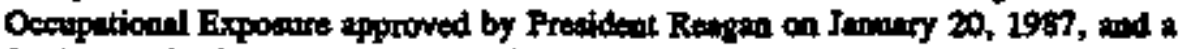 \\ Aminmental principle umderlyins this Mnanal is: \\ exposuto of werkers to ionizing radiution without the \\ There should not be sny ocenpetionel \\ expectation of an overall benefit from the activity censing the exposure." \\ The Departmeat of Enersy is firmly committed to having a Radiological Control \\ Program of the hiphest quality. This ipplies to those DOE uctivities then \\ mannge radiation and radioactive materials and that may potentinlly realt in \\ rediation exposure to workers, tho public and the environoment."
}

\section{SITE REQUIREMIENT SOURCE: DOE-N\$480.6 Section 111[02]}

"Department of Enorgy Rodiological Control Policy

\section{ALARA}

Pereonal ratiation oxpoowirs shall be maintained As-Low-As-Reasomably-Achioveble (ALARA). Radietion expostre of the work force and poblic stall be exatrolled such that radiation exposures tre well below regatetory limite and that there is no radiation expostre withont commengunto bentfit.

\section{OWNERSHIP}

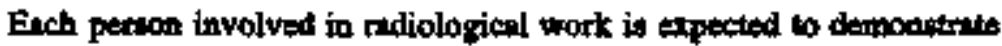
responsibility end accountability through an informed, disciplined and contion sttinude toward andintion and mationetivity.

\section{EXCET ENCE}

Ercellent performence to trident when ratiation exposures are maintenined well below requiatory limite, contamination is minimsl, ndiosctivity is well controlled and rediological spills or umcontrolled releases are provented. Continuting inprovement is esseutial to oxcelleope in rediolopical control."

\section{SIrE REQUIPEMENT SOURCE: DOE-N5490.6 Section 114.1}

"Sito-Speciffe Manurl

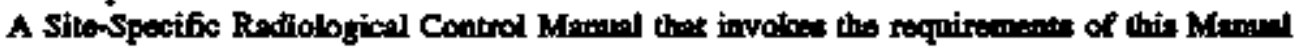
shall be issued and ondorsed by the contrector senior sito arective. The Sitospecific Radiolotical Control Mandil does not requite review of appoval by the DOE ODe

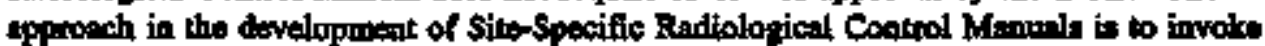
the provisions of this Mamisl as written will sito epecific additions, sopplements and clarifications elearly incicated, included in the approprinte chapters and directity referenced to the corrosponding Articlo. Addition and sufpitements to thdrese uniquo tibutions of to provide more detalled or preceriptive direction uney be included only if these elditions do not conflict with or diminish the nexuirements of this Mamsl. The contructor aenior sib executive is that person at a DOE contractor-opersted fucility of site who hes finel on-sibe corportite muthority and is often celled President, Genert Manager, Sito-Minnger, or Direter." 


\section{REQUIREMENTS IDENTIFICATION DOCUMENT FIGA LEVEL WASTE STORAGE TANK FARMS \\ Radiological Protection \\ Revision 0}

SITE REQUIREMENT SOURCE: DOENS480,6 Section 114.2

"Mangemeat policios, requiriomente, expectations and objectives for the sith

Radialogical Cootrol Program should be cievity and unumbiguousty staved."

\section{STTE REOUIREMENT SOURCE: DOENS4\%0.6 Section 114.3}

The Sito-Specific Mamel shall be kept ctrrest and eatered into tho contrector document control system."

\section{SUE REQUREMMENT SOURCE: DOE-N3490.6 Section 114.4}

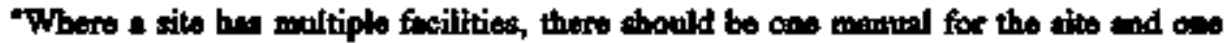
Rudiological Control Organization. If a prime contractor monages soverl DOE sits;, effort should be made to have ano corports Rediologieal Control Mammal the spplied to all of that prime contractor's DOE sited. For a site that has multiple prime contrecton, a

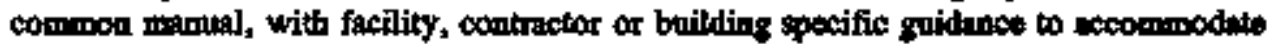

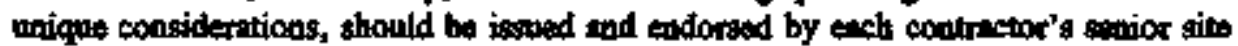
executive. For prime contractoiss who manige severil sites but whe aleo cperate sites with more than one prime contrector, the site mamal should take precedence over the corporate Radiological Cootrol Menual."

\section{SITE REQUIREMENT SOURCE: DOE-N5480.6 Section 114.5}

"Subcontractors shall cotwply with the Site-Specific Radiologival Coatrol Moming."

\section{STrE REQUIREMENT SOURCE: DOE-N5480.6 Section 115.2}

The degree of progrtem formelity and exteot of the ussocisted administrative process are expected to be commensturate with the putionctive material ecatomination and dow

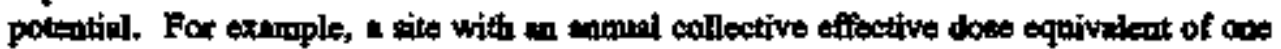

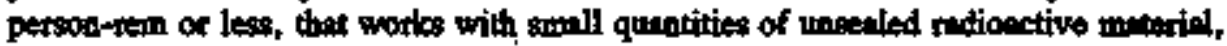
would not be expected to have in ALARA progrem as complex al ans required at higher

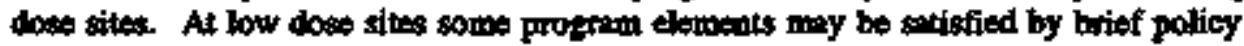

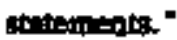

\section{STIE REQUIREMENT SOURCE: DOE-N5490.6 Sectlon 116.2}

"To aesist contractors in identifying and sdopting proven practices and inplementing procedures in 6 timely maneer within the DOE Complex, contrutors are

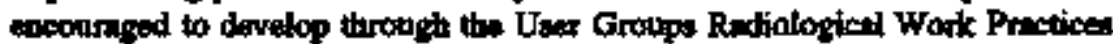
Eandbooks that cin be used by $\bullet$ given category or clase of fecilities essocinted with the User Group.

Suggested User Group cetegories are af follows:

- Rextors

- Utriuar

- Envimonmental Restoration/Waste Menagerment

- Pjutcrium

- Tritiam

- Accelerators 


\section{REQUIREMENTS IDENTIFICATION DOCUMENT HIGH LEVEL WASTE STORAGE TANK FARMS \\ Radiological Protection \\ Revision 0}

- Large Reserith and Development Leboretory Operitions

- Small Research and Development Laboratory Operations (enminl collective effective dose equivilent of one person-rem or less)

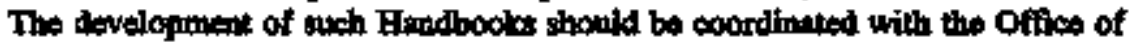

Ervinonm.ont, Sefecty and Health."

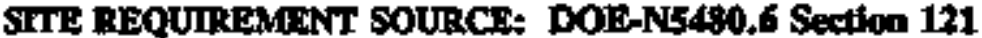

Teadersiotp in Rudiologicil Control

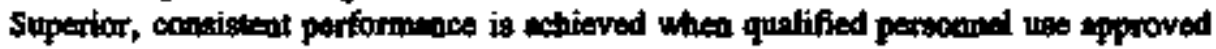
procedures and monegtonent extively monitors the worlplace and sesecses ongoting sctivities. Such activities include, but are not limitad to, operatione, remediation, labortory work, research and developentent and stessip. Constant rovien and informed

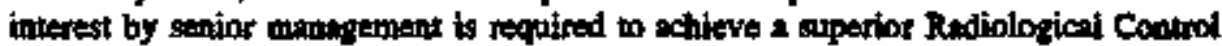
Propram. Mansgement leads by example. What minngement does speaks louder thrin wiat management says. Mangpernent at all lovels should emphusizs the need for high standards for radtologteal control through direct comeminicetion, instructice and inpection of the work spece. The DOE Field Office Menages mot the contrector senior site

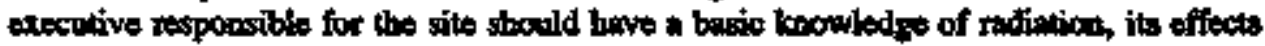
and ratiological control requiremsets. The DOE Flejd Office Manager and the contrictor senior sito executive should also be familier with the correat radiological performanos

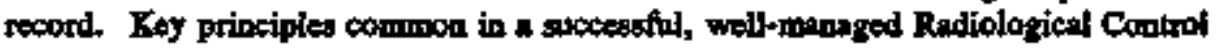
Progren ant provided in this Chapter."

\section{RELATED REFERENCES}

\section{DOEJEH0256T Artikle 121, Paragraph 9}

\section{SITE REQUIREMENT SOURCE: DOEN5480.6 Section 122.3}

"The attimde that condant improvement is required in radiolopical work nods to be developed at all levels of mantigement and in the what furte. Cooperntion between the work force and tho Radiolocieal Control Oreanization has to be developed and foctered. The workers should not bolk upon ratiological controls as beurdiles or restrictions to be bypassed."

\section{SITE REQUIREMIENT SOURCE: DOE+N5480.6 Section 122.4}

'Redialogical Control Orqanization persoaned should be belpful in thowing workers bow to follow the rules. This spirit of cooperition neds to be developed without sutwerting the coutrol functions of the Raliclogical Control Tectnicians. A situation in which rndiological controls arp left solely to tho Rudiological Control Orgmization is wasceptabler"

\section{SITE REQUIREMIENT SOURCE: DOE-N54\$0.6 Section 123}

"Wotkes Responsibilities

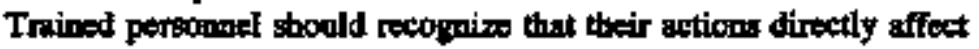
contemination control, persomell radiation expossers and the overnil radiolotical environmeit associated with their work. The followins radiological control rules are appliesble to each person in the workplace. A 


\section{REQUIREMENTS IDENTIFICATION DOCUMENT HIGH LEVEL WASTE STORAGE TANK FARMS \\ Radiological Protection \\ Revision 1}

ponter then displyys the worker responsibilities listed below should be produced and disphayed at appropriate cocess poinss and work areas."

\section{SITE REQUIREMFNT SOURCE* DOE-N5480.6 Section 125.5}

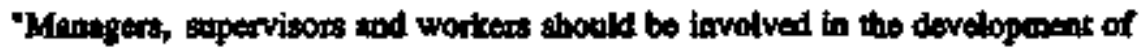
exturate, clest, written procedures for perfoctring rediological work. If during the use of procedures a written requirement cunat be rasponsibly followed, the wort should be stopped and paldiace obsutaned."

\section{SIIE REQUIREMENT SOURCE: DOE-N54\$0.6 Section 125.9}

"Subcontractors and rabeontructed employess shostld be treated the sume as facility staff in the area of radioiogienl matters, should brve comparable training and shall meet the same requirements and expectations."

\section{SFTC REQUIREMENT SOURCE: DOE-N5480.6 Section 373}

- Other Worleiece Hazards

Radiological coutrots shorild be inplemented in a boinnced way to ensure that protection from sll workplace herarde can bo implemented. Other hronds to Consider includis:

1. General contrinction hazerdes

2. Confined speces;

3. Flammable materinls;

4. Reactive chemicals;

5. Heat stress;

6. Chemital exposures;

7. Energized eloctricel equipmeat;

8. Biological basucs;

9. Rotetiog equipmenc;

10. Noiso and vibntion;

11. Excrevations,"

\section{STIE REQUIREMENT SOCRCE: DOE/EFH0135 RP.1.11}

"11. Procedures aproved by site/facility menagement ane in plece to implement tho radiological protection propram and are updaked periodically."

\section{SITE REQUIREMENT SOURCE: DOE/GHOL3S RP.1.12}

"12. Rudiological protection problems aro dactmented and ovalunted. Theso evaluations are feviewed for treada, and ections are trken to conned the cruses.

\section{SITE REQUREMIENT SOURCE: DOELAH013\$ RP.10}

"PERFORMANCE OBECTIVE: The rediation monitoring end conmingtion control program should ensure worker protection from radiation exposures." 


\section{REQUIREMENTS IDENTIFICATION DOCUMISNT HIGH LEVEL WASTE STORAGE TANK FARMS \\ Radiological Protection \\ Rorision 0}

STE REQUIREMENT SOURCE: DOEMGH0135 RP3 PROCEDURES.1

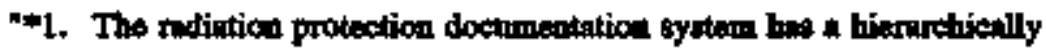
erranged cystem that dflows the trecing of DOE Order requitrements from:

- Tho Oriars to policy,

- Policy on contractor stendats and contronts, and

- Copinetor standards und controls to procedares."

SITE REQUIREMIFNT SOURCE; DOE/EHOL35 RP.3 PROCEDURES2

"m. The contractor has 2 written policy on modietion protection (including ALARA).

SITE REQUIREMENT SOURCE: DOEEHD) 35 RP,3 PROCEDURES.3

-*3. Redjation protection etendards, procedures, and costrols brve recogaizabile of formel

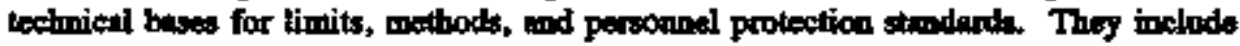
sound radiological requiptinents such as those recommended in Americio Netions! Stondards tontitute (ANSI) and Nationel Couneil on Radiation Protection and Meagrameuts (NCRP) docuturnts."

\section{STTE REQUIREMENT SOURCE: DOEJAHOt35 RP3 PROCADURES.5}

-5. Radiation protection procedures are adequately documented and apdated periodically. This inchedes, bat is not limited to:

- Sitoffacility porting,

- Developing and maintaining all atdiution protection records,

- Reporting umusunl rediation ocourraces,

- Operating radimion-genertiting equipment,

- Using notivation monitoring instrumeats,

- Using radiation sources (e. \&, neferease and celibration),

- Trucking porsomel medical eveluation,

- Reporting ridiation exposures.

- Uaing protective clothing,

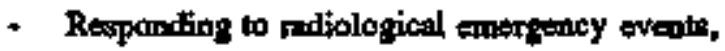

- Surveying and monitoring. 


\section{REQUIREMINTS IDENTIFICATION DOCUMENT HIGH LEVEL WASTE STORAGE TANK FARMS \\ Radiological Protection \\ Rerision 0}

- Providing ecouting room equipmeat and procedures, and

- Utilizing instrumeat mintzanco and control,"

\section{RaCILITY RJOJIRGMINT SOURCE: DOE5400.5 Chapter I, Section 5}

It it the policy of DOE to impleaneat legally applicable ndintion protection stroderto end to coosider and adopt, as appropriata, recommendations by mothoritative ongroizations, e.g., the National Council on Rudiation Protection and Meanurements (NCRP) and the International Commicrion on Rutiological Protection (ICRP). It is also the policy of DOE to adopt and implerreat studards genendly consistent with those of the Nucilent Refulationy Commission (NRC) for DOF facilities and activities not mobject to licensing anthority."

\section{STE REQUIREMENT SOURCE: DOES480.1I Section 5}

-a. It is the policy of DOE to implement radiation protection stonderds that are consistent with the Presidential approved guidance to Federal A fencies promulatted by the Eavironmontal Protsetion Apency (EPA) and besed an the recommendutions by athoritutive orgenizestions, a.g., the Nationel Council on Radiation Protoction and Meacuremente (NCRP), and the Internationel Commissioe on Radiological Protection (ICRP).

b. It is the polity of DOE to operate its ficilities nod condut its ectivities so that rediation exposures are mainmined within the Limits promelanted by this Order ard as far below the limits of this Order a ressonably ackievatile. This policy applies to andur, committed, and cumplative dnoe oquivalents.

\section{Rolicy for Reaponse to Ahnorm:al Situgtions}

This element included requirements for approprinte response to thormat sinutions which

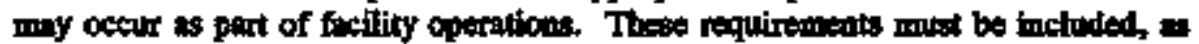
cypropriate, in tho troining curriculum for both RP and other facility plant peranonel and ment also bo incleded, as eppropriater, in RP policies and procedurce.

\section{STIF REQUIREMIONT SOURCE; DOEAN540,6 Section 144.2}

"Radiolopical Conerol Technietans and their supervisors stull hrve tho responsibility nod wothority to stop wort or mitigate the effect of m activity if they suepect that tho initintion or contimud perform nce of a job, evolution or will result in the violation of rectiologieal control seanderds or reselt in inminent denger or uneceptable rist Aly

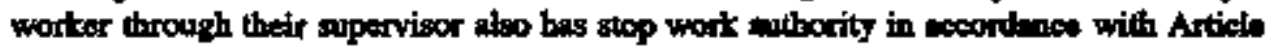
345."

\section{SITE REQUIREMIENT SOURCE: DOE-N3480.6 Section 345.1}

"Stop Radiologised Work Authority

Rutiodogical Controd Technicians and their sapervisors, line aupervision, and 


\section{REQUIREMENTS IDENTIFICATION DOCUMENT HIGH LEVEL WASTE STORAGE TANK FARMS \\ Radiological Protection \\ Reristion 6}

any worker through their anpervisar has the mathority and respomibility to

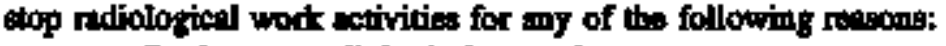

-. Inadequate ndiologicel controls;

b. Restialogiteal coutrols not being taplentented;

c. Reatiological Control Hold Point not being entiafied."

\section{SHE REQUIRBMENT SOURCE: DOE-N54\$0.6 Section 345.2}

"Stop rafiological work wathority shall be trercised in a juetifiablo and responsible Iranner."

\section{SIITE REQUIREMIBNT SOURCE: DOE-N5490.6 Section $\mathbf{3 4 5 , 3}$}

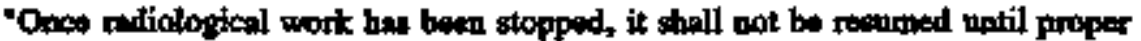
radiological coatrol has been trestablished."

\section{SIrT: RSQUIREMIENT SOURCE: DOE-N5490.6 Section 345.4}

"Resurpotion of rediological wort requires the approwal of the lino mantiger responsible for the work and the Redialogical Coatrol Monnger."

\section{SITE REQUIREMENT SOURCE: DOE-NS490.6 Section 346.1}

"Reoponses to Abnormal Situations

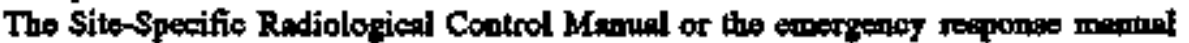
shall establish requixements for alarm rosponse procectures. Sito alarm respones procedures should addrees the generel extions in itemin 2 through 6 below, modified as nocessery to refloet specific fucility conditions."

\section{SITE REQUIREMIENT SOURCE: DOE-N5480.6 Section 346.2}

"Response to a Contimosus Air Moniter alanen should inclede the following Bctione:
1. Stop work mecivities;
b. Inmodistely oxit the area;
c. Notify Radiological Courol peranoll."

\section{SITE REQUIRHMINT SOURCE: DOE-NS480.6 Section 346.3}

"Respones to incressing or unanticiputed radiation levele, as identified by a supplemental dosimetor or Arta Ratiation Monilor Alarm, should include tho following tions:
1. $\operatorname{sinp}$ work sctivities;
b. Alert ochers:
c. Aftected personnel immodiately exit the arsey
d. Notify Radiological Control personnt."

\section{SITE REQUIREMIENT SOURCR: DOE-NS480.6 Section 346.4}

"Response to a criticality alarm should include the following action: 


\section{REQUIREMENTS IDENTIFICATION DOCUMENT HIGH LEVEL WASTE STORAGE TANK FARMS \\ Radiological Protection \\ Rerivion 0}
2. Inmediately ovecunte the area, withoun stoping to remove protsetive clothing or perform exit momitoring;
b. Report to destanitiod antembly artan,"

\section{STIE REQUIREMENT SOURCE: DOE-N5480.6 Section 346.5}

Teaponse to a personed contaminution monitor alam should include the following extions:
a. Remoin in the immodiate area;
b. Notify Radiologicat Control personnel;
c. Tako actions thet may be availeble to minimize crosu-contamination, such - palting a glove on a continmingled hiod;

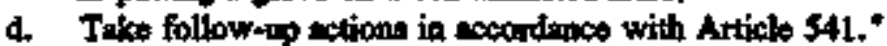

\section{STTE REQUREMENT SOURCE: DOE-N5480.6 Section 346.6}

"Response to n spill of audionctive material should include the following actions:
2. Stop or secure the opention causing the spill;
b. Warn othen in the erea;
c. Isolate the spill area if poesiblo;
d. Minimize individunl exposire and contamiantion;
c. Secure unfiltered ventilation;
f. Natify Rudiological Control personnel.

For tpilis imvolving highly toxic chtmicols, workers should immodincely exit the are without ettempting to stop or secure the epill. They should then prompitly notify the Industritl Hypiene or Hizondous Moterial trate nod Radiological Control personel.

\section{SAIE REQUIREMIENT SOURCE: DOEKHO13S RP.2 ACCIDENTS/INCDENTS.7}

-7. Management will stop work if necessary to enrure that my correctivo extion is tuken to preclude repetition of an accident."

\section{Rad Protection Prouram Assessments/Internal Audits}

This element includes ratuirallets for the performence of Rediation Protection AssessmentuInternal Audis and the we of the dita reasting from those

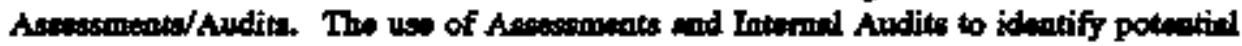
problems of deficianies in programs is estential on enstring contiquad complitance with requirements and inchustry rood practices. Menigenent commitment to respoeding in an

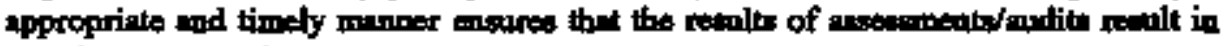
ongoing program improvements.

\section{STYE REQUIRBMENT SOURCE: DOE-N5490.6 Section 134.1}

-Assesamonar

Atrossment, as used in this Manuel, refort to the process of providims independene foedbeck to senior line manegers to inticate the selequacy of the Rediological Control Program. lespections, audits, roviown, investigations ind self-asostements are part of tho 


\section{REQUIREMENTS IDENTHICATION DOCUMENT \\ HIGH LEVEL WASTE STORAGE TANK FARMS \\ Radiological Protection \\ Rerision 0}

numerous checks and balances noeded in a good Rudiolocical Control Prognim Intornil

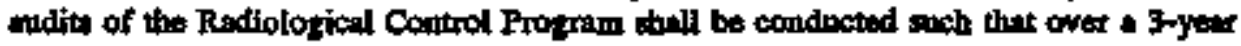

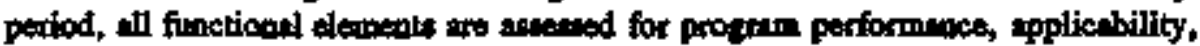
content and implomentation. These should be performed by the Rarliological Control Organization, the quelity Assorance Organization and ofher organizations."

\section{RELATEO REFERENCES}

1. DOE/EH0256T Anticle 134

STIE REQUIREMINT SOURCE: DOENS480.6 Section 134.2

"Managers, stpervisors and workers sbould loak upon asessionens as helphul. It is desirihle to approwh sosestents wilh nothing to bith and with the Radiological Control Program es an opeo book. Results of assesumenti should be incorparated into the ongoing process of improving radiological control."

\section{RELATED REFERENCES}

\section{DOEREHOZS6T Article 134}

\section{STIE REQUIREMINTI SOURCE: DOE-NG4\$0.6 Section 134.3}

-Managers should encourage the positive view that identifying oven minor deficieacias represeats an opportanity for further improvement The number of

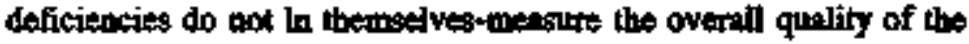
Radiological Control Program. A prioritization system to implement actions for resolving the deficiencies should be implemented."

\section{RELATED REFERENCES}

1.

DOE/EHO256T Article 134

\section{SIIE REQUIREMENT SOURCE: DOE-N5490,6 Section 134,4}

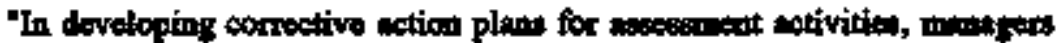
should adtrees besto woderlying resecos for the itentified deficiencies or concerns, not just the epecifie symploms ideatified by the roviewne."

\section{RERLATED REIDERENCES}

\section{DOEFHO256T Articie 134}

\section{SITE REQUIREMENT SOURCE: DOE-N3489.6 Section 134.5}

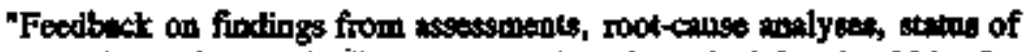
corrective actions and allberence to action plan schetules thould bo frequently provided to mensegments." 


\section{REQUIREMENTS IDENTIFICATION DOCUMENT HIGH LEVEL WASTE STORAGE TANK FARMS \\ Radiological Protection \\ Rerision o}

\section{RETATED REFERENCES}

1. DOE/EHO256T Articls 134

SIIE REQUHREMENT SOURCE: DOE-N5480.6 Section 146.1

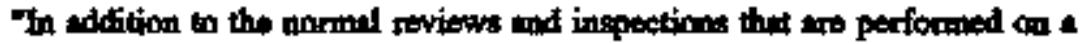
periodie basis as specified in DOE 5482.1B, an adfitional level of assessment is inportunt in identifying problems to senior mentgemeat. A Raciological

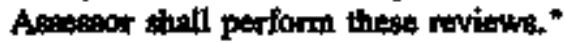

\section{SITE REQUIREMINT SOURCE: DOE-N5480.6 Section 146.2}

"The Radiological Assessor stould bove scesestreport to the contractor senior site axecutive and should be curside the line orotinizations and the Ratiologicol Control Organization. Fot emoller sites it is reasonmble to obtain independeot, external review of radiolocical control operaican on a periodis busis. For langer funilitis or for those controctors responsiblo for multiple sites, a full-tims positions should the ansjoned."

\section{SITE REQUTREMENI SOURCE: DOEVHH0135 RP,1.1}

**1. Inepections and endits utilizing DOE 5492.1B, Section 10, wo sectuduled and performed by contractor sufety personed indepeedent of the opention to determine the effectivedess of the todiological protection propirm to identify problems and to initiate nocesery corrective metions."

STE REQUIREMENT SOURCE: DOE/EH0135 RP.2 INTERNAL AUDTS.I

- 1 . The internal mdit progrum complies with DOF 5487.1B, Section 9.d and DOE 5480.1B, Chapter XI."

\section{SITE REQUTEMENT SOURCE: DOE/EH0135 RP.2 INTERNAL AUDIS. 2}

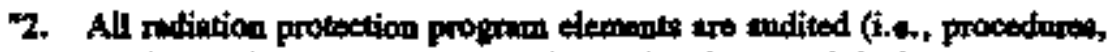
recorde, rouvine aurvey program, thternol end externel doximetry, instrumeatetion, calibration, etc.)."

\section{SITE RFQURRMLNT SOURCE: DOE/DH0135 RP,2 INTERNAL AUDTS.3}

3. The internal sudit is conducted by individuels knowledgeablo in ractiation protection but independeat of the program being actited."

\section{STE REQUTEMIENT SOURCE: DOE/EH0135 RP 2 INTERNAL AUDIS.4}

*4. Internal mudits are conducted on a specified frequency, at leass overy 3 yetrs." 


\section{REQUIREMENTS IDENTHICATION DOCUMENT \\ HIGH LEVEL WASTE STORAGE TANK FARMS \\ Radiological Protection \\ Rerision 0}

SITE REQUIREMENT SOURCE: DOE/EHOT3S RP.2 INTERNAL AUDITS.5

5. Internal pudits aro documented."

\section{SFTE REQUIREMENT SOURCE: DOES490.11 Section 9.r(1)}

"Contractor intermal andits of all functional elements of the rediation

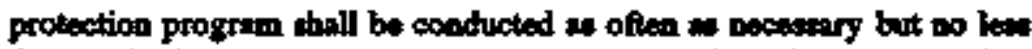
frequently then every 3 years. The andit should incluste, but is not linited to:

(a) External dosimetry;

(b) Internal dogimetry:

(c) Fortable and fixed instrumartation;

(d) Respintors;

(o) Contamination control;

(f) Rudiologicial monitoring:

(g) ALARA program;

(h) Nuckar aceideut dosimetry;

(i) Source moterial control;

(j) X-ray protection;

(k) Truining;

(I) Posting;

(m) Reconds."

\section{FACILTY MONITORING AND SURVEYS}

This element addreses the requiremend for Radiation Protectica persomed to monitorfarvey rrdiological conditions in the freility. Requirements for deterwining and

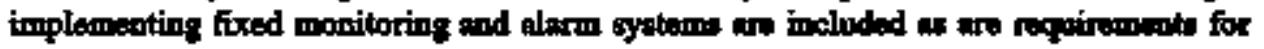
performing survoys using portable radiation monitoring/mesturing equipmeat.

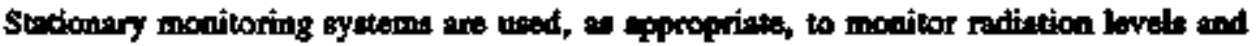

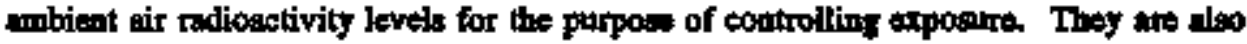

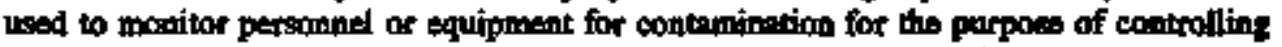
and limiting tho spread of contumination and thes redocing persomel exposire. Alerm.

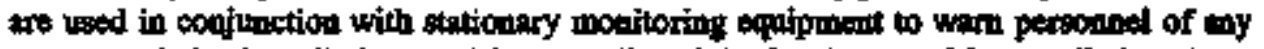

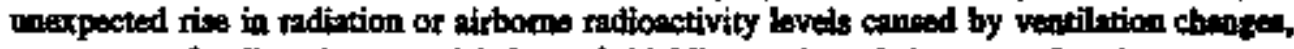
movernent of ndionctive material, loss of shieiding, umintended process fonction ovente or 


\section{REQUIREMENTS IDENTIFICATION DOCUMENT \\ HIGH LEVEL WASTE STORAGE TANK FARMS \\ Radiological Protection \\ Revision 0}

accidents, of by my other ectivitite which could affect these lovelo. Simiturly, alarms wo

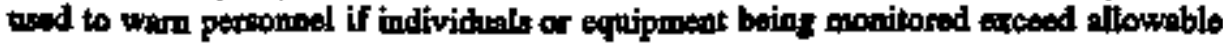
contumination levelo.

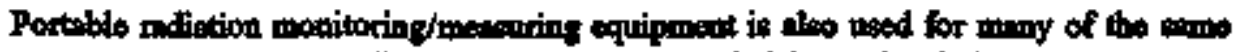

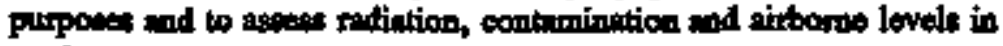
Work areas.

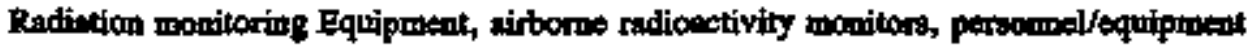
conterminution monitors and associated alarm systems are mintriged by the RP onguization. Criticality alarm systeme are the responsibility of the Nuelear Sufaty

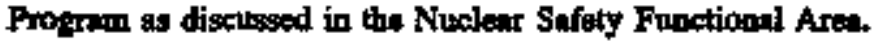

The Radiologion Monitoring/Surveys element includes requirements for performing surveys in sappont of personiel protection as well as generd requisements for performint: surveys. Redietion Procection personnel may also provide services requined es part of the Exvirommental Protection functional area by collecting samples or performing monitoring in subpors of Envirommental Protection. General requirement for performing arveys will cpply end any adtitional requintents specific to performing environmental surveyt will be inchuted as part of the Environmental Prowotion requirements identification doenment.

\section{SIIE REQUIREMENT SOURCE: 10CFR20 Part 20.201.a}

"Precentionary Procedures. Surveys.

2. As used in the regulations in this part, "sorvey" means wn ovatuation of the mdiption hazards incident to the production, use, release, diepoesl, or presence of ndiogetive materials or other sources of radiation under a specific set of conditions. When sppropriater exch evaluation ibclades a physical survey of the location of materials and equipment, and meacunements of lovele of radiation or coneatrations of rationctive muterial preseat."

\section{SITE REQUIREMENT SOURCE: DOE-N5480.6 Section 551.t}

Rediological Monitoriting and Surveys

Requitioments

Radiological montitoring of ndiation exposure levelo, coanmination mi

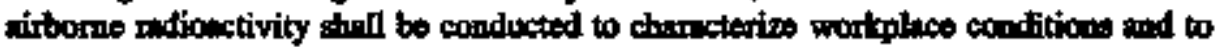
ilentify areas requirizes postinge "

\section{REHLATED REFERENCES}

1. DOERH0296T Article 551

\section{STIE REQULREMENT SOURCE: DOENS490.6 Section \$\$1.11}

"Motitoring recults sbould be made avaitetle to line mengespent and used in support of pre- and post-job evaluations, ALARA preplaneing, centsmination control und untragement of rodiological control operetions." 


\section{REQUIREMENTS IDENTIFICATION DOCUMENT HIGH LEVEL WASTE STORAGE TANK FARMS \\ Radiolopical Protection \\ Revision 9}

\section{RFIATED REFERENCES}

\section{DOE/EFOOEST Article 551}

\section{SITE REQUHREMINT SOURCE: DOE-NG490.6 Section 551.12}

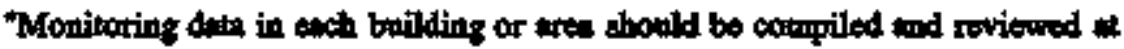
leoes quarterly. Changes or trends abould be noted and consective metions astigned."

\section{RELATED REFER FNCES}

1. DOE/EH0256T Articlo 551

\section{STIE REQUIREMENT SOURCE: DOE-NS490.6 Seetion $\$ \$ 1.2$}

"Monitoring shall be performed only by trained and qualifiod personnel using properly calfibrated instruments."

\section{RELATED REFGRENCES}

1. DOE/EHO2S6T Article $\$ 51$

\section{SITE REQUUREMENT SOURCE: DOE-N\$480.6 Section 551.3}

"Surveys for radietion, contamination and aitborne endioactive matoride thatl be performed as specified in Techniesl Work Documonta and Radiolorical Wort Permits."

\section{RELATYD REFERENCES}

\section{DOE/EH0OS6T ATticle 551}

\section{SIIE REQUIREMIENT SOURCE: DOE-N5480.6 Section 351.4}

The Retiological Control Otgenization phall perform and doctment a reviaw of tho adequncy of satipling and moniloring syutents at pert of any fecitity of operational changes affecting radiologicel control. In the sbesence of such chenges, a review should bo condected annulully."

\section{REIATED REFERENCES}

\section{DOE/EHO256T Articlo 551}

\section{SITE REQUIREMENT SOURCE: DOE-N5490.6 Section $\$ \$ 1.6$}

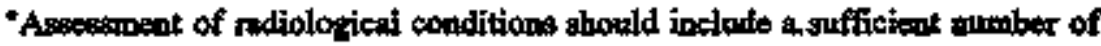
sarvey points to charecterize the rodiation present ind to verify boutedaries." 


\section{REQUIREMENTS IDENTIFICATION.DOCUMENT \\ FIGH LEVEL WASTE STORAGE TANK FARMS \\ Radiological Protection \\ Revision 0}

\section{RELATED REFERENCES}

1. DOE/EHOZSGT Articie 351

\section{SIIE REQUIREMENT SOURCE: DOE-NS480.6 Section 551.7}

"Strveys should be performad boforn, during and at the completion of wort thet hes the poteatial for crusing changes in leveis of tactiotion and madioastivity."

\section{RELATED REFERENCES}

1. DOEREIORSGT Article $\$ 51$

SITE REQUIREMISNT SOURCS: DOE-N5480.6 Section 551.8

"Sarvey frequeacies should be establistod besed on potuotial radiolopical conditions, probability of chenge in conditions and ween cocenpancy factors."

\section{RELATED REFERENCES}

1. DOE/EHDOS6T Article 551

\section{SITE REQULREMENT SOURCE: DOE-N5480.6 Sectian 551.9}

"Monitoring results should be reviewed by the cogrizant radiological stperviscr. The revien sbould ensure that atl required soneys bave bean performed and that the documentation is accirate ind complete."

\section{RELATED REFERENCES}

1. DOE/EH0256T Article 551

\section{STTE RECUIREMENT SOLRCE: DOE-PNL-6534 Section $\mathbf{4 . 6 . 4}$}

The fint sep in the design of a propective surveillange proptam in to cherecterize the potential for intoles of plutonium mol othor ndioanclides that moy be present in the fecility.

The second step is to angintain a quality progran for moutine mensuremont of the workpline, sweh warfoce conlemination moniloring, wif sumpling, tad continuoph sir monitoring. The restits of these messirements should be used to indiceto when retrospective bionssay mensurements wro neoded. The routios

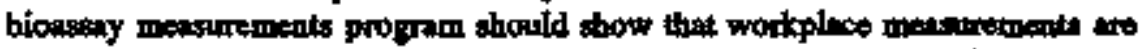
effective in identifying conditions that vesalt in confirmed intales of plutonium." 


\section{REQUIREMENTS IDENTUHCATION DOCUMENT HIGH LEVEL WASTE STORAGE TANK FARMS \\ Radiological Protection \\ Revision $\theta$}

\section{STE REQULREMENT \$OURCE; DOE/ERU13\$ RP.10 RADLATION MONITORING.3}
3. Procedores and criteria for completion of arvey forms, acceptable rudiation lovets, evaluation of survoy resolta, and reposting of offebinderd survoy reoulto are availiblo."

\section{STE REQUIREMENT SOURCE; DOE/EH0135 RP.10 RADLATION MONITORING.5}

"3. Documented procedures are avilable mil trining conducted to ensare that routite dose rete and contuningtion surveys are conducted in a

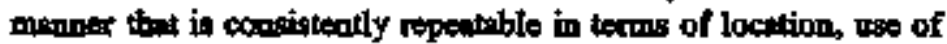
stmetrs, and instrument interpretation."

\section{SITE REQUIREMENT SOURCE: DOE/EH0135 RP.5 ROUTINE DOSIMETRY.12}

-12. Adequate field arveys of wort locesions are performed end documented to deternifice when routine and specilal dosimetry are nesiled."

\section{FACHTY REQUIREMENT SOURCE: DOB6430.1A Division 1300, Section} 6.5 .3

"Use of devices to wara persocunel of possible contemination or other hazardous meferials shill bo eveluated and such devicen thell be peovided in accordance with this evaluation. Provisiona shall be made for personnel monitoring devices, such as hand and foxt acuntern, in the vicinity of work stations. Installed monitors (aupplemented with personal monitoring methode

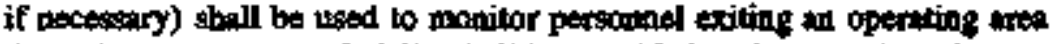
through access ways. CAMSe chall be provided to detect and to alarm at prescribed wirtorne radiometivity levels."

\section{FACILITY REQURREMENT SOURCE: DOE6430.IA Sectom 1300-6.5.7}

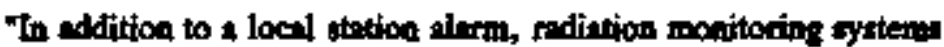
(eriticelity alorm, CAMSs, alarm aesociated with tack monitoring system, and so on) shell have central (i.e. control noom of rndiation mooritoring oftice) readout and alorm panels that wre pocessible after a DBA to evaluate internel conditions:

STE REQUIREMENT SOURCE: INPO-88-010 Chapter VL, Seetion C.3(2), Parastaph 2

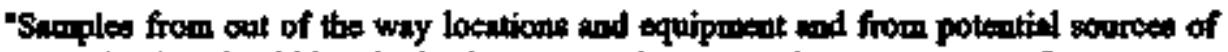

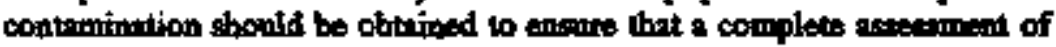

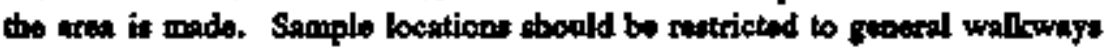
for routine surveys." 


\section{REQUTREMENTS IDENTIFICATION DOCUMENT \\ HIGH LEVEL WASTE STORAGE TANK FARMS \\ Radiological Protection \\ Revision 0}

STE REQULREMFNT SOURCE: NUREG-1761 Section 7.b(1)

"Roution Surveys - Generil

(a) Radietion protection surveys at required by 10 CFR Part 20, Section 20.201 should include not only physional meesurements and uncuitaring but lso investigation and correction of abmormal radiclogical conditions which may be discovered.

(b) Frequencies of swveys and monitoriag should be wablinhed besed on the potential bexpent, probability of chenge in tadiolopical conditions, and cocupancy factors. Surveyo should be performed in both restricted and unrestriated aress to piovide positive verification that radionctive moterials ave being wequately controfled and are nok sprequeting to, $\alpha$ buildiog up, in uncontrolled areas.

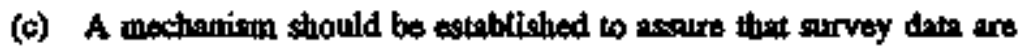
eveilable and used for informing personnel of herads, job evaluation, tread enalysis, and ALARA pro-pienning."

\section{SITE REQUREMENT SOURCE: WAC-402-24 Section 085}

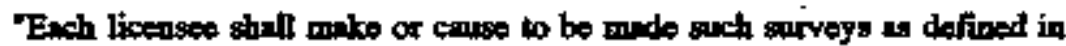
WAC 402-12-050, as way be necessery for the licensece or registrunt to establish compliance with these regulations and are reasonsbile under the

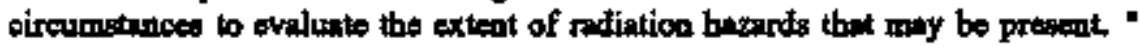

\section{RELATED REFERENCES}

\section{10CFR20 Purt 20.201.b}

\section{Bacingtion Monitors and Alarms}

This element atdressed the requirements for monitoring work area modintion does rates. The requirements are primerily simed towards the use of stretionssy moniboring equipment. This equipment may or Iney not be expipped with alermis or with rewoto resdouts in the control toom or in some other part of the facility.

\section{STTE REQUIREMENT SOURCE: DOE-N5480.6 Section $\$ \$ 33.1$}

Ave Radiation Momitors

In addition to the requirements of Article 551, ares ndidtion moxitors (not to include ara monitorimg dosimeters discessed in Articlo 514) stould be installed in frectuently accupied locstions with the posential for unerpected increases in dose rates and in remote locations where there is a need for locel indication of dose nates prior to personnel entering remote locations." 


\section{REQUIREMENTS IDENTIFICATION DOCUMENT \\ HIGH LEVEL WASTE STORAGE TANK FARMS \\ Radiological Protection \\ Repision 0}

\section{RELATED REFERTENCES}

1. DOE/EH0256T Article $\$ 53$

STIE REOUIREMENT SOURCE: DOE-N\$480.6 Section S\$3.2

"Area radiation monitors should aot be subetituted for radiation expoours surveys in churacterizing a worlpluce."

\section{RELATED REFERENCES}

1. DOEREROZSGT Article 553

STTE REQUTREMENT SOURCE: DOE-N5480.6 Section 553.3

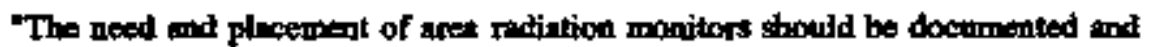
assesed when chroges to facilities, systems or equipment cocur."

\section{RELATED REFERENCES}

1. DOEJEH0256T Artiole 553

SITE REQUTEEMENT SOURCE: DOE-N5480.6 Section 553.4

"Area radiation monitore should be tected at leat quattody to verify audible dlarm system operability and endibility under ambient working sonditions and operibility of visual alnems when so expipped."

\section{RELATED REFERENCES}

1. DOE/EHO2S6T Article 553

\section{SITE REQUIREMENT SOURCE: DOE-N5499.6 Section 553.3}

Tf instelled instrumeatation is removed from service for mainteasecos of

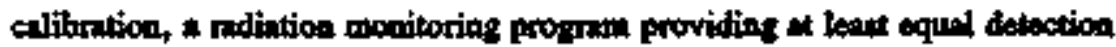

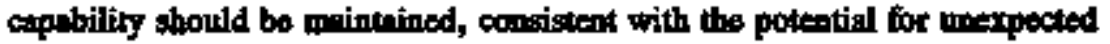
inereases in ratiation dose rates."

\section{RELATWD REFERENCES}

1. DOE/EEORS6T Article 553

STHE REQUIREMENT SOIRCE: DOE/EHO13S RP.IO RADTATION MONITORING.6

6. Facility are monttoring readouts and alarms tre alequits to infom workers of workplace madiation levels." 


\section{REQUIREMENTS IDENTTFICATION DOCUMENT HIGH LEVEL WASTE STORAGE TANK FARMS \\ Radiological Protection \\ Revision 0}

SITE REQUIREMENT SOURCE: DOES480.11 Section 9.-g(3)(b)

-Redintion Moritorimp. Appropriste stationary (aren) ind/or portable ratietion incruments still be available and used to mensere dowe rites for the porposs of controlling expostro to radiztion. These instruments stall be rovtipely colibrated and maintitined. The combination of instrumedes used stull provide capability to mesoure types of radiation (neotron, efmina, bets, or I*

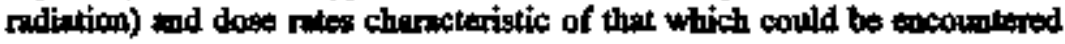
at that fecility."

\section{FACILYY REQUREMENT SOURCE: DOE6.30.1A Section 1360-6.5.4}

Where ionizidg radintion is present (dwe to procese muterial, equiprent, or operations), an ares radiation monitoring and alarms system shell be prowided to alert personnel of unexpected increases in ionizing radiation levele."

\section{Dose Rate Survers}

This etement includes the requirements for sarveying the radiation levels prior to and during tho performonce of work activitieg. Thess requirements are cimed primarily it the

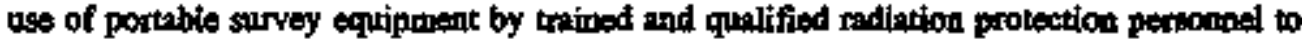
asess and document rodiation levels in plant areas.

\section{SITE REQUREMENT SOURCE: DOEN5480.6 Seetion 234.2}

Dose mate messurescents used to determine criteria for Ratiation Areas ahould be mads at a distance of 30 centimaters from the ndiarion source or from acy surficos thron th which the radintion penetrates. For Very High Radiation Areas, the mensuremed aboold be mude $\pm 100 \mathrm{~cm}$.

\section{RELATED REFERENCES}

1. DOEREOMSGT Article 234

\section{STIE REQUIREMENT SOURC: DOE-N5480.6 Section 234.3}

"Contert rewings shoold be wed to determine the presenes of Hot Spots."

\section{REHATED REFERENCES}

1. DOE/EH0256T Artick 234

\section{SIIE REQUIREMINT SOURCE; DOE-N5490.6 Section 552.1}

Rudition Exposunt Surveys

In addition to the roquirements of Articlo 551, contins adintion marveys should bo perforted in weordence with the following miaimmon frequentive:

2. Drily, in offere space locted in Rudiological Buffer Areas where the potential exiets for external malistion expouro;

b. Woesdy, in routinely occugied Radiologieal Buffer Areas and Radiation Arews; 


\section{REQUIREMENTS IDENTIFCATION DOCUMENT \\ HIGE LEVEL WASTE STORAGE TANK FARMS \\ Radiological Protection \\ Revision 6}

- Upon injtial atry, weekly during contimuing operation, and when levets ano expocted to change in High Radiation Areas

d. Weetdy, for operoting HEPA-fillered veditation nits;

- Weekly, for temponry Radietion Aree bounderies to ensire that fadietion anes do nox extend beyond posted bemolaries;

f. Monthly, or upon entry, if extries ins lese froquent then wonthly for Radiontive Matorial Ares;

g. Monthly, for potentially conturainnted dects, piping and hoses is uee outside radiological facilities."

\section{RELATED REFERENCES}

\section{DOEEHO2S6T Articlo 552}

\section{SITE RBQUIREMENT SOURCE: DOE-N5480.6 Section 558.2}

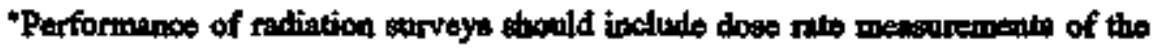
reneral ares, dose antes at a distapes of 30 centimeters from a source or parfice of interest to evaluete potential whole body expostress, and dose rates on continet with poteotiol sources of rediution where there is a poteotial for bronds-od work."

\section{REILATED REFERENCES}

1. DOE/EAO256T Articlo 552

\section{SITE REQJIREMENT SOURCE; DOE-NS490.6 Section 552.3}

"Surveys should be conductad whenevar operationa are being pertormed that milght regult in personnel being exposed to anall ietense beems of cudiution, such ss those generated by

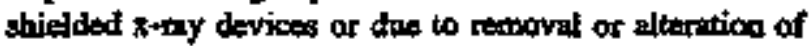
shietding."

\section{REIATEO REFERENCES}

\section{DOEEH0256T Article 5S2}

\section{SITE REQUIREMIENT SOURCE: BOEJEH0135 RP.10 RADLATON MONITORING 2}

* 2. A documented ndiation monitoring propasm is in place that inclades tho frequency and location for mitiation sarveys."

\section{SIE REQUREMINT SOURCS: NUREG-0761 Section 7.b(2)}

"Dose Rate Surveyg

(o) Dose rate aurveys should be perfomed with instrumente calibnited for the bpe and rmge of ndietion being monitored, e.t., bete survey instruments soould be calibrated for bets radintion. 


\section{REQUIREMENTS IDENTIFICATION DOCUMENT HIGH LEVEL WASTE STORAGE TANK FARMS \\ Radiological Protection \\ Rerision 9}

(b) Surveillance performed within large wreas posted as bigh radintion sress where wholo-body does rates very tignificently thould include the pacting of "hot" spots med identifying low dowe rato

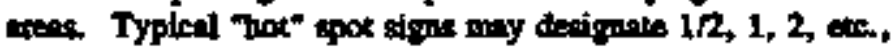
rember areas."

\section{Airborme Radiogativity Monftorse.Ahrms and Sintexa}

This edement includes requirements relating to the assessuent of arborne radicentivity at

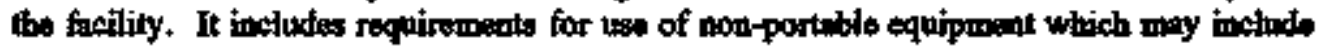
locel area aldiens andor remoes readouts in the control room of antber area of the frectity. It also incinces requirements for the use of portable equipment by trained and qualified radiation protection personnel.

\section{SITE REQUIREMIFIT SOURCE: ANST-Z88.2-1980 Section 3.5.12}

The concentration of the airborne radianctivity level of the roppintiony buzant in the work area shail bo monitored initially prior to respinter selection and periodically during respirator use to ensure that the proper type of respiretor is being utilized.

\section{STIE REQUIREMENT SOURCE: DOE-N5480.6 Section 555.1}

"Airborme Radiosctivity Monitoring In addition to the requiremente of Article 551, air monitoring equipment should be wed is situotions where tixborne tadionctivity levels cen fluchares and early fetection of sirhoms mationetivity could prevent or minimize inherlation of radiostivity by personent. Selection of wis moniming equipinent should be besed on the specifle jab being monitored. Air momitoring equipmert iacludes portable and fixed sir sampling equipubent and contimxus air monitors."

\section{REIATED REFERTNCES}

\section{DOEFEHO2S6T Article 555}

\section{STIE REQUIREMENI SOURCE: DOE-N5480.6 Section 5552}

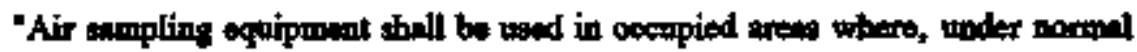
oporatint conditiona, a person is likely to teceiva an anmuel intols of 2 percent or mots of the specified Ansulal Limit of Intake (AL) values (40 Derived Air Consentrion (DAC) bours). AFI innulil intule of 2 percent of a specified ALI genesally tepresents a committed effectivo does equivalent to a person of appoximately 100 mrom."

\section{REIATED REFERINCES}

1. DOE/EH10256T Article 555 


\title{
REQUIREMENTS IDENTIFICATION DOCUMENT HIGH LEVEL WASTE STORAGE TANK FARMS \\ Radiological Protection
}

Revision

\section{STTE REQUIREMENT SOURCE: DOE-N5480.6 Section 555.3}

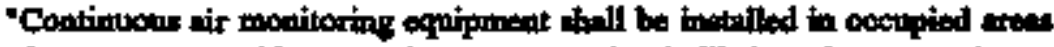
where a person without respirntory proesction is likety to be expoued to 1 concentration of redionctivity in aif exceeding 1 DAC or where thene is a need to nlert poteatially exposed worteon to unexpected ineromines in the nirborns

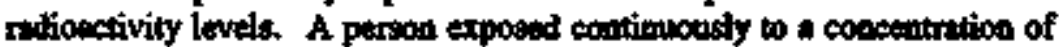
rediasctivity in air of 1 DAC for 1 work week wonld geoeritly receive a committed effective dose equivalent of npproximatedy $100 \mathrm{mrom}$.
\end{abstract}

\section{RELATED REFERENCES}

1. DOE/EH0256T Article 555

\section{STE REQUIRGMENT SOURCE: DOE-N5480.6 Section 555.4}

-Air sampling equiprent should be positioned to mearure air concentrations to which persoas are exposed. If this semant be whieved, a propprm of parsoant bresthing-mose air sompline should be initiated. *

\section{RELATED RERERENCES}

\section{t. DOE/EH0256T Article 5S5}

\section{SLTE REQUIREMENT SOURCE: DOE-N5480.6 Section 555.6}

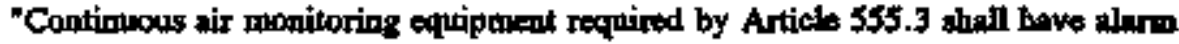

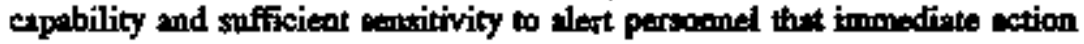
is necessery in order to minimize or torminate inholation exposures."

\section{RELATED REFERENCES}

\section{DOE/EEROSGT Auticle 555}

\section{SITE REQUIREMENT SOURCE: DOF-N54\$0.6 Section 555.7}

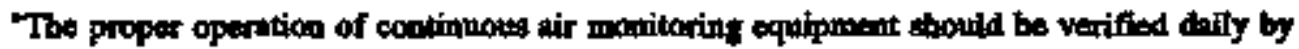

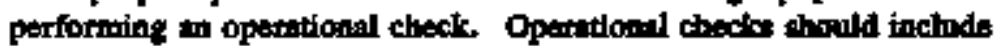
poritive gir-flow indication, non-zero responsen to backgrowd wetivity, and internal check sources or $60 \mathrm{~Hz}$ electronic checks when wailebla. Contionous nir monitoring equipment should be verified weekly by checking for instriment response with a cbock source or with nmbient levels of radon nid thoroa deughters."

\section{RELATPD REFERENCES}

1. DOE/EH0256T Article 555 


\section{REQUIREMENTS IDENTIFICATION DOCUMENT HIGH LEVEL WASTE STORAGE TANK FARMS \\ Radiological Protection \\ Rerision}

\section{SITE REQUREAIFNT SOURCE: DOE-N5480.6 Section 555.8}

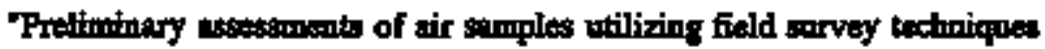
abould be performed promptly upon removal. in eimutions where bakground

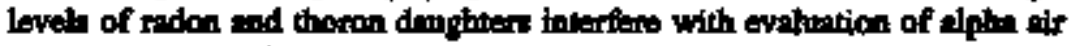
smpies, prompt field assenments my not be posible."

\section{REILATED REFERENCES}

\section{DOE/EHOZSET Article 555}

\section{SITE REQUIREMISNT SOURCR: DOE-N5480.6 Section $\$ 55.9$}

"Air sample resulte stopald be walunted as quickly ap pactiontle for evaluetion of the need for respiratory protection, ane evenution (if necessary), worker intoles and worker relief from tespifator ues."

\section{RELATED REFERENCES}

1. DOE/EH0256T Articlo $\$ 55$

\section{STIE RSQUIREMENT SOURCE: DOE/EHO135 RP.10 RADIATION MONITORING.1}

- 1. Survey limits for breathing air are established. These limits are related to the controlled are concestrution vatues in DOE quidence."

\section{SIIE REQUIREMENT SOURCE; DOEJHA13S RP.6.3}

-3. Acourate and tomely airborno radianctivity survey information is avilable for determining the boundaries of airborne radioactivity wests, poxting entry requirtonent, and minimizing interend exposure to workert during work wetivities. Tbo boudaries of these areas are clearly identified and posted."

\section{STTE REQUREMENT SOURCE: DOE/EH0135 RP.6.7}

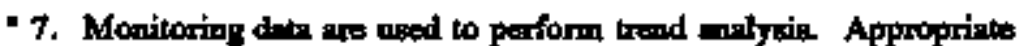
corrective action is taloen whenever these are significant aumbers of positive in-vivo counts oberred or when air concententions are elevined, oven though the obeerved lovels are lees thas neguletory limits."

\section{SITE REQUIREMENT SOURCE: DOE/EH0135 RP.}

TERFORMANCE OBFCTIVE: Air wowitoring tystens through election, location, collibration, and maintenance should ensure relinble eatimates of air activity for radiological control purposes." 


\section{REQULREMENTS IDENTIFICATION DOCUMENT \\ HIGH LEVEL WASTE STORAGE TANK FARMS \\ Radiological Protection \\ Reristion}

SIIE REQUIREMENT SOURCE: DOE/EH0135 RP.9.1

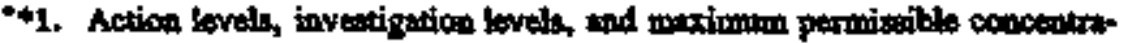
tions (MPC) used uro based on eppropriete bechnical eriterie to ovaluats

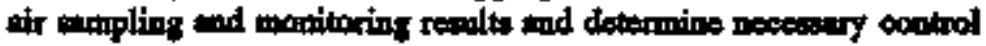
procedareat"

\section{SIIE REQUIREMENT SOURCE: DOF/EH0135 RP.9.10}

-10. Appropriate nodiation dectectors aro used to anelyzo air anmples."

\section{STIE REQURRMMENT SOURCE: DOE/EH013S RP.9.11}

-11. Adequare connting equipmed for filless is avaitabie. The equipmed is propedy calibratted and maintained. Counting procedurse wo avilhble and followed by technicins. Adequate reconds ase mainteined to permit QAVQC veriffetion of bample results. Corrections for counting lasses dus to abeorption end/or backsenter within filters ane mado for alphe and beta rodietion."

\section{SIIE REQUIREMENT SOURCE; DOE/EH0133 RP.9.12}

-12. Comections for radon dughter-product interference are mide."

\section{STTE REQUIREMENT SOGRCE: DOEHEH13S RP.9.2}

"72. The minimum detection timiks (MDL) or minimmm detectable sctivitiea (MDA) for the specific radionusclides of intereat aro provided. The detection levela provide optimum watur protection and wo appropriate for establtshed ection levela, investipation levels and MPCs are documented."

\section{SITE REQUIREMIENT SOURCE: DOEVEH0135 RP.9.4}

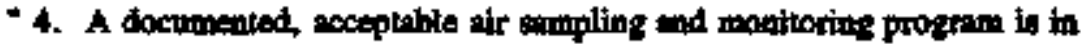
plece, and is supported by anficient sudien (o.g., sir flow pattern, purticto siza distribution)."

\section{STE REQUIREMENT SOURCE: DOE/EH0135 RP,9,3}

* 5. Air mupling and monitoring equipment ia ued and is approprinte for the morte of the operation and bources."

\section{SImE REQUIREMENT SOURCE: DORJEHO135 RP.9.6}

- 6. The nominal flow rates and sampling intervale used by the contractor for

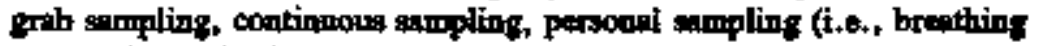
zone), air monitoring, and emergency sempling ato based on appropriats technical criteria." 


\section{REQUIREMENTS IDENTHICATION DOCUMENT \\ HIGH LEVEL WASTE STORAGE TANK FARMS \\ Radiological Protection \\ Rerition 0}

\section{SITE REQUIRTMENT SOURCE: DOEJIAG135 RP.9.7}

-7. Appropriate filtex media are used for particulates."

STEE REQUIREMISNT SOURCE: DOEJEHO135 RPS.9

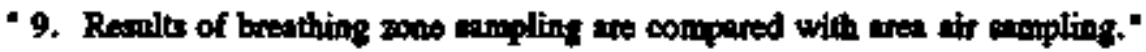

\section{SITE RBQUIREMENT SOURCE: DOE5480.11 Section 9.8(3)(a)}

Wortploos

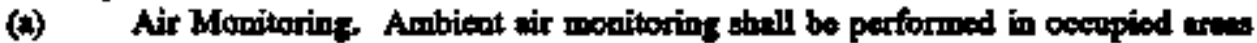

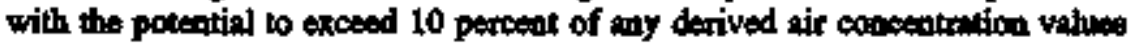
given in Altochment 1. Representative ambient sir monitoring etmples shootd be

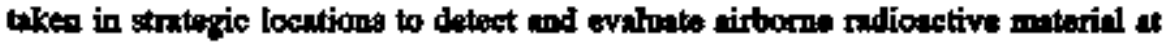
work locetions. Date obcrined from tit moutitoring shell be used for ansessing the control of airbomo radiosctive meterinl in tho workplace; it should not normally be used to evalunte the dose equiniledt to radiution workers. Air monitors shall be routinely collibrated and minterined, and should be capable of measuriose an DAC when everaged over 8 hours (B DAChours)."

\section{SITE REQUIREMIENT SOURCE: DOE6430.1A Section 1300-6.5.2}

"Air moatitoring and waming syotsens skall bo instolled in work arese where

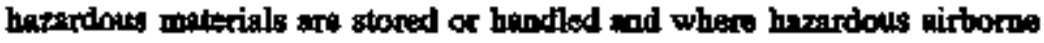
particles or vapors may bo present. Air sampling heads shall be loceted to provido a representative sample of potential aitorne radioactive materials being breathed. Air moaitoting cysteins shall comply with ANSI N13.1."

\section{SITC REQUIREMIEN SOURCE: INPO-88-010 Chnpter IV, Seetion 3(a)(2), Parngraph 2}

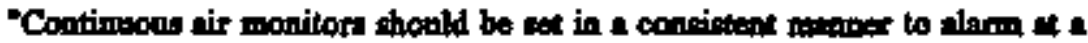

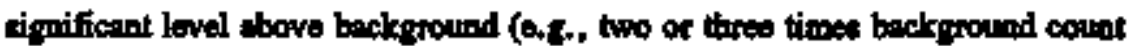

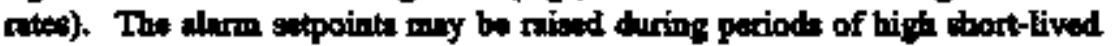

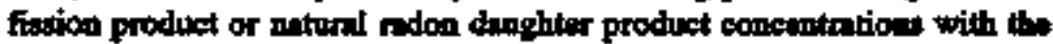
approval of radialogicel protection supervicion. Alarm stpoint chonge: should be docentented so the setpoint can be returned to normil when short-

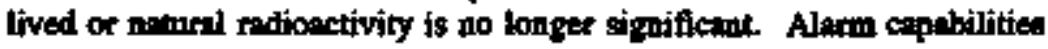
and alarm setpoints abould be chectred periodically (e.g., dify) to entare incper opention."

\section{SITE REQUIREMIENT \$OURCE: NUREG-1761 Section 7.o(4)}

\section{"Airborme Radionctivity Surveys}

(a) When continuous air monitoring is performed, periodic high vohume grab stmples or brouthing zone tir samples should be token to verify that gir monitoring is representutive of the actad work area. 


\section{REQUREMENTS IDENIFICATION DOCUMENT \\ HIGH LEVEL WASTE STORAGE TANK FARMS \\ Radiological Protection \\ Rerision 0}

(b) Copobilitios should be provided for exhrusting greb semplea bect to their source when extremely high levels of activities are expected.

(c) A mintimum decectoblo activity for the equipurent in we should be entoblished.

(d) Collection efficiencies for particulate and iodine sampling modia should be establistued."

\section{Contamination Monitoring and Surregs}

This element addresses the requirements for monitoring contamipetion in plent arese

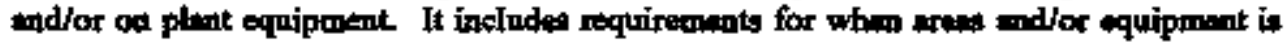
to be monitored end for eppropriate we of monitortog equipiosent.

\section{STIE, REOUIREMENT SOURCE; DOE-N5430.6 Section 554.1}

\section{"Contamination Starveyg}

In addition to the requirements of Article 551, routios contemination surveys should be conducted as follow:

2. Prios to trimefer of equipment and material fom one Radiological Buffer Arca to abother;

b. Prior to trinsfer of equipmeat and material from bigtly contamingted areas within Radiologicil Buffict Aress unlesa precultions such as bagging or wrapping are batren prior to transfer;

4. Only, at contamination arse control points, chenge areas, or step-ofi pods when in yos, or per sthitt in high we sintitions;

d. Daily, in office space located in Radiological Buffer Areas;

- Dilly, in lemch rooms or eating arcas near Raciolojical Bafier Arosir

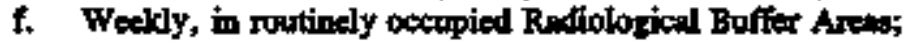

2. Weetly, or upon entry if equites ane lesin frequent, in aress where rodicective materials ane handled or stondi

b. Weskly, of upoin entry if extries are less frequenth whero conturnimation boumdaries or postimgs are locitod:

i. During initiol tontry into a known of auspected contamination ures, periodicatly during wort, a completion of job, or as specified in 2 Radiological Wort Permit;

j. After a kak or spill of refiometive materiala."

\section{RMATDD REFERENCES}

\section{DOE/EH0256T Articke 554}

\section{SIIE REQURREMENT SOURCE: DOE-N5480.6 Section 554.3}

"Contamination arrveys should insorporate tectmiques to detect both removable ond fixed countimination." 


\section{REQUIREMINTS IDENTIFICATION DOCUMENT HIGH LEVEL WASTE STORAGE TANK FARMS \\ Radiological Protection \\ Rerition 0}

\section{RELATED REFERENCES}

1. DOE/EHO256T Article $\$ \$ 4$

SIIE REQUIRTMENT SOURCE: DOE-N5480.6 Seetlon 554.6

"Swipe alrvoys for removable coatuminntion shalt be reported in units of disinsegrations per mirutes per $100 \mathrm{~cm} 2(\mathrm{dpw} / 100 \mathrm{~cm} 2)$. For swipe earweys of

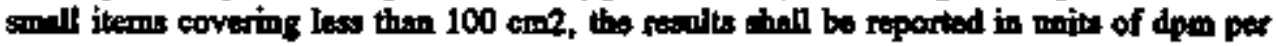
neter awiped."

\section{RELATED RMFERENCES}

\section{DOE/EHO2S6T Articto 554}

\section{SITE REQUIREMFNT SOURCE: DOEN5480.6 Section $\$ 54.7$}

"Large aten wipes are encournged and shondf be used to sapplement standard

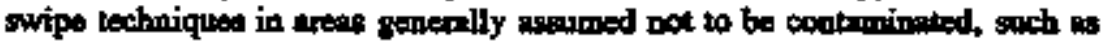
entrobces to Radiological Buffer Arean. If in ovaturion indicates thet an area wiped is contaminated, thorough contamination saipe sorvey should be pertormet."

\section{RELATED REIEERENCES}

\section{DOEJEHO2SGT Anticle $\$ 54$}

\section{SITE REQUIREMIENT SOURCE: DOEJEFO135 RP.10 CONTAMHNATION CONTROL.11}

-11. Contaminated or potentially cootaminnted aress are adequetely surveyed, documented, and posted at spexific frequescien, besed upon the contentinution levels, traffic patterns, and occupuncy levels."

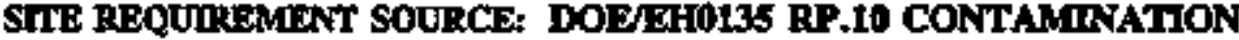 CONTROL.12}

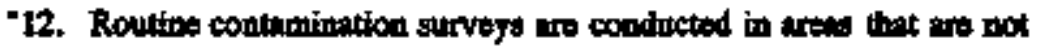

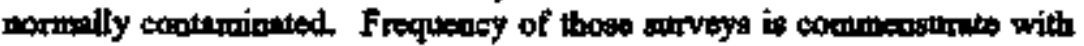
tho polentiel for contentinetion and with the siguificance of findting condamination in a perticular area."

\section{SITE REQUIREMENT SOURCE: DOEIEH0L35 RP.10 CONTAMINATION CONTROL.23}

23. Adequnte cormting equipment for swipos is avilable. The equiparent is properly calibrated and nuintained. Combing procedures tre availablo and followed by tochnicianc. Adequate toeont ase maintrined to permit QA/QC verification of ample resalta." 


\title{
REQUIREMENTS DENTHFCATION DOCUMENT HIGH LEVEL WASTE STORAGE TANK FARMS \\ Radiological Protection \\ Rerision 0
}

\author{
PERSONNEL EXPOSURE MONITORING
}

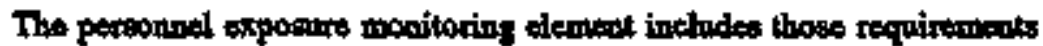

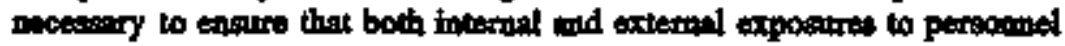
to properfy monitored und assesed. It atoo inchudes rapairements relating to

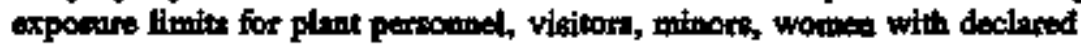
proiguncies and the groenl pablic.

The personed monitoring program is developed for the purpose of monitaning and trating personad exposure to improve radiation protection prostices/prosedures and for demonatrating conmlimes with regulatory and

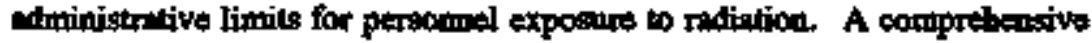
personnel exposure monitoring program defines the sten of stations where monitoring is to be performed and the appropriate type of monitoring to bo used considering the types, form and energies of the radiation present in thet ares or situation.

\section{SITE REQUIREMENT SOURCE: DOE5480.11 Section 9.g}

Monitoriag. Oceupational workers staill be monitored, as appeopriate, $\infty$ demonstrate complinnce with the radiesion protection esondants in paragraph 9.b. ind to eatimute the dose equivaients received from externil ind internal

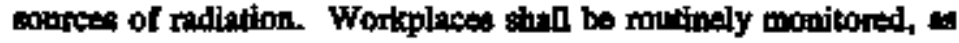
apponpriate, for identification and control of potential exposate sounces."

\section{Estposure Limlits}

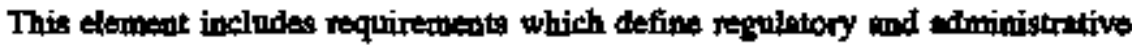
exposure limits for plent personnel, visitors and the geteral public.

\section{SHTE REQUIREMANT SOURCE: DOE-N54t9.6 Section 211}

\section{Administrative Control Levels and Dose limit}

The DOE's ohjective in to meiatain personmel rediation expocure well below regulatory does limik. To acconplish thin objectivo, challenging mumetical

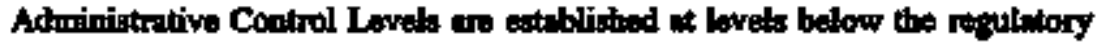
limits to adminintratively control and belp reduct individusl and oollective radiation doos. These control levels are multitiened with increasing levels of athority required to spprove higher Administrative Control Lovela. With issunce of this Marial, the committed effective dose equivilent is used to apeign internil dose received by personnel at DOE faciltitie. The committed effective dose equivalent is tho resulting dose committed to the whole body from internsily deposited milionclides over a 50-yenr poriod aftor intals."

\section{RELATEN REHERENCES}

1. DOE/EHO256T Articlo 211 


\section{REQUTREMENTS IDENTIFICATION DOCUMENT HIGH LEVIL WASTE STORAGE TANK FARMS \\ Radiological Protection \\ Revision 1}

SITE REQUIREMENT SOURCE: DOE-N5480.6 Section 211.1

-Adminietrative Control Leval

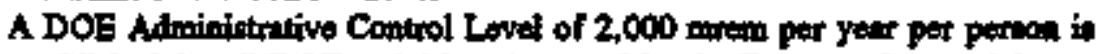

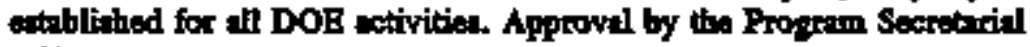

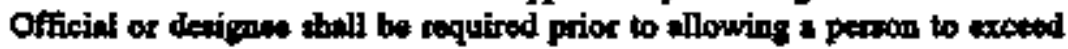
2,000 metem.

\section{RELATED REFERENCES}

\section{DOE/EHO256T Articlo 211}

\section{SITE REQURRMENT SOUTRCE: DOE-N5430.6 Section 211.2}

-An ampun facility Administrative Cootrol Level shell be eatrbitished by the contractor senior site executive based upon an evalnation of historical and Frojected nadiation expositros, work lond and mission. The selection of the specife value shall be mote restrictive then the DOE Adrninistrative Control Lovel. This control level should bo resvaluated annmally. The choice of a low lovel for 1 yeer sbould not preclude choosing either a higher or lowwer lovel

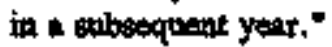

\section{REILATED REFERENCES}

1. DOEEBO2S6T Article 211

\section{STIE REQUIREMENT SOURCE: DOE-NS480.6 Section 211.3}

For most fucilities, an zenarl fucitity Administrative Control Levst of 500 mrant or lea should bo challeoging and achiovable. An sannel Adruinistrative Conerol Lovel above 1,500 mrem is in most cesces not sufficiently challengins: to mest the goels of this Menmal."

\section{RRIATED REFERENCES}

1. NUREO-0761 Section 5.b(3)

2. DOEEHO2S6T Articlo 211

\section{SITE REQURREMENT SOURCE: DOE-N54\$0.6 Section 211.4}

No person shell be allowed to 90 sbove the ficility Administrative Control Lovel without the prior approwal of the contractor seatior site executive."

\section{RELATED REFERENCES}

1. DOEREHOZS6T Articie 211

STIE REQUIREMENT SOURCE: DOE-N5480.6 Section 212.1

'Lifotime Control Level 


\section{REQUIREMENTS IDENTIEICATION DOCUMENT \\ FIGH LEVEL WASTE STORAGE TANK FARMS

\author{
Radiological Protection
} \\ Revision 0}

To administratively control a worker's lifecine oceupational radiution expostrot, a Lifotime Control Level of $\mathbf{N}$ rem thall be ectablisted where $N$ is the age of the parson in yeers. Special Control Levets (Axtielo 216) ahall bo extablished for perponnel who have does exeecding $\mathrm{N}$ rem."

\section{RELATED REFERENCES}

\section{DOEJHO256T Articils 212}

SITE REQUIREMIENT SOURCE: DOE-N5480.6 Section 212.2

The intemal contribution to lifetime dose should cortinue to be reaspeded as furtber bioussay results and improved methods for assessints inlernal dowe become vailable."

\section{ROLATED REFERENCES}

1. DOE/EH0256T Article 212

\section{STTE REQUIREMIENT SOURCE: DOE-NS480.6 Section 213.1}

"Ratiological Worter Dose Limits

Dose linits are provided in Table 2-1 and sholl not bo axceoded. Thao Nogulatory limits are consistent with the "Radiation Procection Guithence to Federtal Aceacies for Occupationel Exposare" sipned by the Prestident."

\section{REATTD REFBRENCES}

1. DOE5490.11 Section 9.6

2. DOE5480.11 Sextion 9.b(1)

3. DOES480.11 Section 9.b(2)

4. DOES480.11 Section 9.d(1)

5. DOES480.11 Section 9.\&(2)

6. DOE5480.11 Section 9.8

7. DOE/EH0256T Articlo 213

\section{SITE REQUIREMENT SOURCE: DOE-NS480.6 Section 213.2}

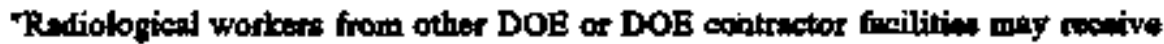
Decuputional exposure as a radiologionl worker if they:

2 Provite record of current Radiological Wotter I or II stenderdied core tróning

b. Rective site-specific Radiological Worker I or If training at the facilities where they will be working

c. Providy their rediation dose records for previoul years and written extimates for the curreat yeer.

\section{REHATED REFERENCES}

\section{DOE/EH02S6T Article 213}




\section{REQUIREMENTS DENTIFICATION DOCUMENT HIGH LEVEL WASTE STORAGE TANK FARMS \\ Radiological Protection \\ Repision 0}

SITE REQUIREMENT SOURCE: DOEN5480.6 Section 213.3

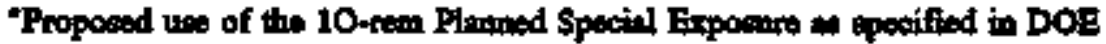

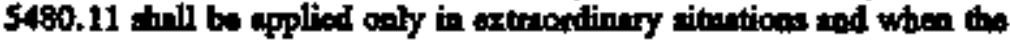
following requirements hove been mot:

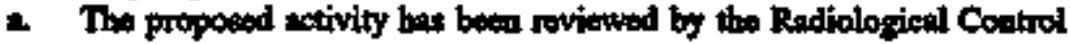

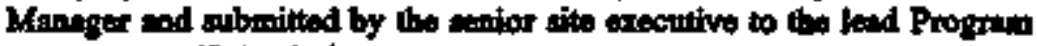
Seeroturial Officital for approval by tho Program

b. The propased ectivity has been jotwely approved by the Profarm Secreterial Official and the Ascistint Sectetary for Envircoment, Safery and Bealth."

\section{RELATED REIERENCES}

1. DOEJHOOSTT ATticle 213

SITE REQUIREMIENT SOURCE: DOE-NS490.6 Section 213.4

"Emergency exposare limits are not Planned Special Exposare limits. Guidelines for emergency exposures are provided in Appendix 2A."

\section{RELATEW REFERENCES}

1. DOE5480.11 Section 9.c

2. DOEJEHO256T Artifle 213

\section{SITE REQUIREMIENT SOURCE: DOENS480.6 Seetlan 214}

"Visitor Dose Limit

Visitors to DOE vites shall be linited to en mnual radiation doet of 100 anresm from the srom of internal and external rectiation sources ninless they either qualify as andiological workers in accordunce with Article 632 or 633, or mot the spexial considerations of Article 657."

\section{RELATWD REFERENCES}

\section{DOE/EHO2SOT Articlo 214}

\section{STIE REQUIREMIXNT SOURCE: DOE-N490.6 Section 215.1}

"EmbryorFetue Dow Limits

After a femele radiological worker voltraterily notifies her owployer in writing thet sha is projesant, for the purpowes of fetol/embryo dose protection, she it condidered a dectared pregnent workes.

The enmloyer shall provide the option of a mutually agresabie asodament of work tasks, without loss of pay or promotional opportunity, sach that further cocupational radiation exposurs is unlitody."

\section{RELATED REFERENCES}

t. DOE5480.11 Section 9.b(3)

2. DOE/EH0256T Articlo 215 


\section{REQUIREMENTS IDENTLICATION DOCUMENT \\ HIGH LEVEL WASTE STORAGE TANK FARMS \\ Radiological Protection \\ Rerision 1}

\section{STTE REQUIREMENT SOURCE: DOE-N5480.6 Section 2152}

For a declived pregrant worker wbo chooses to continue worting as a matiological worker.

- The dow limit for the embryolfeten fios conception to birth (entite gestution period) in 500 menem.

b. Efforts should be mede to avoid exceeding 50 mrom per month to the propingut wortser."

\section{RELATED REFERENCES}

1. DOE5480.11 Sectios 9.6(3)

SITE REQUIRSMENT SOURCE; DOE-N5480.6 Section 215.3

"If the dose to the embryolftes is detemined to heve already excesded 500 ment whed * worker aotifies ber employer of ber prejmancy, the worker shrll

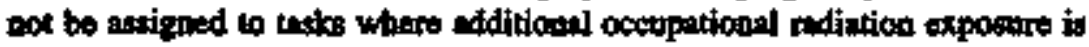
likely during the reanainder of the gestation period."

\section{REI $\triangle T$ TE REFERENCES}

1. DOES480.11 Section 9.b(3)

2. DOE/EH0256T Article 215

\section{SITE RECUIREMENI SOURCE: DOE-N5480.6 Section 216}

\section{"Spectol Coatrod Levela}

Certsin sibutions require lower individualized exposure control leveis. In addition to consideritg rocommendutions from senior radiological control and medictl officials, the contractor senior site executive should obtain edvice trom professions ls in other disciplines guch as bumin resources and leptil in

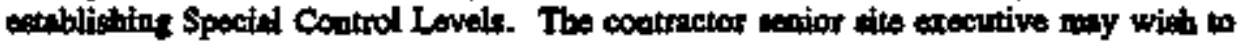
artablish theos Special Control Lovels using a rodiologioal benth adviery group."

\section{REIATED REFGRENAS}

\section{DOE/EH0256T Article 216}

\section{SITE REQUIREMINT SOURCE: DOENS480.6 Section 216.1}

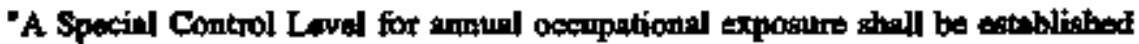
for esch person with a lifetime occupational dos excesding $\mathrm{N}$ reen, where $\mathrm{N}$ is the ate of the person in years. The Spectal Control Level shall not exceed 1 rem and should allow the person's lifecims oceupational does to approech $N$ rean at additional oceupational exposire is received." 


\section{REQUIREMENTS IDENTIFICATION DOCUMENT HIGH LEVEL WASTE STORAGE TANK FARMS \\ Radiological Protection \\ Revision o}

\section{RELATED REFORENCES}

\section{DOEJEFO256T Articlo 216}

\section{STE REQUIREMIENT SOURCE: DOR-NS490.6 Section 216.2}

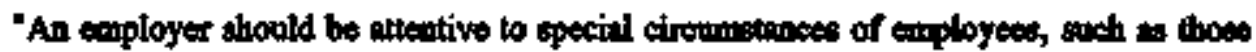
undergoing radiation thorapy, and exablish epectit Control levels at upproprinte."

\section{RELATED REFERENCES}

\section{DOEftH0256T Articls 216}

\section{SIIE REQUIREMENT SOURCE: DOE5480.11 Section 9.b}

"Rudintion Protection Stendxds for Interanl and External Exposure for Osoupecionel Workers

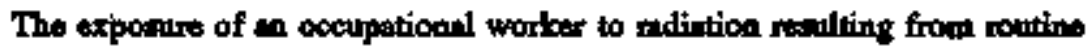
DOE setivities shall pot cense the limiting values for assossed dose specifiod beroin and summarized in Figure 1 to be treeded. Continued exposure of iny worter over a substential portios of a worling lifotimn at or near the limiting values for asesesed dose to indivituol workent should be avoided. (Note: Natural backgrousind and therepentic and diagnoetic medical exposures

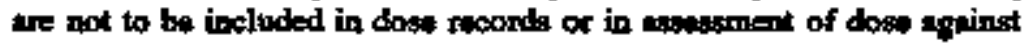
limiting values.)"

\section{SUEE REQUEREMINT SOURCR: DOE54\$0.11 Section 9.6(1)}

"Stechustic Effects. The limiting value of amanal effoctive does equivalent from both internel and exteronl sounces tecetyed in any year by in occupational worker in $5 \mathrm{rem}$ (0.05 sievert)."

\section{SITE REQUTREMENT SOURCE: DOES480.11 Sectioa 9.b(2)}

"Nom-Stochertic Effects. The limiting ralve of anmoll dose equivaleat received in any year by moceupationl worter fox individual ongens and tisese is 15

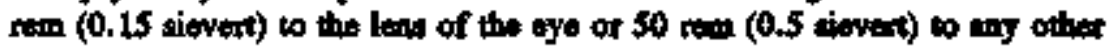
orgm, sissus (including the stin of the whole body), or extromity of the body."

\section{SIIE REQUIREMIENT \$OURCE: DOES480.11 Section 9.b(3)}

"Unborn Child. The limiting value of anmul dose equivitent noceived by the unborn shild from the period of conception to birth (extire gestation period)

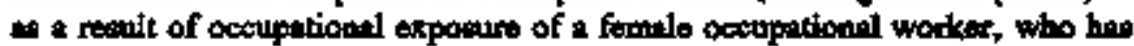
notified her enployer in writing that she is preguamt, is 0.5 rem (0.005 sievert). Efforts should be mado to evold subantial variation above the

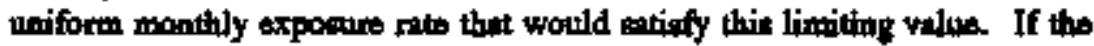
dose to the unborn child is determined to have slready axceeded $0.5 \mathrm{rem}$ (0.005 sievert) by the tima a wotker notifies ber enmployar in writint of ber 


\section{REQUIREMENTS IDENTIFICATION DOCUMENT \\ HIGH LEVEL WASTE STORAGE TANK FARMS \\ Radiological Protection \\ Rerition 0}

proppancy, the worker aball not be assigned to tusks whero ndditional occupetionet exposure is likely. Tho liniting valus of does equivilent to the

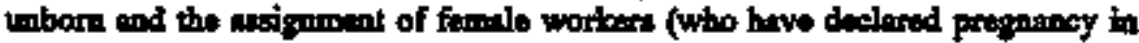

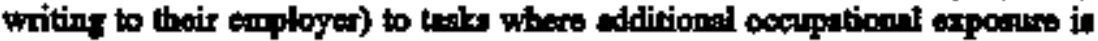

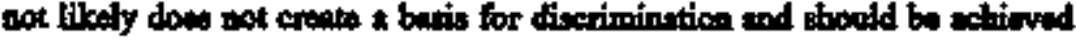
in conformon with the provistone of Tito VII of the Civit Rtghtes Act of 1964 [Se0 Einvironmeatel Protection Agency (1) - peges 2829 and 2892 of Federal Register, Vol. 52, No. 17, 1987]."

\section{SITE REQUIREMIENT SOURCE: DORS480.11 Section 9.c}

Pisaned Special Expoetro. Planked specil exposures (bon-emeryency) thet would result in in indivistul exceeding the sumpunt effective dose equivilent limit are aflowed in highly unounl siturtion where alternatives which would avoid hipher exposures are unavailable or impractical. Such planned specis

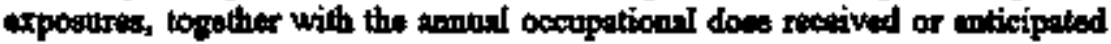
to be toceived in that year, shall not exceed 2 timos tho nunal effective does equivalent limit specified in pungraph 9.b.(I). Planeod special sxporares requite the spprovel of the Head of the DOE Field Orgenization. A secoud pienned special oxposure to the same individual at any time recuires the sppoval of the Assistent Secrtary for Erviroament, Siffety, and Henlth 9EH-1). Documentation of planmed epecial expoesures ghall be mainteined in in individisal's oce-upationel expostre history."

\section{STTE REQUIREMENT SOURCE: DOES480.11 Section 9.d(1)}

"Rodiation Probetion Strodards for Internal and Extersal Expodero to Minon and Shidents

(1) Minon. An individusl under age 18 thesl neither be entoloyed in, nor allowed to enter, controlled areas in such a mennes that ho of ahe exceeds a tiraiting valus of $0.1 \mathrm{rem}$ (0.001 stevet) per yeer from the sum of the committed effective dose equivalent from intemol irmoltation and the enpusil effective dose equivalent from external imadiation."

\section{SITE REQUIREMENT SOURCE: DOXS480.11 Sation 9.d(2)}

"Students. Students moder apo 18 stall not be exposed to radiation during indivitually anthorized eductiontl metivities anch that ho of she exceedia a limiting value of 0.1 rem (0.001 sievert) per year from the sum of the committed effective doso equivalent from internal irredimions and the annul offective does equivalent from extemel irreitiation. This exporane thell bo considered a part of the limit for worters moler age 18 and not supplem .nthl to is [i.e., whese individuals moder ago 18 are exposed to rediation both an a student and as a mixor in a year, thair exposure as a student shsil be adied to their exposure as a minor and the total is not to exceed the singlo imiting valus of 0.1 rem for minars]."

\section{SIIE REQURREMENT SOURCE: DOE5480.II Section 9.e}

Rediation Protection Sunderds for Puhlic Entaring \& Controlled Aree The effective dose equivalent received by ny mamber of the public renaling from 


\section{REQUIREMENTS IDENTIFICATION DOCUMENT \\ HIGH LEVEL WASTE STORAGE TANK FARMS \\ Radlological Protection \\ Revision 0}

exposure derring direct onsite access at a DOE focilty shall not treed a limiting value of 0.1 rem $(0.001$ sievert) per year from the committed effective dose equivalent from internul irredintican plus the effectivo dose oquivalent from eny oxternal indimition. In eddition, oxposures shall oot

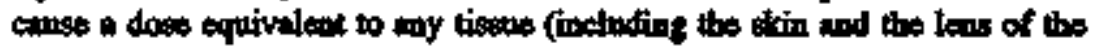
oye) to oxeed 5 reen (0.05 sievert) per year for ay nomber of tho pablia. Guideace for enky dusting emergency condition is prowided in partegreph 9.p. of this Outer."

\section{SITE RBQURREMENT SOURCR: DOE5480.11 Section 9.1(1)}

"Combining Intarnal and Excernal Dose Equivalent The anemeal offective dowe equivalent to an individal shall be determined by summing the annmit offoctive doses equivalents from internelly deposited radioauslides and from external exposure to madioactive material and/or radiation geoseatint devices resulfing from DOE activities. Whes in-vivo pod/or in-vitro mensurements confirm the retention of redionuclides in the body, with recpect to ovaluating conformance with the limiting value for occupational exponure, the ennusl effective does squivalen das to ell rndiomuclides retained in the body from

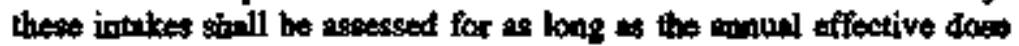
equivalent is 10 mrem of greater. Expoaures to the stin, extremities, and leas of the eye wre nox incluxted in the deternimation of the annisal effective does equivalent. For uniform externat irrediation of the whole bocty, a weiphing factor (W) equal to one may bo used. This whole body dose is to be measured in accordance with the provislons in paragraph $9 \mathrm{~g}(1)$. Non-uniform

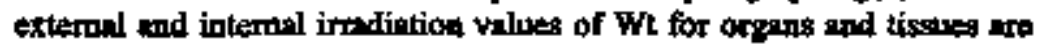
defined in paragraph $8 \mathrm{e}(12)$."

\section{SITE REQUIREMENT SOURCE: NUREG-0761 Section 5.b(3)}

"Thers should be en edministrative dose ecotrol system, requirimg approval by line

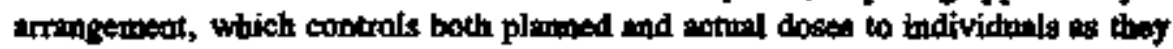
progressively (incrementally) approech limits of 10 CFR 20.101 or edministrative limito attabliabed for the fineility. It is considered good practice and recommented by the ftaff that doses to pertonnel bo mininined to the NCRPICRP/EPA resommendation of 5

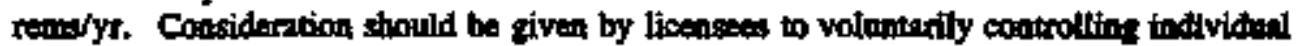
doese to 5 reme/yr. Such 2 prectice is to be und to reduce the rivis to those amill namber of people who maly exceed this criterin while providing a tool to reduco collective doee to the plent woriters. The RPM sbould require review of all tindividual doees thet exced or arp expected to exceed a specified investigator level, which should andreilly be 1.5 reme

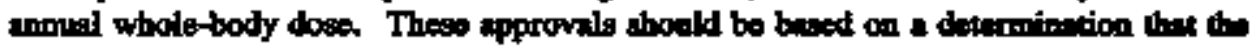
does to be received by the individual is ALARA. Intivitual operetions ind stoppont proup

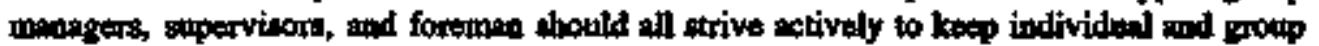
exposured at a minimum and to keep the number of worters exposed at a mintimum. Guidelines and policies governing emergeacy exposeres nod overexposures should bo outlined. This dose cempral syateates should bo inplemented vis the Radintion woit Permit (RWP) syatem." 


\title{
REQUIREMENTS IDENTIFICATION DOCUMENT \\ HIGH LEVEL WASTE STORAGE TANK FARMS \\ Radiological Protection \\ Revision 0
}

\section{Esternal andintenal Monitoring}

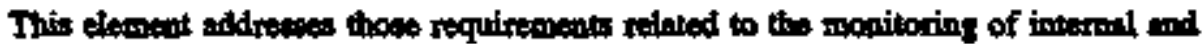
externil exposair to rediution. These requirements defins when monitoring is to be performed and provido the basts for the overill monitoring progriem.

\section{SITE REOUREMMINT SOURCE: ANSIN343 Section 16.2}

Intemal Dasimetry Records An intengal dosimetry record shall be maintained for each individurt who is monitored. The minimmm records tull includs data an:

(1) Current employees who purticipate in the bicassay progran

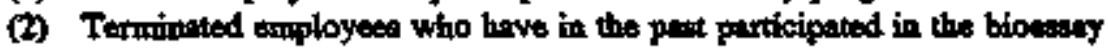
program

(3) Vtsitons of contractors who participets in the bioneny program"

\section{SIEE REQUIREMINT SOURCE: DOE-N5480.6 Section $\$ 11.1$}

\author{
"Fxtern:l Dosimetry \\ Requirtenteuts \\ Personnel dosimetry shall be required for persomed who are expected to \\ receive an annapl externil whole body dose greater then 100 mrem or wa annual \\ dose to the extremities, less of the oye or skin gremer thro 10 pertint of \\ the corresponding linits apecified in Table 2-1. Neutron dovimetry shall bo \\ provided when a person is tikely to exceed 100 mrew enmotlly from aeutrous."
}

\section{RELATEW RFFERENCES}

1. DOE5480.11 Section 9.g(1)

2. DOEEHOZ56T Articlo 511

\section{SIIE REQUREMATNT SOURCE: DOE-N5480.6 Section 521.1}

\author{
TInternal Dosimetry \\ Requirwonats \\ Persoment who enter Radiological Buffer Ares shall participate in a bioningy \\ protrine wben they are likely to receive intabes resulting in a committed \\ effective dose equivalent of 100 mrem or mors."
}

\section{RELATED REFERENCES}

\author{
1. DOES480.11 Section 9.g(2) \\ 2. DOE/EHO2S6T Articio 521 \\ 3. ANST-N343 Section 6.1
}

\section{SITE REQUREMENT SOURCE: DOE-N5480.6 Section 521.2}

"Perscomel shall purticipate in follownp bicassuy monitoring when their routine bioameny resples indicte an intake in the curreat year with a commilted affective dose equivalent of 100 mirem or more. " 


\section{REQUIREMENTS IDENTIFICATION DOCUMENT HIGH LEVEL WASTE STORAGE TANK FARMS \\ Radiological Protection \\ Rertion 0}

\section{RELATED REFERENCES}

1. DOE/EROES6T Attich 521

STRE REQUIREMENT SOURCE: DOE-N5480.6 Section 521.3

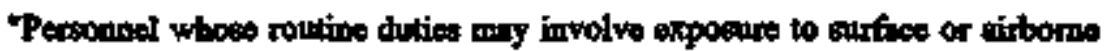

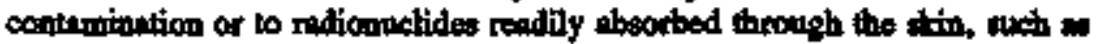
tritium, should bo consiaked for partiolpetion in the bionesay program."

\section{RELATED REFERFNCES}

\section{DOE/EHO256T Article 521}

\section{SITE REQUIREMENT SOURCE: DOE-NS480.6 Section S21.4}

"Personmel shall submit bioassry samples, such as utime or fecal samples, and

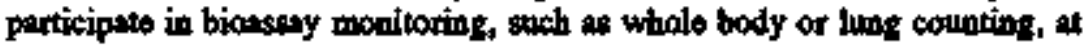
the frequency requirod by the bionathy progand "

\section{RFXATED REIERENCES}

\section{DOE/EH0256T Article 521}

STIE REQUIREMIENT SOURCE: DOEN54\$0.6 Section $\$ 21.5$

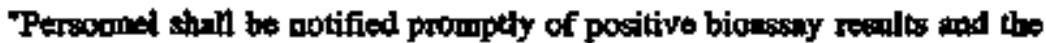
resalts of dose assessiments and subsequent refinements. Doce astessiment results athall be provided in terms of ntritm."

\section{REILATED REFERENCES}

\section{DOE/ER0256T Articlo 521}

\section{SITE REOUTROMIXNT SOURCR: DOE-NG4\$0.6 Section 522}

Techni=l Requirsments for Internal Dosimetry

DOE plans to implemeat tecreditition prograws for bipassey mesurements and internel dow areserentent and to provide supplementel techniced guidance on the implementation of internal docimetry prograns. Uutil thes ancreditorion programa are svilable, this Mambal provites the lechnical guidapce to implement the internal docimotry program."

\section{RELATED RETIRENCES}

1. DOE5480.11 Section 9.R(2)

2. DOE/EH0256T Article $\$ 22$ 


\section{REQUIREMIENTS IDENTIFICATION DOCUMENT HIGE LEVEL WASTE STORAGE TANK FARMS \\ Radiological Protection \\ Revision 0}

SIT RECUIREMENT SOURCY: DOE-N5480.6 Seetion 523.1

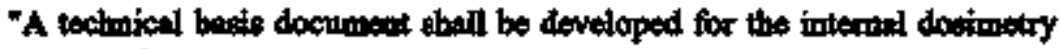
program."

\section{REILTEO REITERENCES}

1. DOEREH0256T Artiklo 522

\section{STIE REQUIREMENT SOURCE: DOE-N5480.6 Section 522.2}

Buselino bionessy monitoring of persomed who are likely to receive intakes resulting in a conmittod effective dose equivileat grenter thin 100 mrem sholl be

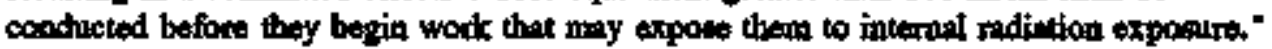

\section{RELATED REFERENCES}

1. DOE/EH0256T Aaticle 522

\section{SHE REQUIREMENT SOURCE: DOE-NS480.6 Section \$2..3}

"Periodic bionsay monitoring methods and frequencies ghell be extablishad for

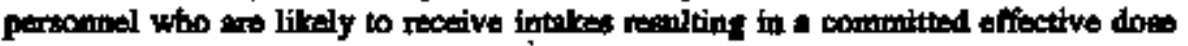
equivalent grenter than 100 arean. The tectarical basis for the methods mo firedu=acy of bionssing monitoring stould be documented."

\section{RFLATED REFERENCES}

\section{DOE/EHO2SGT Article 522}

\section{SITE REQUIREMFNT SOURCE: DOE-N5480.6 Seetion \$22.4}

Menagement thall requirs termination bionesay monitoring when a pertec who

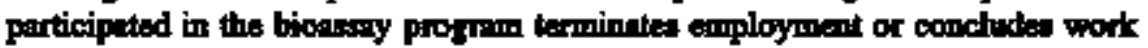

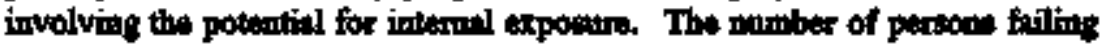
to achieve this wonitoriag should be tevtewed periodically and sthould bo uaed to determipe whether further efforts is get oxpperation are warninted."

\section{RELATED REEERENCES}

1. DOE/EH0256T Article 522

\section{STE REQUIREMENT SOURCE: DOEN5480.6 Section 522.5}

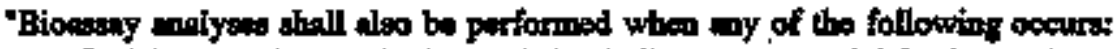

- Pacial contanination is detected thet indicates a potontial for interal contamination;

b. Nasel contumination is detected;

c. Airborue monitoring indicutes the potential for intaites axcending 100 mom committed effective dose equivaleat; 


\section{REQUIREMENTS IDENTIFICATION DOCUMENT HIGH LEVEL WASTE STORAGE TANK FARMS \\ Radiological Protection \\ Revision o}

d. An intake is gropected for any touson."

\section{REIATED REFERENCES}

1. DOEAEHO256T Article $\$ 22$

2. ANSI-N343 Section 6.2 .5

SITE REOUIREMENT SOURCE: DOE-N3480.6 Section 522,6

"Levels of intakes that werrmt the consideration of modical intervention thall be wbilibed for sito-spaxific radionuclidea. The effectiveneses of medicel

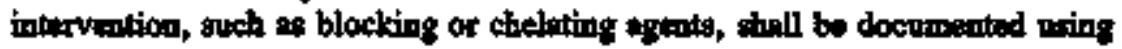
bionssay reselts."

\section{RELATED REFERENCES}

1. DOEEHO256T Articto 52

STTE REQUIREMENT SOURCE: DOE-N5480.6 Section 522.7

"A prestiminary assesament of any intakes detocted should be conducted frior to permitting an employes to return to moliological work."

\section{REIATED RWFERENCES}

1. DOE/EHO256T Article 522

\section{STIE REQUTREMENT SOURCE: DOE-N\$480.6 Section \$22.8}

"Interpal doeimerry program personnd should use mdionmelide standardy from of traceabile to the National Institute of Stondards and Texhnology (NIST)."

\section{RELATED REFERENCES}

1. DOE/EH0256T Articlo 522

SITE BEQUIREMISNT SOURCE: DOE-N5480.6 Section 522.9

"Iniernal dosimetry program personnel should particjputo in the conduct of intercomperison studies and should use the "DOE Phantom Librery."

\section{RELATED REFERENCES}

\section{DOE/EHO256T Article 522}

SIrE REQUIREMIEAT SOWRCE: DOE-N3480.6 Setion 523

"Technicel Requiraments for Dose Astestoment

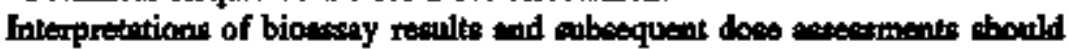
include the following: 


\section{REQUIREMENTS IDENTHICATION DOCUMENT HIGH LEVEL WASTE STORAGE TANK FARMS \\ Radiological Protection \\ Rerision}

1. Characteristios of the rediomuctide, sach ex chemical and physical form.

2. Bicassing resolts and the persen's previous expostro history.

3. Exposure information, such es ruto of istalle and tims and fonation of exparatro.

4. Biological models und for dontmety of nadioneclides;

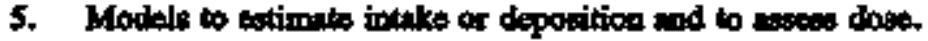

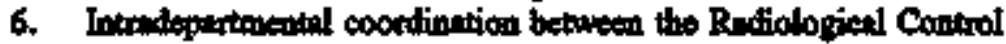
Organization and the medical organization for doese thet may require mectical intervention."

\section{REXATED RETEERENCES}

\section{DOE/EH0256T Article 523}

\section{SIIE REQUIREMTNI SOORCE: DOE-NS480.6 Section $\$ 43$}

\section{Exposares to Airbome Radionctivity}

Potential infukes of rediometive meterial are indicated when perennel without respitatory protection ere exposed to sirborne ratiosetivity or when respiratory protection has been compromised. If intenkes of adionctive material aro indicated which could result in a committed effective dose equivalent greater than $100 \mathrm{mrom}$, the following actions should bo thent

1. Ideatify perscounel potzatially exposed to airborme radiototivity.

2. Oboin nasal emeart for quelititivo todicetion of inteaked whore appropriata.

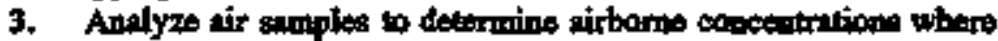
appropristo.

4. Determine dusntion of poteatial exposure to nirborne rodionctivity.

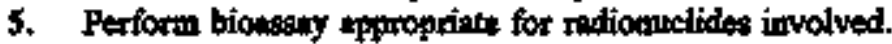

6. Evaluate does prior to permitting the worker to return to radiological wort."

\section{SITE REQURREMENT SOURCE: DOEJEHO135 RP,5 ROUTINE DOSTMETIRY.10}

-10. Extrenity dosimetry devices aro wow when performing work where extremity

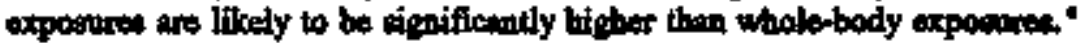

\section{SME REQUIRLMENT SOURCE: DOE/EFDI3S RPS ROUTINE DOSIMETRY.12}

12. Adequate field surveys of wort locentions ars performed ind documented to detertmine when routine and speciall dosimetry are needed."

\section{STE REQUIREMENT SOURCE: DOB/EHO135 RP.S ROUTINE DOSIMETRY.4}

-4. Visitors to radiation aress are movitored to determina any exponares. Erposures are reported in acoordance with DOE 5484.1." 


\section{REQUIREMENTS WENTIFICATION DOCUMENT \\ FIGH LEVEL WASTE STORAGE TANK FARMS \\ Radiological Protection \\ Rerision 0}

SITE REQUREMMENT SOURCE: DOE/EH013S RP.S ROUIINE DOSFMETRY.6

- 6. Technicel criteris and dow rato levela for ascizmment of extrenity mid perconnel doximotern ate exablished and documented."

\section{SIIE REQUIREMENT SOURCE: DOE/EHOL35 RP, ROUTINE DOSTMIETRY.7}

1. Procedured to identify workors for whom monitoring is required and the frequency with which their dotimeters aro processid wro aviliablo wad wo tectmically besed."

\section{SHE REQUIREMENT SOURCE: DOE/JH0135 RP.5 ROUTINE DOSIMERY.8}

- 8. Personnet who enter radioloptically controlled krens wear appropriats daefinetry devices capablo of accirtity metratring whole-body andlor extremity exposures from the typer of ndiation present."

\section{SITE REQUREMENT SOURCE: DOETHE0135 RP.6.7}

7. Monitoring data are uped to perforth tread andysio. Appropriats cortactive action is token whenover there are sigrificant nombers of poutive in-vivo counts observed or wben air concedratrations aro elovited, oven though the obearved lovels ane leos thin regulatory fimitz."

\section{SIHE REQUIREMENT SOURCE: DOEFH0135 RP.6.9}

- 9. Procedures and rescares are avaitable to perform dose celcurlations when significant internal exposures ocetr."

\section{SIY: REQUIRPMENT SOURCE: DOE/EHO135 RP.7}

"PERFORMANCE OBJECTIVE Tho internal roditution docimetry progenem showid encire that persounal rafiation expoures ane acenritely determined and recorded."

\section{SITE REQUIREMENT SOURCE: DOBAHO135 RP.7.t}

*1. The technical criteria employed to determins which employes are inchuded in the biosssey program, and the frequency of bionseny are documented and are consistent with ANSI N343, ANSI N13.30 (draft), and ALARA practices.

\section{STTE REQULREMENT SOURCE: DOE/EH0135 RP.7.10}

-10. Procedures are employed to present cross contanimation of (indirect) bionsany sanples." 


\section{REQUIREMENTS IDENTIFICATION DOCUMENT \\ HIGH LEVEL WASTE STORAGE TANK FARMS \\ Radiological Protection \\ Rerivion 0}

\section{SITE REQUIREMENT SOURCE: DOE/EHO135 RP.7.11}

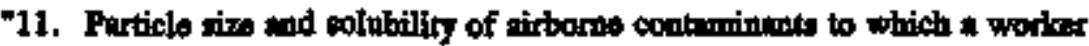
by or my bav been axposed are determised."

\section{GIE REQUIREMENT SOURCE: DOEHE0133 RP,7.12}

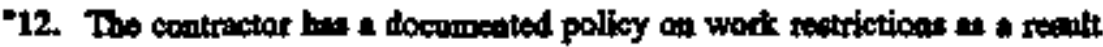
of intarmil radiation exposure (i.e., to permit dow assessmant mod/or for touponiny or permment work restrictions)."

\section{SITE REOURRMENT SOURCE: DOEIEHO135 RP.7.13}

"13. Procedure are established and documosted to identify indivivitus who fiil to kervo routine in vitro bionseny sanaplea."

\section{SITE REQUIREMENT SOURCE: DOEEHO135 RP.7.14}

-14. Procedures for in vitro and/or in vivo btoessay of visitums, if apropriate, to ratiation arter are established and documented."

\section{SITE REQUIREMIENT SOURCE: DOE/EHOL135 RP.7.15}

-15. The minimum detection level for in vitro and/or in vivo bioessay procedures are documented."

\section{SIIE REQUIRSMENT SOURCE: DOB/EH0135 RP.7.2}

"2. A quaticy control program, inctuding the ase of internil andtt simples, is aruployed by the contractor."

\section{STE REQUREMENT SOURCE: DOE/WH0135 RP.73}

"*3. The frequency and tinelines of in vitro sod/or in vivo biousing and notification of field persomed of nemito is appropriste for the

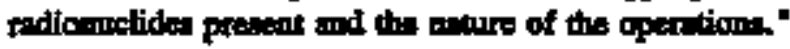

\section{SITE REQUIREMPNT SOURCE; DOE/EA0135 RP.7.4}

"*4. Procedures to identify worken for whom bionesen is required and the frequency is technicetly baged."

\section{STIE REQUIREMTNT SOURCE: DOKJEHU135 RP.7.5}

15. The typer of routine monitoring of watkest (in vivo and/or in vitro) ane appropriat for the radicanuclides present." 


\section{REQURRMENTS IDENTIFICATION DOCUMENT \\ HIGH LEVEL WASTE STORAGE TANK FARMS \\ Radiological Protection \\ Rerision 0}

\section{STIE RGQUIREMENT SOURCE: DOE/EH0135 RP.7.6}

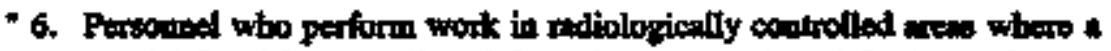

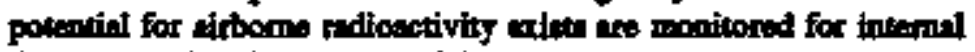
deposition of rediosctivity as follown:

- At lenst mantulliy;

- Prior to puforming radionetive work, eftor initial employment, and upon termination of elliployment;

- Whenever it is suspected that porsonod bresthed high nirborne ridioestivity;

- Periodically for those worters who have the kighest potontid for breathing bigh airbornt radioctivity, and

- Following persontel contenineticas, unless exampted by the radiological protection manager or his decigase."

\section{SIIE REQLIREMENT SOURCE: DOE/EH0135 RP.7.7}

7. Procedurus for tho intermel radiation dosimetry and updated perioticelly."

\section{SIIE REQULREMIENT SOURCE: DOEJEH0135 RP.7.8}

4 8. Trigger points to instigato an investigation of in intalse or mipposed intake are eateblished and technically based."

\section{STIE REQUIREMIENT SOURCE: DOEJEH0135 RP.7.9}

- 9. A raciation dow wo argans is compulod following an intebe. If doces are cakculated for some intakes but axt for otbers, a tachnical bestio

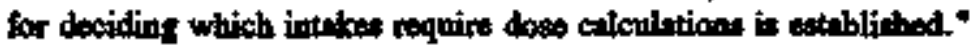

\section{SITE REQUIREMMENT SOURCV: DOE/ERT0250T Article $\mathbf{5 2 3}$}

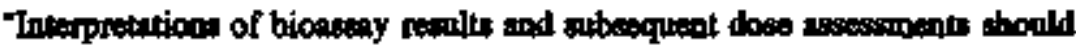
ivelocie the following:

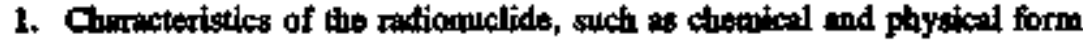

2. Bionssny results end the perbons previous exposare history

3. Exposare information, such as routs of intale and time and duntion of exposure

4. Biological models nesd for dosimery of rudionmellides

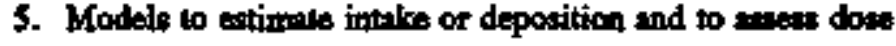




\section{REQUIREMENTS IDENTIFICATION DOCUMENT HIGH LEVEL WASTE STORAGE TANK FARMS \\ Radiological Protection \\ Rerision 0}

6. Intradepartmental coortinution between the Rodiological Control Organization the medien orfenization for doces that my rectuis medical intervention.

\section{SHE REQUIREMENT SOURCE; DOE\$480.11 Section 9.7(1)}

Extermal Radistion. Personinel doetimetry progume thall bo adequito to demonstrats conmilianee with the mdiation protection standards provided in paragrtph 9.b. Personeel dosimeters strall be routindly calibrated and

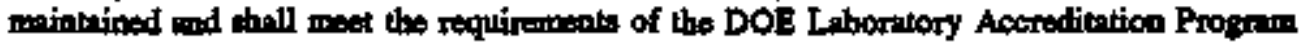
for Personned Dosimetry as specifief in DOE 3480.15. Persomel dosinekry shrll be prowided to redintion workers who hrve the potential to axced in a year any ones of the following from extermal sountes:

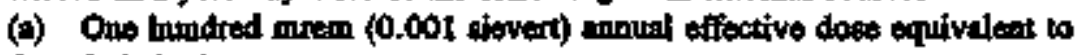
the whole body.

(b) Five sem ( 0.05 sievert) nanula dose equivalent to the slin.

(c) Fire rem (0.OS sievert) anmul dow equivalent to any extremity.

(d) One end a balf rem (0.015 sirvert) anmal dose equivalent to the leas of the eya."

\section{SITE REQUREEMENT SOURCB: DOES490.11 Section 9.g(2)}

Intermal Radiation. Irtemal doso eveluation programs fincluding routino bionsacy progrims) shall be adectante to demonstrite complimes with the rudiation protection

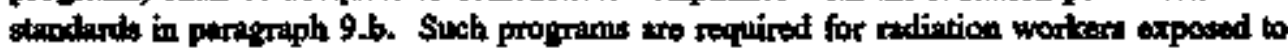
surface or airborno radiosctive contamination whero the worker could receivo 0.1 rem (0.001 sievert) ennual effective dowe equivaleat from all intekes of all nadipatulides from ochuputional sources, or if any organ or tiosus dose equivalent could exeend $5 \mathrm{rem}(0.05$ sievert) neraral dose equivaleat."

\section{Donimetry Proqaram}

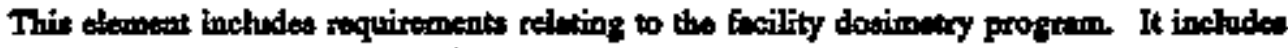
nexuirenents of the selection of equipenent, quelification of the program, and other

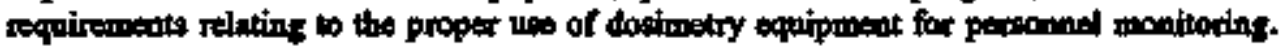

\section{STLE REQUIREMINT SOURCR ANST-NB19-1976 Section 4.1}

\section{Dasimetry System Performpose}

The dosimecry bystem shall be capable of delecting a minimum quarterly ueutron dose equivalene of 300 mrem. Therefore, the lower limit of detection for the docimetry gyotem shall be no greater than $300 \mathrm{mrem}$ divided by the nomber of dosimetry periods per

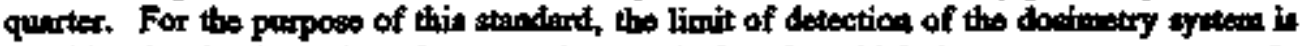

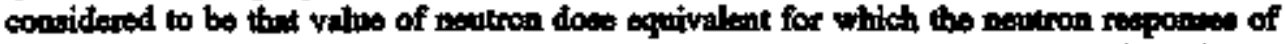
a set of ten or mone dosimetera ideaticelly exposed will have a standard devietion of no preater then 50\%."

\section{SIIE REQUIREMENT SOURCE; ANST-N319-1976 Section 4.2}

The dosimetry system shail be capalble of determining a dose equivalent up to 10 rem." 
Rerision o

\section{SHFE REQUIREMENT SOURCE: ANSI-N319-1976 Section 4s}

The doenimeter shall meet the requirements of 4.1 theough 4.4 when whjected to the following enviroamentil factors after exposare to the lest spectrum. (Exch of these enviroimental tests my bo performed sopentely.)

(1) Temporaturs extromes of $0^{\circ} \mathrm{C}$ and $45^{\circ} \mathrm{C}\left(32^{\circ} \mathrm{F}\right.$ ated $\left.113^{\circ} \mathrm{F}\right)$ for ane whe

(2) A reletive bamidity of $90 \%$ for one wook

(3) Normel extificinl roon light or normel sunlight for the extent of the dosimetry period

(4) A drop to a hard surface from a beight of 1.5 meters (4.9 feet).

\section{SIIE REQUIREMENT SOURCE: DOE-NS480.6 Section $\$ 11.2$}

"Dotianeters shall be isaved caly to personnel formatly inatructed in theit wes and shall be worn conly by those to whom the dosimeters were issued."

\section{RELATED REDERENCES}

\section{DOE/EH0256T Article 511}

\section{SITE REQUIREMENT SOURCE: DOFNS480.6 Section S11.3}

To miniumize the number of personnet in the dosimetry program, the ismance of

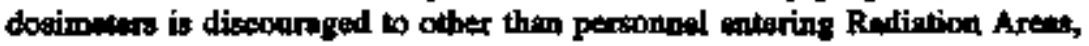
High Radiation Area or Radiological Buffer Aread where these is a potential for extertill exposwo. Altbough issuting dosimeters to persumel who we not occopationally expoesd to radiation cen eppent a a conervative prectice, it crestes the impression that the wearers are pecorpationally exposed to redintion."

\section{RETLATED REFERENCES}

\section{DOE/EHOZST Article 511}

\section{STrE REQUTREMENT SOURCE: DOE-N5490.6 Section \$11.4}

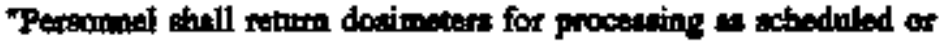
upon request, and should be restricted by lime-munegement from contimbed radiological work until dosimeters are teturned."

\section{RETATED REFERENCES}

\section{DOE/EH0256T Articlo 5I1}

\section{SITE REQUIREMENT SOURCE: DOE-N5480.6 Seetion \$11.S}

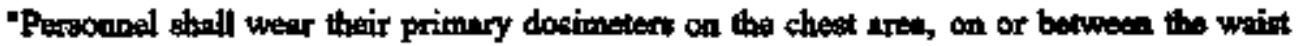
and the neck, in the manoer prescribed by dosimbery persomnel." 


\section{REQUIREMENTS IDENTIFICATION DOCUMENT \\ HIGH LEVEL WASTE STORAGE TANK FARMS \\ Radiological Protection \\ Rerision 4}

\section{RELATED REFERENCES}

1. DOEJEH0256T Articlo 511

\section{STTE REQUIREMINT SOURCE: DOE-N5480.6 Section \$11.7}

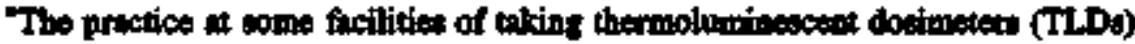
off-ite is divcournsed and shulf not be implemestod where nox in plece."

\section{RETLATE REFERENCES}

1. DOEFH0256T Article 511

\section{STFE REOUIREMENT SOURCE: DOE-NS480.6 Section $\$ 11.8$}

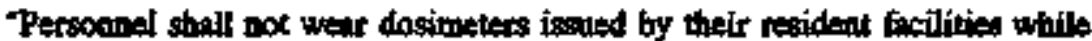
being monitored by a dosimeter at snother gite. Pereonnet strill not expoes their dosimeters to security $x$-rny devices, excensive heat, or medical sources of nadiation."

\section{REILATEO RETERENCES}

1. DOE/EH0256T Article $\$ 11$

STE REQUREMIENT SOURCE: DOE-NS480,6 SEtion \$11,9

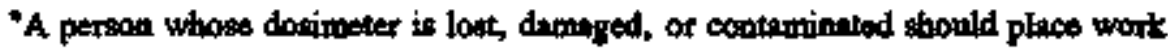
in a safe cosotition, immediately exit the arsa and report the cocurnence to the Radiological Control Orpenization. Reentry of the person into

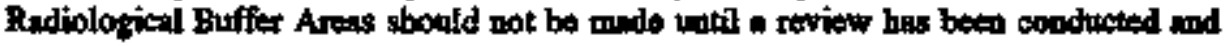
muangement has appowed reenkry."

\section{RELATED REFERTNCES}

\section{DOE/EHC2S6T Artiolo 511}

\section{STIE REQULREMENT SOLRCE: DOR-N5480.6 Section 512.I}

"Technical Requiremode for Extertal Dastimetry

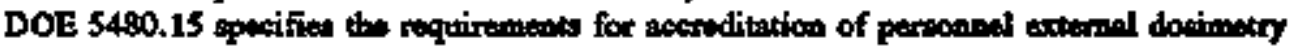
monitoring progratus by the DOE Laboratory Acreditution Propan (DOELAP). A technical besit doctuonent shall be developed for the external

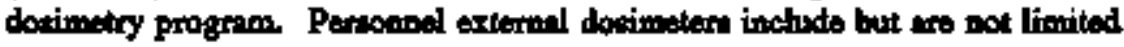
to TLDs, trock etch doximeters and weatron sengitive film."

\section{RELATEO REFERENCES}

1. DOEJEH0256T Articlo 512, Paragraph 1 


\section{REQUIREMENTS IDENTIFICATION DOCUMENT \\ HIGH LEVEL WASTE STORAGE TANK FARMS \\ Radiological Protection \\ Rerision 1}

SITE REQUIREMIFNT SOURCE: DOE-NS480.6 Seetion 512.2

The technical busis document shall slso address dosimeters monitoring

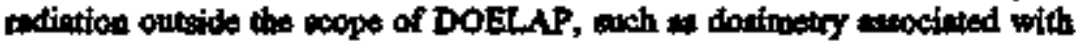
high-energy meelerntors and extreanity dostimeten."

\section{RFLATW REFERENCES}

1. DOE/EH0256T Article 512

SIIS REQUIREMENT SOURCE: DOE-N5480.6 Section 512.3

Tacilities shonld purticipate in intercomparison studies for oxternel dosimetry proprams."

\section{RELATED REFERFNCES}

1. DOE/EHO256T Article 512

STIE REQUIRFMENT SOURCT: DOH-N5480,6 Section 512,4

Tersocumel exposang to the skin, lens of the eye and extremitios shatl be reported expuntely when moaitored.

\section{RELATED REIFERENCES}

1. DOE/EH02S6T Article 512

SIIE REQUIREMIENT SOURCE: DOE-N\$4\$0.6 Section \$12.5

Multiple dosimeters should be iseund to porsonel to wate whole body

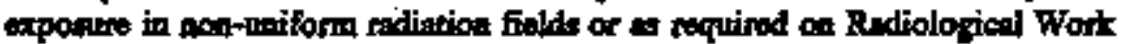
Permits. Non-uniform adintion fields exist when the dose to a portion of the whole body will exceed the doso to the primary dosimeter by wore then 50

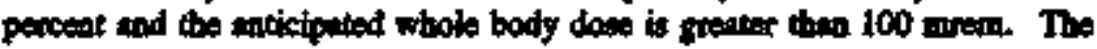
technioal besif document thould deacribe the methodology oned in detomining the doos of resord when multiplo dogimetert aro uped."

\section{REKLATWD REIERENCES}

\section{DOEEH0256T Article 512}

\section{SIIE REQUTREMENT SOURCE: DOE-N5480.4 Section 512.6}

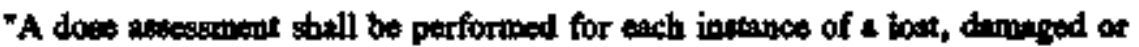
contamineted personnel dosimester."

\section{RELATED REFERENCES}

\section{DOEJER0256T Article 512}




\section{REQULREMENTS TENTIFICATION DOCUMENT HIGH LEVEL WASTE STORAGE TANK FARMS Radiological Protection Revision 0}

\section{SITE REQUIREMENT SOURCR: DOE-N5480.6 Section 513}

"Pocket and Eloctromic Dosimetext

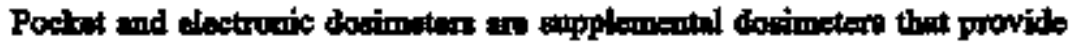

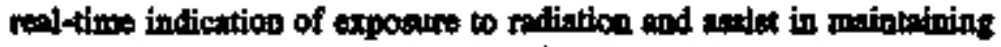
porgonnel doses leas then Adminietrative Cootrol Levelo."

\section{REATED REFERENCES}

\section{DOE/EH0256T Anticle 513}

\section{STIE REOUIREMFANT SOURCE: DOE-N5490.6 Section $\mathbf{5 1 3 . 1}$}

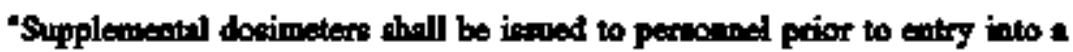
High Radiution Arem, when a person could exceed 10 percent of an

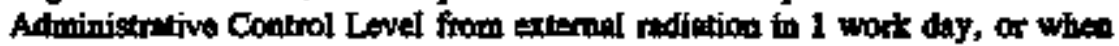
required by a Radiological Woth Permit (RWP). Poctet dosimeters athould bo

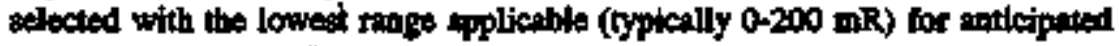
personalel exposines."

\section{RELATED REFERENCES}

\section{DOE/EHO256T Articlo 513}

SITE REQUIREMENT SOURCE: DOE-N\$490.6 Section $\$ 13.2$

"Strplemental dosimeters tholl be worn timltuncoucly with the primery dosimeter and hocated in weordinoes with Articks 511.5."

\section{RELATED REFERENCES}

\section{DOEIEHOOS6T Article 513}

\section{SIE REQUIREMIENT SOURCE; DOE-N\$4\$0.6 Section 513.3}

"Supplemental docimeters shall be rend periodically while in wes and should wot be sllowed to exceed 75 percent of full exele.

\section{RELATEN RFFERENCES}

\section{DOEJHO256T Article 513}

\section{SITE REQUIREMENT SOURCE: DOE-N\$40.6 Seetion \$13.5}

The energy dependence of sapplementil dosimeters, particularty to kw-energy beta molistion, should bo considerod in determining their epplicenbility."

\section{RELATED REFERENCES}

1. DOEREHOZS6T Articls 513 


\section{REQUIREMENTS IDENTIFICATION DOCUMENT HGH LEVEL WASTE STORAGE TANK FARMS \\ Radiological Protection \\ Rerision 0}

STIE REQUIREMIENT SOURCE: DOE-N5480.6 Section 513.6

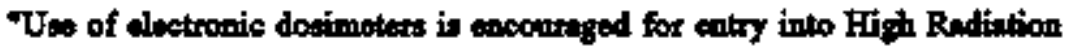
Arews or when plonned doese greater then 100 metem in 1 work day ane expected. An slectronic dosineter provides an early warning of elevated exposare through the ues of alam est pointe at epecified doee netes of integrated doses."

\section{RELATED REHERENCES}

\section{DOEEH02S6T Atticlo 513}

\section{STrE RSQUTREMENT SOURCE; DOE-N54\$0.6 Section 513.7}

When the does reanles from the pocket ox eloctronic dosimetest diffir by mort theo-S0 percent from the primary dosimeter result and the primery dosimeter

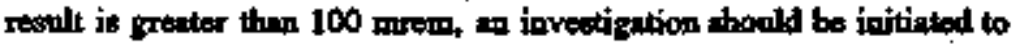
explein the difference."

\section{RELATED REFERENCES}

\section{DOE/EHO256T Articlo 513}

\section{SIIE REQUIREMNT SOURCE: DOEN5480.6 Section 514.1}

"Area moritoring dosimeters shall be used to rocord and documont ndiation levels in routinoly occupied areas adjecent to arese where radiation or operations with matiotion exist."

\section{RFICATED REFERENCES}

\section{DOE/EH0256T Article 514}

\section{SIIE REQUIREMENT SOURCE: DOE-N5490.6 Section 514.2}

"Are montitoring dosimeter resulta should be ned to sapport dosimetry investigations where personal express concerne ubsit their wort envinomente and exposure to ionizing adirtion."

\section{REI,ATED REFERENCES}

\section{DOE/EHO256T Article 514}

\section{SITE REQUIREMINT SOURCE: DOE-N5480.6 Section 5143}

"Area monitoriog dosimeters sbould be used in Coutrolled Arees to stppternent existing monitoring programs and to provide date in the event of an enercency."

\section{RELATED REFERENCES}

1. DOE/EHO256T Article 514 


\section{REQUIREMENTS IDENTUFICATION DOCUMENT HIGH LEVEL WASTE STORAGE TANK FARMS \\ Radiological Protection \\ Rerivion}

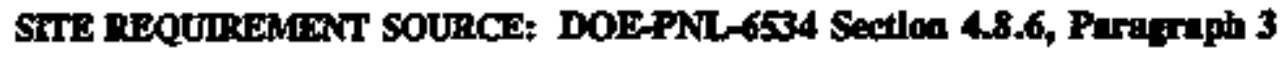

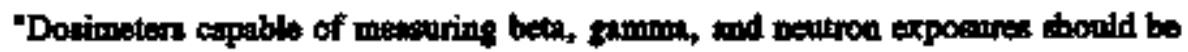

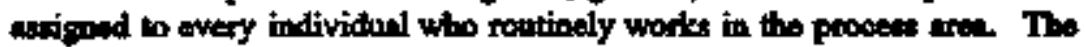
exchunge period should be bared on fietilty experience. Normally mouthly to

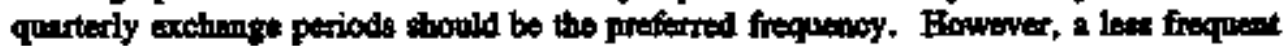

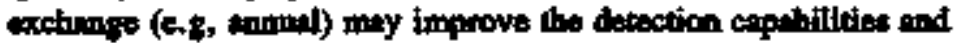
rectuce the smount of frise dose equivilents reconded"

\section{STTE REQUTREMAINT SOURCE: DOE/EFA135 RPS}

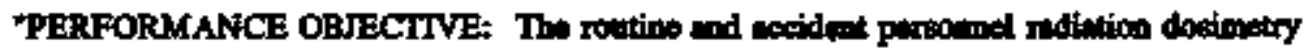
program thould ensure thet pessonned rodiation exposures are vecurately determined and recorded."

\section{SITE REQUIREMENT SOURCE: DOR/EHOL135 RPS NUCLEAR ACCIOENT} DOSIMETRY 3

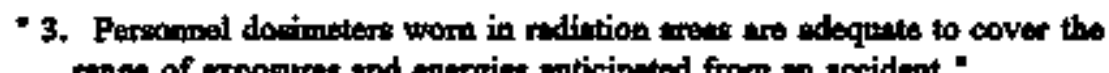
range of exposures and energies anticiputed from $\mathrm{m}$ aceident."

\section{STTE REQUIREMENT SOURCE: DOE/EHO13S RP.S ROUTINE DOSIMLTRY.1}

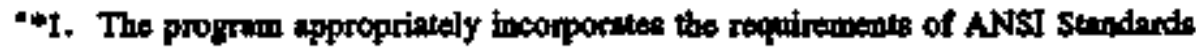
13.5-1972, N319-1976, N329-1978, and Department of Energy Leboratory

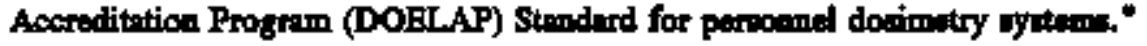

\section{STTE REQUIREMENT SOURCE: DOE/EFH0135 RP.S ROUTINE DOSIMETRY.14}

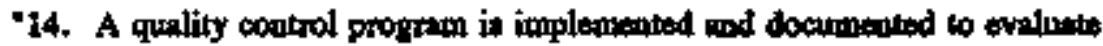
dosimetry program performence which inchudes intercomparison studies and laboratory validation procectures."

\section{STIE REQUREMENT SOURCE: DOE/LFHOT3S RP.S ROUTINE DOSMIETRY,1S}

-15. Correction factors or other appropriate methods are employed to ensare exposures from the types of ndintica preent and hight and low-anercy permmes ato weurately recorded in rem."

\section{STTE REQUIREMIENT SOURCE: DOEFH0135 RP.S ROUTINE DOSTMETRY.16}

16. Dosimeter opentions art performed by and nesults interpreted by qualified persominel. 


\section{REQUIREMENTS IDENTIFICATION DOCUMENT \\ HIGH LEVEL WASTE STORAGE TANK FARMS \\ Radiological Protection \\ Revision 0}

\section{SITE REQUIREMENT SOURCE: DOE/EHOH3S RP.S ROUTRNE}

DOSIMETRY,21

21. A procedure for extimating the dose from a bet dosimeter is avalibles"

\section{SIIE REQUIREMLAT SOURCE: DOEAHH013S RP.5 ROUTINE DOSTMETRY.9}

- 9. Whabobody exposures dosimeters we worn in the proper lacention and

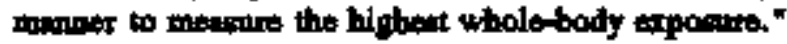

SITE REQUUREMIFNr SOURCE: DOES490.15 Section 9h(1) thru

"Heads of DOE and DOE Coutractor Personinel Dootinatry Programis or their Deeigneted Repreonatedives stant;

(1) Complete and gubmit in mitiol appitication for a DOE Laboratory Acereditation Program performence eviluntion through the Head of the nppiopriato Field Elemert who must concur on the applicetion (paragteph $90(4)$ ). Appticetions aro conteined in DOEJEH-A026.

(2) Submit dosimeters for teating upen request of the Performence Evahtation Program Administrator. Eaph test repairea thres exparate submissione of dosimaters at intervals of approxim:tely one month.

(3) Evaluate irreciated dostaneters in terms of the units specified by DOEVEH-ON27 and neport the vahee to the Performance Evaluation Prognm Administntor.

(4) Allow site nsessours to expmine all spects of the program, tecluting fucilities, equipowent, dosimeters, procedurts, notebooks, records, reports, poation descriptions, personnel qunlificatione, and training docunnateition.

(5) Respond in writing within 45 days of receipt of the site

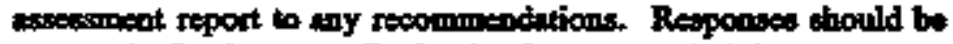
seal to the Performence Evaluation Progrtan Administrator, with

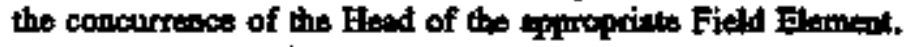
The response shall ibclude corrective action (as approprinte) and confuletion deter.

(6) Within 60 dnys, ideatify ad inglement plons to mine appropriate changes in equipment, procedmres, sod/or portontwel to sehitive a program cexpable of receiving scereditation in the event that acterefitition is denied. PImes hall have the concurrence of the Head of the sppropriate Fitud Element. 


\section{REQUIREMENTS IDENTTFICATION DOCUMENT HIGH LEVEL WASTE STORAGE TANK FARMS Radiological Protection Rerision}

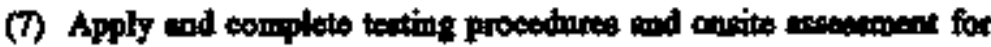

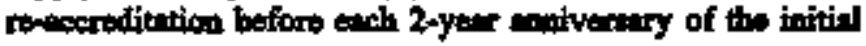
actoditation,"

\section{Calenatgition Methods/Models}

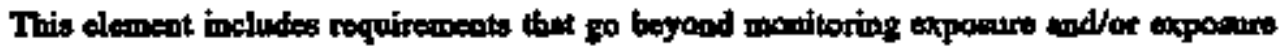
levels to calculating expomure to plant wotkers and the rolative biobjical effect. It

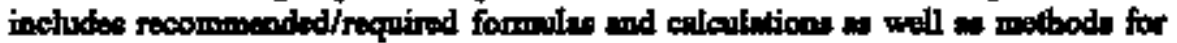

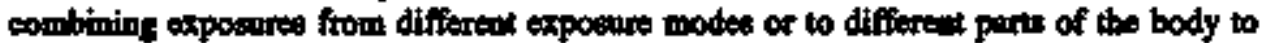

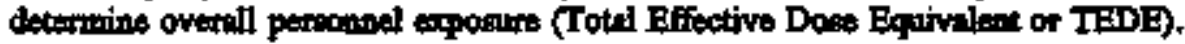

\section{SITE REQUIREMENT SOURC: ANST-N13.6-1966 Section 6.2}

"Procedures and Methods for Interpitation and Evalution of Individual Expotare Dite. Procedures desribing tbe techniquen and methods employed to obtein, procese, and

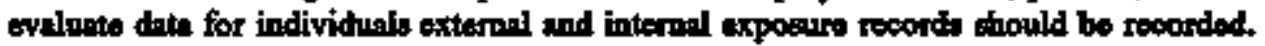

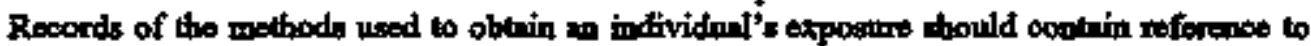
pertinent publisbed documents of reports, and should abow the period of applicebility of wuch methode.

\section{SITE REQUTREMENT SOURCE: DOE-PNL-6534 Section 4.6.7, Paragraph 2}

There are several publishod mothods for etimnting intake from bioasery dete (Strable at 1. (in); Strmble 1983; King 1986; Jobneon nnd Curver 1981). These method ewoh comloy

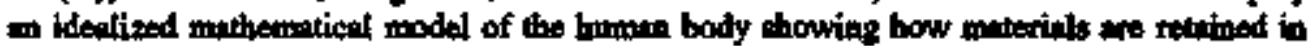
and excreted from the body over time following the intake. An intoke rebention model is a simplified methenntical description of the complex biokinetics of n ndiometive material in the humen body. These models are bed to prefict the friction of in intent thot will be detected in whole body or chest meacurements and in uripe of fecti amples. Intake retention models consist of in uptete retention moded thet relates uptalse to bioansay data,

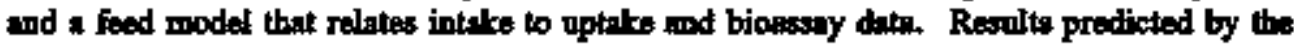
model may then be conduared with the observed bionssay dath. The model may be

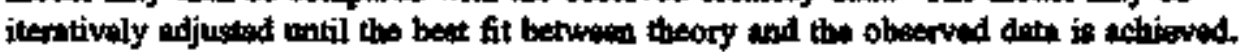

ta Sirahte, K. W., G. E. Chabex, C. S. French, and T. R. IABone 1986. "Intake Retontion Funetions and Their Applientions to Bioeseny and the Eetimetion of Internel Redintion Doses." Healh Physics (eubmitted tor poblication in 1986)."

\section{SFIE REQUIREMINNT SOURCE: DOES490.11 Section 8.e(12)}

-Weighing Fector (Wt). Is usod in the calculation of anmul and committed effective does equivaleat to equate the risk arising from the irradiation of

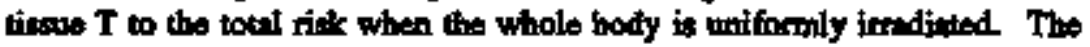
weiphing factors ar defined in ICRP Publicution 26 and NCRP Report 91 are:

$$
\text { Organs of Tissues Weighing Factor }
$$

$\begin{array}{ll}\text { Gonads } & 0.25 \\ \text { Breasts } & 0.15\end{array}$




\section{REQUIREMIENTS IDNTIFICATION DOCUMENT \\ HIGH LEVEL WASTE STORAGE TANK FARMS \\ Radiological Protection \\ Rertioin 0}

\begin{tabular}{|c|c|}
\hline $\begin{array}{l}\text { Red Bone Marrow } \\
\text { Lungs: } \\
\text { Thyroid } \\
\text { Bowo Sunf } \\
\text { Remoinder U }\end{array}$ & $\begin{array}{l}0.12 \\
0.12 \\
0.03 \\
0.03 \\
0.30\end{array}$ \\
\hline
\end{tabular}

11 "Remininder" meand the five ofher orgens or tiane with the hiphest dose

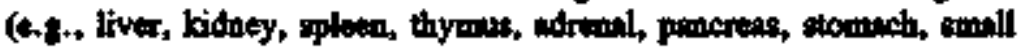
intestine, upper taro tutestine of lower lappe intertine). The weiphins

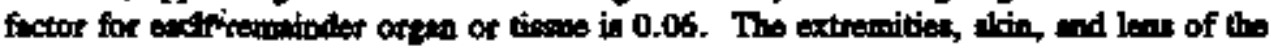
oye are exchuded from the "rempinder" organe or tiven for

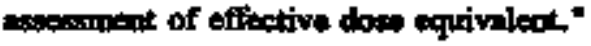

\section{SITE REQUARTMENT SOURCE: DOES489.1I Seation 9.1(1)}

"Combining Intarnal md Externel Dow Equivilent. The amanal effiective dow

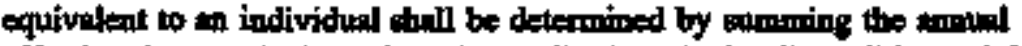
effective dose equiralents from internally deposined radicouctides and from external exposure to rdiostive miterial andjor radietion generating devices resalting from DOE activitiss. When in-vivo and/or in-vitro mensurements confinm the retention of molionnclides in the body, with respect to swalunting conformnnce with the limiting valus for accupetion ol exposure, the ennust effective dose equivatent tue to all radionuelidis retrined in the body from these intelkes shall be assessed for es long as the amoin effective dose equivileat is 10 mrem of greater. Expocunes to the akin, exmemitiea, and lens of the oye no not included in the determintion of the mand effective doese equivalenc. For wniform extersal irrefiation of the whole body, a weighing fector (Wo) equel to ons my be ued. This whole body doce is to be

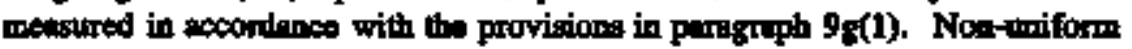
extermal and internal irredtation values of Wh for argans and tissure ate defined in parngriph 8e(12).*

\section{SITE REQUREMENT SOURCE: DOES480.11 Section 9.t(2)}

Non-Uniform Exposare to Stin. For non-miform exposures to stin from $x \mathrm{mys}$, beta rafiation, or skin contumination, one of the following assecsments stall be mexto and reconded:

(a) When the are of akin expoed in $>100 \mathrm{~cm} 2$ the minrimum value of does warraged over my aren of $100 \mathrm{~cm} 2$ is to be aseessed, recouded, and inctuded in the anmual skin (etollow) dow equivaleat."

\section{SITE REQUIREMENT SOURCE; DOE5480.11 Section 9.(2)(b)}

When the area of akin expoed is $>10 \mathrm{~cm} 2$ but $<100 \mathrm{~cm} 2$ the does equivaleat to that tisswe is to be determined by:

$$
\mathbf{H}=\mathbf{f D}
$$

where: $D$ is the merimam dase veraged ower $a 1 \mathrm{~cm} z$ of atom and $\mathrm{f}$ is the fraction of shin exposed compared to $100 \mathrm{~cm} 2$. In no case shall en "f of $<0.1$ be used. This vilus of dase is to be neconded nond inchuded in the numbal skin (shailow) doese equivaleots." 


\title{
REQUIREMENTS IDENITHICATION DOCUMINT HIGH LEVEL WASTE STORAGE TANK FARMS Radiological Protection Revision 0
}

\author{
STIE REQUIREMBNT SOURCE: DOES480.t1 Section 9.1(2)(c)
}

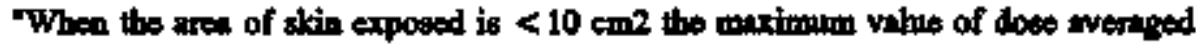

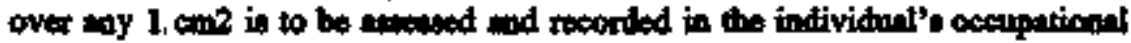
exposure history as a speciel entry but is not to be included in the anowil shin (shollow) dow equivaleat."

\section{SIIE REQUREMENT SOURCE: DORS480.11 Seetion 9.1(4)(a)}

- Air and Wates Concentration Guides

(4) Ait. Derived nir concentration (DAC) vatues for contral of the workplaces are given in Attmbment 1. They were derived from the ICRP Publicetion 30 values for committed effective does equivalent values, tronedated to convedtiond U.S. wits of rem and curie. The ICRP Publication 23 nocommended monulal inholetion volum for molo morken (40 $\mathrm{br} / \mathrm{wt}, 50 \mathrm{wb} / \mathrm{yr}$ ) was asouned to be $2400 \mathrm{m3}$. The DAC values or other tir concentrition vilues shall not be verd for the celtulation of titernal dose equivalent metived by a wortar except for unurasel circumetinces where bicassay data is unevaituble or inadequate."

\section{SITE REQUREMENT SOURCE: DOE5480.11 Section 9.1(5)}

"Quality Factors. The dose equivalent limits specified in this chupter are expressed in terms of remi this requires that the sbeorbed dose (expresed in rads) be moltipited by an appropritto quality fator (Q). The quality factort to bo used for determining dowe equivaleat in rem noe bbown in Fignros 2 and 3."

\section{SITE REQUIREMENT SOLRCE: DORS480.1I Section 9.h}

Mothods of Estimating Doses Equivaleat. Methods of extimating the dose equivalent from exterentl and interasl sounces of radietion tre to be eppropriats to the workpluce conditions and consistent with the recommendations of NCRP, ICRP, and EPA."

\section{ENTRY AND EXTT CONTROL}

This element addresses the requirements for controlling entry to and exit from

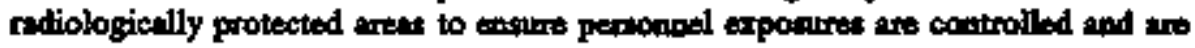
mintuined As Low As Reesconably Achievable (ALARA). It inclodes requirements for plysical controls, procodural controls and for providing appropriate information to

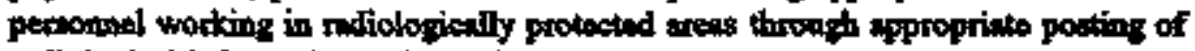
radiological information and wartiongt.

\section{SITE REQUIREMENT SOURCE: DOE/EA0135 RP.3 FOSTING.4}

-4. Entranoe to arew where radioactive materials are usod or sored in restricted bused upon established eriterin." 


\section{REQUIREMENTS IDENTIFICATION DOCUMENT HIGH LEVEL WASTE STORAGE TANK FARMS Radiological Protection Rerision *}

\section{STTE REQUIREMENT SOURCE: DOB\$40.11 Section 9.1}

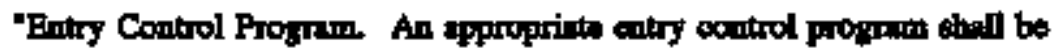

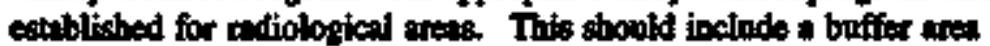
prior to eatry to a matiological ares whe epproprinte. The lovel of

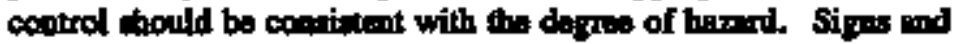

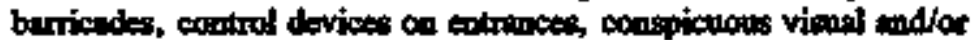
andible alarms, locked ontruce way, and/or adminimentive procechnes should be used at approprinto to ensure that peroones enky into radiologisal ares is controlled. Step-off pads nud protective clothing thatl bo required for entry to contuminated areat. For very bigh reciation areac, the entry control program shall inclede at a minimam one of the following:

(1) Control devices con each entrence or acess point which finnetion astomatically to provent entry when a very high rediation anos exists; permit motry only after the nalintion level is reduced below $0.1 \mathrm{rem}$ (0.001 sievert) per hour; and prevent ue of operntion of the radiution source, thereby preventing the exidunes of a vary high radintion arter, while an individan is in the arte.

(2) A control device which eseryizes a conspicuous visible or andible alarm signat so thet the individuol entering the very high radietion area through $\&$ faiked control device is awre of the radiation lovel and rediation protection personnel wre whate of the entry. Admitaistretive procedures shall deflos the requited actions of perconinel when alsms ate uctivited.

(3) Locked altry whys, except during periods when wcress to the aree is required, with positive control ower and radiation arreys made for the initial entry and periofically at necenary.

(4) Control devices that will antomatically genergte gadible md visiblo alarme sigmals to alert persomel in the ares befort use or sperstion of the radiation source and in suffictent time 10 permil evearntion of the aree or the ectivetion of a secondery control derice which will prevent ase or operation of the expres."

\section{Accest Restrictlon:}

This element addesses requinements for controlling socess into trilitien and areas through the we of either procectural or physical coutrole. These controls, when extablishest in ndiologically protected areas are inteoded to efither warn pernconed of hazands, to pbysically cootrol entry and exit or to limitfcontrol exponare when entering arean.

\section{SITE REQURREMENT SOURCE: DOE-N5480.6 Section 231.10}

"Physical burriers should bo placed so that they are clearly visibts from all 


\section{REQUIREMENTS IDENTIFICATION DOCUMENT \\ HIGH LEVEL WASTE STORAGE TANK FARMS \\ Radiological Protection \\ Bertion 0}

directiona and at various elovations. They should not be encily walled over or toder,

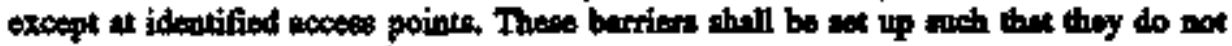
impedo the intended use of aresrgensy exits or ovenution routes,"

\section{RELATED REFERENCES}

\section{DOE/EFHO256T Aticle 231}

\section{SITE REQUREMANT SOURCE: DOE-N5490.6 Section 233.1}

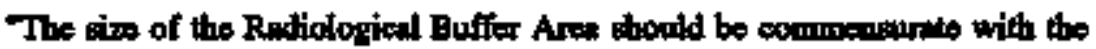
potential for the spread of contamination outride Contrmination, Bigh

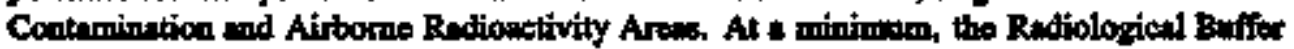

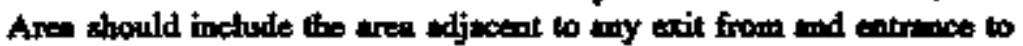
Conkanination, Bigh Contaminition and Airboms Radionctivity Areas."

\section{SIIE REQUIREMIENT SOURCE: DOE-N3480.6 Section 2332}

"A Rudiological Buffer Area is oot reepired for High Contamination Aress then are completely within Coamuination Areas."

\section{SFTE REQUIREMENT SOURCE: DOE-N5480.6 Section 233.3}

"A Radiological Buffer Area should surround or be contiguou with Ratiation, Figh Radietion and Very High Radintion Areas. The boemdiry tor the Radiological Buffer Ares and these rediation aress may bo oos in the same."

\section{STTE REQUIREMENT SOURCF: DOEN5480.6 Section 332.1}

Tadiological Bufter Ares:

Minimum requirements for unescorted entry into Radiological Buffer Arses shall inchude the following:

2. Radiological Worker I training:

b. Personed dosimetry, as approprinte."

\section{SITE REQUIREMENT SOURCE: DOE-N5490.6 Section 332.2}

"Persomel wto exit a Radiologicat Buffer Area containing Contaminntion Areas, High Contaminition Areas, of Aitome Radionctivity Avers should monitor as specified in Articlo 338."

\section{STIE REQUTREMEN SOURCE; DOEN5480.6 Section 333.1}

"Roticantive Material Areals

Redialogical Worker I trining shall be required for toeseorted watry into Rediowesive Material Areas containing either of the following:

a. Senled rudionctive souress;

b. Rufouctive material labeled and packeged in econdance with Articles 412 and 413." 


\section{REQUIREMENTS IDENTIFICATION DOCUMENT \\ HIGH LEVEL WASTE STORAGE TANK FARMS \\ Radiological Protection \\ Berisiou o}

\section{SITE RDOUIREMENT SOURCE: DOFN5480.6 Section 333.2}

Entry into Radivactive Mnterial Areas where whole body do6e rates exced I mr/hr or removable contamination levels exceed Table 2-2 values thall be in wecordanes with the requirements of Articles 334.1 an 335.1, reepectively."

\section{STIE REOUIROMENT SOURCE: DOE-N5480.6 Section 334.1}

"Resistion, High Rndietion and Very Hrop Rediation Arese

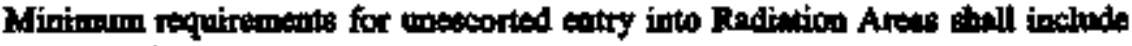
the following:

a Radiolopical Worter I triming;

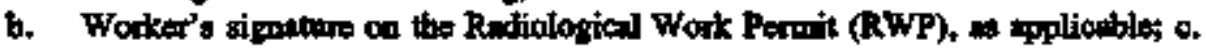
Personnel doeimetry."

\section{RELATEO REFERENCES}

\section{DOE/EH0256T Article 334}

\section{STE REQUIREMENT SOURCE: DOR-N5490.6 Section 334.2}

Thysical controls to prevent inmivertent or unautborized acoess to Hiph and Very High Radiation Areas stell be mointined in ecoordence with Appendix 3B."

\section{RELATED REFERENCES}

\section{DOE/EHO256T Article 334}

\section{SFTE REQUIREMONT SOURCE: DOE-N5480.6 Section 334.3}

"Minimum requirements for unescortod entry into Figh Radiation Areas shell include tho following:

- Ratiologial Worker II tmining;

b. Worker's sipheture on the RWP;

c. Perromen and supplemental docimeters;

d. Survoy meter or dose rato ixdienting device nvailable at the wort area."

\section{RELATED REFERENCES}

\section{DOEFH0856T Article 334}

\section{SITE REQUIREMAENT SOURCR: DOE-N5480.6 Section 334.4}

Minimum requirements for mescorted entry into High Redietion Ares where dese rates arist such that $n$ worker conld exeeed th whole body dose of 1 rem in tono

hour shall include those items listed in Article 334.3 and the followings:

h. A determination of the worker'a current exposurt, based oe primery and supplemsental dosincter readings;

b. Pro-job briefing, as applicable; 


\section{REQUIREMENTS IDENTIFICATION DOCUMENT \\ HIGH LEVEL WASTE STORAGE TANK FARMS \\ Rodiological Protection \\ Rerision 0}

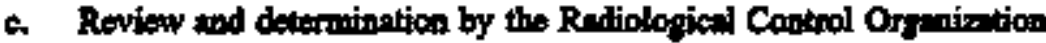
nogriting tho required kevel of Rediological Control Technicien coverige."

\section{RELATED REFERENCES}

\section{DOE/EH0256T Article 334}

\section{SITE REQUREMIENT SOURCE: DOE-NS490.6 Sedion 334.5}

Wodkere shall be preveated from entry to Very High Redintion Arese when the

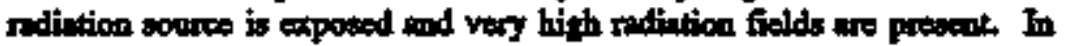
wdition to the controle rexputrod in Articles 334.2 and 334.3, a surver thall be mede prior to the first entry to the aren after the wource hus been encured or enioided to verify the very hith ratiaticn field hes been thepinetod."

\section{RELATED REFERENCES}

\section{DOEEHO2S6T Article 934}

\section{STIE REQUIREMENT SOURCE: DOE-NS480.6 Section 334.6}

-Facility cperations perscanel should be notified prior to persomel entry to wress where operational or systen chingen mede by cperations persomed could result in ipgificantly increased area dow ratea."

\section{REIATFE REFERENCES}

1. DOE/EH0256T Article $\$ 34$

STTE REQUIREMAENT SOURCE: DOE-N5490.6 Sectior 334.7

The number, isane and use of keys shatl be strietly controlled where locked entryways are used to confrol woess to High and Very High Radiation Aven."

\section{REL.ATED RHFERENCES}

1. DOE/EH0256T Articlo 334

\section{SITE REQUIREMENT SOURCE: DOE-N54\$4.6 Section $\mathbf{3 3 4 . 8}$}

The Rafiological Control Organization should maintain an inventory of High and Very Hijga Rediation Areas."

\section{RELATED REFERENCES}

1. DOEJEHODS6T Article 334 


\section{REQUIREMENTS IDENTIFICATION DOCUMENT HIGH LEVEL WASTE STORAGE TANK FARMS \\ Radiological Protection \\ Revision 0}

\section{STTE REOUIREMENT SOURCE: DOE-N5480.6 Section 334.9}

Weakly inspections of the physical eccess controls to High and Very High Rediation Aress should be mode to verify controis ase adequate to prevert numutboritus eotry."

\section{RELATED REFERENCAS}

\section{DOE/EHO256T Article 334}

\section{SITE REQUIREMANT SOURCE: DOEN5490.6 Section 335.1}

"Contuminalion, High Contamination and Airborne Rudioactivity Aras

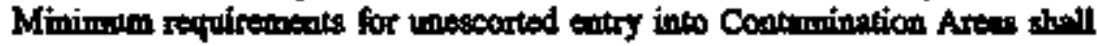
incluado the following:

a. Radiological Wotter II thining;

b. Worker's signature on the RWP, as epplicable;

c. Protective clolting;

d. Personnel dosimetry, as eppropritute."

\section{RELATED REFERENCES}

\section{DOE/EH02S6T Anticlo 335}

\section{SITE REQUILEMENT SOURCE; DOE-N54\$0.6 Section 335.2}

"Minimum requirements for unescorted entry into High Conteraination or Airbome Redinemivity Arees stall include the following:
2. Rediological Worter II triming;
b. Worke's signature on the RWP;
c. Protective clothing and reepintory protection, as specified by to RWP;
d. Pro-job briefing for High Contmination or Airborme Radionctivity Ares, as applicable;

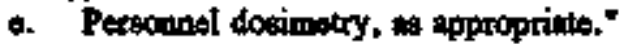

\section{RELATED REFERENCES}

1. DOE/EHO256T Article 335

\section{SITE REQULREMENT SOURCE: DOEN5480.6 Section 335.3}

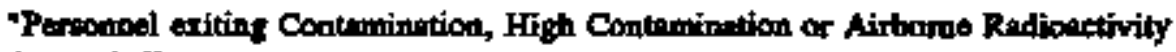
Areas stall:

2. Remove protective cloxhing as specified in Appendix 3C;

b. Perform whole body fristring to detect porsonnel coumentuation in mecordince with Article 338;

c. Tools ar equipmeat being removed from the ares shall be monitored for release in accordance with Article 421 or for retention in the contkminated tool crib in acoondance with Article 442.5." 


\section{REQUREMENTS IDENTLICATION DOCUMENT \\ HIGH LEVEL WASTE STORAGE TANK FARMS \\ Radiological Protection \\ Revision}

\section{REILATED REIEXENCES}

\section{DOE/EH0256T Article 395}

\section{SITE REOUIREMENT SOURCE: DOE-NS480.6 Section 335.4}

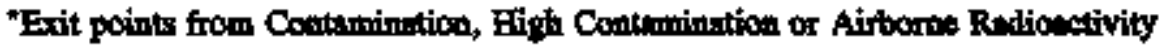
Arees should include the folliowing:

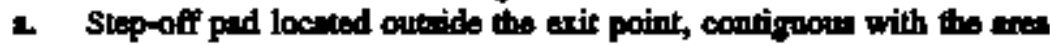
boumilery:

b. Strp-off padz mrintained fine of mdiontive conteminution;

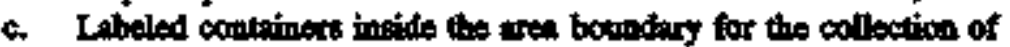
protective clothing and equipment;

d. Conteminution monitoring equipment loceted es clowe to the itep-off ped a background radiation lovels permit."

\section{RETATED RBFERENCES}

\section{DOE/EHO256T Article 335}

SITE REQUIREMINNT SOURCE: DOE-NS490.6 Section 335.5

Multipto step-off pads stould be used at the erils from High Contaminution Aress. Use of multiple step-off pads is deseribed in Appeodix 3C."

\section{RELATED REFERENCES}

\section{DOEFHOZS6T Article 335}

\section{SITE REQUIREMIENT SOURCE: DOF-N3480.6 Seetion 336.1}

"Visitor Entry Requireanente

Site proeedures ahall identify wrot enfry requirements and mocese restrictions for visitors."

SIIE REQUIREMENT SOLRCE: DOE-N54R0.6 Section 336.2

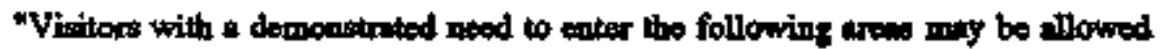

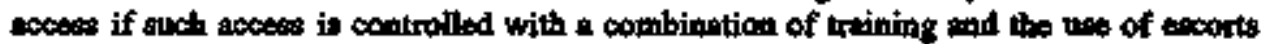
trained for tho specilic grea:

- Rmiological Buffer Arees;

b. Recliation and High Rudiation Areas;

c. Contaminetion Aresa;

d. Redionctive Material Areas."

\section{SITE REQUIREMENY SOURCE: DOE-N5480.6 Section 336.3}

"Visitors shall be prevented from encering Very High Radiation Areas in ascordepes with Articlo 334.5 and should bo prohibitod wecess to Figh Contamination and Airborale Radiontivity Areas." 


\section{REQUIREMENTS IDENTIFICATION DOCUMENT HIGH LEVEL WASTE STORAGE TANK FARMS

\author{
Radiological Protection \\ Revision 0
}

\section{SITE REQUHREMENT SOLRCE: DOR-N5480.6 Section 353.6}

Where en area mdintion moaitor is incorponted into 1 satety intelock system the

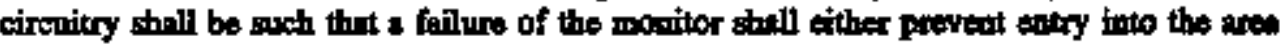
or prevent opentice of the radintion producing device."

\section{RELATED REWERENCES}

1. DOE/EH0256T Atticle 553

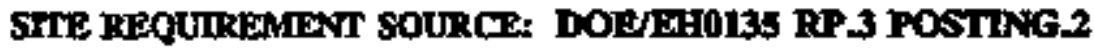

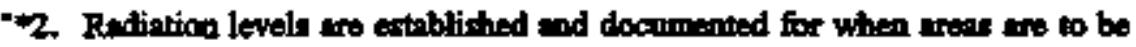

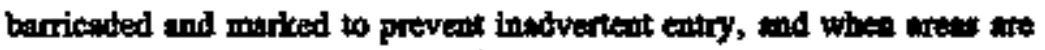
to be phyicilly lacked to preclude toonthorized ontry."

\section{SITE REQUIREMENT SOURCE; DOES480.11 Section 9.I(1)}

For very high rediation arsas, the entry control progrim thell inclodo at a minimutm one of the following:

(1) Control devices on each entrance or woces potint which function antomatically to prevent entry when 1 very high radiation are existse perenit anty only ofter the ridiation level is reduced below 0.1 rem (0.001 sievert) per how, and provent un or operition of the redintion source, thereby preveoting the existeose of a very high taliation ares, while an individual in in the area."

\section{SRE REQUMREMENT SOURCE: DOE5480.11 Section 9.1(3)}

"Locked entry ways, except durint periods when acoess to the aren is required, with positive coatrol over and nudiation anrveys made for the initial andy abd periodicolly to necsary."

\section{SITE REQUIREMINT SOURCE: DOE5490.11 Section 9.1(4)}

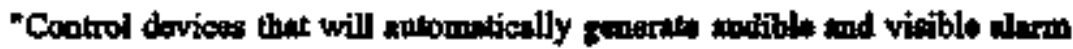

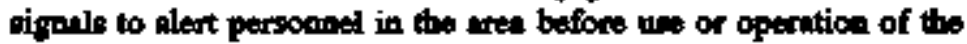
radiation source and in sofficient time to permit evactation of the area or the setivation of a secondery control device which will provent wes or cperation of the source."

\section{SIIE REQUTREMENY SOURCE: WAC-402-24 Section 09A(1)(e)(ii)}

Fich entrmase or meass point to a high redietion area shell be:

(A) Equipped with a control device which shall ange the level of ndiotion to bo reduced below that at which in individual might receive $a$ dowe of 100 mitlineans in 1 bour upos entry into the area; or

(B) Equipped with a control device whith shall enerpizta conspietonos visible or endible slarm signel in such a maner that the individual entering the high rediation area and the licensec of a aupervisor of the activity wre mode whare of the eatry; or 


\section{REQUIREMENTS IDENTIFICATION DOCUMENT \\ HIGH LEVEL WASTE STORAGE TANK FARMS \\ Radiological Protection \\ Rerislon 4}

(C) Mrintuined locked troept during perioda when eccess to the aren is tequired, with poditive control over each individuel entry."

\section{ROATTED REIFRENCES}

1. TOCFR20 Part 20.203.c.(2)

\section{SITE REQUREMENT SOURCE: WAC-402-24 Section 090(1)(t)(iti)}

The controls requined by parapraph (e)(ii) of this section thell be

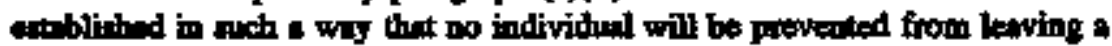
high matiotion mese"

\section{RELATED REFERENCES}

1. 10CFR20 Part 20.203.c.(3)

SITE REQURREMENT SOURCE: WAC-402-24 Section 090(1)(e)(iv)

In the cese of a high radtation area established for a period of 30 days or lens, direst surveillan to prevent ungutborized entry moy be subetinited for thic controls required by pongraph (e)(th) of this section. Diroct surveillimos requirs the coatinooss physical presence of an individus

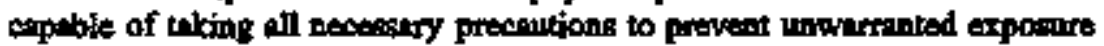
of individusls."

\section{RELATED REFERENCES}

1. 10CFR20 Part 20.203.c. (4)

\section{Rosting}

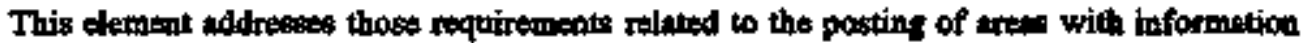
concerning tither the various types of adiologicel hezarde contained in the erees or with

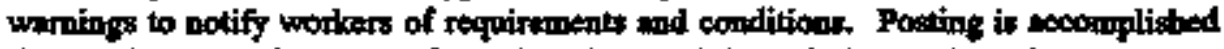
through both the placerenent of warting sigan fod through the poeting of arvey informetion for woekers to roview wher entering arees.

\section{SITE REQUIREMFNT SOURCE: DOE-N5480.6 Section 222.1}

- Contraninetion Control Levelp

A artace shall be considered contruminited if either the removable or total radionctivity is detected above the lovels in Tablo 2-2. If an wron connot be decontaminited promply, then it thell be posted os specified in Articlo 235."

\section{RELATED RRFERENCES}

1. DOEJH0256T Article 222 


\section{REQUIREMENTS IDENTIFICATION DOCUMENT HIGH LEVEL WASTE STORAGE TANK FARMS \\ Radilological Protection \\ Revision 0}

STTE REQUREMMENT SOURCE: DOE-N54\$0.6 Section 223.2

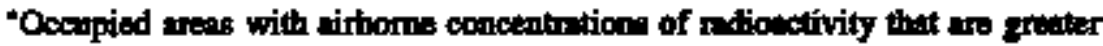
than of potentially greater then 10 pereent of a Derived Air Concentrition

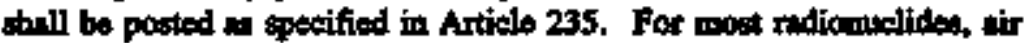
containing 10 pencent of a Derived Air Concentrotion nathis in 1 committod effective doese equivilent of approximetely 10 mrem if inheled coutimuonsly for one wort week. Viloes of Derived Air Coosetrations are providad in DOE 5480.11."

STTE REQUERE:MENT SOURCE: DOF-N5430.6 Section 231.1

Posting

Postine Requirementes

Raficlogical posting thall be aned to slest penonnet io the presence of

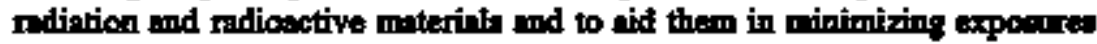

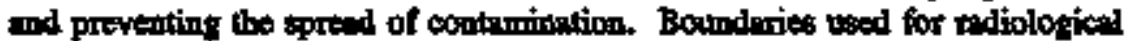
control purpases are depicted in Figure 2-1,"

\section{RELATED REFERENCES}

1. DOE/EHO256T Article 231

SITE REQUIREMIENT SOURCE: DOEN5480.6 Section 231.11

"Poting of doors should be aush that the portings rewain vieible when doon are opan or closed."

\section{RELATED REFERENCES}

1. DOE/EHOPS6T Artiale 231

\section{STIE REQUIREMENT SOURCE: DOE-N5480.6 Section 231.2}

"Signs thall contain the standend radiution symbol colored magenth or bluck on - yellow background. Lettering antl bo ether magentu or blact. Magente is the proferred color over blatik. Standarized silons, as decoribed in tho stendandizod corr training, should be weod whers procticable."

\section{RELATED REFERENCES}

t. DOE/EH0256T Articlo 231

SITE REQUIREMENT SOURCE; DOE-N5480.6 Section 231.3

"Radiological postings should be displayed caly to tignify metual or potential rediotogtical conditions, Sigen used for tonining should be clearty morked, such as "For Training Purposes Only." 


\section{REQUTREMENTS IDENTIFICATION DOCUMENT HIGH LEVEL WASTE STORAGE TANK FARMS \\ Radiological Protection \\ Rovision}

\section{RELATED REFERENCES}

1. DOEJEROESTT Atticle 231

SITE REQUEREMENT SOURCE: DOE-NS490.6 Section 231.4

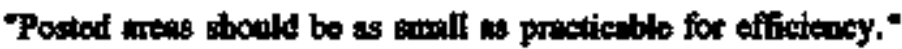

\section{RELATDD REFERENCWS}

1. DOE/EH0256T Article 23t

SITE REQUTREMTN SOUACE: DOR-N5480.6 Section 231.5

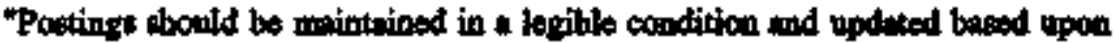
the resilts of the most rectent morveys."

\section{RELATED REFERENCES}

1. DOE/EHt0256T A sticle 231

\section{STTE REQUIREMENT SOURCE: DOE-NS480.6 Section 231.6}

"If more thn one rediological coadition (such as contamination and high

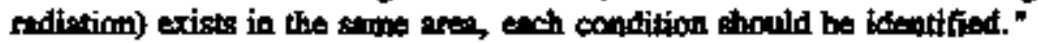

\section{RELATED RETERENCES}

1. DOE/EHO256T Article 231

SIFE REQUIREMENT SOURCE: DOR-N5480.6 Section 231.7

"In ares of ongoing wott activities, the dose nate end contemination lovel or rage of each should be included on or in conjuntica with tach pastiog as applicablo."

\section{RELATED RETERENCWS}

1. DOE/EH0256T Article 231

\section{STE REQUIREMENT SOURCE: DOE-N5480.6 Seetion 231.8}

"Entremce points to areat of ongoing work activities centrolled for ndiologital purposes should state busic entry requirements, web w dosimetry, Radiological Work Permit (RWP) wnd respirator required."

\section{RELATED REFERENCES}

1. DOE/EH0256T Article 231 


\section{REQUIREMENTS IDENTIFICATION DOCUMENT FIGH LEVEL WASTE STORAGE TANK FARMS \\ Radiological Protection \\ Berision 0}

SITE REQUIREMENT SOURCE; DOENS480.6 Section 231.9

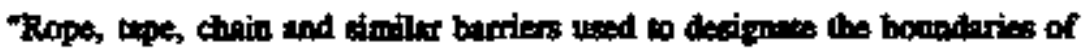
pooted arees shanld be yellow and magents in color."

\section{REIATWD REKERENCES}

\section{DOE/EHO256T Articlo 231}

\section{SITE REQUIREMIENT SOURCE: DOE-NS490.6 Section 232.1}

Pouting Controlled Aress

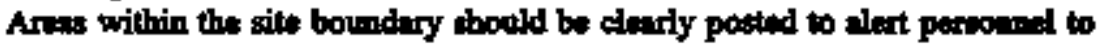

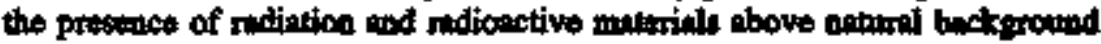

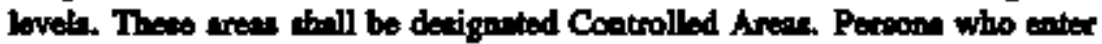
only the controlled Arte without entering Rutistion, Contuminition, Airtorne Redionetivity or Ratiological Buffer Aress are bot expected to tective mone than 100 mrem in a year. *

\section{SIFE REQUIRDMENT SOURCE: DOE-N5480.6 Section 232,2}

-The contractor my select the type of aign uesd to avoid confitict with lacal security requirements. This selection shall be upproved by the sith maior executivive-

\section{SITE REQUIREMOANT SOURCE: DOE-N5480.6 Section 233}

\section{"Pasting Radiological Buffer Areas}

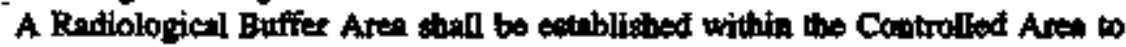
provide 1 second boundary to mimimize tbe spread of contamination. The Radiologicel Buffer Area is intended for uno where ongoing work tetivitien may create sirborne ndiouctivity or the spread of contumination It is not expected that Radiologicel Buffer Arens be establisted groued inectivo or gecured Contrmination Arens. The need for Radiolocical Buffer Arnta in conjunction wilh Radinsctive Material Aress should he evalunted."

\section{SITE REQUIREMENT SOURCE: DOE-N5480.6 Section 233,4}

Poeting of Radiological Euffer Areas shisl be in moconthine with Articto 231 and shalt contuin the wording "CAUTION, RADIOLOGTCAL, BUFFER AREA."

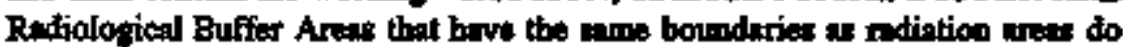
nol have to be posted."

\section{STE REQUIREMINT SOURCE: DOB-N5480.6 Section 234.1}

"Posting Radiation Arteus

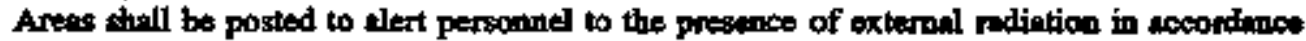
with Table 2.9 and Article 291." 


\section{REQUIREMENTS IDENTIFICATION DOCUMENT \\ HIGH LEVEL WASTE STORAGE TANK FARMS \\ Radiological Protection \\ Rerizion 0}

\section{REIATED REFERENCES}

1. DOE/EHO256T Articlo 234

SIIE REQUIREMENT SOURCE: DOENS480.6 Sectlon 234.4

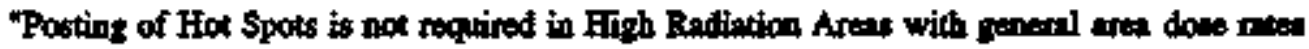
greater then 1 rem/hr of in Very High Rediebion Areas."

\section{RELATHD REFERENCES}

1. DOERHOOSGT Article 234

STIE REQUIREMANT SOURCE: DOE-N5480.6 Section 2345

The type of personel dosimeter used thy the twility shopla be included on the sim if the

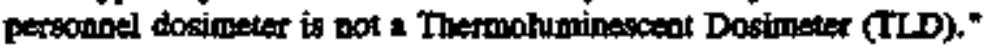

\section{RELATED REFERENCES}

1. DOE/EHO2S6T Article 234

SIIE REQUIREAIENT SOURCE: DOE-N5480.6 Section 234.6

The repuirement for 4 RWP should be included either $\infty$ or in conjunetion with the posting."

\section{RELATED REFERENCES}

1. DOEEHO255T Articlo 234

SITE REQUIREMIENT SOURCE: DOE-N5490.6 Section 234.7

"Dose received in in bour may be uad as the criterion for posting (Colurmn 2 of Tablo 2-3). In this Table, tho unit "rad" is sesocinted with dose rites that pose in immoditte droger."

\section{RELATED REFERENCES}

1. DOE/EHO256T Article 234

\section{STIE REQUIREMIENT SOURCE: DOE-NS480.6 Section 235.1}

"Postiog Contermination, High Contamination, agd Airbone Rediouctivity Areas Aress shell to posted to alert personnel to contamination in sccordance with Tablo 24 and Article 231."

\section{RELATED REFERENCES}

1. DOE/EHO256T Article 235 


\section{REQUIREMENTS IDENTIHICATION DOCUMENT HIGH LEVEL WASTE STORAGE TANK FARMS Radiological Protection Rerision 9}

SITE REQUTREMIENT SOURCE: DOE-N5480.6 Section 235.2

The rexuirement for an RWP should be inefoded eitber oe of in coujunction with each posting at spplicable."

\section{RELATED REFERENCES}

1. DOEREHO2S6T Ardide 235

STrE REQUIREMIFNT SOURCE; DOE-NB460.6 Section $\mathbf{2 3 5 . 3}$

Derived Air Concentration (DAC) valum for ues with Table 2-9 are found in DOE $5480.11 . *$

\section{RELATED REFERENCES}

\section{DOE/EH0256T Atticle 235}

\section{STIE REQUIREMIENT SOURCE: DOE-N5480.6 Section 236.1}

"Postiog Radioective Miterial Aress Areat where radioactive materiats an used, hendied of coored shoutd be posted "CAUTION, RADIOACTIVE MATERIAL." The pousting shofl meet the requirewents in Article 231."

STIE REQUIRTMENT SOURCE: DOE-N3480.6 Section 236.2

"Radipactive Mntroinl Areas should be lochated withun Controlled Arans."

SIIE REQUIREMENT SOURCE: DOE-N5480.6 Seution 236.3

"Pouting for Redionctivo Materint Arean is not xoquired whed the rndionetive material is inside a Contamination or Airbomo Radionctivity Area."

STIE RBQUIREMIENT SOURCE: DOE-N5480.6 Section 237.1

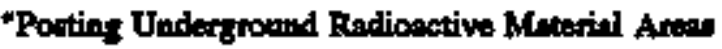
Underground Redionctivo Material Artas shall be estrblished to indictte the

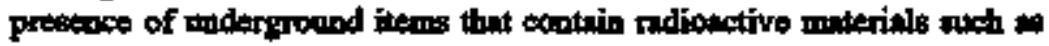

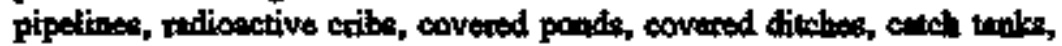

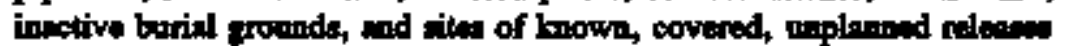
(spills)."

SITE REQUREMIENT SOURCE: DOE-NG480,6 Section 2372

"Underground Rediosctivo Material Aree thall bo posted "UNDERGROUND RADIOACTIVE MATERLAL." The posting shall mees the applicable requireanents of Article 231." 


\section{REQUIREMENTS IDENTIFICATION DOCUMENT HIGH LEVEL WASTE STORAGE TANK FARMS \\ Radiological Protection \\ Revivion 1}

STTE REQUIRFMENT SOURCE; DOE-N5480.6 Section 237.3

"Uaderground Redionctive Meterial Arese be loceted ineide or outride Controlled Aress and are exempt from the entry mat exit requirements of Chapter 3."

SIIE REQUIREMENI SOURCE: DOR-N5480.6 Section $\$ 51.1$

"Radiological Monitoring ind surveys

Requirement:

Radtolopical monitoring of radiation axpoctro lovets, contaninetion and

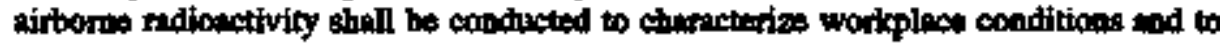
identify artess requiring pastinge."

\section{RELATED REFERENCES}

1. DOE/ERT0256T Article 551

STIE REQUREMENT SOURCE; DOEJEHO135 RP.10 CONTAMINATION CONTROL9

-9. Conthmingted arens are ctearty identified and hove the contamination levels and the protective meagures rectived clearly posted at the entrance."

\section{SITE REQUIREMIANT SOURCE: DOE/FHO139 RP.IO RADTATION} MONITORING.4

- 4. Dose mate values are established for postiog rediation urean and ipproximate doee rates are posted."

\section{STTE REQUIREMERT SOURCI: DOE/EHT135 RP.3 POSTING.1}

"w1. The tochnicel criterih, and dose rato and/or levels, for defining nadiation, high

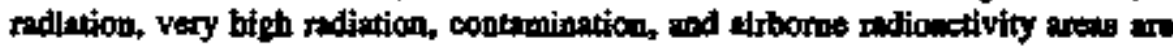
establisbed, documented, and constistently applied."

\section{SITE REQUIREMENT SOURCE: DOEEHT0135 RP.3 POSTING33}

*3. DOE required forms sro posted in all facilities co the eife,"

\section{SITE REOUREMENT SOURCE; DOEMRHIU135 RP,3 POSTING.6}

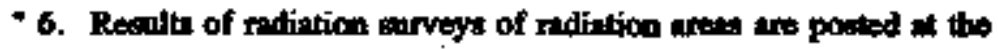
entrance."

\section{STTE REQUIREMENT SOURCE: DOEEHO135 RP.3 POSTING.7}

"7. Ajborde activity aress are posted to alext personnel to postiblo respiratory protection requirements." 


\section{REQULREMNTS DENTIFICATION DOCUMENT \\ FIGH LEVEL WASTE STORAGE TANK FARMS \\ Radiological Protection \\ Rerision 1}

\section{SITE RRQUIREMENT SOURCE: DOR/EH0t35 RP3 POSTING.9}

9. Aness where natioactive miterisis are handled or stored aro clearty and cecuntely posted."

\section{STIE REOUIREMIXNT SOURCR: DOEJXI0135 RP.6.3}

-3. Accurates and timely sirbone milontivity gurvey information is evailble for determining the bonderies of aibares radionctivity awe. posting entry requirements, and minimizing internal exposule to workers during wort attivitien. The boundacies of these aves are cleatly identified and posted."

\section{SITE REQUTREMINT SOURCE: DOE/EHO135 RP.6.4}

- 4. Aceurate und timely contaminestion sarvey toformation is avoilahte for determining the boumduries of sifbore radiostivity aress, posting entry requiremeats, and minimizing internel expomire to worters derins: work activities. The boundaries of these rets are clearly identified and poeted."

\section{SIIE REQUIREMENT SOURCE: DOE5490.11 Section $9 . k$}

"Pasting and Labeling. Areas to DOE uxcleur fucilities ghall be posted in ecoordance with the provisions given below. Rudionctive miteriel andior ive contwiner strall bo individerilly labeled where normal postint of the area nod control of the moterinl would not provide adequate protection. The desigal of sizpos, labels, and the ndiption symbol shall ecoform to ANST N12,1-1971 and ANSI N2 1-1971. The background color is to bo yellow; the eymbol color woy bo biack or magente."

\section{SITE REQURRMIENT SOURCE: DOE5480.11 Section 9.k(1)}

"Controlled Aros. The mecess to any controllest area where rationctive meterials or elovated rodiation fields may be present shall be clearly md conepicuously poeted as a controlled ares. The type of sign used may be selectod by the controctor with the approval of the field organization to aroid conflict with locel security requirements."

\section{SITE REQUIREMENT SOURCE: DOES480.11 Section 9.k(2)(a)}

"Rudiologieal Ares

(a) Poeting for External Rudiention. The wocess to my uren where in individual ten at any time turing normal operations receive a dose squivalent greaker thrn 5 mrem ( $50 \mu \mathrm{sv}$ ) in 1 hour at 30 centimetess from the redintion source or any surface through which ractiation pepetrates thall be posted as below. In teldition, the anticipated dose rate or range of dose rates stull be ineleded on or in conjunction with each of tho sigas, as appropriate." 


\section{REQUIREMENTS IDENTIFICATION DOCUMENT \\ HIGH LEVEL WASTE STORAGE TANK FARMS \\ Radiological Protection \\ Revision 4}

\section{SITE REQUREMEENT SOURCE: DORS480.11 Section 9.2(2)(a)t-3}

"1 "Rudintion Ares" for my ato within a controlfed aren where an indivitual cen receivo a dose equivalent grenter thap 5 in tem (SO pSv) bat lesa then 100 mrom $(1 \mathrm{mSv})$ in $1 \mathrm{hr}$ at $30 \mathrm{~cm}$ from the radietion

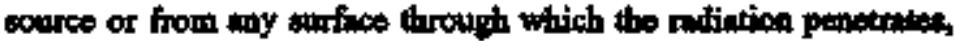

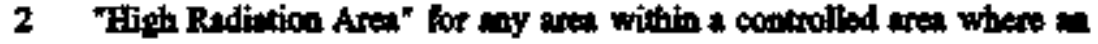

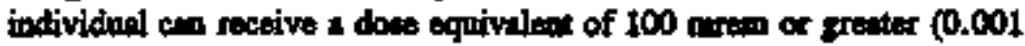
nievert) bet kes than $5 \mathrm{~mm}(0.05$ sievert) in 1 he at $30 \mathrm{~cm}$ from the

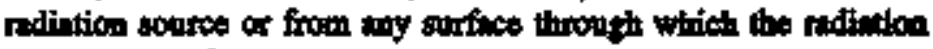
penetrated, and

3 "Vey Hiph Ratietion Ares" for eny anea withth a centrolled ane where $m$ individual cm resive $a$ dose of 5 rem (0.05 sievert) or greater in 1

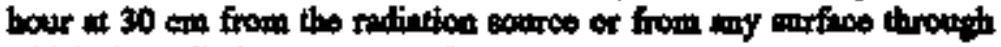
which the rediation peoctintes."

\section{SIIE REQUIRTMENT SOURCE: DOES480.11 Section 9.1(2)(b)}

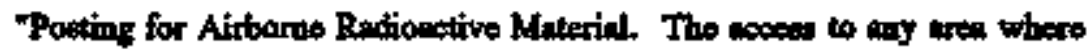

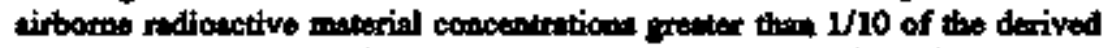
air concentrations (Attectment I) are present shall be cleorly and contepicuosuly posted with as sign thet identifies tho rudiologioal conditione which exist (a.g., "Ajtbore Rudiouctivity Area"). The type of sigo usod shall be consistent with the mdiation protection control policiss esteblisted at the ficility and may be selected by the contractor with tho approval of the field organization."

\section{SITE REQUIREMANT SOURCE: DOE5480.11 Section 9.k(2)(c)}

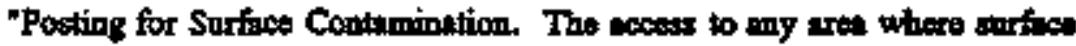

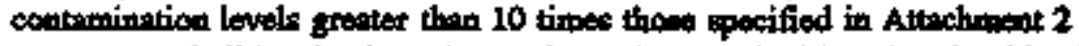
are precest sholl be clearly and conepievoucly poeted with a sign the identifiee the radiological cooditions which exist (e.g., "Contamination Aver"). The type of sign used sholl be consistent with the ndiation control policies entablished it the frocility and may be exlected by the centractor with the approvil of the field orpteniztion.
}

\section{SIFE REQOIREMENT SOURCE: INPO-38-010 Chapter III, section 4.b}

Postities and Use of Survey Information

An aneas should be posted and controlled as required by regulation. For trimsitory high radiation areas, auch as moving a large cource through the RCA, the are need not be poeted, bat positive control should exist using mean such as a radiological protection technicien in attendence. Flot spots

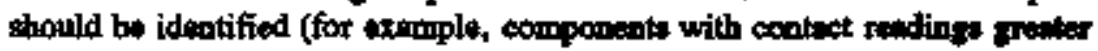
then $100 \mathrm{mream} / \mathrm{h}$ sind more then five times the general area dose retes).

Survey information in the form of nops, stens, RWPs, of stams boatds ahould be readily available it wort aress ind easy to understund. This strvey informotion should also be aufficiently detailed to allow workers to be knowledgeable of the exposure rate profile in large arees such as the reactor building or continmeat tend stould be dated so workere are awre of it 


\section{REQUIREMENIS IDENTIFICATION DOCUMENT \\ HIGH LEVEL WASTE STORAGE TANK FARMS \\ Radiological Protection \\ Rerivina: 0}

timelinoss. Workes should roviow this information prior to ontering

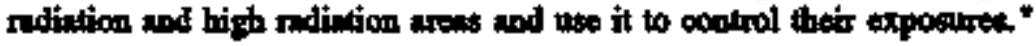

SITE REQUIREMENT SOURCE: WAC-402-24 Section 090(1)(a)(b)(c)

"Generl.

(a) Except as otherwioe mithorized by the department, cymbole prescribed by this section shall use the conventionel redintion centican colors (magenth or prople on yellow beckpround). The cymbol preasribed by this section is the ponventionel threobleded derign.

(b) The conventiont redietion symbol at described in (a) of thit mbection thell bo used only for:

(j) Inetructing individuals to be cogrizent of a potential redietion havand a prescribed in (c) through (j) of this subection

(ii) Indicatint that information presented pertains to the topic of radiation.

(c) In widition to the conkents of signs and labels prescribed in this exction, licensees may provide on or near such sigas ind lathels thy additional informetion which moy be appropriate in aiding individasts to minimizs exposure to radiation or to radiococtive mesteriel."

\section{RELATED REFERENCES}

1. 10CFR20 Pant 20.203..

SITE REQUIREMENI SOURCE: WAC-402-24 Section 090(1)(d)

Radintion areas. Each radiation area and entrance thereto chall bo conopicuonsly posted with a sige or aigns bearing the rediation caution symbol and the works:

\section{CAUTION}

RADIATION AREA*

\section{RELATED REFGRENCES}

1. 10CFR20 Part 20.203.6

\section{GITE REQUIREMENT SOURCE: WAC-402-24 Section 090(1)(e)(0)}

"Hith radiation istats.

(1) Each high fudiation area and extrance thereto shall be cooppicapusly posted with a sign of signs bearing the rediation cention symbol and the wordes CAUTION

HIGH RADIATION AREA*

\section{RELATEO REFERENCLSS}

1. 10CFR20 Part 20.203.t.(1) 


\section{REQUIREMENTS DENTIFICATION DOCUMIENT \\ HIGH LEVEL WASTE STORAGE TANK FARMS \\ Radiological Protection \\ Rerision 0}

STIE REQUIRTWINT sOURCE: WAC-402-24 Section OSO(1)(t)

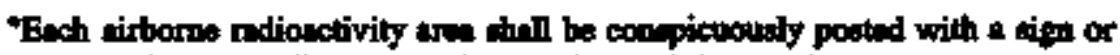
sipas bearing the radintion ention bymbol and the wonds:

CAUTTON

AIRBORNE

RADIOACTIVITY AREA"

\section{RELATED RDFERENCAS}

1. 10CFR20 Part 20.203.d.(2)

\section{SIEE REQUIRRMENT SCURCB: WAC-402-24 Section 090(I)(g)(i)}

"Additionel requitrements.

(1) Eech ares of room in which liceaced motatel if ueed of etored and which contrims any modiosetivn muterial (other than maturt uraninim or

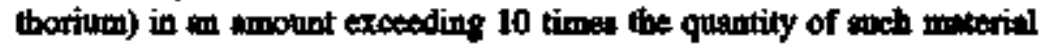
epecified in Appendix B of this part thent be conspicnowedy poesed with - sign or sigm bearing the radintion caution symbol and the worts:

CAUTION

RADIOACITE

MATERIAL(S)*

\section{RFILATED REFERENCES}

1. LOCFR20 Part 20.200.0.(1)

STIE REQUIREMENT SOURCE: WAC-402-24 Section (190(1)(h)(i)(fi)

"Containters.

(1) Except provided in this section, exch contriner of rationctive moterial shull bear a durable, elearly visible libel identifying the redicantive contente

(2) A label required porasent to (b)(i) of this mabection thell bear the rediation caution symbod and the words; "Cnution, Radiontetive Material". It thall also provide penfificint informition to permit individuels bondling or usting the contuinest, of warking in the vicinity thercof, to take prectutions to avoid of minimize exposires."

\section{RELATEN REFGRENCES}

1. 10CFR20 Part 20.203.f

STIR REQUIREMENT SOURCE: WAC-402-24 Section 090(2)

"Notwithstending the provisons of subsetion (1)(h)(i) of this section labeling is not requined:

(a) For laborztory contribers, such s belkers, flesks, and teot tubes, wed transiently in leboratory procedures when the perron using such contriners is 


\section{REQUIREMENTS DENTIFICATION DOCUMENT HIGH LEVEL WASTE STORAGE TANK FARMS \\ Radiological Protection \\ Rerision 0}

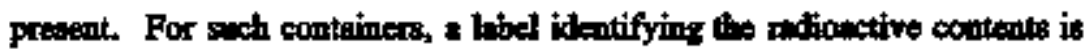
required.

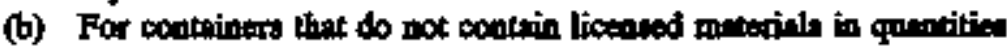
greater there the spplicable quantities lieted in WAC 402-24-230, Appendix $B$.

(c) For conkainers conthining only meturd nnming or thorium in quntities Do greater thin 10 tiones the applicolate quantities fieted in WAC 402-24-230, Apponix B.

(d) For contribers thet do not contrin licenoed meteriels in concedtrations Frenter then the appliestle concentrations lieted in WAC 402-24-220 Coluen 2, Table I, Appendix A.

(c) For onteiners when they aro atteaded by an individual who the tho proctutione necesescy to provent the expoenro of any indivituel to rediation or redionctive meterials in exceses of the limitr exteblinhed by the regulintions in this part.

(f) For containers when they aro in transport and packeged and labeled in

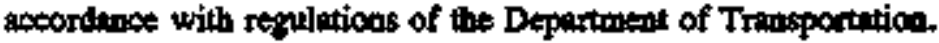

(9) For contrints which are accessible coly to todividnels anthorized to handis or use them, of to wort in the vicinity thereof, provided that the cortents wre identifised to such individunla by a rendily ovailablo written record.

(h) For menuficturing or process equiproent, sush w paclent reactors, reactor corroponents, piping and unk."

\section{RELATED REFERENCES}

1. 10CFR20 Part 20.203.f.(3)

\section{SITE REQUIREMENT SOURCE: WAC-402-24 Section 090(3)}

"Each licensee stall, prior to disposal of an empty umcontaminnted contuiner to unostricted sres, remove or defuce the radionctive mintorial label or otherwise clearly indicate that the contain no longs contating radionetive matterinls."

\section{RELATED REFERENCES}

1. 10CrR20 Part 20.2003.f.(4)

\section{SITE RSQUIREMENT SOURCE: WAC-402-24 Section 095(3)}

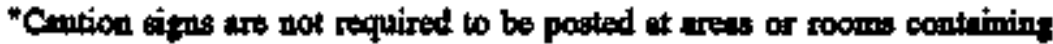

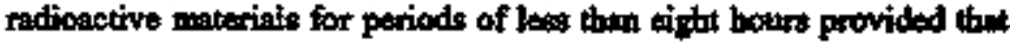

(1) the materinls aro constently atteoded dering such periods by an individual who sull the the precenutions necessary to prover the exposure of any individual to rediution of ndionetive materinls in excess of the limits estebliched in the regrilations it this parts and

(2) such arew or room is subject to the licenese's control." 


\section{REQUIREMENTS IDENTIICATION DOCUMENT HIGH LEVEL WASTE STORAGE TANK FARMS \\ Radiological Protection \\ Rarision}

\section{RFLATIU REPTRENCES}

\section{10CFR20 Part 20.204.4}

\section{Radiation Wort Permitk}

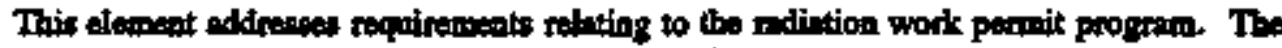
midintion work permit progran is mother type of procectural control bot is purticularily importint as it plays a myjor mole in ecusuring that the ridiation protection propram worts on all levele.

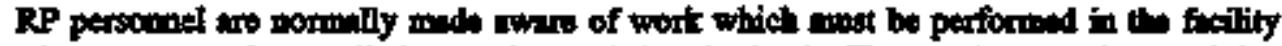

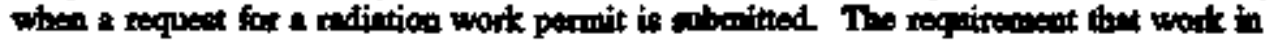

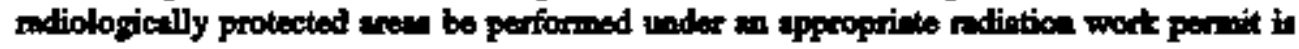
the primary method of ensuring appropriate surveys fire performed prior to the wort,

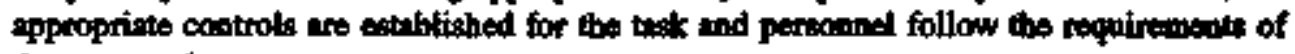
thoos controlle.

Finally, the rediation wort permit program is the mijor vebicie for documenting the nidiological espects of the jot.

STTE REQUIREMIFNT SOURCE: DOE-N5400.6 Section 321

-Wort Preparation

Rudintogical Work Permits

The Rediological Work Permit (RWP) is an edminisantive mechenism used to etablish adiologienl controla for intended work activitien. The RWP infomm worken of 살 radiological conditions and atry requirsments and provides a

IItectranism to relate worker exposuse to specific wort setivities. The RWP should include the following information:

1. Description of work

2. Work area robiological conditions

3. Dotimetry rexuirements

4. Pre-job briefing requirements, as applicable

5. Traiming requirements for entry

6. Protetive elothing and recpirntory protection requirenonts

7. Ratiologitel Control coverage requiromonts and atay time cortrols, wo Tpplicablo

8. Limiting ndiological conditions thut may void the RWP

9. Specin dow ar contamination reduction coosideretions

10. Special pessonnel frisking concideration

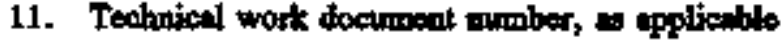

12. Uniqu identifying number

13. Date of issus and expiration

14. Antboriving signetures."

\section{REI_ATED REFERENCES}

1. DOE $2 H 0256 \mathrm{~T}$ Article 321 


\section{REQULREMENTS IENTIFICATION DOCUMENT \\ HIGH LEVEL WASTE STORAGE TANK FARMS \\ Radiological Protection \\ Reviston 0}

SITE REQUIREMAENT SOURCE: DOENS480.6 Section 322.1

Use of Radiologicat Work Permits

RWP shatl be need to control the following activitios:

a. Entry into Eight and Very Figh Rudiution Aress

b. Eotry into High Contumination Areas;

c. Enery into Airborso Redicactivity Areas."

\section{SITE REQUIREMIFNT SOURCE; DOE-N5480.6 Section 322.2}

RWPs abould be used to control the following ectivities:

n. Entry into Rediation Arear;

b. Entry irto Contromination Arteres

c. Hendlins of makeriali with removable contemination thet exceed the values of Table 2-2."

STIE REQUIREMENT SOURCE: DOE-N5480.6 Section 322.3

"Job-ppecific RWPs shall be used to control ncon-routioe operations or wort in ares with changing natiological condition. The job-ipexific RWP thll remain in effeet only for the chutation of the job."

STIE REQUIREMENT SOURCE: DOE-N5480.6 Section 322.4

"Genenl RWP. nny be used to control suatine or repetitive nativities, ach $\omega$ cours and inspections or minor work activities, in wreas with well-characterized and stable rediological conditione Generel RWPs thopld pot be appoved for periods longer then 1 yeur."

STTE REQUTREMENF SOURCE: DOE-N5480.6 Section 322.5

"Rediological surveys shall be routinely reviewed to eveluate sdequacy of RWP

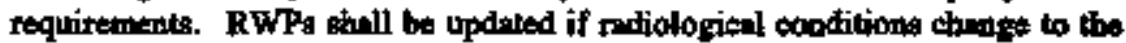
extent thit protective requirements beed modification."

STIE REQUIREMENT SOURCR: DOE-N5480.6 Section 322.6

"RWPs should be poded it the encese point to the epplicelbio radiological work areat"

STTE REQUIREMENT SOURCE; DOE-N5480.6 Section 322.7

-Workers atsill sigo that they heve read, uoderstand and wall comply with the RWP prior to initial entry to the aree end after any novirions to the RWP."

SITE REQUEREMENT SOURCE: DOE-N5480.6 Section 322.8

Worter pocket or sioctronic dosimeter readings thould be rocordad in that identifies and provides linking to the appliceble RWP." 


\section{REQUIREMENTS IDENTITCATION DOCUMENT HIGE LEVEL WASTE STORAGE TANK FARMS \\ Radiological Protection \\ Rerision 1}

SIIE REQUIREMIENT SOURCE; DOE-N5490.6 Section 322.9

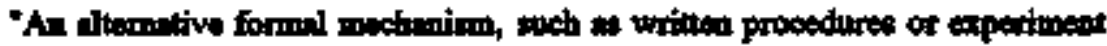

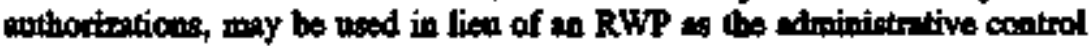
over radiclogical wotk activitie. If an sltemetive mechmimm is ued, it thould meet the requirements of this Article and Articles 321 and 323."

SITE RDQUIREMIENT SOURCE: DOE-NB480.6 Section 323.I

"Rediglopical Work Permit Preparation

The roponsibility for enourins edequeto planning and control of wot

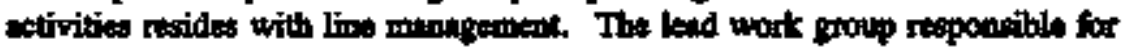

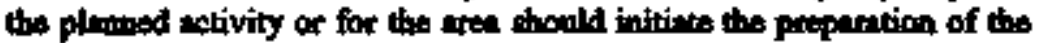
RWP."

SIIE REQUTRMIONT SOURCE: DOE-N5490.6 Section 323.2

"RWPs aball be reviewed and approved by the Radiolopiol Coutrol Organization."

SITE REQUIREMENT SOURCE: DOE-N5480.6 Section 323.3

"The RWP shall be based on curreat ndiclogical sprvery nod anticipated endiological conditions."

SITE REQUIREMENT SOORCE: DOE-N5480.6 Section 323,4

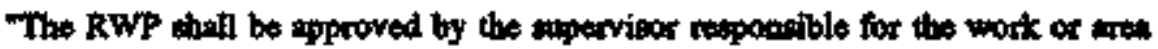
and the eppropriate Radiological Control aporvisor. Revisions or extentions: to RWPE uhill be subject to the emo epproval prooes.

\section{SIEE REQUIREMENT SOURCE: DOE/EH0135 RP.10 CONTAMINATION} CONTROL.3

-3. Radiution work permits or similar controls are used to control ecoss to contuminated aress."

\section{STTE REQUIREMIENT SOURCE: DOE/EFO135 RP.3 POSTING.5}

-5. Current rndiation work permita (radintion zons entry permits) meeting the requirements of the site/ thility are posted at entrnices to wurt arean. Thoy reflect actual working conditions Out-of-date work porsith are removed in e timedy munnex."

\section{SITE REQUIRFMANT SOURCE: DOE/EHO13S RP.3 PROCEDURXS.4}

- 4. Radietion wort procedures (permits) ane used for all raliation area work. These procedures are approved by bealth physics steff ant contain adequate provisions for.

- Protective epperel, 


\section{REQUIREMENTS DENTIFICATION DOCUMENT HIGH LEVEL WASTE STORAGE TANK FARMS \\ Radiological Protection \\ Revision o}

- Wott limituions,

- Job dacpiptions,

- Rediolojical constitions, and

- Special inatructione."

\section{SITE REQUIREMANN SOURCE: DOE/ER.9135 RP.6.5}

- 5. Redintion wort pesmitt or similar controls are and to ecatrol personned

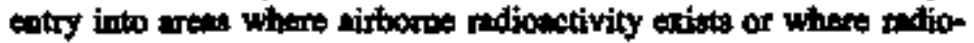
active anterial may becoms sibame due to work heing perfomed."

\section{CONTAMINATION CONTROL}

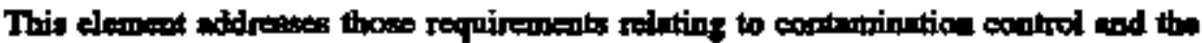

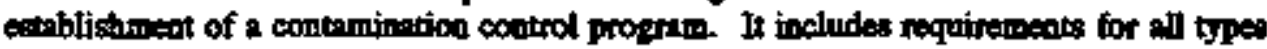
of contranination - solid, waterborne or airbome.

Controtling contamination is directly related to reducing expoeure to pessonnet at the fueility for severai rensons. The wost importint reason involves the anoumt of time it tokee for personanel to work in contaminesed ereas (particularly if respiratory protectivo equipanent is required) versts worling in clen arces. The most direct relntionstip betwen contamination control and expasure involves the potentiel for contemintition to be ingested or inhsled while performing work in conteminebed enes.

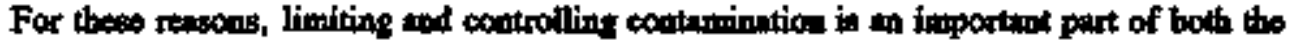
overall Radiation Protection program and the factlity ALARA program.

\section{SITE REQUTREMENT SOURCE: DOE-N5480.6 Section 221}

-Contamination Control and Control Lovela

Coatrol of mdionctive cuntumination is achieved by using eoginesriag controls and worker performance to contain conteningtion at the source, rediesting

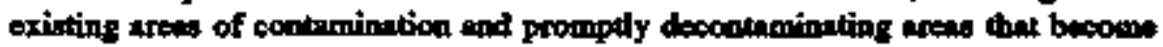
contaminoted"

\section{SIIE REQUIRPMENT SOLRCE: DOR-N5480.6 Section 316.1}

Minizization of Intratel Exposere

The minimizetion and control of interat expostro es discused in Articlo 136

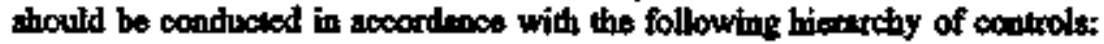
Enginescing controls, inchuding conleinment of redionctive matorill at the source whovever practicable, should be the primary method of minimizing tirborre radioactivity and internal exposure to whorkers." 


\section{REQUIREMENTS IDENTHFICATION DOCUMENT HGH LEVEL WASTE STORAGE TANK FARMS \\ Radiological Protection \\ Rerision 0}

SITE REQUREMENT SOURCE: DORAN5480.6 Section 316.2

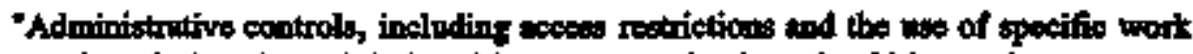

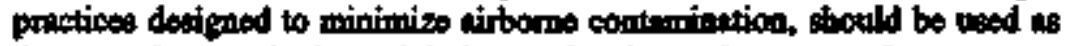

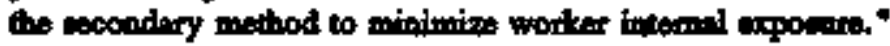

STTE RBQUIREMEENT SOURCE: DOE-N5460.6 Seetion 463.1

-Decoormanination

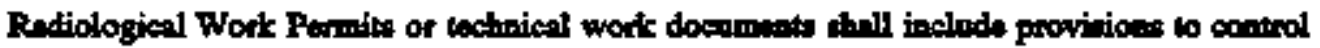

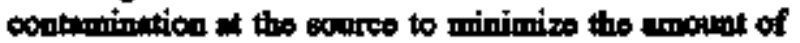

decontontination neded."

RELATED REIERENCES

1. DOE/EHO2S6T Artith 463

STTE REQUREMFENT SOURCE: DOE-N5480.6 Section 463.2

Work prepianning eboll iaclude consideration of tbe bandling, teuponsy storage, and decontamination of materials, toobs and equipment."

FELATED REFERENCES

1. DOE/EH0256T Article 463

\section{SIIE REOUIREMENT SOURCE: DOE/EHO135 RP.10 CONMAMTNATION CONTROL.17}

"17. Operations with $\mathrm{a}$ high potestial for relecse of contrminesion are performed in accordance with job-specific procedures thet minimize the potentinl for relesse."

SITE REQUIREMENT SOURCE: DOF/BH0135 RP.10 CONTAMINATION CONTROL.18

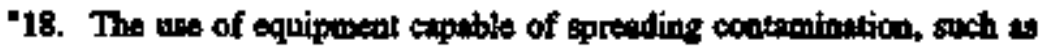
blowers, fins, and vacurem cleanens, is controlled lo provent the rpreed of contrmination-"

\section{SITE REQUIREMIENT SOURCE: DOEJHO135 RP.10 CONTAMINATHON CONHROLS}

" 5. Adequate doctunented protoctive meanures are employed, whene practicable, to maximizs contamination control." 


\section{REQUIREMENTS IDENTIFICATION DOCUMIENT HIGH LEVEL WASTE STORAGE TANK FARMS \\ Radiological Protection \\ Rerision 0}

\section{SITE REQUIREMENT SOURCE: DOEARO135 RP.10 CONTAMWNATION CONIROL.6}

- 6. Leske from radionctive systems are promptly conbined and ropeirad, nod afiected ares are decounminuted."

\section{STIE REQUTREMIENT SOURCE; DOEIEH0135 RP.10 CONTAMINATION CONTROL.7}

-7. Contantination and dose rate limitr for equipment and mola strered and used only in rediation zones are enblished."

\section{SIIE RSQUREMIFNT SOURCE: INPO-88-010 Chapter IV, Section 3(b), Butlet 3}

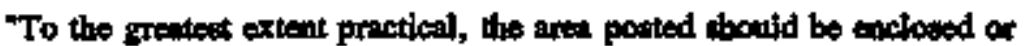
contained within a room, tent, bag, box, or acher dovice to provent the spread of sirbore and locse surface rndiouctivity."

\section{Source Containment. Confinenent, and Ventilation Control}

This etemeat addresses those requirements relating to the costrinment and confinement of

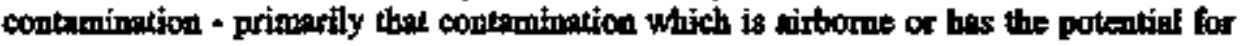
becoming nitborge. It includes requirtments for the approprinte maintengose and upe of ventikation and other types of equipment to coatrol contamination. It also incleded requirements reluting to sppropriste wark practices to provent airforne contaminntion and spproptitate enginesring controls to limit and control tirborns contminimation.

\section{STIE REOUIREMIENT SOURCE: DOE-NS480.6 Section 136}

\section{Intemal Exposires}

Control and prevention of internel exposurs from long-lived rectionuelides in the workplece present special challeages to a Rodiotogited Control Program and warrant particalar attention. Even though interual exposure is mensured in the exmo mits as extemin

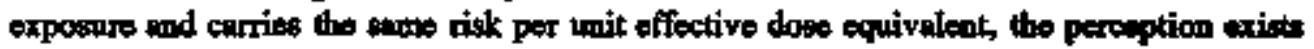
that it is of grester sigrificance since the exposure is the reanlt of realioisotopes retuied within the body.

Aoministrtion of internal dose assessment is costly in dollars ent worker time. Control and enalysis of anmples is also mone complicated then the elemente of external docimetry.

In order to minimize internal exposures, maneges should tak delibente ection to control

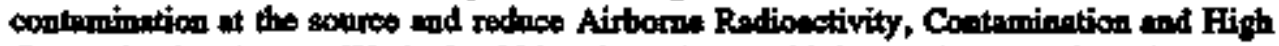
Contemintion Arean. Work should be planned to avoid the routine use of respiratory protection devices. Internal exposures thould be refuced to the minimom protictalo level ind the following shoutd be considered:

- Workers may be exposed to unanticipated levels of elevated tirtaroi radionctivity. Colletiong representative siborse rediosctivily samples and the time required for technicians or witomited instruments to 


\section{REQUIREMENTS IDENTIFICATION DOCUMENT \\ HIGH LEVEL WASTE STORAGE TANK FARMS \\ Radiological Protection \\ Rerision 1}

determine the vitbornt concentration of ndionuelides may contributo io worker intakes of radionctivity.

- If controle fril, intornal depositione of radiomelides can ocour in a short period of titns.

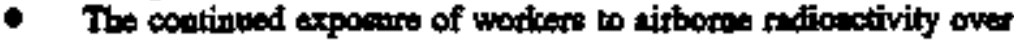

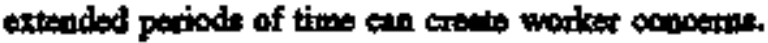

- Doses from somo internal ndionoclides are difficolt to mesorre.

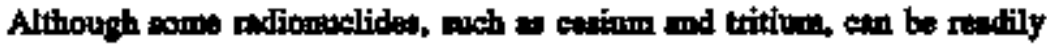

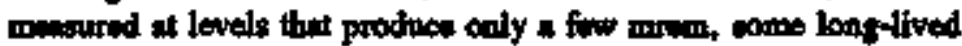

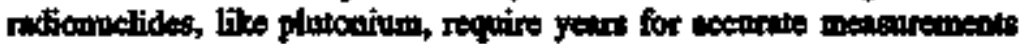
of tmadieds of mrem

- Medical intervention, weh as the comainidtetion of blocking and

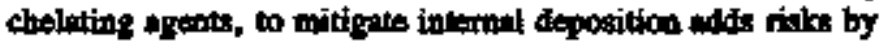
introducing additionel chemicels into the body."

\section{STTE RBQUREMIENT SOURCE: DOE-N54\$0.6 Section 316.2}

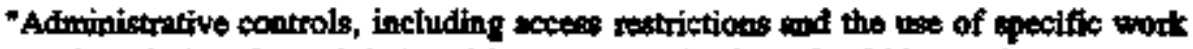
practices designed to minimize sirbome contumination, should be ued at the scoondary method to minimize wotker internil exposure."

\section{FACHLTY REQUIREMENT SOURCE: DOE-N5480.6 Section 45.1}

"Coutrol of Radiosetive Drains

Redionctive drain systems are desigoed to transport radionetive liquids. Improper use may cuuse a environmental releese.

Radioutive drain systoms stoonld nok dischnrge to the environment nor be uned for the disposel of nonratioactive liquide."

\section{FACIITY REOUIREMIENT SOURCE: DOE-N5480.6 Section $\mathbf{4 5 2 . 2}$}

"Existing radiosetive drains should be evaluated to encowo the following:

h. Verifiention of the existing mdionctive denin piping configuration;

b. Instellition of Alow-indicating devices in lesk-off lines;

c. Use of pluge to prevert nonedionctive toputs

d. Consideration of alternetive work controls before systeme are drained for mininterentse;

- Controls prohibiting unouthorited nse of driass."

\section{FACIL,ITY REQUIREMIYNT SODRCE: DOE-NS480.6 Section 452.3}

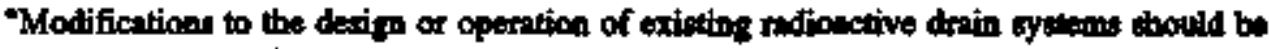
contralied to includes

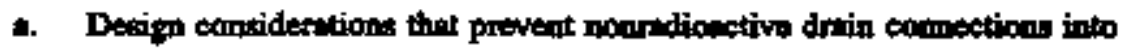
redioactive dring;

b. Procedural and desifip controls to prevent crose-connoctions of

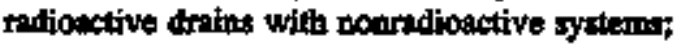

c. Menagement review of absequent chenges to the design of midactive drain syatems of radionctive dring controls;

d. Mansgement controlit to restrict the fatroduction of bazindots wastes into radioustive drain syrterm." 


\section{REQUIREMENTS IDENTIFICATION DOCUMENT HIGH LEVEL WASTE STORAGE TANK FARMS Radiological Protection Revision 1}

\section{FACILITY REQUIREMIENT SOURCE: DORN5480.6 Section 453.1}

\section{"Control of Aitborne Redionettivity}

Procesese and netivitios with tho potential for producing virborns

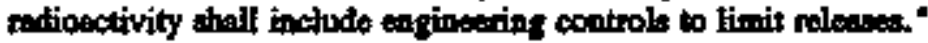

\section{FACIIIY REQUIREMENT SOURCE: DOE-NE480.6 Setion 453.2}

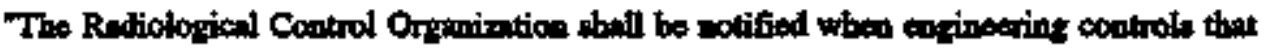

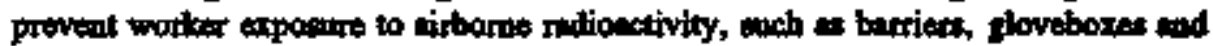

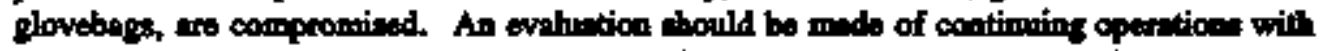

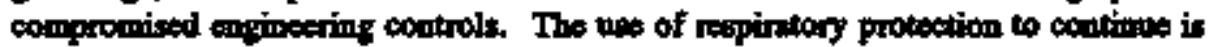
Hescounged. Inplementation of ebort-term engtinering modifictitiong that provide a commengurpto level of worker protection is the proferred silemeative."

\section{FACILITY REQUIREMRENT SOURCE: DOE-N54\$0.6 Section $\$ 33.3$}

"Preventive mainteasoce fod surveillence procedores shall be extablithed to enture equipment controls are tritintained in an operable condition for contatimeat of airborn nedioactivity."

\section{SITE REQUIREMENI SOURCE: DOEJER0135 RP.6.2}

- 2. Enginesed controls are wed to prevent the intike of radicactive materisl, incloding the following, when feusible:

- Portable filtration systems are ued 10 control airborne contemineats.

- Containmeal struchures, wach is tents, wro used to protect personnel worting in abjocent aress, and

- Unique fitting are used for tho plent benthing sir syotem."

\section{Personnel Contamingtion Monitoring}

This element addresses the requirements relating to the monitoring of personnel for contumitination duriog and efter work in rndiologically proteted areas. Theoe requirements define when monitoring must bo performed and epecific requivemeate for properly perforning personel monitoring.

\section{SITE REQUIREMENT SOURCE: DOE-N\$480.6 Section 221.2}

"Monitoring for contemination ahould be parformed neing frisking equipment that wodes labotatory conditions con detect total contionimation of at lest tho values specifiod in Table 2-2. Use of autometic monitoring unite then meet the whowe reypiremeots is encounged." 


\section{REQUIREMENTS IDENTIFICATION DOCUMENT HIGH LEVEL WASTE STORAGE TANK FARMS \\ Radiological Protection \\ Rerision 4}

\section{SITE REQUREMENT SOURCE: DOE-NS480.6 Section 338.1}

Monitoring for Personind Contrininetion

Persomed ethall perform a whole body frist under the following conditions

a. Immodintaly upon exitin: Contuminution Areas, Hidh Contemination Arans and Airborne Relloactivity Areos;

b. As direted by the RWP or the Rediological Coatral Orgarization."

\section{STIE REQUIREMINTT SOURC: DOF-N5480.6 Sectlon 338.2}

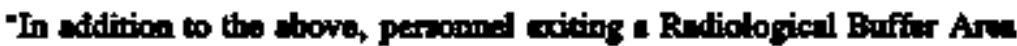
contrinies Contamintion, High Contrinination or Atrome Redionetivily Are:

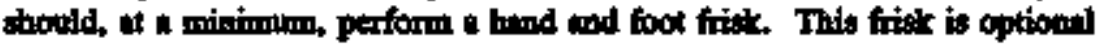
If the Rutiolopical Buffer Aree exit is immodintely adjecent to tho bocation where the exiting worticer has already performed i wholo body frisk."

\section{STTE REQUIREMENT \$OURCE: DOENS490.6 Section 338.3}

Where fristing cunnot be performed at the exit from Contaminition Arres, High Contumination Aress of Airborne Ratiosctivity Arese tue to high backgroand radietion levels, persoinel tholl:

a. Remove sll protective equipment and clothing at the exil;

b. Proceed dirotly to the nesrest designated moaitoring station;

c. Coodret a whole body frist."

\section{SITE REQUIREMENT SOURCE: DOEN5480.6 Sectlon 338.4}

Terromel frisking shall be perforned after removal of protective clothing and prior to washing or showeriog."

\section{SITE REQUREMENT SOURCE: DOEN5480.6 Sectian 338.5}

"Perscomed frisking shall be parformed using instruments thet mext the minimum

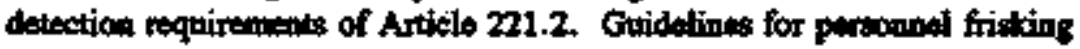
are provided in Appendix 3D."

\section{SITE REQUIREMIENT SOURCE; DOE-NS480.6 Section 338.6}

The us* of antometed personnel contumination monitors is encosonted."

\section{SITE REQUIREMIENT SOURCE: DOE-N5480.6 Section 338.7}

Personal itents, such as notebooks, papera and ftenhlights, shall be wojoct to the same frivkting requiremants as the persoe cerryin: them."

\section{STME RRQUIREMIENT SOURCE: DOFNS480.6 Section 338.8}

Finstructions for persomel frisling should be posted afjecent to perwomel frisking inktrumpents or monikors." 


\section{REQUTREMENTS DENTIFICATION DOCUMENT \\ HIGH LEVEL WASTE STORAGE TANK EARMS \\ Radiological Protection \\ Revistan 0}

SITE REOUIREMENT SOURCE: DOEN5430.6 Sextion S41.1

"Handing Radiologically Contaminatad Personeal

Srin Contenination

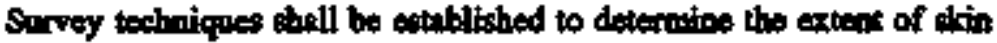
conthimintin."

\section{RELATFD REFERENCAS}

\section{DOE/EH02S6T Anticlo $\$ 41$}

STIE REQUIREMENT SOURCE DOE-N5480.6 Section 541.2

When personnel detect tin contaminetion, they shull notify the Rediological

Control Organization."

RELATEO REFERENCES

1. DOE/EH02S6T Article 541

STIE REQUREMIENT SOURCE: DOE-N5480.6 Section 5413

The extent of skin contomination stould be determined prior to mitiatinst deconthimination procedures."

\section{REILATED REIFERENCES}

\section{DOE/EFHO256T Artitile 541}

SITE RBQUIREMENT SOURCE: DOE-NS480.6 Section $\$ 41.5$

"Lovels of skin contamination that trigger the need for dose aesecements should be atroblishod for sibsospecific radionuclides. These trigper lovels should not exceed 100 urem."

\section{RELATED REFERENCES}

\section{DOE/EHO256T Articte 541}

\section{STTE REQUIREMIENT SOURCE: DOE-N\$490.6 Section $\$ 41.6$}

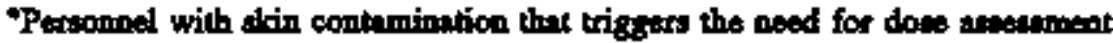
should be informod of the initial dose estimate to their skin 15 soon a practicable, preferably prior to the ead of their work dry."

\section{RELATED REFERENCES}

1. DOE/EHO2S6T Artide 541 


\section{REQUIREMENTS IDENTIFICATION DOCUMIDNT HIGH LEVEL WASTE STORAGE TANK FARMS \\ Radiological Protection \\ Rerision 1}

\section{SITE REQUIREMINT SOURCE: DOE-N5\$0.6 Seetion $\$ 41.7$}

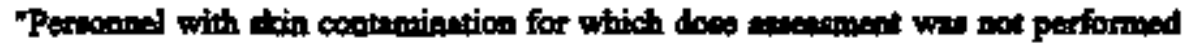
ahould be informed of the neture of the contanimation and al upper stimath on the

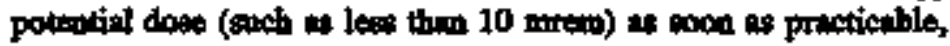
preferelbly prian to the ead of their work day."

\section{RELATED REFEIINCES}

\section{DOE/EH0256T Articls S41}

\section{STE REOUIREMENT SOURCR: DOENS480.6 Section 541.8}

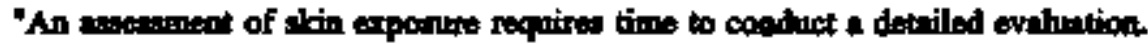

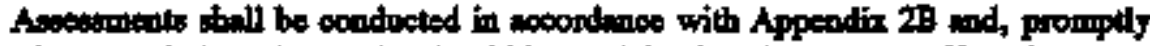
after completion, the tegultes should be expleined to the pereone affected."

\section{RELATED REFE?ENCES}

\section{DOE/EHO2S6T Article 541}

SIIE RECUIREMENT SOURCE: DOE-PNL-6534 Section 4.4.2, Page 4.30, Paragrapb 3

"After performing work thet, in retroepect, irvolved a hiph potentill for

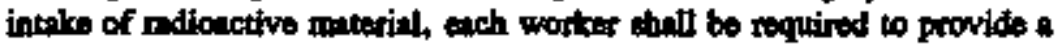
swipe of the nesnl passages, which sinll be comted inmedintely. If respiritary protection was worn there is no oed for nasal swipes unleas a brexch of the reppinator seal is suspectet. If facial contaminntiod is detected at the exit contrmination survey, a nasol sivipe shotald be counted

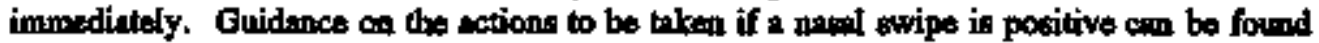
in Sections 4.6 and $4.7<$ DOE-PNL-6534>."

\section{SIIE REQUIREMENI SOURCE: DOE/FH0135 RP.10 CONTAMINATION CONTROL.20}

20. Perconed exiling posted contuminution aress to required to monibor their whole body and extremitien for contminintion. For personnel exiting a moliologically controlled ures, the degres of monitoring is based an the potsatial for contamination. Appruprivte motitoring equipment is aveilable."

\section{SIIE REQUIREMENT SOURCE: DOEIEHOL35 RP.IO CONTAMINATION CONIROL 21}

"21. Portal monitort ere not wsed as the primary monjtoring method for parnoned cortamingatio." 


\section{REQUIREMIENTS IDENTIEICATION DOCUMENT HIGH LEVEL WASTE STORAGE TANK FARMS \\ Radiological Protection \\ Rerision 0}

\section{SITE REOUIREMENT SOURCE: DORS480.11 Section 9. $(4)(c)$}

Teseomel and Personel Propenty Contumination Monitoring thill be provided, es sppropriate, and ined immedietely priof to or atter exits from rodiological

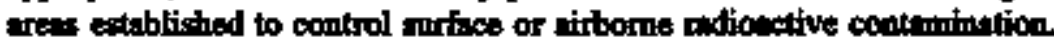

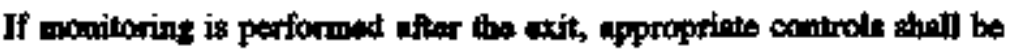
impiemented to prevent the loss of cootrol of contrinination. Delectuble contarrination on personnel and personal property hould be removed by appropriats decontamination methods."

\section{FACHITY REOUREMIENT SOERCE: DOS6430.1A Divislon 1300, Seetion 653}

Ten of devices to wam personel of possiblo contumination or other

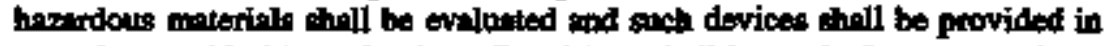
accordence with this eveluntion. Provietions shull be made for personenel monitoring devices, such $\approx$ hand and foot counters, in the vicinity of work stations. Installed monitors (mpplemented with personil wonitorimg methods if necessiry) shall be tod to monitor persongel exiting in operationg wen through access ways. CAMSs sholl be provided to detect and to alorm at prescribed sirborne ractionctivity levels."

\section{Personnel Contamination Control}

This element addresses those requirenente relating to enoning thet the contumination of

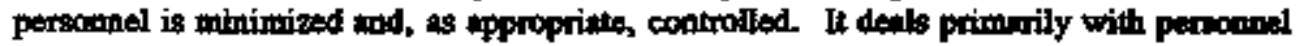
practices which support personnel contemination coatrol. Decontemination of persomel is covered under o separme sub-element of contaminiation control.

\section{STE REQUIREMENT SOURCE: DOEN5480.6 Section 221.1}

\section{"Pessonnel Contamination Coatrol}

Personel exiting Contumination Aves, High Contnmination Areas, Aitborne

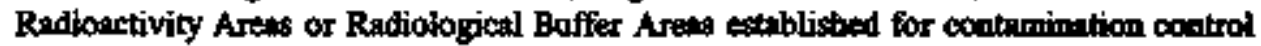
shatl frisk for cortiomination as required by Article 3318. This does not mpply to persomed

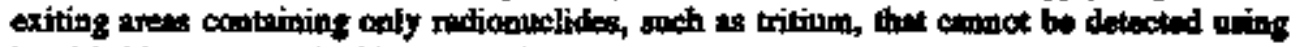
hond-held or alomatic frising equipment."

\section{SITE REQUIREMENT SOURCE: DOE-N54\$0.6 Section 342.11}

\footnotetext{
"To minimize intakes of radiometivo material by personnel, emolting, eating, or chewing shall not be permitted in Contumination, High Comtamintion or

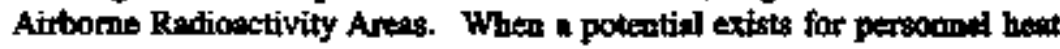
ctrese, drinking may be permitted within a Contomination Area boder the following conditions and controls:

2 . The potential fin heat tress camnot be raduced by the use of edminietrative of enginesting controle;

b. All drinking is from afproved containers or sources;

c. At a minimam, worker's hands and fices are monitored for contamination prior to drinkting.

d. Particjpeting workers are monitored as part of the bioassy program.
} 


\section{REQUIREMENTS IDENIHICATION DOCUMENT HIGH LEVEL WASTE STORAGE TANK FARMS \\ Radiological Protection \\ Rerition 1}

6. The eqplicable requirements and controls aro deceribed it eqproved procudurea."

\section{STTE REQUIREMIENT SOURCE: DOE-NS490_6 Section 542.1}

-Contramineted Wounds

Emergency medical care thould bo administered immatiately for injuries

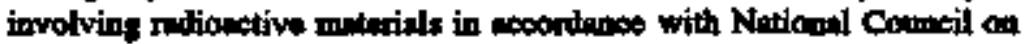
Radiation Protection and Measurerrents Report Number 65. Medical tredtment of

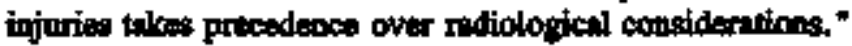

\section{GIFE REQUIREMENT SOLRCE: DOB-N5480,6 Seetion 542.2}

The treatment of contrminaled injuries shoxld include the followinge

2. Treatment of contorrimbed wounds by metioslly qualified pertomed;

b. Monitoring of wound and asoocinted bodagos for contaminution, including alphe entitters if upplicabies:

c. Ientifiction of the redionclides involved;

d. Modiced determinntion of the need for therepentic intervention axch a bloctiong of cheluting areats;

6. Initiation of epproppiate bicassay monitoring:

f. Determinution of peed for wark restrictions."

\section{STE REQUIREMINNT SOURCE: DOE-NE480.6 Sectlan 542.3}

"An injured persion thould be cotmseled poingtly on the modical and radiologikel

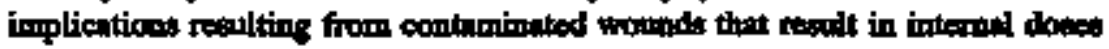
greater then 2 percent of the Table 2-1 limilis. The coumseling should be

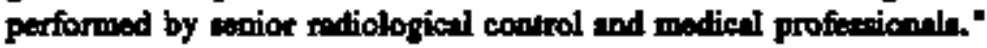

\section{SITE REQUIREMANN SOURCE: DOEJEH013S RP.10 CONTAMINATION CONTROLIS}

-19. Procedures for use of utep-off pade and the removil of protective clothing tre paeted where such removit if required and are consistently followed."

\section{SITE RDQUIRBMINT SOURCE: DOEJEHT0135 RP.10 CONTAMINATION CONIROL.4}

"4. Maximum permissible personnel contamination levels (stin wod clothing) heve been ectiblisted. Detected contumination in excese of thees levels aro invertigated and documented a to sourcen, probublo crase, and other pertiment fnformation. Records of thess investipations are maintrined and reviewed by radiological protection manogement for trende, and tornetive metion taken as acosisary."

\section{SITE REQUIRAMIDN SOURCE: DOEJEH0t35 RP,6.8}

" 8. Estitte, Arinking, smoking, nod chewing sre not permitted in contarrinced of pokentially conterminated ures." 


\section{REQUIREMENTS IDENTIFICATION DOCUMENT HIGH LEVEL WASTE STORAGE TANK FARMS \\ Radiolapical Protection \\ Rerision 0}

SIR REQUnRHMNT SOURCE: DOES490.11 Section 9.g(4)(b)

Workpleos Surfaces in Rediologionl Area tholl bo poeted (parageoph 9l) end

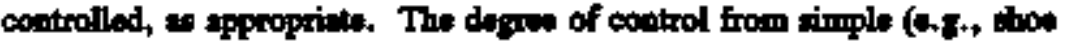

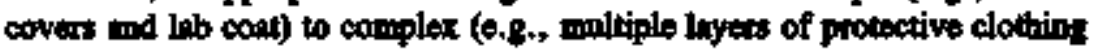

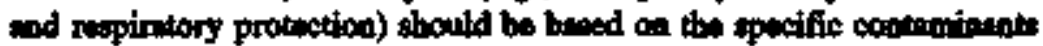
presene and the level of conturnimation."

\section{Eatupument and Aree Contamination Contred}

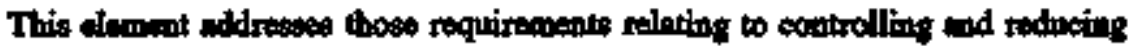

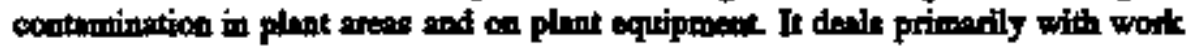
peatices which anpport contamination control. Decontemination is eovered nuder a

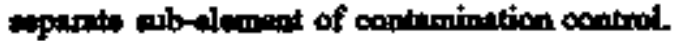

\section{STTE REQUIREMENT SOURCE: DOENS480.6 Section 125S[02]}

"Conditions thet eould cause or promote the epread of conterminntion, wach as a leaking roof or piping, stould be ldentified and cometed on a prionity bacis."

\section{SITE REQUIREMENT SOURCE: DOE-N\$480.6 Stetion 222.3}

"In addition to the posting criberia in Articlo 235, the wonditions for esteblishing and maintaining Fixed Contarimation Areas imolsdo all of tho following:

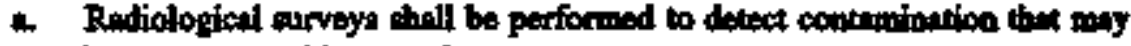
become removable over time.

b. A formal invertory shall be mintrind of Fixed Contumination Arose.

c. Matking stull bo kept logible.

d. Removable contaminition should be reduced to below detectable kevels before a fixative conting is ipplied.

- Fixed contemination thould be covered with two layers of fixntive coxtings heving different colors.

f. Martings should include the iteadied nodiation symbol, be clearly visibio from all directions and contrast with the colors of the surface cotingt.

g. Additional couting ahould be applied when the bothen colst appens.

f. A plen for tidentifying ard adding to the inventory of exteting exese of fixed conbumintion not included in the imitinl irventory shonld be dentoped."

\section{REHATED REFBRENCES}

\section{DOELEHORSGT Article 222}

\section{SIrF REOUIREMTNT SOURCR: DOE-N5480.6 Section 222.4}

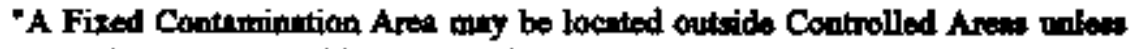
unsestricted acesess is likely to result in a dose to any person greater then 100 mrem in 4 year." 


\section{REQUIREMENTS IDENTIFICATION DOCUMENT HIGH LEVEL WASTE STORAGE TANK FARMS \\ Radiological Protection \\ Revilation 8}

\section{RELATED REFBRENCES}

1. DOE/EFI02S6T Ariclo 222

\section{SITE REQUIREMIJNT SOURCE: DOE-N5480.6 Section 222.5}

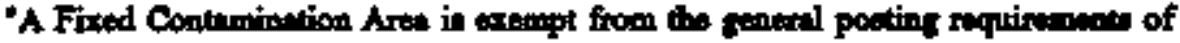
Articlo 231 and entry and exit requirements of Chapter 3."

\section{RELATDO REFERENCES}

\section{DOEfEHO26T Artide 222}

\section{SIIE REQUIREMENT SOORCE: DOE-NS480.6 Section 222.6}

For contaminnted soil thin is not relesubte in nocondance with DOE 5400.5, a

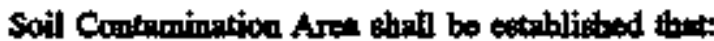

a. Is posted as epectified to Article 235. Posting hould inclode intructions or pecinl warrings to worters such as "Consalt With Radiological Control Organization Before Dizging" or "Subsurfece Coutanimation Existis."

b. Meets the requirements of Article 231.1 through 231.8."

\section{RELATED REFERENCES}

1. DOE/EHO2S6T Article 222

STIE REQUREMENT SOURCE: DOEN5480.6 Section 222.7

"Soil Contamination Arese moy be located cutside a Rediological Buffer Area * RETATED REFERENCES

1. DOE/EHO2S6T Article 222

STE REQUIREMENT SOURCE: DOE-N\$480.6 Section 337.1

"Controlling the Spread of Coctaminntion

The following measures thould be wed to prevent the spresd of conbumination acrosa the boundary of Contaminetion Ares, High Conkamination Arest and Airborms Rediosetivity Arew:

Use solid hariers to eqfolose aress wherever precticable;"

STE REQUIREMENT SOURCE: DOEN\$480.6 Section 337.2

"Mark and secure ivens such wo hoses and cords that crose the boundery;" 


\title{
R EQUIREMENTS IDENTHICATION DOCUMTNT HIGH LEVEL WASTE STORAGE TANK FARMS \\ Radiological Protection \\ Reriston $\bullet$
}

SITE REQUIREMIENT SOURCE: DOE-N54\$0.6 Section 337.3

"Coningl and direct itrflow from arese of lester to grenter ramovable contminioation;"

\section{SITE REOUIREMIENT SOURCE: DOE-N5480.6 Section 337.4}

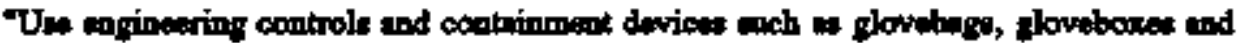
tenke.

\section{SITE REQUIREMTWNT SOURCI: DOE-N3480.6 Section 342.2}

Tools and equipment should be inzpected to verify optrabitity before being beought into Conterninution, High Contamination or Airbome Reclionctivity Arens."

\section{SITE REQUIREMANTT SOURCE: DOE-N\$490.6 Section 342.3}

The ues of molologionlly cleen tools of equiponent in Contaninetion, Hith Contanimation or Airborne Redionetivity Areas skonld be minimized by the

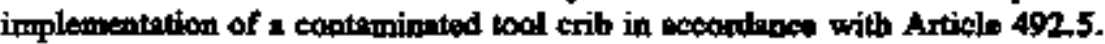
When axh use is necessary, loods of equipinent with complex or ineccessible aress stould be wrapped or sleved 20 minimize contamination."

\section{SETE REQUIREMENT SOURCE: DOE-N5480.6 Section 342.4}

\begin{abstract}
"Engineering controls, muth as conthinned devices, portable or mailiny ventilation and temporary thietifing, alhould be instolled in mocordence with the technical wort documents and infected prior to nese"
\end{abstract}

\section{SITE REQUREMENT SOURCE: DOE-N5480.6 Section 342.5}

"Hoses and cebles antering the wort area should be secured to prevent the epread of oputionionation or anfety buands."

\section{SITE REQUIREMTNT SOURCE: DOE-N5480.6 Section 372.1}

"Eoviramental Conditions

Incloment weather or other envirenmedtut contitions may disupt moliological opntrols. If that oceurs, the following actions chould bo confidered: The uee of coverb, wind sersens wid rumoff colloction basins to prechude tho

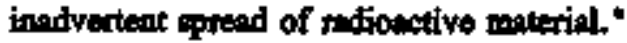

\section{SIIE REQUIREMIENT SOURCE: DOE-N5480.6 Section 372.2}

"Prowisions for worksite personned to assemble and be mopitored paitor to relesse ot resstablistument of work." 


\section{REQUIREMENTS IDENTIFCATION DOCUMIONT HIGH LEVIL WASTE STORAGE TANK FARMS Radiological Protection \\ Rovition 0}

SITE REQUREMMONT SOURCE; DOE-NS490.6 Section 3723

"Evaluation of wort are to determino if a noed exinta for modified work ecatrols or decontemination."

\section{STIE REQUIREMENT SOURCE: DOEJEH0135 RP.10 CONTAMINATION CONIROL.13}

-13. The contamination coatrol progrem provides maximum eccesibility to all aress with minimum use of anti-coalmminntion ckothing."

\section{SITE REQUREMIENT SOURCE: DOE/DFOT35 RP.10 CONTAMTNATION CONIROL.16}

"16. Contomination control levels heve been estoblished. Controls ate employed for ereas, equipment, mnierials, tools, and ocher tiems if contamination levels axomed the extablisbed lovels. Releans arvern are perfomed by quafilied perteonel."

\section{STTE REQUIREMENT SOURCE: DOE/EHOL35 RP.10 CONTAMINATION CONTROL.8}

- 8. Methods, ach as coffer dems, drip pans, and conteinments, are uged to minimize the spread of contaminition."

\section{SITE REQUHEMIENT SOURCE: DOEMEO13S RP,6.6}

- 6. The number of areas where reepiratory equipment is required in minimized."

SIT REQUIREMIENT SOURCE: DOE5480.11 Section 9.g(4)(0)

"Conmpination Control and Moritoring. Approprinte instruments wod tedmiques thalt be used to provide conturnination monitoring and control ts deceribed below:

(a) Wotplace Sufhes Outside Ratiological Aress thould be mintrined eesentially free of removable contumination bet in any cose contomination ethall not exceed the bevels defined in Athohnent 2.

Acceptable levels for total (fixed plus removable) contamingtion are also listed in Attachmont 2."

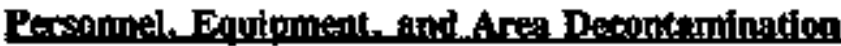

This dewent addresees those requirements rolatimg to decontaminition. Included ero

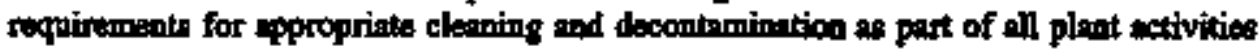
invalving cooburinated mattrial or systems. It also includes requirements for the

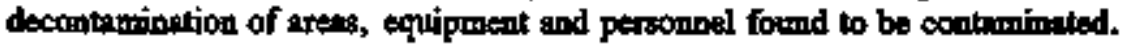




\section{REQUIREMENTS IDENTIEICATION DOCUMIENT \\ HIGH LEVEL WASTE STORAGE TANK FARMS Radiological Protection \\ Rerivion}

SIFE REOUIPEMIENT SOURCL: DOE-N5430.6 Section 221.3

Pesaonoel found with detectable contaminution on their ibin or personel

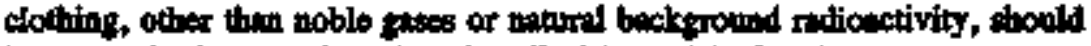
be prompdy decopaningted as deacribed to Article \$41."

\section{STTE REQUUREMIENT SOURCE; DOE-N5480.6 Section 222.2}

"Surfuces exceeding the values of Table 2-2 for total contaminition may be corvered with a fixetive conting to prevert the apread of contaminition.

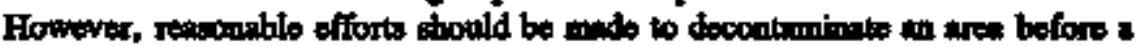
conting is applied. A fizative conting hall not bo applited withon the approwal of the Ratiological Coutrol Mmiger."

\section{REIATHW REFERFNCAS}

\section{DOE/EHO256T Articlo 222}

\section{SITE REQUIREMISNT SOURC: DOE-N5480.6 Section 342.1}

Work Conduct and Practices

Contamination levely ceused by oogoing work thall be montored and meinteined ALARA. Wort should be curksiled and decontamination performed at pisestablished levele, talking into wocoknt worker axposure."

\section{SIIE REOUIREMENT SOURCE: DOR-N5480.6 Section 342.10}

Requirements for ares cleemp should be tucluded to the technicoll work focuments. Wort activities should not be cosaridored comples until auppont

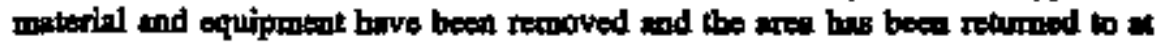
least prewort stutus."

\section{SITE REQUIREMINAT SOURCE: DOEN5480.6 Section $\mathbf{4 6 3 . 3}$}

"Decoummination activities thall be controlled to prevent the sprewd of costraminition."

\section{REWATED REFERENCES}

\section{DOE/EHO2S6T Article 463}

\section{SITE REQUHREMENT SOURCE: DOR-NS490.6 Section 463,4}

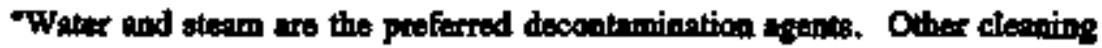
apenta should be sefected beosd opos their effestiveness, herardous

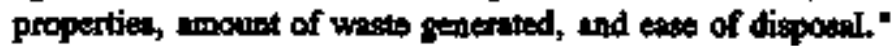

\section{REILATED REFERENCES}

1. DOE/EHO256T Articlo 463 


\section{REQUIREMENTS IDENTIFICATION DOCUMENT \\ HIGH LEVEL WASTE STORAGE TANK FARMS \\ Radiological Protection \\ Revision 6}

\section{SITE REOUIREMENT SOURCE: DOEN5490.6 Section 403.5}

"Decontamination methods should bo used to reduce the mmber of contaminated araiss."

\section{RMLATED REFERENCES}

1. DOE/EH0256T Articlo 463

STTE REQUIREMIENT SOURCE: DOE-NS4\$0.6 Section 463.6

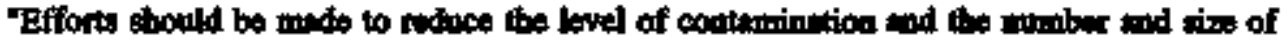
cantaminated aneas that connot be eliminated.

\section{REIAATID RFWERENCES}

1. DOE/EHO266T Article 463

SITE REQUIRTMENT SOURCE: DOE-N5480.6 Section 4 53.7

"Facility line managemeat shotild be nesponsible for directing decontuminution efforts."

\section{RELATED REFERENCES}

1. DOEJEHO2S6T Artiklo 463

\section{SITE REQUIRRMENT SOURCE: DOE-N5480.6 Seetio4 464.1}

-Vacenm Cleaners and Portuble AirHendling Expupment

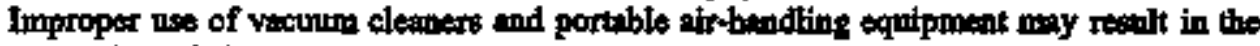

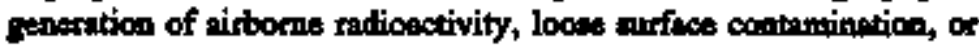
hight dose rates.

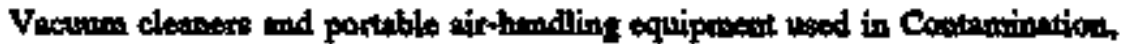
High Contamination, Atrborns Redionctivity, Redionctive Matenial of Rediologicol Buffer Arens tall be oquipied with Hidb-Efficiency Particulato-Air (HEPA) filters."

\section{SITE REQUIREMENT SOURCE: DOE-N5480.6 Sextion 464.2}

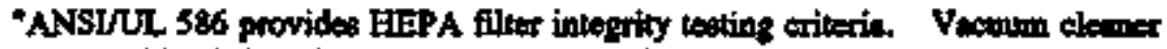
and portable air-hancling equipmant HEPA filters cheff bo integrity tocted

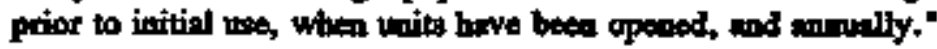

\section{STIE REQUIREMENT SOURCR: DOE-NS480.6 Section $\mathbf{4 6 4 . 3}$}

"Vacuum cleaners ued for radiologicel work shall be;

a. Uniquely marked and lubeled;

b. Controlled by an RWP; 


\section{REQUIREMENTS IDENTIFICATION DOCUMENT \\ FIGA LEVEL WASTE STORAGE TANK FARMS \\ Radiological Protection \\ Revision 0}

c. Controlled to provont unathorized uns:

d. Designed to enane HEPA filter integrity under conditions of use;

- Designed to provent unimuthorized or wocidental exeess to the inner sorfinees of the veciorm."

\section{SIIE REQUIREMIDNT SOURCE: DOE-N5480.6 Section 464.4}

"Redietion and coatuminntion surveys shall be performed periodically for vecund clamers in ane and labele on these units shell be uxdated. The frequency of rediation morreys should depend an the specific tore of the vecuar cloner."

\section{STTE REQUREMENT SOURCE: DOE-NS490.6 Section 464.5}

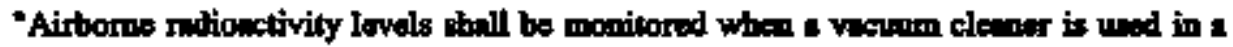
hiphly coatomingled ares."

\section{SITE REQUREMENT SOURCE: DOE-N5480.6 Section S41.3}

"The extent of skin contionination should be detarmined prior to ivitinting decontomination procectures.

\section{RELATED REFERENCES}

\section{DOE/EH0256T Articlo 541}

\section{SITE REQUIREMINNT SOURCE: DOE-N5440.6 Section 541.4}

"Stin decontamination methods chould be eetabliehed for sito-epectific madionuctides. Stin abrasion skorald be avoided during the decontominetion procest. Intrusive decortaminetion melbods, such is tissto removal, require medical agriatence."

\section{RESATED REFERENCES}

\section{DOE/EHOES6T Article 541}

\section{SIIE REQUIREMENT SOURCE: DOEJEH0135 RP,10 CONTAMINATION} CONTROL22

22. Pacilities for decontamination are avifable."

\section{SIIE REQUIREMENT SOCRCE: DOE/EH0135 RP.5 ROUTINE DOSMMETRY.13}

"13. Personed decontamigntion equipmenk, supplites, end procedures are propety stored and rootinely inveatoried" 


\section{REQUIREMENTS FENTHICATION DOCUMENT HIGH LEVEL WASTE STORAGE TANK FARMS \\ Radiological Protection \\ Reristion 0}

\section{STIE REQUIREMENT SOURCE: DOE/EH0135 RP.8.8}

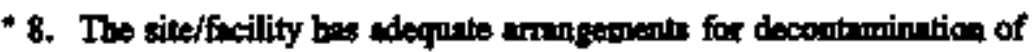
operative and inoperntive instrumants."

\section{Hat Particte and Soecific Niugllide Contron}

This element addresses thowe requirements relating to control of contaminition frome

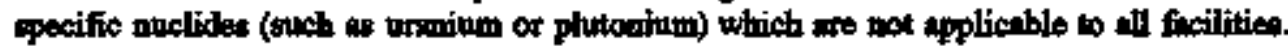

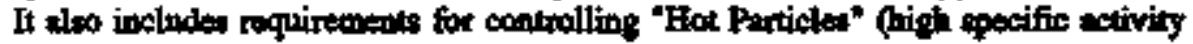
individual rationetive particles) which may be encountered at a facility.

\section{STIE REQULREMIENT SOURCE: DOE-NSAt 0.6 Section 363.1}

\section{Tritium Operations}

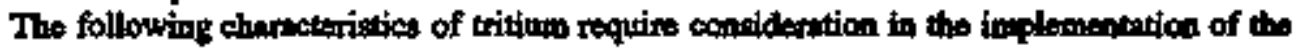
Rutiological Control Progen at tritium facilities: Tritium emits low eacry bete particles which cennot be monitored using external dosimeten, consequently requirimg the ars of biceasty mesurements to evaluate worker tose."

\section{STIE REQUIREMENT SOURCE: DOE-N5480.6 Section 363.2}

"Worker expoeare to tritium af water vepor censes a mosh greater dom then

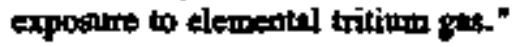

\section{SIE REQUIREMENT SOURCE: DOEN5480.6 Soction 363.3}

"Normot peraconel frisking tochnigues are inoffective for tritinm.

Consequestly, a high relianes is planed on worker bionsany and routine contamination and ir monitoring programs."

\section{STIE REQUIREMENT SOURCE: DOE-N5480.6 Section 363.4}

"Dne to its high parmeability, tritium is difficult to contrin. Specill altention thonld be directed to the seloction of persondl protective equipinent and clothing. For the above

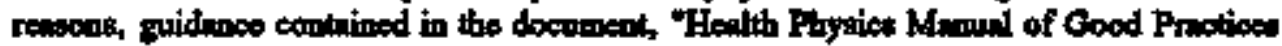
at Tritism Fecilitios," MLM-3719, sould bo considered for tritium opentione in preparing the Site-Specific Radiological Control Manual. This mannel providec apecific

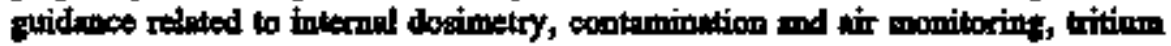

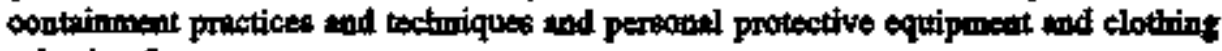
eelection."

\section{Respiratone Pontection}

This element adtresses those requirements relating to the selection ind appoprite veo of respiratory protection equipment is purt of the fesility contamination control progenom. 


\section{REQUIREMENTS DENTIFICATION DOCUMIENT HIIGH LEVEL WASTE STORAGE TANK FARMS \\ Radiological Protection \\ Rerision 0}

SIFE REQUIREMIFNT SOURCE: 10CFR20 Purt 20.103,e.(4)

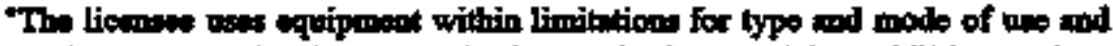

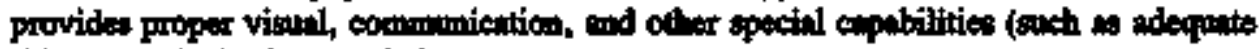
skin protection) when needed."

\section{STTE REQUIREMINT SOURCE: ANSI-Z88.2-1980 Section 3.3.3}

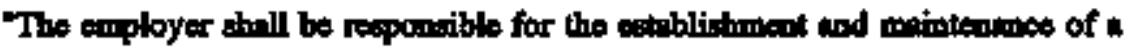
respirtiony protection proptam which shall inclucto the genepel nequipeipents outined in 3.5."

SIrE RECUIREMIENT SOURCE; ANSI-283.2-1980 Section 3,4.1

"The enployes thall wes the provided respiretory protection in acorilence with instructions and training received."

\section{STTE REQUIREMENT SOURCE: ANSI-238.2-1980 Seetion 3.4.2}

"The eunjoyes shall guard against damige to the respirator,"

STTE REQUTREMENT SOURCE: ANSI-Z358.2-1990 Section 3.5.1

"Written standard operating procedures cowering a complete respirator propram sholl bo thished ind implemented in conformance with 3.5.2 throweh 3.5.15. -

SIIE REOUIREMENT SOURCE: ANSI-Z289.2-t990 Section 3.5.10

The respintor thall be inspected by the wearer prior to its we to ensure that is in proper working condition. Euch respirator stored for emexpency or rescive use sull be inspected at least ouce anonth."

SIIE REQUREMIENT SOURCE: ANSI-Z88.2-1980 Section 3.5.14

"Respintor matintennice thall be performed regulorly."

SIT REQUIREMFNT SOURCQ; ANSI-Z\$8,2-19\%0 Section 3.5.15

"An apprisal of the effectiveness of the respirator protram shall be cerried out at leas aminilly. Action shall be tokeo to correct defects found in ths program-"

\section{SITE MEQUIREMENT SOURCE: ANSI-Z88.2-1980 Section 3.5 .2}

"The plint or conmeny industrial byjiene, beelth physics, or safety enginseting department thatl edrtuister the respiratror program in clowe liniege with the modical deportment. Responsibility and anthority for the reepirator progrim shnll be assigmed to a single person." 


\section{REQUIREMENTS IDENTIFICATION DOCUMENT HIGH LEVEL WASTE STORAGE TANK FARMS \\ Radiological Protection \\ Rerrision 0}

\section{STIE REOUIRFMENT SOURCE: ANSI-Z8\$,2-1980 Section 3.5.6}

"Eech recpitotor wearer thall be given troining which thall inchude explametions and dincuarions of (1) the nespintory hrand ord what hoppene if the respirstor is not used property, (2) tho mipinesing and edministrative contuols bethe used end the need for reepirutore to provide probetion, (3) the reaston for selecting a particular type of respirator, (4) the finction, crpabilities, and limitetions of the seleced nepirntor, (5) the method of fonning the nespintor and checting its fit end operation, (6) the pioper

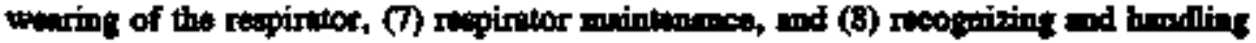
enperiency stuations."

\section{STE REQOIREMIENT SOURCE: ANSI-288.2-1980 Section 7.2}

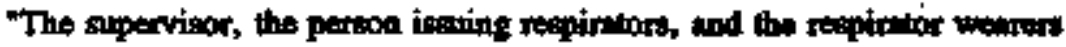
thell bo given adequits tnining by 1 qualified person to enirore tho proper use of respirators. Written records shill be kept of the names of pertonts tringed and tho dates when trining cocmurred."

\section{SITE REQUIREMENT SOURCE: DOEN5480.6 Sectlon 223.1}

"Ajporae Radionctivity Contral Levels

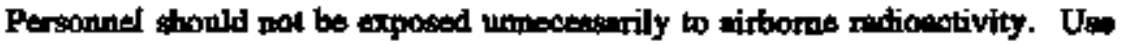
of engineering ind strainistrative controls to reduce the potentinl for

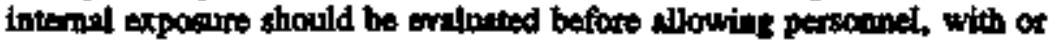
without respitratory protection, to enter anese with tirbome ndionetivity."

\section{RELATED REFRRENCES}

1. INP0-88-010 Chaptes IV, Section 3(c)(1), Paragraph 1

\section{SITE REQUIREMFNT SOURCE: DOF-NS480.6 Section 316.3}

"Whan enginearing and administretive controle have been applied and the

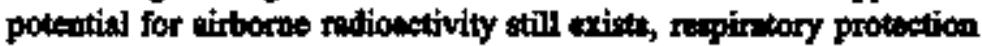

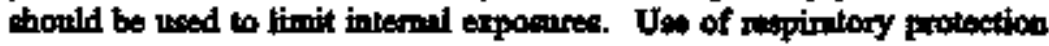
Honld be ecosiderted under the following conditions:

- Entry into posted Airborno Realipactivity Aress;

b. During breach of contuminited symems or coimponents;

c. Wort in areas or on equipment with removablo conteminetion levele greater then 100 timet the values in Tublo 2-2;

d. During work on contaminied of activated surfines with the potrential to geocerate airbome radionctivity."

\section{RFATED REFERFNCES}

\section{DOEFHO256T Articie 316, Item 3}




\section{REQUIREMENTS IDENTHICATION DOCUMENT HIGH LEVEL WASTE STORAGE TANK FARMS Radiological Protection \\ Revision $\theta$}

\section{SITE REQUIREMENT SOURCE: DOE-N5490.6 Section 316.4}

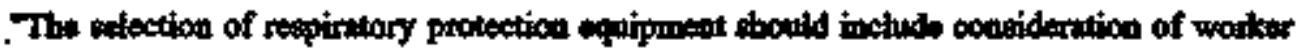
anfaty, comfort and efineieccy. The use of positive preenure respirtiony protection devices is recommended wherever practichle to ellovitu fitign and inereses comfort."

\section{RELATED REFERRNCES}

\section{DOE/ERT0256T Aticlo 316, Irem 4}

\section{SIrE: REQUERFMANT SOURCR: DOE-N5490.6 Section 316.5}

In specific eimations the use of repintory protetion min be

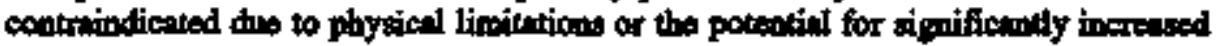

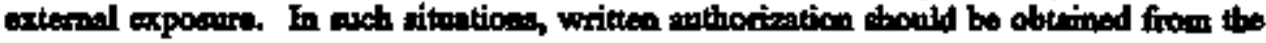
line orgutization menuger and the Rediologienl Control Manger prior to incureing intermal expoesure Specific justificention of the need to aceept the expostre, including a deecription of metrutes then to mitigne the nithorbe redionctivity, should be documeatiod at part of the suthorization process."

\section{RELATED REFERENCES}

1. DOEFH025GT Article 316, Item 5

\section{STTE RPQUTREMINT SOURCI; DOE-N5490.6 Section 316.6}

"The following costrole are afplicable for ectivities arthorized in mocorthose with the abowe:

a. Stay time controls to limit intoke should be established for the entry;

b. Eviluntion of workplece aishorse radionctivity lovels should bo provided throush the use of extinuous air wonttors or atitumplers with expedited acsesernent and analyeis of resulta."

\section{SIE REQUIREMIENT SOERCE: DOFNS480.6 Setion 531}

\section{"Respiratory Protection Progran}

Respinatory protection equipment tuchades respintore with partisolate or

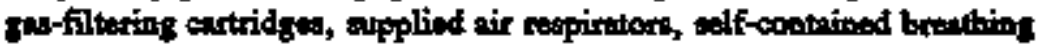

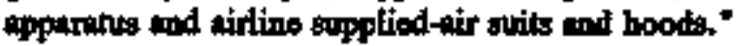

\section{STE REQUTRSMENT SOURCE: DOE-N5480.6 Section $\$ 31.1$}

\section{Requirements}

Use of respiratory protection shall be reduced to the minimum practicable by implementing engineering controls and wark practices to contain redioantivity at the source." 


\section{REQUIREMENTS IOENTIFICATION DOCUMENT HIGH LEVEL WASTE STORAGE TANK FARMS Radiological Protection Rerivion}

\section{SITE REQUREMIENT SOURCE: DOR-N3480.6 Section $\mathbf{3 1 2}$}

DOE S480.4 mendates the requirtonents contaied in ANST 288.2 end 29 CFR 1910.134 for implementation of the Respiratory Proceotion Properm and asocinted trining of persturet."

\section{SITE REQUIREMENT SOURCE: DOE-NS480.6 Section 531.3}

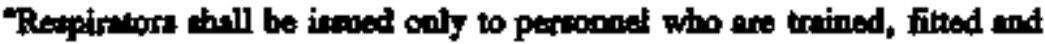
medically qualified to want the specific type of reopirator.

Trining and qualifiention testing shill be performed anmally."

\section{STIE REQUREMMENT SOURCE: DOE-NS490.6 Section 531.4}

-Poeldive controla shall be meinteined for the ivane, we nd renam of

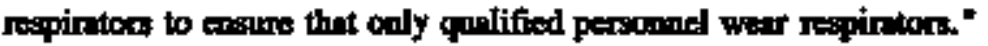

\section{STIE RECUIREMINT SOURCE: DOR-NS490.6 Section $\mathbf{3 3 1 . 6}$}

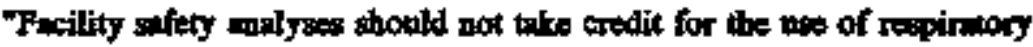
protection for routine work involving potentid exposuro to sirborme radioective materinls. Eaginesing contrals should be desigued to control rediasctive materiala at the cource, so that respitratory protection cist be reduced."

\section{SITE REOUIREMENT SOURCE: DOE-N5480.6 Section 532}

Medical Assessment

Bech prospective nespintor wester steill heve a medicel ancesment parlor to being fit-tested. The modical assesament shull determine if an employes'c medical condition procludes the use of recpirators and stould foillow the gutidunce in ANSI Z88,6 on frequency and conteat of the exramination. The abifity of an employee to necommodets the edditionel Arves pleced on the body when working in a respitator is purt of this assectument.

\section{SITE REOUREMIENT SOURCE; DOE-N5480.6 Section 533}

Uso of Respiratory Procection

Pertonnel using respintory protection shall:

1. Bo issued nespisators caly upon verification of modical approval, crining and fit testing.

2. Peform fit chacts of their respirators to enmare a proper seal before

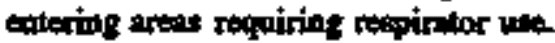

3. Be clean shiven in the area of fit.

4. Use orrective leaves, if needed, that ne approved for respintors.

5. Be instructed to letve the wort aree whed experiencing respintor filuro.

6. Be instructed to removo their respirators to evoid lifo-threatening sibutions whed exiting in orea efter respirstor frilure." 


\section{REQUIREMENTS IDENTIFICATION DOCUMENT FIGH LEVEL WASTE STORAGE TANK FARMS Radiological Protection Rovision $t$}

\section{SIFE REQUIREMISNT SOURCE: DOE-N\$490.6 Section $\mathbf{3 3 5}$}

\section{"Ealf-Face Respitators}

The current rovision of 10 CFR Part 20, which is to tolse effore Jinnery 1 ,

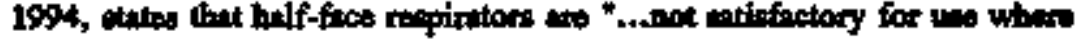

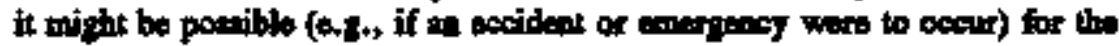

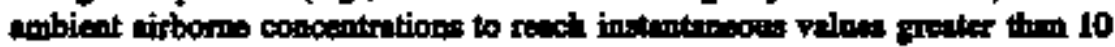
times tho...[DAC velues]." This typo of recpintor is nok sritiblo for

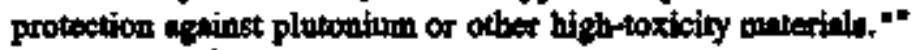

\section{SUIE REQUHREMENT SOURCE: DOE-N5490.6 Section 535.1}

"Half-face respirators shall not be used co 1 routine beris at a precentionery messure for protecting workers from potential dirborne ndiourtivo miteriule. Hilf-face repirators are undesirable becoule their seal with the fice is nome likely to full then with full-fuce respirators, particulerily during bevy work. As a reselt, their permitted protection fuctor is low."

\section{SITE REQUIREMENT SOURCE: DOE-N5480.6 Section 535.2}

The use of half-face respirators is not prohitbited in situotions where intolsel of adiowetive meterinl will be low, such as a few morn, wod where industrinl

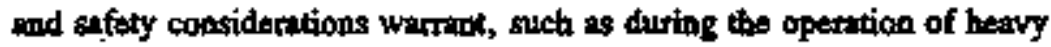
equipment."

\section{SITE REQUTREMINI SOURCE; DOE/EFT135 RP.6.1}

-*1. A respiratory protection program conmplying with ANSI 288.2 defines reponsibilitie ind requiremente in the following areas:

- Troinins,

- Control and use of recpirators,

- Mask and fit testing, and

- Brenthing air parity."

\section{RADIOACTIVE MATERIALS MANAGEMLANT}

This element didreses the requinenents nesocinded with the stonge, in-plant transportation and buding of ralioactive materials. Retionetive meterials inchude seoled courcen, itom: with mos-removable (fixed) contamination abd other materinls which at decigunted by regoletions a redioative metterials and thus require appropriate controls.

\section{SITE REQUIREMENT SOURCE: DOE-N5480,6 Section 411}

-PART 1 Redioactive Matoriel Identifiention, Storige and Control For the porposes of this Mmusal, redioactive material is any moterisl, equipmed or syster conpocent determined to be conternineted. Iteres 


\section{REQUIREMIONTS IDENTIFCATION DOCUMENT \\ HIGH LEVEL WASTE STORAGE TANK FARMS \\ Radiological Protection \\ Revision 0}

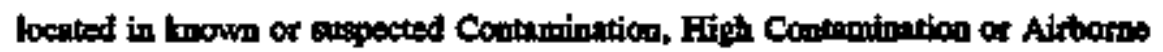
Refionctivity Arese and beving the poventint on become contamineted are considered ndiouctive materinl. Redionstive material ntso inchudes activated

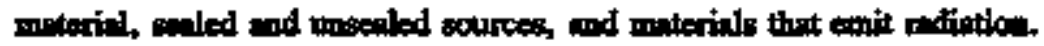
Controlit for weoled cources are dewribed in Articlo $4 \$ 1 . "$

\section{SITE RECUIREMINT SOURCE: DOE-N5480.6 Section 411.1}

\section{"Requiramenks}

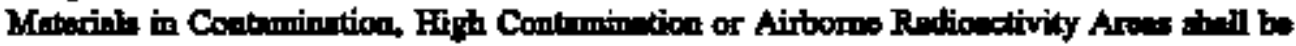
constidered radionctive meterial uotil surveyed and relepod. These mirvey and relespo requiremente do not epply to Airbome Redionctivity Areat where only gasows, short-lived (helftife of $I$ hoor or lese tetivition Frothets are propent."

\section{SITE REQUTREMENT SOURCE; DOENS480.6 Section 411.4}

The Radiolofical Coatrol Organization shall develsp respouse wod wotificution requirements associated with a lose of redicoctive meterial, tnctheding seorchec, internat investigation, documentotion and reporting. The Radiological Control Organization shall be notified in the ovent of a loos of radionctive material."

\section{SITE REQUREMENT SOURCE: DOE-N5480.6 Section 431.8}

"Receipt surveys of ndiological meterial shipments atsill be parformed by the Rodiolopical Control Orgtionition."

\section{Radionstize Material Fondlins:}

This atement adtresect requiremeats for the receipt, opening and handling of fridiosctive material at the freility.

\section{SITL REQUIREMENT SOURCE: DOE/EH0135 RP 3 POSTING.8}

" 8. Only traiped, wuthorizad personnol bandlo radicactive meteriale."

Radioactive Material Packaging and Labeling

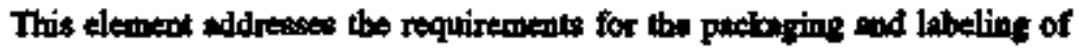
radioective meterial at the fecility.

\section{SIIE REQUIREMENT SOURCE: DOEN5480.6 Section 411.2}

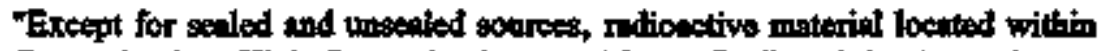
Conkmination, High Contomination or Aitbono Radiontivity Areas does not require specific tabaling or peckaging." 


\section{REQUIREMENTS IDENTIFICATION DOCUMENT HIGH LEVEL WASTE STORAGE TANK FARMS

\author{
Radiological Protection \\ Revision 0
}

STTE REQUIREMENT SOURCE: DOE-N5430.6 Section 412.1

"Radionetive Materinl Labeling

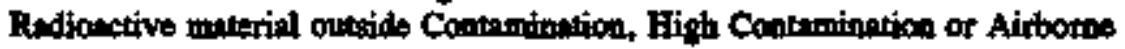

Redianctivity Areas shofl be labeled in accontence with Table 4-1."

\section{STIE REQUIREMENT SOURCE: DOE-NS480.6 Section $\mathbf{4 1 2 . 2}$}

The following are oot enbject to labeling requtrowestse

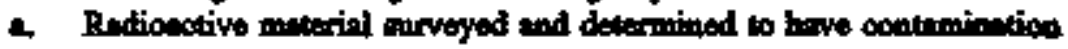
lovala lowe then Tablo 2-2 values;

b. Redionctive material or contriness pacteged and labeled for off-site shiponent in accordence with Deportment of Treneportation Reorulatione;

c. Peroon:d Protective Equipment and clothing;

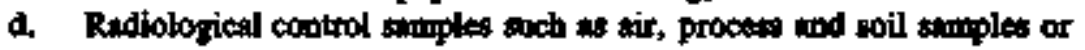

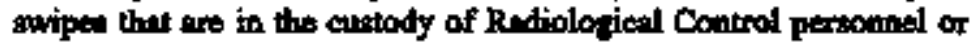
personnel property trained in the handling, packaging end tranport of these anmiles;

a. Egquipment of installed system components underzoins moirtenence covered by a Rediological Wort Pesmit;

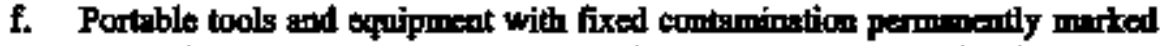

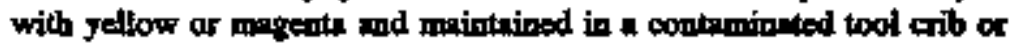
storage und distribution area;

h. Nucletr werpon components;

i. Historical items, such as urinium hexafluoride cylinders and larpe iterss used in demonstration projects, located within a Redionctive Meterital Ares; such ittems binll be properly labeled when they tre removed from a Radiosctive Meterial Area."

\section{STIE REQUIREMENT SOURCE; DOENS480.6 Section $\mathbf{4 2 . 3}$}

Labels stalt have a yellow background with a migente or biack stmindard radiation symbal. Lettering sball be megeota or bluck Magente is tho prefarred colot."

\section{SITE REQUIREMENT SOURCS; DOEN5480.6 Section 412.4}

"Labels stould inclode sontuct ndiation levels, removiblo mutice contamination kevels (spectfied salpha of beta-gamma), dales surveyed, earveyor's anms and description of items."

\section{STIE REQUIREMENT SOURCE: DOE-NS480.6 Section 412.5}

"Pectaged radionetive materiel should buve the label visiblo through the packege or affixed to the ontsids."

\section{SITE REQUTREMENT SOURCR: DOE-N5480.6 Sectlon 413.1}

"Rodioactive Material Perkaging

Rudionctive material that is outside Contunination, High Contanination of 


\section{REQUIREMENTS IDENTIFICATION DOCUMENT HIGH LEVEL WASTE STORAGE TANK FARMS \\ Radiological Protection \\ Rerition 1}

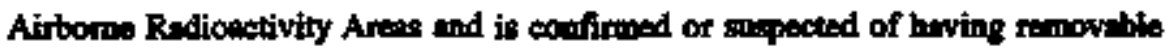

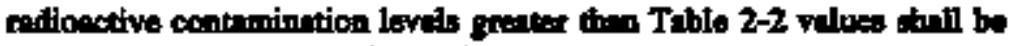
secoredy wripped in plastic or plesed in a contriver."

\section{STTE REQUIREMENT SOURCT: DOR-N5480.6 Section 413.2}

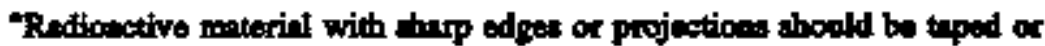

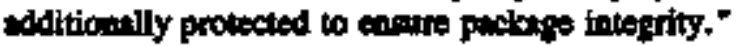

\section{STE REOUREMIENT SOURCE: DOENS490.6 Section 413.3}

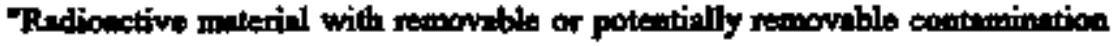
levels in exceses of 100 tims Table $2-2$ values thould have wditional

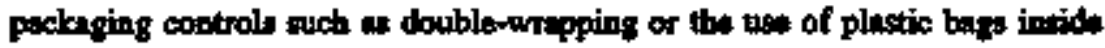
containers."

\section{SUE REQUIREMENT SOURCA: DOE-N5480.6 Section 413.4}

"Yellow plestic wroping material should be used for peckeging rodioective material. Yellow plastic sheets or bugs stould not be uped for non-radiological purposes."

\section{Radianctive Materitl Stomate}

This dement adidresses the nequirements for the moterialts at the focilities and the requirements for and which are

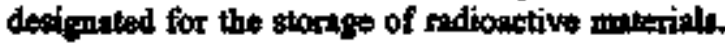

\section{SIIT REQUIREMIENT SOURCE: DOR-N5480.6 Section 4113}

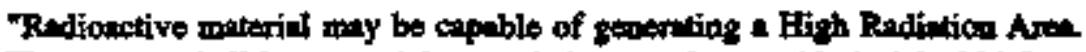
These areas eball have special controls in accordance with Articlo 334."

SIIE REQJIRBMENT SOURCE: DOE-N5480.6 Section 414.1

"Radiosctive Material Stornge

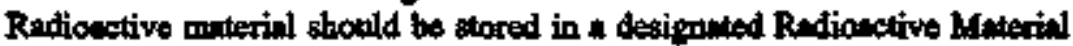
Aren,"

FACILITY REQUIREMENT SOURCE: DOE-N5480.6 Section 414.10

Thdiocctive materill should be stored in a momer that redoces combretible

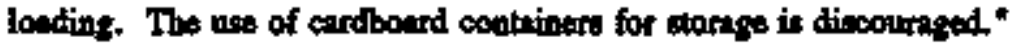

FACHITY RBOUIREMENT SOURCE: DOR-NS480.6 Section 414.11

-Flammable or combustible materials should not be stored adjocent to Radicactive Material Areas." 


\section{REQURRMENTS IDENTHFICATION DOCUMENT \\ HIGH LEVEL WASTE STORAGE TANK FARMS \\ Radiological Protection \\ Rertition 0}

FACILTY RRQURRMAENT SOURCE: DOE-NS480.6 Section 414.12

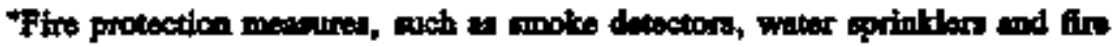
extinguishen, should be considered when establishing a Radioactive Material Ares."

\section{SUTE REQUIREMINANT SOURCE: DOE-N5480.6 Section 414.2}

"Lang-term (more then 60 days) storase of tadionctive materiel should be in a upeinlly designated Radioactive Motential Anew"

\section{SIIE REQUIREMINT SOURCR: DOLNS480.6 Stetion 414.3}

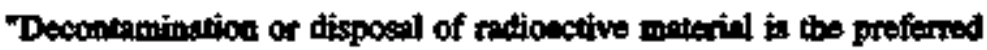
alternative to long-tern storage."

\section{SHE REQUIREMINT SOURCA: DOE-N5480.6 Section 414.4}

"Ench Radioactive Matertal Area should be epproved by the Radiological Controt Mranger."

\section{SITE REQURREMENT SOURCE: DOE-N5480.6 Section 414.5}

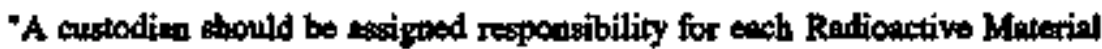

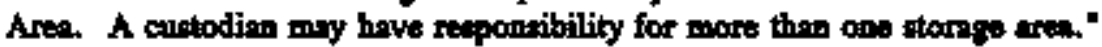

\section{STIE REQUREMIENT SOURCE: DOE-N5490.6 Section 414.6}

The custodian shoild conduct walldhroughs of Redionctive Material Aness to check container integrity."

\section{SIIE REQUIRIDMENT SOURCE: DOB-N5480.6 Section 414.7}

Tho consotian should conduct annunl of more frequent neviewa of excle Rudiouctive Meterial Area, with emphesis on decontaminution, movemont of muterial to long-term stongs locations and disposel of macoded metarinl."

\section{SIIE REQUIREMENT SOURCE: DOEN\$480.6 Section 414.8}

"Storage of nonradiosetive material in a Radianctive Matenial Area is diecourged."

\section{STIE REOUIREMENT SOURCE: DOEN5480.6 Section 414.9}

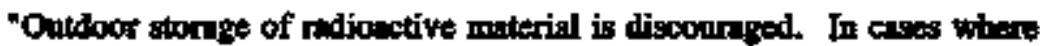
outdkor stonge is necespery, be integrity of conteiners uved ahnll be ensured to prevent degradation from weathering and subsequent relewsen of redicactive material. The custodian should check contriver integrity monthy at outdoor Radiometive Materinl Artass," 


\section{REQUIREMENTS IDENTIFICATTON DOCUMENT HIGH LEVEL WASTE STORAGE TANK FARMS \\ Radiological Protection \\ Ropision}

\section{SIIT REQUIREMENT SOCHCL: NUREG-0761 Section 6.b(2)}

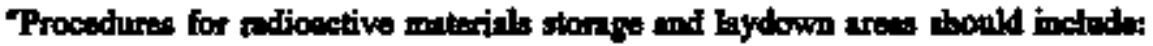

(a) critorin for posting and isolatins

(b) mey requirements

(c) accosen requiremente.

\section{Befease of Material ind Equioment}

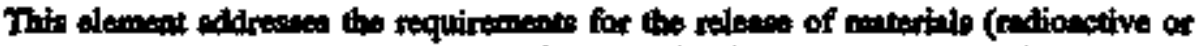

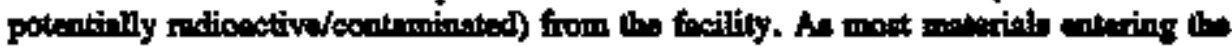

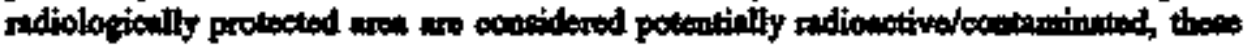

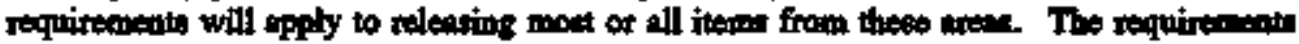
include boch free relespe requiremente and requirements to relesse for wos in other areas of the fucility.

\section{STE REQUIREMENT SOURCE: DOE-N5480.6 Section 421.1}

-Releeses ind Triasportation of Redionctive Muteritl

Release to Controlled Arwes

Redionetive meterial in Contamination, Bigh Coatumination or Airbomo

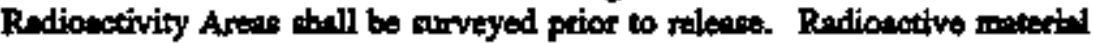

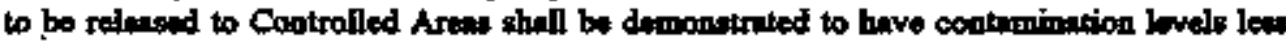
thin Table 2-2 values. Redionetive material to be reteesed to uncontrolled ares shall be rurveyed in acconinince with Article 422.

\section{RELATED REFERENCES}

1. DOE/EH0256T Article 421

SITE REQUIREMIENT SOURCE: DOE-N5480.6 Section 421.2

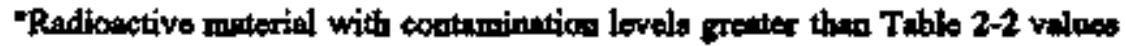
sholl bo labeled and packaged prion to releane to Controlled Areas."

\section{REHATED REFERENCES}

1. DOE/EHOESGT Articlo 421

\section{SHTE REQUIREMENT SOURCE: DOE-N5490.6 Section 421.3}

"Radioactive material not immodiately released after sarvey siall be coutrolled to provent recontaminntion whilo awaiting release."

\section{RETATED REFERENCES}

1. DOE/EH0256T Article $\mathbf{4 2 1}$ 


\section{REQUIREMENTS IDENTHICATION DOCUMENT \\ HIGH LEVEL WASTE STORAGE TANK FARMS \\ Radiological Protection \\ Rericion 0}

SITE REQUIREMTENT SOURCR: DOV-NB480.6 Section 421.4

"Records for release of potentially contartinated mentives should dworithe the

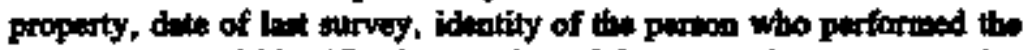
survey, typo and identificention mumber of the arvey inetrument need, ind aurvey resulta."

\section{RELATED RELERENCES}

1. DOEJEH026T Articlo 421

SITE REQUIREMENT SOURCE: DOENS490.6 Section 122.1

"Release to Unoxutrolled Aress

Radiosotive material is Controlled Arese of Rediosetive Material Aren thall bo sorveyed prior to toleato to umcontrolled arean."

\section{REWATEM REFERENCES}

1. DOEIEHO256T Article 422

\section{STrE REQUREMENT SOURCE; DOE-N5480.6 Sectlon 422.2}

"DOE 5400.5 describes evitorie for relansing fadionctive meteriel to unowotrolled aress. Rudiouctivo material being relewed suill aloo be

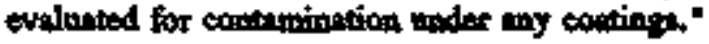

\section{RETATED REFERENCES}

1. DOE/EH0256T Article 422

SITE REQUIREMENT SOURCE: DOE-N5490.6 Section 422.3

DOE 5400.5 described criteria for releosing rationetive apterial that bat bece contaminated in depth or volume, such as activated mpterinl or samelted conthuinated motoinl."

\section{RELATDD RFFRENCES}

1. DOE/EH0256T Article 422

SIIE REQUTREMENT SOCRCE: DOE-N5480.6 Section 422.4

Radionctive material not immedinedy relkased after survey shell be controlled to prevent conturnination while awaiting relewse."

RELATED REFERENCES

1. DOEJEHO2S6T Article 423 


\section{REQUIREMENTS IDENTHTCATION DOCUMENT \\ HIGH LEVEL WASTE STORAGE TANK FARMS \\ Radiological Protection \\ Rerision 0}

STRE REQURTMMENT SOURCR: DOEN5480.6 Section 122.5

"Lebels sholl be removed or defeced prior to relese of radionctive anoteriel for minetricted use."

\section{REX LATED REFERRENCES}

1. DOEREHO2 6 T Article 422

\section{SITE REQUIREMIENT SOURCE: DOE-N5480.6 Section 554.2}

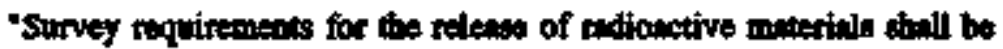
conducted in acondence with Articles 421 and $422 . "$

\section{RELATED REFERENCES}

1. DOE/ERO256T Articlo 554

STTE REQUIREMENT SOURCE: DOE-N5480.6 Setion \$54.3

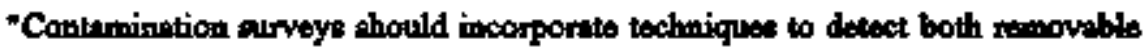
and fixed contromination."

\section{REILATED REFERENCES}

\section{DOE/EFOES6T Article 554}

\section{SIIE REQUIREMIENT SOURCE: DOE-NS480.6 Section 554,4}

Thems with inecessible surfaces which were locited in known or saspected cootumination srees and hud the potential to become contaminated at levels likely to exceed Tubate 2-2 values should be treated to potentially

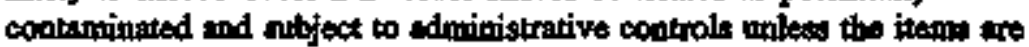
disamatied and monitord or special morvey techniques aro uned to arvey all swruce."

\section{RELATEB REFERENCES}

1. DOEIEFOZSTT Article 554

\section{SIE REQUIREMENT SOURCE: DOE-NE480.6 Sextion 554.5}

The requirements for ascesting tepresenotive sumples of balk material, such as good, sweaping componnds or plate steal, which are not alitable for normet loove and fxed contmaingtion-tevel sosessmeat techniques, are specified in DOE 5400.5."

\section{RELATED REFERENCES}

1. DOEIEH10256T Articlo 554 


\section{REQUIREMENTS IDNTIICATION DOCUMENT HIGH LEVEL WASTE STORAGE TANK FARMS \\ Radiological Protection \\ Repision 0}

\section{SIIE REQUIREMIENT SOURCE: DOE-N5480.6 Section 554.6}

"Swipe morveye for nemovebie conteminetion thell be neported in mito of divintegrations per miniate per $100 \mathrm{~cm} 2(\mathrm{pm} / 100 \mathrm{~cm} 2)$. For ewipe arvejs of

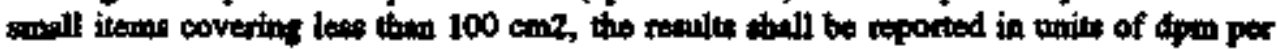
area swiped."

\section{RELATED REFERENCES}

1. DOEJHO256T Article 554

\section{STIE REQUIREMIENT SOURCE: DOBJHHO135 RP,10 CONTAMINATION CONIROL.1}

**1. Unrestricted rediological contamination release levele for pormonnel, equipanot and moterials, and farility sartices are defined and coongly with appropriate atenderte."

\section{STTE REQUREMENT SOURCE: DOE/EH0135 RP.10 CONTAMINATION CONTROLZ2}

"2. The system for unrestricted radiological contaminution relense (i.e.,

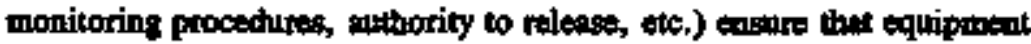
ond materials removed from contaminated areas are not conteninineted abowe release levele and are not mixed will cleso items prior to * find release:

\section{FACILITY REQUIREMENT SOURCC: DOES400,5 Chapter II, Sectioa 5.b}

"Rekesse of Persond Property. Personal proparty, which poientinlly conto be contoninited, may be relensed for vourestricted uso if the results of a survey with appropitate instnimeats indicats that the property is within the contamination limits gresented in Figure rV-1."

\section{FACIITY REQUTREMENT SOURCE: DOB5400.5 Chapter II, Section 5.C,} Item (5), a-t

The records of relessed property thilf include:

(a) A description or identification of the property;

(b) The dete of the last ridintica sarvoy;

(c) The identity of the orpanization and the individum who performed the monitoring operation;

(d) The type and identification number of monitoring itstrounents;

(e) The results of the monttoring operation; nid

(f) The identity of the recipient of the releosed material." 


\section{REQUIREMENTS IENTIFICATION DOCUMENT \\ HIGH LEVEL WASTE STORAGE TANK FARMS \\ Radiological Protection \\ Rerition 0}

FACILITY REQUIREMENT SOURCE; DOES40.5.5 Chapter II, Section 5.C, Items (1) -4 )

Releats of Meterials and Equipmert.

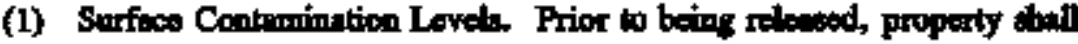
bo surveyed to determing whether both removible ad total eurfice contanimation (includieng contaminution present ba and under nny conting) is greater then the Levele given in Figure IV-1 and thet the conthmination bes been arbjected to the AILARA process.

(2) Potential for Contaminution. Property thell be coneidered to be

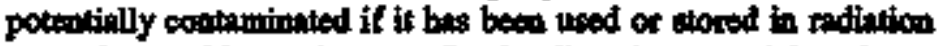
areat that conld contain unconfined radionctive moteriel of that an

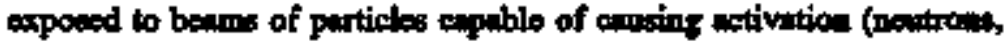
protons, etc.).

(3) Surveye. Surfaces of potentislly contmmineted property shall be surveyed uxing instraments md techniques sppropriato for detecting the limits atad in Figure IV.1.

(4) Inscessible Areas, Where potentinlly contaninuted surfoces art not scessible for mesuremeot ( $m$ in some pipes, drains, nod doctwork), such property moy be relensed after cesse-by-cese evaluetion ind documentetion besed ca both the history of its use mi svilatle

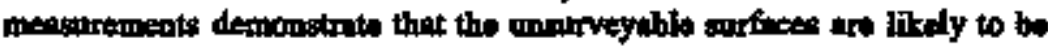
within the timits given in Figure TV-1."

\section{SITE REQUREDMINT SOURCE: DOES480.11 Section 9.}

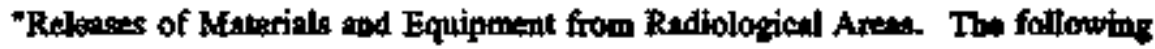
requiremeabr apply for the release of materialn and equipment from rediolofical areas for conditional use in controlted sreak. In ifl caves, contominited property skell bo cleaned is thoroughly w pactical beforo nelease. These requirements me not applicabto to the relesse of miterinls

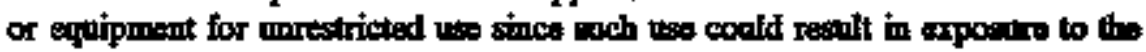
generl pubtic. (NOTE: Requirements combined in this Onder do not perthin

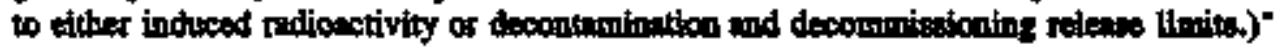

\section{SITE REQUIRGMANI SOURCE: DOES480.tI Section 9.t(1)}

Material nond equipment in ndiological areat etablished to control mutice or sirbone rodicentive meterial shall be trented as radipactive material trid hill not be relessed from radiological aress to controlled areas if any of the following conditions exist:

(a) Measurements of messible surfuces biow that either the totel or removablo contamination levels eresed the prides apectified in Attachmort 2; $\boldsymbol{\alpha r}$

(b) Prior use suggests that the contemination lovels on incocessible sarfaces are likely to exceed the guides apesfied in Athont 2." 


\section{REQUIREMENTS IDENTIFICATION DOCUMIENT HIGH LEVEL WASTE STORAGE TANK FARMS \\ Radiological Protection \\ Rericion 1}

\section{STrE REQUREMENT SOURCE: DOES480.11 Section 9.J(2)}

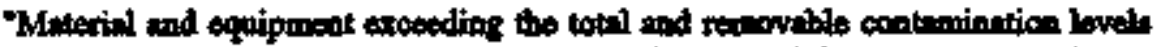

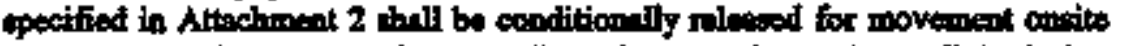

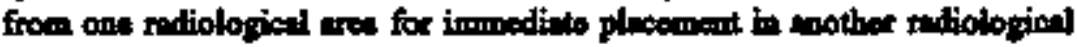

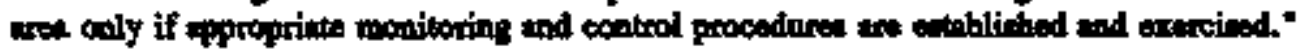

\section{SITE RBQUIBENIENT SOURCE: DOR5480.11 Section 9.i(3)}

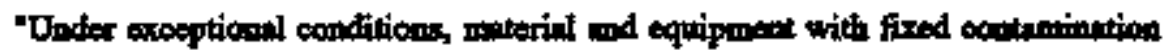

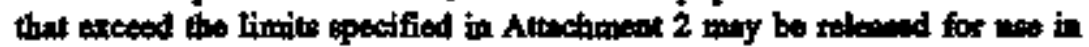
controllied areas outside fodiological areav. As a condition of such reletse,

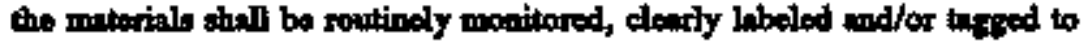

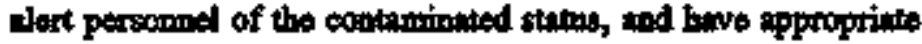
administrativo procedures ectublithed ind exerciesd to maintoin control of theoe iteme."

\section{L.6.5}

\section{Segled Source Manasenen}

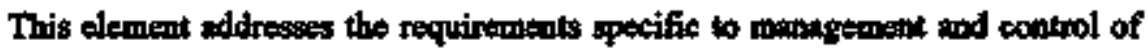
seiled souroes.

\section{SITE REQUIREMINT SOURCE: DOE-N\$480.6 Section 431.1}

\section{"Redionctive Source Controls}

Ths following provisions apply to wealed and unsealed borres.

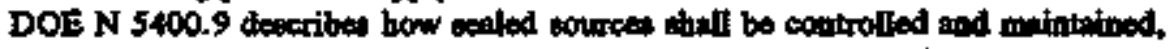
and specifies requirementr for receipt, inventory, etonge, trancfor, dieposal and integrity

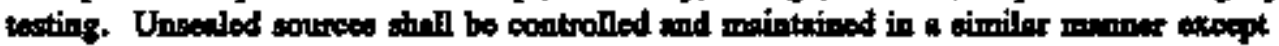
for integrity testing."

\section{STIR REQURREMENT SOURCE; DOE-N5480.6 Section 431.2}

The Rediological Control Organization shall maintain, or cense to be meintmined, mocontrability records for sealed eources"

\section{STIE REQUIREMIENT SOURCR: DOENB480,6 Section 431.3}

"Sounce curtodians shall be appointed to matintain radionctive cource controle."

SITE REQUREMENT SOURCE: DOE-NS450.6 Section 431.4

-Sounce cestadians strill notify the Radiological Coutrol Organization of chenges in ues, storige, tranefer, dispocel of loes of a meated sources."

\section{STIE REQUIREMENT SOURCE: DOE-NS480.6 Section 431.5}

-Sealed source integrity testing shait be done at least every 6 months or whenever damage might bave occaned." 


\section{REQUIREMENTS IDENTIFICATION DOCUMENT \\ HIGH LEVEL WASTE STORAGE TANK FARMS \\ Radiological Protection \\ Rerlivion 4}

\section{RELATED REFERENCES}

1. DOE/EHODS6T Articlo $\mathbf{4 3 1}$, Item 5

\section{SME REQUIREMENT SOURCE; DOENS490.6 Section 431.6}

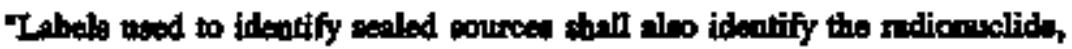

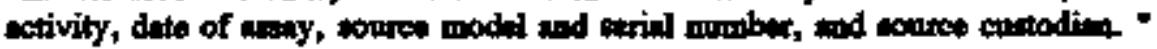

\section{SITE REQUIREMIDNT SOURCE: DOE-NS490.6 Section 431.7}

"Procanement of radionctive sources thell be coontinuted with the Rediological Control Organizution."

\section{SIIE REQUIREMENT SOURCE: DOEN5480.6 Section 431.9}

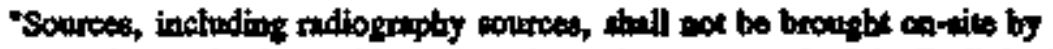
externel ortenizations withent the prior written approval of the Radiological Control Organizition.

\section{LABORATORY ANALYSIS}

This element addresses requirements for the eppropriste handing and Inborntory an:alysis of anmples.

\section{SITE RBQUIRRMANT SOURCR: DOE/EH0173T Section 6.1.1}

"Each manitoring and sorveillanse orgenization shoald hive a somple identification tystem thet providea poritivo identificution of amples and stiquess of armples throughout the inilytical process. The syotem thould incorpornte a method for trecking all pertinent informetion obtribed in the s.miplings procets."

\section{8}

\section{RADIOLOGICAL PROTECTION EOUIPMENT AND SUPPLIES}

The Rariologital Protection Expipment and Supplites eloment inclentes requirement that address the costrol and meintennce of RP equjpment and

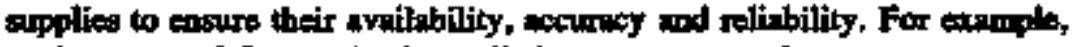
equipmeat used for monitoring tatiation expomares and exposure raties wre sequired to most defined tocknical stenderds for sceurncy, sensitivity,

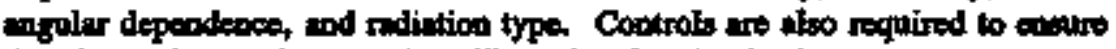

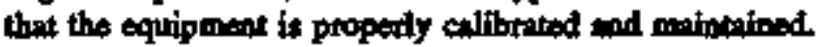

\subsection{Monitoring and Surxey_Instrumentation}

This clemept addreses the requitements for certification, we and control of rafietion monitoring equipment. The elements within are specific to the equipment itsolf. Requirements molating to surveys performed with the equipiment or the monitoring or aress using the equipment ane included in Section 11.2, Facility Monitoring and Sarveys. 


\section{REQUIREMENTS IDENTIFICATION DOCUMIENT \\ HIGH LEVEL WASTE STORAGE TANK FARMS \\ Radiological Protection \\ Rerieion 1}

\section{MITE REQULREMANI SOURCE: ANST-N323 Section 4.1}

Precalibention. The following exoditions inll be cotablisbed prior to exposing the instrument to a soure for ajjustment and calibretion:

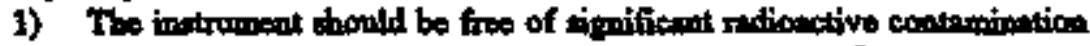

2) The mever thell be edjuted 0 zero or the point apecified by the mapuf fotures uning the adjutmont or adjusments provided

3) The batteries or power sopply eholl comply with the instrubcat monutintrer's specification

1) The inetrumint stell be tumed on and allowed to warm up for the tire period spocitiod by the manuficturer

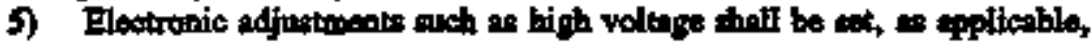
to the manufeaturex's epecificoticar

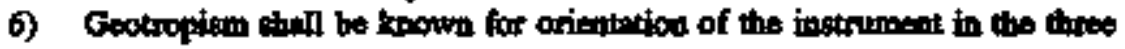
metually perpendicular planes, and this effect mall be taken into eccount during colibntica and performance teating

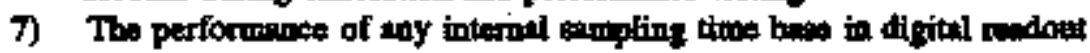
instrimeats should be verified ss beins within the minuficturer's spectifictions."

\section{STE REQUTREMENT SOTRCE: ANSI-N323 Section $\mathbf{4 . 6}$}

Poriodic Performence Test. To assure proper opention of the instrumeat between ellibrations, the instrument sholl be tested with the check scarce during operation and prior to each intermittent usen."

\section{SITE REQUIREMENT SOURCE: ANGI-N323 Section 4.6[02]}

"Reforence readinge whall be obtrined on ach instrument when expeced to a

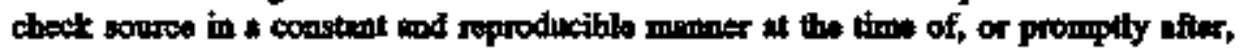
primary celibretion. If it iny time the turstrumene responso to the check source differs from the reference reading by more then \pm 20 pereed, the instruareat shall be returned to the calibration fiecility for calibration of for meintenonse, repair and recelibertion, es required. Reference readings should bo obtained for one point on etch weale of decede normally ued. The check source should accompeny the inetrument if it is spectific on that instriment:

\section{STIE REQUIREMENT SOURCE: ANSI-N323 Section $5.3[02]$}

"A periodic imstrament check procedure theil bo ecteblished by the uner to nssetre continued proper operation."

\section{SITE REQUIREMIENT SOURCE: ANSU/ANS-13.5 Section 10}

"Certificate A certificto shall aceormpiny anch exposturo meter and shill includs the following information:

(1) Mart or type of the instrument

(2) The manufacturet's nome

(3) The exposure in milliroentgen or roentged, correspouding to the scals valus 


\section{REQUIREMENTS IDENTIFICATION DOCUMENT \\ HIGH LEVEL WASTE STORAGE TANK FARMS \\ Radiological Protection \\ Revision 1}

(4) The thergy dependence corve of the inetrument (that is, the respones por

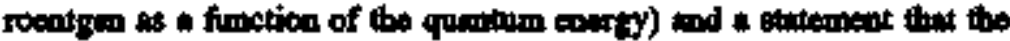

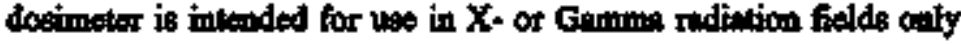

(5) The lacetion and dimensions of the seneitive rotums

(6) Tho indication "sirtight" or "not sirtight" se sppropristo

(7) The mexitunl perminible exposure rite for the inetriment

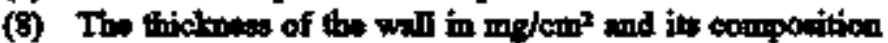

(9) The viriation of the execitivity with the engle of incidence of rediation roferned to a welli-defined aris of the instrument

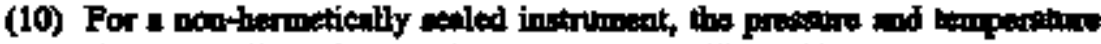
which provoiled when the instrument was colibreded"

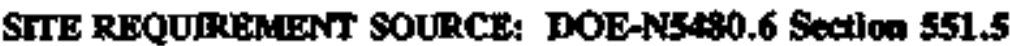

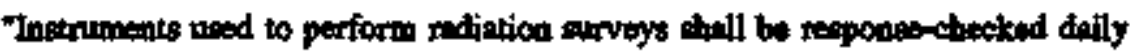
or prior to operation. When respone checken are not within +20 percent of the expected vitus, the instrement stould be taken out of nervice. Wher

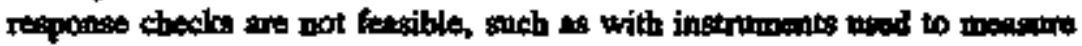

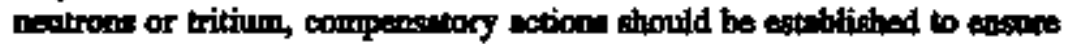
proper inetrumest performence."

\section{RELATED REFERENCES}

\section{DOE/ERMO256T Article 551}

\section{STTE REQUIRENENT SOURCE: DOE/EETOLSS RP.10 CONTAMINATION CONTROL 23}

23. Adequato cometing equipmeat for swipes is availablo. The equipment is properfy ellibrited and mintuined. Countins procedures are trailablo

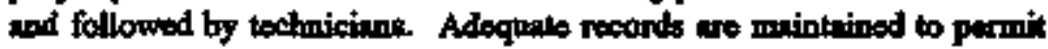
QNQC verification of smplo results."

\section{STIE REQUREMENT SOURCE: DOE/EHO135 RP.8.13}

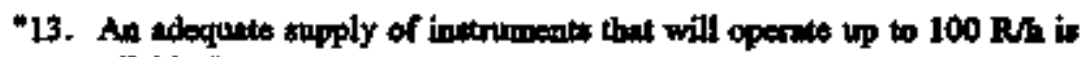
svailnble."

\section{SITE REQUIREMENT SOLRCE; DOPVHH0135 RP.8.14}

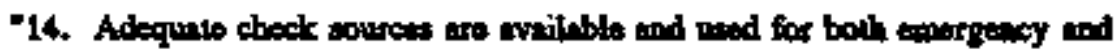
routine instrumeuta to tosute they cperate pacpexty prior to noe."

\section{SIIE REQUIRPMENT SOURCE: DOD/ER0L3S RP.8.15}

"15. "Extendable" detectors are availablo for remote monitoring under accident conditions." 


\section{REQUIREMENTS DENTIFICATION DOCUMENT HIGH LEVEL WASTE STORAGE TANK FARMS \\ Radiological Protection \\ Revision 1}

\section{STTE REQUIREMENT SOURCE: DOE/EHO135 RP.8.17}

"17. Procedufes aro avtilable for workess to determine if indruments, auch se hand and thoo counters, are operating."

\section{STE REQUIREMENT SOURCE: DOE/LHOL35 RP.8.18}

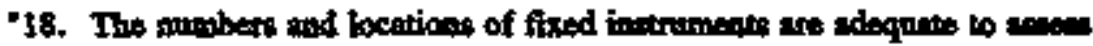
scoident conditione. (They would not be affected by eloveted beckpound

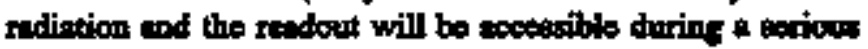
emergonsy.)"

\section{SIIE REQUYREMENT SOURCE: DOEJEH0135 RP.8.19}

-19. Fixed instrumeats alucm at a contral location in addition to the alem at the instrument locetion."

\section{STE REQUIREMEENT SOURCE: DOE/EHO135 RP.8.20}

20. The exuct bocations of fixed instruments aro documeated (beight above floor, atc.) 80 that the shitelding tffect can be celculeted from drawings and the exposure rate in araby locetions extimaled in the event of a secious motident (i.e., in eriticality ascident)."

\section{STIE REQUIREMENT SOURCE: DOE/MFO135 RP.8.3}

- 3. Inetrumentation selection is based an objective culteria (such as per formince sterdards, site recpirements, efc). Selected imstruments ure

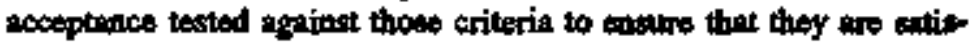
factory, and the results are documexted."

\section{STIE REQUIREMENT SOURCE: DOE/EH0135 RPA.6}

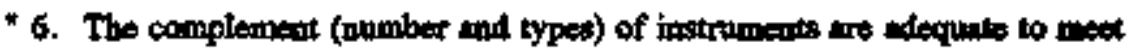
dis needs of botb ths routipe and non-routioe thiation protection surveillance program and are approprinto for the ectivitios and radistica sourtes present."

\section{SITE REQUIREMINT SOURCE: DORS480.11 Section 9.8(3)(b)}

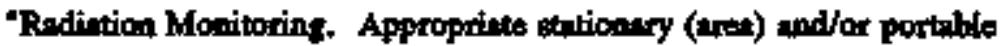
andiation instruments shall be avilable and asod to measore doce nates for the

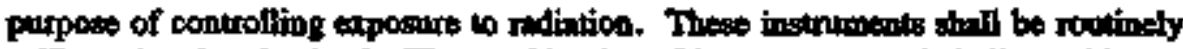
cellibrated and maintained. The combination of inetruments ueed tand provide capability to mesture types of radiation (neutron, $8 \mathrm{mmm}$, beta, or $x$-redietion) and dose rates characteristic of thit which could be encoututed at the finility."

118.2 Respiratory Futipmentand Supplis

This elenteot addresses the requiremeats for centibetion and mainienence of reppiratory protection equjpment. The requirements address the respiratory protection equipowent 


\section{REQUIREMENTS IDENTIFICATION DOCUMHNT \\ HIGH LEVEL WASTE STORAGE TANK FARMS \\ Radiological Protection \\ Revivion 1}

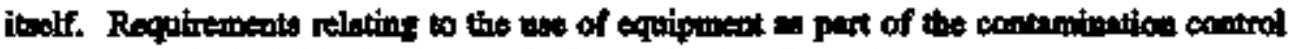
program are ixclnded in Sectice 11.5, Contamination Control.

\section{SITE REQUIREMENT SOURCE: 10CFR20 Part 20.103.c}

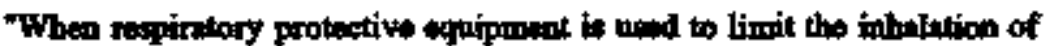
sirbome radiosctive miterial purstont to paragraph (b)(2) of this asction, the licenese shall use equipmint that is certified or had certifiction

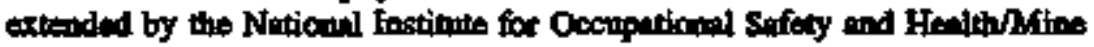
Safery and Fealth Administrotion (NIOSH/MASA)."

\section{SITE REQUIREMENT SOURC: 10CFR20 Fart 20.103.t}

"Only oquipment that bus ben tpocifically certified or had certification axteeded for emergency use by NIOSHMSHA thell be used es emergency devices."

\subsubsection{Brotective-Clothing}

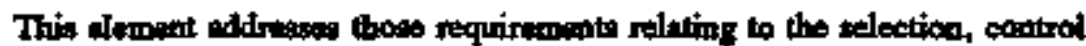
and uee of protective elothing.

\section{STE REQUIRFMENT SOURCE: DOE-N5480.6 Section 325.1}

\section{Fersonal Protective Equipment and Clathins:}

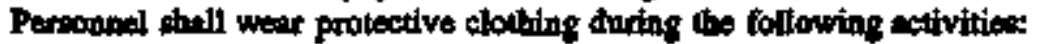

- Habdling of comminated moterills with removible contrmination in excess of Tible 2-2 lovetsi

b. Work in Contunination, High Consmmintion and Airborne Rediowetivity Are:se;

c. As dirseted by the Rodiological Controd Orgenizution or as required by the RWP."

\section{RHLATED REFERENCES}

1. DOEJEHO2S6T ARtiele 325

\section{SITE REQUIREMENT SOURCE: DOE-NS480.6 Section 323.2}

"Protsetive cloching and shoes destignated for radiological controd ahall be:

a. Marked in ecordance with Article 451;

b. Used anly for indiological control purposes."

\section{RELATXB RFAERTMNCES}

\section{DOE/EHOES6T Article 325}

\section{SIIE REQUIREMENT SOURCE: DOE-N5480.6 Section 325.3}

Protective clothing dress-out aress should be established directly adjecent to the work area. Workers stould proceed directly to the radiological work area sfter doming Personal Protective Equippent and clothing." 


\section{REQUIREMENTS DENTIFICATION DOCUMENT \\ HIGH LEVEL WASTE STORAGE TANK FARMS}

\section{Radiological Protection}

Reristion o

\section{REI.ATDD REFERENCES}

1. DOE/EHORS6T Anticlo 325

SIIE REQUIREMINT SOURCE: DOE-NGA80.6 Section 325.4

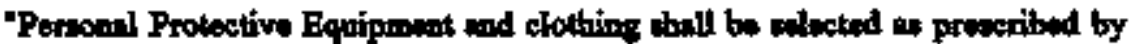
the controlliog RWP. General gatidelipes for protective clothing election and we we provided in Appendix 3C and in Table 3-1."

\section{REATIED REFERENCLS}

1. DOE/EH0256T Article 325

\section{SIIE REQUIREMIFNT SOURCE; DOE-N5480.6 Section 325.5}

The use of labeonts as radiological protective clothing is appopriate for

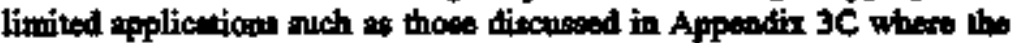
potential for personal contamination is limitad to the hends, arens, and upper front portion of the body. Labeonts should nok be used ns protective slothing for performing physical work ectivities in Contaminetion, High Conteminetion or Airborne Radionctivity Areas."

\section{RELATED REFERENCES}

\section{DOE/EHO2S6T Articlo 325}

\section{STIE REQUIREMENT SOURCE: DOE-N5490.6 Section 325.6}

"Instructions for domaing and reanowing protective clathing steould bo pasted at the troborat and step-off pat aren."

\section{RRLATED REFERENCIS}

\section{DOE/EHO256T Articls 325}

\section{SITE REOUREMENT SOURCE: DOE-NG490.6 Section 325.7}

The use of Pernonal Protective Equipment or clothins [including reipintary protection) beyond thit auhorized by the Ratiological Control Oranization detrictis from work performose and is contrary to ALARA principlos and waste minimizotion peactices. Such use should not bo anthorized."

\section{RELATPD REFERENCES}

1. DOE/EH0266T Article 325 


\section{REQUIREMENTS IDENTIFICATION DOCUMENT HIGH LEVEL WASTE STORAGE TANK FARMS \\ Radiological Protection \\ Berioion 0}

STIE REQUIREMIENT SOURCE: DOE-N5490.6 Section 325.8

"Compeny-iesped clothing, ach es wott coverall and thoes, lhould bo

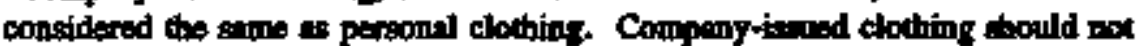
be used for miological control purposer.

\section{RELATIDD REAERENCES}

1. DOE/EHOZSGT Article 325

GITE REQUIREMISNT SOURCE: DOE-N\$490.6 Section 461.1

Soupport Activities

Pesconel Protective Equipment and Clothing

Protutive clothing designeted for miliological control use shenl be

specifically identified by olor, symbol of tiptopriate lubeling."

\section{RALATED REFERENCES}

1. DOE/EH0256T Article 461

SIIE REQUIREMENT SOURCE: DOE-NS490.6 Section 461.2

"Protective clothing designeted for rediological control use shat not be wed for son-rotiological work."

\section{RELATED REFERWNCES}

1. DOE/EHO256T Article 461

STIE REQUIREMENT SOURCE: DOE-N5480.6 Section 461.3

"Personal Protective Equipment end clothing chall not bo stored with porsonel strect clothing."

\section{RELATED REFERTNCES}

\section{DOE/EH0256T Article 461}

SITE REQUIREMENT SOURCE: DOE-N5480.6 Section 461.4

"Cleoned Peromel Protective Equipment, guch as face ehields and nespiritron, that comes into conlact with the weater's face and compeny isened non-perrond protective clothing shell be surveyed. This nurvey shoult bs capable of detecting contuminetion lovels equivatent to Tuble 2-2 total contaminution values prict to rense. The nes of stotistically representativo sampline is exeptable." 


\section{REQUIREMENTS IDENTIFICATION DOCUMENT FIGH LEVEL WASTE STORAGE TANK FARMS Radiological Protection \\ Rorision 4}

\section{RELATED REFERENCES}

1. DOEVH02S6T Anticl 461

\section{SITE REQUIREMENT SOURCE: DOE-NS480.6 Section 461.5}

"Landened prowective clothing thonld be survoyed using statisticnlly representativo sarroling tod should met the following criteria priar to renpes

- Betreamme tefipectivity less thes 10,000 dpon/100 cm2;

b. Alphe radionctivity less then 1,000 dpan/100 cme.-

\section{RGLTDD RGKGRNCWS}

\section{DOE/EHO256T Article 461}

\section{STrE REQUIRFAENT SOURCE: DOR-N5480.6 Section 461.6}

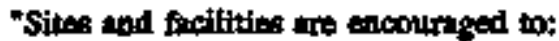

a. Apply the latest techniques and instrumentsation to detect contrmination on Personal Protective Equipmont and abothing below Table 2-2 total contaninitation values.

b. Continus efforts to reduce contamiration levels con reuteble Percond Probetive Equjpment mod clothing."

\section{RELATED REFERENCLS}

1. DOE/BFFESSTT Articlo 461

SIIE REQUHREMENT SOURCE: DOE-N5490.6 Section 462.1

"Linmdry

Clothing and eqtipment stonld bo laundered according to frecility, color, type, and level of conthminution."

\section{STE REQURRMIENT SOURCE: DOE-NS480.6 Section 462.2}

Inedry ectivities honld be performed using proceves that minimize beth potenticl worker exposure and the volume of wate genesnted."

\section{STIE REQUIREMENT SOCRCE: DOEN3480.6 Section 4623}

"Clothing and equipipeat should be exteenod before they are loundered to

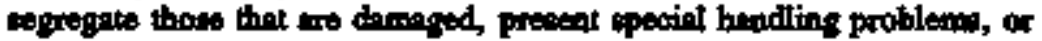
requirs dipposal."

\section{SITE REQUIREMENT SOURCE: DOE-NS480,6 Section 462,4}

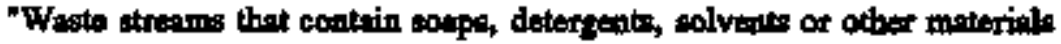
which confl interfere wilh processing largo-volume liquid wasto strums alcould be segnegated for exparote processing-" 


\section{REQUHREMENTS IDENHIFCATION DOCUMENT \\ HIGH LEVEL WASTE STORAGE TANK FARMS \\ Radiological Protection \\ Rerition 0}

STE REQULREMINT SOURCE: DOE-NS490.6 Section 462.5

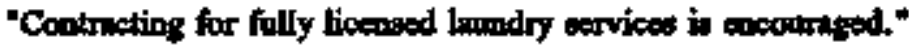

STIE REQUIREMIENT SOURCE: DOEN5490.6 Section 40.6

"Cleenet Personel Protective Equipment and l-andered protective clothing dull

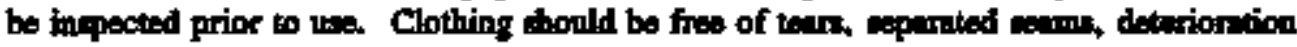
and demage, or repeired in a moner thit provides the originei bevat of protection."

\section{STIE REQUIREMIENT SOURCE: DORJEH0135 RP.10 CONTAMINATHON CONTROL.14}

14. Sufficient quntities of protective clathing are wrilahte, and we consistently uged where required."

\section{STIE REQUIREMENT SOURCE: DOE/5ROU35 RP.10 CONTAMINATION CONTROLIS}

"15. Linndry procedures minimize spread of conntamtinestion."

\section{SITE REQUIREMRNI SOURCE: DOE/EH0135 RP.4.3}

73. Proper controls are used to drinimize expostrot to the atin and eyeen, e.5., by use of protective alothing and equipment."

\section{Dosimetro Evitionent}

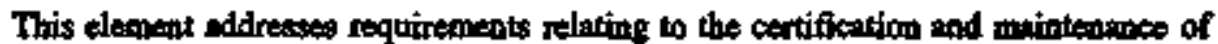
dosimetry equipment. The requirements relate to the dosimetry equipment itself. Requirements reinting to the dosimetry progrum and the uwe of dowimotry equipment a part of that progrikm aro inchuded in Section 11.3, Persomel Exposure Monitoring.

\section{STIE REQUIREMENT SOURCE: ANSW/ANS-13.5 Section 9.1}

The coergy dopendence of the instrumpent, thet is, respones per roentgese, over its stated ronge stall not exceed \pm 10 percent of the value of the sensitivity at coe epeoified eneray."

\section{SITE REQUIREMENT SOURCE: ANSUANS-13.5 Section 9.2}

"In the range of exposure ratea as indicated in the directions for use, the deviation of the rensitivity as nesult of recombinetion shall not exceed 10 percent. This deviation stall be meastured with respect to sensitivity for al

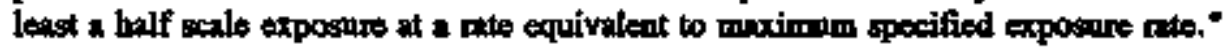




\section{REQUIREMIENTS IDENTIFICATION DOCUMENT HIGH LEVEL WASTE STORAGE TANK FARMS \\ Radiological Protection \\ Rerioion 1}

\section{SITE REQUIREMENT SOURCE: ANSI/ANS-13.5 Section 9.3}

The discharge of a full charged docimeter with 1 nome of 100 midliroentgen or mome thall not exceed 2 percent of full ectle in 24 boun, if it is pleced in

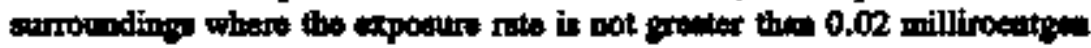
per bour and in eneibient cooditions:"

\section{SITU RECUIREMENT SOURCE: ANSI/ANS-13.5 Section 9.4}

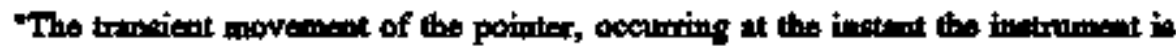
diecomected from the charging cource, shall nok exceed 5 peicent of full

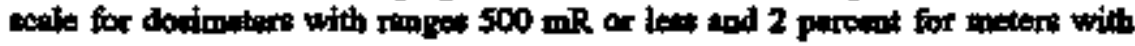
renges in excees of $500 \mathrm{mR}$."

\section{SIIE REQUIREMRNT SOURCE: ANSUANS-13.5 Seetion 9.5}

"Under tho conditions specified in section 8 of this ctenderd, the total exros of mesourement of the 95 percent confideres lovel shall nok exceed \pm 12 peocent of the ftill seale value"

\section{SITE REQUIREMENT SOURCE: ANSUANS-13.5 Section 9.6}

The indications stull not very by more then 5 percent of the maximum scelo value with ary change tm position of tho axposure metor. If this condition cennot be fulfilled, the operting intrution thall give the proper position of the expowers motor during the reating."

\section{STTE REQUREMIFNT SOURCE: ANST/ANS-13.5 Section 9.7}

The rediation resposse of the inetrument at every angle not exceeding $50^{\circ}$ from the dirsction of mixximum reoponse of the instrument shall not be loss thm 70 percent of the maximum."

\section{SIFE REQUIREMENT SOURCE: DOE/EH0135 RP.S ROUTHN DOSTMETRY.18}

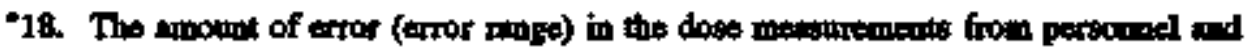
oxtromity dosimeters erro documented."

\section{SIIE REQUIRSMENT SOURCE: DOEEA0135 RPS ROUTINE DOSDEFTR.19}

19. The minimum detaction lovela of personnel and extremity docimethen for

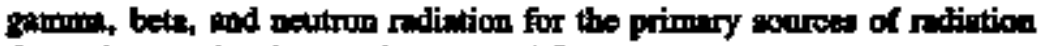
that exists on the site are docaunonted." 


\section{REQUIREMENTS IDENTIFICATION DOCLMENT HIGE LEVEL WASTE STORAGE TANK FARMS \\ Radiological Protection \\ Revision}

\section{SIIE REOUHEMENT SOURCE: DOEMEH0135 RP.5 ROUTINE DOSDIETRY2}

"2. The contractor perticipated of plane to participats in DOEl AP to tost its donimoter."

\section{STE REQUIREMINT SOURCE4 DOE/BF0135 RP,S ROUTINE DOSIMETRY.3}

"W. Actions heve been then to correst defieiencies identified by participation is DOELAP."

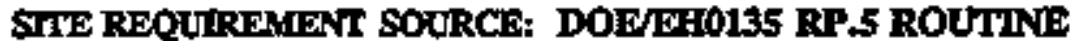 DOSMMETRY.S}

-5. Dosimeter (whole body md extromity) calibration turilitize nod procedores to adequito to cover the rimge of exposures, energies, and type

of todiation entictiparest"

Equiponen Maintenange and Callbcation

This element addresses requirements relating to the maintensnce and celfibration of rwdiation protection equipmedt.

\section{GITE REOUIREMWNT SOURCE: ANST-N323 Section 4.2.1}

Primary Calibretion

Genert. Ths reprodacitility (prectsion) of the inotrument thould be keow priot to making colibtotion odjustments. This is particuleriy importunt if the instrument failed to poss the source check (cos 4.6) or if repeins have been mede. To check reproducibility, the instriment stould be exposed to a

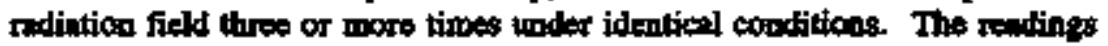
obleined ehould normelly wot deviate from the neen value by mome then \pm 10 percent."

\section{SITE REQUIREMENT SODRCE: ANSI-N323 Section 4.2.2.2}

"Iinear Readout Instruments.

Linear instrumentw usually hove a ceale selection whitch. If coutrolu ane

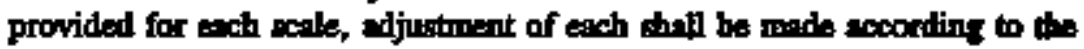
minnficturer's specificetion: or at the midpoine of ach scale. If only on coatrol is provided, affustment shall be mide either (1) at the potnt

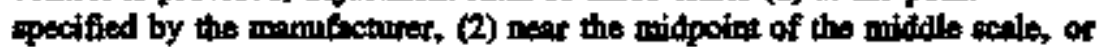
(3) near the midpoint of a scalo that is particolesty importint to the uner's requiritomats."

\section{SITE REQUIREMENT SOURCE: ANSI-N323 Section 4.2.2.1[02]}

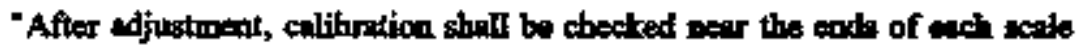




\section{REQULREIENTS DENTIFICATION DOCUMENT HGI LEVEL WASTE STORAGE TANK FARMS \\ Radiological Protection \\ Revision 0}

(Approximately 20 percept and 80 percent of full scale). After m adjecment or etjuetments hevo been completed, instroment roudinga tholl bo within \pm 10

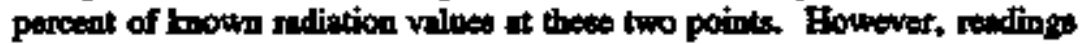

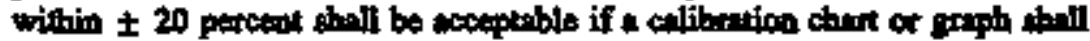

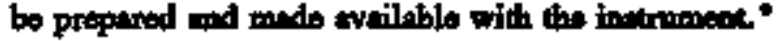

\section{STIE REQUIREMINT SOURCE: ANGINB23 Section 42.2 .2}

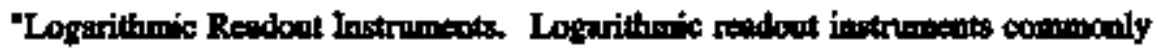

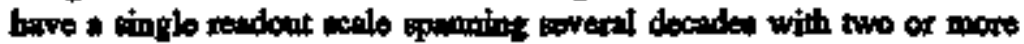

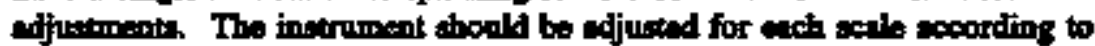
tho mennficturer's specifications ar, alternetively, it points of purticular importince to tho user."

\section{SHE REQUIREMENT SOURCE: ANSI-N323 Section 4.2.2.2[02I}

"After djustreat, celibration shall be performod at a mintimem of one point

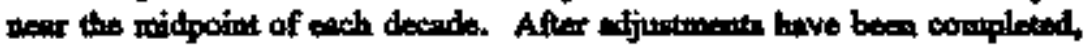
instrument readings shall be within \pm 10 percent of the known radintion value at thes points. However, readings within \pm 20 percent is aceptahle if a

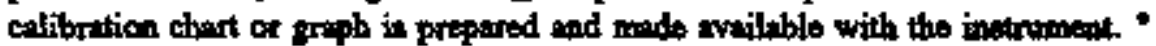

\section{GITE REQUIREMENT SOURCE: ANSI-N333 Section 4.2.2.3}

-Digital Readout Instrumente. Digital inotrumesta may have usomial acols switching, mutomatio acule swikhing (ato ranging) or no ecale switching. For instruments with eitbor montal or antomatic switching, to coliburstion shall be performed at in 4.2.2.1. For inetruments withoir acole switching, the oulibration shall be performed as in 4.2.2.2."

\section{SUE REQUIREMANT SOURCE: ANST-N323 Section 4.3.1}

"Collibrtion for Specint Conditions

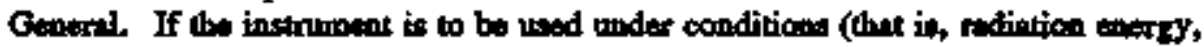
temper ans and pressure, or source/detector geometry) which vary rignificumly from those for which the instrumed is deslened, tho instramet

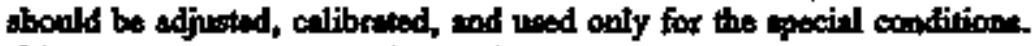
When an instrument it celibrated for speciel condition, a special condition identification label shall be aftuched (in wdition to ton required cetibration labele) to iodiente its ipplicabitity for this pecial wes only. Howeves, if the indroment is atso to be need withis its deatio limite, the adjustments mado during primery calibention (ceo 4.2) stell nemain the wene, and instrament readinge for the speciel ecoditions thell be corrected uins correction fictors obtained from approprinte tables or graphs. Only ons parmetor chould bo veried at a time durieg calibention for the spectiol conditions, bat the interrelationships of the variebles should be known."

SITE REQUIREMENT SOURCE: ANSI-N323 Seetion 5.1

-Calibration Equipmeat Required

Calibntion Standerds. Instruments should be catibreted aithor topaines 


\section{REQUIREMENTS WENTIFICATION DOCUMENT HIGH LEVEL WASTE STORAGE TANK FARMS \\ Radiological Protection \\ Rerivion o}

Natioual Strodurds or with Derived Stonderde. If National or Derived standards are not sveilable, Laboratory Sundards, obatained in one of the following waye should be need:

\section{SITE REQUIRTMENT SOURCE: ANSI-N323 Section 5.1, Last Paragraph}

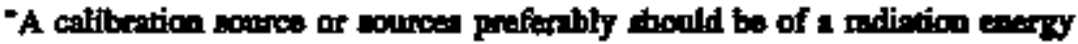
similer to thex with which the instrument will be used and of a ndination

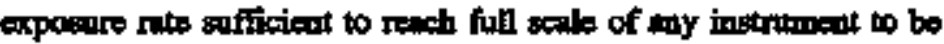
calibrued. If the source is o radionuclide, the half-life strould be long, proforble greater than severil yean to minimize consctione and enon. The uncertuinty of souree calibration atell be no greater then \pm 2 percent with Iexpect to U.S. Nettounal Stenderds."

\section{SIEE REQUIRWMINT SOURCE: ANST-N323 Section 5.1.1)}

"Comparison of the radiation field from 1 arer's source with the rudintion fleld form a Nationsl or Derived Standerd cource in the seme geometry, wsing s 'tronnfer instrument' with a reproducibility of \pm 2 percest. The trinsfor colibretion shall utilize a cafibertion curvo for the transfer instrument laker with the Nations of Derived sonwe over a range that covers both the

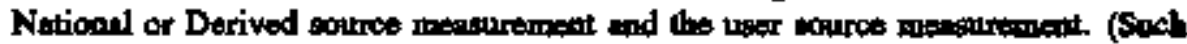
a curve reduces to a single point if the transfer allibration procedure is anch that the trinsfer instrument readinges are jdentical for both

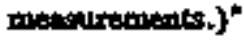

\section{SIIE REQLIREMENT SOURCE: ANSI-N323 Section S.1.7)}

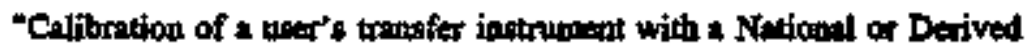
Standerd source, followed by ovaluetion of a uses's worres with the sane transfier instrumeak, Tho transfer instrusent shall heve a reproducibility of \pm 2 perceat and the procecture shail utilize a calibntion eurve $=2$ in 5.1(1)."

\section{SITE REQUTREMENT SOURCE: ANSI-N323 Section 5.1.3)}

"Where on Netional or Derived Strodard exists, es in the exse of specific

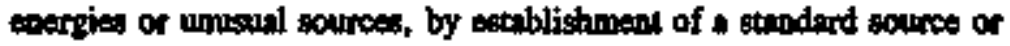
instrument with documented empirical and theoretical output or repones charncteristice "

\section{SITE REQUREMENT SOURCQ; ANSI-N323 Section $\mathbf{5 . 3}$}

"Stmdind Instraments. An instrament used a a Derived Standerd sholl hrve an

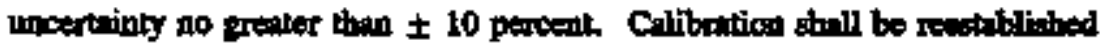
after mainiennoe or repoit or at intervals specified by the monutucturer bax in no case at intarvals greater then throe yeart." 


\section{REQUIREMENTS IDENTIFICATION DOCUMENT \\ BIGH LEVEL WASTE STORAGE TANK FARMS \\ Radiological Protection \\ Rerision 0}

\section{SITE REQUIREMENT SOURCE: ANSI-N323 Section 6.1}

Mninteratase of Quality of Calibration.

Rediation Fielt. Either nerrow of brood beam geometry may be uned to compare the response of similar instriments with that of a standerdized instrument"

\section{STTE REQUIREMENT SOURCE: ANSH-N323 Section 6.1[03]}

"Ajphe ndintion sources sholl be atendardied in terms of activity or activity per writ nrea

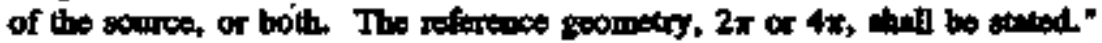

GTE REOUIREMENT SOURC: ANST-N323 Section 6.1[09]

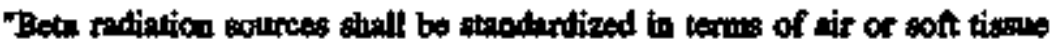
absorbed dose rute at the aurace or at a spesified distance from the wourcen or in terms of activity."

\section{STIE REQUIREMIENT SOURCE: ANST-N323 Section 6.1[0.5]}

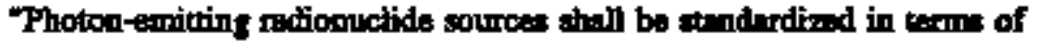
exposure nte (in roentgent per bour) at a apecified distance form the source. "

\section{SITE REQUIREMIENT SOURCE: ANSI-N323 Section 6.1[07]}

- Por photon and neutron monitoring inetrument cellibrations, the sourch-to-detector distonce stall be the distance mensured between tho effective center of the ndiowctive sounce and the effective center of the

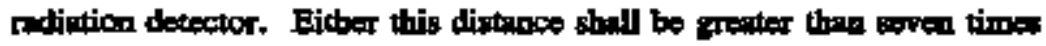
the maximmm dimession of the source or detector, whichever in larged, of srituble corrections shall be used."

\section{SITE REQUREMENT SOURCE; ANSI-N323 Section 6.1[08]}

The expoesure rals or the flux density of the rediation field thall be keown

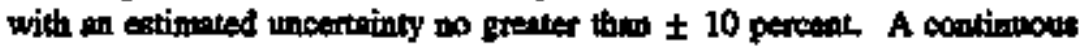
monilor of other device should be wed to determine whether the redintion field hal chenged."

\section{SITE REQUIREMENT SOURCE: DOE-NS484.6 Section \$55.5}

"Air menitoring equipmeat shall bo routinely celibrated and maintuined at a

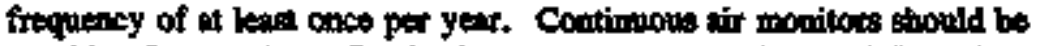
coppoble of meaguring 1 DAC when averaged ove 8 hours (8 DAC-houm) wadk libofatory conditions."

\section{RELATED REFERENCES}

1. DOE/EHO266T Article 555 


\section{REQUIREMENTS IDENTIFICATION DOCUMENT HIGH LEVEL WASTE STORAGE TANK FARMS Radiological Protection \\ Rerision 0}

\section{SITE REQUIREMIENT SOCRCE; DOE-N\$480.6 Section 561}

Instrumentation and Calibration

Standartitzation

Standandization using commencinlly evrilable ndiologted instrumentation in the DOE is highly eneouriged. In sppport of stenduritizition, DOE mitenth to

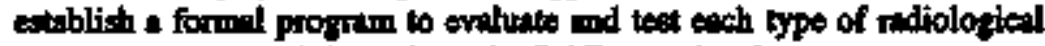
instrumeotation uad throushout the DOE complex."

\section{STE REQUIREMENT SOURC: DOE-N5490.6 Section \$62.1}

Inspection, Cntihration and Performonce Tests

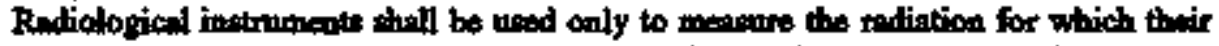
calibrations are valid. DOE 3480.4 mondates the requirements conaninod in ANSI N323 for ndiolopical instrumentation cellibration. Colfibrations shall wee Nisionsl Inetitute of stendirds and Tecknology (NTST) traceeble cources."

\section{RELATED REFERENCES}

\section{DOE/EH0256T Article 562}

\section{SITE REQULREMIENT SOURCE: DOE-N5480.6 Section 562.2}

"Calfibration procedures thould be doveloped for ench inetrument type and irolude frequency of calibrotion, precalibration requirementa, primary colibration requirements, periofic performonse test roguirements, calibration recond requirements and meintenence reppirements."

\section{RELATED REFERENCES}

\section{DOE/EH0256T Article 562}

\section{SITE REQUIREMENT SOURCE: DOEN\$4\$0.6 Section $\$ 62.3$}

-Pecket and electronic doximeters and ares rodiution monitons should be calibrated at kest annofly and in scoordmce with Article 562.1."

\section{RELATED REFERENCES}

\section{DOE/EH0236T Articlo 562}

\section{SITE REQUREMENT SOURCE: DOE-N5480.6 Section 562.4}

"Rediation instrumentation responsw to interfering baizing and noo-ionixing radietion end environmentel conditions chould be determined. The effectu ach interfertions radiation hes on an instrument should be lnowa prior to use."

\section{RELATED REFERENCES}

1. DOP/EH0256T Article $\$ 62$ 


\section{REQUIREMENTS DENTIFICATION DOCUMENT HIGH LEVEL WASTE STORAGE TANK FARMS Radiological Protection \\ Beripion 0}

\section{SITE REQUREMIENT SOURCE: DOE-NS480.6 Section \$62.5}

"Functional tests should be ued to assess instromentutiou desipas

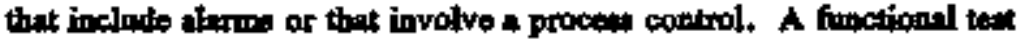
abould be developed to test all conposents involved in in alarm or trip function and performed at least ennmelly."

\section{RELATED REFERENCES}

\section{DOEJER0256T Articlo 562}

\section{SITE REOUHREMANT SOURCE: DOE-N5490.6 Sedion 562.6}

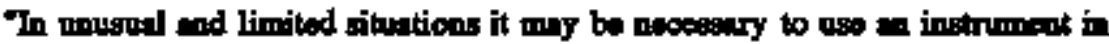

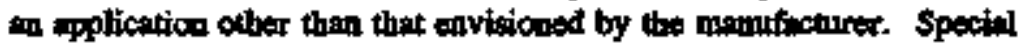
calibrations should be perfermed for use of instrumentation out.ido minufacturer's specificntions. The instrument should be adjusted, calibrited and labeled to idensfy the special conditions and used conly under the special conditions for which it was calibnted."

\section{RBLATED REFERENCES}

1. DOE/EH0256T Artacle 562

\section{SITE REQUIREMENT SOURCE: DOE-NF480.6 Section 362.7}

Instruments should bear $a$ thell or test with the dete of calibration and dots culibrition."

\section{RELATED REFERENCES}

\section{DOE/EH0256T Article 562}

\section{STRE REQUIREMENT SOURCE: DOE-N5490.6 Section 562.8}

"Instruments whose "as formod" resdings indicale that the instrument mey hrve been used whille our of celibrition shell be reported to the Ratiological Coutrol Organization. The Radiological Control Organization thould review surveys performed with the instrument while it wan out of caitibation."

\section{RELATED REFERENCES}

1. DOE/ERO256T Article 562

STE REQUIREMISNT SOURCE: BOE-N54\$0.6 Section 563.1

-Maintenance

A program for preventive and eorrective maintenance of mdiologion instnumentation thould be testablished and doctumented." 


\section{REQUIREMENTS IDENTICATION DOCUMTNT HEI LEVEL WASTE STORAGE TANK FARMS Radiological Protection \\ Rerision 1}

\section{REATED REFERENCES}

1. DOEJER0256T Article 563

\section{SITE REOUREMMONT SOURCE: DOE-N5480.6 Section 5\$3.2}

Proventive and corrective maintenonce shonid be pertormed using conponongs and

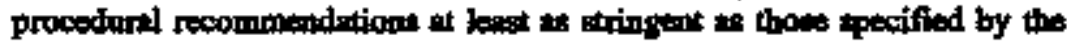

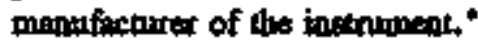

\section{REMATID REMERRENCES}

1. DOE/ER0256T Article 563

\section{SITE REQUIREMIAN SOURCE: DOE-N\$480.6 Section $\$ 63.3$}

"Radiological instrumeoss shall undergo calibration prior to use following any perventive or corrective meinterance or wy adjustroent that voids the proviows celibration. A buttery shango is not nurmolly copstdered maintenance."

\section{RFIATED REFERENCES}

\section{DOELET0256T Articlo 563}

\section{STE REQUIREMENT SOURCE: DOE-N5430.6 Section 564.1}

"Colibration Facilitios

Calibrotion facilities ehould perform inspections, ellibrations, performance tents, celibration equipment solection and quatity eanurance in eceondance with the recommondations of ANSI N323 und take the following actions:

a. Locete activities in a manner to misimize radiation exposure to operting personet and to persomel in stjecent ares;

b. Minimize souress of interference, such so beckseatter and non-ionizing radiation, during the collibretion of inetrumentoston end correct for interferences at nocessiry:

c. Oparite in ecoordsmes with the retenenced standerdy;

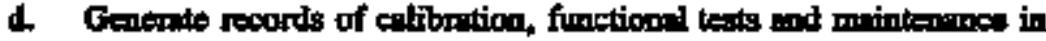
eccontrace with the refereaced stendards."

\section{RELATED REDERENCES}

\section{DOE/EHO2S6T Axtoles $562 \& 564$}

\section{STTE REOUIREMIJNT SOURCE: DOE-NS480.6 Section $\$ 64.2$}

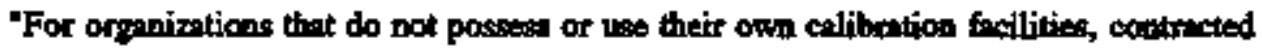
coliberion serviess should be performed in sccordance with the referenced stondords." 


\section{REQUIREMENTS IDENTIFICATION DOCUMENT HGH LEVEL WASTE STORAGE TANK FARMS Radiological Protection. \\ Rerition}

\section{RELATED REFERIFNCES}

1. DOE/EH02S6T Articles 562 \& 564

\section{STIE REOUIREMINNT SOURCE: DOR/EHO13S RP.7.16}

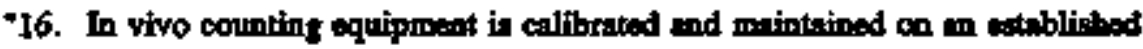
frequency."

\section{STIE REQUIRTMENT SOURCE: DOREHOLIS RP.8}

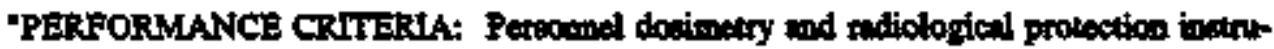

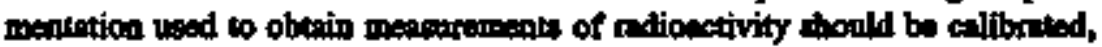
ueed, and mointained so that renults ane acenntely determined."

\section{SIIE REQUIREMIENT SOCRCE: DOEJEHOI35 RP.8.1}

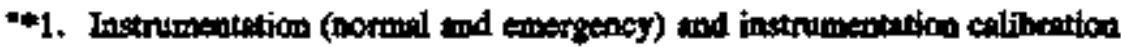
are consistent with ANSI N42.17, ANSI N323, ANSI N320, ANSI N317, ANSI N43.1, and ANSI N42.18, as approprinte."

\section{SITE REQUIREMENT SOURCE: DOEHEH0135 RP.8.10}

"10. The instrumeat repeir facility has adequately trained personol and freilities to service the indruments in ase in a produpt ond safo manner."

\section{STFE REQUIREMENT SOURCE: DOE/EH0135 RP.\$.11}

"I1. Methods hove been established to periodically test averlonit rexponte, temperature sensitivity, linearity, and stability."

\section{STTE REQUIREMIENT SOINRC: DOE/EH0135 RP.8.12}

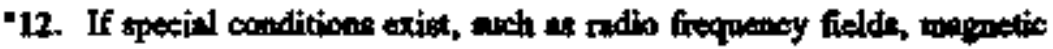

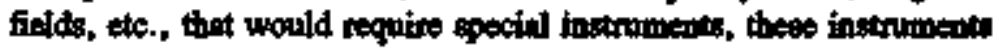
have been tented to enoure a lack of susceptibility to these fectors."

\section{STTE REQUIREMIENT SOURCE: DOE/EH0135 RP.8.16}

"16. The calibration facility cen celfibrate tho high ranges and textr for overlood response and is done pariodienlly."

\section{STTE REQUIREMENT SOURCE: DOEJEHO135 RP,4,}

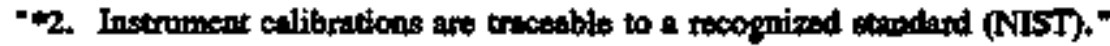




\section{REQUIREMENTS IDENTIFICATION DOCUMENT \\ HIGH LEVEL WASTE STORAGE TANK FARMS \\ Radiological Protection \\ Rerision 1}

STTE REQUIREMIFNT SOURCE: DOEFHTO135 RP.4.4

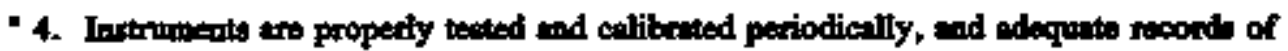
earvicting and calibration are mointrined by the ritedfacility."

\section{SUIE REQUIREMIENT SOURCE: DOE/EFO135 RP.8.5}

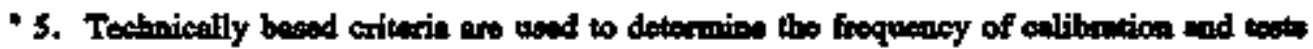
for opertios."

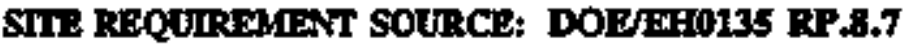

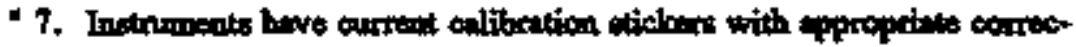

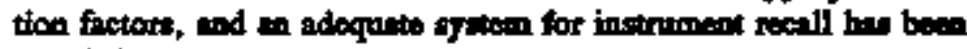
extablished."

\section{STE REQUIRGMENT SOURCE: DOWEHOLBS RP.8.9}

- 9. The calibration facility (onsits or vendox) bes well-churacterized dose

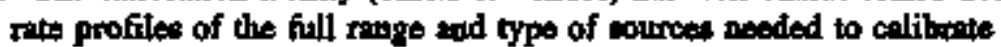
instroments for the sibuations encounlered in tho facility or on the with, ato is periodieslly quality-eontrol checked."

\section{SITE REQUIREMIENT SOURCE: DOEVEF0135 RP.9.13}

"13. Procedure for calfibretion of air monitors ane documented. Inchuded are source chect, stability check, olectronics check, and ir flow enlibration."

\section{SITE REOUIREMIENT SOURCE: DOE/EH0135 RP,9.3}

-m. Routine air monitor calibrations includo minimmm detectable wetivity; energy dependence; effeiency; precision; responso time; stability,

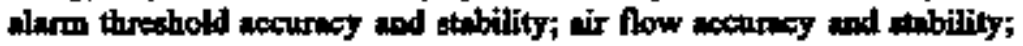
ait to-leakat; and effects of tornperature, bumidits, and ambient pressurn."

\section{SITE REQUIREMENT SOURCE: DOE/EH0135 RP.9.6}

* 8. The celfitration procectures (nod frequency) for the tir sempling and monitoring equipment are beed on appropriete technical criteria."

\section{STIE REQUIREMENT SOURCE: DOE5480.5 Section 13.b(5)}

Documented periodic inspections, in sitn tests, and moventive maintentince shall be performed at deeignated frequencies to assure that the enfery systems and components necessary for eriticality control, fire control, radiatica detection, and environmental monitoring, well as their alarm systems, ate being properly maintained in readipess for use." 


\section{REQURREMENTS DENIIFICATION DOCUMENT HIGH LEVEL WASTE STORAGE TANK FARMS Radiological Protection Rerision 0}

FACILITY REQUIREMENT SOURCE: DOB6430.1A Sextion 1300-6.5.1

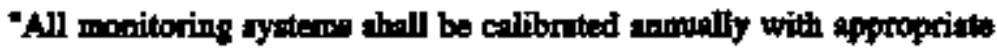

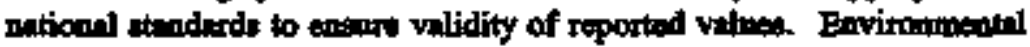
monituring is discussod in Section 1900-9, Efflesent Control and Monitoring.

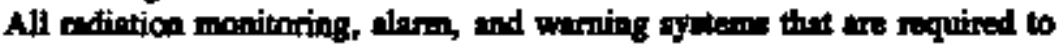

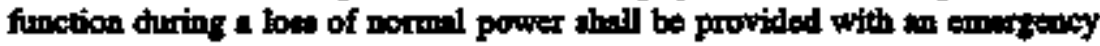
UPS (intertal or exteritl o. line) mless it is demoratrotad that they cen

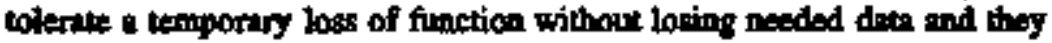
tes provided with stondby or emergency (avieched) powes. Determinntion of the power supply type and yunlity shrll be besed on the safety

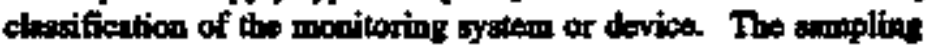

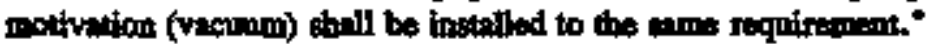

\section{EXPOSURE RDDUCTION AND ALARA}

The Exposure Rechuctiog/AI,ARA element tinchutes those requirements reinted to redncing tadiation expogure (primarily extemol expooure) and for meintnining exposure to molintion Af Low As Reaconahly Achiovable (ALARA). The coocept of AL_ARA in to mingss and control exposines (both individual and colloctive) to

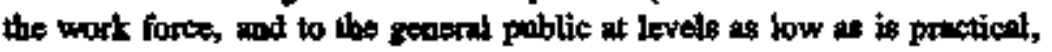
taling into account social, technical, cocoomic, prectical, end public policy considentiors. ALARA is n process, which has the objective of altaining doses as far below appiticable regulatory limits as is teasconably whitovalle and is the premise on which DOE baned its RP Policy. Specific tequirements for reducing rndintion exposurn are ibeluded with Al.ARA requirements of thy we an inteptal part of the overall ALARA program wat wro the wein methods by which ALARA requinenenty ame implemented Although limiting contamination (Section 11.5, Contarsination Control), the monitoring of ruliation (Section 11-2, Facility Monitoring and Surveye) and Entry and Exit Control (Section 11.4, Entry and Exit Control) are also integral parts of the overall ALARA

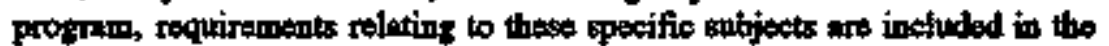
fndividuals extions of the facility RID.

\section{SITE REQUIREMENT SOURCB: 10CRR20 Part 20.1.C}

In uceordanoe with recommendetions of the Fedent Radiation Concil, approved

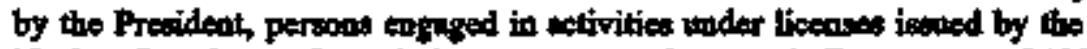
Nuclear Reguletory Coumiesion purmant to the Atomic Evergy Act of 1954, as amonded, and the Evergy Reorganization Act of 1974 should, in eddition to

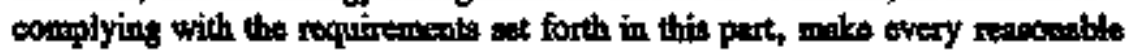

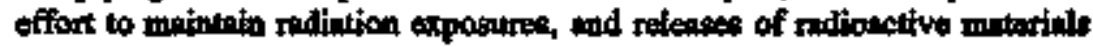

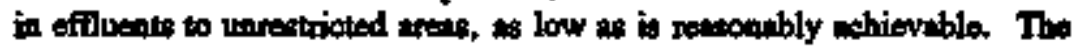
torm "ks low en is reasondbly achiovable" means as low as is ressonably

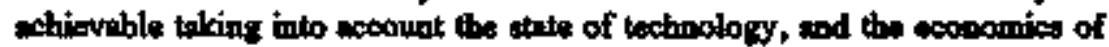
improvements in rejation to benefits to the public healfb and senfety, and other soxietel tond socibeccovomic considentions, nnd in relation to the utilization of atomic enorgy in the pulblic intarest." 


\title{
REQUIREMENTS DENTIFICATION DOCUMENT BIGH LEVEL WASTE STORAGE TANK FARMS \\ Radiological Protection \\ Rerision 0
}

\section{SITE REQUIREMENT SOURCE: DOR-N5490.6 Section 311}

\author{
Pinening Radiologionl Wook \\ Requiremente

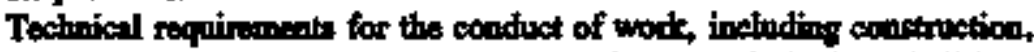

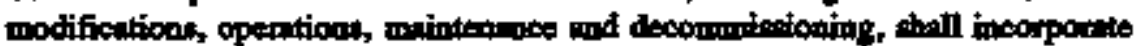 \\ Indiological criterit to ensure enfecy and mintain sodintion exposures ALARA. To \\ ceomplieh this, the deejgen and planning proseseces thould incorparate

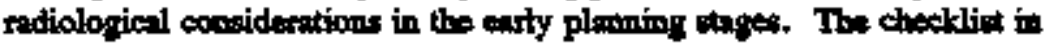 \\ Appeodix 3A is helpful in rectuxing oceupetional reciation exposure-"

\section{RELATED REFERENCES}

\section{DOEAED256T Article 3II}

\section{SITE REQUIREMIENT SOURCE; DOE-PNL-6577 Section 1.1, Paragraph 1} \\ The purpose of this documeat is to provide assistance to those who ere \\ responsiblo for developiog, implerpeoting, andior ovilhuting ALARA programs. \\ Becture esch DOE fecility has neede, specific and eritical to its individuol

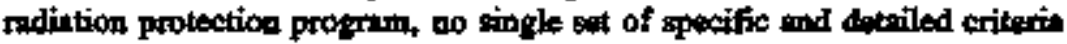 \\ can be decreed at a presatiption for whiseving ALARA goals. Howner, guidmce \\ such as defining olemeats of m ALARA program and ideatifying techniques for \\ indelementation an be conpled with sitg-opecific criterit to sosist in \\ developing a formally structured ALARA proginm."
}

\section{SITE REQUIREMENT SOTRCT: DOR-PNL-6577 Section 1.3, Prongraph 1}

"The bestic ALARA philosophy simply steted in a singte ptorese is "timiting pexconoel and eavironmental rediatice exposures to tbe lowest lovela commensurnte with sound economic and socjal considerations." This besic etatennent presuppoess that no rediation exposure should ocen withont a positive net benefit, considering tochnological, economic, and societol fretors. Inplicit in the ALARA philosopiny is the cantious assumption thet

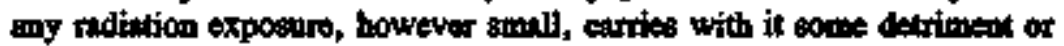
probebility of decriment (i.e., rist), which stoutd be bellanced by an offsetting benefit. Indeed, this is the beart of the ALARA philosophy, and it impliss that ons stould not stop looking for whys to inctur bor doso for a given ortiput of work, as kong at the cost of the consideration does not exceed the possible equivalent cost of the potential dose saving-"

\section{SITE REQUREMENT SOURCE: DOE-FNL-6577 Section 3}

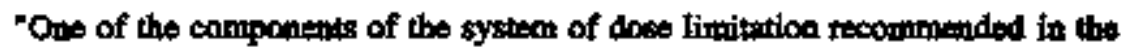
Internal Commission on Rediological Protection (ICRP) Publication 26 in thet "all expostures shall be tept as low an resongbly achiovabie, economic and

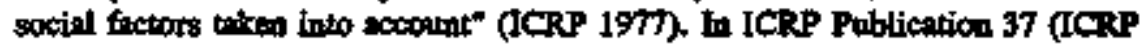
1983), this component was referred to an "the optimizision of ratiotion protection." 


\section{REQUIREMENTS IDENTIFICATION DOCUMENT HIGH LEVEL WASTE STORAGE TANK FARMS \\ Radiological Protection \\ Revition 0}

\section{SIIE REQUIREMENI' SOURCE: DOIHPNL-6377 Section 6.1.3}

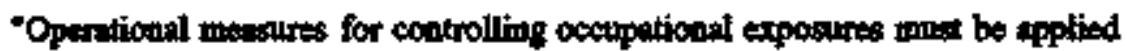

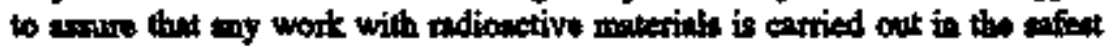
mermer that is reasoubly ichtevible."

\section{SIEE RECUIREMIFNT SOCRCE: DOE/EH0135 RP.11}

TERFORMANCE OBJECTIVE: A formelly pructered, nditelble program thould be in

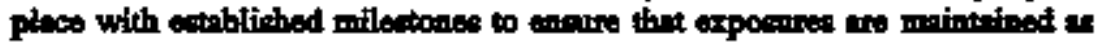
low at rowsonably metiovablo (ALARA)."

\section{SITE REQUREMANT SOURCE: DOEJAHOL35 RP.11.1}

-*1. A documented ALARA progrem imoorponting tho guidence contenined in DOE/EV/1830-25 as Ipropriate is estabtished and andited on a specified frequedey."

\section{STIE REQUREMIENT SOURCE: DOBS480.11 Section 9.A}

-Maintaining Radiation Exposurs As Low As Reasombly Achiovable (ALARA). It

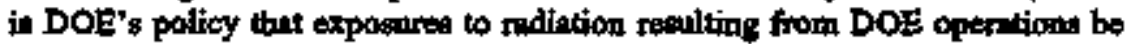
maintained within limiting values given in paragraph 9 and as for below all limiting values as ressonsbly achievable. This poliey applies to amual, committed, and cumulativo dose equivalente. Pitens and peograme ued to

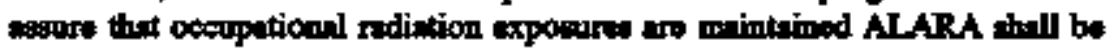
documented The DOE publication PNL-6577, "Health Phystca Minall of Good Pructices for Reducing Radintion Exporuse to Levele that are As Low As Reesonably Achievable (ALARA), "presents o guide on useful practicen for mathieving the objective of the ALARA proses."

\section{Expasure Controls}

This doment includse requirements mlating to techniques for controlling and minimizing

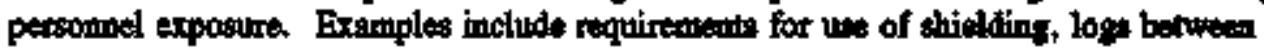

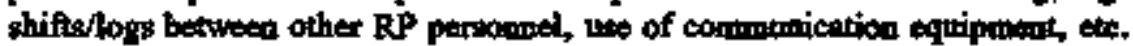

\section{SITE REQUIRBMENT SOURCE: DOE-N5480.6 Section 314.1}

Teumparary Shielding

The inctellation, use and removil of temporary shislding would bo controlled by procedure."

\section{SITE REQUIREMINT SOURCE: DOE-N5480.6 Section 314.2}

The effecs of the additiongl weipht of tomponty stielding on systers and compconents ghould be evaluated and estobliathed to bo within the desigos beasis prior to installution." 


\section{REQUIREMENTS IDENTIFICATION DOCUMENT \\ HIGH LEVEL WASTE STORAGE TANK FARMS \\ Radiological Protection \\ Rerition o}

STIE REQUREMMENT SOURCE: DOE-NS490.6 Sectlon 314.3

Thothlled cemporary lhiekling chould bo periodtenly inspected and gurveged to verify effectiveness and intergity.

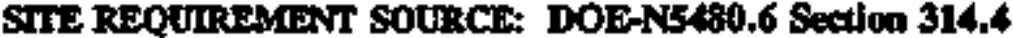

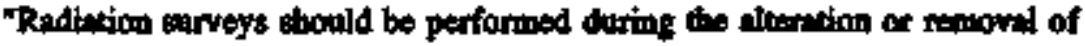
inctulled temporary abielding."

\section{STTE REQUIREMIENT SOURCE: DOE-N5480.6 Section 314.5}

Tinetilled tumportry thielding thould be visibly morted or labeled with the foltowing or equivileat worting: "Temponny Shielding - Do Not Reresve Without Permission from Rediologiten Control. **

SIIE REOUIREMENT SOURCE: DOEN5430.6 Sectlon 314.6

"Intalled temporary thielding thankd be periodically oviluated to anees the ned for its removal or neplecement with permsnemt strielding."

\section{SIE REOUIREMENT SOURCE: DOE-NS480,6 Section $\$ 14.7$}

"Site procedures myy identify specific mielding applicatione, such at the shielding of low wetivity sources or amplex, that fill outsid the reconmendations of this Article."

\section{SITE REQUIREMENT SOURCE; DOE-N5490.6 Section 342.8}

"Where pacticable, parts and condposeats should be removod to sreas with low dose rates to parform work."

\section{SITE REQUIREMIENT SOURCE: DOE-N5480.6 Section 342.9}

"Upon ideatification of ndifological concerns, woth ts inupproprite wort

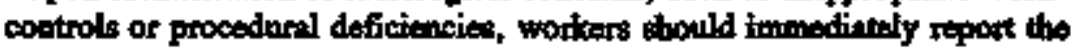
concern to lino expervision or tho Rediologied Control Organiation."

\section{SITE REQUIREMIENT SOURCE: DOE-NS480.6 Section 343.I}

"Loga and Commonications

Redialogical Coatrol personnel stould maintein logs to document ratiologital acelurtences, etatus of work ectivities and other relevent informetion."

\section{SITE REQUIREMENT SOURCE: DOE-NS480.6 Section 343.2}

"During continuous or exterded deily opertions, oncoming Radiological Control personntl should review logs and receive a tumover briefing from the personnel they are relieving." 


\title{
REQUIREMENTS IDENTIFICATION DOCUMENT HIGH LEVEL WASTE STORAGE TANK FARMS \\ Radiological Protection \\ Rerigion 9
}

\section{SIrE REQUDEMIENT SOURCE: DOE-N5430.6 Section 343.3}

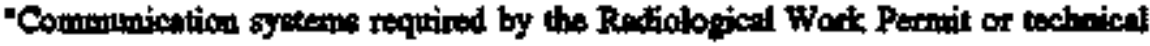
work document ahould be checked for cperability bofioes being bronght into the work tren and pariodically doring work."
\end{abstract}

\section{SIFE REQUIREMENT SOURCE: DORAN5480.6 Section 343.4}

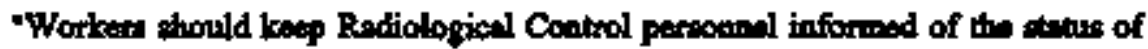
wort activitien thet affect radiologisal condition."

\section{STIE REOUIREMBNT SOURCE DOE-N5480.6 Section 344.2}

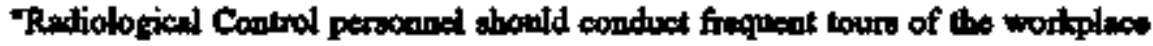
to reviow the extoquacy of mdiological work practices, posting and wee costrolis."

\section{STIE REQUREMLNT SOURCE: DOE-N5490.6 Section \$13.4}

Routine work on a Rediological Work Permil shatl be atopped when nuppleamental dosimeter rendings irdicate total exposure or rate of exposure substantinlly greater than planned. The Radiologicel Control Organization shall be consulted prior to continution of wark.

\section{RELATEO REFERENCES}

\section{DOEJEHO2S6T Articlo 513}

\section{SITE REQUIREMENT SOURCE: DOE/DHOLIS RP.11.10}

"10. The site bas been strveyed to locale ny sources of non-productive, low-lovel redintion exposure and such sources have been eliminated."

\section{SITE REQUEREMENT SOURCE: DOE/PHO135 RP.4}

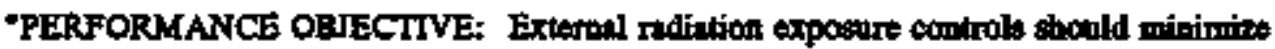
perconnel mofiotion exposute,"

\section{SITE REQULREMENT SOURCE: DOE/EHO135 RP.4.1}

-1. Effective expostre coutrol methods we in use, which isclode:

- Determining tho bounderies of radiation and high rodistion areas, and posting entry requiremeets besed on accurite and timely

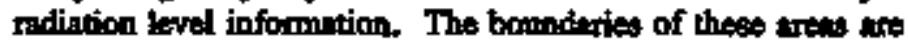
clearly identified and posted (see RP.3 POSTING);

- Cleardy posting "Hot spots;"

- Using riditition wort permits or similar controls to control exposeres essocieted with epecific jobs (se RP.3 PROCEDURES); 


\section{REQUIREMENTS IDENTIFICATION DOCUMENT HIGH LEVEL WASTE STORAGE TANK FARMS Radiological Protection Rerision 1}

- Controlling persoanel exporares in wort areas involving high exposare rates by a combination of ppecial tooles ativelfing,

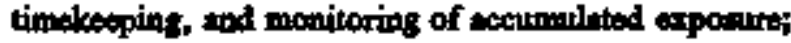

- Routing personed tnffic through lower expowis nate trent, and

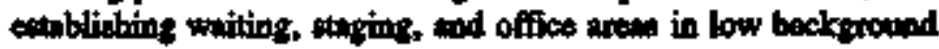
artaes and

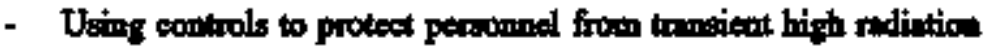
levets ach so those involved in moving matioective mestiale."

\section{STIE REQUIREMIANT SOURCE: DOEJDE0135 RP.4.4}

- 4. The radintion exposure reduction progartm incledes the following:

- Planiting for the work,

- Work seboduling that provides for completion of expoenve reducticn offorts prior to and during wout and encures the onder of work provides the lowest exposures,

- Besing job gools upon estimates made usins facility and inchustry experience, and

- Deteruiging job goals that arte reolistic bat string=nt enough to encourase improvernents."

\section{SIIE REOUIRSMENT SOURCE: DOERH0135 RP.4.6}

" 6. Analysis of ctrrent practices and comparion with indantry-wide exposure controls are angoing attions to exhieve mitningem expostores."

\section{STIE REQUIREMENT SOURCE: DOEJEH0135 RP.6}

"PERFORMANCE OBJECTVE: Internat pediation exposure controle chould minimize internal exposures."

\section{Exposure Control Reouirements for Spocific Work Activities}

This elemeat includes specific requirements for controlling the expocanes

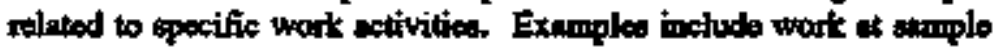
stations, benchtop work, wort with fume hooks, tet.

\section{SITE REQUIREMENT SOURCE; DOE-N5490.6 Section 347.1}

"A Rediologies Wort Pesmit (RWP) sbould be isoued to control rediological wort in

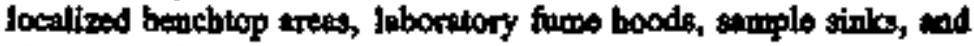
glovebores." 


\section{REQUIREMENTS IDENTIFICATION DOCUMENT HGH LEVEL WASTE STORAGE TANK FARMS \\ Radiological Protection Rerision 4}

\section{SITE REQUREMENT SOURCE: DOE-N5480.6 Section 347.2}

The following controls ipply to localized benchtop and taboritory fume hood opentions:

- Protective clothing shall, at a miniming, inckods labcosts and gloves. Giloves should bo secuned at the wrist a necentiry.

b. Shocervert thould be conidered bued on the potential for floor contaminition;

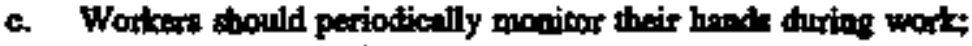

d. Upon completion of work or prior to leiving the ares, worters ahelf mowitor those aress of their body that are potsotially contrininated. At - minimam, this ineludes hendh, arms, nod froent portions of the body. Workers should perform a wbolo body friak."

\section{SITE REQUUREMENT SOURCE; DOE-N5480.6 Section 347.3}

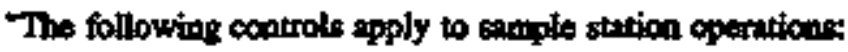

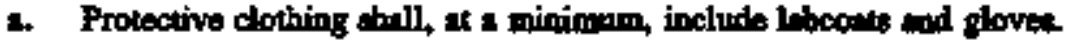
Gloves should be secured at the wriat es necessary;

b. Sbcecovers should be corstidered based on the potential for filor continmination;

c. If there is a potential for splashing or sirborme molianctivity, such ta when taking pressorized somples, additional controte ath wh nuber aprons, feo stields, full PCs, or respiratory protection should be instimted;

d. Workers should periodically monitor their hands during wort

- Upon conpletion of wark or prior to leving tho arom, workers beall

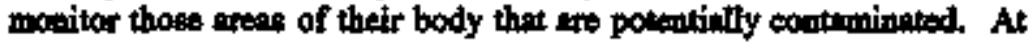
a minimim, this inchuder hande, arms, and froat portions of the body. Workers should perform 1 whole body frist."

\section{SITE REQUIREMENT SOURCE: DOR-N5490.6 Section 365.5}

"Control requiremate for rediogrophito devices arde

a. Or-sito operations with devices containing seoled comres sbonld be coaducted in weortionse with the requitremonts contuined in Trtlo 10 CFR Part 34 entitled, "Licenese for Rutiography and Rutiation Safety Rexpiroments for Radiognopic Oparationn.

b. DOE 5480.4 mindites the ws\% of ANSI N593 matilled, "Geoontl Sufety Standand for Installation Uning Non-Medical X-Ray and Sealed Gamma-Ray Scources, Energies of to $10 \mathrm{MeV}$, for on-oite openticen with devices other then seciled sounces.

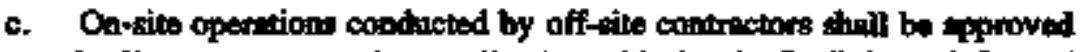
by line menegeonent in coordination with the site Radiologienl Control Orgenization. This process sthil envure the contractor hes a valid Nuelear Regulatory Commission or Apresenent State licants and that the operational and emerpency procedtres are current and availobito."

STTE REQUIREMENT SOURCE: DOE-N5490.6 Section 365.6

"Safey devices and interlocks at fixed installations shall be opendional 


\section{REQUIREMENTS DENIIFICATION DOCUMENT HIGH LEVEL WASTE STORAGE TANK FARMS Radiological Protection \\ Rerision}

prior to and during genoration of a radiation field. Operational antus shall be verified by toting."

\section{SITE REQUIREMENT SOURCE: DOE-N5480.6 Section 371}

- Congtruction Red Rectoratica Projecte

Constrution and rostomtion projects, incloding decontaninetion and

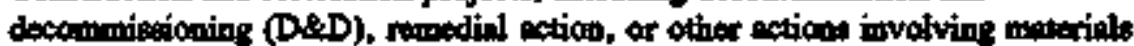
which contrin bow levels of redioactivity my prosent apecirl pobblems and require sito-pecific or prognm-pecific control methode. Ealth mol Sufity

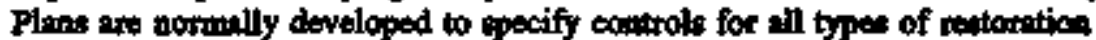

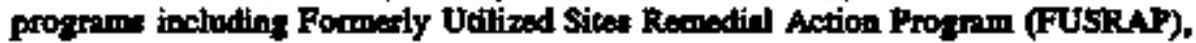
Uramium Mill Tailings Remodial Action (UMTRA) and otber restoration projects."

SITE REQUIREMIENT SOURCE: DOB-N5480.6 Section 371.1

"Pexformanoe goils and indicators appropripte to remedial ectivities."

STE REQUIREMENT SOURCE: DOEN5480.6 Section 371.11

"Evalpation of outdoor sir monitoring methodologies that take into socount dost loading, environmeotol fuctore, and supplemental breathing toes sampling."

STTE REQUIREMENT SOURCE: DOE-N5490.6 Section 371.2

"Personal Protective Equipment requinemente end practices to mecotumodate other hezends on the tite."

STTE REQUREMARNT SOURCE: DOE-N\$4\$0.6 Section 371.3

"Use of respiratory protection 4 normal conduet of operation dive to lack of engineering cootrols and remporary neture of the wort."

SHE RECUIREMENT SOURCE: DOE-N\$480.6 Section 371.4

-Use of Contamination Reduction Corridors to mecommodate wovement of perocanel and hervy equipment through a variety of decontaminetion atutiona."

STTE REQUREMMENT SOURCE: DOE-N5480.6 Section 371.5

"Mechods to abcitio representertive samples for ralense of equipmest and materital from the wort ans."

\section{STIE REQUIRBMENT SOURCE: DOR-NS480.6 Section 371.6}

"Surveying of materinls relessed from Soil Copmminetion Aress that exhilbit sizaificuat contamination ternsfes properties." 


\section{REQUIREMINTS IDENTIFICATION DOCUMENT HIGH LEVEL WASTE STORAGE TANK FARMS \\ Radiological Protection \\ Reripion 0}

\section{STTE REQUIREMIENT SOURCE: DOE-N5480.6 Section 371.7}

Precedence of tato md Federilly manduted soil clemup criterin over motise

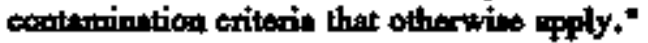

\section{STTE REQUIREMENT SOURCE: DOE-N5490.6 Section 371.8}

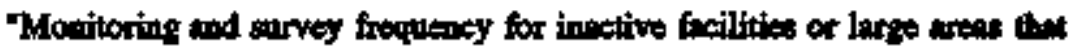
ine infropuedty occupied.

\section{STE REQUIREMTENT SOURCE: DOR-N5490.6 Section 371}

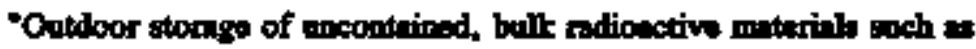
contarianted axil."

\section{SITE REQUIREMINT SOURCE: DOEN\$480.6 Sectlon 371[02]}

\section{Tequirements}

Refiological operetions and work activities at constraction and arironmonts

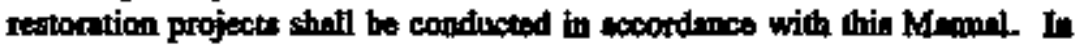
light of the specinl mature of these activities, which typically i.volve low-lovels of ndioustivity and the use of henvy construction or earth-mowing

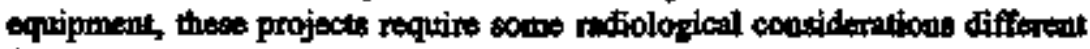
from other activities governed by this Manual.

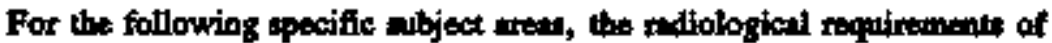
this Mminl may be modified by the limited eppliention of the provisions of Articlo 113.3. The Radiological Control Mminger is authorized to change mendutory "beall" requirements to "should" to fesilitate impilementation of

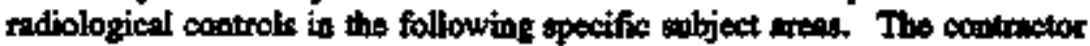
has the responsibility to docomment the totuteal equivalency of altorutivo solutions."

\section{STIE REQUREMMENT SOURCE: DOEJEH0135 RP.4.5}

\section{-5. Specific job-releted exponure reductica efforts are incorposited tro} wotk procedures, including the following, whese approprian:

- Using temponsy or permenent shialding,

- Using spexial tools,

- Flustiong and decontuminution, at epproprinta,

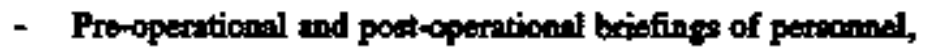

- Specialized tmining and "dry nos" on mock-up equjpmewat,

- Utilixing mxiliary lighting and a worting esvironment with comfortable tewperanure and humitity and dequate space, where feasible. 


\section{REQUTREMENTS IDENTIFICATION DOCUMENT HIGH LEVEL WASTE STORAGE TANK FARMS \\ Radiological Protection \\ Revision 0}

- Providing adequate commanicution cenpubilities, and

- Astigning to the job sito coly the minimnm namber of personed needed to perform the wort:

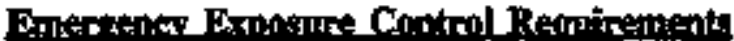

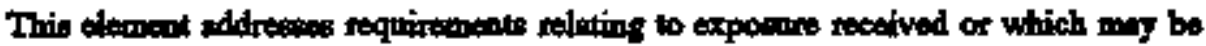

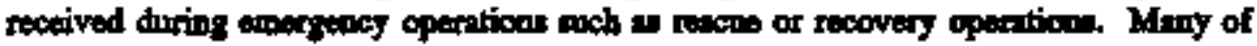

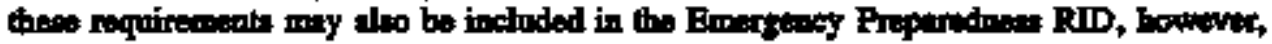

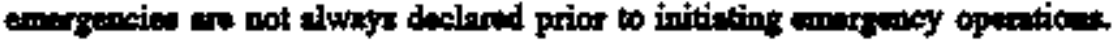

The Emergency Prepanedness Punctican Arat containd moch moso detriled and extruivo

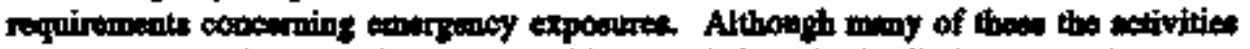

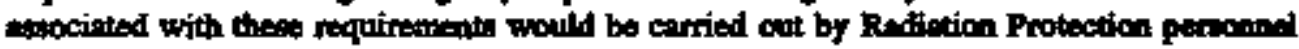
and Rudiation Protextion would have respensibilitis for conplianes with these

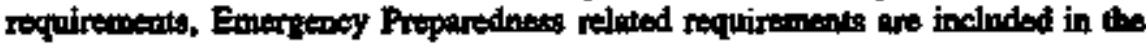
Emergency Preperednees Functional Aret as they are more clocely suociatod with that gubject.

\section{SIME REQUHEEMINT SOURCE: DORS480.11 Section 9.p(2)(a)}

\section{-Geoeral Considentions}

(a) Controlfing exposure to radintion dering rescue and recovory wetions is

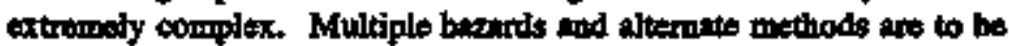

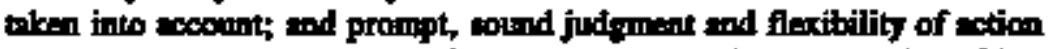

un crucial to the suceses of any emergency nions. The rist of injory

to thoes persons involved in the resente and recowery ectivities athould be minimied, to the extent proctical. However, the control of tadiation exposunts should be consinteot with the immediate objectives of toving human lift, reconseing decesed victims, and/or procoction of bealth and property."

\section{SITE RBQUREMENTI SOURCE: DOES480.11 Section 9.p(2)(b)}

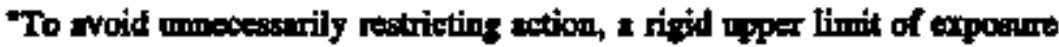
for lifienving ation is nox pecified; rufber, judgowet is left up to tho offichals in cherge to ovelnete any proposed action trrotving further

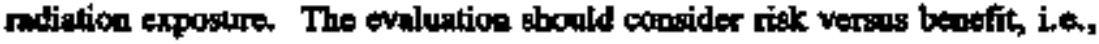

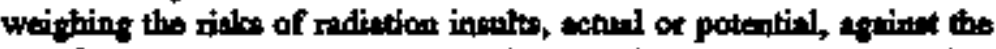
benefits [social, ocosomic, ote.] to be grined. Essentiol elerrente in rit deteruinations include potential expoure, tiological consequences reluted to the exposure, and the number of people isvolved."

\section{SITE REQUIREMENTI SOURCE; DOES480.11 Section 9.p(2)(c)}

These inetructions also recoprize that mocident sthutions involving the saving of lives will require different basis for action than thoes required to recover deceased vietims or to protect property. In the tatter instances, 


\section{REQUIREMENTS IDENTIFICATION DOCUMENT HIGH LEVEL WASTE STORAGE TANK FARMS Radiological Protection \\ Revidion 0}

the amount of exposine expected to be received by perwos thould be controtled as

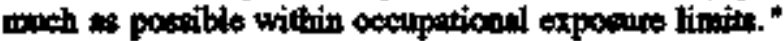

\section{SIIE REQUREAIENT SOURCR: DOR5480.11 Section 9.p(2)(d)}

"Any necue action that might involve aubatantial personel ci.lk thould be performed by vohunteen. When fessible, volmicess chald bo ovaluated with

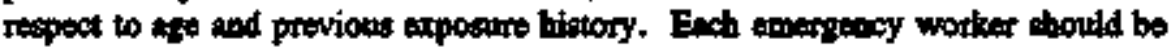
advied of the knowe of anticipeted herrorde prior to perticipation by the

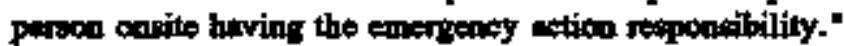

\section{STrE BEOUIREMIFNT SOURCE: DOES480.11 Section 9.p(3)}

Thurgency Situatione. Specific dose criteria and judigment foctors ans ax forth for the three types of earergensy actice: Type 1, eaving of bomen lifot Typo 2, resovery of decelued vietims; end Typo 3, protection of health and property."

\section{STRE REQUIREMENT SOURCE: DOES480.11 Section 9.p(3)(a)1}

"Sivitiog of Huan Lifo.

1 Attempts to tescue victims of an incident should bo repartiod in the came

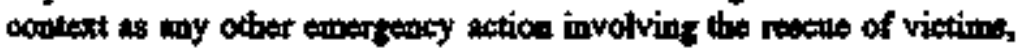
regardlese of the typo of hazerd involved."

\section{SITE REQUIREMENT SOURCE: DOR5480.11 Section 9.p(3)(n)2}

"If the victim is considered to be alive, the course of ection sbould be

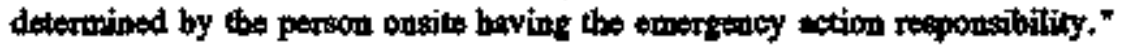

\section{STIE REQUTREMENT SOURCE: DOE5480.11 Section 9.p(3)(a)3}

The poteatial nmount of exposure to rescue personecl for anch epecific Type 1

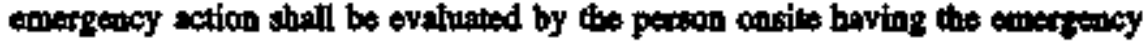
ection responsibility. The espergency nituation should be immodiately

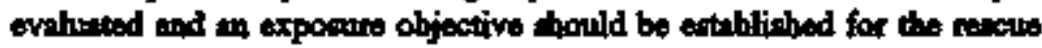
mission. The evaluation of the inherent risto should consider:

- The relinbility of the predietion of ridiation injory from measured/estimated dose ratea. In this content, ocosideration should be ziven to the uncertainties associated with the specific instraments

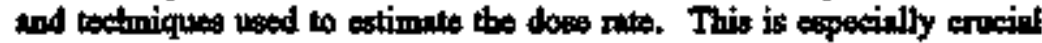
when the ectimeted doee approximites 100 rad (1 grisy) or more.

b Tho effect of cute extaral and/or intermel exposire.

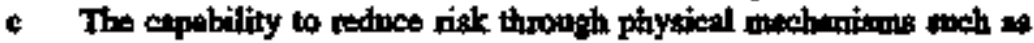
the use of protective equipment, reanote menipulation equipuent, or gimilar meins.

d The probulitity of aucess of the resctin netion."

SITE REQUIREMENT SOURCE: DOE5489.11 Section 9.p(3)(b)1

"Recovery of Decensed Victim. 


\section{REQUIREMENTS IDENTIFICATION DOCUMENT HIGH LEVEL WASTE STORAGE TANK FARMS Radiological Protection Revision 0}

1 The roovery of decesed victims hould be well plinned. Excepe as

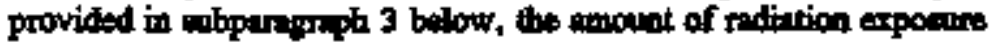
rectived by persoed in recovery opentions atholl be controlled within existing ocerpationsl expomre limita."

\section{SITE REQUIREMIENT SOERCR: DOES480.11 Section 9.p(3)(b)2}

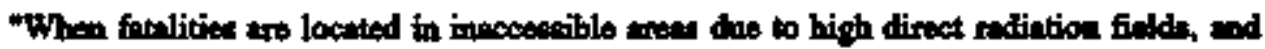
when the rucovery miscion would resolt in exposure in exceses of acerpationel exposure linits epecified in this chepter, epecinl remote necovery devices should be uned to retrieve bodies, ss eppropriata."

\section{SUTE RBQUIREMENT SOURCE: DOES490.11 Section 9.p(3)(b)3}

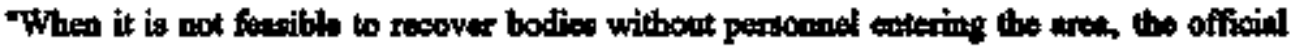
in charge miny determins it pecewsiry to exeeed the ocenpetional

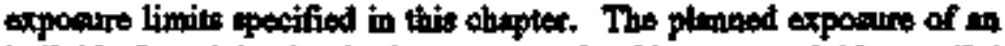
individur participeting in the rocovery should not exceed 10 rem (0.1 siovert) por year."

\section{SITE REQURREMENT SOURCE: DOES480.11 Section 9.p(3)(c)}

Protection of Health end Property. Whet the rist (probebility and magnitude) of the rediation hazard either bears sigaificontly on the atato of health of people, or misy rasult in loes of property, wo the immodinte remedial netion is oeded, the following criterit stuould apply:

1 When the officitil in cherge deeme it essentint to reduce a potentiol haned to protect health or prevent a nubetantiat loses of property, a plenned exposare objective not to exced $10 \mathrm{mb}$ (0.1 sievert) par year may be permitted for individuals porticipating in the operition. However, under special circumstences, the official in charge of

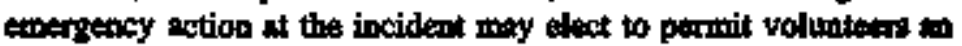
emergency expaeare objective not to exceed 23 nem (0.25 gievert) in any year.

2 Whan the rist of nodiation following the incidant is such that life wight be in jecpandy, or that there might be sevtre effects on heilth of the pablic or loss of property inimical to the pablic zafety, the criteris for eaving of mamin lifo shall apply."

\section{Radiological Work Planuin:}

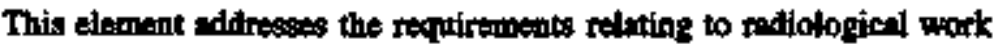
planming. Rediological work plamning is a primary method for recuseing exposares mod ensoring that exposures wo maintained ALARA. As a reselt of wort pleming, ocher exposuse redection/ALARA tectuiques are often identified and then utilized during work ativities. Becous of this relationship and becunse work planning is a mijor vehicle to tnsuring appropriate expoeste reduction the woriques are included in the wrocess, it is included as a separite elentent. 


\section{REQUIREMENTS IDENTIFICATION DOCUMENT HIGH LEVEL WASTE STORAGE TANK FARMS \\ Radiological Protection \\ Revition 1}

STIE REOUIREMENT SOURCE: DOE-NS490.6 Section 312.1

"Plensing for Moincenonos, Opentione and Moctifications

Meintenence and modificetion plans and procedures shell be reviewed to

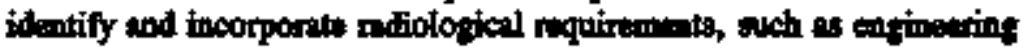

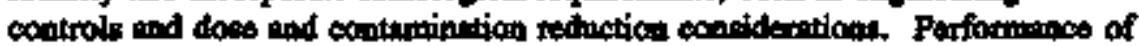
this review is the respomibility of line menagement, with enppont and coneurrence from the Rudiological Control Orpatization."

\section{RELATED REFRRANCES}

1. DOE/EH0256T Articlo 312

\section{SITE REQULREMENT SOURCW DOEN5400.6 Sectios 322}

"For roution taske, such as arveillence, tous and minor non-rediological matinterance, pesformanes of the abowe roviow and doctumentation of ideatified rediological requirements may be conducted wo part of the Rudiologieal Wort Permit process (seo Article 321)."

\section{RELATID REFERENCES}

1. DOEJEHO256T Article 312

\section{SITE REQUIREMENT SOURCE: DOENS480.6 Section 313.1}

Infrequent or Finet-Time Axtivities

At those failities with rontine, necurring process operations, epecinl minagement attention should be directed to ndiological ectivitiea that are infrequeotly canducted or represent fint-time operntions. Plenning for such ectivities should incluate:

Formal radiologicel review in eccordance with Articlo 312.4"

\section{STIE REQUIREMIENT SOURCE; DOE-NS490.6 Section 313.2}

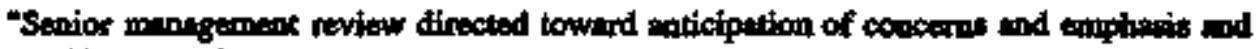
specification of protective mearars:

SIE REQUIREMIXNI SOURCE: DOE-NS490.6 Section 313.3

"Roview and approvel by the ALARA Comoritteo"

SIIE REQUIREMENT SOURCE: DOE-N3490.6 Section 313.4

"Enhanced line and Ratiological Control montyement ovessight during the initintion and conduct of the wort:" 


\section{REOUIREMENTS IDENTIFICATION DOCUMENT HIGH LEVEL WASTE STORAGE TANK FARMS \\ Radiological Protection \\ Rertion 0}

\section{STIE REQUIREMENT SOURCE: DOE-N5480.6 Section 315.1}

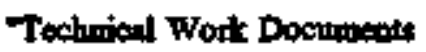

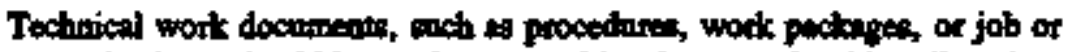

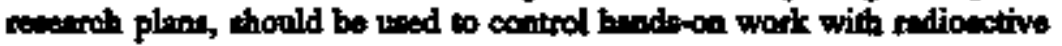
meterisle. Technienl work documents ase not required for incidertal or

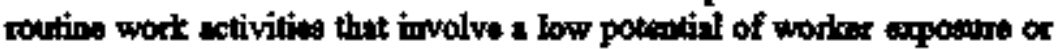

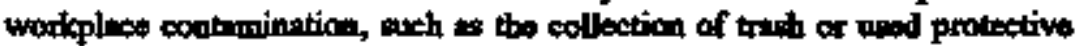
clothing."

\section{STTE REQULREMENT SOURCE: DOE-NS49B.6 Section 315.2}

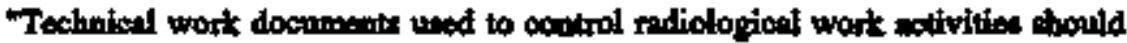
be raviewed and appowed by the Radiolofical Coatrol Organization."

\section{SITE REQUIREMIFNT SOURCE; DOB-N5480.6 Section 315.3}

"Rosiological Control Hold Paints stould be incosponated into toshnisel wodk documents for ateps thet requine action by the Radiological Control Organization to prevent refiation expontres in excess of Administrative Control Levels, high titboras malionctivity concentrations, or the relewse of redionctivity to the environment."

\section{SITE REQUIREMIENT SOURCE; DOE-N5490.6 Section 324.1}

\section{Pro-Job Briefings}

At a miniman, projob briefings should be beld prior to the coeduct of wort aticipated to exceed the trigges levels identified in Article 3123."

\section{SIIE REQUTREMENT SOURCE; DOE-N\$490.6 Section 324.2}

"At a minimen, the pre-jos briafing should includs:

- Scope of work to be performed;

b. Radiotorical conditions of the workelwi

c. Procedintal and RWP requitiounents;

d. Special ratiological coperol requiremente;

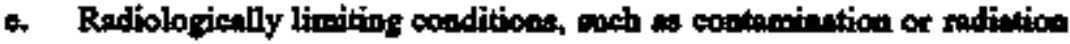
levels that ming void the RWP;

f. Rusioloticed Coattol Hold Pointa;

8. Commenication and contilistion with oftar groppi;

b. Provisions for bonsekeoping and final cleanup;

1. Emergency response provisions."

\section{STE REQUIREMENT SOURCE: DOE-N5490.6 Section 324.3}

"Projob briefinge should be conducted by the cognizent work mupervieor." 


\section{REQUTRMIENTS IDENTIFICATION DOCUMENT HIGH LEVEL WASTE STORAGE TANK FARMS Radiological Protection \\ Rerision 6}

SIME REQUTREMIENT SOURCE: DOE-N5480.6 Sectim 324.4

Wodken and apervioun dixecty participating in tho job, cognizan Rediological Control personest, and nepresentutives from involved enpert orpinizetions stowld thend tho briefing."

\section{STIE REQUIREMIENT SOURCE: DOEN5490.6 Section 324_S}

"A aummery of topice diecuesed and atteadence at the projob briefing shondd be

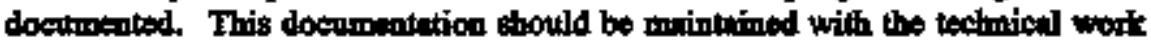
doctureot."

\section{STE BPQURRMIENT SOURCE: DOE-N5480.6 Section 341.1}

Rediologied Work Controis

Requirtenents

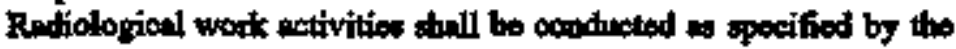
controlling technical wort docment and Radiologicel Work Permit."

SIIE RPQUIREMENT SOURCE: DOE-N5480.6 Section 3412

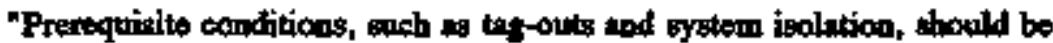
verified in sceordence with the technical work documents before wort is inititued."

\section{STE REQUIREMAENT SOURCE: DOENS490.6 Section 342.6}

"The tdentity of compcosents nind syetems should bo verified prior to work."

\section{SITE REQUIREMENT SOURCE: DOEN3480.6 Section 342.7}

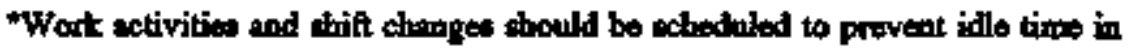
radiation ureas."

\section{SIIE REQUIREMINT SOURCE; DOP-N5460.6 Section $\$ 34$}

"Heat Streen

Heat these may result fiom working in areas of high beat, humidity and rutiant heat; worting in procective clothing; and using respirators, partienledy where other protective equipment is requined. Heat trest he cocurned at ambient temperatures less than $70^{\circ} \mathrm{F}$ when maltiple sets of

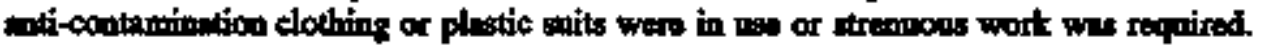

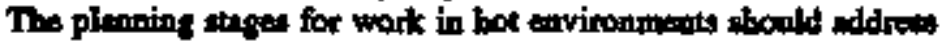

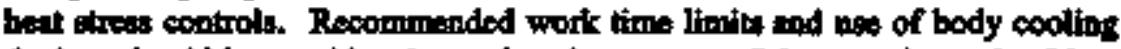
devicen should be considered to reduce beat beres. Iob supervisors should inform their personnel of heot strest procentions prier to work on job asignmests it hot environments. If a person begins to feed symptoms of heat illness, the persoe chould immediately notify the neared co-worker, exit the area, remove personal prolective equipment, notify the stpervisor and rest in a cool ane? In such cuses, modical assiatence should be provided" 


\section{REQUIREMENTS IDENTIFICATION DOCUMENT HIGH LEVEL WASTE STORAGE TANK FARMS \\ Radiological Protection \\ Revision 0}

\section{STTE RBQUREMIENT SOURCE: DOE-N5490.6 Section 551.11}

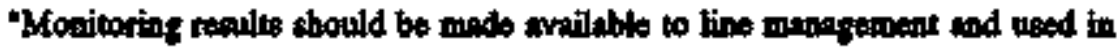
cupport of pro and poet-jot ovaluetione, ALARA preplenning, conteminatinn control md munngement of radiological control opantione."

\section{RELATED REDERENCES}

\section{DOEEHO256T Articlo 551}

\section{SITE REQUIREMANT SOURCA: DOE-PNL-6577 Section 6.13, Paragraph 3}

The need for comprehensive and detriled operetiond prosedures in dictuted by the need to think through and andentend exch tets on a dep-by-atep besia. Eanth in a proceduro shopuld be fully thought out and ita inopect on expostre rigorously evaluated. Shieldiag, nemove operation, distance, speciulized tools, protective equipinzit, menpower requirements, exposure

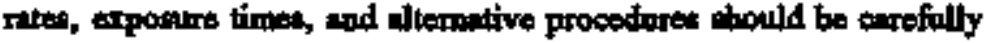
considered. The procedures should ales convey a clear pictore of whit needis to be done to tosomplish the tut while keeping the exposures ALARA. The procedures cent the bo ueed to a component of a worter's traiting wid as a besis for practicing the tasks. The final, conplete procedure should be the

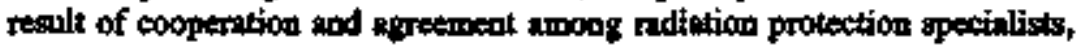
mentargement, and workers."

\section{SITE RDQUMEMINT SOURCE: DOEJEHD135 RP.2 ACCIDENTSINCIDENTS.9}

-9. Adequate projob plunning is performed to reduce or minimize the poteatial for to eccident."

\section{ALARA Revicws}

This demeut addresser requireaneats specific to the performance of ALARA roviews. ALARA toviows are rexuired for certing types of wark, for certin levels of exposire and under certain specific situntions. Although related

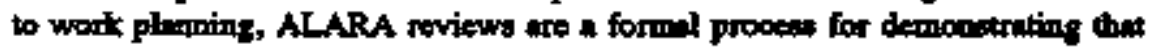
appropriate iscis which meet procechurally required criteria have been

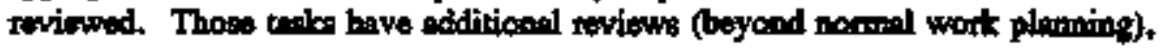
up to and including reviews by the fociltity ALARA Committen to identify adrititional controls wod/or processes to rotuce expostor.

\section{SITE REQUTREMENT SOURCE: DOE-N5480.6 Section 312.3}

"The Site-Specific Radiological Control Manued hanll extablish trigfer lovelo requiring formal radiological reviow of non-roution of complex work ectivities. These epproprinte trigger levels should tinctude:

2. Extimated individual or collectivo dose gevater then prestrablished valnes;

b. Predieted airbome mdiontivity concentrations in expess of presestobilshed valuse; 


\section{REQUIREMENTS DENTIFICATION DOCUMENT HIGH LEVEL WASTE STORAGE TANK FARMS \\ Radiological Protection \\ Revision 9}

- Work arte remonable contomination greatar theo 100 times the valuen in Table 2-2;

d. Entry into cteas where dose rates exceed 1 rem/bowr;

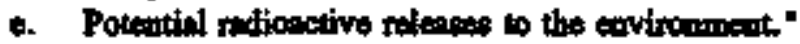

\section{REMLATE REFERENCES}

\section{t. DOE/EHO256T Article 312}

\section{STIE REQUIREMENT SOURCE: DOE-N3480.6 Section 312.4}

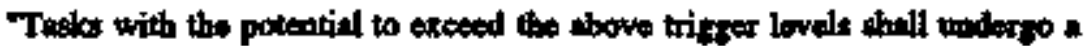
formal, documested rediologicel or ALARA neview. At a ninisum, this goview abould cecenide the following:

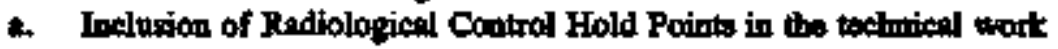
documents;

b. Elimination or reduction of radionctivity through line futuhing and decontominetion;

c. Use of work proceseses and epecisl tooling to rechese time in the wort nren;

4. Une of engineersd conirols to minimize the apread of contaminution and gensration of sirborme rodiometivity:

*. Specification of tpecial nodiological trining or monitoritis requirementsy;

f. Use of mock-aps for high exposure or complex tasks;

g. Enginesing, design and use of temporary shiebling to redoce ratiation tevels;

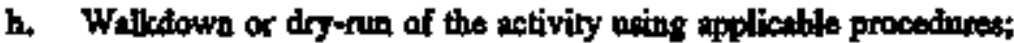

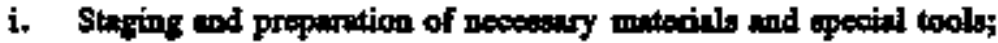

j. Marimization of prefibrication ind shop work;

1. Review of abnotmal and emergency procedures and plane;

1. Identificution of points where signetures and ecood party of independent verifications iro required;

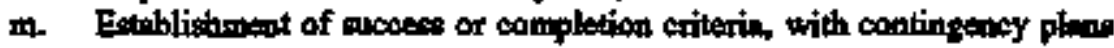
to inticipato difficulties;

n. Development of a pre-job estimate of colloctive exposure to be incurred for the job;

D. Provisions for waste minimization and dispocal."

\section{RELATED REFERENCES}

\section{DOE/EH0256T Article 312}

\section{SITE REQUIREMIENT SOURCE: DOE-NS480.6 Section 312.5}

"Radiological requirements identified as part of the above radiological neview should be documented in the job plans, proesdures of work packenges."

\section{RELATED REFERENCES}

1. DOE/EH0256T Article 312 


\section{REQUIREMENTS IDENTIFICATION DOCUMENT HIGH LEVEL WASTE STORAGE TANK FARMS Radiological Protection \\ Revision 1}

\section{SIIE REQUREMIENT SOURCL: DOE-N5\$BD,6 Section 344,1}

Rowiow of Wot in Propios.

As pert of their nosmil work roview, work appervisoss chould periodically

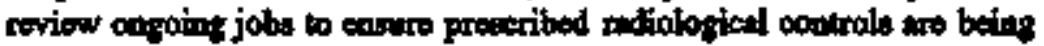
implemented."

\section{STIE REQUTREMANT SOURCR; DOE-N5490.6 Section 352}

"Poot-Jab Roviows

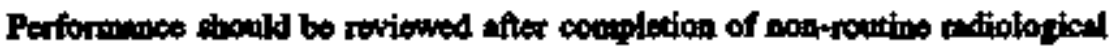
wort Requirements for poet-job revisws should be delineeted in the Sito-Spexifie Radiological Control Mrumil."

\section{SITE REQUIREMENT SOURCE: DOE-N3480.6 Section 353}

\section{"Lesons Leimed}

Leosons learned are available from podijob reviows and reporte of pait

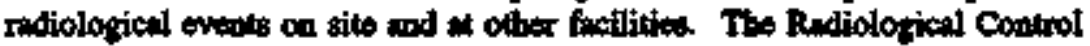

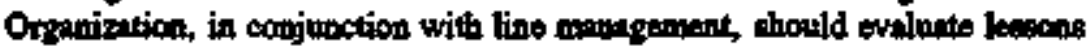

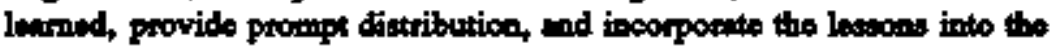

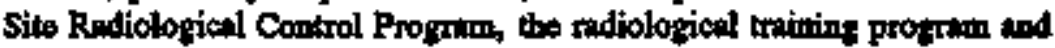
releted operetion."

\section{SITE REQUREMIENT SOURCE: DOEJEH0135 RP,11.7}

7. ALARA nvitewe are routinely performed pior to issutiog ractiation wort permits."

\section{Alara Dne Goglg}

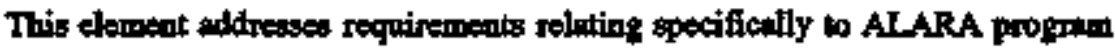
dow goale.

\section{SITE REQUIREMENT SOURCE: DOE-PNL-6577 Section 4}

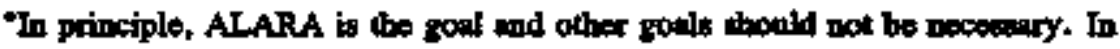
practice, bowever, aubler gosls ere required to assist in asouning that the primery goal, ALARA, is echieved. Goals for the ALARA progrim should be

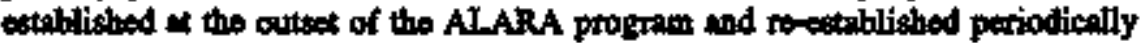
therestter. Typicilly, sools are establithed end schiovenent is evahuted at lenst anroully. The goaln should be releted to epecific chersacteristics of operatione or programs and should conrespoud to real problems. Sotting practical ALARA goals iepends on bow well the ALARA proppen is undsostood end cen be chareterized."

\section{SITE REQUIREMIENT SOURCE: DOE-PNL-6577 Section 4.3}

-An ALARA program stould be eveluated in terms of whievemeat of ganls. In

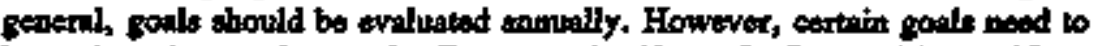
bo evaluated more frequenty. For example, if an ALARA goil is specific to a 


\section{REQUIREMENTS DENTIFICATION DOCUMENT BIGH LEVEL WASTE STORAGE TANK FARMS \\ Radiological Protection \\ Revision 1}

short-duration higb-exposaro job, the goal should be avelunted at the completion of the job. In addition to periodic malution of ALARA ponls,

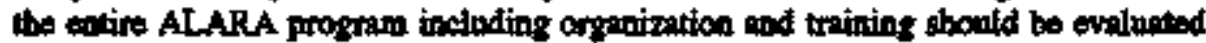
munuilly."

\section{SITE REQUIREMENT SOURCE: DOERHO135 RP.4.2}

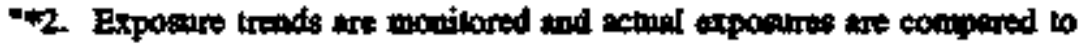
eetablinhed ALARA soals (cee RP.11). Actions tre initioted to correct a problem or adjust the soals as mproprinto."

\section{ALARA Performange and Trainine Recitixements}

This element adpeses requirementre relating to training which is conducted to trin worters on the ALARA program or trining which is conducted $=0$ part of spexific ALARA ectiont. It difo includes requirementr for thining individuals who wro active in the feility ALARA program fond roptuirements to

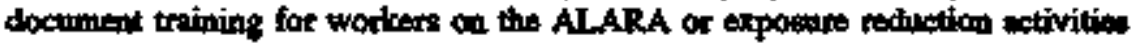
ensocialed with individural jobs.

\section{STIE REQUIREMENT SOURCE: ANSI-N13.6-1966 Section 4.10}

Rediation Work Orientution and Trining. The employer should record the date, mumber, and the subject mater of orientotion diectserions and formel on-tho-job triening sostions on the redintion protuction mopects of tho work. The erosoliderted record file for the individueil thould include reference to his porticipation in these activities."

\section{STE REOWIREMENT SOURCE: DOE-N5480.6 Section 652}

-Technicel Support Pertonoed Appropriate technical support personmel (eagineers, schednlers, procecture witers) would be tnined in the principles of ALARA, busic ALARA techniquen

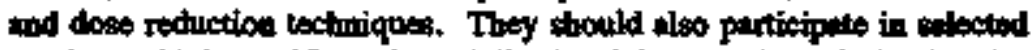
portions of job-specific and epecialized training. perticularty in stontions using moct-upi."

\section{SITE REQUIREMENT SOURCE: DOE-N5490.6 Section 654.4}

"Radiologieal support personnal who ate responsible for inplewerting the tite ALARA program shall reckive ALARA troining."

\section{STTE REQUIREMAENT SOURCE: DOE-PNL-6577 Section 2.1.3, Fige 2.10, Paragraph 2}

In tdition to the ratiation protection orientution required for all employee, on-the-job training for operating personel in specifics relnted to ALARA is ossentint, and whenever possibilo should include assignint inexperienced persounel to wort with experionced stuff. Training thould include the description. demonstration, and protice of specific actions neceesary for radiation control. In addition, each worter chould receive 


\section{REQUIREMENTS IOENTIFICATION DOCUMENT HIGH LEVEL WASTE STORAGE TANK FARMS \\ Radiological Protection \\ Rerition 0}

some busic informatice resating the compeny's radiation protoction programe, aloag with an introduction to the philoeophy and purpous of the ALARA progran.

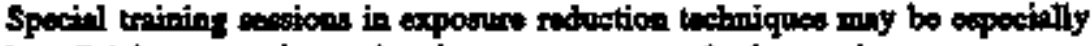

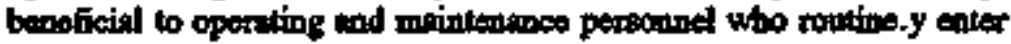

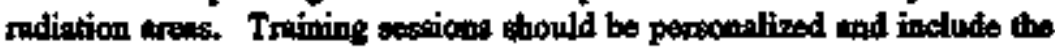
introduction of tey radiution protection personnel .. Finnlly, optional additional edueation and trining in indiation protection should be wede available to all who dective it."

\section{SITE RIQUIREMENT SOURCE: DOEPNL-657 Section 2.13, Page 2.6, Parngraph 2}

"Specific ALARA tniming should be provided to selooted grotupa to enjuro

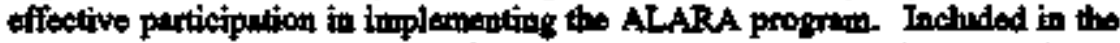
groups that sbould receive specific ALARA training ore the ALARA and ndintion

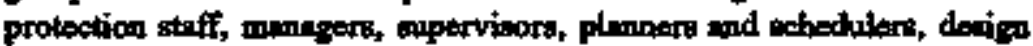
engineers, and radintion workers."

\section{GIIE REQUIREMENT SOURCE: DOE/EHH0135 RP.11.3}

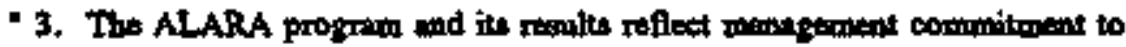
ALARA. The rodiation workers ane convinced of management's commitmeat to ALARA. The rediatice workers themsetves aro committed to ALARA."

\section{SIIE REQUIREMENT SOURCE: DOEJEHOLI3S RP.11.4}

- 5. The methode and procedures to ovdlunto ALARA date ca a apecified fircipuency are estublistrod."

\section{STE REQUIREMENT SOURCE; DOEJER0135 RP.11.6}

-6. The Alara dea car be ued to identify opesatione and ectivitios that miy neod extre nttertion."

\section{SITE REQUIREMIENT SOURCE: DOEVEHA13S XP.11.8}

7. ALARA is discussed in training giver to mdintion workers. Specific methods wo described fur limiting exposuns."

\section{SITE REQUIREMENI SOURCE: DOE/ER0135 RP.11.9}

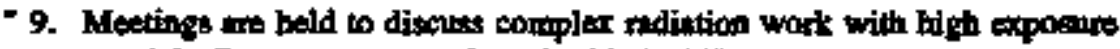
potential. Dry nus are cenducted with "cold" syatems."

\section{ALARA Committee and Stafon:}

This element addresses requirements retating to the staffing of and actions of the facility ALARA Committe. The ALARA Committee is in intezal part of the ALARA propram $\triangleq$ it includis members from various departments/groups of the facility. It is the direct lintr to involvement in ALARA by all groups and persons at the ficility. 


\title{
REQUTREMENTS IDENTIFCATION DOCUMENT HIGH LEVEL WASTE STORAGE TANK FARMS Radiological Protection Revisition 1
}

\section{SIIE REQUIREMENT SOURCE: DOE-N\$80.6 Section 138}

\begin{abstract}
-138 ALARA Commilteo

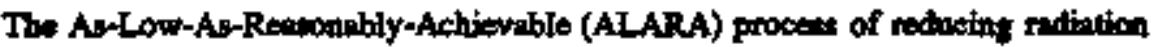

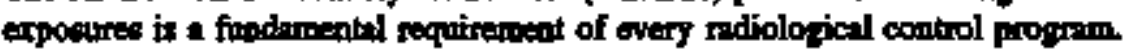

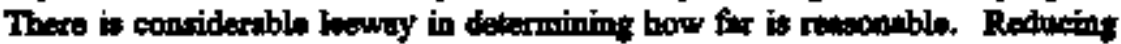
exposure is desinble becangen of the direct refation to the beolth aed safiecy of trorkess axd the pubtic. Retheing fadintion exposine ingerves the quality

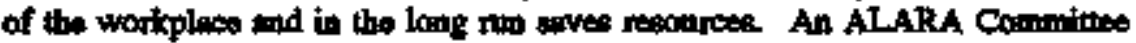

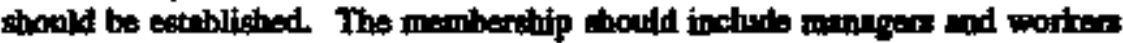

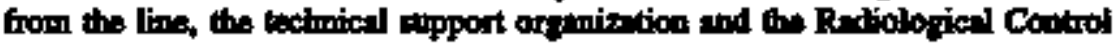

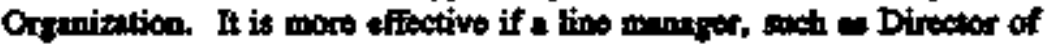
Operotione, Recesch, of Meintenance serves an the Charter. This Corninitteo

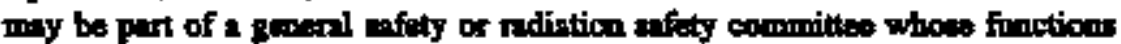

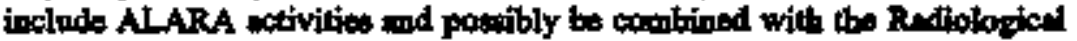
Awareness Cominittee (sec Article 132) for amsiler ficilities.

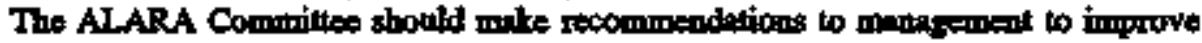

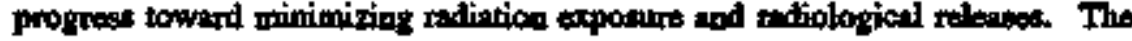
Commiltec ahonld ovalunte jtems such es construction and desipn of ficilitiea and syetems, planned major modifications or work metivition, as well ex

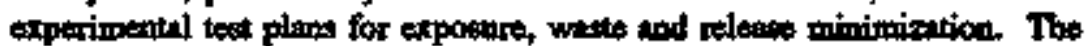
Committes should atso receive, as a minimim, tho resoltt of all reviews and audith, both interal and externll, and thould review the overall conduct of the Radiological Control Progme.

\section{RELATED REFERENCES}

\section{DOE/EHO256T Auticle 138}

\section{STIE REQUIREMENT SOURCE: DOE-N3490.6 Section 312.6}

"Radiological tasks anticipated to exceed individunl or collective doce criteria estnblisted in the Site-Specific Radiological Control Manal thonld be roviewed and approved by the ALARA Committer."

\section{RELATED REFERENCES}

\section{DOE/EFHO256T Afticlo 312}

\section{STE REOUIZEMENT SOURCE: DOEJEH0135 RP.11.2}

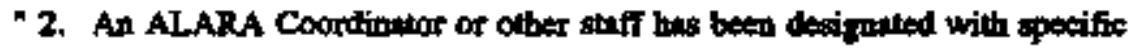
ALARA responsibilities. These respongibilities ure documented and integrated into the rediological protection piogram."

\section{Dose Trackine and Trendins}

This efement addresses requirements relating to the tracking and trending of dose and the use of that tracked dots as purt of the overall facility exposure reduction/ALARA program. 


\section{REQUIREMENTS IDENTIFICATION DOCUMENT HIGH LEVEL WASTE STORAGE TANK FARMS \\ Radiological Protection \\ Reristan 0}

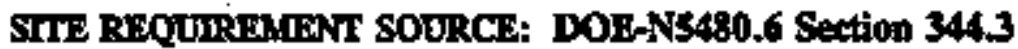

During the performance of jobs for whith a pre-job dowe extimat was made the Radiological Coatrol Orgunization, in coopention with line periodically

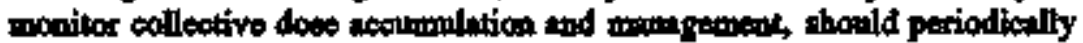

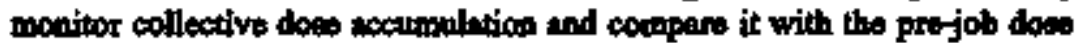

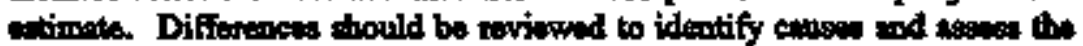
noed for corroctive tions."

\section{STE REOUREMIJNT SOURCE: DOE-PNL-65T Sectlon 2.1.2, Paragraph 5}

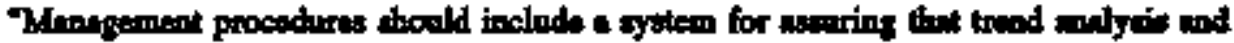

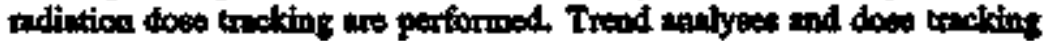

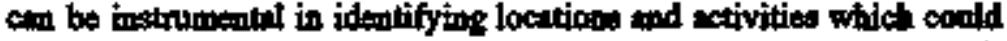
benefil from an in-depth ALARA ovnhation, oven in low-exposure facilitien (Mahnthy, Bailoy, ond Lay 1984). Preparing mod anolytiog control chast for

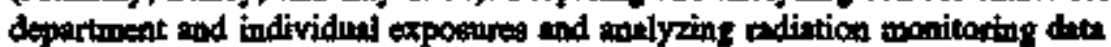
are juet two of their many ues."

\section{SITE REOUIREMIENT SOURCE: DOE/ER0135 RP.11.11}

11. Trend analysis is performod for both routine ind repetitive cperations, Managemont reviewa these analyses on a Epecified trequancy and takes eppropritive action."

\section{FACTIIT REQUIREMENT SOURCE; DOE5490.19 Chepter II, Section C.5, Last Paragraph}

-Opentions supervisary personol should periodically review expouare trends of operatiog persopnel under their appervision. Emplasis shonld be placed co determining tho adverse factors thet condribute to personed exposures and

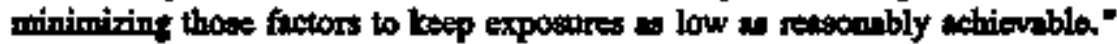

11.910 ALARA Derign. Renuirements

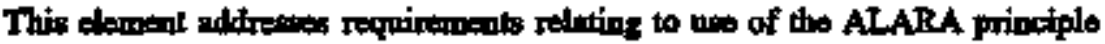
when derigaing facilitios and syatens. Theos nequirements do not finclude specific requirements for specific pieces of equipment, nther ovenill

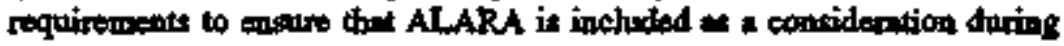
desiga procesess.

The Enginesing and Desiga furetional ares interfoces with Refiation Frotection when performing facility or tweility equipment engineoring of desipn. Specific requirements for spesific typee of Radietion Protection

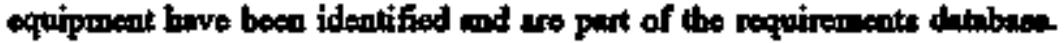
Persomet perfoming design reliting to Ratiotion Protection Syatems or Equipment must easure that these reguirements are reviewed and complied writh whor performing design. The ALARA Design elament includes the requirementy for exsuring that Rediation Protection is incladed in the review/upproval of enginecring and derign ectivities which may inget the exposedre to plint personnel or the genent public. The Radiation Protection Oroxaization is 


\section{REQUIREMENTS DENTIFICATION DOCUMENT HIGH LEVEL WASTE STORAGE TANK FARMS Radiological Protection \\ Rerision $\theta$}

required to ensure proceses for appropriate ALARA rovieus of Enginesting and Desipo ftemctions ate effected. Tho Engineering and Desigon Organization is responeible to couply with ALARA Decign requirementr.

\section{STIE REQUIREMIJNT SOURCE: DOENS490.6 Section 128.1}

"Fecility Modifications and Rediological Deripo Considwntions

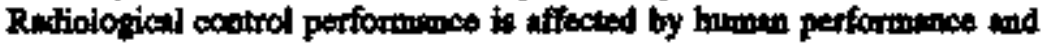

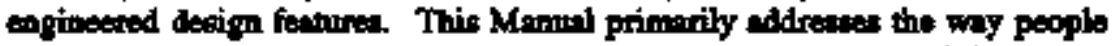

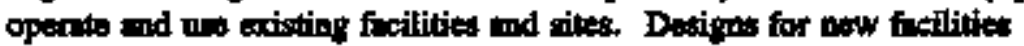

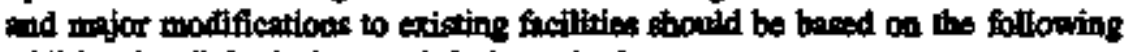
Adtrional mdiolopical control derion critoris:

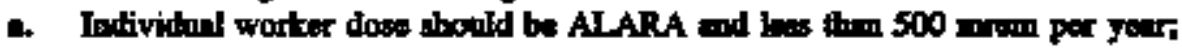

b. Discherpes of radionctive lipatid to the evirunment are coverod by the provisions of DOE 5400.5 ad bottild not deprede the groundwater,

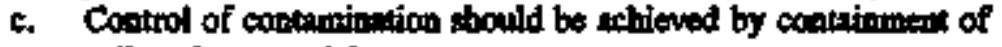
modionctive moterial;

d. Eficiency of mintenance, decontamination ard operations should be maximized;

- Components should be selected to minimize the buildup of mdionetivity;

f. Support fucilities thould be provided for dostinint and ramomal of protective ctothing and for personnel monitoring, where approprinte;

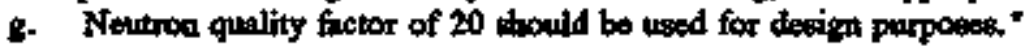

\section{SITE REQUIREAIENT SOURCE: DOE-NS480.6 Section 128.2}

"Feciltities currently uoder construction thould be evalunted and the shove critoria applied where pracliceble."

\section{SIIE REQUIREMENT SOURCE: DOE-N3480.6 Section 128.3}

"Existing fucility designs that have office space wod hochrooms or enting areas within Radietion Areas, High and Very High Radiation Aress, Contamination aod High Contrmination Ares, Airborre Rudioutivity Arews,

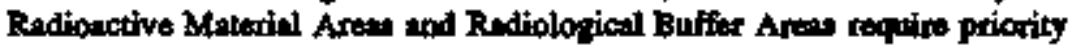
attention. Generally:

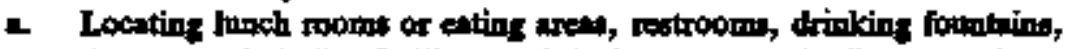

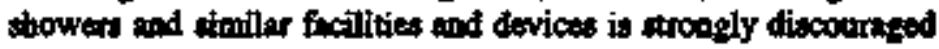
within these areas;

b. Locatiog office spuces within these treas is atrongly discouraged; to the extent thit sock space is essential to support ndiolopical wort,

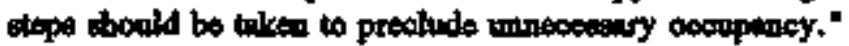

\section{STTE REQUIREMENT SOURCE: DOE-PNL-6577 Section 5}

The basic design criterin for ALARA is the optimizntion coocept ibelf. If ALARA (optimizntion) is implemented throughout the derign of a facility, no otber radiation protection desiga criveria should be required beyond that necessary to keep exposures below the regulatory limits." 


\title{
REQUIREMENTS IDENTIFICATION DOCUMENT \\ HIGH LEVEL WASTE STORAGE TANK FARMS \\ Radiological Protection \\ Rerigion 4
}

\section{SITE REQUIREMTRN SOURCE: DOXs489.11 Section 9J}

\begin{abstract}
Design and Control. Rediation exposine rates in controlled woriplece enves

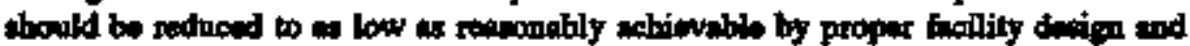

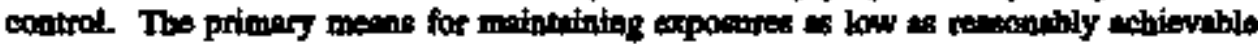
are to be through physicol controls, t.8., cenfinemeat, ventilation, remoto bundlins, end sielding. Administntive controls and

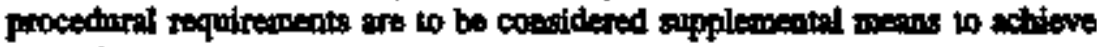
control."
\end{abstract}

\section{SITE REQUREBMENT SOURCE: DOES480.11 Section 9.J(1)(a)}

Dexign. During the design of fecilities, the followitig objoctives thall be applied:

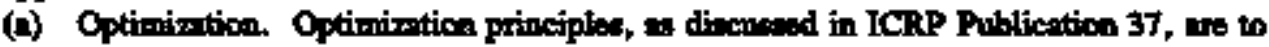
be utilized in developing and jutifying fecility design and physical controln."

\section{SIIE REQUIREMENT SOURCE: DOK3484.11 Section 9.j(1)(b)}

"Extersal Radiation Exposare. The decign objectives fot pereonel exposure

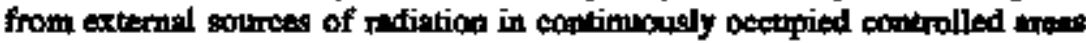
so ALARA and not exceeding 0.5 mrem $(5 \mu \mathrm{Sv})$ per hour on everage. The dexipon objective for exposerere rates for potential exposure to a radietion wodror

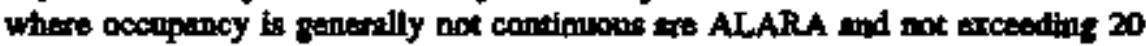
percent of the घpplicable stanilurd in pangaphs 9.b.(1) and (2)."

\section{SITE REQUIREMIENT SOURCE: DORS4a0.11 Section 9.J(1)(c)}

Tnternal Radiation Exposure. As a decign objective, exposure of personmel to inhalution of aiborto madioactive materialn is to be svoided ander nommat operating conditions to the extent resconably schiovislo. This will sormally be eccomplisted by confinement and veatilation."

\section{FACIITY REQULREMENT SOURCE: DOE5480.11 Section 9.J(1)(d)}

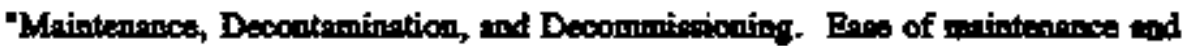

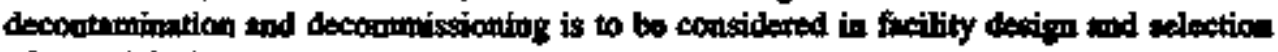
of moterials:

\section{SITE REQUIREMENT SOURCE: DOE6430.1A Section 1300-13}

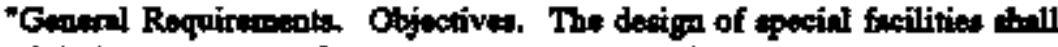
minimize exposurs of persoined and the general public to hanrdow meterialn by emphasizing ALARA concerns during all design, conetruction, and operatioul phasts: of specinl facilitios."

\section{STTE REQUIREMENT SOURCE: DOE6430.1A Setion 1300-1.3[04]}

"Oxcupational expocuse to radiation shall be limited ecording to DOE \$480.11.

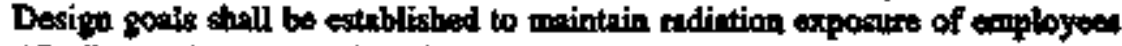
ALARA. The antore of the hezandous mitterinls in the fieility, inctuding 


\section{REQUIREMENTS IDENTIFICATION DOCUMENT HIGH LEVEL WASTE STORAGE TANK FARMS \\ Radiological Protection \\ Rerision 9}

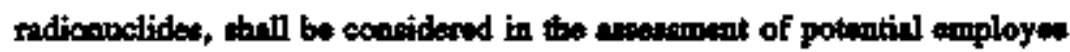
exposinte"

\section{SHIE REQUIREMENT SOURCE: DOE6430.1A Section 1300-1.4.1}

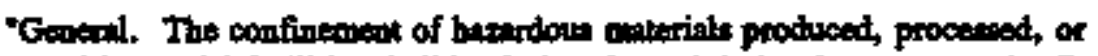
stared in special facilitios shell bo desigred to minimize dow to is mrimally exposed menber of the poblic."

\section{Co:t-Benefit An:lysis}

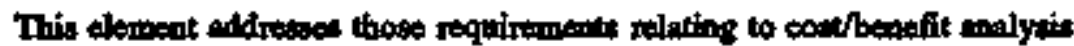
a part of the overnll ALARA proprill. The concept of ALARA incluties

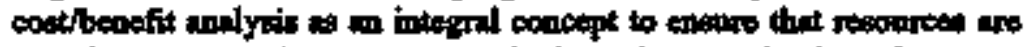

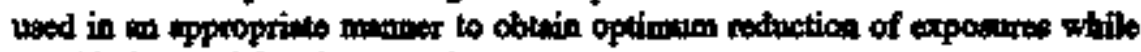
conetidering eocisl and economic coste.

\section{STE REQUIRIMENT SOURCE: DOE-PNL6577 Section 3.2, Paragraph 1}

"Cost-benefit analysis is thoroughly deseribed is ICRP Publication 37 (ICRP 1983) and is the preferred optimization method if sufficient dath are avileble for its use. Cost-benofit amlysis involves the quantificetion of all variables in monetary torms to determine the net besofit of a radiotion protection practice."

\section{SHE REQUIREMIXNT SOURCE: DOB/BH0256T Article 312, Item 7}

-Optimization tochniques, including costbenofit ennlysis, represent a

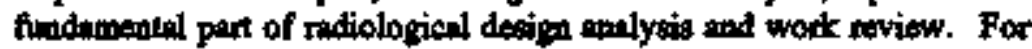
neviow of minos ectivities with low peseciated doses, 1 cost-benofit ovalution is an intrinsis purt of the engineering review process and a detailed evaluation is not necossiry. For review and planing of mijor

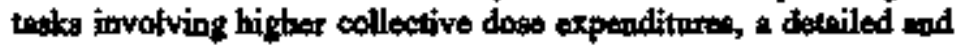
docunomted ovaluation should be performed."

\section{ALARA Audits}

This element eddreases the requirements for costucting modits of the ALARA program. Tbes undits my be performed by the Qunlity Coutrol Orgenization or by some other of graizotion, however, thees requirements tre epecific to ALARA andits and do not apply to other types of nudits which may bo performed by thees groups of by Radiation Protection persotumel.

\section{SITE REQUREMIDNT SOURCE: DOE-PNL-6577 Section 2.2, Paragraph 1}

Manngement responsibilitio for reviewing, euditing, and ovahuting the ALARA progrem shall be clearly documeated. Documeatiotion should inclode deseriptions of the purpose, scope, and frequency of ALARA proprem reviews ond of tecturiques for these reviewa. Doctmentation shoutd be clearly atitiblo." 


\section{REQUIREMENTS IDENTIICATION DOCUMENT HIGH LEVEL WASTE STORAGE TANK FARMS \\ Radiological Protection \\ Revision 0}

SUIE RJQUIREMENn SOURCE: DOE-PNLAS77 Sectian 2,2, Partgraph 2

Evaluntion of the ALARA program athell be condueted by ton individed $\alpha$ individunds who have no direat reponsibility for inplemedting the prosfrem.

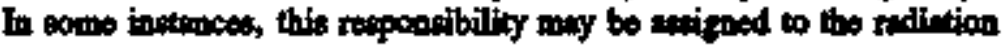

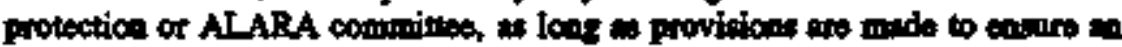
objective and anbiaced evilution. The eraluetion thould be coimminsioned by cenior menegement. Persomed condecting it stoold , for the porpow of the oraluntion. meport directly to them. The use of indepeodeat velm for larto

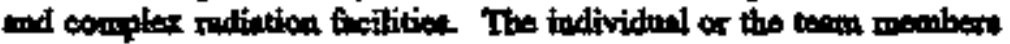
conducting the evaluation soodd, imdividually or jointly, heve knowledge of and experience in bet/th phystes, fuctlity cperatione, desien, monagement syatem, and ALARA. A formul report on the eraluation thould be inesod to

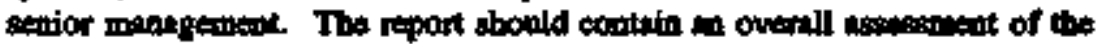
program ond include the findings of the ovalnution. areas of trengthe and

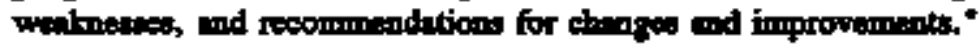

\section{STIE REQUIRGMENT SOCIRCE; DOEJEHD135 RP.11.1}

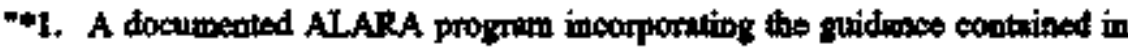
DOE/EV/1830-TS a eppropriate is eetrbliched and muditad co a specified frequency."

\section{OCCURRENCES AND INVESTIGATIONS}

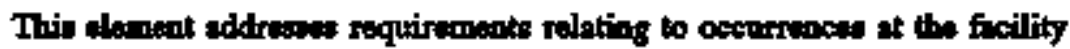

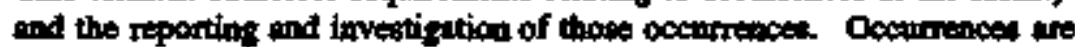
ebroimal events which hevo specific requiteonentr to dermonetrate thet the ficility has appropriately responded to the event, reported the oveak to approprinto proups, stencies or individnals, has thoroughly investigated the event fond has taken approptiat detions to prevent a nentreace of the event.

This element inclsdes requiremente redeting to the appropriate response to

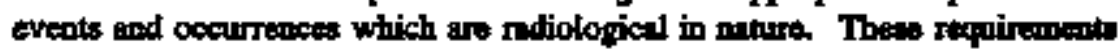

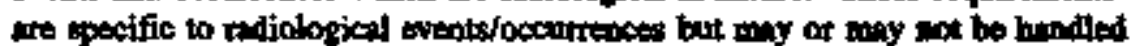
by the Radiotion Protection Orgorizotion. The Compliance Absessment and Resolution femctionel sre include genenl rexpinements for emsuring

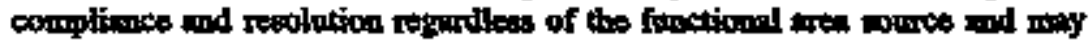
also include specific requitements for radiological evenal

\section{Ocarrenced Frents}

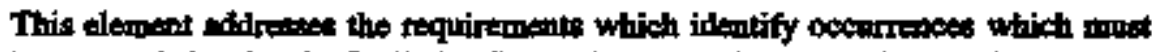
be responded to by the Patiation Protection Organization and generel requirements for responding to oceurrences and eventl.

\section{SIrE REQUIREMENT SOURCF: DOE5490,11 Sextioa 9,m(I)}

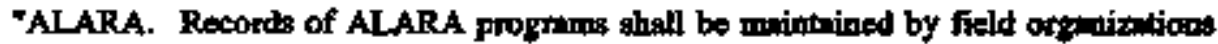

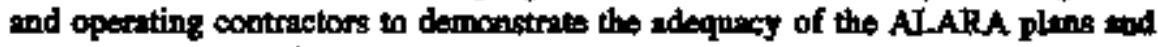
proparims and their inplemention. 


\title{
REQUIREMENTS IDENTIFICATION DOCUMENT HIGH LEVEL WASTE STORAGE TANK FARMS \\ Radiological Protection \\ Revision 1
}

11.510.2

$\mathbf{1 1 . 1 0 . 3}$

\section{Qxarrence Nintifictions:}

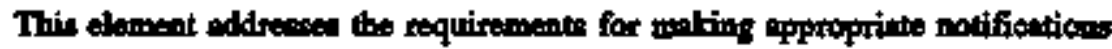
to provps, agencies or individunts in a timely end epproprinte mennex followiting oceunenes the theiltity.

\section{Oenurrence Inzestipations and Critinuses}

This elemeat addrecoses the requirendenty for performing tovestigations and

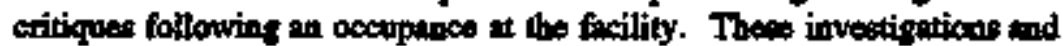
critiques are simed at identifying the emeses of ocenrreacen and identifying aproprinte actions to provent recurrence.

\section{SITE REQUIREMITNT SOURCE: DOE-N5490.6 Section 127}

\section{"Critiques}

It is the Department's desire and expeotation, based on concent for the sefoty and

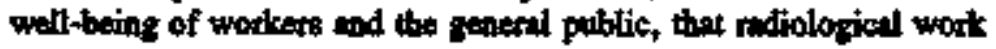
prectices be contimsally wertinized and questioned wo that opportanities for improvement cen be identified, masessed and incorporetod into this Manel and the Sito-Specific Mantroits.

\begin{abstract}
A formal pnocess stoxuld be atrolisbed to obenin pertinent facts following in

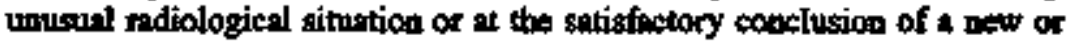
tonaral operation involving rediological controls. This peocess complemente

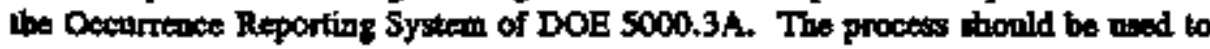

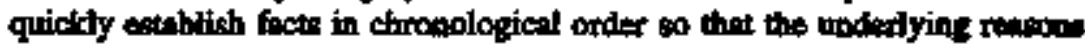

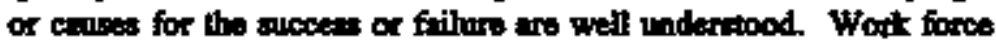
participution should be encouraged. Critiquea the a manisenent tool and should not be used to "fix blamp" or "shoot tho mesonots."."
\end{abstract}

\section{SIIE REQUIREMIFNT SOURCE; DOEN5480.6 Section 351}

"Evilustion of Performance

During the conchuct of radiolopical work and the haxpling of radionetive moverits, sbnormel event may accur which could indicete a weaknese or wron of proyrammatic brewkdown of radiological controls. Prompt, contintent gathering of faets related to such ovents is required to satisfy reporting and investigation requirtments and to formulate conbective actions to provent recurrence. In addition, snecessful performence or complesing of unique

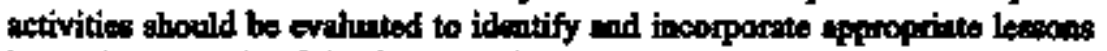

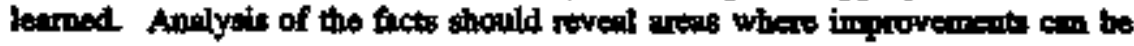
made or identify methods to perveot the recurreace of undesired testlts."

\section{SITE REQUIREMANT SOURCE; DOE-N5480.6 Section 351.1}

- Conduct of Crtiqued

Critiques are meetings of the personnel knowledgeable about wh event (either a success or motnormal event) to document a chrosologicel listing of the facts. The purpose of the critiqus is not to assign blame, but to estrbilin and record the ficts. Critiques should be conducted for soceesses and abnomel eventh." 


\section{REQUIREMENTS IDENTIFICATION DOCUMENT HIGH LEVEL WASTE STORAGE TANK FARMS Radiological Protection Reristion 0}

\section{STIE REQUIREMENT SOURCE: DOE-N5480.6 Section 351.2}

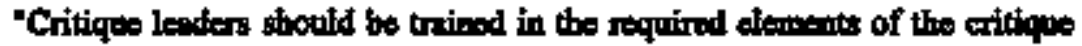

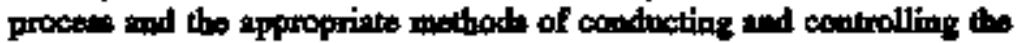
critiqua."

\section{SITE REQUIRRMENT SOURCE: DOE-N5480.6 Section 351.3}

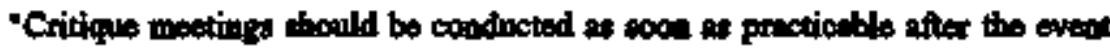
or situntion is strilized, or sfler a brecesoful evolution is complated. Critiques of abaomel wents should prefienbly be condected before involved perromenl lewe for the day."

\section{SITE REQUIREMENT SOURCE: DOE-NS450.6 Section 351.4}

"At a minimum, the generil critique process should inchude the fo'towing Alemontor:

- Formal meotinga, chained by a critique leader;

b. Alt=ndines by all who can contribub;

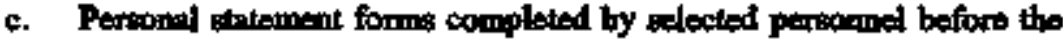
mexting;

d. Altendince reconds;

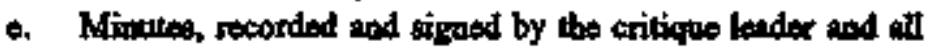
contribulors;

f. Persoanl atatoments, signod and atteched to the meetins mimates;

c. A listing of the fuet in chromological order;

b. Sapporting materiale, troluting doctumests, rocords, photopraphe, parts and loge, mintained by the critique leades."

\section{STTE REQUIREMENT SOURCE: DOE-N\$480.6 Sectlon 351.5}

"Evaluation of complex evolutions or events may requirs miltiple critiques."

\section{Ocurrence Reports}

This cheront eddresses requirements for reports which are generated fallowint

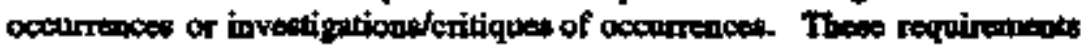
ensure thet actions taken following the ovent ant appropriately documented and communicuted to gropqs, agencies and/or individunls.

\section{OCCURRDNCE REMORTS}

This element addreves the requirements for mointeining records related to radintion protection metivities end for genereting reports. Recorde and Jifporting requirtments tro established for the RP Proprim to document the

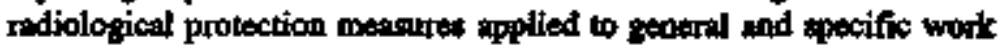
totivities end to demonstrate RP complinese with requiromenth furing andita, inspections and evajuations. Exposure reconds and reports are a necessary tiement for demongtrating cormpliance aud for informing monngement, visitors, personnel, terminated employses, and rogallatory groups of both the infiviturit and collective axposures. Fimally, these records may be used to demoatrats 


\section{REQUIREMENTS DENTIFICATION DOCUMENT FIGH LEVEL WASTE STORAGE TANK FARMS \\ Radiological Protection \\ Rerision 0}

the rndiologicel protective activitieg taken by the facility in response to

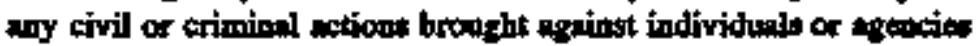
sosecieted with the forility.

The Records Manngement element includes rexpirements wich tre specific for

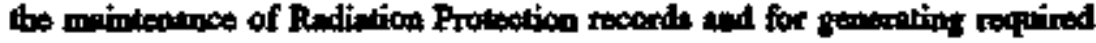
Ratiation Protection Reports. The Document Conerol and Recontis Minesenens functional area under Management Syttems provides ovenll requinements for mainmining records and the Document Control Orgenizstion will titaty the responsibility for the long term hrmilling ind control of Rudition Protection

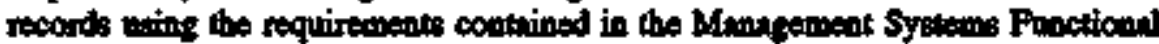

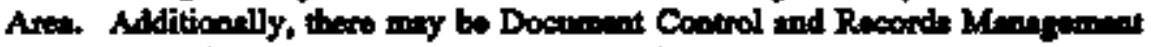

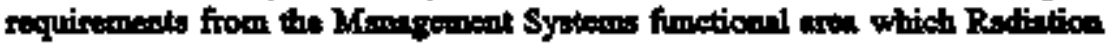
Protection (and other functional weate) ane reponeiblo for complyting with.

\section{SITE REOUIREMENT SOURCE: ANS1-N13.6-1966 Section 7.1}

Retertion ard Stonge of Retordis.

Retention Period for Reconde. The aymproins of ratiotion-ceneed injory of disuse wey sok become for yeurs after the ndiation expooure bes oceurred.

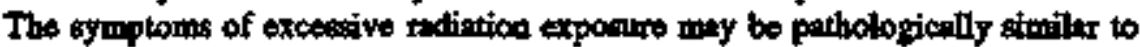
the sympions for a disenes or irjury that was not caneed by radiation. axposars. The retention geriods for the more sifpifiesent rwoonds must necessarily be of long dunation in viow of the following two fuctors

(1) The requiremedts for tetention imposed by opplicathe regulations Affecting certinin rodiation recorda

(2) The possible futher need for cortain records to provide information for

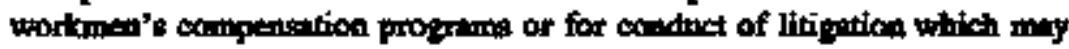
tromepirs many yeats in the future.

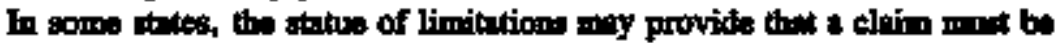
filed within a pesctibed time finm the employee's awarenese of the diseesen or injury and tas reletionship to his employment in other states, the rule ney be different.

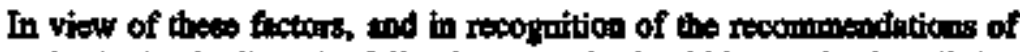
autboritutive bodies, the following records should be retriped until the yeer in which the individuel woukd have reached the 290 of 75 years or until 10 years after be known death of the individuat.

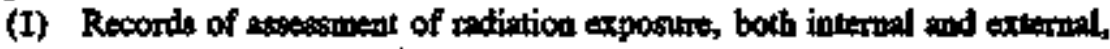
roceived by the individunl

(2) Records of control and culfibration dath associnted with evaluetion of the individuel'a exposuts data

(3) Reconds of procedures and methods uned for interpretation and ovaluntion of the individusal's expecours deta

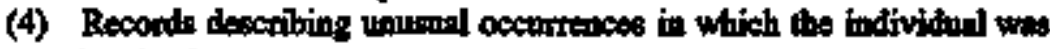
invotved.

Records other that the forvgoinf (0. B., radietion survers) may be equally viluable in establishing the redintion exposure of an individusl and their retention my be desinble, tryending on the circumstances, for a similar period of time. All records deectibed in this stmendurd should bo rotnined for $n$ minimum of 5 years. In nny event, tho employer should peck logel sivice before effecting the dextruction of 


\section{REQUTREMIENTS IDENTIFICATION DOCUMENT HIGH LEVEL WASTE STORAGE TANK FARMS \\ Radiological Protection \\ Rerishon}

\section{STIE REQUIREMENT SOURCE: DOE-N5480.6 Section 711}

\section{Requirements}

Puppose

Thil chopter contains the prescribed prectices for preparing and retaining mdiologically related recorde. Radiological control reconds aro meded to despondrate the effectivenes of the overell program. The woit force end

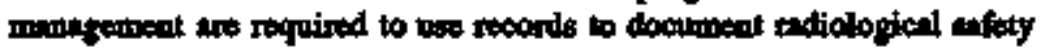
sfionded to perexand onsito. Recorts of radiological programe my bo required to support wodres heolth chudies end future dippotes or eleime. Therafore, these reoonds should bo high quality, readily retriovablo end Ineneged for the preseribed retiotion period. Consideratic should be given to

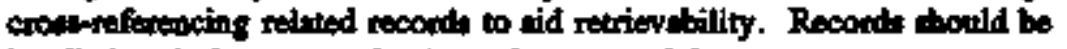
hendled soch that porsooul privecy is protected."

\section{STTE RBQUIREMINT SOURCE: DOE-N54\$0.6 Sectiog 712.1}

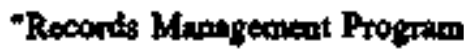

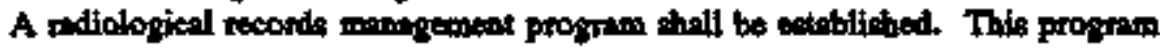
whell envire that nuditablo records and seports aro controlled throggh the

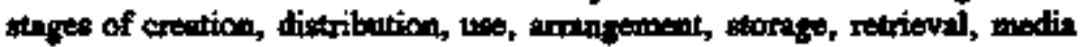
converion (if applicable) and disporition. The records mnagsment program stonld include the following:
a. Radiological Pelicy Sutemens;
b. Rudiological Control Procedures;
c. Intivionpol Radiological Doos;
d. Intormal and Externll Doaimetry Policies and Proceduris (inchuding Base Docments);

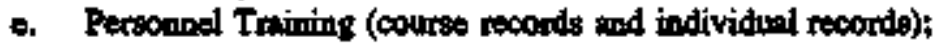
f. ALARA Records;
5. Radiological Instumentation Test, Repair and Calibrition Reconds;
h. Rodiologínel Surveys;
i. Ares Monitoring Dosimetry Results;
j. Rodiologitol Wort Permits;

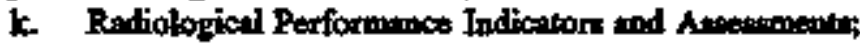
1. Radiological Sufety Amlysis mit Evaluation Reports;
m. Quality Assurmoc Records;
n. Radiological Incidest and Oceurresco Reports (end Critique Reporta, if Applicable);
o. Accoumtability recontis for sealed sontres;
p. Records for relenes of meterial to Controlled Arees;
q. Reports of toes of motiontive matrial."

\section{RELATED REFERENCES}

\section{DOEJEHO256T Article 712}

\section{SITE REQUREBIENT SOURCE: DOE-N5480.6 Section 712.2}

\footnotetext{
Where radiotogtical services (for example, dosimetry and laborntory ansiyses) ere purchased, there should be a clear agreement regerding reconds
} 


\section{REQUREMTNTS IDENTIFICATION DOCUMENT \\ HIGH LEVEL WASTE STORAGE TANK FARMS \\ Radiological Protection \\ Reristan 0}

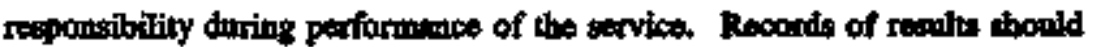
reide in the cuetody of the originating contrest argenimition."

\section{RELATED REFERENCES}

1. DOE/EHO2S6T Atidlo 712

\section{STTE REQUIREMENT SOURCE: DOE-N5480.6 Section 713.1}

"Recordkeeping Stendridb

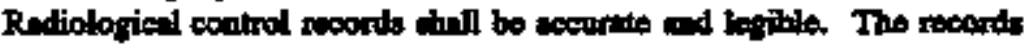
shoold tinchude the following:

2. Itentifieation of the focility, equecific location, functica and procesp;

b. Sipnatore or other identifying codo of to prepwrer and dater

c. Lepibls entries in binte itk;

4. Corrections ideotified by a single line-out, initialed and dectod;

- Supervisory signeture to ensure neviow and proper completion of fons."

\section{RELATED REFERENCES}

\section{DOE/EFO256T Article 713}

\section{SITE REQUREMINT SOURCE; DOE-N5480.6 Section 713.2}

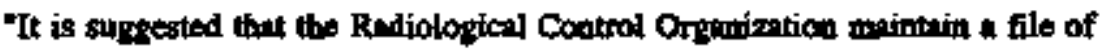
nomes, sigaterures and initials for future identification of the person who rigned or initialed a record."

\section{RELATED REFGRENCES}

1. DOE/EH0256T Article 713

\section{SITE REQUIREMENT SOURCE: DOE-N3480.6 Section 713.3}

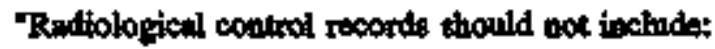

- Opuque abotone for corrections;

b. Shorthend of other nonetenderdized torne."

\section{RELATED REFERENCES}

1. DOE/EH0256T Articlo 713

\section{SITE REQUIREMENT SOURCEA DOE-N5480.6 Section 713.4}

"Sirritar procedinal standands should be establisbed for computerized recorde."

\section{RELATED REFERENCES}

1. DOE/ER0256T Article 713 


\section{REQUIREMENTS DENTIFICATION DOCUMENT HIGH LEVEL WASTE STORAGE TANK FARMS \\ Radiological Protection \\ Rerision 0}

\section{STE REQUIREMENT SOURCE: DOE/EHO135 RP.12.1}

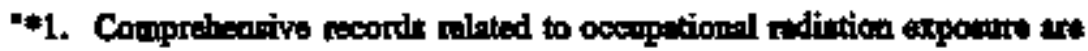

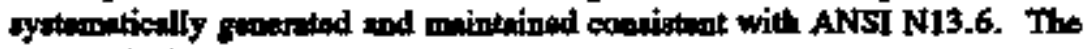
retords inchude:

- Ratiation recordt related to in indivitant, 0.8., prior exposurs history, bionssay dalh, doso assecsmeat methodology, persomel dosimetry tesults, atc;

- Rafiation records related to the stamis of work freas, us.,

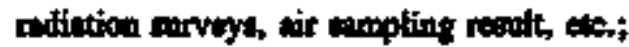

- Records the decribe the tecturical and administritive hasis for rutiologicel protaction progtams, a.g., stondatd, policiea, procedurea, methods of fose evaluntions, etc.; nd

- Reconds of unusial occurreoces, accidents, aed incidents, a.t. investigations, correctivo action, folluw-mp, etc."

\section{STTE REQUIREMENT SOURCE: DOEJEH0135 RP.12.4}

7. Records are minthined in a centralized location, protected from loes, such thet the level of effort required to retiove all the records relevert to 2 given incident (including field monitoring recorde, air

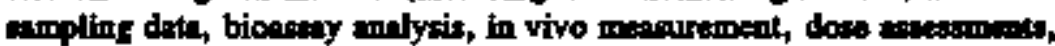
etc.) would be minimal."

\section{STIE REQUIREMENT SOURCE: DOES490.11 Section 9.In}

"Resonds. As a minimum, be records specified below of the redintion protection progrnm and dosimetry records for all indivitionls for whom monitoring is provided thall be generated and maintation, commencing with the effective dats of this Order. Information ind date developed pursannt to this Order shall be retained consigtent with the requirealents of DOE 1324.2A, RECORDS DISPOSIIION."

\section{SIIE REQUIREMENT SOURCE: INPO-88-010 Chapter III, Section C(3)(S)}

"Records that document the infortant activities asecinted with this chapter should be mointained tin a retrievable, ingible form. Examples of such records incturit the following:

- Indimion survey tecord records

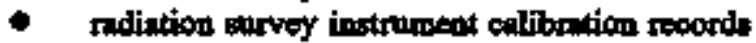

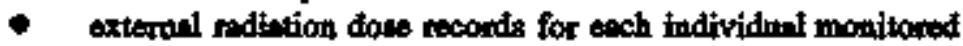

- results of area moditoring dosimeters when used to confirm thos unmonitored persounal do not require doeimetry

- records of dosimetry device calibration, testing, and quality control checks

- dose nsseveriontits 


\title{
REQUIREMENTS IDENTIFICATION DOCUMENT HIGH LEVEL WASTE STORAGE TANK FARMS Radiological Protection Rerision 0
}

\author{
- timekteping records \\ - ratiation wott perpits"
}

\section{SII REOUIREMENT SOURCE: INPO-88-010 Chapter VI, Sectlon C.4}

"Records thet document the inportant wetivitios absociated with this chenter

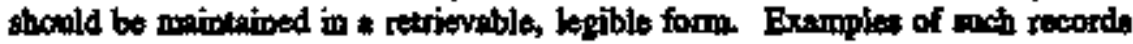
include the following:

- contuminaticn survey recorde

- contanination survey inetrument calibantios documentution

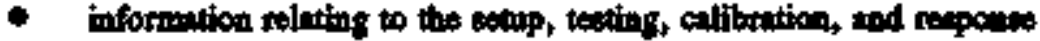

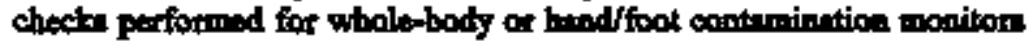

- reports of abin, slothing, and eren contaraination-Stin contamination reports shoold be filed in the todividual's radiation expoense records. A centeal file of sll teportr chould bo meinteined for neview by radiological protection personenel."

\section{Personnel Exposire Reench}

This element eddresses requirements for maintoining personsel exposwro reorords. These records inelude documented information concenting external

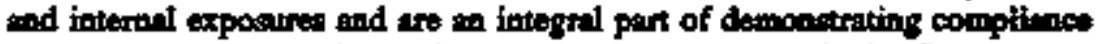
with other programmatic roquiremeats relnting to the Ruciation Protection flocetional wrem.

\section{SIIE REQUIREMIENT SOURCE: ANSI-N13.6-1966 Section 3.2.3}

Individuat Persomel Records. Since one of the primary purposes of the

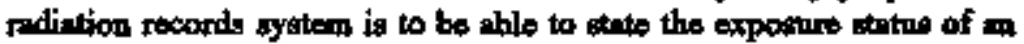
individual, the employer should extablish and muincuin a consolidnted necord for each individual. Radiation records specifically related to tho expoate

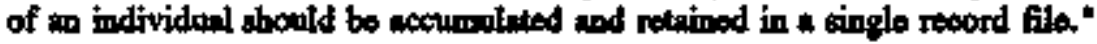

\section{SIrE REQUIREMMNT SOURCE: DOE-N5480.6 Section 722.1}

Perroneal Radiological Records

Radiution dose records shll be maintained for all contractor, mbecatractor and Feders al moloyes who at purt of the persomed dosimetry program at DOE facilities.

\section{RELATED REFBRENCES}

\section{DOE/EFHO256T Article 722}

\section{STIE REQUIREMENT SOURCE: DOE-N\$4\$0.6 Section 722.2}

-Radiation dose records shell contain information sofficient to identify osch person, including social security or employes number." 


\section{REQUIREMENTS IDENTIFICATION DOCUMENT \\ HIGH LEVEL WASTE STORAGE TANR FARMS \\ Radiological Protection \\ Rerision :}

\section{RELATED REFERENCES}

1. DOE/EHD256T Article 722

\section{STTE REQUIREMIENT SOURCE; DOE-N5480.6 Section 722.3}

"Routine and special records relatod to radistion doses ethill bo retained for

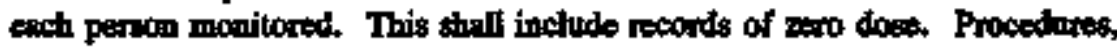
dita and supporting infortution peeded to reconfirm a persen's dose at a later date whould be mointnined."

\section{RFTATID REFERENCES}

\section{DOE/EHO256T Article 722}

\section{STIE REOUIREMENT SOURCE: DOE-N5480.6 Section 722.4}

"Externol dose reconds shoutd inciude the following:

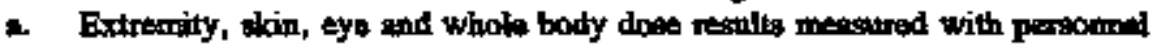
dosimeters, including all multiple dosimeter badging resulte.

b. Evaluations resulting from nnomplous dose results such as ureexpected high or low doses.

c. Dose reconstructions from lost or dumiged dosimeterts or for mbedged workers.

d. Evaturtions of nosuniform matietion doces."

\section{ROLATED REEERENCES}

1. DOE/EROOS6T Anticle 722

\section{SITE REQURREMENT SOURCE: DOE-N54\$0.6 Section 722.5}

"Internel dose resorde would include the followingt

- Whole body and hug counting rwoults (including chest wall thickness

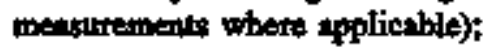

b. Urine, fecel and specimen enatyoser

c. Dose assessment, es required."

\section{RETATED REFERENCES}

1. DOEJHHO256T Article 722

SUE REQUIREMIENT SOURCE: DOE-NG480.6 Section 72.7

"Recorde of anthorimition to exced Administrative Control Levalu thall bo retained."

\section{REIATTED REFERENCES}

1. DOE/EH02S6T Article 72 


\section{REQUIREMENTS IDENTIICATION DOCUMENT HIGE LEVEL WASTE STORAGE TANK FARMS \\ Radiological Protection \\ Revistion a}

STTE REQUIREMENT SOURCR; DOE/EH0135 RP.12

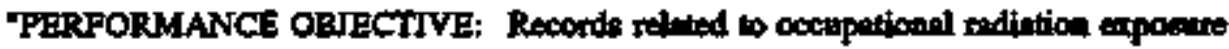

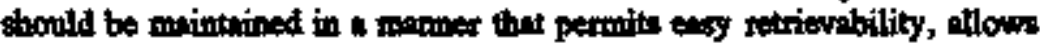
wend anelyois, and side in the protection of an individuel ind control of rediation exporurs."

\section{SITE REOUIREMENT SOURCE: DOE/EHO135 RP.12,2}

*2. Resords related to oceupational radiation expocase ase adequate to

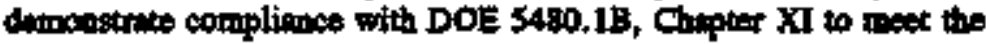
seporting requirements of DOE 5484, IA for enployees and visien, and the tocorde retention requirementa of DOE 1324-2."

\section{SIIE REQUIREMINT SOURCE: BOES490.11 Section 9.m(2)(n)}

Intoimel Expoane.

1 Amunl effictive dose equivalent reowived daring the year from niniantive paterist deposited in the body;

2 Anmul dose equivalent to organ or tissue of coneern received during the yeur from retionetive meterinl depoxited in the body;

3 Committed effective dase equivalent from intakes occurring during the yesr;

4 Committed dose equivalent to orgun or tissoe of concem from intelke occurring furing the year."

\section{SWE REOUIREMENT SOURCS: DOES480.I1 Section 9.m(2)(b)}

\section{Erieruel Exposarte.}

1 Annuel effective dose equivalent from extermal sounces of mdietion received during the year.

2 Antural dose equivaleat to the lens of the oye.

3 Annual dose equivalent to the stin.

4 Annul dose equivalent to the extremities naceived during the year. incloding; (1) hrods ond forearn befow the elloow and (2) fect nod lepa below the lmee."

\section{SIIE REQUHREMENT SOURCE; DOESA80.11 Section 9m(2)(c)}

"Sumbetion of Internal wad Exteral Dose Equivalents.

1 Summetion of the enminal effective dose equivalints received from external and internat sotures during the your.

2 Crmulative memal effective dose equivilent roceived from extertal and internal cources while employed at the ferility, ince the effective drete of this Order."

\section{STIE REQUIREMENT SOURCE: DOE5480.11 Section 9.m(z)(d)}

-Programs to Determins Individual Exposures. Deto necessary to support or ro-calculate doses at a bier date shall be meintrined pursuant to Sectoon 4 of ANSI N13.6-1972." 


\section{REQUIREMENTS IDENTIFICATION DOCUMENT HIGH LEVEL WASTE STORAGE TANK FARMS Radiological Protection Rerision 4}

\section{Personnel Previous Exponsure-Rechads}

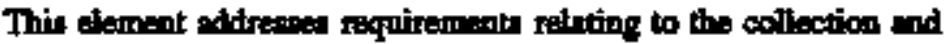
meintenunce of previous exposare necords for persentel worting at the

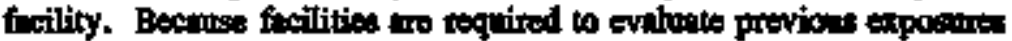

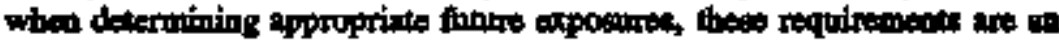
intortant pert of the overall facility exponere centrel prognim.

\section{SME REQUIREMIENT SOURCE: DOE-N5400.6 Section 721}

\section{Employes Records}

Employusent Etrotary

Records decriling an employee's preemployment and exmploynent hiotory and the associated ridiation dose thell be meintrined. Whore proticol, the

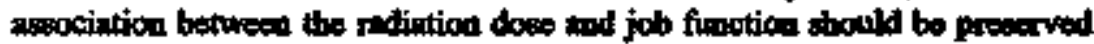
for trending parpoess and future wotker beilth stadties. The following information should be meintained:

1. Privious work listory detriling nodioloyical work essignmenth, to the

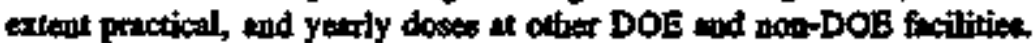

2. Nuclear Reguletory Commission Form 4 or equivalent thet documente previous occoupetional rudiation doses.

3. Ongoing wort history documenting wort assignments and ratiestoo doses; the fecility and cocupationst codes delined in DOE \$484.1 should be wed for this process.

4. When issud, DOE standaptized forms to document provions and ougoiog Indiation doses."

\section{RELATHA REFRRENCES}

\section{DOE/EHO256T Article 721}

\section{GIF REQUIREMIENT SOURCE: DOE/EH0135 RP.5 ROUTIVE DOSIMEIRY.11}

11. Persomel exposare histories aro readily avilable to those who aro responsible for expostre control (e.5-1 ndiation protsetion and opertional supervisors).

\section{SITE REQUIREMIENT SOURCE: DOES480.11 Sectioa 9.m(Z)}

"Individud Ocoupationnl Dose Records, Individul ocedpational internel and extermil dose reconds and records of the programs used to essess individural doses shull be generated and meinteined sufficient to provide tymoprims

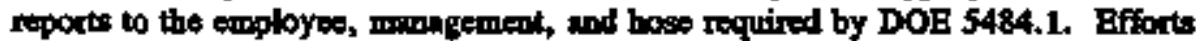
shoutd be made to obteis records of ocenpertional expostare received prior to empioyment at the site. Records should be readily availablo for all cultient tomployes." 


\section{REQUIREMENTS IDENTIFICATION DOCUMENT HIGH LEVEL WASTE STORAGE TANK FARMS \\ Radiologieal Protection \\ Revision 1}

\section{Personned Bropsure Reports}

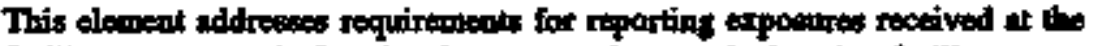

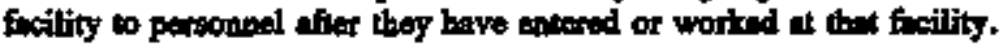

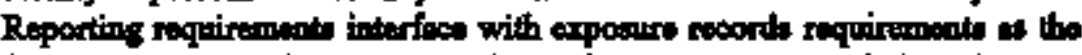

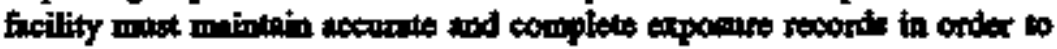

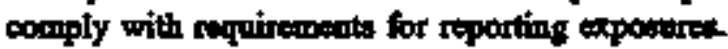

\section{SITE RBQUREBMENT SOURCE: DOE-N\$480.6 Section 781}

"Rodiological Reporting

Reports to lintivitanals

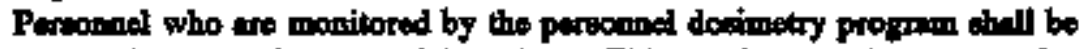

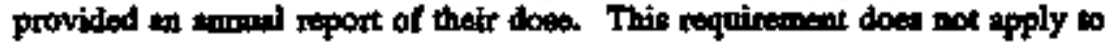
visitors covered by Articlo 732. Upon request, a person thould receive a curreat ndintion dowe record. Terminating tomployece thall be providod a teport, withition 90 daye of the taet day of amploynent, the armminime miliation does for the totel period of employment at the reporting freility."

\section{REIATTWO REFERENCES}

\section{DOE/EH0256T Article 78I}

\section{SIIE REQUIREMENT SOURCE: DOE-N5480.6 Section 782}

-Annual Rediation Report

DOE 5484.1 provides reporting requirtments for the "Ammel Redistion Dose

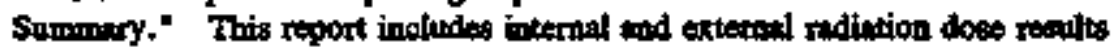
for monitored DOE and DOE cenotractor exployeos, and for monitored visiton."

\section{RELATED REFERENCES}

\section{DOE/EH0256T Article 782}

\section{SLTE REOUIREMENT SOURCE: DOE/DH0133 RP.12.6}

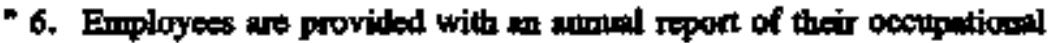
exposure history."

\section{STTE REQUTREMENT SOURCE: DOE/EA0135 RPS ROUTWN DOSTMIETRY.17}

"17. Records of personnel exposures and methods of determining exposares it the sito are permentendy meintained and rotrierable."

\section{STTE REQUIREMENT SOURCE; DOES480.11 Section 9.n}

"Reports to Employess. Records of exposure ebould be meds avilitble to all cecupational worters on en individual basis and should be provided to cerminated employees as scon as the date is avilable hut within 90 days of 


\section{REOUIREMENTS DENTIFICATION DOCUMENT HIGH LEVEL WASTE STORAGE TANK FARMS \\ Radiological Protection \\ Revicion 0}

tomimetion. A summery of annusl, comelative, and committed effoctive dose

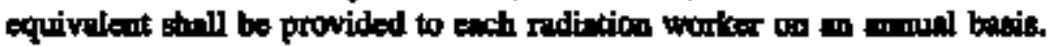

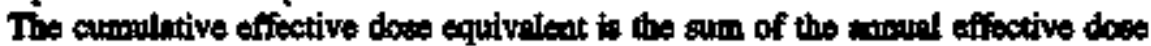
equivelents reconded for euch yest of employment since the effictive dave of tho Ondar. Detriled informution conserning a worker's exposare shell be mode trailable to the worker upon the request of twe worker, consibtent with the provistong of the Privacy Aet (S USC SS2A)."

\section{STTE REQUIREMENT SOURCE: DOE5484,1 Chapter IV, Section 3.c}

Report of Rudintion Exposurns to Headqrarters Employeex. Report in rocorded

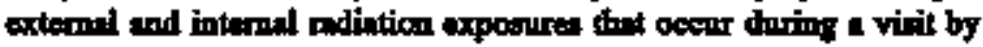

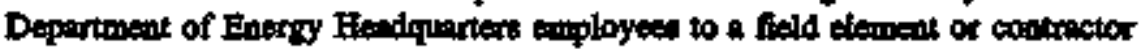
facility. Complets appropriate portions of DOE F 5484.8, and mobmit it to tho System Safety Developmeat Center (SSDC). EGeG Ideho, Ine., within 30 dye after the individuale's dete of visit or witbin 30 days after his or her exposure hes been determined, whichever is tuter."

\section{Visitor Exposure Records ind Reorgty}

This eleanent edidresses requirements relating to the meintenence of exposure reconds for visitors to the fucility and for reporting visitor exposures to gomps, agencites and individuals.

\section{SITE REQUREGENT SOURCE: DOE-N5480.6 Section 731}

"Visitars

Record Requitroments

For visitors entering on area where radintion monitoring is required, the following records shall be mintrined:

1. Docarmentation of completion of Rudiological Orientation.

2. Radiation dose records, inchuding zero do6e."

\section{RELATED REFERENCES}

\section{DOE/EH0256T Article 731}

\section{SITE REQUREMENT SOURCE: DOE-NS480.6 Section 732}

\section{Teports}

All non-zero radintion doces thell be reported within 30 doys of the does determinution, but no later th.m \$0 daye after the end of the virit, to ench visitor who received a dose It it desirnble that all viritors who receive zero does atso be provided a repent. Zero dase reports shall be provided to those visitons who request a etport."

\section{RELATEA REFERIENCES}

\section{DOE/EHO256T Article 732}




\section{REOUIREMENTS DENTIFICATION DOCUMENT HIGH LEVEL WASTE STORAGE TANK FARMS Radiological Protection Rorision 1}

\section{STTE REQUTREMENT SOURCE; DOE/EHT135 RP.12.2}

- 2. Records reieted to occupational radietion exposors are edequate to demonstrate compliance with DOE 5480.1B, Chupter XI to meet the reporting requiruments of DOE 5484.1A for erployeses and vioitors, nod the reords retention requirements of DOE 1524-2."

\section{SHE REOUIREMANT SOURCE: DOEEHO135 RP.12.3}

*3. Vieitors are provided informetion with respect to their expoumb in scocdince with DOE 5484.1."

\section{SITE REQUREMAENT SOURC:: DOE5484.I Chapter IV, Section 3,d(1),(2)}

Teport of Rudintion Exposures to Visitors.

(1) Report all positive external and internal sadietion exponures recorded for visitors during the period of their visit to a Departanent of Enery or cerstractor ficility. Complete the appropriate portious of DOE F 5484.8 and suberit copies of these reports to the visitor's exployer (or to the visitor if ho or she has no employer) within a period of 30 days after the date of the visit of within 30 doys after the visitor's exposture has beed determined, whishever is later. For visitors who wre enployees of the Department of Eutergy or Department of Exerpy contractors, a report should be aubinitted only to the viritor's employer.

(2) Any radiacion exposure in excess of the rufintiod dose equivaleat stonderde extedistied by DOE \$480.18, Choper XI, thall be reported within 24 hours after the exponure or wilbin 24 bowrs after the expontine has ben determined, whichever is later, to the viuitor and his employer

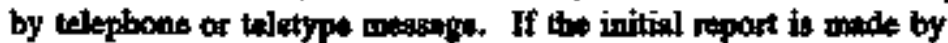
tetephone, a written report skoll follow within 30 days. -

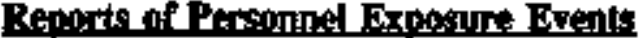

This alement addresses requiremente relnting to the reporting of expoetures received is part of in event/ocelpoince. Theac requiremeats are spectific to events whick involve sippificant expodures (normally in excest of allownble

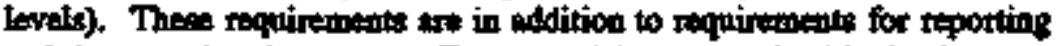
and doenmenting OccurrencestEventu which aro contrined in Section 11.10, Occuntences and Investigations.

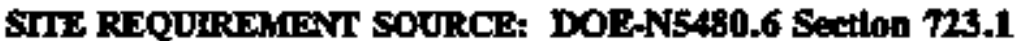

-Other Personnal Radiological Records

The complete records of ratiolotical incidents and ocurrences itvolving perseanel dose shell be retrined." 


\section{REQULREMENTS IDENTIFICATION DOCUMENT HIGE LEVRL WASTE STORAGE TANK FARMS \\ Radiological Protection \\ Berition 0}

\section{RELATED REFERENCISS}

\section{DOSTEHO2 $65 \mathrm{~T}$ Article 723}

\section{SIIE REQUIREMIENT SOURCE: DOES484.1 Chapter II, Section 1.e(4)}

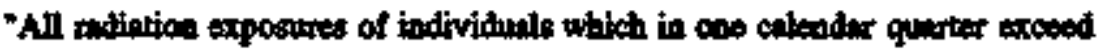
the following thall be reported by memo to the Opectionol and Environmentel Safery. Division:

(A) 3 rem to wole hody.

(b) 5 rem to thin of whote body or thyroid.

(c) $10 \mathrm{rem}$ to forterms.

(d) 25 rem 10 hands or foet."

\subsection{6}

\section{Sucrer Recorits/Radiological Word Contmol Reconds}

This element imeludes requiremeats retuting to monitoring md/or aurveya of rodiution (including contuminatica, dirborme relitition, ote.). These requirements enoure thet the fecality can demomitrate that appropriate monitoring has been performed to comply with the requilrewents of Section 11.2, Facility Monitoring and Sorvoys Additionelly, the requintmenter it this alempert sdirese roconts to demosetrate that sreas which are radiologicolly protected hrve been toproprititely coratrolled to protect worker and to mintein expoaree ALARA.

\section{STIE REQUIREMENT SOURCE: ANBS-N13.6-1966 Sectlon 5.6}

"Airbome Radionctive Material Monitoring Records The records of monlyes of

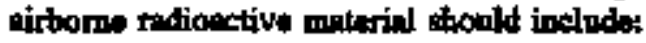

(1) Period (date and timo) of sompling

(2) General location of the rir-ampling stotica, i.e., building and room

(3) Specific location where the air sample wat collected

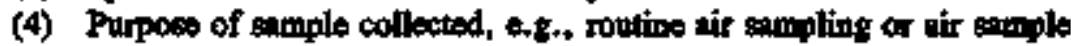
for special eratumion

(5) Type of sample collection exuipment ueed, e.g., filos, impacter, or evacuated icnization chamber

(6) Collection efficiency of anpling system

(T) Flow rata, duration of anpling, and toul volume of air tapled

(8) Identification of sumple indysis equipment tood

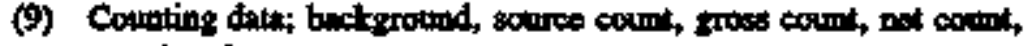
cownting time

(10) Referebte to salewlated correction fictors, 0.g., beck scelter, self absorption ant efficiency of amalytical egpipunent

(11) Calculated sirbone redioactivo meterial conceutration

(12) Identity of the air contuminint, if determined

(13) Identification of the individual performing the analyas

(14) Type of instrumset, t.g., fixed filter or moving tepe 


\title{
REQUIREMENTS IDENTIFICATION DOCUMENT HIGH LEVEL WASTE STORAGE TANK FARMS \\ Radiological Protection \\ Revision 1
}

(15) Trpe ind churt speed

(16) Identity of entle or range of openation

(17) Specific calibrition ind relutionship betwent the chart fivioions and the concendration of the aitbone milioective moterial depending on the tope speed ad flow rate of moving filter unit, of the flow nte of a fixed filter mit.

SHE RECUIREMINT SOURCE: DOE-NS480.6 Section 741

"Radiological Control Procedures

Policiss, Procedures and Rentiolopienal Wort Permits

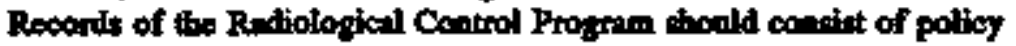
Antenenti, procedures, Radiological Wort Fermits and apporting dath The

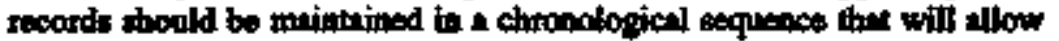

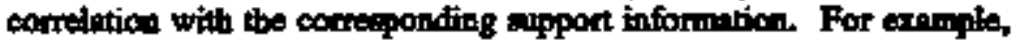
procectures for performing radiation surveys shoold be identifisble with the survey resulta. Completed Ratiologienl Work Permits should be meintaind."

\section{RELATED REFERENCES}

1. DOE/EH0256T Article 741

\section{STIE REQURREMENT SOURCE: DOE-N5490.6 Section 751}

\author{
"Radiologictl Surveya \\ Recuirement: \\ Rudiologiteal Control Programe reguire the performenco of raditition, stiborne \\ redionctivity and contemination surveys to determino exiating conditicas in a

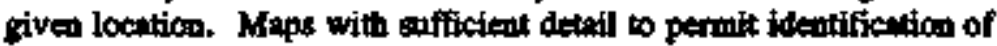 \\ originet earvey and ampling loceticns hould be mointeined. Reconts thonld

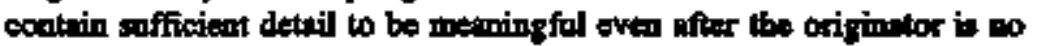

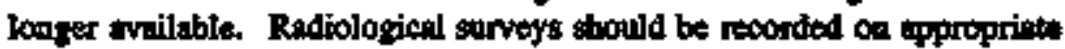 \\ stundard forms ind include the following commone elements: \\ 1. Date, time and purpose of the sarvey. \\ 2. Genteril and epectific locution of the sirvey. \\ 3. Name ind sigutoure of the surveyor and analyat \\ 4. Pertinent informetion needed to interpret the survey resulth. \\ 5. Reference to a epecific Rediolopical Wotk Permit if the survoy is \\ perfortued to support the peranic."
}

\section{RELATED REFERENCES}

\section{DOHEHO256T Article 751}

\section{STE REQUIREMIENT SOURCTH DOE-N54\$0.6 Section 752}

"Rediution Survega

In addition to the elemonts provided in Article 751. records of radiention surveys shall inchute, al a minimum, the followitos information:

1. Instrument model and serial number.

2. Resalts of the metsurements of area dose rates." 


\section{REQUIREMENTS IDENTIFICATION DOCUMENT \\ HIIH LEVEL WASTE STORAGE TANK FARMS \\ Radiological Protection \\ Rerision 1}

\section{RETATIFD REFERENCES}

\section{DOE/EHO256T Article 752}

\section{SIIE REQUIREMENT SOURCE: DOE-N5480.6 Section 753}

\section{"Airborre Radioestivtty}

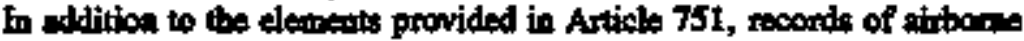
radioectivity shell includs, at a minimam, the following informetion:

1. Moded and serinl momber of the balmgler and labonatary cotiting

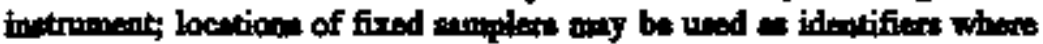
model ind ariel mmbers ane not wailoble.

2. Air concentritions in gerencl aitborns aress and breathing anes.

3. Supporting peramoters, inchuding colloction officiency, flow into, duration of eampling, correction factors and filter medium.

\section{RELATIDD REFERENCES}

\section{DOE/EHOQSST Article 753}

\section{SIIE REQUIREMIENT SOURCE: DOE-NS490.6 Section 754}

\section{"Contumination Surveys}

In adtition to the elementr required by Articte 751, records of conterminetion sorveys shall inclucte at a minimum, the following informution:

1. Model aad secial mumber of coanting equipment.

2. Contamination levels (using approprinte tupits) and aupporting parametens including counting efficiency, counting time, correction fectors, type of ndiation and whether the contminntion was fixed or removible.

3. Location of areas found to contain bot particles of high conpentritions of tocalized contumination.

4. Follow-up survey results for decontumination processes erces-referenced to the oripinal enrvey."

\section{RELATED REFERENCES}

\section{DOEJEH0256T Article 754}

\section{SITE REQUIREMENT SOURCE: DOK5480.11 Section 9.m(3)}

-Monitoring and Area Control Records. Records the establimt the conditione under which individuals were exposed, such ss ficility rediological conditions (a)

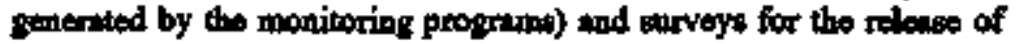

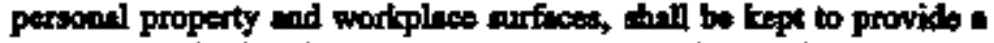
chronological, historical record parsiant to Section 5 of ANSI N13.6-1972.

\section{SITE REQUIREMENT SOURCE: DOES480.11 Nection 9.m(4)}

"Monitaring Methods Reconts. Recards stall be kept to document the appropristesess, quality, and accuracy of monitoring pethods, tectoniques, ind procedures in use during any given period pursuant to Section 6 of 


\section{REQUIREMENTS IDENTIFICATION DOCUMENT HIGH LEVLL WASTE STORAGE TANK FARMS \\ Radiological Protection \\ Rersion 0}

ANSI N13.6-1972. Chengee in equipment techniques, and procedure ano to be doctumented and the docanouts mintaived."

\section{Material and Equipment Release Reconds}

This element includes requirsments relned to records of sarveys performed in conjumeticn with the reless of equipment md materis. These recouds ars meininined to demonetrete compliance with the requitrements for releses of minterial and equipment contained in section 11.6, Rofiloctive Meteriels Menongemact.

FACHIIY REOUIREMANT SOURCE: DOESA00.5 Cupter I, Sectioa S.e, Item (5), of

The recosde of releaced property thell include:

(a) A description or identification of the property:

(b) The dnte of the last radiation survey;

(c) The identity of the organization and the fadividuat who performed the monitoritis operation;

(d) The type end identification number of monitoring instrumentis;

(e) The reoults of the monitoring opention; and

(f) The ideotity of the recipient of the released material."

\section{SITE REQUIREMENT SOURCF: DOES480.11 Seation 9.j(4)}

The recorde for releace of potextially contumingted materiat ind opupponent shall describe the property, the dets of the last remitoring operation, the identity of the individual who performed the monitoring cperation, the type ind identification nimber of the monitoring instrument uted, and the reolto of the monitoring operation."

\section{L.11.8}

\section{ALARA Reriew/Protam Records}

This dement uldrases the requirements related to records of the ALARA Joviews and ALARA progenm activities. These tocords document demonstroted complinose with the requirements included in Section 11.9, Exposure Reduction and AL,ARA.

\section{SITE REQUIRIMINT SOURCE: DOE-N5480.6 Section 742}

\section{"ALARA Recordin}

Records of As-Low-As-Reacontably-Achiovible (AL-ARA) phens nend goots strell be

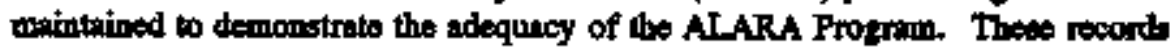
should inchuds the minutes of ALARA committes and other committees whero notiological safety iseusect are formally discussed." 


\section{REQUIREMENTS IDENTIFICATION DOCUMENT \\ HIGH LEVEL WASTE STORAGE TANK FARMS \\ Radiological Protection \\ Rerision 0}

\section{REXTADD REFERENCES}

1. DOEAHOZSGT Articlo 742

\section{SIIE REGUIREMLNT SOURCE: DOEVER:0135 RP.12.7}

"7. Records are wod to determine if ALARA proprams as being effectivo to roduce radiation exposturs."

\section{SITE RRQUIREMIONT SOURCI: DOES490.11 Section 9.m(1)}

"ALARA. Reconds of ALARA progerme shull be motiptoined by field orpanizations and operating contractors to demonstrate the adequacy of the ALARA plent and program and their implemeotation."

\section{STIE REQURRMIENT SOURCE: NPO-88-010 Chapter V, Section C.4}

"Recends that document the iroporting netivities associnted with this cheptor

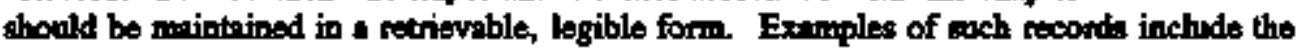
following:

- pre-job exposure reduction reviews and planing shects

- post-job expossurs reduction reviews"

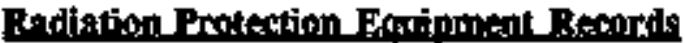

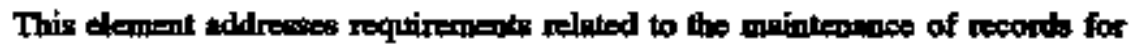
Radiation Protection Equipment. Records for mdietion protection equipment

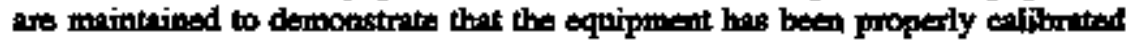
and maintrined and to provide confidence in the aecurtey of the dats obteined using thet equipment.

\section{SITE REQUIREMFNT SOURCE: DOE-N5490.6 Section 761.1}

"Instrumentation and Calibration Records

Colibration and Operational Chects

Rexords of enlfbration and periodic operationn chects of ixred, portable and loboritory padintion mesanring equipment shall be maintained and include frequeacies, metbod, dottes, persomel, trainin and traceability of calibration scurces to Nationel linstituts of Science end Techmology or other coceptable tandards."

\section{RELATED REFERENCES}

\section{DOE/EH0256T Article 761}

\section{SITE REQUREMENT SOURCE: DOE-N5480.6 Section 761.2}

"Calibration recordr should be maintained for the following equipunats

-. Portable survey indrumente;

b. Bioscay mearirement equipmed; 


\section{REQUREMENTS IDENILICATION DOCUMENT HIGH LEVEL WASTE STORAGE TANK FARMS Radiological Protection Revision :}

c. Loboratory, counting room nod fixed andintion menpring equipmont;

d. Procees ind offhwat monitors and anding equipment;

a. Radiation area moniton;

f. Portl monitors and other perconnel contamination monitosts

8. Pockut and elwetronit dosimenters;

b. Air empling equiniont;

i. Tool and wuste monitoring equipment;

j. Prokective clothing and equipment monitors:"

\section{RELATED REFERENCES}

\section{DOE/EHOZ65T Article 761}

\section{STE REQUIRQMGarr SOJRCE: DOE-N5480.6 Section 761.3}

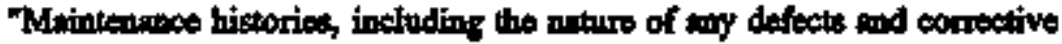

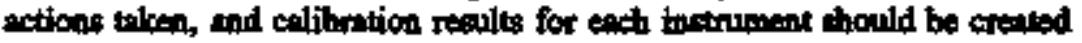
and atrined."

\section{RELATED REFERENCES}

\section{DOE/EHO256T Article 761}

\section{SIIE REOUIREMENT SOURCE: DOE-NS480.6 Seetion 762}

Spocial Calibsation Recordi

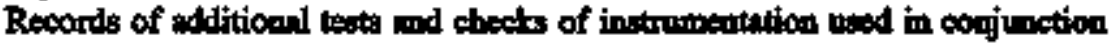

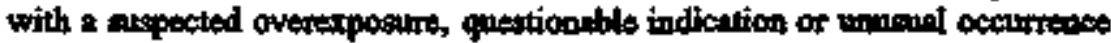
hould be retained. In addition, records of tpecial instrument calibration ind modifisations mede in accordances with Articlo 562.6 should be rotained."

\section{RELATED REFERENCES}

\section{DOE/EH0256T Artiele 762}

\section{Trining and Ounlification Records}

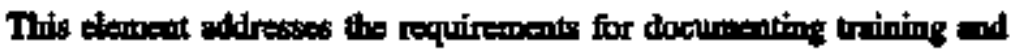
qualffiction withtin the Rafintion Protection fusctibnal ares. It does not include those requirements which are gtoneral to sll personed et the facility or which ure required under the Training fusctional area.

\section{SETE REQUIREMINTT SOURCE: DOE-N5480.6 Section 725.1}

"Redicłopical Truining ani Quatification Reconts Records of training and qualification in radiological control thall be menintained to demonetrate that a person recetved appropriate information to perform the work sseignment in a tafe menner. Qualification stodunt records shall be retained for on-the-job and prectical fator training as well as for format clissproom training." 


\section{REQUIREMENTS IDENTLICATION DOCUMENT HIGH LEVEL WASTE STORAGE TANK FARMS \\ Radiological Protection \\ Rerision 0}

\section{RELATED REIBRENCES}

\section{DOE/EHOZSGT Articlo 725}

\section{SITE RBOUIREMENT SOURCE; DOENS490.6 Section 725.2}

"Formal recards of thiting and qualificution stall be restily svailable to

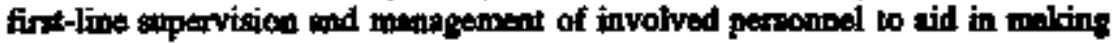
work sstignments."

\section{RELATED REFERENCLS:}

\section{DOE/EH0256T Article 725}

\section{SIIE REQUIREMTNT SOURCE: DOR-N5480.6 Section 725.3}

Fersoined treining records shall bo controlled and retnined. At a minimum, these records sthal include the following:

a. Course titte;

b. Amendence sheets with instructor's name;

c. Employes's nome, identification number and signeturs;

d. Dute of training;

e. Idsulfifiction of the exautination of evalusation form, inchuding sufficient data to idertify which test esch persou completed;

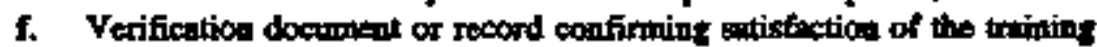
requirement;

2. Documentstion releted to erceptions for training requirements and extensions of qualifxution;

h. Quims, tests, nespunses and achowledgemants of trrining, with the dute and siguature of the person trained;

i. Special instructions to fermiles, their sapervisors and cownotrera concerning preastal radiation dose, actrowledged by the worker's siquenures"

\section{RELATED REFERENCES}

\section{DOEJEHOZSOT Article 725}

\section{STTE REQUHEMLNT SOURCE: DOE-N5490.6 Section 725.4}

Records shell be retained for the following types of trining

a. Goneril tmployes ndiological training;

b. Rediolopical Worker trining;

c. Pertadic tetnining;

d. Restitutory protection texiging;

- Training of mdiological coatrol personnel;

f. Instructor training;

e. Qualifleations for specist tests or operetions;

h. Orientation and training of visitors;

i. Tnining of emergency response personnel. 


\section{REQUIREMENTS IDENTIFICATION DOCUMENT HIGH LEVEL WASTE STORAGE TANK FARMS

\author{
Radiological Protection
} \\ Rerition 6}

RELATED REFERENCES

1. DOE/EHO2S6T Atticle 725

SETE RECUIREMIENT SOURCE: DOBNS480.6 Section 725.5

The following inetrutional moterinto chall be moinminede

2. Course nome, with revision and approvil date;

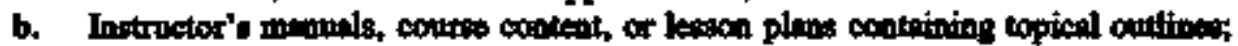

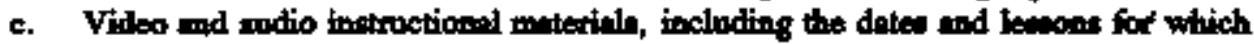
they were uned;

d. Hadouts or cther meterials retined with the master copy of the conme;

- Job-specific trining documents, such s: instrument uss, nitiologicol

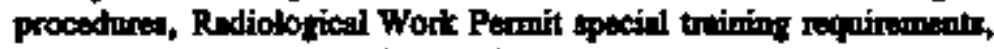
projob briefings and mock-up tratining."

\section{RBLATED REFERENCES}

\section{DOS/5H0256T Aticle 725}

\section{SITE REQUMREMENT SOURCE: DOE-N5480.6 Section 725.6}

-Documentation of training and qualification ruceived at suother DOE locetion need not be dupliceted. Such teconds sthould be provided to the person's bome office for retrotion."

\section{REIATED REFERENCES}

1. DOE/EH02:6T Article 725

\section{SIXE REQUIREMIRNI SOURCE; DOREHO13S RP,2 ACCDDENIS/INCIDENTS.10}

"10. Training of worken is documented for the highrotik jobs to momote * sofety awaremess altibuds."

\section{Mlsc. Radiafion Protection Renarik}

This element includes requirements for matnienence of ntice. types of reconds

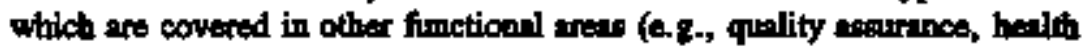
and safety, etc) bac which inchude spocitio requirements relating to the

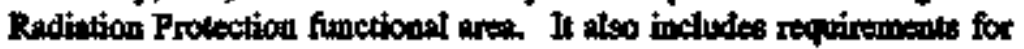

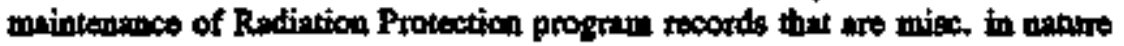
(e.8., documentation of employee concerns).

\section{STTE REQUIREMENT SOURCE: DOEN5480.6 Section 722.6}

"Counseling of persons about radiological concerns fhould bo documented and this documentetion retsined. It is desirable that the counseled pesson ston the docamentation to acknowledge participation." 


\section{REQUIREMENTS IDENTIFICATION DOCUMENT HIGH LEVEL WASTE STORAGE TANK FARMS \\ Radiological Protection \\ Rerision 0}

\section{RELATED REKERENCES}

1. DOE/EHO256T Articlo 722

STE REOUIREMENT SOURCE: DOE-N5430.6 Section 723.2

"Reconds of employe rediological enfaty concema that hrve been formilly

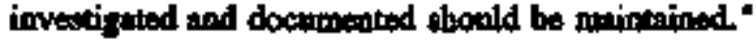

\section{REI.ATED REFERENCES}

1. DOE/EHO2S6T Auticle 723

STIE REQUIREMENT SOURCE: DOE-NS480.6 Section 724.1

Medienl Records

Premployment medteal records, if available, and reports of periodic mecicol exnmimations should be msintuined."

\section{RELATED RERERENCES}

1. DOE/EHO256T Article 724

\section{STIE REQULREMENT SOURCE: DOE-NS480.6 Section 724.2}

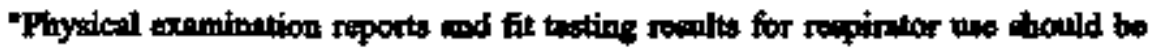
maintained for respirstor usens."

\section{REILATED REWERENCKS}

\section{DOEEHO2S6T Artido 724}

SITE REQUIREMENT SOURCE: DOE-N5480.6 Seetlon 724.3

"Medienl evaluaticas and treatment performed in support of the ratiologion program stould be documented."

\section{REILATED RETERTNCES}

\section{DOE/EHO256T Article 724}

\section{SHE REQUIREMENT SOURCE: DOE-N540.6 Setion 724.4}

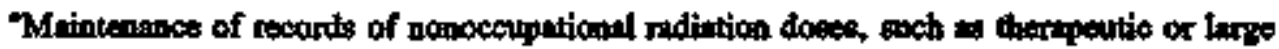
amourts of dingnostic radintion dosed for medical purposes, it encouraged. Where prectical, maintennece of reconds of preeroployment nonoceupational radiption doses js colcournged." 


\section{REQUIREMENTS IDENTIHICATION DOCUMENT \\ HIGH LEVEL WASTE STORAGE TANK FARMS \\ Radiological Protection \\ Rerision 1}

RELATED RETERENCES

1. DOE/EH02S6T Articlo 724

STIE REQUREMENT SOURCE; DOE-N5490.6 Section 743

"Quelity Mesiriace Reconds

Recortis of quility sseurtice reviews and andits developed for Rediolopical

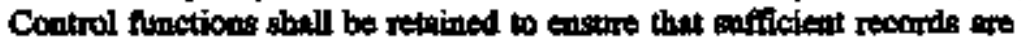

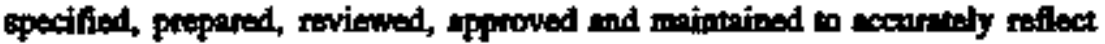
completed work. DOE 5700.6C provides additionsl information regarding quality essurence recortis."

\section{RELATEW REFERENCES}

1. DOE/EHO2STT Article $\mathbf{7 4 3}$

SIIE REQUIREMENT SOLRCE: DOEJEH013S RP.1.10

10. Auditable reports of inepections, autils, and resulting contective actions taken, ure maintained."

So buefaces

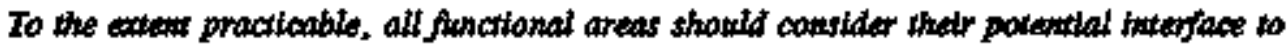
Radiation Protestion to essire thas plans and activtiles are reviowed based on the ALARA

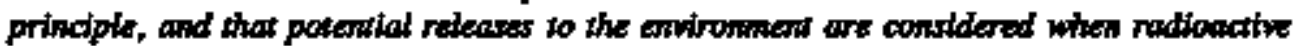

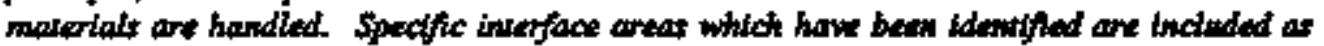
swb-ilemens.

Manazement Swoms

An interface to Management Systems is needed to ensure that a commitment to radiation protection and $A L A R A$ is incorporated into every aspect of operations at the highest managentent level.

Qualto dssurance

An interface to the Quality Assurance Funtional Area is needed to ensure that al reguiremens for the rationton protection of the workers and the genenal pubitc and all reporting requirements are properby incorporated buto operantons.

\section{Confouretion Manderement}

Activities in the Configuration Management Functional Area must interface to the RP Functional Area to enswre that current radiation protection systems are not compromised by modificotions, and that new activities receive the proper review in case new systems are needed. 


\section{REQUIREMENTS DENTHCATION DOCUMENT HIGR LEVEL WASTE STORAGE TANK FARMS \\ Radiological Protection \\ Rerision 0}

0.124

$L .2 .2 .5$

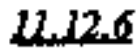

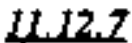

1.12 .8

11.12 .2

U.t.2.10

Wh.12.11

\section{Trainine and Ouflifications}

An interface to Training and Qualifications is recessary to enswre that the specific $R P$ training requirements are included in the worker tratning proftites.

\section{Enercency Piantins}

Because of the potental for emergency simuctions involving radioactive moterial and potential exposure of emergency response personnel, an interface to Emergency Planning is required.

\section{Enqueqrine Prosrow}

The Engineering Program should ensure then an ALARA interface is defined and established for the routine review of new construction and modifications.

This review stould include a cast/beneft analysis for radiation exposure reduction fearures beyond those required by regulatory exposture ilmits.

\section{Operations}

An interface to the Operotions Functional Area is needed to ensure that radiation protection and the ALARA principle is incorporated into daily exercise.

\section{Maintenance}

An interface with the Malntenance Functional Area is needed because the monttoring systems used for radiation protection must hove a mabutenance plan, and because other areas of maintenance must be aware of patential radiation hazards.

\section{Packasing and Transporiation}

Physical managentent of radioactive materials requires an interface to the Packaging and Transportation Functional Ared to ensure proper Tabeling. packaging and transportation of those materials.

\section{Beseorch ond Develoment and Experineartal Activitites}

The Research and Development Functional Area must interface to the $R^{P}$ Functional Area so thet current or proposed experimental activities are conducted within personnet rediation protection guldelines and environmental prosection standards.

\section{Nuclear Sintery}

Because of the Nuclear Safety Functional Area encompasses the operation of mustear facilities from design through decomnitssioning, it should interface with 


\section{REQUIREMENTS IDENTIFICATION DOCUMENT HIGH LEVEL WASTE STORAGE TANK FARMS \\ Radiological Protection \\ Revision $\theta$}

the $R P$ Functional Area to enswre that radilation protection standands are incorparated turo the nuclear safecty progran.

0.22 .12

Enviromental Protection

Because of the nequirements for Uniting release of rodlosative materlals to the

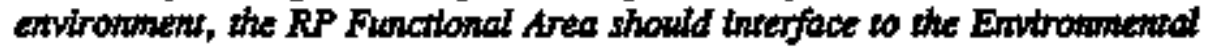
Protection Functional dree to ensture a consistent approach to application of environmental protection requirements. 


\section{WESTINGHOUSE HANFORD COMPANY}

\section{REQUIREMENTS}

\section{IDENTIFICATION}

\section{DOCUMENT}

EAcurty:

HIGH LEVEL WASTE STORAGE TANK FARMS/242-A EVAPORATOR
ElictoMAL ABEA:

Operations

\section{REVISION 0}




\section{REQUIREMENTS IDENTIFICATION DOCUMENT \\ FIGH LEVEL WASTE STORAGE TANK FARMS \\ Operations \\ Rerision 0}

\section{TABLE OF CONTENTS}

9.0 OPERATIONS $\ldots \ldots \ldots \ldots \ldots \ldots \ldots \ldots \ldots \ldots \ldots \ldots \ldots \ldots \ldots \ldots \ldots \ldots$

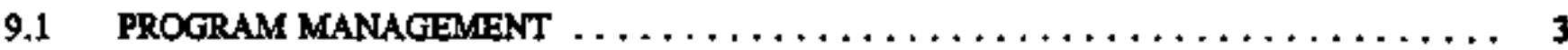

9.1.1 Operations Organization Policies $\ldots \ldots \ldots \ldots \ldots \ldots \ldots \ldots \ldots \ldots \ldots, 3$

9.1 .2 Resources $\ldots \ldots \ldots \ldots \ldots \ldots \ldots \ldots \ldots \ldots \ldots \ldots \ldots \ldots \ldots$

9.1.3 Monitoring of Operating Pefformance $\ldots \ldots \ldots \ldots \ldots \ldots \ldots \ldots \ldots \ldots$ 6

9.1 .4 Accuntability $\ldots \ldots \ldots \ldots \ldots \ldots \ldots \ldots \ldots \ldots \ldots \ldots \ldots, \mathbf{8}^{8}$

9.1.5 Manggement Training $\ldots \ldots \ldots \ldots \ldots \ldots \ldots \ldots \ldots \ldots \ldots, \ldots \ldots$

9.1.6 Planaing for Safery $\ldots \ldots \ldots \ldots \ldots \ldots \ldots \ldots \ldots \ldots \ldots \ldots \ldots \ldots, 8$

9.2 SHIFT ROUTINES AND OPERATING PRACTICES $\ldots \ldots \ldots \ldots \ldots \ldots \ldots \ldots \ldots$

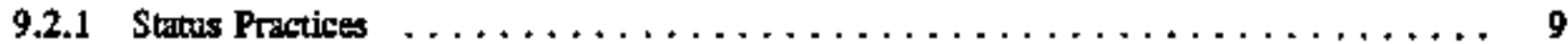

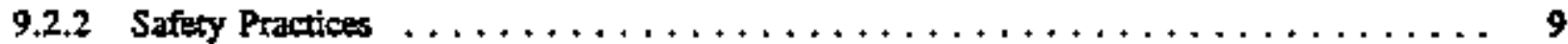

9.3 Operator Inspection Tours $\ldots \ldots \ldots \ldots \ldots \ldots \ldots \ldots \ldots \ldots \ldots \ldots \ldots$

9.2.4 Round/Tour Inspection Sheets $\ldots \ldots \ldots \ldots \ldots \ldots \ldots \ldots \ldots \ldots \ldots \ldots \ldots, 11$

9.2 .5 Personstel Protertion $\ldots \ldots \ldots \ldots \ldots \ldots \ldots \ldots \ldots \ldots \ldots \ldots, \ldots \ldots, \ldots \ldots$

9.2.6 Response to Indications $\ldots \ldots \ldots \ldots \ldots \ldots \ldots \ldots \ldots \ldots \ldots \ldots \ldots, \ldots \ldots$

9.2.7 Resetring Protertive Devices $\ldots \ldots \ldots \ldots \ldots \ldots \ldots \ldots \ldots \ldots \ldots \ldots \ldots, \ldots$

9.2.8 Load or Process Rats Changes $\ldots \ldots \ldots \ldots \ldots \ldots \ldots \ldots \ldots \ldots \ldots \ldots \ldots$, 15

9.2 .9 Authority to Operate Equipmetat $\ldots \ldots \ldots \ldots \ldots \ldots \ldots \ldots \ldots \ldots \ldots \ldots$

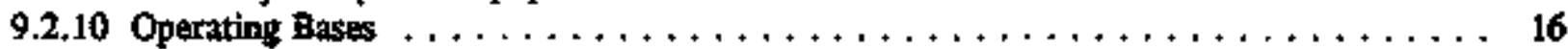

9.2.11 Potentilly Distractive Written Maretial and Devices $\ldots \ldots \ldots \ldots \ldots \ldots \ldots \ldots 16$

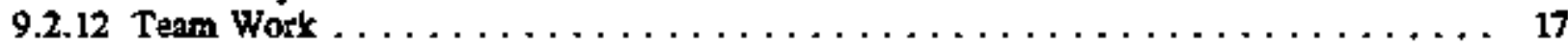

9.3 CONTROL STATION ACTIVITIES $\ldots \ldots \ldots \ldots \ldots \ldots \ldots \ldots \ldots \ldots \ldots \ldots \ldots \ldots$

9.3.1 Control Station Access $\ldots \ldots \ldots \ldots \ldots \ldots \ldots \ldots \ldots \ldots \ldots \ldots, 17$

9.3.2 Professional Behavior $\ldots \ldots \ldots \ldots \ldots \ldots \ldots \ldots \ldots \ldots \ldots \ldots, 18$

9.3.3 Monitoring the Main Control Panels $\ldots \ldots \ldots \ldots \ldots \ldots \ldots \ldots \ldots \ldots \ldots$

9.3.4 Control Station Operator Ancillary Duties $\ldots \ldots \ldots \ldots \ldots \ldots \ldots \ldots \ldots, 18$

9.3.5 Operation of Control Station Equipment $\ldots \ldots \ldots \ldots \ldots \ldots \ldots \ldots \ldots \ldots$. 19

9.3.6 Control Room Appearance, Habitabiity, and Equipment $\ldots \ldots \ldots \ldots \ldots \ldots$ 19

9.4 AUDRLE COMMUNCATIONS $\ldots \ldots \ldots \ldots \ldots \ldots \ldots \ldots \ldots \ldots \ldots$

9.4.1 Emergency Communication Systems $\ldots \ldots \ldots \ldots \ldots \ldots \ldots \ldots \ldots \ldots, \ldots \ldots, \ldots \ldots$

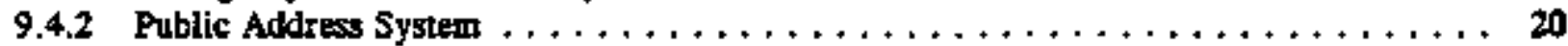

$9.4,3$ Contanting Operawors $\ldots \ldots \ldots \ldots \ldots \ldots \ldots \ldots \ldots \ldots \ldots \ldots, 20$

9.4.4 Radios and Telephones $\ldots \ldots \ldots \ldots \ldots \ldots \ldots \ldots \ldots \ldots \ldots \ldots \ldots \ldots, 21$

9.4 .5 Abbreviations and Acronyms $\ldots \ldots \ldots \ldots \ldots \ldots \ldots \ldots \ldots \ldots, 21$

9.4.6 Audible Instructions and Informational Communications $\ldots \ldots \ldots \ldots \ldots \ldots 21$ 


\section{REQUTREMENTS IDENTIFICATION DOCUMENT EIGH LEVEL WASTE STORAGE TANK FARMS}

\section{Operations}

Rerision 0

9.5 CONIROL OF ON-THE-IOE TRAINING $\ldots \ldots \ldots \ldots \ldots \ldots \ldots \ldots \ldots \ldots \ldots$

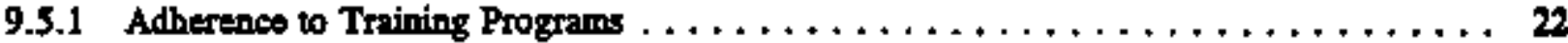

9.5.2 On-The-Job Instructor Qualification $\ldots \ldots \ldots \ldots \ldots \ldots \ldots \ldots \ldots \ldots \ldots, 22$

9.5.3 Qualified Operator Suparvision and Control of Trainees .............. 23

9.5.4 Operator Qualificution Program Approval $\ldots \ldots \ldots \ldots \ldots \ldots \ldots \ldots \ldots \ldots$. 23

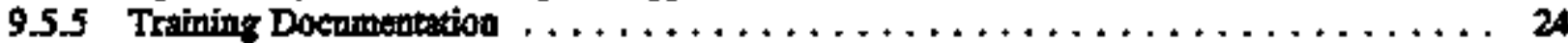

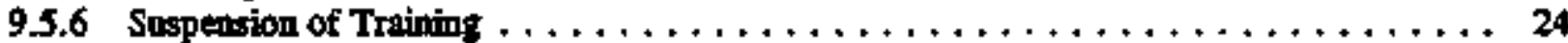

9.5 .7 Maximum Number of Trainees $\ldots \ldots \ldots \ldots \ldots \ldots \ldots \ldots \ldots \ldots \ldots, 24$

9.5 .8 Use of Trainees to Support Operations $\ldots \ldots \ldots \ldots \ldots \ldots \ldots \ldots \ldots \ldots$ 25

9.6 INVESTIGATION OF ABNORMAL EVENTS $\ldots \ldots \ldots \ldots \ldots \ldots \ldots \ldots \ldots \ldots$

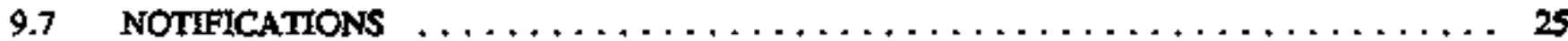

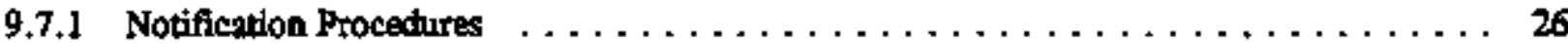

9.7 .2 Notifiction Responsibility $\ldots \ldots \ldots \ldots \ldots \ldots \ldots \ldots \ldots \ldots \ldots \ldots, 26$

9.7 .3 Names and Phone Numbers $\ldots \ldots \ldots \ldots \ldots \ldots, \ldots \ldots \ldots \ldots \ldots \ldots, 26$

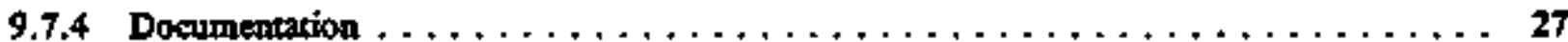

9.7 .5 Commanication Equipment $\ldots \ldots \ldots \ldots \ldots \ldots \ldots \ldots \ldots \ldots \ldots \ldots 27$

9.8 CONTROL OF EQUIPMENT AND SYSTEM STATUS $\ldots \ldots \ldots \ldots \ldots \ldots \ldots \ldots, 27$

9.8.1 Operations, Testing, and Staas Change Authorization and Reporting . . . . . . . 27

9.8.2 Equipmeat and System Alignment $\ldots \ldots \ldots \ldots \ldots \ldots \ldots \ldots \ldots \ldots, 28$

9.8.3 Equipment Locking and Tagging $\ldots \ldots \ldots \ldots \ldots \ldots \ldots \ldots \ldots \ldots \ldots$ 29

9.8 .4 Operational Limits Compliance (TSRs) $\ldots \ldots \ldots \ldots \ldots \ldots \ldots \ldots \ldots \ldots \ldots$

9.8.5 Equipment Deficiency Identification and Documentation $\ldots \ldots \ldots \ldots \ldots \ldots \ldots, 30$

9.8.6 Work Authorization and Documestation $\ldots \ldots \ldots \ldots \ldots \ldots \ldots \ldots \ldots \ldots, \ldots \ldots$

9.8.7 Equipment Post-Mairtenance Testing and Return to Service . . . . . . . . . . . 31

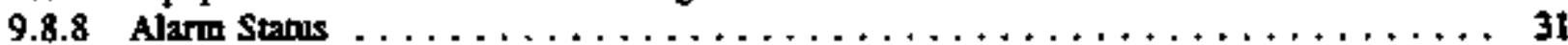

9.8.9 Temporary Modification Control $\ldots \ldots \ldots \ldots \ldots \ldots \ldots \ldots \ldots \ldots \ldots \ldots, 31$

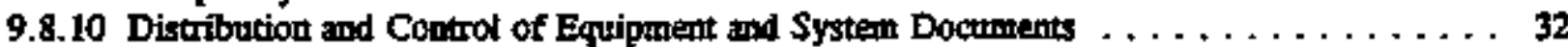

9.8.11 New Constraction or Modification $\ldots \ldots \ldots \ldots \ldots \ldots \ldots \ldots \ldots \ldots \ldots, 32$

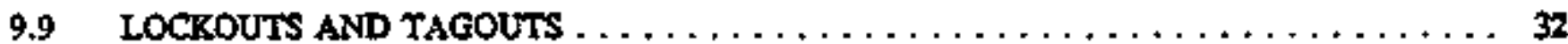

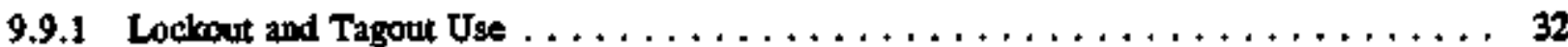

9.9 .2 Lockout and Tagout Irmplementation $\ldots \ldots \ldots \ldots \ldots \ldots \ldots \ldots \ldots \ldots \ldots \ldots$

9.9 .7 Protective Materials and Hardware $\ldots \ldots \ldots \ldots \ldots \ldots \ldots \ldots \ldots \ldots \ldots \ldots \ldots \ldots$

9.9.4 Lockout and Tagout Program $\ldots \ldots \ldots \ldots \ldots \ldots \ldots \ldots \ldots \ldots \ldots \ldots, \ldots \ldots, \ldots, \ldots, \ldots$

9.9.5 Procedures For Lockout and Tzzout $\ldots \ldots \ldots \ldots \ldots \ldots \ldots \ldots \ldots \ldots \ldots \ldots$

9.9.6 Application of Lockout and Tagout $\ldots \ldots \ldots \ldots \ldots \ldots \ldots \ldots \ldots \ldots \ldots \ldots, \ldots \ldots$

9.9.7 Testing or Positioning of Equipment or Components $\ldots \ldots \ldots \ldots \ldots \ldots \ldots \ldots$. $\ldots \ldots$

9.9.8 Periodic Inspection $\ldots \ldots \ldots \ldots \ldots \ldots \ldots \ldots \ldots \ldots \ldots \ldots \ldots \ldots, \ldots \ldots$

9.9.9 Administrative Control Tags $\ldots \ldots \ldots \ldots \ldots \ldots \ldots \ldots \ldots \ldots \ldots \ldots$

9.9.10 Training and Communication $\ldots \ldots \ldots \ldots \ldots \ldots \ldots \ldots \ldots \ldots \ldots \ldots$, 39

9.9.11 Notiflestion of Personnel $\ldots \ldots \ldots \ldots \ldots \ldots \ldots \ldots \ldots \ldots \ldots \ldots \ldots, 41$ 


\section{REQUIREMENTS IDENTIFICATION DOCUMENT FIGH LEVEL WASTE STORAGE TANK FARMS \\ Operations \\ Rerision 0}

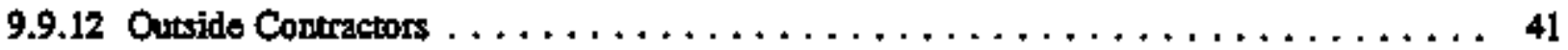

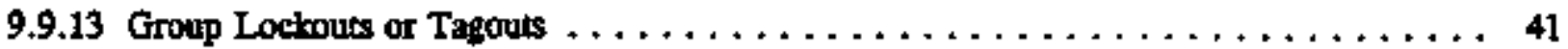

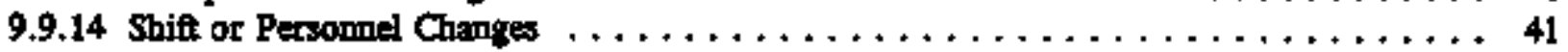

9.10 INDEPENDENT VERIFICATION $\ldots \ldots \ldots \ldots \ldots \ldots \ldots \ldots \ldots \ldots \ldots \ldots \ldots \ldots$

9.10.1 Components Requiring Independent Verification $\ldots \ldots \ldots \ldots \ldots \ldots \ldots \ldots$

9.10.2 Oecasions Requiring Independent Verification . . . . . . . . . . . . . . . . . 43

9.10 .3 Verification Techniques $\ldots \ldots \ldots \ldots \ldots \ldots \ldots \ldots \ldots \ldots \ldots$

9.11 LOG KEEPING $\ldots \ldots \ldots \ldots \ldots \ldots \ldots \ldots \ldots \ldots \ldots \ldots \ldots \ldots \ldots$

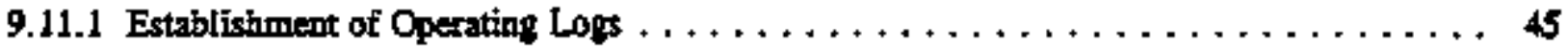

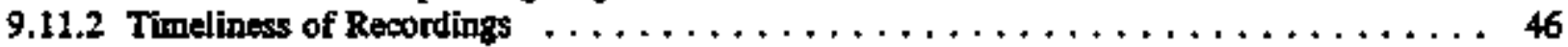

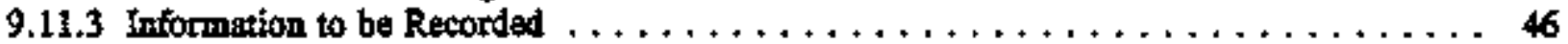

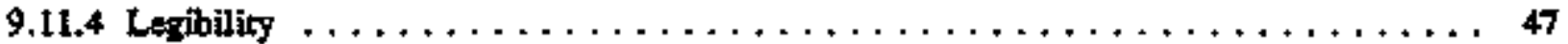

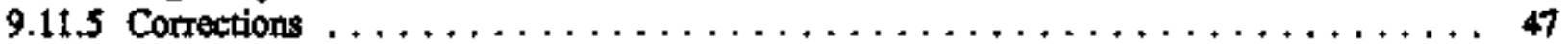

9.11.6 Log Review . . . . . . . . . . . . . . . . . . . . . . . . . . 47

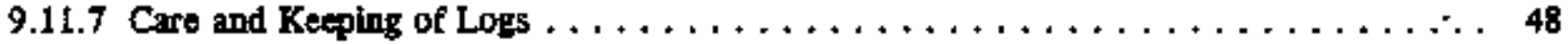

9.12 OPERATIONS SHIFT TURNOVER $\ldots \ldots \ldots \ldots \ldots \ldots \ldots \ldots$

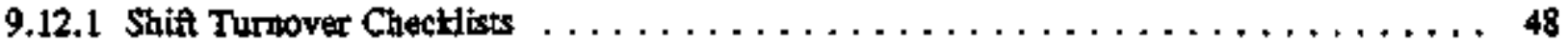

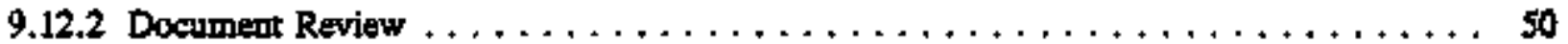

9.12 .3 Control Panal Walkdown $\ldots \ldots \ldots \ldots \ldots \ldots \ldots \ldots \ldots \ldots \ldots \ldots \ldots$

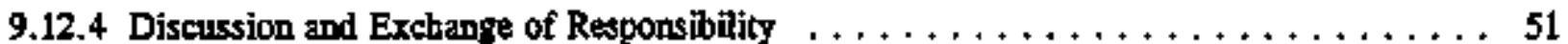

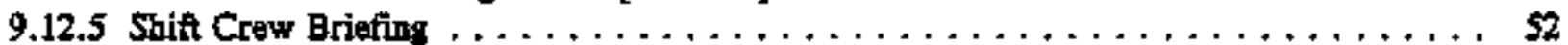

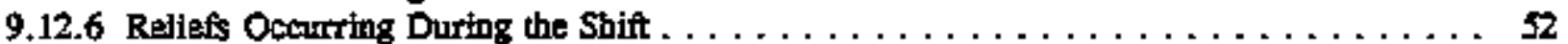

9.13 OPERATIONS ASPECTS OF FACILITY CHEMISTRY AND UNZQUE $\ldots \ldots \ldots \ldots \ldots$

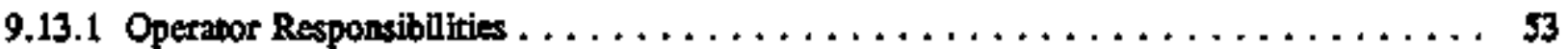

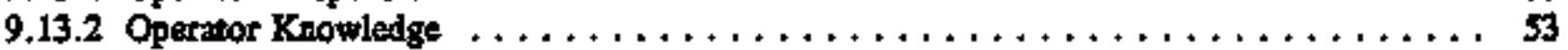

9.13.3 Operator Response to Chemistry or Process Problems . . . . . . . . . . . 53

9.13.4 Communication Between Operations and Technical Process Support Personnel . . . . . 53

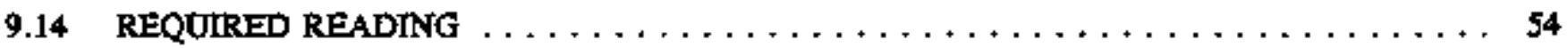

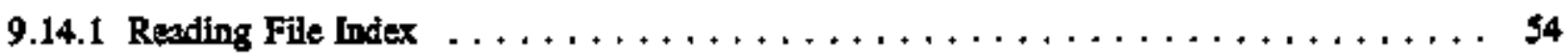

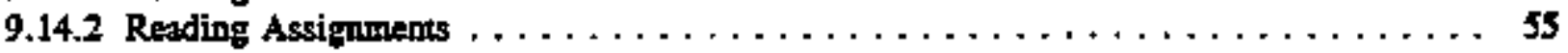

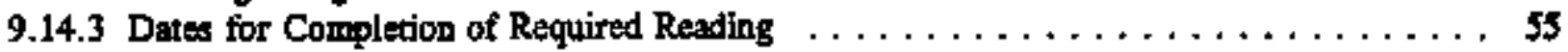

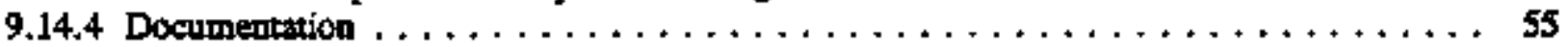

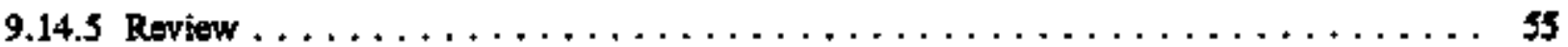

9.15 TTMELY ORDERS TO OPERATORS $\ldots \ldots \ldots \ldots \ldots \ldots \ldots \ldots \ldots \ldots \ldots$ 


\section{REQUIREMENTS DENTIFICATION DOCUMIENT HIGH LEVEL WASTE STORAGE TANK FARMS \\ Operations \\ Rention 0}

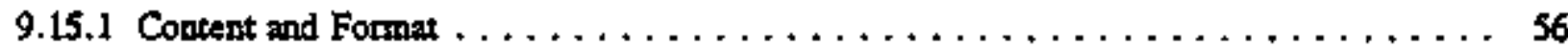

9.15 .2 Issuing, Segregating, and Reviewing Onders $\ldots \ldots \ldots \ldots \ldots \ldots \ldots \ldots \ldots, 56$

9.15 .3 Rewoval of Orders $\ldots \ldots \ldots \ldots \ldots \ldots \ldots \ldots \ldots \ldots \ldots \ldots \ldots, 57$

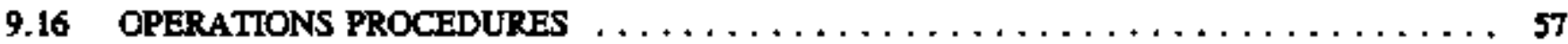

9.16.1 Procedure Development $\ldots \ldots \ldots \ldots \ldots \ldots \ldots \ldots \ldots \ldots \ldots \ldots \ldots$ 57

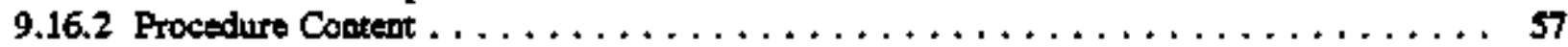

9.16.3 Procedure Changes and Revisions $\ldots \ldots \ldots \ldots \ldots \ldots \ldots \ldots \ldots \ldots \ldots \ldots, 57$

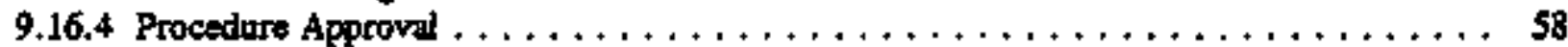

9.16 .5 Procedure Review $\ldots \ldots \ldots \ldots \ldots \ldots \ldots \ldots \ldots \ldots \ldots \ldots \ldots \ldots, \ldots$

9.16 .6 Procedure Avaitability $\ldots \ldots \ldots \ldots \ldots \ldots \ldots \ldots \ldots \ldots \ldots \ldots \ldots \ldots, \$ 8$

9.16 .7 Procedure Use $\ldots \ldots \ldots \ldots \ldots \ldots \ldots \ldots \ldots \ldots \ldots \ldots \ldots \ldots \ldots \ldots, 58$

9.17 OPERATOR AID POSTINGS $\ldots \ldots \ldots \ldots \ldots \ldots \ldots \ldots \ldots \ldots \ldots \ldots \ldots \ldots$

9.17.1 Operator Aid Develognent $\ldots \ldots \ldots \ldots \ldots \ldots \ldots \ldots \ldots \ldots \ldots \ldots \ldots$, 59

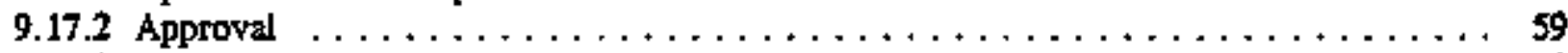

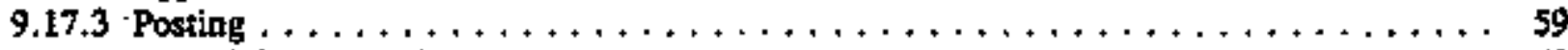

9.17 .4 Use of Operator Aids $\ldots \ldots \ldots \ldots \ldots \ldots \ldots \ldots \ldots \ldots \ldots \ldots \ldots \ldots \ldots$

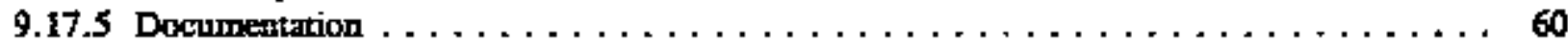

9.17 .6 Review $\ldots \ldots \ldots \ldots \ldots \ldots \ldots \ldots \ldots \ldots \ldots \ldots \ldots \ldots \ldots, 60 \ldots$

9.18 EQUIPMENT AND PIPING LABELING $\ldots \ldots \ldots \ldots \ldots \ldots \ldots \ldots \ldots \ldots$

9.18.1 Components Requiring Labeling $\ldots \ldots \ldots \ldots \ldots \ldots \ldots \ldots \ldots \ldots \ldots \ldots$ 61

9.18.2 Label Information $\ldots \ldots \ldots \ldots \ldots \ldots \ldots \ldots \ldots \ldots \ldots \ldots \ldots \ldots \ldots, 62$

9.18 .3 Label Placement $\ldots \ldots \ldots \ldots \ldots \ldots \ldots \ldots \ldots \ldots \ldots \ldots \ldots \ldots, \ldots \ldots \ldots$

9.18 .4 Replacing Labels $\ldots \ldots \ldots \ldots \ldots \ldots \ldots \ldots \ldots \ldots \ldots \ldots \ldots \ldots \ldots \ldots$, 64

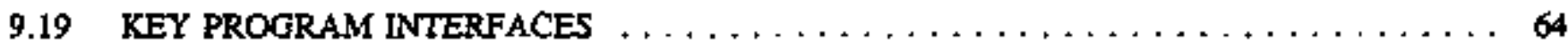




\title{
REQUIREMENTS IDENTIFICATION DOCUMENT \\ HIGH LEVEL WASTE STORAGE TANK FARMS \\ Operations \\ Rerision 0
}

9.0 OPERATIONS

\author{
INTRODUCTION
}

\section{SCOPE}

The Operations Functional Area encompasses all aspeets of site and facility operations as detailed in DOE Order 5480.19, Conduct of Operations for DOE Facilities. The functional area does not deal directly with the technical details and requirements of operations, but rather sets standards for a consistent approach to disciplined and safe operations. The requirements established by DOE Order 5480.19 are equivalent to and firmly based on industry standards. Many sections of the Order are verbatim excerpts from the Institute of Nuclear Power Operations (INPO), "Guidelines for the Conduct of Operations at Nuclear Power Stations."

This Requiremeats Identification Document (RID) describes an operations program for the Tank Farms Facility as defined through the application of relevant DOE Orders, regulations, industry codes and standards, industry guidance documents, and as appropriate, good industry practices. The definition of a program as specified by this document is intended to address Defense Nuclear Facilities Safety Boand Recommendations $90-2$ and 91-1, which call for the strengthening of DOE facility activities through the identification and appication of relevant standards which supplement or exceed requirements mandated by DOE Orders.

This RID includes those functional area elements/sub-elements and requirements necessary to maintasin an operation that minimizes the risk to persomel, the facility, and the environment while maintaining safe, efficient, and productive operation. The specific focus of this RID is the identification of the regulatory requirements and the industry standards relevant to the activities typically performed at the Tank Farms. It should be recognized that the requirements identified in this RID are not equally applicable throughour the Tank Farms facility because of the unique physical arrangement, level of activity and mission in differeat areas of the facility, and the diverse nanire of the activities carried out. For example, the requirements relating to Control Area Activities will be applicable only at the 242A Evaporator control room and not at individual equipment operating stations throughout the facility, such as those in the various compressor and instrument buildings. The latter are not continbously manned and are not considered to be control areas. The 242-A Evaporator control roon is a control area, but is a control area only for the evaporator itself; other widely fistributed facility operations such as sampling and purmping tanks are controlled from the Shift Manager's office which is an administrative office area. Actual tank operations are performed locally at the individual tank valves and at local motor control centers.

This RID applies to the activities, personnel, structures, systems, components, and programs involved in operating the facility and executing the mission of the Tank Farms. The physical boundaries within which the requirements of this RD apply are the Single Shell Tank Farms, Double Shell Tank Farms, 242-A Evaporator-Crystallizer, 242-S,T Evaporators, Liquid Effiuent Retention Facility (LERF), Purgewater Storage Facility (PWSF), and all interconnecting piping, valves, instrumentation, and controls. Also included is all piping, valves, instrumentation, and controls up to and including the anost remote valve under Tank Farms control at any other Hanford Facility having an interconnection with Tank Farms. The boundary of the structures, systems, components, and programs to which this RID applies, is defined by those that are dedicated 


\section{REQUIREMENTS IDENTIFICATION DOCUMENT HIGH LEVEL WASTE STORAGE TANK FARMS \\ Operations \\ Revision 0}

to and/or under the control of the Tank Farms Operations Department and are specifically implemented at the Tank Farms.

This Functional Area impacts all aspects of operating a site or facility. The techrical aspects of the operations are addressed in other functional areas; for example, the maintenance DOE Order $4330.4 \mathrm{~A}$ addresses the specifics for the Maintenance Functional Area; however, the principles and discipline of this Operations Functional Area are directly applicable to the conduct of mainterance. This applies to all aspects of operations, such as training. The Operations Functional Area uses the chapter structure of DOE Order 5480.19 to identify the following elements:

1. Operations Organization and Administration

2. Shift Routines and Operating Practices

3. Control Station Activities

4. Audible Communications

5. Control of On-The-Job Training

6. Investigation of Abnormial Events

7. Notifications

8. Control of Equipment and System Status

9. Lockouts and Tagouts

10. Independent Verification

11. Log Keeping

12. Operations Shift Tumover

13. Operations Aspect of Facility Chemistry and Unique Processes 14. Required Reading

15. Timely Orders to Operations

16. Operations Procedures

17. Operator Aid Postings

18. Equipment and Piping Labeiing

Requirements that apply to Operations organization and administration in general may be found in the Management/Administration area of the Management Systems RID. Reçtirements that are applicable only to the Tank Farms Operations area or satements relative to non-applicability of general requirements are found in this RD. 


\section{REQUIREMENTS IDENTIFICATION DOCUMENT HIGH LEVEL WASTE STORAGE TANK FARMS \\ Operations \\ Rerision 0}

PROGRAM MANAGEMENT

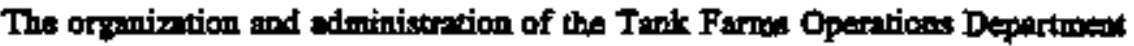

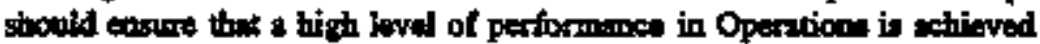
through effective implexoentetion and control of Operations wetivities. Operations manigement philosophy, policies, procetures, and activities stould acogrixe that anfity, environimeatal protection, and productivity are counputible gouls. Poticies describe the philosophy of stimdinds of excellence under which ths fecility is operated. Clear lines of responsibitity for normal and entergency conditions should be established. Iffoctive implenentation and control of operating ectivities may be schieved by establishing wituten standards for Operations, periodically momitoring and

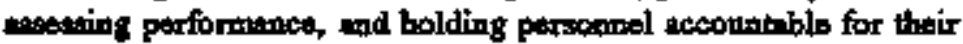
performince. This element includes the policies, resources, monitoring, and accountability aeded in Tank Furms Operations. INPO 84-021 (Good Prwetice OP-204), Conduct of Operitions, is an exaraple program thent cen be of ascistance in imple:menting the inteat of some of the stidelines of this element.

Requiremeats for operations ortanization nend administration may be found in the Mamagement/Adrrinistation section of the Management Systeme RID.

\section{Onemtions_Oconenization Poligies}

Tank Farms operations management should communicate a firm conmitment to the safery health, and general welfase of employees and the general public and the protection of tho sturrownding anviroament through the developanent, distribution, and ixpilementation of formal policy statements. These policy statameats should deseribe the philosophy and standerds of excellence under which operations activities ars eondurted.

The requirements relative to operations organization ind policies can be fonod in the Management/Administration Functional Area of the Management Systerns RID.

\section{STTE REQUIREMENT SOURCE: DOE5480.19 Chapter I, Section C.I}

"Prosedures or othor definitive documentation stould specify policies that art to be applied for operations. These doctromens storald also provide for the types of controls necessery lo implement policies as diseussed in this and other chaptars of the guidelines. Operations procertures sbould support forlity aud DOE guidone for operations. Responsibitities for implementing these poticies, inctuding the responsibility of shift personnel, if applicable, should be elearty defined. Operations personnel stould elearly noderstand their wthority, responsibility, accountability, and interfaces with other groupe. Physical security sthould be in accortines with DOE 5650.11."

\section{STTE REQUIREMIENT SOURCE: DOE5480.19 Section 4}

-It is the policy of the Department that the coeduct of Opersitions at DOE 


\section{REQUIREMENTS IDENTTFICATION DOCUMENT HIGH LEVEL WASTE STORAGE TANK FARMS \\ Operations \\ Rerision 0}

faciltitis bo managed with 2 consistent and andituble get of requiremerts, stindands, and responsibilities and thak, consistent with the requirement of this Onder.

s. Operations at DOE facilities be managed, ortenized, and conducted in

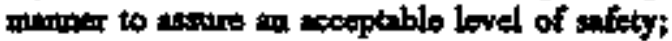

b. Operrators at DOE factlitive have procectures in plece to control the conduct of their opertions;

c. Lim organdations roviow extisting and plasened programs inportent to sato and reliable facility operstions; and

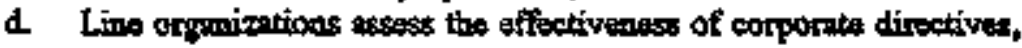

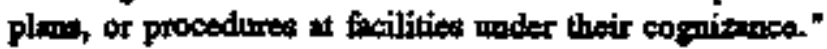

\section{SITE REOUIREMENT SOURCE: DOR5480.19 Section 3.2}

"Each DOE sontractor shall use this Onder and Attachereat I in the review ind development of existing and proposed directives, pinnt, or procechers relating to the concust of operations at DOE facilities."

\section{SIYE REQUIREMENT SOURCE; DOES480.19 \$etion 5.b}

"A greded approsach stull be used in the opplication of the guidelines provided in Attachment I to assure that the depth of detail required and the mapritude of resources expeaded for operations are commensurete with each fecility's programanntic imfortance end potentiai environgental, sufaty, and/or health impact.

\section{SIIE REQUIREMENT SOURCE: DOE5480.19 Section 5.c}

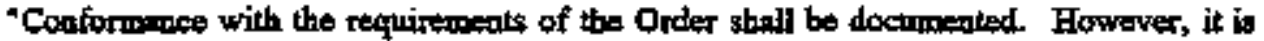
not necessary to develop a separate mantual or plang. As a minimum, a document (6.5., a matrix) shall be prepared in coordination with the Head of the Field Element and the cognizant Program Secretarial Offieinl(s) that:

(1) Indicates whether a specific guideline spplies to a fecility;

(2) Inticesed where and how ench of the guidelines (Attechment D) of this

Ond art applied within the contractor's existing polieted and

procedurex; and

(3) Identifies any devintions or exentutions firmon the glideines

This document stail, as a minimum, be approved by the Head of the Field Element."

\section{Resoujures:}

The Tant Farms Operations Departatent should be staffed by 2 team of highly quelified and experiented personnel to achiovo stafe, selinble, and efficient operations. A long range staffing plan stovuld be doviloped to ensure continantion of required staffing levels. Additionslly, material resources stoudd be provided to ensure safte, relinble, and effictent operations. 


\section{REQUIREMENTS IDENTIFICATION DOCUMENT HIGH LEVEL WASTE STORAGE TANK FARMS \\ Operations \\ Rerision 0}

Repuirements rolutive to Opertions orgmization rescorces may be found in the

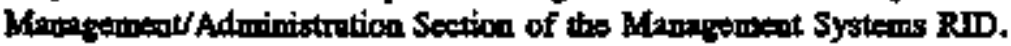

\section{SITE REQUIRGMENT SOLRCE: DOE5480.19 Chapter I, Section C.2}

The Operations supervisor for DOE feifitied stould be provited with sufficiege reconrces

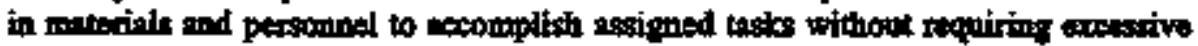

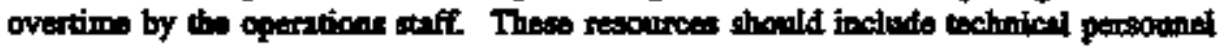
Deeded to soppont the opertions. A lons-range stafing plan that anticjpates personned koseses should be devaloped and implemented."

\section{SITE REQUTREMANT SOURCE: DOE5480.20 Chapter I, Section 15}

"LIMITATIONS FOR OVERTIME WORKED. Adquinistentive procectures shall bo developed and impitemented to limit the worling hours of operating orgunization personmel who perform safory-related functions (e-g., certified operators and supervisors,

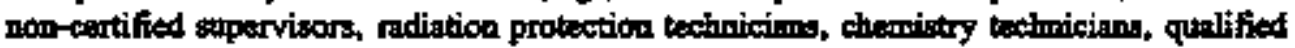
operators; and mointenence craftyersons and supervisoes, both facitty force and construction).

2. Adequate shiff coverage shall be mainkined without beavy use of overtime. However, in the event that unforeseed problems rexpire sabstentival amounts of overtime to be used (such as during extended shutdown periods for tefiveling, mujor mointenance. major Exility modifications, tochnical problems, or weather selated

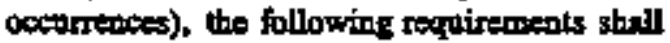
be wplied on a temporary basise

(1) A person shall aot be pormitted to wort more then 16 consocutive bours, axcinding shift numover times

(2) A person stall pot bo perritted to wort mote 24 houres in any 48 bour period, excluding shift trinover time;

(3) A purson still oot bu permittad to work move thin 72 boums in ary 7-day pariod, axclodieg shiff turnover time;

(4) A porson shall act be perraitted to wort mone then 14 consecutive days witbour haviag two oconecontive dnge off; and

(5) Except dering exteonied stutdown periods, brief pto-or

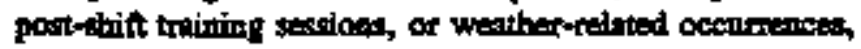
the use of overtime shall be considiented on an individurl basis and not for the entire shift crow.

b. Any deviatice from the overtime requirements gholl be athorized oa a cespoby-cuse basis in advatas by the Plant/Facility Manager or tats or her designos in woondance with established procedares and with documentation of the besis for grinting the deviation. Individual overtime shall be revieswed monthly by the

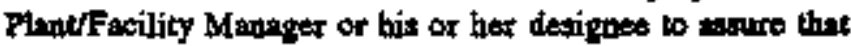
excesive bours bave bot been workad. 


\section{REQUIREMENTS IDENTIFICATION DOCUMENT HIGH LEVEL WASTE STORAGE TANK FARMS Operations \\ Rerision 0}

c. If * person is required to worty in exess of 12 continsous bours, his or har duties scould be cerrefully selected. It is profenable that this porson not be ansigned any batk that conld potoibly

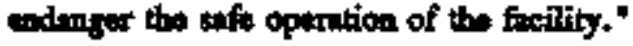

\section{FACIIIY REOUIREMFNT SOURCE: DOBS480,20 Chapter IV, Setion 4}

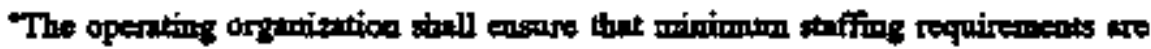
mer for safe and reliable operations. Aly temporary deviation from these

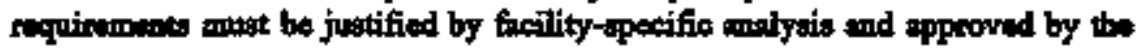
Wread of the Fintd Oromitertion.

2 Overill stofiring shall be boed on the freility Safoty Analysir Report and Oparational Safety Roquireameots. Facility oparation shall be contingeat upon moeting the criteria contsined in these tocuments.

b. A list of facility personnel by name, itte, and work and bome trieghone numbers shall be readily aveilable in the control room or ather appropriat ceatral lostion within the facility for ase by the operpting crew. The list shall include:

(1) Mansgetreent personnei;

(2) Rutiation sefecy persoctusi; and

(3) Tectmical support personnel.*

Manifgring of Oparating Parformance

Performance monitoring of Tant Farss operationa pessonnel through frequent direct observations by spervisors and managers is essentiat to performance improvements. Operating probiems should be doxumented, evaluated, and consective nctions tinplemented to improve performances. Performance go:sla should be ostubliahed and performance indicators used as a memogement tool for improving performence and for measuring

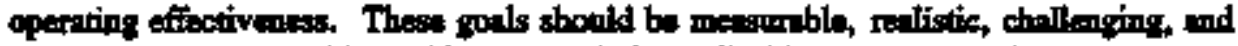

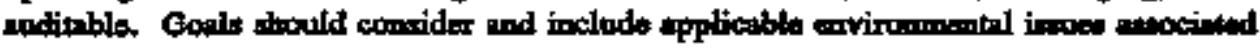
with Tautk Fargas operations.

Requirewentis relative to monitorist operating performmes moy bo formed in the Management/Adeministration Functional Area, and Corrective Action Munsemeat alements of the Menapemeat Systems RID; the Quatity RID; wad the Self A RID.

\section{MITE REQUTREMENT SOURCE: DOE5480.19 Chapter I, Section C.3, Paragraph 1}

'Opertitite problems should be documented and evaluated. Besed on assessments of these probleme, corrective setions stiould be talken to inprove tho

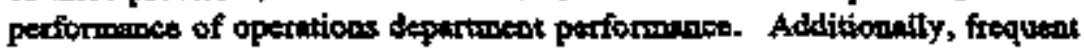




\section{REQUIREMENTS IDENTIFICATION DOCUMENT HIGH LEVEL WASTE STORAGE TANK FARMS Operations \\ Berision 0}

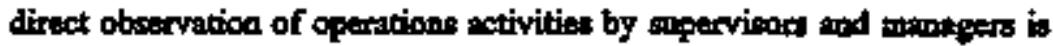
worotivl to pertormance of monitoring operstiona."

\section{SHIE REQUIREMENT SOURCE: DOES490.19 Chapter I, Setion C.3, Paragraph 2}

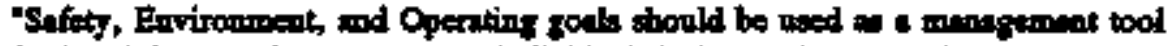

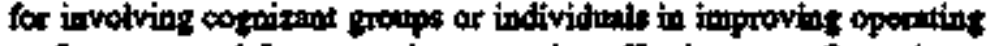
performence and for meascring operating effectiveness. Operating goels in

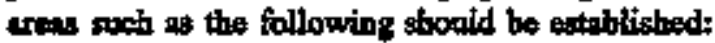

- minimizing the unxvailability of sefery systems;

- minimizing personoel orrost;

- As-Low-Al-Reasonably-Achiovablo (ALARA);

- minimiting lost fuility capabslity;

- minimizing the member of unscheduled facility shutdowne per yent;

- timely completion of schechled atrveillance;

- minimizing the emount of overtion;

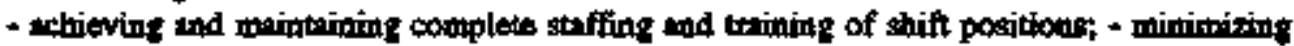
waste; and

- minimiting the cumber of lighted annmoigtors."

\section{SIIE REQUREMENT SOURCE: DOES480.19 Chapter I, Section C.3, Paragraph 3}

"Gorls should bu mulitable, measurable, realistic, and challenging. Marting gouls should require a definite set of actioss or an action pien. The action pimn should be developed with input from persongel involved in cooduct of operations, reviewed by the operstions supervisor at DOE facilities, and approved by management. The progeses toward completing the actican plan and achieving goals should be monitored periodically. If resiles ahow a

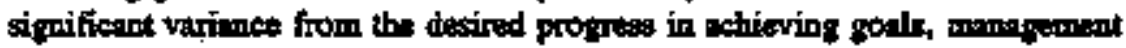

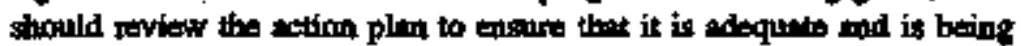
execonted. An molit of perforpence relative to operiting goall stould be provided to Eveility memigement and DOE. This srmmary should includo an aplametion of parformence and sctions phened to improves futars performance."

\section{STIE REQUIREMENT SOURCE: DOL5480.19 Chapter I, Section C.3, Paragraph 4}

"Openting and safery gouls should be set and nsed as motivitors for idprovernent, not at ends in themselves. The purpose is not simply to mest 2 mumerical gosl; niths, the perpose is to improve and monitor operating

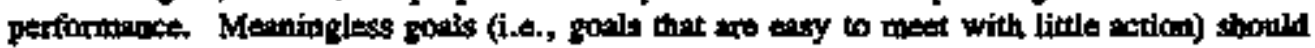
not be ugect.

\section{SITE REQUIREMENT SOURCE: DOE5490.19 Chapter I, Section C.3, Paragraph 5}

"Inspections, andits, reviews, investigations, and seif-assessment are a part of the checkn and balances peoded in an operatint program. Line manazers and 


\section{REQUIREMENTS IDENTIFICATION DOCUMENT HIGH LEVEL WASTE STORAGE TANK FARMS \\ Operations \\ Revision 0}

supervivors should perform routint obeervations of personand parformins openting ativities. Deficiencies idencified should be dochmented, treaded, and corrected. Also, ocher proups, awch es Qurity Assurares. shoild

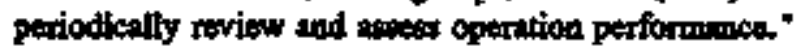

Accountsabflity

Tank Firms opentions personnel ahould be beld accountable for their performince

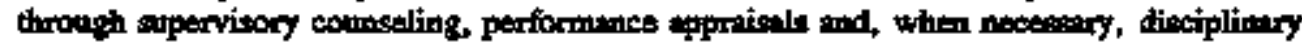
messures. Remedisl training my be provided when eppropriate. Performence apprisste for, and consideration for promotion of supervisory persormel should incloble an

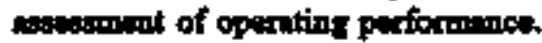

\section{SIIE REQUIREMINIT SOLRCE: DOE5480.19 Chapter I, Seetion C.4}

Workers and their sapervisors should be beld scoountable for operaxing performunce. Personal invalved in sigrificant or frequeat violations of operating proctions should be

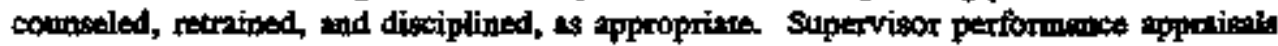
and promotions should inciuds an assessment of operating performince."

\section{Managenent Training}

. Formulized supervisory apd mangement trining should be incorponted into pilnat triming progrims for Tent Farms ogerations personinel. This is especially important to the first line sopervisers to aid them in menaging shit opertions.

The requirements relative to managemeat training in operations may be fommd in the Tnizing and Quvlification Functional Area RID.

The requirements relative to managenesent training may be fouted in the Manatement/Adoinistration Fuoctional Arta RID.

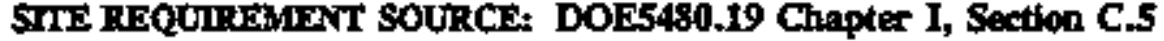

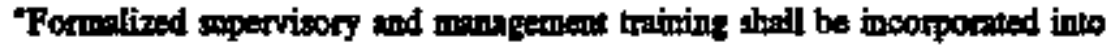

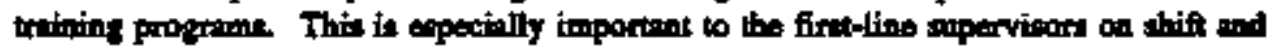
should aid them in monging shift activities."

\section{Elaming for Safery}

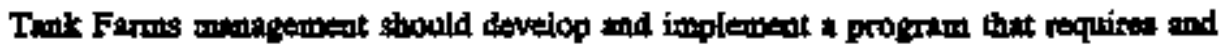
describes plonning requirements for all operations setivities. This proprem stould detnil

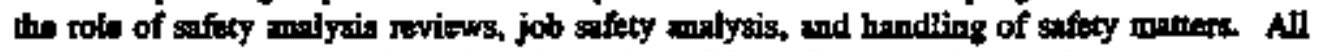

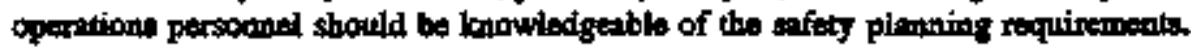

\section{SInE REQUIRBMENT SOURCE: DORS480.19 Chnpter I, Section C.6}

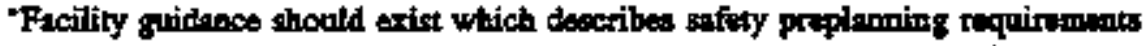
for aft operrtional activities. The guidenco should explain the sole of safery malysis reviews, job safecy analyses, and the handling of safery 


\section{REQUIREMENTS IDENTIFICATION DOCUMENT HIGH LEVEL WASTE STORAGE TANK FARMS Operations Reristion $\theta$}

motters. All operations personnel should underaterd the safory pienning mequiraments."

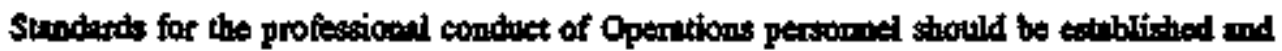

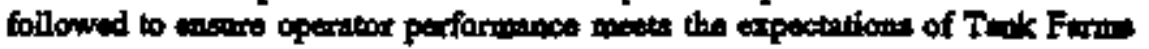
menegement and tho DOE. Al operationel activities should be ane contucted in a precise, formel, and professional menner that wehtoves safe nod reliablo aperstion of all componests within the Tank Farm finility. This lovel of openticand excolleoce operntion may be enhioved through the development of shift routines and cperating prectices then an

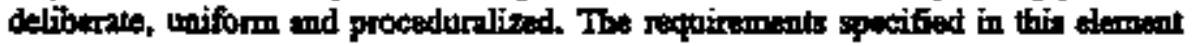
comprise tho expectutions of Operitions persomel relutive to staift roatinen end opernting practices. Requirements, routines and practices with a moro specific focts are delineoted in Saction 9.3, Control Station Activities and Sextion 9.4, Audibje Communiontion.

Status Practicas

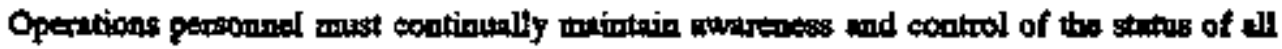
Tank Farms facility systeme and equipmeat and should be sware of the effect of non-opantional systems and equipment on continued operations. This awarenese is maingained through personal observation of equipmont, equipmeat instrumeatution and alarms, through timely and accurate logkeeping, and through the reports of statns information provided by others in the Exeility. The cperstor(s) responsiblo for the feelity should be prompty notified of all chenges in faility status, ebnocmentities, or difficulties encountered in performing assigned tusks. The operator(s) should astify the shift supervisor of unexpected situations. This notifiestion is to ensure that proper attealion is given to changing and/or off-armal croditions.

\section{SIrE REQUIREMENT SOURCE: DOES480.19 Chapter I, Section C.1}

The operator resposesible for the fecitity should be promptly notified of all changes in

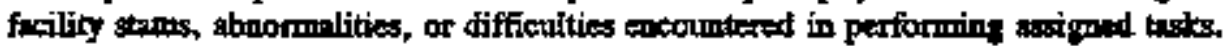

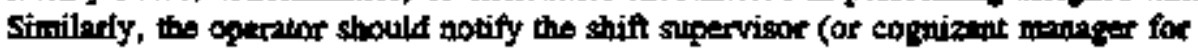
weserch and tos focilties) of any unexpected sinuations."

\section{Sifcry Practlces}

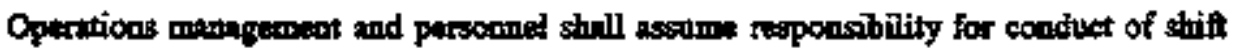

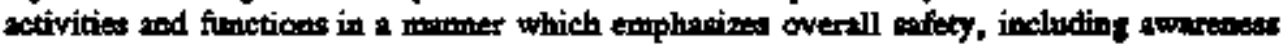
of and complinnce with the fecility intustrial safery program. Proper bosting, wo, head,

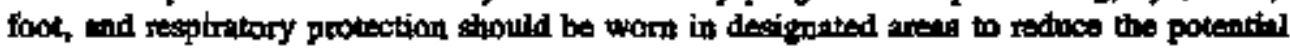

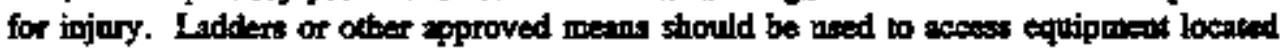
in the overhead when perminent steps or extwaiks ant aot avaikhble, thes nimimizing the pocential for acciderts. Pexsommel should not reutinely citimb or walt on fieility

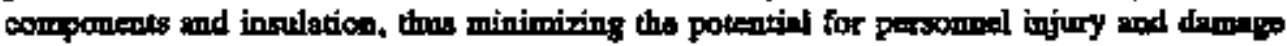
to equiptmest. Persomed should exerise appropritte precautions when enfering or working in or anound energized electrical parels or equipment. 


\section{REQUTREMENTS IDENTIFICATION DOCUMENT HIGH LEVEL WASTE STORAGE TANK FARMS \\ Operations \\ Revision 0}

This sob-element provides geosral requirements for gafety practices in Operatione.

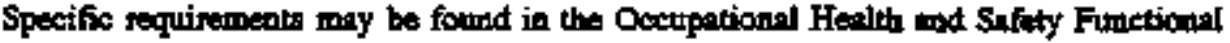
Atro RID.

\section{STE REQULEMIFNT SOUkCE: DOE5480.19 Chnpter I, Section C.2}

-Operations persomel should sthere to the requirements of the facility industrial safety proptam. Proper betring, eye, head, foot, and respiratory

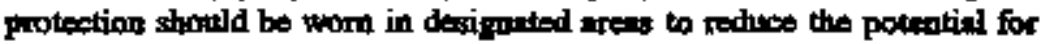

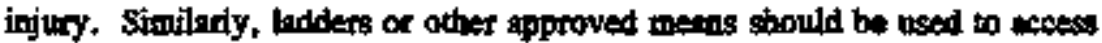
equipinent located in the overbead when permonent stege or catwilike sto not availables thes minimizing the posentini for cocidents. Operators stoold not routipely elitub or walle on factlity cocoponents and insulation, becterse this could resplt in personnet irjury or damage to equipment. Operators should exercise approprinte pec-ntipus when entering or worling in or aroubd energized ganel or equipment. For exampte, operatora should engure that electried panel closures are securely testeded prior to making the breakers

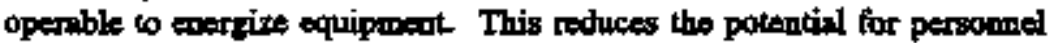
injury if a fanlt causes breakes arcing during operation.

\section{Operator Inspection Tours}

Operator inspection tours are important in the maintenance of sefe plent operations, equipment relinbility, operztional efficiency ind personel safety. Each operntor shonakt comduct a thorongh tour of all aress within his/her responsibility, moling appropriate opuiprent inspections at designated times ar least once per stifif Operitor tours should be of sutreient detril to mosure that the status of equipmed is known. The operationst

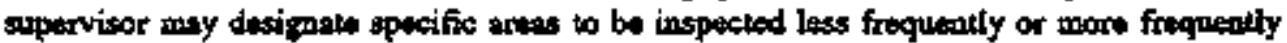

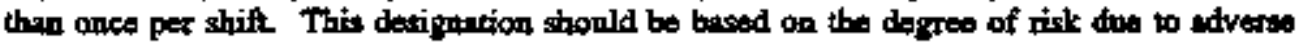
rodiological or other industrint safity considerations balloced with brown or suspected compoisen and system problems and their potential impact on the operation of the ferility.

An inspection topar is normotly mede early in the shift in onibr to allow the operater to

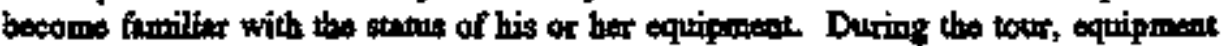
should bo inspected to ensure it if opertins properly or, in tho cese of stardby equipment, thet it is folly opezabia Operators strould tale appropriats action to correct or report doficiencies noted during tours. Equipment deficiencies storld also be documeated in

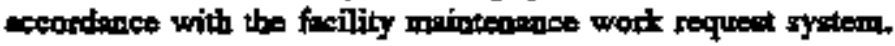

\section{SITE REQURREMENT SOURCE: DOE5480.19 Chapter II, Seetion C.3, Paragraph 1}

\footnotetext{
-Operator tonfa shouid be of sufficient desail to ensure that the statra of equipmeat is known. Exh operator sbortd conturet a thorouph tour of all aress within hith/her respoussibility, meling appropriate equipment inspections at designated times at leat oneo poz shift. Fowever, the operations slpervisor may designete specific rooms to be inspected lese frequently becense of atverse ndiolopicol or equivilatent persosind safoty conditions, of more frequently if problems have been encountered. In these cases, the cperations supervisor (or congrizant manager for research test facilities) should specify m aiternate inspections schedule. Plent sectrity coocerns sbould not
} 


\section{REQUIREMENTS IDENTIFICATION DOCUMENT BIGH LEVEL WASTE STORAGE TANK FARMS \\ Operations \\ Rerision 0}

override opesator sefiety essessmeot duties. A wour mormilly should be made early in the shift, before the operator atteods to other duties, so that holshe cm becoms frmiliar with the condition and staws of equipment for which he/ste is resporsiblo. During the tour, equipment should be indpected

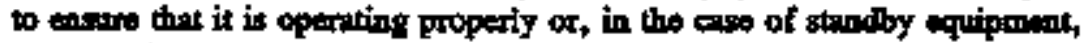
the it is fully operible."

\section{STE REQUIREMENT SOURCE: DORS480.19 Chapter II, Section C.3, Paragraph 1, Sentence \&}

In adfition, the following setrivities shmuld be conducted in conjunction with the tour.

2. The stotus of squiputed (i.e., opteralting, stendby, work in gropress, $\alpha$ out-of-sarvice) should be cetermined so that the operator will be best able to respond to problems he/she may foce during his/her stiff.

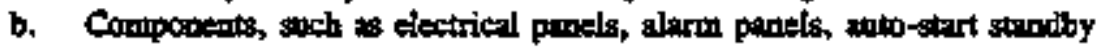
equipment, breakers shoold be inspexted for abnomat or unasenal

conditions. Unexpected conditions axch as equipment vibrations, umusual woises of smells, or excessive temperatures should be teportios to the controi room so that suptervisors will be aware of the condtions and be able to direct repais, troublestooting, or additionn operstor action, as necessary.

c. Equipment panel atarm light bulbs and mannciators should bo periodiceslly checked to ensure satisfactory operation of visual and indible atoontull conditions indicenters.

d. Each operator sbould inspect all areas for which he/she is responeible and aote any deficiencies that may be present. These deficiencies may include steam, oil, or water leoks; fire and safety hazands of radiologieal problems; seismic concerme suxth as open electrical peneis

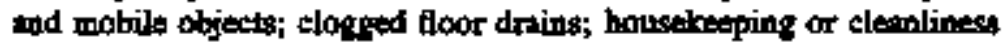
problems; add building defticacios such as imperative lighting, toof leais, of doof that do not close properly. *

\section{STE REQUIREMENT SOURCE: DOES480.19 Chapter If, Section C.3, Paractraph 2}

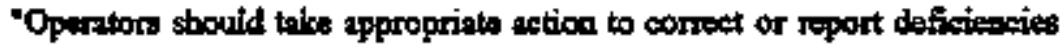
apted doring torrs Equipment defeiencies should also bo doctumented in acordance with the facility mainsensance work request system.

\section{Bounderour Insuection Sheas}

Round inspection theots are in effective method for providing operntors with gaidnen on the extert to whish equipment and acess shoult be inspected dering routine tourk. They should be developed apd approved by the operations supervisor or highor anthority. The round inspection sheets stould include gridence for the monitaring of all arens within 4 particular shift position and for the reeording of importank parzmetes for facility equipment. Where appropriate, maximum/minimum values or expected operitiog nonoes of equiproedt paraweters should be included to exable operators to recoguize abincrmal 


\section{REQUIREMENTS IDENTIFICATION DOCUMENT FIGH LEVEL WASTE STORAGE TANK FARMS \\ Operations \\ Rerision 0}

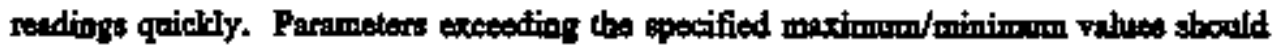
be circled of otherwise highlighted by the cperator. Safory limite derived fiom Teehnisil Specifications or Opartioanl Safoty Reqpiromenti should bo hightighted

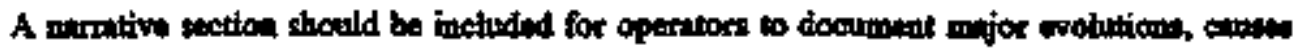

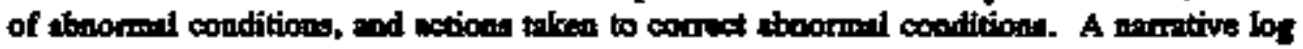

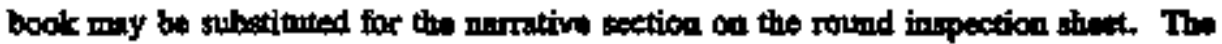

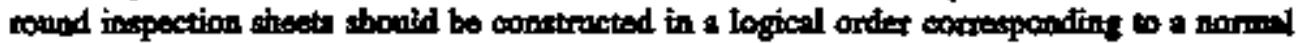

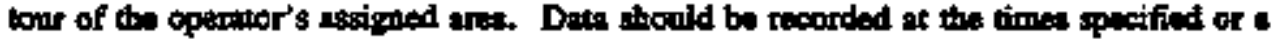
notation expiaining the reason for deviation should he included, Supervisory personiel

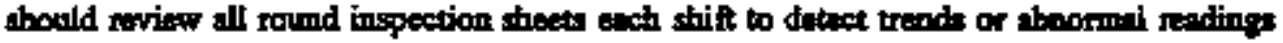

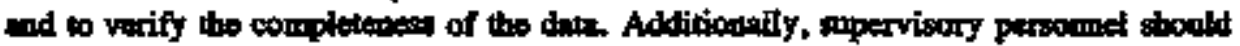

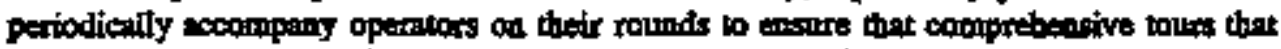
antisfy the expectations of Tenk Farme manogement are being conducted.

\section{STTE REQUREMMNT SOURCE: DOE5480.19 Chapter II, Section C.4, Paragraph 2}

"Round inspection shets sbonld be developed and approved by the operations supervior

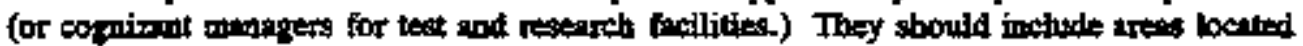
within the porticular shift position and important parameters for equipmant. Where

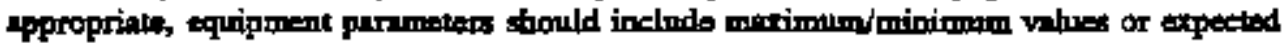
operoting rarges to enable operators to recognize atroonmal readings quictly. Safery limits derived from Tectmical Specifications or Operational Sitity Requireanen's should be highlighted. Equifonout should be listed od round steets in the some order thet it would be entountened during a nomal tour of the operating station, and the round sheets should ibolnde a antertive section.

\section{STE REQUIREMENT SOURCE: DOES480.19 Chapter I, Section C.4, Paragraph 3}

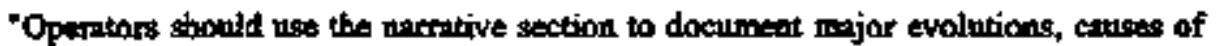
almormel conditions, and extions talese to correct eboormal condition. A narrative log bock mny be sobstituted for the tarritive section on the round sher. Datu should be roconded on round sheets at the times spocified by the operntions supervisor. When cound shest dete is aot obtained within one hour of the specified time, the acturl time the dath

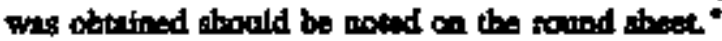

\section{FACILITY REQUTREMENT SOURCE: DOES480.19 Chapter II, Section C.4, Paragraph 4}

Parmentes exceeding the specified maximum/minimm values should be circled or

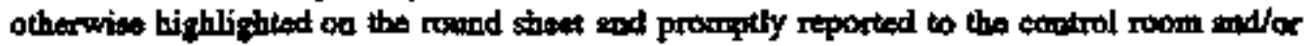
the cosmizunt operations manager. The censes of aboormal indicetions should bo prompty investigated with supervisors becoming involved st appropriate. The roumd sheet dats should be roviewed by a sapervisor each shift to identify trends or aboormal reading and to verify then date has been properly recorded. 


\title{
REQUIREMENTS IDENTIFICATION DOCUMENT BIGH LEVEL WASTE STORAGE TANK FARMS \\ Operations \\ Revision 0
}

\author{
SITE REQUIREMENT SOURCE: DOE5480.19 Chapter II, Section C.4, \\ Paragraph 5
}

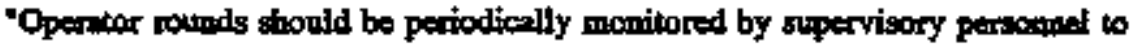
enfure thro comprehensive tours continut to be conducted, inchuding, as mesesary, periodio inspections of expipment and ereas nox listed on the round shents."

\section{Bersonnel Protection}

Operations personnel sbould be appropriatoily quelified to follow good personel proustion

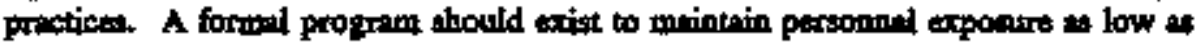
teasonably schievable (ALARA) to busndous meterinls, including rediation, cheanicals, electrical magnetic felds, toxic meterials, ac. Tank Furms opentions supervisory

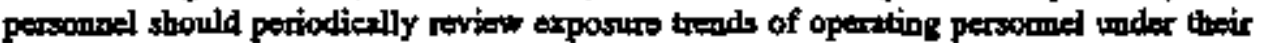
stpervistoo. The parpose of this review is to identify and ninimize adverse factors that contritulte to personentl expopares in order to maintzin exposures ALARA.

This sub-lement provides geaterl requivements for personnel protention ín operations at the Tank Farms facility. Specific requirements relative to qualifiction and protection practices are found in the Traising and Qualffication Functional Area RW.

\section{STE REQUIREMENT SOURCE: DORS480.19 Chapter II, Section C.\$, Paragraph 1}

"Operations personnel should be appropriately qualified to follow good personned protertion prectices to meintain personnel exposure as low 28 ressombly whievable (ALARA) to rediation (DOE 5480.11), chemicals, electromagretic fields, toxic meterials, or other parsonnol lazerds. In partictlax, optrations personnel should observe the following reguirements:

- Oparatora stoxuld whero to atl posted personnet protection requinements and observe proper practices and precautions whilo in controlled areas.

b. Cpentor should correctly utilize ipproprinto manitoring instruments when requitiod.

a Operators sbonid be cognizant of their own exposure levels and toine opproprinto setion to miniming exposures.

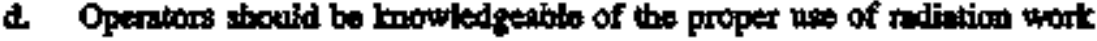

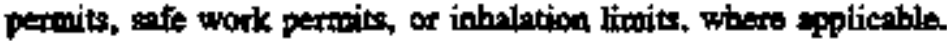

2. Operators stovidd promptly soport protection deficieacies and beazards to the control personed and/or appropriate protection persontol. In adition, operators shouid lake approptiate immediate actions to reduce or correct the hazards.

f. Appropriate protection persomel should be informed priot to evolutions or ectivities that have 2 potential to signiffeantly change conditions in the facility.

\section{SIIE REQULREMIENT SOURCE: DOF5480.19 Chapter II, Seetion C.5, Farsaraph 2}

"Operations supervisery pexsonnel should periodically review expostre trends of operating personnel under their supervision. Emphasis should be placed on 


\section{REQUIREMENTS IDENTTFICATION DOCUMDET EIGH LEVEL WASTE STORAGE TANK FARMS \\ Operations \\ Rerision}

determining the adverse factors that contribute to persomel exposures and minimizing those factons to kerp expostures as low is rensonable achimble."

Response to Indications

The Terk Furms operations department mest exteblish an operting philocophy, throngh

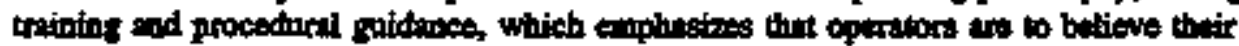

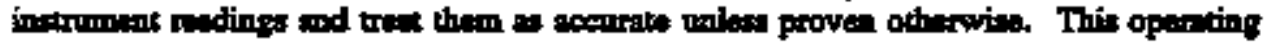
philowphy will requito that, in situtions of operitor doubt, operators will act to achions

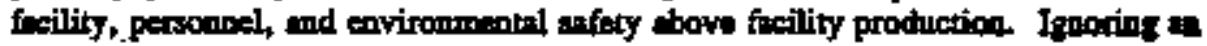

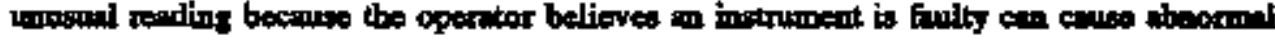

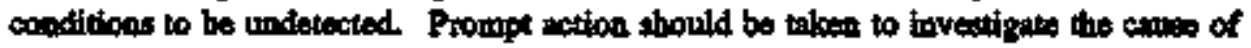
eboormal or unexpested intications so that prommk corrective extion can cecut.

\section{STIE REQUIREMENT SOURCE: DOE\$480.19 Chapter I, Section C.6}

"Operaters sbould believe instrument readings and treat them as aceurate umbess parvea otberwise. Ianoring an meusnel reading becuuse the operator beliteves m instriment is foulty can cause aboormal conditions to be undetected It geosenl, operntors should thect othar indications if possible, when unexpected resdings are observed. Prompt action should be wiken to investipute the cause of abnormol or umexpected indications 80 that

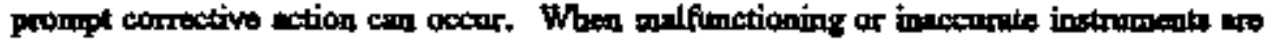
discovered, they should be eppropriately identified to prevent subergutent confusion and instrumert and control personnel should be axtified to effect repairs. In sitnotions of

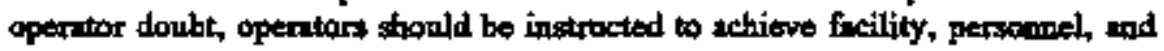
environmental safecy above facility production.

\section{Besetting Protectipe Devices}

Tank Farms opentions manegenrent should develop formil controis to ensure openations persomel are knowledpeable in the proper hundling of protective devices steb as ciratit breaters and fuses. Because tho consequences of nesenting tripped devices varies widaly

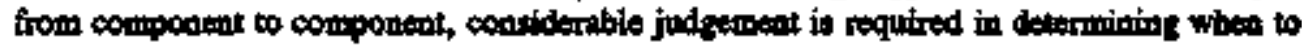
reses a device. In tho case of a tripped device, the operator should atsempt to understred the cans of the tip betors it is reset. Additionilly, the operator should ensaro on

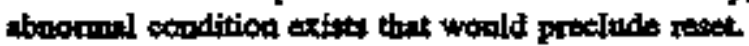

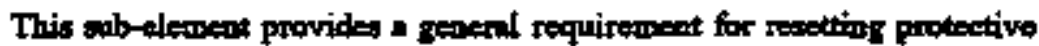
devices in Opentions. Specitic requirementh relative to ocentrence reporting if the trip relates to in urplamned ovent are found in the Occurropes

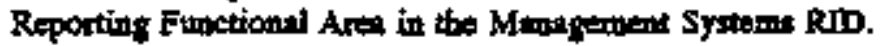

\section{STTE REQUIREMENT SOURCE: DOES480.19 Chapter II, Section C.7}

"When protuctive dovices trip (a-f, cinsuit breatkers, fuset, resetor

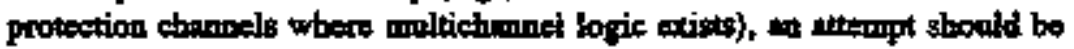
mont to understent the cense of the trip before the device is reset.

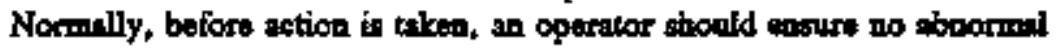
condition exists that would predude reset. However, because the consequences of insppropriately resetting probsctive devices vary considerably, good 


\section{REQUIREMENTS IDENIIFICATION DOCUMENT FIGH LEVEL WASTE STORAGE TANK FARMS \\ Operations \\ Rerisition}

judgment md specitic guidance are necessary in this ares. The operations mantigeneat should provide the appoprinte gaidance so thet tripped protective devices will be properly addressed.

Facitity trips and tuplaniod forced shutdowns requtire a thorough investigation in exeordence with the gridente of Chaptar VL."

\section{Load or Process Rate Changes}

The shift supervieor and control room kead operator are woroutable for sofo, retioble, and

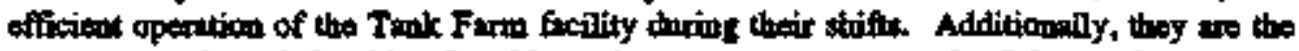
persons most lmowledgeablo of problema that may oceur as a resilt of the storting, stopping, or chenging of process ates in the ficility. Therefore Operntions menegtement should tsablish in operatiogs philosophy and artministrative controls neceseary to ensuto that all procese rave changes be approved by the shift supervisor or coatrol room lest opentor. These sontrols should recoppize that other shift operators wro authonized to dectesese or terminite processes without approval if necessery to respond to a fineitity

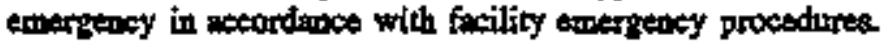

\section{FACHITY REQUFREMENT SOURCE: DOE5480.19 Chapter II, Section C.8}

"The stift supervisor, the control room lead operator, or the copainant munger for a teat and resenth facility stoonld afprove all power or process tate changes because these

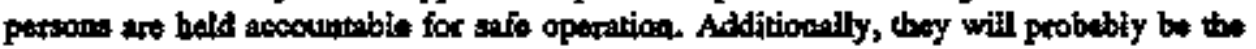
persone mos krowledgeable of problem that oceur as a result of lond changes. However, the operator could decrease loud or nte withont epprovil, if neceseary, to respoed to a facility omergaty sinuation in aceordance with the facility's emsergency procedures."

\section{Anthoxity to Operate. Endipment}

Operiting policies and procedures stould be astablistived to ensare that the overell operstion of the Tonk Firm facility is directed by the opseations supervisor. Controls shonld be developed to ansure that only properly arioed and qualified personnel operinto sudfor diret the opperation of focility equipement. The operator and the shift sopervisor should be awrate of all activitied sfiectins equipment end systems within the Tank Farms.

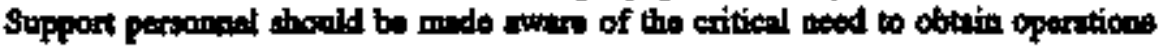

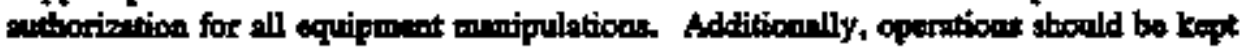

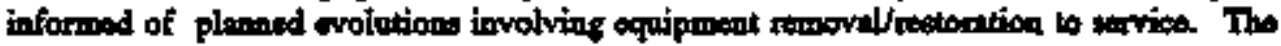

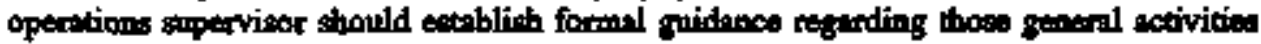
thet many be performed without informing the operator or shift stapervisor. All persternal sbould be trained to place teility stafety over production for off normed and emerigency

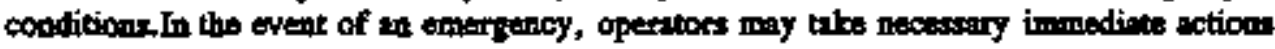

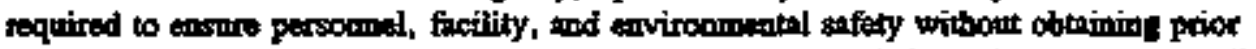
approval. However, the approptiatis supervisor(s) should be informed as sope is poesible of the actions taken.

\section{STIE REQUTREMENT SOURCT: DODS480.19 Chapter II, Seetion C.9}

"Operations management should ensurn that only trined and quelified personned optrats

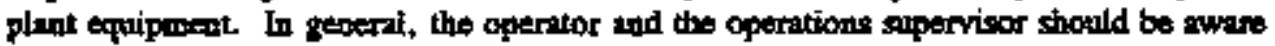
of all extivities affecting equipment. The opestions supervisor sbould spectity those 


\section{REQUIREMENTS IDENTIFICATION DOCUMENT FIGH LEVEL WASTE STORAGE TANK FARMS \\ Operations \\ Rerision 0}

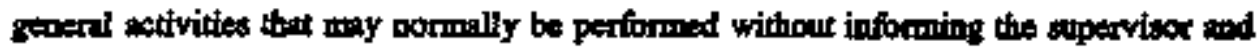
should amplify these spectifications as appropriate. However, nonrouting operation of

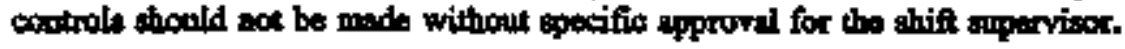

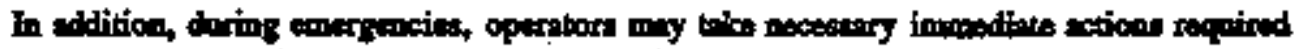

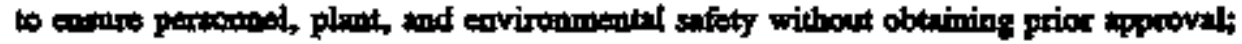

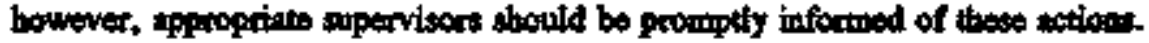
Opecators stoold be instructed that plant safuty shoald be achioved over fueitity production for of normal and tworgency farility corditions."

\section{Operatin: Bases}

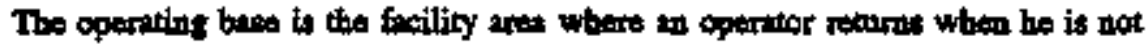
perforrening inplant duties. An operating bose should be establishod for ench shift position within the Tant Farms. Eech opentins bese stonld be equipped with appropriate office equipment for tho opentar to meintein nexestery procedures and references und to conduct administrative datios such as shift turn over. Necesory communication equipment storald be available at the openating hase. The operatiog bases sbould be loceted at a convenient phes within the area of respomeibility for that shitt position.

\section{STE REQURREMENT SOURCE: DOE5490.19 Chapter II, Section C.10}

The operating base is the fecility area where an openator returns when he is nox performing in-pinnt duties, An opertiting bese should be entabished for exch shift

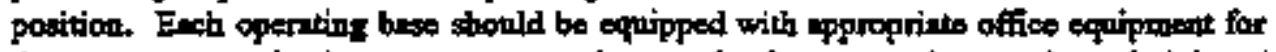

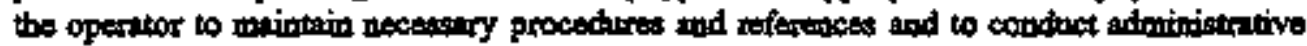
Intiee, and nocessary comminication equipment should be available at the operating buse.

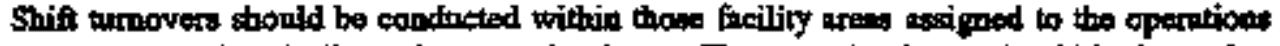
department and typically at thoperating bese. The operating beses stould be located a 2

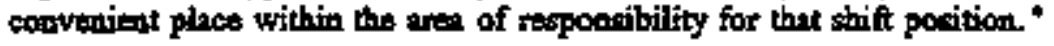

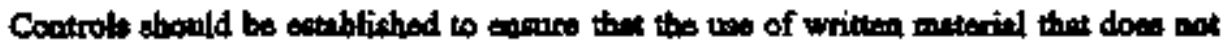

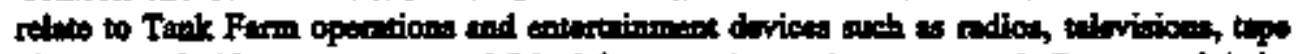

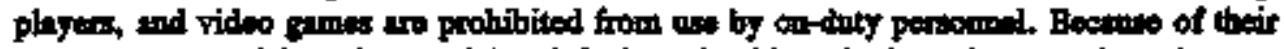

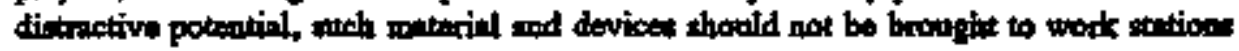
within the Tint Farms facility.

\section{SIV REQUREMENT SOURCE: DOE5480.19 Chapter II, Section C.11}

Written materiel that does not celeto to operation and entertainment drvices (such 해 radios, televisions, tope players, and computer games) should be prohibitod from use by an-duty optrations personnel in order to mimimize distractions from their rwoponsibilitien.

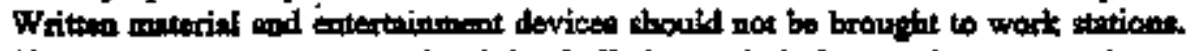
However, operetors may read training bullotins, tochnical manuals, of operoing experience informetion or review other written, andtble, of visal moterisls that relete to operstor tuties. Judgment should be used to encure the operators' primery dutios are not compromised. 


\section{REQUTREMENTS WENTIFICATION DOCUMENT \\ HIGH LEVEL WASTE STORAGE TANK FARMS \\ Operations \\ Rerision *}

The operations supervisor (or equivaleat) should provide guidance to the shift rande for the we of potertially distractive meterials and devices."

2.2.12 Te:mwodk

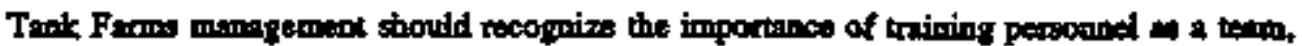

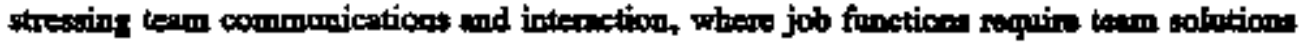
ind activitios.

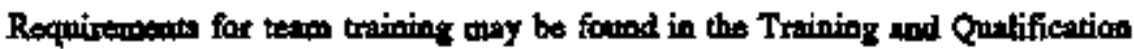
RID.

\section{SITE REQUREMENT SOURCE: DOE5480,20 Chapter I, Section 7a(I), Sentence 2}

The concept of training personed as a tear, stressins torm comarmications and interaction, shall be used where job functions requine team solutions and activities."

The control area or controi room is the most critical tacility operating base and the coostinestion point for all important facility activities. Therefore control area setivities tuast be cooducted in 2 manoer that achieves safe and reliable facility operntiogs. Activitios in the control area or control room mist be businessalite, and a profissional umospese conducive to safo and efficient operation mast be minintained. In addition, conircl ares operaters should not be overburdened with administrative respousibilitten, and control inte access stould bo limited so that opesators will not be distrected from properly monitoring fucility panmeters. The only area cousidered to be a control room or control tren at the Tank Farms is the tootrol trom for the 242-A Evapotator/Crystallizer. Other Tank Furms equipinent is operated locelly of from motor sorttrol seations such as those coatnined in compressor buildings and instrumeat stakeks. These locations are not mented on a contimens betsis and ate therefort not cosesidered to be control room or control 4yos.

\subsection{Cogirel Station Access}

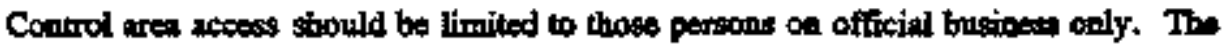
"at-the-controls" area of the control room should be cleatly identified, and its bomptery should be understood by all persons who are gronted aceses to the tootrol room. Access to the "at-the-controls" are should be restricted to persons who need to be in the aroa. Eatry into this are should be grented by designated individuols, and persons wto might veed to enter this ares should trow who ean grant weeses.

\section{SIIE REQUIREMENT SOURCE: DOES480.19 Chapter III, Section C.1}

"Control area mocess should so limited to those pessons on officisil besineso colly. The "at-the-eontrois" aren of tise control noom sbovuld be clearly identified, and its boundary should be waderstood by all persons who are granted access to the control room. Apoess to the "at-the-controls" aren should bo restricted to persons who noed to be if the areet 


\title{
REQUIREMIENTS IDENTIFICATION DOCUMENT HIGH LEVEL WASTE STORAGE TANE FARMS Operations \\ Rerision 0
}

Entry into this area should be grated by desiponted iodividuals, and persons who might nead to ectur this aree should know who then grent access."

\section{Professional Aethavior}

Professiotal behavior stould be displayed in the control area at all tima. Only activitios

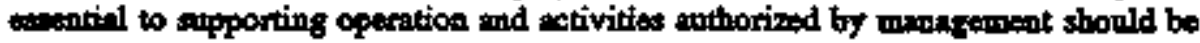

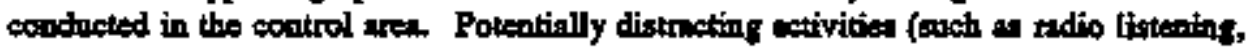
gano playing, and hotsolay) thould bo probibited Non-job-related discassions shoold be

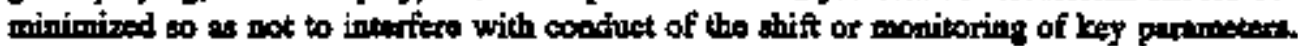

\section{SITE REQUIREMENT SOURCE: DOES480.19 Chapter II, Section C.2}

-Professional betovior shoutd be displayed in the cortrol aren at all times.

Only activities essential to supporting operation and activities atthorized by mankptment should be cooducted in the control trea."

\section{2,3,3 - Moritoring the Main Control Panels}

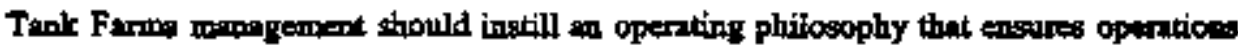
persomei are atteative to control board indications and alarmst. Operstors should be alert, should anditor their cootrol panels freajuently, should tread incications to detest potential probiemes early, should sale prompt action to dotermine the catuse and correce aboormalities, and shouid respond to and corrext alarming conditions. Becalsse of their

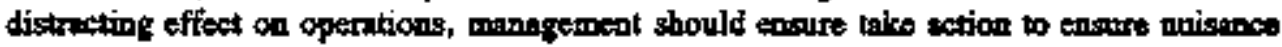
slarms ate not allowed to become chroric. Additionally, the mirnber of evolutions in progress exscurrently should be controlled to ensure the operators' ability to control the evolutions sefely and to deteat and respond to ebsormel situations is not compromiseci.

\section{STIE REQUIREMENT SOURCE: DOF5480.19 Chapter III, Section C.3}

\begin{abstract}
-Operators should be alest and attentive to control paned indicuticus and alarms. Conirol pored indications should be monitored frequeatly, and prompt action should be taken to detormine the centre of and correct abnorranlities. Enphesis stould be plaeed on closely

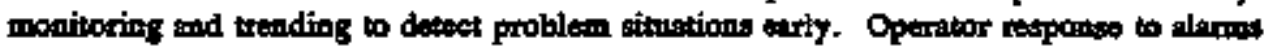

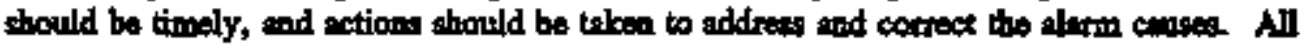
reavorablo setion should be tuken to cher alarming conditions. The anmber of wolutions

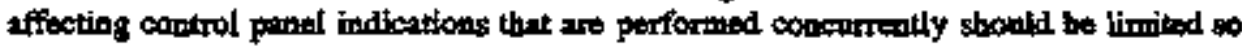
that the opesators' ability to detect and respond to abeormal condition will not be cormpromised. If compuiter or antomated systeme are in place, tbere should be an apropriate beckap to those systems."
\end{abstract}

\section{Control Station Operator Anciltar Duties}

Administrativa tusks assignod to Tank Farmes operttors should bo minimized to arcid interfetiog with their ability to monitor asd respond to fucility control station indications and their ability to control oogoing wetivities. Wha adminietentive funetions are necessary

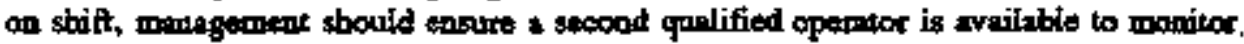

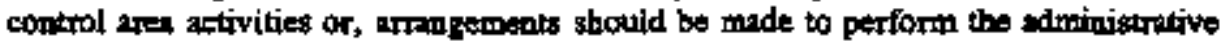
fienctions atray from the atthe-controls ares. 


\section{REQUIREMENTS WENTIFICATION DOCUMENT HIGE LEVEL WASTE STORAGE TANK FARMS \\ Operations \\ Rerision 0}

\section{SHR REQUIREMENT SOURCE: DOE5480.19 Chapter III, Seetion C.4}

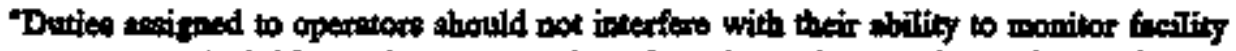

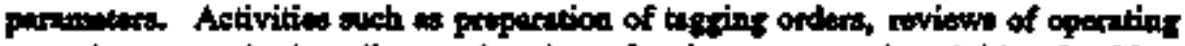

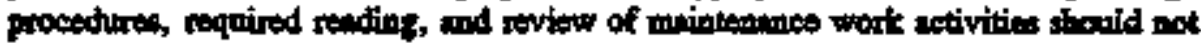

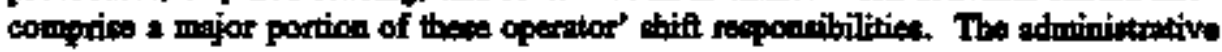

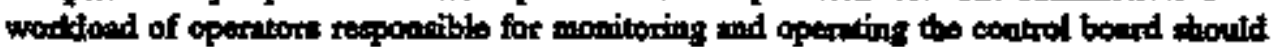
be minimizad. If one operstor is involved in administntive bsik, other operrtons should

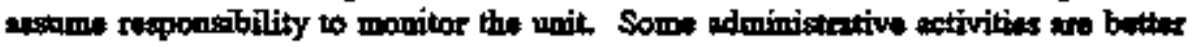

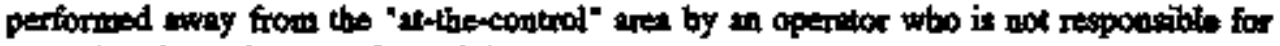
opesating the minin controd panel."

\section{Oneration of Control Station.Egripment}

Only those pessons speciffeally authorized by the administrative ptocedures of the Tink

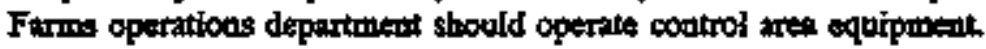

\section{SITE REQUIREMENT SOURCE: DOE5480.19 Chapter III, Section C.5}

"Only persons specifically antboriand by the administrative procedurta of the operationa

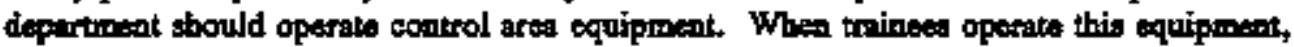
they shovid be supervised and ecotrolled by the operator who oormelly would perform the operations."

\section{Control Room Appearance, Habikghijltp and Eoulpment}

Controls should be eatablisted to enstre that be control reom and control wesp are mainteined in 4 slean and orderly condition to promoto safo and efficient opentione, All dusting and cleming of control consoles stould be performed by Tank Farme shift operating personem to minimiza the libolibood of inedvertent control actuntion.

\section{STIY REQUIREMEINT SOURCE: INPO-24-021 6.10}

The control room will be cleen and orderly to promote mefe and offejint

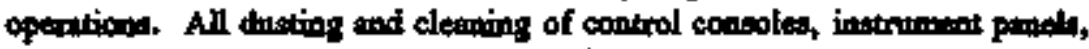
and computer consoles will be performed by shift opernting personed wing

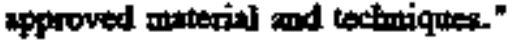

\section{ALDIBLE COMMUNICATIONS}

Accurate and precise commonications aro esential to the safo and afficient opezation of

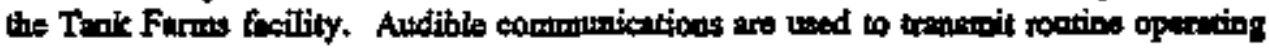
and ambighery information throughout the fecility. Becouse of the potential coosequences of ntiscommumicetion, Tent Farms operations menegrement should inplemint formal

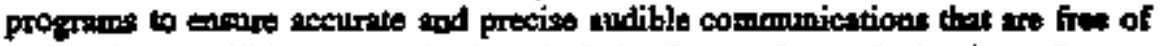

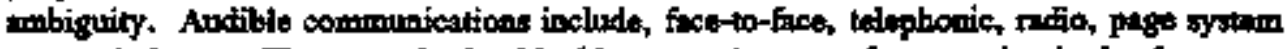
use, and alarms. The controls should aldress requinements for tepeatiog bact of instroctions, use of abbreviations, uso of a phonetic jiphabet, priocity for torergen commumications, and meastires bo casure public addiress systems are act ued in such a monner that they disropt normal operatione. 


\section{REQURREMENTS IDENTIFICATION DOCUMENT BIGH LEVEL WASTE STORAGE TANK FARMS \\ Operations \\ Revision o}

\section{Emergency_Commutication_Sxstems}

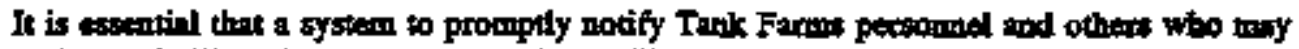
be in the fincility of emeryency sinutions. Those arear where the public address system

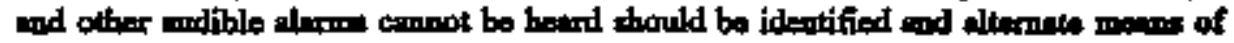
alortine peraomed in these teres should be provided.

\section{STIE REQUIREMIENT SOURCE: DOE5480.19 Chapter IV, Seetion C.1}

"Methods stoonld be implemented to arsure af fraility persoanel are prompty alerted to

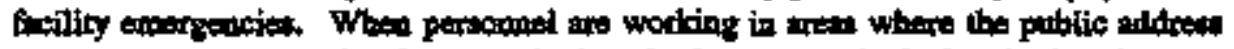

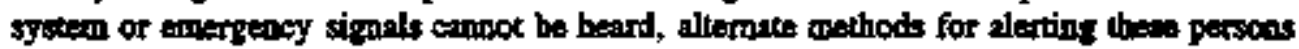
should be wtilized. Flashing lights, personal pagers thet vibrate and can be fatt, and

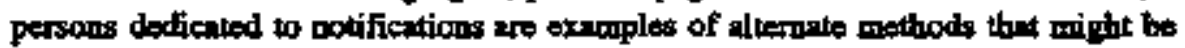
effitive.

Emergency communications systems should be periodically tested to ensure that they aro

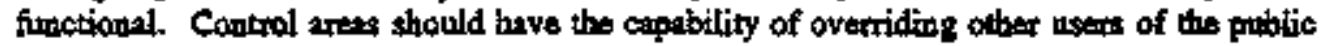
addrese aystem for exrergency innouincements."

Public.Adiress: Sretem

Aduinistrative controls for the 242-A Evaporator public address system are escentid to ensure that the system retrins its effectiveness in contacting facility personnel. Cistral use

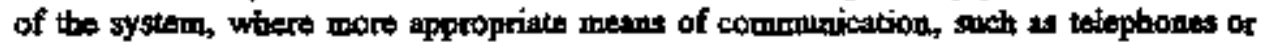
radioa are avaitable should be controiled to ensure the impact of important announoements is not compromised.

\section{STTE REQUIREMENT SOURCE: DOE5480.19 Chapter IV, Seetion C.2}

Wee of the fxility public address system (page) should be administratively controlled to onsare it rethiss its effectiveness in contacting plant personol. Excessive wos of the

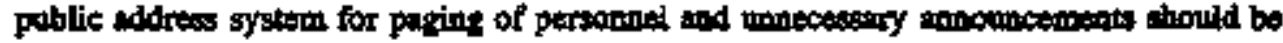
avcided becruse excesive upe cell nedres the impect of important ansonincements end con be distracting. Facility telephones and otber point-to-point commomicentions chemell thould

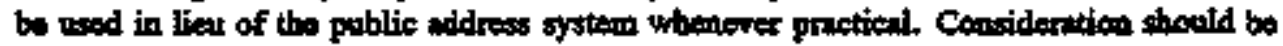
given to dediceting certuin pering system channels to specifis groups or functions, (o.g.,

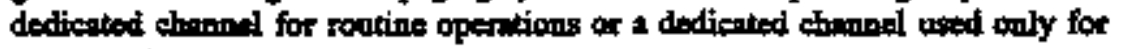
empropiciec)."

\section{Contactine Operators}

The Traik Farms Shift Matuget and ocher pezsoneel in costrol troas should be ablo to

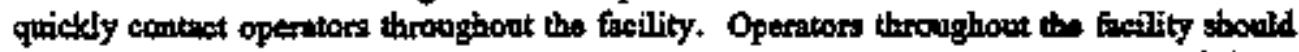
be provided with the mene to quidkly comminicess with supervisory persomel mid thoso in control areas. 


\section{REQUIREMENTS IDENTIFICATION DOCUMENT HIGH LEVEL WASTE STORAGE TANK FARMS Operations \\ Rerision 0}

\section{SITE REOUIREMENT SOURCE: DOE5480.19 Chapter IV, Section C.3}

"Methods should be implemented to ensare that control aress can quickly contuct can-ihift operntors or supervisors. Examples cited above in item 1, Emergacy Commmication.

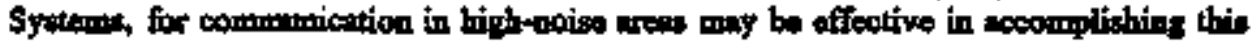

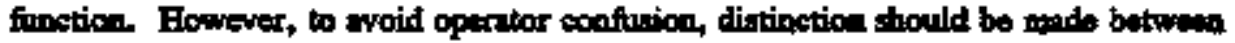
routine and emerpensy notifications."

\section{Batios and Tetephones}

Administrative controls shouid be developed to ensure thet the use of portible todion in effective and does not adversely affect sensitivo olectronic exuipment within the trility. The dedication of specifie frequetecies to specific groups, activities, or artos thay improve the effiectiveness of communications. Additionally, the dedication of certain wephone circuits for critical functions or areas may improve effectivesess.

\section{STIE REQUIREMENT SOURCE: DOES480.19 Chapter TV, Section C.4}

-Portable ardios can be an effective means of providing mobtle point-to-potin commanications and may be used for this plappose. Howwer, radios sages should not be

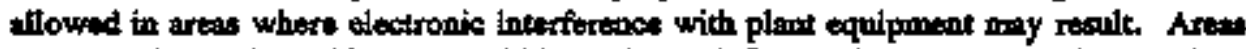

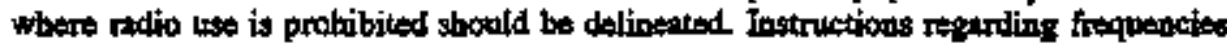
(chennels) and postings shoutd be provided. Consideration should bo given to dediesting certain radio chamels to specific groups or fumctions $9.8 \%$ a dedicnted channel for security or dedicated chamel employed intrograted surveillance tests)."

\subsection{Abbrevintions and Acrongurs}

Tank Farms manegeneat should develop a list of approved ecronyms and abbeviations to improve the clarity and preciseness of commumicationts. Use of the approved list stould be uned for both spoken and witten conamurixations.

\section{STTE REQUIREMENT SOURCE: DOES480.19 Chapter IV, Section C.S}

"Only abbrovirtions ind acroayms obteined from ton taproved list stonild be tused in facility commanications. Both written and spoicen terms should be proporibed in the tiat.

\section{Audithe Insfarcions and Informationgl Comrmunications}

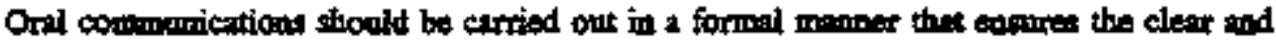
concise trenemistion of information from one person to enother. In all communicuticns, the identity of the sender and the receiver sbeculd be extablished and verification that the conmumication wed received ind understood thould be provided by the recipieat. Tank Farms minigement shombl entiblish administntive controls addressing the need to reptet back instractions when the commanicatione relets to the operation of facility equipment. Additional guidmos should be provided to easure that facility operations communications which are somplex or lengthy art endmumicated in writing. 


\section{REQULREMENTS IENTIFICATION DOCUMTENT HIGH LEVEL WASTE STORAGE TANX FARMS \\ Operations \\ Rerision 0}

SITE REQUREMENT SOURCE: DOE5480.19 Chapter IV, Section C.6

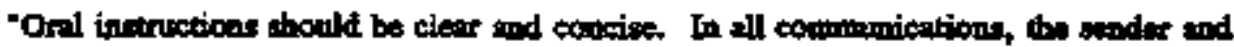
intended reserive sbould be readily identifiable. Instrwetions invoiving tho opterision of

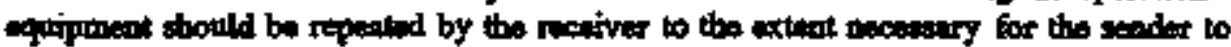
terose the intructions are courectly understood."

\section{CONTROL OF ON-THE-JOB TRAINING}

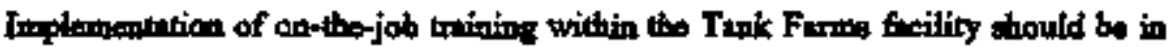
cecondence with striet administrive controls to ensurs maximum beneffit to the troines

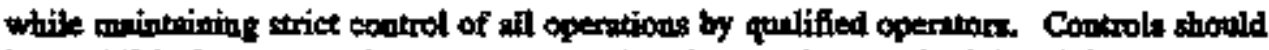
bo established to ensure those operators assigend to condust on-bo-job trining tre thentelves trained in the techuiques of an- the-job trainiog. The prognim shoutd be structured to easure tbe trainee in able to setisfictorily complete all tequirements of the progersm. The requirements of this element estebligh the standard for troining activities cootucted by the Tack Farms Operations Departiment.

\subsubsection{Afherence to Training Prodrams}

Tanti Farms on-shift traiging should be conducted in weordince with formally diefined trining progratos that specifically identify items the trxines mist aceomplist an shift. Tha knowledge requireneots for ach ittem should be defined as well as what the trines

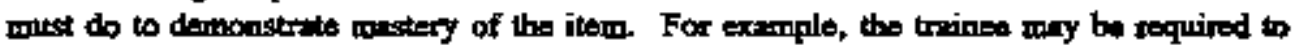
actually perform a task; simulate performence of a tasi (trally-through); observe the

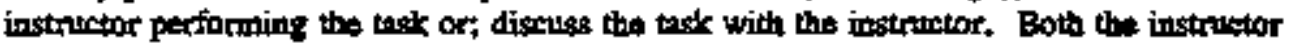
and the traines should imderstand whes is required for the successful completion of each triming item.

\section{STE REQUIREMISNT SOURCQ: DOES480.19 Chapter $\nabla$, Section C.1}

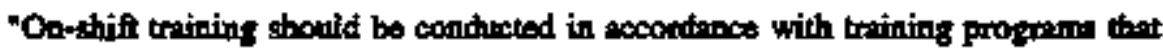
specifically ideatify itoms the traineo mast accomplish on shift. Tho knowledge

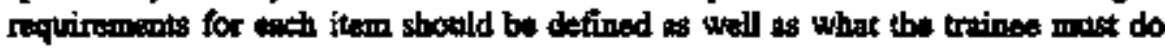

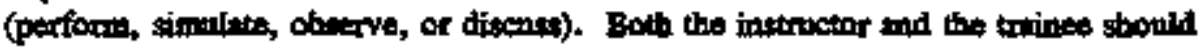
underetend whet is requited for ench training item-"

\section{OnJTherlab Instructor Oualificotion}

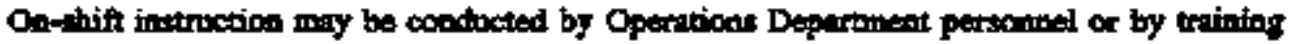
depertment instructors. In eitber cose, the introctors should heve completed appropriste

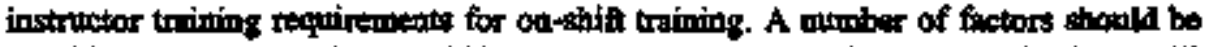

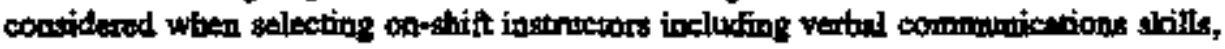
technical knowledge, and ability to prowide the trines with hands-on experiedce while mintrining control of tacility operations.

\section{SHE REQUIREMENT SOURCE: DOR\&480.19 Chapter V, Section C.2}

"On-shift trining should be condurted by quilified operztors. This may recanine the succesufut completion of appropriate instructor training requiremerts for on-shift trining. Eowever, sperator-qualified tnining departmear personnel maxy also be lased. The on-ohift 


\section{REQUIREMENTS IDENTIFICATION DOCUMENT \\ HIGA LEVEL WASTE STORAGE TANK FARMS \\ Operations \\ Berision o}

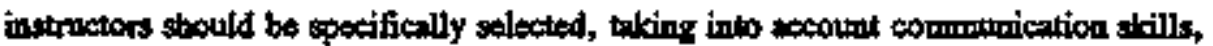

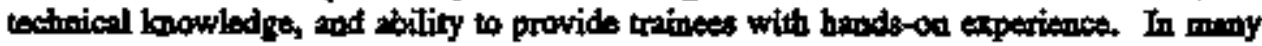

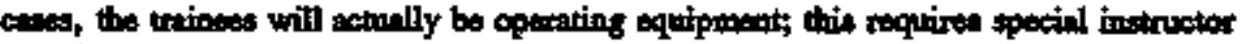
vecturiques in order to prevent miscperation or dormage of equipineat."

\section{3}

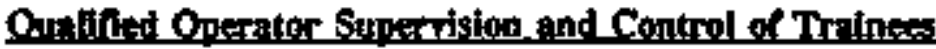

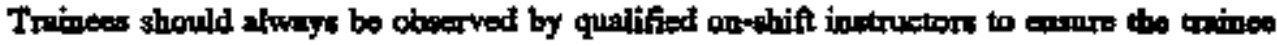
does not matre an exror that would affect Tant Farms opertions. Close monitoring of

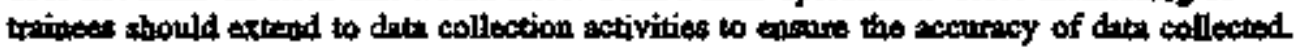

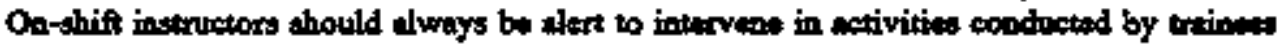

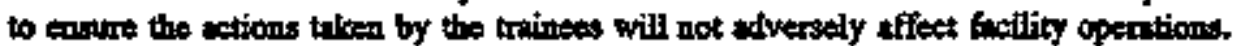

\section{SIIE REQUTREMENT SOURCE; DOL\$480.19 Chapter V, Section C.3, Paragraph 1}

"Whenever traines cperate exaipment, a qualified operstor serving as m on-shift

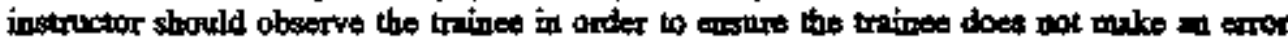

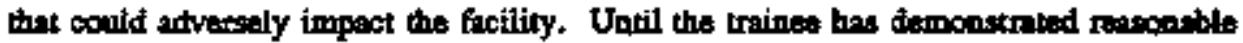

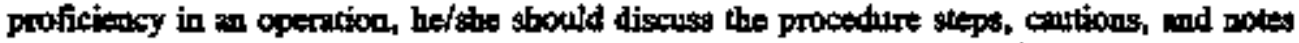
with the instruetor. Trainees should also demonstrate astions to be performed by pointing to the cotrol switrh, valve, breaker, etc., that will be romipulated."

\section{SIE REQUREMENT SOURCE: DOE54\$0.19 Chapter V, Sectlon C.3, Paragraph 2}

"Os-shift instructors should sot become complacent with aniness. Just becinge a tringo has performed a tasic ooce does not menn be is aware of all problems that conld ocenr.

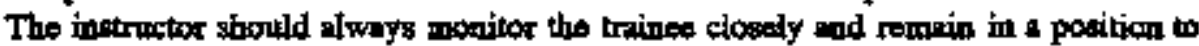
intervens of aesume control, if necessary."

\section{SIIE REQUREMIENT SOURCE: DOK\$4\$0.19 Chropter V, Section C.3, Parmgraph 3}

When triness record equipment parameters on officied round sheess (as opposed to

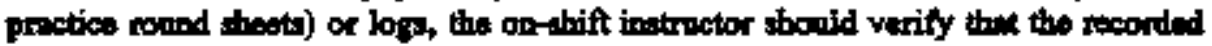

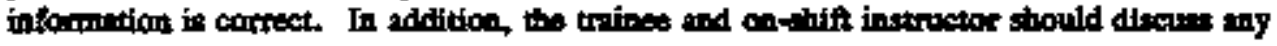
out-of-specification readings and the consecpleaces of allowing soch trod to comtinuen"

\section{Onemator Onalifiction Program Appromal}

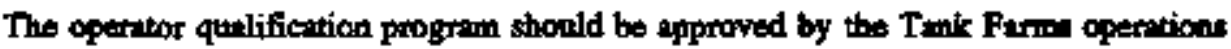
sugervisor. Changes to the program should be coordinated with the Training Department.

\section{SITE RIQUUREMENT SDURCE: DOES480.19 Chapter $\nabla$, Setion C.4}

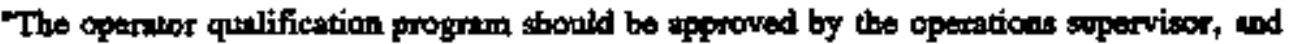
chenges to the program should be coordinated with the troining depurtwent. For coperatiog positions requiring certification, qualificatinns should bo based on cov-bo-one instrection if that station." 


\section{REQUIREMENTS IDENTIFICATION DOCUMENT \\ HIGH LEVEL WASTE STORAGE TANK FARMS \\ Operations \\ Rerision 0}

2.5.5 Trainins Documentation

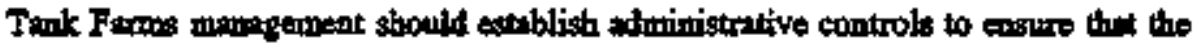

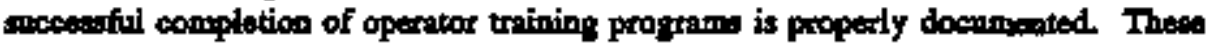
controts strould roquire that classroom training and writben examinations be docamented by

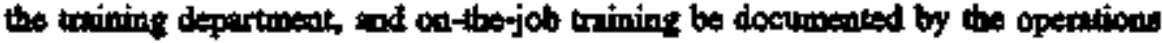

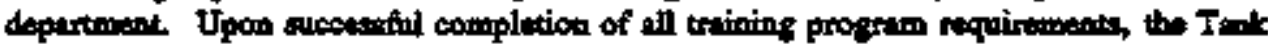
Farms operetions supervisor stould entify the traines to perform a specific job position.

\section{SHE REQURREMFiNT SOURCE: DOE5480.19 Chapter V, Section C.5}

"Compietion of the operator qualfication program showld be formilly docturented. Clessroom requirements and written exnm results sboxid be documented by trining depurtment instructors. On-shift training and system checkouts should be doctumedtad by

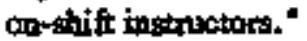

\subsubsection{Suspension of Training}

On-shift training of Tank Famm operator trainees should be immediately suspended during unanticiputed, or aborormal evepts, accident canditions, or whemever the on-shift instructer deem staspension is prodent to support the safe operation of the facility. Traineses shoutd assist qualified operators during aboormal or emergebcy conditions oniy at the fiscretion of the qualified operator.

\section{SITE REQUIREMENT SOURCE: DOE5480.I9 Chapter V, Section C.6}

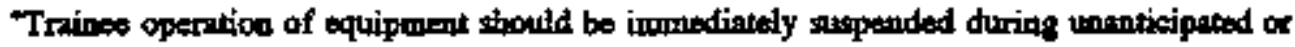
ibnormal events, accident conditions, or whenever the operations personred or on-shift

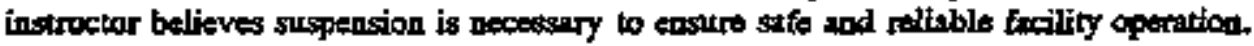
During boormal or eccident confitions, trinees stould provide susiation at the discretion of the qualified operator."

\subsubsection{Maximum Number. of Traines}

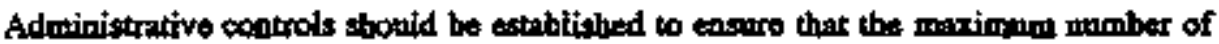

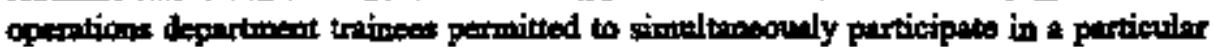

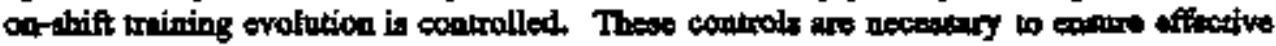
instruction for all trainess and to lierik the potential edverse inpact on the Tenis Furms fanility shouid the qualified operators become districted.

\section{SITE REOUIREMENT SOURCE: DOES480.19 Chapter V, Section C.7}

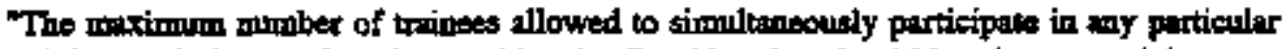
treinieg ovolution neds to be considered. Considertion should be given to training effectivedess and to the potenlizil for adverso effects on the facility. A miximum limit for the traines-to-instructor ratio will ensure that the trines is provided with the woot effective indruction and will ensurs that the instructor is not distonted by heving tos many trimess at oace. Shift supervisons should ensure that wablished limits ane observed * 


\title{
REQUIREMENTS IDENTIFICATION DOCUMIENT FIGE LEVEL WASTE STORAGE TANK FARMS

\author{
Operations
} \\ Rerision 0
}

\subsection{8}

\author{
Use of Traines to Support Operations
}

The Tmk Fums opections supervisor may develop administrutive controlk 6 pemit

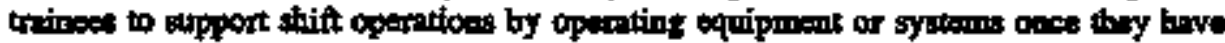
accesefilly completed the trining and qualifleations for that system. Controls mest

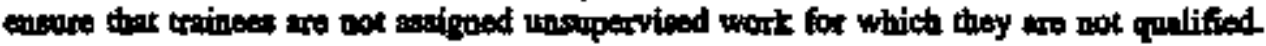

\section{FACIITY REQUTREMENT SOURCE: INPO \&5-017 General}

4. Use of Tringes to Support Opertione The operations superintendent or shift

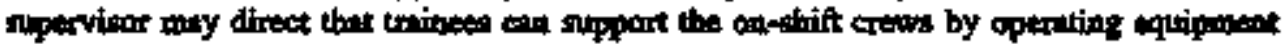

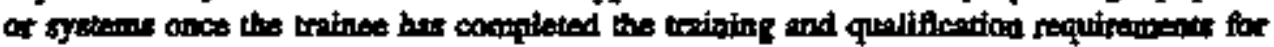

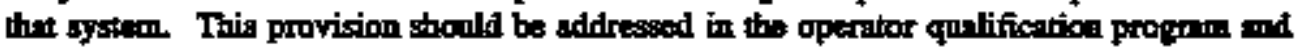

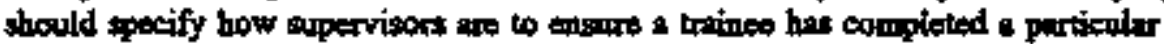
quntiffeation requirearent before he is ascigned to a tast on that systean- Supervisom should be cautioned not to use unsugpervised trainess to conduct operetion that requirs licensed operators. Additionally, use of a trinee to perforon shift tasla stoonld be dono with consideration of be trinter's need to make progess in tis trining work."

\section{INVESTGATION OF ABNORMAL EVENTS}

A propram for the investigation of abnormal eveats ensures that facility eveats are

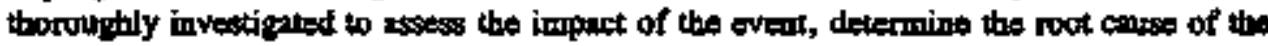
ovent, 2scertain whether the event is reportinle $\triangle \mathrm{DOE}$ (in wecordence with DOE Order 5000.3B, Oceurrence Reporting and Processing of Openticns Information) or to obter ropulinary agencies, and idertify corrective actions to provent recurrence of the ovent. The progrem should include the investigation of "ator miss" sintations, thes redicetes the probability of a similar situation recuring as an "actual" becility evert. Abnormel events are not waique th the Tank Farms Optrations organization. Adjitionally, not all everts that affect operation are totally controlled by Operations. Therefore, the gridetines of thit atoment miny hove applicability in other finctionel aress.

The requirements of this elledient may bo found in the Occurrenes Reporting \$yotem

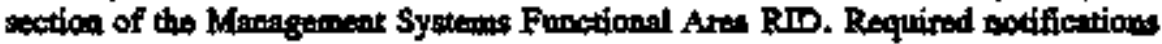
associated with aboormal orents are adtresed in Section 9.7, Netifications, and in DOE

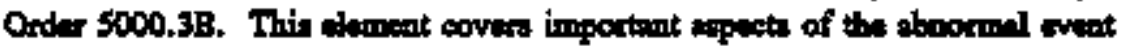
urvertigation program. INPO 84-020 (Good Practico OP-211), Poat-Tip Reviown, and INPO 85-000 Rov, 1, (Good Prection OE-902), Le-Eouse Cperationg Experioder Review, aro exampio programe that can be of eserstence in meting the intent of somo of the guidelines of this olement. This etement interfices with the elemeat of Octurrence

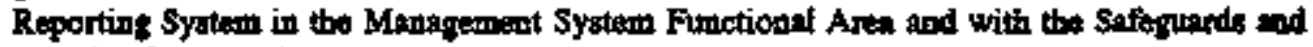
Socurity Fumetional Aret

\section{NOTIFICATIONS}

Timely notification of sits mangemeat, approprimt DOE persomel, and other agencies

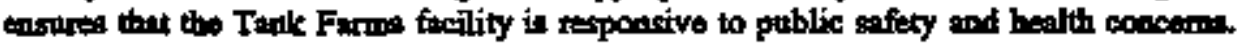
This demest provides gridelines to ensure uniformity, efficieacy, and thoroughanes of these notifintions to wet requirements that to consistent with DOE 5000.3A. INPO 84-021 (Good Prestice OP.204), Conduct of Operations, is th exsangle program that on be of assistence in meeting the intent of the guidelines of this element. This thement 


\section{REQUIREMENTS IDENTIFICATION DOCUMENT HIGH LEVEL WASTE STORAGE TANK FARMS \\ Operations \\ Resrision}

interfines with eleaneat of Oceurnice Reporting System in the Mamagement Systems

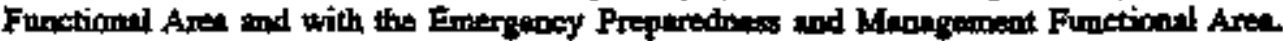

Nontification Procesilures

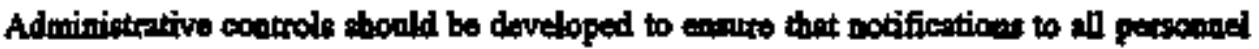

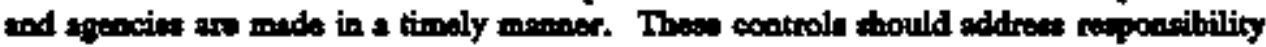

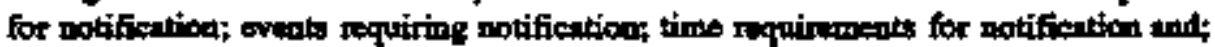
recond leeping requirements.

\section{SITE REQUUREMENT SOURCE: DOE5480.19 Chapter VI, Section C.1}

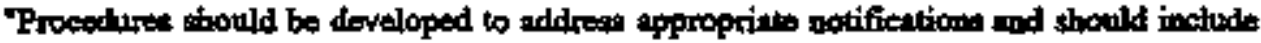
tho following olendits:

a. Specific repponsibilities for actifications;

b. Identification of events and contitions requiring natifications;

c. Ideotification of primary and altemate personnel to be notified for vertous situations;

d. Establishment of tims requirements for notiffentions that are with the fectity emergency pisin; ind

c. Detinition of recordkepping requirements that documorats the resson for notifications, the time of notificatiogen, and the persen notified."

Notfication Responsibility

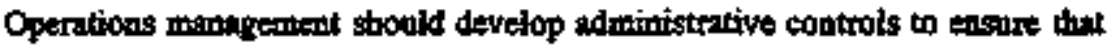
abontmol ovente are classified and totifications are minto to all agencies and individurala in a timeily monos.

\section{SITE REQUTREMEN SOURCE; DOE5480.19 Chtpter VII, Sefitan C.2}

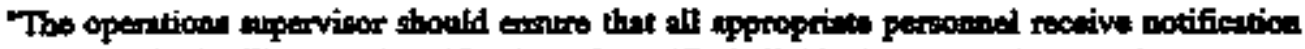
when required. The metul notifiention of eperific individants or epencies may bo scoormlished by other individusls."

Names and Phone Numbers

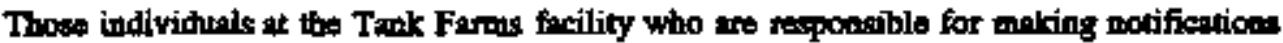
should bo provided with an up to date listing of all reguired names and phose wambers in order to ensone the timeliness and accuracy of notifientions.

\section{STIE REOUIREMENT SOURCE: DOE5480.19 Chapter VII, Section C.3}

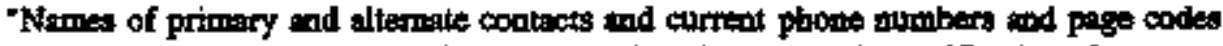
strould be readily available to the peeson assigned to make the ootifications." 


\section{REQUIREMENTS IDENTIFTCATION DOCUMENT HIGH LEVEL WASTE STORAGE TANK FARMS Operations \\ Rerision 0}

2.7.4 Donumentation

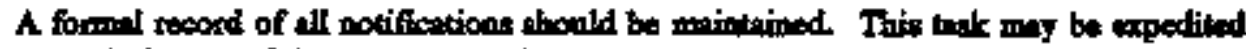
through the use of fill-ide-bo-blenix forms developed prior to need.

\section{STIE REQUREMENT SOURCE: DOE5480.19 Chapter VI, Section C.4}

"All notifications ahould be documented. Fill-in-the-blanic formen for differtat types of situtions might be useful as a chectlist and for providing necesesry docamentation, in ay conse, a tormal record of antifications sbould be mintained."

27.5 Commonication. Equipents

Tanic Farms insnggement should ensure that didequits commmrications equipuent is provided and minteined in en operabis concition to sappors operations activities.

\section{STIE REQUIREMENT SOURCE; DOE\$480.19 Chipter VI, Section C.5}

"Adequato commanicetion equipment should be maintaired in the mein control eree to met the oljectives of this cintert."

\section{CONTROL OF EQUTPMENT AND SYSTEM STATUS}

Good operating disciplioe will ensure that the Tmk Farms tacility and process . configutation is maintained in aceordance with design roquirements, and will ensore that tho optrating steff kaows the stanes of the focility, process equipmint, and syocem

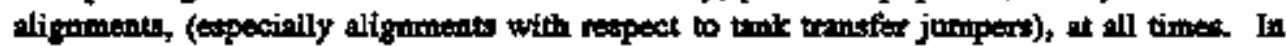
addition, confiptration monagement should be applied in the administration of projects, ativities, frilities, systems, equipment, and softworte which ment the criterit for conflguration monagement applicebility as tiscoussed in the Configuration Maragerneat Functional Area. Specific applications of equipment control are addresed below in Section 9.9. Lockort/Tagouts; Section 9.10, Independent Verifiention; Section 9.11, Log Keoping; and Section 9.12, Operstions Sthift Turnover. This tement provides an overall

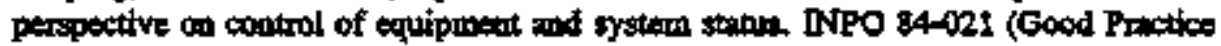

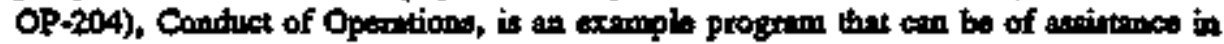
metiog the intent of some of the guideliped of this elemant.

\section{Operations, Testine, and Status Change. Avthorization and Reportins}

Tho Trak Farms Shift Mannger should be aware of the stwus of all gystems and

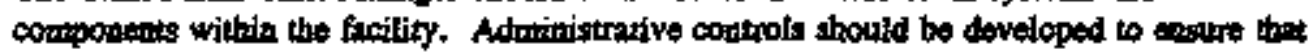
the Shit Manager tither personally anthorizes equipment opecations and configurstion

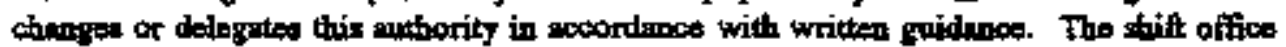
should be the focal point of system operitions, apd controls stould be in pluce wo ensore that all indivining maling system or component line-up or status changes maks the thift office mwere of their ectivities. The 242-A Evepontor Control Rocm should be the focel poirt of oraportar operetions, and controls should be in place to ersure thet all individuals raking system of componeat lins-up $\alpha$ staths changsed make the shift sopervisor aware of their wetivities. All porsonnel peforming equipment of system testing should be thoroughly knowledpetite of the teatiog poucedures and the overall intent of the test. 


\section{REQUTREMENTS DENTIFICATION DOCUMENT HIGE LEVEL WASTE STORAGE TANK FARMS \\ Operations \\ Revision 0}

STTE REQUIREMENT SOURCE: DOE5480.19 Chapter VIII, Section C.1

The operations supervieor it rerpontiblo for meintainins proper configuratica and shooid

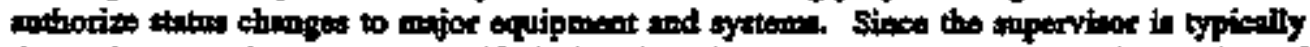

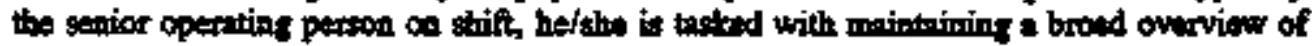
freility operations. His/her perspective of stents mes necoesorily be the focal point of shift oputition.

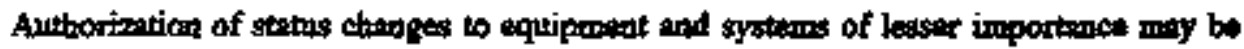
delegated by the operations supervisor to other cogaizant shift positions. For exrmple, ndwaste operations may be aspigned to 2 modwaste cpentor of to a foremen who

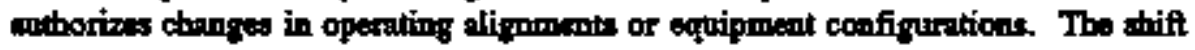

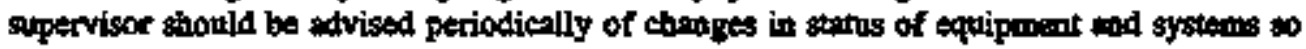
assigned.

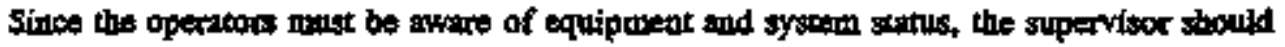
ensure that all changes in status aro communicated to these persons. Typically, the control eree opentor is in the line-of-information flow to and from the supervisor.

Covoges in the stinus of farility equipment and systems should be reported to the governing slations (0.g., control area) or to the individus (or his relief) who mothorized the cbange. Typically, chenges in status of sufety- related equipment and systems should be anthorized by the supervisor and reported to the cantrol arte-

\section{FACILITY REQUIREMENT SOURCE: INPO-85-015 TC.6.Z}

"All participants in a test ane thoroughly briefed as to their duties and the inteat of the to."

\subsubsection{Equinment and Sxaten Aliponment}

Tank Farms operating procedures stiould reçuire that approved aligmmeat chectlists be completed, reviewed, and approved prior to placing expipment and systems into operation.

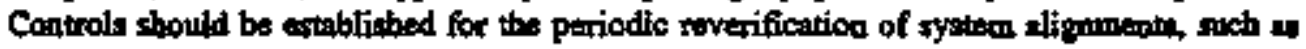
following major mintenance tectivities.

\section{SITE REQUIREMGNI SOURCE: DOES480.19 Chapter VII, Section C.2}

"Prior to firs pilacing the equipment or systom into operation, individurl componenter for ficility equipment and systems shonld be properly aligned or chectred for proper

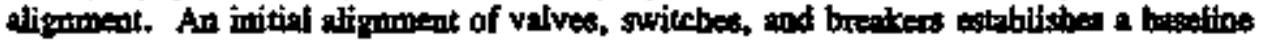
configuration aptinss whith further operations moy bo measured. Once the equipionen of system is propery aligned and is operating in acondance with operating procedures,

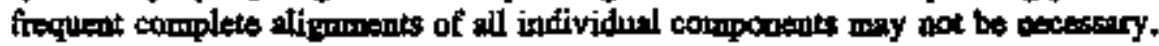
Aligument dreckliste should bo used to grido the operator in esteblisting the correct component positions. The alignment chectilists should inchude provisions for exuipment

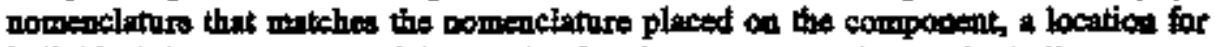
intividual documestation of the checte of each component, the roptired alizmente position for ench component, and a location for annotating devintions from the reciuired alipment.

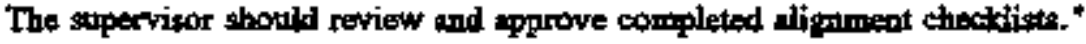




\section{REQUIREMENTS IDENTIFICATION DOCUMENT mGGH LEVEL WASTE STORAGE TANK FARMS \\ Operations \\ Revision 0}

Equiponent Locking and Tagsing

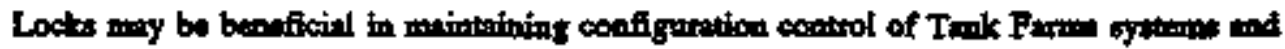
components. The wo of locking doviess should be administratively controlled and shonld

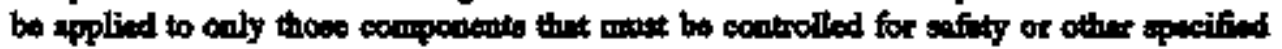

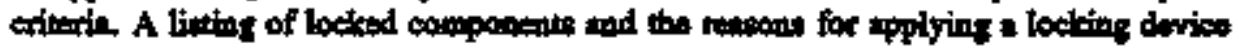

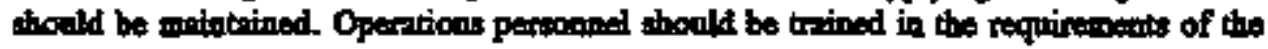

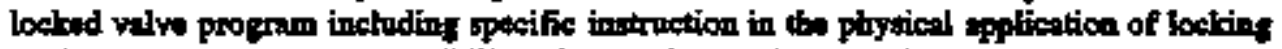

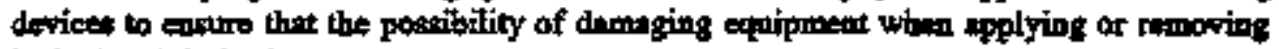
locks is minimized.

\section{SUTE REQURREMENT SOURCT: DOES480.19 Chapter VII, Section C.3}

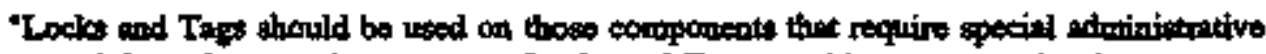

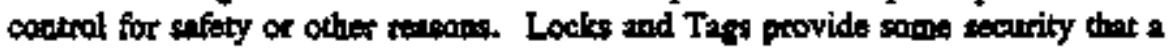
component will bo opested oaly by wthorized tacility personnol performing required ovolutions in a controlled fashion. Additionally, Loch and Tags should alent the operimar of the importence of the componeat and remind him/ber that special controls ovar reposittoning are to bo mintained. In this respect, all parsomed should recsive training regarding their rosponsibitities conoeraing the menipulation of locked or thged controls."

\section{Operational Limits Compliance (TSRs)}

The Trak Farms Shif Manager should be cognizans of all Ereties into limiting conditions for operations. Admidistritive controls stould be exabliabed to require that entries into limiting conditions for operation are documented. Additionally, documedatation of actions boled to comply with the requiremeats of the attion statements should be required. Additionel administrative controls should be establistod to ensure thet all performentes

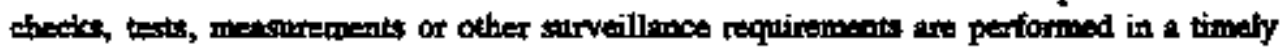
manter.

\section{EACIITY REQULREMENT SOURCE: DOE/EHO135 AX.8}

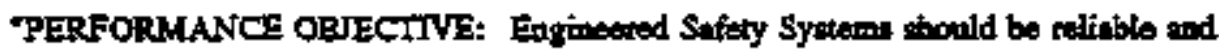
avialable to provide protection to die fecility whed requined."

\section{BACILITY REQULREMENT SOURCE: DOEJGH0135 AX.8.1}

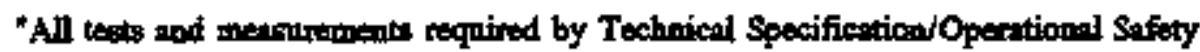
Requirements are mode in 1 timely manmer and in accordence with opecified Surveillonea Requirements."

\section{FACILITY REQUIREMENT SOURCE! DOE/GE0135 AX.8.4}

"Start-on-demend syatems aro periodieally checked for pertiormance, mod reconds of the results mointeinges. 


\section{REQUIREMINTS IDENITICATION DOCUMENT HIGH LEVEL WASTE STORAGE TANK FARMS \\ Operations \\ Reristion 0}

FACILITY REQUIREMANT SOURCE: DOE/EH0135 AX.8.5

Monitoring and testa ere provided to give wartititg of pending failure of continuondy operting systeme. *

FACHITY REOUIRTMENT SOURCs: DOE5480.19 Chapter VII, Section C.4

"Admimintrativs costrols sbould be established to docursent complinace with requirsments of operational limits (limfting conditions for oparation). The operations supervisor siould

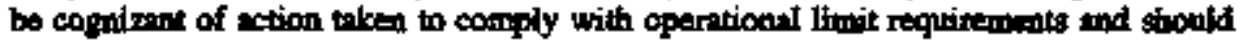

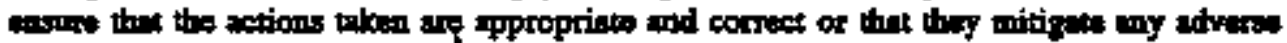
consequences to the facility. Loos, stetus sheets, turover checklists, of other ypropilate documentation should reflect the entry conditions and actions that are baken in respones to opentioned limixs requirements. Appropriese operating personnel should be upprised of limiting cooditions for operations and actions for which they moy bo responsible. Responsible persouned should periodicarly review the linsting conditions for operation and action stetements in effect to ensure thor the required actions are met"

Equipment Defictency Identification and Documentation

A formal systern enable Tank Farms personod to ideatify and report equipmant

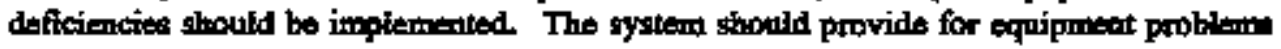
to be reported to operstions personed and identified in the worit controi progrim for rasolution.

\section{SITE REQUIREMIINT SOURCE: DOES480.19 Chapter VIII, Section C.S}

"Equipanent deficieaties should bo roted by facility operating personnel and identified in the work control system for correction. Methods that identify deffelent equipment to

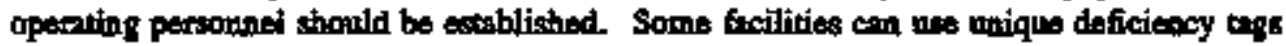
to identify equipuent problems. Others may use logs, stahus sheets, shift turnover stiecth,

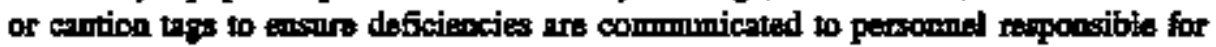
monitoring tod operating the equiptorent."

Fork Authorization and Documentation

All entivities, inchuding mointenamce, thet involve operetions, indications, or alarms importunt to safory should be anthorized in writing by the Tenk Ferms Shift Manager. To ensore that mo ambigrity existis, the shift

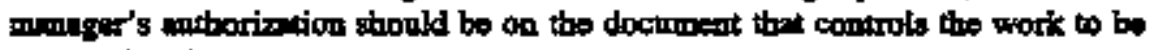
menomplished.

\section{SIIE REQUREMINT SOURCE: DOE\$490.19 Chnpter VII, Section C.6}

The operations supervisor or hisher designes should authorizo ill shift activities

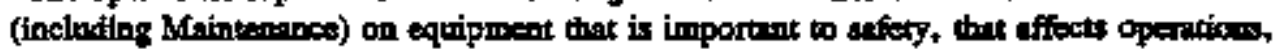

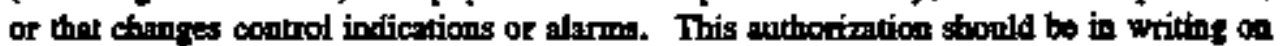
the documbert comtrolling the wiot. Doctimeatation of the stutus of work in progres sboald be rvilabie in the control area for roview by operationg persomel. These activitien

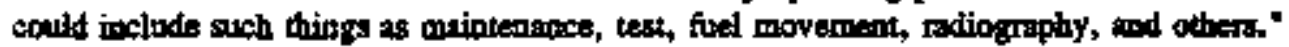




\section{REQUIREMENTS IDENTIFICATION DOCUMENT HIGH LEVEL WASTE STORAGE TANK FARMS Operations Revision 0}

\section{Equipment Post-Mainten:ance Testing and Retuen to Serrice}

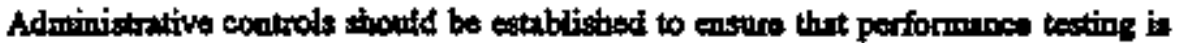

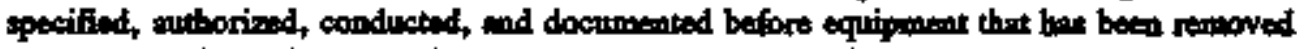

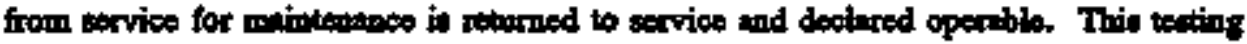

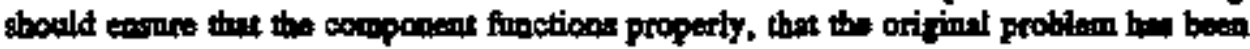

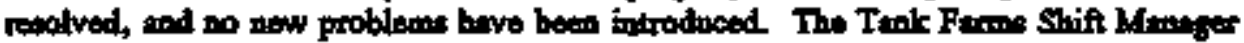
should tpprove all equipment petom to service nuthorizations.

\section{SIrE REQUIREMANT SOURCE: DOES480.19 Chapter VII, Section C.7}

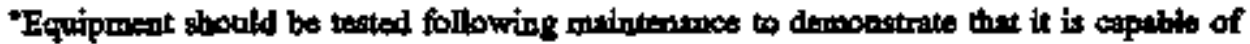
performing its intended function. The testing shocld include performence of all functions

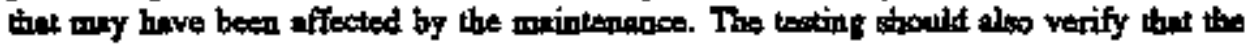
minitentuce performed served to correct the original problem and the no new probiens

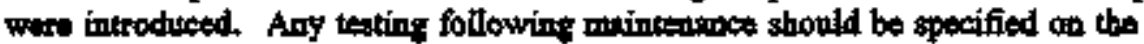

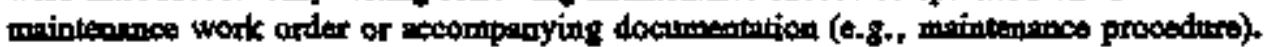
The operations sepervisor should ensure that testing sppropriately proves equipment optrabilfty."

\section{Alarm Status}

Intormation regarding the stoms of both control room and remote pand aferms should be aviilable to Tank Farms operations personnel. This information should include ctanges mado to setpoints, disabled alarms, alarms that are normelly lighted during normal

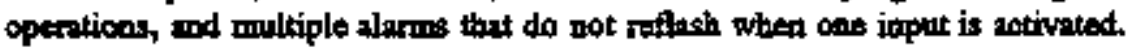

\section{SITE REQURREbENT SOURCE: DOES480.19 Chaptar VII, Section C.8}

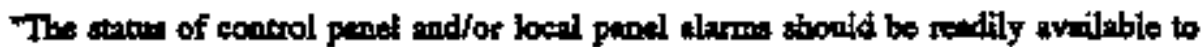
sppropriato operating persomet. Informition that should be svallablo incthedes slarms the

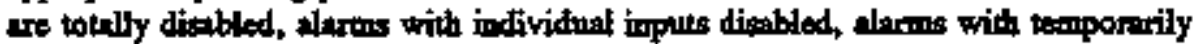
chuged setpoints, alerms thot are normally lightod durins power cpention, and moltiplo

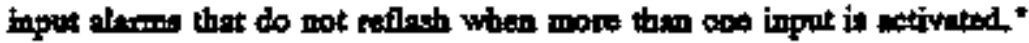

\section{Temporans Modification C Control}

A program should be ootablisted for the controi of all temporary modificationas to any

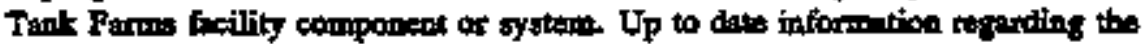
iderification, installation, and pupose of all temporiry modifications should be wavilable to operations personnal in the control aret Cloar definition stould be provided an to whet

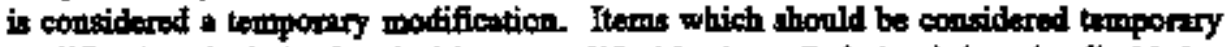
modifition include eloctrical jumpers, lifted loads, pullod sirctit boards, disabled

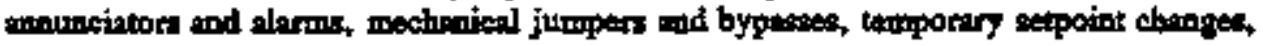
installed or removed block findges, disabled relitef or safely valves, installed or removed filters or striness, phegged floor drains, and temporary pipe sopports. Controls applied should inelude safety revisws, idstullation approvell, inderendent verification of correct installation and removal, updots of operating procedures, trining, marking of indtelled terporary modifications, and periodic audits of outstanding temporary modificontions. 


\section{REQUIREMENTS IDENTIFLCATION DOCUMENT HIGH LEVEL WASTE STORAGE TANK FARMS Operations \\ Revision 0}

SIIE REQUIREMENT SOURCE: DOE 3490.19 Chapter VIl, Section C.

"Administrative costrol systems hould be extablisbed for installation of tomponary

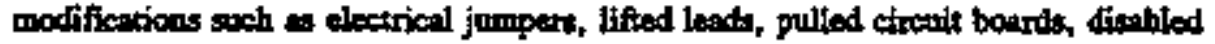
monnciutortalams, mehanical jumpers/bypastes, temporary sepoint chapges, installed

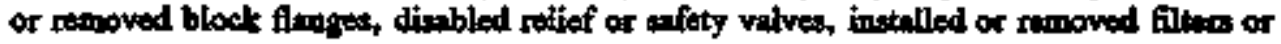
striness, plugged floor dratas, and besporary pipe supperts. Paior to modiffication, these controls stould provide for communicating the installation of temponty modifientions to the desigen authortty to allow for texbrical oversight and in ovaluntion of tho impont on eurrent desiph metivities, and approval of the design modification. These control syatem

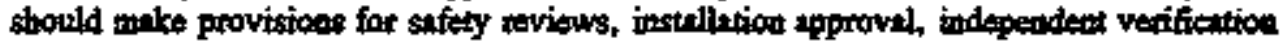

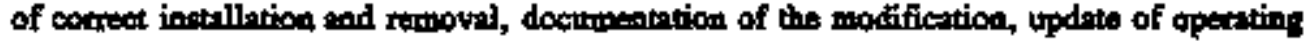
procedures and documerts, inining, marting of instled modifications, and periodis mecitz of cutstading modifications."

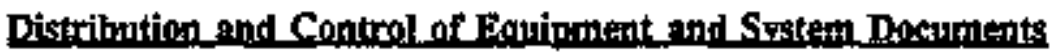

Adulnistrative codtrols shoulf be establisted to ensire that Tank Farme optrations persomelel are provided with and use the latest revision of eaginecring drawings and specifications ind art mido eware of all changes to these documents.

\section{FACILITY REQUIREMENY SOURCE: DOES480.19 Chapter VII, Section C.10}

-A system should be extablished to ensure that the apentions personnel receive and utilize the tatest revisiens of expineering drawings and specifications. Operetions pesangel should be made aware of all clanges to these documents. The doctment distribution should include all operetions related activities such as procedures review grouph, muinterance groups, facitity sefery anglysis groups, agd testing groups,"

\subsubsection{New Construction or Modification}

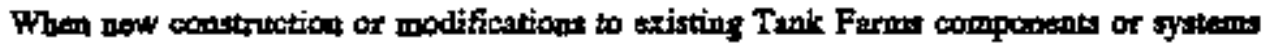

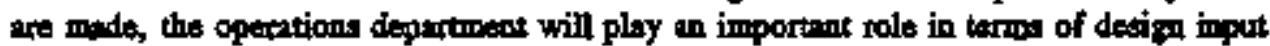

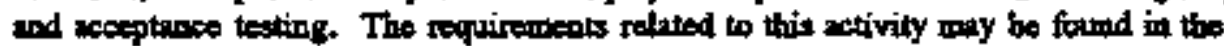
Confipurition Menagrement Functionsl Area RID.

\section{LOCKOUTS AND TAGOUTS}

An administrative control propram should be established to neduce the potential for personal injury and equipment damage during operations, modification, or maintenence wetivities dine to the inadvertent operition on activation of Tank Fardis equipisent. The Tank Farms Lockout Tagout program sbowit provide for control of equipment through composent theying or locking to grevent persoarel injury; protest equipment fiom demige; meintin the opernbility of plent systems and; orintrin the incegrity of the tecitity's ptyysical boumbaries.

\section{Lockout and Tagout Use}

The lockont/tagout program should be teed whenever controls such as valves or switches neted to be controlled for eitber the protoction of pescopnel or for special adminietritive 


\section{REQUIREMENTS DENTIFICATION DOCUMENT \\ HIGH LEVEL WASTE STORAGE TANK FARMS \\ Operations \\ Rerision 0}

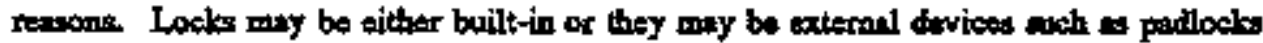
and chrins. Taga should be placed as close to tho control that is to be tasged out at posibito to avoid confunion.

\section{STIE REQUIREMENT SOURCE: DOES480.19 Chapter IX, Section C.t}

"Locks end Tegs should be pleced on controle when for stefty or other speciol administrative resosons controls wust be eatoblisted. Tags should be placed on the coibtrol that is tagged out, or as elose as possible to indicate cienriy the condition."

\section{Lodkout and Tagout Inolementation}

Control of equipment for personpel of equipment sefey should be by lockout witere possiblo or at a minimum by tagout. In either case the controls stould be applied by athorized and qualfified Tant Farms operations persomel.

\section{SIIE REQUREMENT SOURCE: DOES480.19 Chapter IX, Section C.I1}

"Locison of Tagout should only be aceomplisbed by atthorized, qualified personired."

\section{STE REQUREMTENT SOURCE: DOE5480.19 Chapter LX, Section C.2}

-2. If 2 device (e. 2., for energy or toxic material isolation) has the capability of being locked out, it shouild be locked out.

b. If the isoiating device cannot be locked out, it should be tagged out

c. Now equipment design and major aroxiffcations to existing equipwent should be designed to provide the enpability of being locked out.

d. The following administritive guidince is in expmple that could be establisbed to outtine metepteble centrots over locked compoxants:

(1) A list of components that are required to be locted should be extublished end approved by the operations sepervisor or eppropriate moniager. The lise sbonle be separate firom the standand aligarpent cheovelists.

(2) Criterie for locking of alditional componests tad mocessery authorizations should be provided.

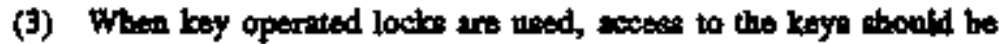
restricted to authorized personnel. Keys stoutd be readily aviulable to appropriats personnal.

(4) Specific techniques for verifying the position of locked compouents should be equthisisbed. A bands-on physical chelt of critical equipment or the otservation of 2 reliablo position indicator should be used whenever possibles.

(9) When locked components must be unlocked of placed in a porition 


\section{REQUIREMENTS IENTHCATON DOCUMONT \\ HIGH LEVEL WASTE STORAGE TANK FARMS \\ Operations \\ Rerision o}

other than the normal locked position, the deviation should be athorized and cocumealed.

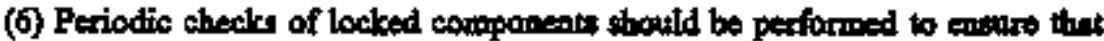

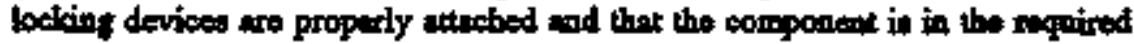
pocition."

\section{FACIIIT REQUIRMMEAT SOURCE INPO-85-017 Chipter X, Sectlon C.11}

\section{"Clearance Tag Audits}

Tagouts should be administratively reviewed at bast monthiy. This review verifies the

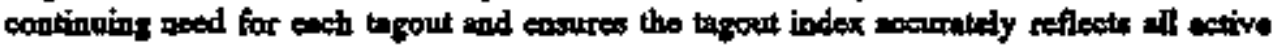

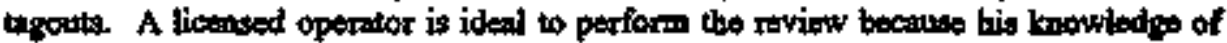
system and equipmeent might bs necessary to eccuracely ofulusto the continuins need for a ugout. Input from the clearance togout hoider should be solisited at aeeded. This neview stoold be documented.

An audit of rendomly selected bogs ind tagouts abould be performed it lent quarterly. All tage should be checked at least annully, and in eomplete audit of all tags stoold be conducted paior to stant-sp from extended outoges. Antits should inelede the following checkes:

- proper placement of each tag

o proper poxition of tagged equipment

- eccuncy, completraess, and legibility of information on tags and tagoot sheets

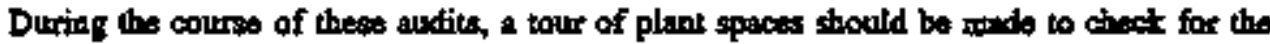
presence of unautborized tags, superseded taga, mil tags for which no recondi exista. These togs should be investigated and either renoved (with concurreace of the indiviount for whom the compoente was tagged, if applicable) or auborized, whichever is appoptiate.

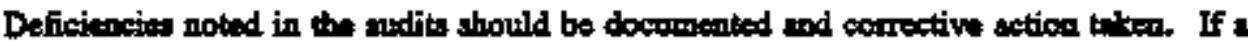

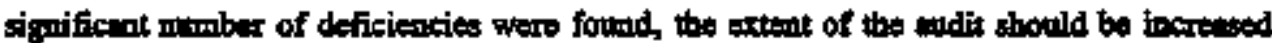

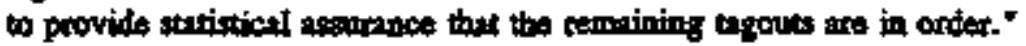

\section{Protective Materials and Fardware}

The mutrials and equipment used for agout and lockout of equiptorat within the Tanik Firms facility should be diverse in novare, as aeceasary to ensore application to the diverse equipment instalfed within the ficility. The materials and expupureat used thould be durable, standerdizac (at least with regard to color, shape, or sixe) in order to provide

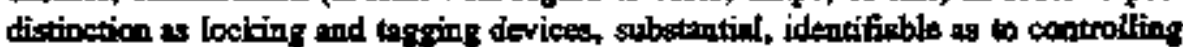

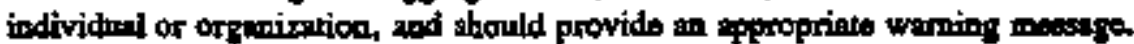




\section{REQUIREMENTS IDENTIFICATION DOCUMENT HIGH LEVEL WASTE STORAGE TANK FARMS Operations \\ Rerision 4}

\section{SIIE REQUIREMENT SOURCE: DOE5480.19 Chapter IX, Section C.3}

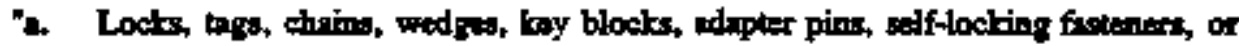

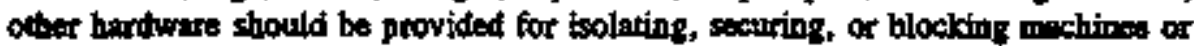
equipmene from energy sources.

b. Locionut and Tagour devices should be singuindy identified (i.e., should be the only devices used for coatrolfing tongy and should aot used for othet purposes) and thould metk the following requirements;

(1) Durable

(2) Stondirdized

(9) Substantía

(4) Identifiable

(S) Waming"

Lockput and Tapout Prouram

The Tant Ferms lockout and agout program should consist of admintistrative controls procedures that esteblish positive control of exerty soturies and that provide for tho trining and qualifiction of operators to perform tagonts and tockoxte.

\section{SITE REQUIREMENT SOURCE: DOES480.19 Chapter LX, Section C.4}

"A Lockout/Tagous program stould be established consisting of procedures to coatrol potentiafly batardous ecergy and materials and personnel training. This program should engure that potentially hasartous energy or toxic material sources aro isolated and readered inoperntive during servising or maintenance or in eny case where unexpected energizing, stertip, or release of stand entrgy or toxic material cen tonse injury."

\section{Brocedures For Lockout and Tagout}

Administrative controls should clearly stote the scope,purpose, enthorization, nulex, and techniques of the Lockout/Tagous propram for Tank Farms. Additionally, requiremens for docimentation of the appliestion and removal of tagouts and lockouss should be etablisted. This doenmentation stould normally be maintined in the control aree and stould be approved by the Sthift Mannger.

\section{SITE REQUIREMENT SOURCE: DOE5480.19 Chapter IX, Section C.5}

"Procedures should be developed, doctmented, validated, and ubilized for control of potentially haxridous enercy or material. Procedures should clearly and spectifienlly trits

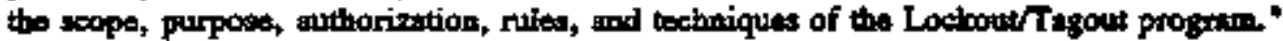

\section{SITE REQURREMENT SOURCE: DOE5430.19 Chapter LX, Section C.5.2}

-2. Procedures sbould inciude, but aot be limited to, the following:

(1) Specific statement of intent of use; 


\section{REQUIREMENTS IDENTIFICATION DOCUMENT \\ HIGH LEVEL WASTE STORAGE TANK FARMS \\ Operations \\ Rerision}

(2) Specific procedural steps for isoleting, blockinte xad seurime mechines or equipment for hrourdess energy or material;

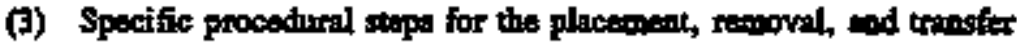
of the Lockot/Tasout dovice(s); and

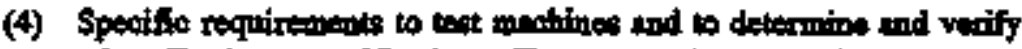
the effectivenos of Lockout, Tegout or other ecutrol menoure.

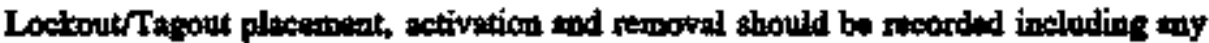

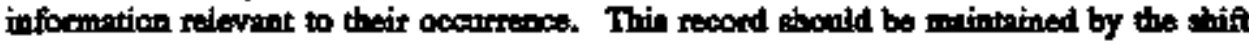

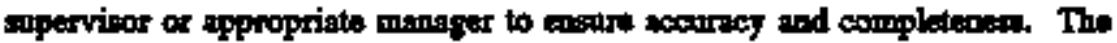

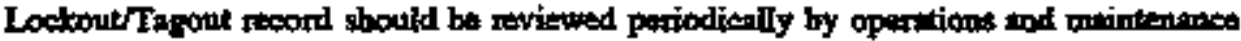
pesconiel as gridance."

\section{SIE REQUIREMENT SOURCE: DOR5480.19 Chapter IX, Setion C.5.c}

"Lockout/Tagout plocemeat, activation and removal should be reordect inciudiog any

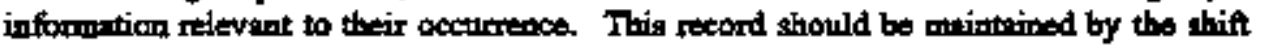
supervisor of appropriate mannger to ensure accuracy and completeossa. The Lostout Tapout record shouid be reviewed periodjeally by operations and mainteanen persomed is guidutuce."

\section{Application of Lockone and Tazout}

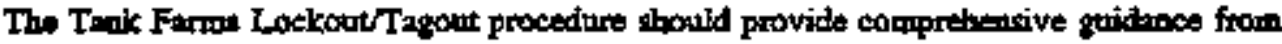
applieation to redease of the fagous/lockout. Elestrents that should be inciuded in the

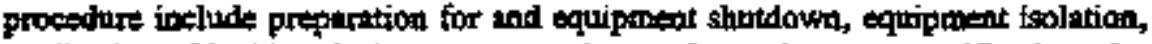
application of locking devices of bags, release of stored energy, verification of correcs instellation, approvit to ralesse, and retpovil of the tapcout/ocibout devioes.

\section{SIIE REQUIREMENTI SOURCE: DOES484.19 Chapter DX, Section C.6}

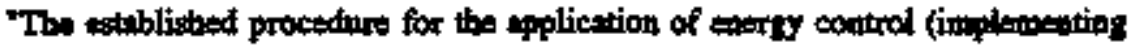
LocksoutTagour) shoutd cover the slements and actions in the following sequences

2. Preparation for Shetdown

b. Mrestins or Equipment Shutdown

c. Equipment Isolation

d. Affixing Locks Tress

c Stored Energy

f. Verification of Installation

g. Relonse from LockoutTagous

(1) Equipment/woraspact

(2) Persol

(j) Loekout/Tagout Device Removai" 


\section{REQUTREMENTS IDENTIFICATION DOCUMENT HIGH LEVEL WASTE STORAGE TANK FARMS \\ Operations \\ Rerivion 9}

\section{STTE REQUREMENT SOURCE: DOES480.19 Chapte $\mathrm{XX}$, Section C.6.9(3), Paragraph 2}

When the person who applied the Lockout/Tagout devico is not ividlable to remove it,

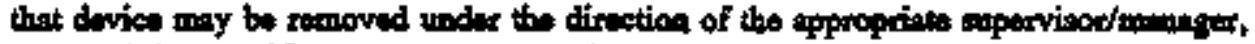

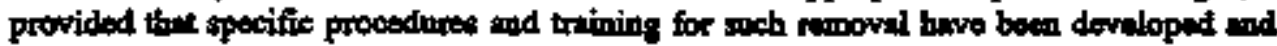

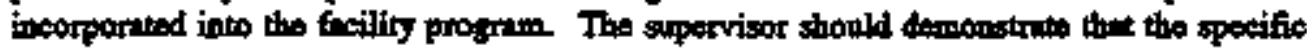
prococture provides equivalent seffaty to the reenovyl of the device by the authorized parsonnol who spplied it.

The specifie procedore should inctudo the following elements

- Verification by tha supervisor/minager that the person who applied the devied in ant avainahle.

- Acsurisece that ail reasonable efforts are made to inform him/her that the derice hes been removed.

- Enguring that all relevant personned have this knowledge before bejste resumes work at the factlity."

\section{Testing oc Positionint of Egnipment or Combonents}

Tank Farms operations management should discourage the temporary removal of locks and trgs. Howover, procedures should be developed to provide for the specific sequence of ovents to be followed in the event a cemponry lock or tap removal is requined. These procesiures should require applictition of the same controls associated with normel removal and tertorition of trogs.

\section{STTE REQUUREMENT SOURCE: DOE5480.19 Chapter LX, Section C.7}

"Temporsty removal of Lockoutragout devices should be disecuraged. However,

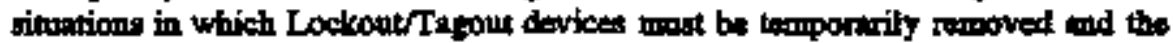
equipuent entrized, the failowing sequence of operations thould be followed:

- Clese the equipinane of tools and materinls.

b. Remove persomed from the e्याipment area.

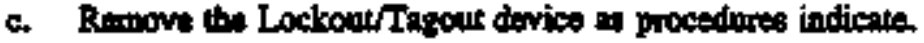

4 Energizan and procesd with testing or positioning.

4. De-energizo all systems and reapply the lockoutitagout."

\section{FACILITY REQUIREMENT SOURCE: NPO 85-017 Chapter IX, Section C.10}

Temporty Romoval of Cleapuce Taps Tzes may be temporacily removed for teatidg or

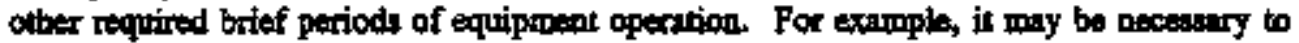
remove of replace a beg severd timos when bolencins rotating mochinary. Temporry

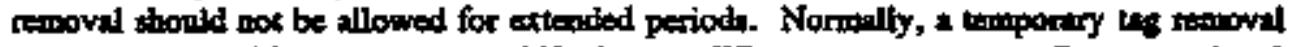
should sot exteat beyoud be next shift change. When tags are temporarily romoved and placed, the seme controls ssbociated with nonmal removel and piecement of tags thould bo

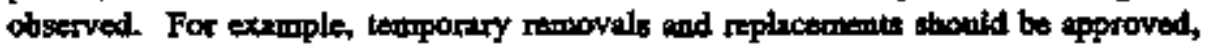




\section{REQUREMTENTS DENTIFICATION DOCUMENT HIGH LEVEL WASTE STORAGE TANK FARMS \\ Operations \\ Rerision 0}

documanted, and vertified in a moroner simifar to those actions for initial teg placement and fimel ratovovil."

2.9.8 Periodic Inspection

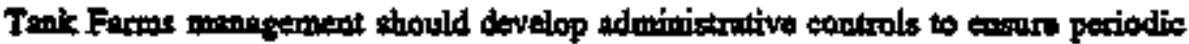

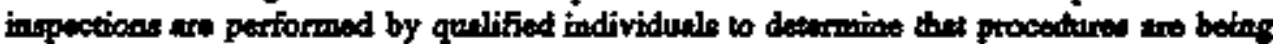

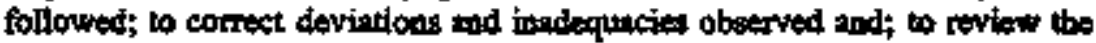
responsibilities of supervisors and other operztions personel.

\section{SIIE REQUIREMENT SOURCE: DOES4\$0.19 Chapter DX, Seetion C.8}

Ptriodic inspections stould be sooducted by muthorized persomel, stpervisor, or appropriate managr, to deternine whether procedures art being followed and is correct any deviations or inadequacies observed. Inspections should includs a noviow of the responsibititied of personnet and stpervisors. The supervisor of sppropriate mantst should certify that the periodic inspectione have been performed, docamenting the equiponeat and procedunes invoived, dates of inspeetion, personsel participaring in the inspections, and personnel performing the inspections."

\section{Administrative Contron Tas}

Use of administrative control taps (crution tags) should be limited to kagging sibution that do not eall for personnel prodection. These togg dhould be used when 1 component of system is functionsl but, some presaution or information necessary for operation needs to bo communicated. Manageanent should administer the cention tag program using procedares similiar to thoes used for the Tagout/Lockout propram.

\section{FACIIIY REQULEMENT SOURCE: DOES480.19 Chapter 1, Section X.C.9.a}

-Coution tage shotld be unicuely identifiable and different in appestrince from ober station tage. The following infornution should bo included on tho tages an an aid in adminintering tho program

(1) crution tas marrber:

(2) coumporat name and number,

(3) effictive date;

(4) precoution or information tppliceble to the particalar situation and/or colmoneat or system; and

(5) siguanute of athorizing individual and orgamization.

\section{FACLITY REQUIREMENT SOURCE: DOE5480.19 Chapter I, Section D.C.9.b}

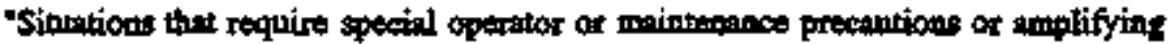
informetion should be brought to the attention of the shift sepervisor or topropriete

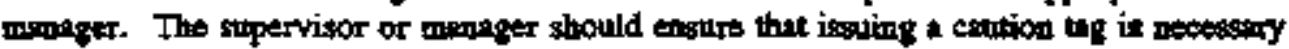
and thet the tag is not being used in place of more approprinte administretive sction (such as a temporary procecture change, placing an operator rido, use of the wott control systerd, or issuance of a safety Lockeut or Tagout). The supervisor neview should also 


\section{REQUIREMENTS IDENTIFICATION DOCUMENT HIGH LEVEL WASTE STORAGE TANK FARMS \\ Operations \\ Rerision *}

ensure that any instruction contaited in the ceuttion tog does not devith from established fucility procedures, technical specifietion s, or OSR's."

\section{FACIIITY REQUIREMENT SOURCE: DOL5490.19 Chapter I, Section X.C.9.c}

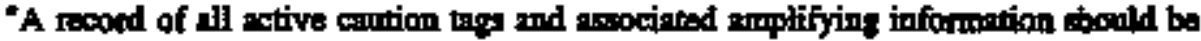

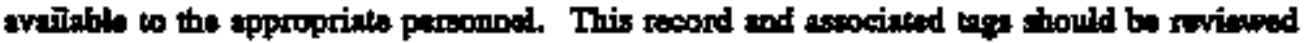

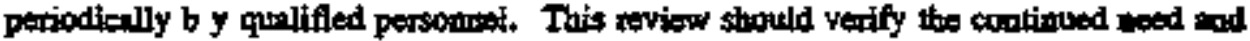

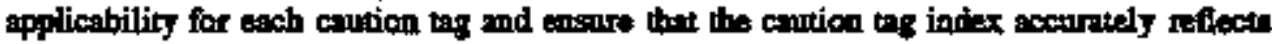
ail setive cantion tugs. This reviow should be documented. Any cuation taps remeining i i

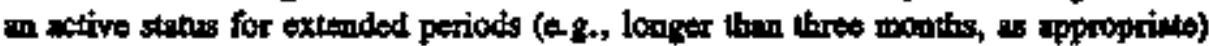
should bo brought to the attedtion of the cpecotions supsisor or maneger. The operations sapervisor or manager shouls determine what extion is netded to resolve the continued use of the cantion lug."

\section{FACFITY REQUIREMENT SOURCE: DOES480.19 Chapter I, Sectlon X.C.9.d}

"Cnution ags sthould be placed in such a way that thoy do not interfere with or abecure indications, switches, or other control devices but are reodily apparent on an iscividanl prior to be operztion of the taeged device. Placentent of caution ing thould be iocumented.

\section{SITE REQUIREMIENT SOURCE: DO154\$0.19 Chapter IX, Section C.9}

"Cantion tops should mox he used for personmel protection (i.e., cention tapa shoceld not bo used whers it is appropriats to use a Lockout or Tagout devise). Administration of cention

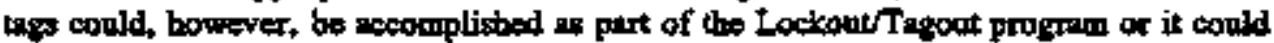
bo covered spparately. The use of contion tags should be reatricted to those sinnations in which a componeat or system is fimctional, but when some presaution of itams (3) of information is necessary prior to operation."

\section{Training and Communication}

Trining and periodic retrining shoold be provided to ensure that all personed who ane

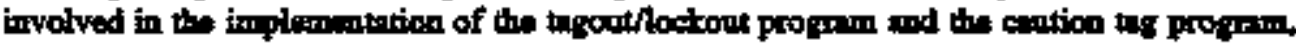

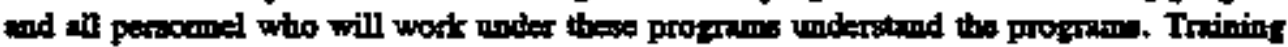

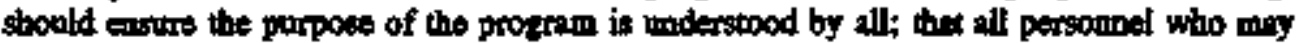

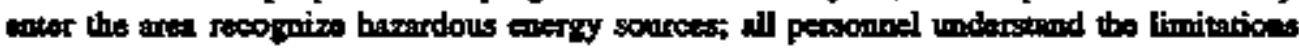

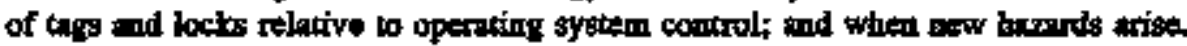

\section{STIE REQUIREMINT SOURCE: DOE5480.19 Chaptex DX, Seetion C.10}

"2. Triming sbould be provided ard documented to ensere thot the purpose and function of the Lockout/Tagout progrom is understood by all persocmed and then they heve the knowledge and stitls ropatired for safe appitication, use, and rewoval of Loctouts and Tagouss.

Training should irchude the following: 


\section{REQUIREMIENTS IDENTFICATION DOCUMENT \\ HIGH LEVEL WASTE STORAGE TANK FARMS \\ Operations \\ Rerision 0}

(1) Reeoppition of appliesble hazardous exergy sources, type and mepritad of entory or miterials irvolved med methods to isolate end control.

(2) Perofond involved stould be instructed in the puppose and use of the Lockont/Tagout procedurses.

(3) All persomel who may onter the ares should be troined to recopmize the Lockout Tagout and to understand the procedure and probibition colating to attompte to rectert of to-edergize machive or equipowert"

STZE REQUHREMENY SOURCE: DOE5480.19 Chapter IX, Section

"b. Whet Tagont systems are used, personnel should bo traired in the limitations of tages

(1) Taga ane essentially warning devices and do ook provide pbysical restrint on those devies as are provided by a lock

(2) When a Tag is attached, it is not to bn rewoved without antborization of the person responsitite for it, it should not be bypased, ipsored, of otherwise defeated.

(3) Taga tmust be legible and underskandabie by all personnet.

(4) Tags and their meand of atrachment shouid be able to withatand the exvirumental conditions encountered In tho woxiplace.

(5) Taga meg evolk a false sease of security and their mesining needs to be understood.

(6) Tags most be secureily attached so they ctanox bo inndvertenaly or identally tetached during use."

\section{SIIE REQUREMAST SOURC:: DOES480.19 Chapter IX, Section C.10.c}

"c. When Lockout syoterns ate used, persomnel should be traiped in tho limibutious of Locks, especially concenting the following:

(1) Cperation of the fucility may be hinctered (this is sigsificant when local component operations ant nectessery, such as tersocte shettiown or remote control).

(2) Locks and chains installed on small instrument line isolation valvea cen contributo to seismic loeding and may not have been considered during safery angilysis." 


\section{REQUIREMENTS WENTIFICATION DOCUMENT FIGH LEVEL WASTE STORAGE TANK FARMS \\ Operations \\ Rerision 0}

SIIE REQUIREMANT SOURCE: DOE5480.19 Chapter LX, Section C.10.d

"d Recreining shouid be provided for all mathorizat of effected paracomol whenever thers is a change in job, procedures, machipes, equipanent or proceses that present oew hererde of periodic inepextion deternines it is nevied."

20.11 Notifieation of Pereonne-

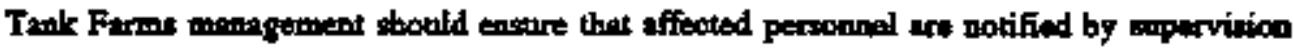
both bafore and after the jemoval of lockouttugout devices.

\section{STTE REQUIREMENT SOCRCE: DOES480.19 Chapter LX, Section C.12}

"A supervisor or appropriate mager should notify affected persomel of the splicotion and ramoval of Lockout/Tagout devies. Notification should be given before the devices art upplied and after they are remored."

\subsubsection{Ontside_Contractors}

Wheo ontside contratetors wark on Tank Furms foilities, both tank forms and the contractor's lockout/tagoul programs should bo commennicated to the other proty. Provisions should be mode for any chenges to either program to be commininicated to the other party.

\section{SIIE REQUIREMETNT SOURCE: DOES480.19 Chapter IX, Sectian C.13}

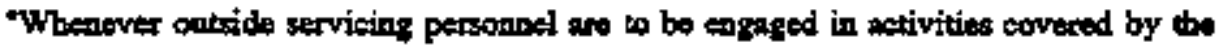
scope of to Lockout/Tagout progrim, the facility and tho outside contrictor shovild inform anch other of their respective Lockout/Tagout procedures and shouid enaure that their persconied are awase of the changes."

Group Lockontg or Tagouss

The Tenik Furms Lockont/Tagort progrem sboitd provide for lockouts and tagouts to be

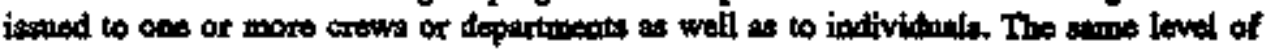

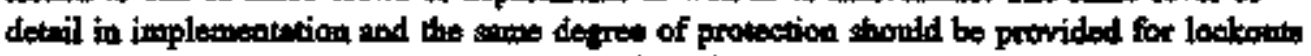
and tugouts issued to orgenizations as those issod to individuals.

\section{SITE REQUIREMINN SOURCE: DOF540.19 Chapter LX, Section C.14}

"When servicting or mointenanco is performed by a ctow, craft, depertment, or other group, they stould utilize e procedure that will provide for equivalent safecy provided by tus personal Locibout or Tagour dovice."

9.9.14 Shin or Personnel Changes

The Tank Farms Lockour/Tagoet program should provide for the orderly transfer of lockout/tegout intormation and devices berween personmed and shitts. 


\section{REQUTREMENTS DENTHFICATION DOCUMENT HIGH LEVEL WASTE STORAGE TANK FARMS \\ Operations \\ Rerition 0}

\section{SHE REQUREMENT SOURCE: DOES480.19 Chapter IX, Section C.15}

"Specific procedurres sthould be utilized during shift of peenonnel chroges to tagure the

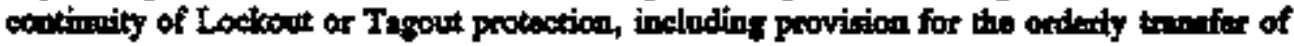

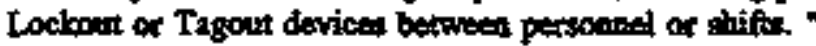

\section{ENDEPINDFNT VERTICATION}

Tant Farm operations should develop and implesnent en independent vatification progrem

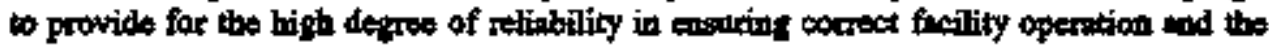
correst pocition of componentes such as valves, pipe jumpes, swiecheo, and cirenit brakens. Independant verifiention in the use of a secoad qualified individual to check that a given opention conforms to establisbed operalional criteris, as well as checking a composent poeition. The second check is performed indepeadeatly of ectivitien related to entablieshing the components position. The Tanl Farm program should provide for the selective application of independent verificution consistent with the impers of the cperation on the safo and affieient operation of the fucility. The cperations menazer should cleariy

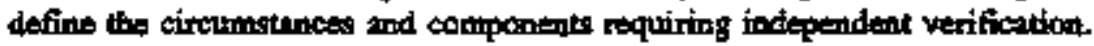

Relatod equipment atatus programs are diseussed in Section 9.7, Control of Equipreant and System Stans and Soction 9.9. Lackouts and Tagoux.

\section{Camponents Requiring Inderendent. Verification}

Indegendent verification sbould be appilied to those tank farms componedts eritictl to engure sefe and reliable operation of the focility. A tist of componstes requirimg indepentent verification should be developed and maintained using acespted sofaty analysis method and/or expert opinion, as approprinte.

\section{FACIITY REQUIREMENT SOURCE: DOE5480.19 Chapter X, Section C.1}

- Componeat that are critical to ensise safe and relinble operation should neceive an

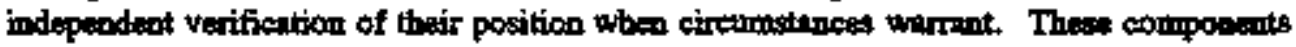
should bo ideatified explikitly in facility procederres or other officint documents so that unecennery interpretation of requirements will be trinimized. In sddition, thin will resalt

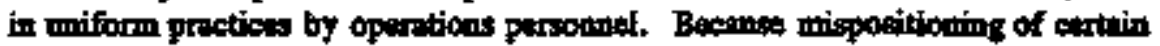

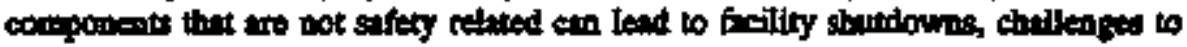
sufery-related equipmeat, or cthes undesirbble effects on feility sofaty and reliability, independent verification sonid not be limiled to safety-nlebed system eomponents. Each

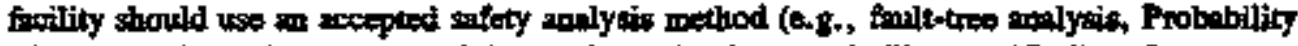
Risk Amlysis) and/or expent opinion to determine its own facility specific list of systems; ad components, which should receive independent verification."

\section{FACIITY REQUIREMENT SOURC:: DOE5480.19 Chapter X, Section C.1.9}

Afl conponents in 8ystems that bave gafery-redated functions should be considered for indepentent verification. 


\section{REQUTREMENTS DENTIFICATION DOCUMENT HIGH LEVEL WASTE STORAGE TANK FARMS \\ Operations \\ Rerision}

\section{FACILITY REQUTREMENT SOURCE: DOES480.19 Chapter X, Section C.1.b}

Independent verifications stould be performed for entwin cormponents that are aok reteted to safey which, if mispostioned, contid lead to moplenned shot- dowris, chnlleoges to stetey syotems, or (through interfaces with safoty- related systeme) ceuce adiontive of toxite montrial relenga."

\section{Occusions Requiring Independent Veriffoation}

Writter guidemes should be provided to assiat operators in determining when to epply the requirements of the indepeodent verification propram. Examples wonld include poior to retuming equipunent to service tollowing manteriages, following surveillance cetivities, and whenever there is doubc in an individuals miod that 2 valve linsump in correct

\section{FACIIITY REQUIREMENT SOURCE: DOE5480.19 Chapter X, Section C.2}

\section{"Ocossions Requiring Indepeadent Verification}

Components sbould recoive indepeadent verification when the equipment they serve muet

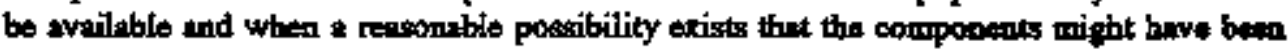
mispositioned. The following gridelines describe situations worre tedependent verifiention would be appropriate:

a. Retarning Equipment to Service Following Maintenance of Testing.

Independent verifications should be performed to ensure that systems are property alizned when equipwent is rearned to service. After maintenonce activities, it is approprioto to verify indepeodently the positions of components that bave been togued to establish an isolition bougdary for tho work.

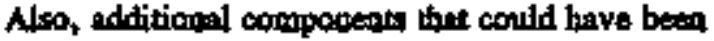
mispositioned during maintennence shonld be selected for verification on a caso-by-cese busis by the individual

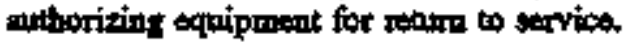

Swch edditional items requirizg verification would iselude any contopodetet(s) that hatt beed worited on and might also include instrument stop valves, bypass valves, switches, and isolation valves located within tho wott houndary.

Failore to properiy sestore gystems forlowing surveitlance testing has restilted in mispositionings. Selected compontents should therefore be independeotly verified during. or after

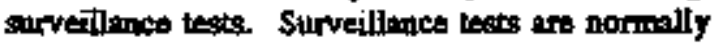
performed in strict adthesence to detailed procedures that specifically address ench operiting compontent Conponents not addressed by the test procedure would not be titely to be mispositioned as a result of tosts, and independent 


\section{REQUIREMENTS IDENTIFICATION DOCUMENT \\ HIGH LEVEL WASTE STORAGE TANK FARMS \\ Operations \\ Rerision}

verifention would be necessary only for components thet had been positioned during telst.

\section{b. Removing Equipenent From Sorvice}

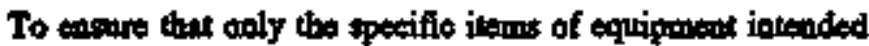
to be removed from servios ate sffected by Tagow, independint verifications should be performed equipment is removed from service. For extuple, when utgins out a pamp, a verification that the redundent pump was not incetvertently affiected should be performed. This might be done by checking for correct alfignment of components on the redicudrent equiporent, or this might be done by verifying that all Tags were pleced on the correct components.

\section{c. System Lineups}

Duxing extended shntilowns, it is often impractical to completely restore system to their Dormal operating aligameat immediatialy after mintennee is completed. Therefort, most factlities delay restoration of systema not noeded for shutdown activities untit shortly befors startup. At thut time, sll systens whase stanis is questionable are checked. When system linelpas tre performed, the considerations of Section C1, Components Requiring Independent Verifentions, should be applied to dattermint the need for indeptendeat verification.

\section{d. Periodic Cbecks During Fucility Opentions}

In order to verify thet all associnted equipoent is folly timetional, DOE fanilities should perform toution, periadic veriffortions of certain critical composents dering normal optratione. Sinos this chect ì independent from my ectivity that might brve consed in compodisut to be minporitionod, it eta be considented an indepeadent.

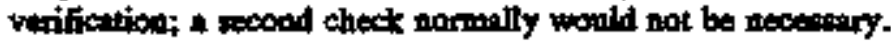
However, if 1 atspositioning were discovered while the periodic check was being performed, the conponent position would the be corrocted ifter review and/or approvil by a palified supervieor, an independent verifiemion of this extion would be approprizte."

\section{BBTATED REFERENCES}

1. 10CER20 Part 20.1.6

\section{Zeriftentiont Technigues}

Many types of components and in usa within the Tank Farnos facility that may require

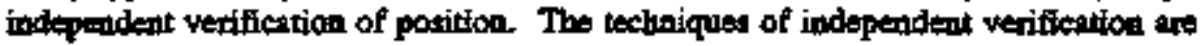
depeodent on the component therefore, written guidnnce should be provided to explain

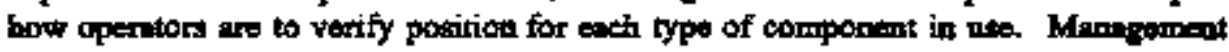




\section{REQUIREMENTS IDENTTICATION DOCUMINT HIGH LEVEL WASTE STORAGE TANK FARMS \\ Operations \\ Revision}

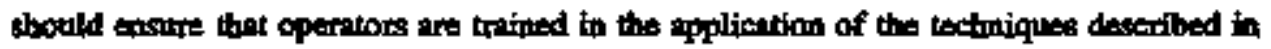
the guidenges document.

\section{FACILITY REQUIREMENT SOURCE: DOE3480.19 Chapter X, Section C3}

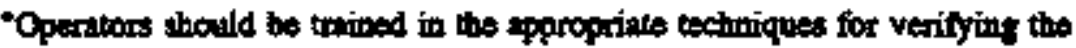
postitions of all facility components. In edifition, a reference dperument thould bo provided explaining whut an operator stould do whele verifyingt a component position. Becmes of the large variecy of components in tres in DOE Exeilities, is is not fessiblo to provide specific instroctions for verification of incividual comporent positions without farility-specific

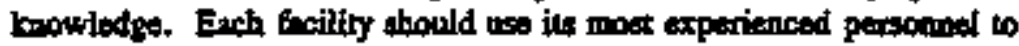
develop these instructions, using applicebie mnmufacturer's resommendesions where svailable. Tho instructions sbould describe the techniques for verifying mancil vaives, motor- and niroperated ralves, solenoid-operated valves, circolit brenkers, blimk flanges, removitible tintes and fused, ind the

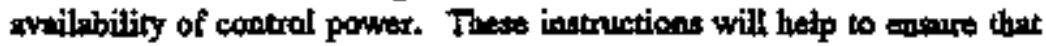
operators use approved methods when verifying component positions and will belp provide uniformity in operator performanse.

The following general guidelines appiy to component verification techniques:
- Independence
b. Remplo Position Indicators
c. Procuss Partmeters
4 Throttied Vaives
2. Surveillance Terting
f. Operations Self-Appraisal and Verification"

\section{LOG KEIPING}

The Tant Farms operations reeords should inelude a merstive los of tho equipmont and

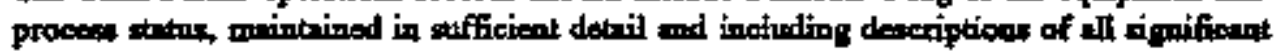

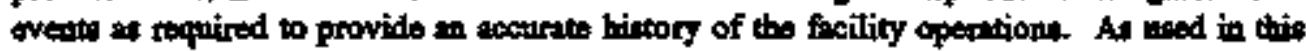
contert, loge ane defined as a narrative seculewe of ovents or functions performed at a

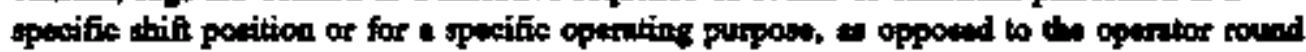

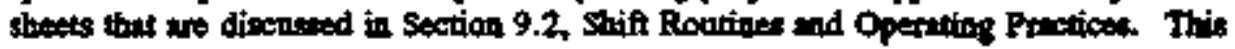
element deecribes the features needed in the Opecations logs to enfure they are propesty mrintained. INPO 84-001 (Good Pratice OP-205), Opentions Nerrative Lot Bonks, is in exinuple proyrem that cen be of acsistance in implementing the iatent of some of the guidelines of this slemest.

\section{Establishment of On ting Loge}

Menagement alowald estabish marative logs for all ley positions. At a

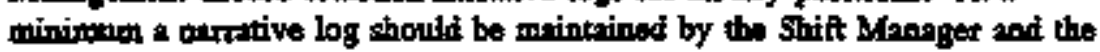
senior operator in the evapontor conirol room. Narrative log sections stoold be considened for each operitor nounds shest to provide for recording important component and process information. 


\section{REQUIREMENTS IENTIFICATION DOCUMENT HIGH LEVEL WASTE STORAGE TANK FARMS \\ Operations \\ Rerising 1}

STTE REQIIREMENT SOURCD: DOE5480.19 Chapter XI, Section C.1

"Narrative logs should be established at all key stift positions. As a minimim, a moretive log should to mainthined by the operitfons supervisor or the control ares operator. For those stift positions that ane misned on $*$

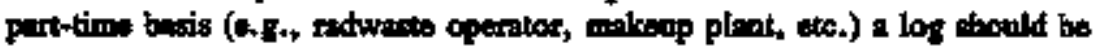

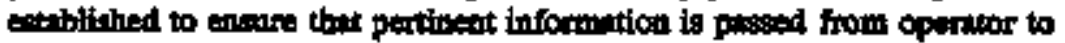
opentor. A nlrative section should be provided on round sheets when 4 nermative lot is not used for a perticular ahift position.

\section{Trincliness of Recorilings}

In order to easire consistent, complete, and aceurate log keeping within tho Tmic Farms fucitify, operetions minagement should develop administrative controts thet require the prompt recording of information in the noneztive lots.

\section{SITE REQUIREMENT SOURCE: DOES480.19 Chapter XI, Section C.2}

Toformation sbould be prompdy recorted in the loge. Delayint the rooprding of activities ar events often leads to incomplete or intecurite sontries."

9.113 Information to beserested

The Tinik Farms opeptions mandger should develop written guidanee to define the type and scope of eatries for each thrrative log and should provide guidanes to define the scope of the entries. Narrative logs are especinlly useful in reconstructing tbe exurse of eveats, therefore as muxh information as possible should be recorded during ahnomal and emergency simutions without laking any from providing primary atteation to safo operation of the tacility.

\section{STIE REQUIFEMENT SOURCE: DOE5480.19 Chapter XI, Section C.3}

"The operetions supervisor should provide written guidence to define thonouphly the type

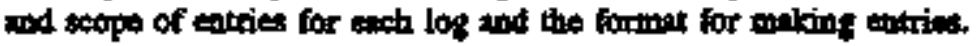

The following tuformation sbould be reconded in at leas one stution los, although any on log might aot conntrin ail these items:

a. Fucflity mode or coadition changes (e.8., shutdown, opersitions, nu, stortup, refueling, tte.);

b. Critionlities and aproprinte critical fata (for DOE reactors);

c. Aboormal coiling configurations;

d. Stwiss chenges to safety-related and ober mujor facility oquipuent;

a. Occurrence of any roportable events;

f. Initiation and conoletion of sarveillance teste; 


\section{REQUIREMENTS IDENTIFICATION DOCUMENT \\ HIGE LEVEL WASTE STORAGE TANK FARMS \\ Operations \\ Revision 4}

8. Entering and exiting operational limit actions;

h. Secarity meidends;

i. Ott-ot-opecification chenistry or process results; and

j. Shift reliefs. *

FACIIIYY REQUREMENT SOURCX: DOE5480.19 Chapter XI, Section C.3, Parngraph 2

To aid in erent reconstrution, to menth sipnificent information as possoble

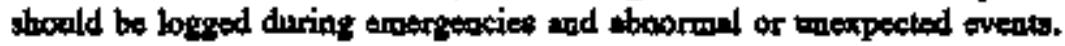
Howeve, logkeeping should not take precedeace over controlling and montitoring tho taility."

Lesibitity

Log entries should be made in accordanse with written Tank Fund optrations instnutions which require entries that are easily read, understood, wad art reproducible.

\section{SITE REQUIREMENT SOURCE: DOES480.19 Chapter XI, Section C.4}

"Log entries shorid be mede in a manner such that they con be easily read and understood. Additionally, the log antries stiould be reafily reproductiblo with standard pholocopy mechines. For these reascans, black, waterpooof int is recomroneuded."

\subsubsection{Corrections}

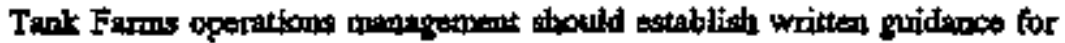

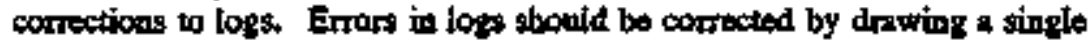
fine through the entry, writing the comest entry nesrby, and then iritialling and derting the antry.

\section{STIE REQUREMISNT SOURCE: DOE5480.19 Chapter XI, Section C.5}

"A standariized method far correcting any trromeous entries sbould be establisted. The method chocen should not obscurs the incorrect entry. Log entries should not be ersed or covered up. Conrections can be mide by placing a single line through the incorntect antry and writing the correct entry in a vearby space. All cornoctions sbould be initialed and dated."

\section{Lod Rerieg}

Log reviewa are an inmortant part of shift tamover both for the off-going operators and shift monager to ensure the logs aro wopurito and complete, and for the oocoming persomed to aid in their understending of the stans of plant optretions. Additionelly, it is impartant for the operations manager to roviow the facility $\log$ on a drily busis. 


\section{REQUIREMENTS IDENTHICATION DOCUMENT FIGH LEVEL WASTE STORAGE TANK FARMS \\ Operations \\ Revision 0}

\section{STIE REQUIREMENT SOURCE: DOES480.19 Chapter XI, Secton C.6}

"Conkral are logs sturald be reviewed periodicolly by the openations appervisor and lops kept by operaines outside the control area should be revitwed by the control area operator of at appropriate supervisor. These reviews shoeld ensore that entries are acentite and arequats."

\section{Care and Kexping of Lop}

The disposition of completed logs sbould be deteiled in Tomk Farms procedures. Written gridance should be provicted to ensure completed logs ars availublo to operations personmel for a reasonable length of time, to provide for the secure filing of completed lons and to ensure their contimbed retrievability.

\section{STTE REQUIREMIENT SOURCE: DOES480.19 Chapter XI, Section C.7}

Management should provide written guidance on the disposition of completed logs. This guidance should address the following:

2 Moking the logs aysilable for operators who rearra after periods of absease from their mglar deties;

b. Storing the completed logs to engure preservation for the expected tifo of the facility: and

c. Retrieving stored logs should this become necessary."

OPERATIONS SHIFT TURNOVER

Whan Iank Farms operstions continut inta the next shite operations shift turnovers stould provides oncoming operstors with an accurite picture of the overall cpenations stans of the Tank Farms. This elemeat compiements the guidelines of Section 9.2, shift Rustines and Operating Practices, and Section 9.3, Control Station Activities, and dexcribes the importiot deprects of a good shith morwer. INPO 84-D0s (Good Pexctice OP-201), stait Relief end Turnover, is en example progrem that can be of astistence in impiementing the intent of sowe of the guidelines of this element.

\section{Shift Turnorer Chedelists}

Shift turmovers within tha Tank Farms fecility should be facilitated by the use of chectlists. Written chectlists should be used by operations persomel as part of a formal process for documenting and commanicating status and other tey information regarding operating systems, operating panmeters, and key evolutions in progress or plinned.

\section{FACILITY REQUIREMIENT SOURCE; DOE\$480.19 Chapter XII, Section C.1}

"As \& mizimum, supervisory positions stoold brve a turnover checklist to bo used in the turrover process." 


\section{REQUTREMENTS DENTLICATION DOCUMENT \\ EGH LEVEL WASTE STORAGE TANK FARMS \\ Operations \\ Rerioion 0}

\section{FACILITY REQUIREMENT SOURCE: DOBS490.19 Chapter XII, Seetiod C.1.A}

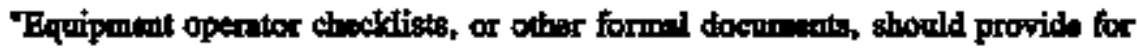

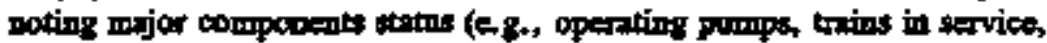

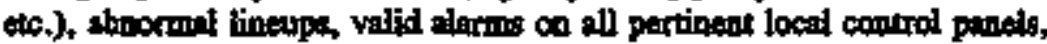
and sorvellences or wolutions plennod or in profress. Provistions sbovid also be moto for documenting that a reviow of round shoets and airrative Iogs bas been performed by the oocoming opertior."

\section{FACIIITY REQUREAIENT SOURCE: DOE:490.19 Chapter XII, Section} C.1.h

"Operter chectitsts or other doctiments teviewed it shift change shoutd provide for recording víat informetion about tho following facility stant. Exomples may include:

(1) Facility power level, test status, or equivalent;

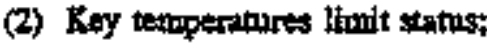

(3) Rey prosures limit status;

(4) Important tank levels;

(5) Safoty equipment satus;

(6) Opentiond limits in effect;

(7) Other important parnimeters:

(8) Required chemistry or process sampie times;

(9) Maintenance, surveillances, vests, or ovolutions (in progess or planued),

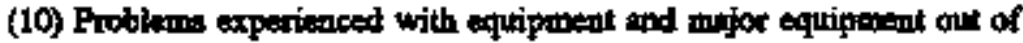
service;

(11) When specific plamed setions are required:

(12) Changes in radiological or hazardous materials conditions; and

(13) Temporary procedure chrmges in effect."

\section{FACILITY REQUREMENT SOURCE: DOES480.19 Chapter XII, Section C.1.b, Paragraph 2}

"Operator checklists may require documenting reviowa of certain facility status documedta. These may include the operator"s own opesatine (narrative) log,

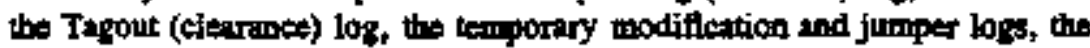
out-of-service anmincistor log, the operational limit action log, the sthift 


\section{REQUIREMENTS IDENTIFICATION DOCUMENT HIGH LEVEL WASTE STORAGE TANK FARMS \\ Operations \\ Rerision 8}

order books, and required reading since the last stiff. Earch opwantor tumover checklist siondd be provided with enough space for the offiping operator to libst other important information his relief shonld bave."

\section{FACIIIY REQUIREMENT SOURCE: DOES480.19 Chapter XII, Section C.1.5}

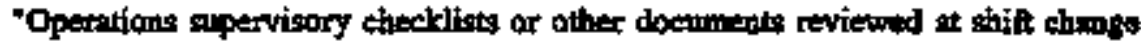
should provido vital information about tacility status. Examples may inciudes

(l) Eacility stas;

(2) Evolutions (completed, in progreas, of planined);

(3) Controlled key stans;

(4) Abeormal lineups or conditions;

(S) Changss in tadiological or hazardouts substance conditions;

(6) Sarvitlance tests planed or in progress;

(7) Maintenance planned or in progress; and

(8) Waste management stakus."

FACHITY REQUREMENT SOURCE: DOE5480.19 Chapter XII, Section C.1.c, Paragraph 2

"Operations supervisory chectists should require documeating revizw of certain statas docaments. These can include the supervisor's own narrative

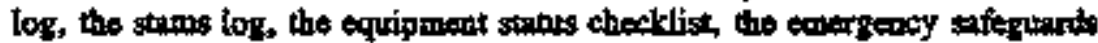
equipment list, soift order books, and requited reading sinco the last shift:

Doxament Reriex:

Writted guidance should be developect to ensure operatoren review the docamentr opecified on their wateh station chectlist prior to essuming responsibility for their stift position.

\section{FACILITY REQUIREMENT SOURCE: DOES480.19 Chapter XII, Section C2}

"Oncouning operitors and supervisors thould revien documents specifted on their chectlist prior to assrming responsibility for their shift position.

Docidment review should be as inteasive as necestery for tho oncoming personal to undersind importent history, present status, and pimned events.

Normally, narrative log entries for the previonu 24-haur period or sinos hisher last ahift should be reviowed. Stutus logs sbould bo roviowed to that

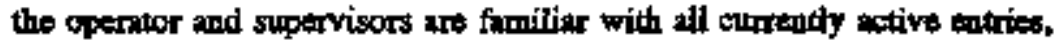
with in emphasis on what bas ahanged sinee betshe last had the stift." 


\section{REQUIREMENTS IDENIHICATION DOCUMENT \\ HIGH LEVEL WASTE STORAGE TANK FARMS \\ Operations \\ Revision 0}

\section{Control Panel Walkdown}

Each Iank Farms olnitt wathestander should perform 2 waltodown of the control penels in his area of responeibility to determine pient stattus through the observation of system linerepe, switch positions, lighted anpanociators, chart

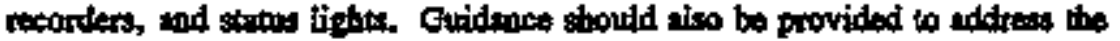
timing of these waltdowns for each wotchstinder, including the Shift Mannger.

\section{FACIITY REQUREMENT SOURCE: DOE5480.19 Chapter XII, Section C3,} Paragraph 1

Wallodown of appropriate control panets should be conducted by ach shift watchstunder. The purpose of a penet walkdown is po determine plant stallus

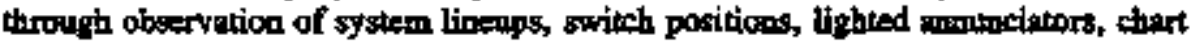
recorders, and stant lights."

FACIEIrY REQULREMENT SOURCE: DOES480.19 Chapter XII, Section C.3, Paragraph 2

"Oucoming operations supervisors should walk down tho main control pacels before, duriols, or shordy after shift turnover. Oncouning and offgoing coatrol area operitors should walk down their unit's min control panel logether. Equipment operators stouid review all pertinent local control panels, (0.t., tist supplies, lubricrion levels, mokeup water treatment, and ventilation) during their tour eary in the shift."

\section{Discussion and Exchange of Responsibility}

Offgoing and ancoming Tank Fams watchstanders should discass all itoms noted on the turnover checklists to schieve understanding before the tesponsibility for the watcinstotion is trinsfierted.

\section{FACILITY REQUIREMENT SOURCE: DOES480.19 Chapter XII, Section C.4,} Parapraph 1

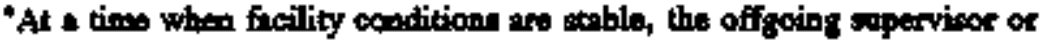

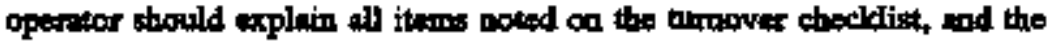
oncorting operator of supervies should ast any pertinent queations."
}

FACILITY REQURRBIENT SOURCL: DOE\$480.19 Chapter XII, Sectinn C.4, Paragraph 2

When all operations personocl tro setisfied that the oncoming crew is fully coprizant of the plant conditions, the concoming opentors and sopavisors should state that heishe is assuming responsibility for the shift position sivith an miny into tho log." 


\title{
REQUIREMENTS IDENTIFICATION DOCUMENT HGH LEVEL WASTE STORAGE TANK FARMS Operatious \\ Rerision 0
}

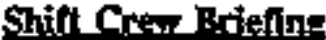

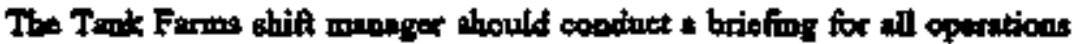

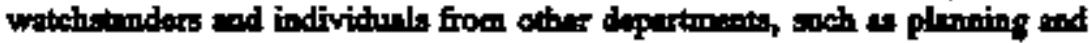

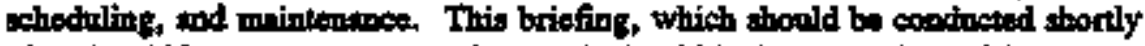
after tho stift mennger mosumes the watch should inchude e reviou of fecility

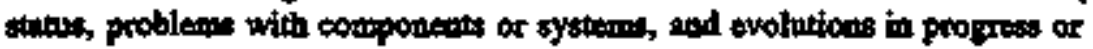
planed for the stritt. The objective of the briefing is to cesure all personed have a good understending of status, objectives, and prioritios for the thith

\section{FACIIIT REQUREMENT SOURCE; DOES480.19 Chapter XII, Seetion C.5}

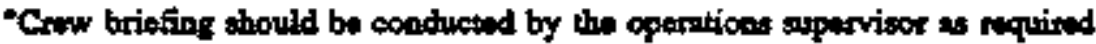

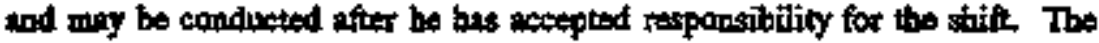
briefing stould include 2 review of the status, problems with equipment, and ovolutiona in progress or planned during the shift. In addition to shift operstors, personel from support groups (e.g., contrectors, vendors, and tust

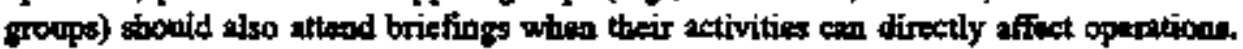
This prectice results in better modersending of shift priorition end objectives amoag operations and support personinel."

\section{Reliefs Oagurering During the Shist}

Written guidance should be provided to moure that when $\approx$ wateh relitef wist oceur during the strift, a tornover sufficient to ensurs tho oncoming person is at least as tnowledgeoble of the facility conditions as be would have been if

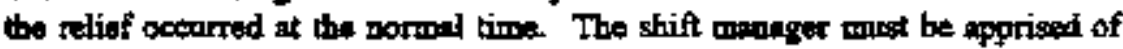
all shift reliefs.

\section{FACILIY REQUIREMENT SOURCE: DOE5480.19 Chapter XII, Section C.6}

"Reliofi occursing during the shith (t. g., exchange of control gupervicory function) should have a hernover to easere that the oncoming peroon it at

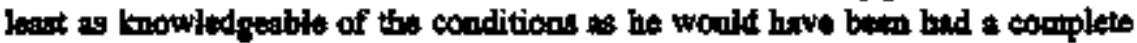

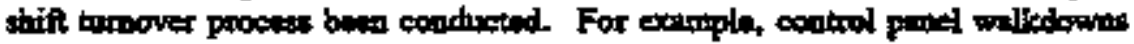
and los reviews may of mey not be accessery, depending on the oncoming person's familinrity with the charreot cootitions."

\section{OPERATIONS ASPECTS OF FACILTY CHEMRSTRY AND UNRQUE PROCESSES}

Operational monitoring of Taml Farms chomistry and process deth and

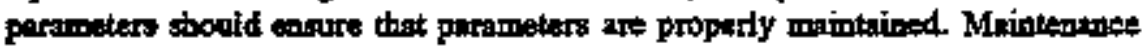
of proper processes will promote maximum corriponent life and the safe and efficient operction of all systems that hendle waste stresms within the fucility. Monitoring will identify problens such as inproper ph, conductivity, of liquíds/soids matio in the evaporater facility, beforo componente or sofery ige adversely affected. In order to eabance proper process control of syatems, Tank Farms opesations personnel mast have an trederstanding of all faility 


\section{REQUIREMENTS IDENTIFICATION DOCUMENT HIGH LEVEL WASTE STORAGE TANK FARMS Operations \\ Revision 0}

processes and must effectively coordinate operations activities with the respective technian process support departments.

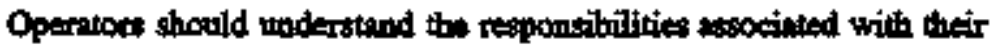
positions (both in process monimoriag and costrol and in interface with the

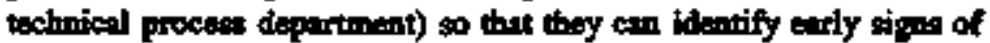

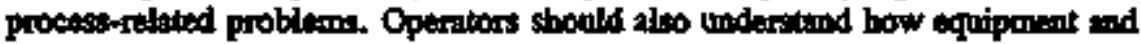
cperationsl problems affect procese copditione. A good morking reletioneship

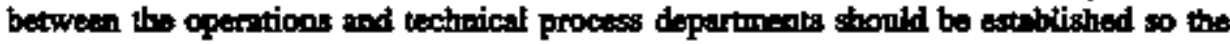
tweitity staff en effectively exontrol facility processest.

\section{Operator Responsibilltiles}

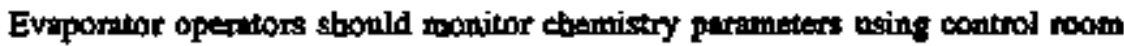
instrumeats and pther instruments related to equipmeat under the operstions department's control. The operations moneger should provide administrative controle that define each operator's specific respossibilities with respect to chemisty control. Through proper monitoring, thd spropriats correttive action, the adverse afroets of ehemistry probitems can be minimized.

\section{STTE REQUIREMENT SOURCE: DOE5480.19 Chapter X7I, Section C.1}

'The operations supervisor stould define' exch operator's specific responsititities with respect to process control. In generoit, operators should montitox chemistry or process parameters using control mom instruments and other instruments rejated to tequipuneat tuder opartions control. Opereters should be able to recogaizo out-of-specification conditions or atverse treads and be familiar with comective sctions assokigted with chemistry or process probiems. Optrators should congult and be atvised by chemistry or bechrical process depertument personnol. By moxitoring toy parameters and taking appropriate action prompty, long-term adverso effects of chenistry or process probloms con be nvoided or minimized."

\section{Oneratoc Knowleside}

Opantort should be imowledgesble of the siprificence of variout process chemistry paramoters an the opention of Evaporator systeme. This bowledpe

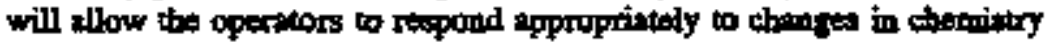
parameters. The operafions enanager should enstre that these subjects ars covered in training programs.

\section{Opecator Response in Chemistret or Process Prohlems}

Tank farme menagement should ensurs that exch operitor is capablo of correctly interpreting the chemistry purameters be is responsible for moditoring and providing appropriate, imply, corrective action when requirext.

Adquinistrative controls stould bo developed to ensure that opertions informb other departmeats when changes in prosess will require their support. Close 


\section{REQULREMENTS IDENTLFICATION DOCUMENT HIGH LEVEL WASTE STORAGE TANK FARMS \\ Operations \\ Reristion 1}

relations between operations and supportins departments should be fostented in anter to moro effectively and efficiently coordinnte activities.

\section{FACIIITY REQUURGMFINT SOURCE: DOR\$480.19 Chapter XII, Section C.4}

"If partible, operions thould itform eppopriate process personed prior to commencing wotutions thet would potentiolly affeet facility processed ot rexpirs sction from support teshnicinns. Opentors should receive reports from the process department on key daytoodny process results and probleme-

\section{REQUIRED READING}

Tank Farras management should develop a required reating propram for operations porsonnel that will ensurs appropriate individusals are mado ewere of important job related informetion, stach as proctedure rovisions and equipmeat chonges.

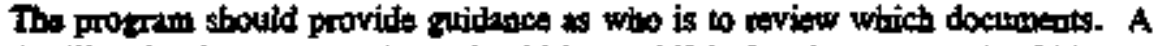
deafline for document reviows should be extebtishod and operators should be instrueted to sect assistance from supervision if they do ast understrad the material.

\subsubsection{Reading File Index}

The Tant Farms operations monsger shonid develop and moincnin a list of the types of documets to be included in the requitred rending file. Eximples of documents to be included are procedure changed, equiponent design changes, operatiog experience, and ather information aeded to keep operations persomel informed of eurrent facility activities.

FACHITY REQUREMENT SOURCE: DOE5480.19 Chapter XIV, Section C.1, Faragraph $\boldsymbol{l}$

"A list of the types of documeass to be included in the rexpired rearing file should be maintained. The list stould include the following documents:

a. Procedire chngeg;

b. Equatpmeant design changes;

c. Related industry ato in-bouse cperating experience information; and

4 Other informition dectessary to kesp operations departartut purtomen awase of cumenk Ecility activities."

FACIIIY REQUREMFNT SOURCE: DOE5480.19 Chapter XV, Section C.1, Paragraph 2

Reading material soould be screened to enzure that oniy appropriate material is placed in the tile." 


\section{REQUIREMENTS IDENTIFICATION DOCUMENT HIGH LEVEL WASTE STORAGE TANK FARMS \\ Operations \\ Rerision 0}

Bearling Assignments

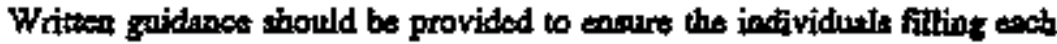
watchastation are awre of which documents they are responsible for reading.

FACIIIY REQUIREMIENT SOURCE; DOES480.19 Chapter XTV, Section C.2

"A method stould be in place to desigmese which documenta veed to be read by

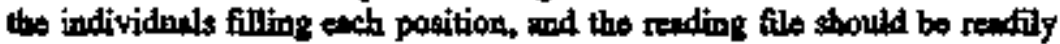
avatable to those individuals."

Dates for Completion of Required Reading

All documents in the required reading file should have a date specified for completion of reading.

\section{FACILIYY REQUIREMENT SOURCE: DOE5480.19 Chapter XTV, Section C.3}

"A required completion date should be desipanted for teadiag each document This date would be detormined bised on the nathe of the mitterial. Persocmed shoold compiete theit reading assignments by the required date. Certain documents may be designated for "immediate reading." Those sboutd be read before assaming responsibility for a shift position."

\subsubsection{Documentation}

Documentation of the completion of each reading stond be retrinat.

FACIIITY REQUIREMENT SOURCE: DOE5490.19 Chapter XTV, Sectioin C.4

"Compietion of reading should be doctumented, and the doctmentation should bo rotainsd."

2.14.5 Revien

Adrimistrative controls should be tobthished to require periodic teviews to exsoure that tequired readings are being conrpleted by the specified thte.

\section{PACIIITY REQUIREMENT SOURCE: DOES490.19 Chapter XIV, Section C.}

The roding filo shoutd bo periodically nevioved to enotre that all departement personmel complete readings by the required dittes. Material that has been read by all approprinte persolvel should bo removed from the attive filie. A "dead" file mry be mointained as a reference."

\section{THELY ORDERS TO OPERATORS}

Oporations mankement should comminticate short-term information andi administrative instructions to department personatit through an establishod formel process. This element provides requirements for operations orders 


\section{REQURREMENTS DENIIFICATION DOCUMENT HIGH LEVEL WASTE STORAGE TANK FARMS Operations \\ Rerition}

relativo to content and format; issuing, segregeting, and seviowing orders; and removing ondes. Otber meass of providing direction to Truk Farm

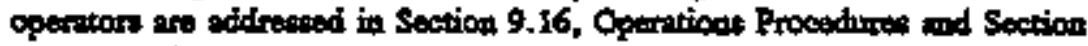
9.14, Required Rewcing.

\section{Content and Format}

Opesabor arders may inciuds meny types of short term informetion, but should opt be treed in place of the operities procedure chenje program. All

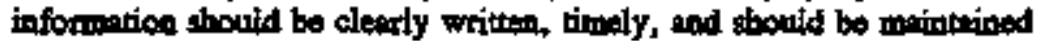
in the shift office to fucilitato its ase. Soms expomples of informetion thes

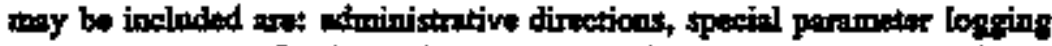
reguiremeats, antifletions of upeomins special usts or other evolations. and similar short-term moiters.

\section{FACILIY REQUIREMENT SOURCE: DOE5480.19 Chepter XV, Seetion C.1}

Trformution such as specill operations, adminitaretive directions, spexinl

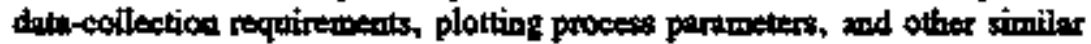

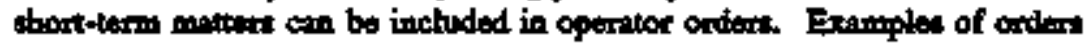
could include instructions on the need for and performence of specific evalutios or tests, it could also ipclude work pritorities, monouncerverte of policy information, and idmimistrative information. Onders should be cletrly written, dated, and meintained in the control noom. Information and policies interied as permeneat should be incorporated into appropritte administrative procedares. The operator orders propram should not be used to change operting procedires, bectuse the changes woted in the operiter orders might be mised by a procedure weer. Additionslly, operator oriters may not receive the epprovel approprinte for a procedural change."

\section{Issuine, Sercectating, and_Reriezing_Orders}

Opernting oxters may be need to provide timaly informaticn that is appliceble over in extended period. In this case the operating ordess should be separted into divily and stinding (boog term) orders in onder to focilitats their soviow. Operatord should roviow orders shortly attes woming their shift and should doctumbat this review.

\section{STIE R5OUREMAFTT SOURCE: DOE54\$0.19 Chapter XV, Section C.2}

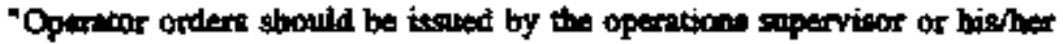

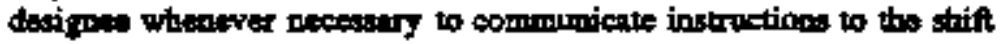
personnel. Operator onders should be segregated into divily and long-inm orders in order to facilitate toview by shift personnes. Deily onders thet are postponed or prolonged ahould hrve daily roview or updetes. Reviews of

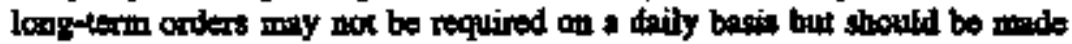

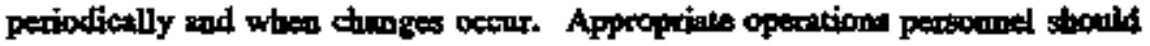
zeview the ordiers early in the shift and docesment their review by initioting the lot or notebook." 


\section{REQUIREMENTS IDENTIFICATION DOCUMENT HIGH LEVEL WASTE STORAGE TANK FARMS \\ Operations \\ Revition 0}

Rernoral of Oraterat

Orders that aro wo longer applicable stoold be removed from the operating orders book. A periodic roview by the operations afonigh should be performed

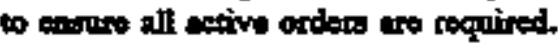

\section{SITE REQUIREMFNT SOURCE: DOE5480.IS Chapter XV, Section C.3}

"Orders that ere no longer appilicable or are ontdated should bo proitpitly removed or comeled. The opentions supervieor should periodically review

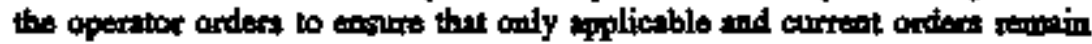
effective."

\section{OPERATIONS PROCEDURES}

Operations procedures are witten to provide specific directions for Tank Farms operations staff to opernte systems and equipment during nomenal end

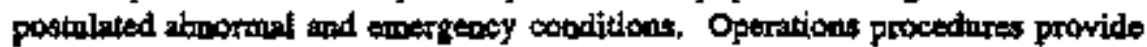
appropriato direction to ensare that the facitity and equipineat is operated is accondence with ito design basis and within its safety envelope (sofo operaling limits). They are effectively used to spport safe opention of the facility. Other methods of disseminating operational information ant addressed in Section 9.15, Timely Orders To Operrators, and Section 9.17, Operetor Aid Postings. This element describes the important spects of operations procedure development and use INFO 84-021 (Good Practice OP-204). Conduct of INPO 84-020 (Good Pratice OP-210), Review of Opericiont Depirtitent Procedures, are example programs that can be of assiotanoe in implementing the intent of some of the guidelizes in this element. The requiremeats for operations procedtere sdministration, approval, and use to bo implemented at the Tant Farms are found in the Policies and Procectures functional area of the Mamagement Systems RID.

\section{Procedyre Detrelongment}

Tank Fernes Opexaions mangetwent should provide written gridance to control the developmeat of operations procedures. This guidances should imetode qualification requireanents for writers and seviewers, maquiriments for the formit to be used (writers gride), types of procedures to be developed, extrat of detril to be included and for the review, verification, validation, and approval process.

\section{Procerilure Content}

The content of operations procedures should be umiform and should be controlled by written guidelines to ensure cecuracy, adegancy for intended purpose, ant east of use.

\section{Progedure Changen and Revisions}

Written phidmes should be provided to ensure that changes and revisions to procechres receive adiocquate review, approval, sad implementarion. 


\section{REQUIREMENTS IENTIFICATION DOCUMENT HIGH LEVEL WASTE STORAGE TANK FARMS \\ Operations \\ Revision 1}

Additionelly gridance drotale be provided to astist operators in determining

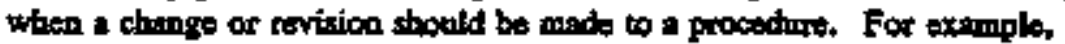
proceduro rovitions sbould be implemented concorrently with modifications to fecillity syatems of componsts.

\subsection{6 .4}

2.16 .5

2.26 .6

2.16.7

9.17

\section{Brocedure Anporyl}

Written guidrocen should be provided detuiling tho lovel of epprowal required for new procectures, for procedure rovisions (they thould recetive the same level of approval as new procedures), for approval of changes the do not affect the intent of the procedure, and for apporvel of chenses thet attor

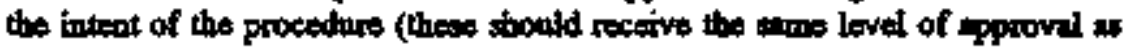
new of rovised procectures).

Procedure Review

Written guidmace should be teveloped to govern the noview of now and rovised operations procedures. The acturecy and applicability of procedures is vital to the sate and efficient operation of Tank Farms. Procedtres should therefors be reviowed prior to issue and at prodectrintined intervals thereafter. Reviews should cousider both the technical woesuracy and the administrativa adequecy of the proceduro.

\section{Procedure Araikahility}

Controlled copies of operations procectures should be motntrined at the shit offies and in other areas as neaded for operation and referwoos by coperetors. Where the uas of working copies it required controls should be stablished to ensine thas ouldated versiom are bot used.

\section{Procedure Use}

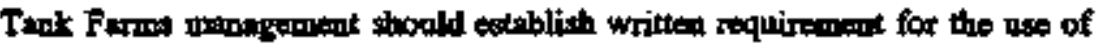
procectures. This gridince stbould address when the procedure mist be in-hnd, and when procedores my be referred to rather beins in hand for step by stop

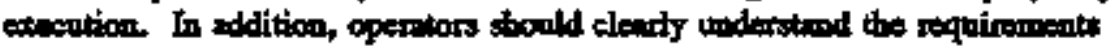
for procedure bse at Tank Furm, and stould understend their oblipations to

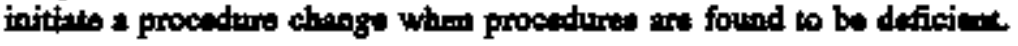

\section{OPERATOR AID POSTINGS}

Operator Aids may be to grovide useful information to operabora in perfoming their duties. Included smong operntor aids wre bankwritten notes,

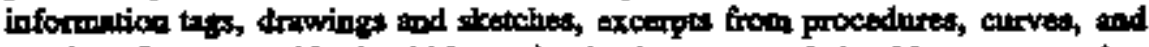
grophe. Operator Aids stbould be mintaimed eurrent and shoold not superoedo or confliet with any other controtled prosedure on informetion. This element

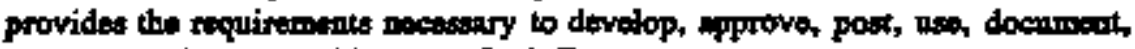
and reviow Operittor Aids at the Tank Farma. 


\section{REQUTREMENTS IENTIFICATION DOCUMENT HIGH LEVEL WASTE STORAGE TANK FARMS \\ Operations \\ Rerision 0}

\section{Operator Aid Dareionnent}

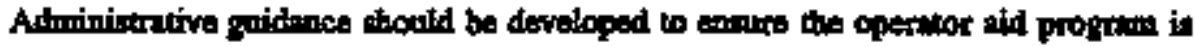
usderitood by all employeses. Normelly operstor side ans developed by

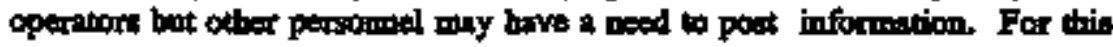

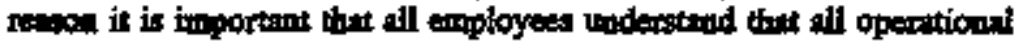
information most be epproved prior to postint. Addtionnlly it it impostont

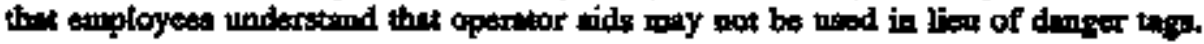

\section{FACIATY REQUTREMENT SOURCE: DOE5480.19 Chapter XVI, Seation C.I}

"Any facility employes conld divelop om opertitor nid; bowever, it sbonid bo approved prior to posting. Operator sids (system drawigs, maintennes procedures, etc.) wny often be posted by individuals other them opertions

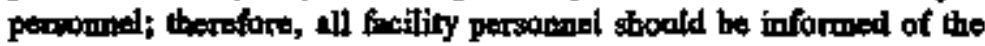
importance of coatrolling pocted informstition and the procedure to be followed when posting informatica."

\section{Apporayal}

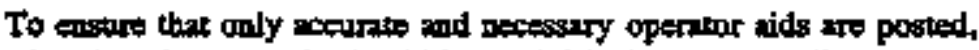
administrative controls stoutd be established to require all operator aidu to be approved by the Tenk Ferms Operations Manager.

\section{FACILITY REQUIREMENT SOURCE: DOE 480.19 Chapter XVI, Sectlon C.2}

The operations supervisor, or a higber anthority, should approve all operator sids. The person approving an operator aits stoxlls easire that the aid is recessary and corret Operator aids tint alter procedures strould not be aproved. Instead, appropriate procechures should be changed to inconporate the atcessery information.

\subsection{Posting}

Generrilly operator mids strould be postod in close proximity to the area of

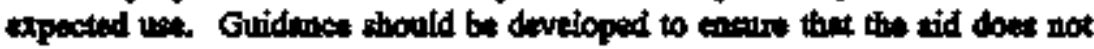

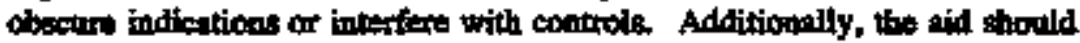

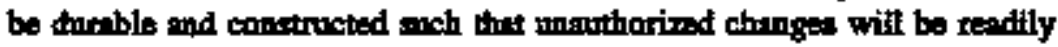
noticed.

\section{FACILITY REQUIREMAFIF SOURC: DOE5480.19 Chapter XVI, Section C.3}

"Operator tids sthould not be pasted in such 2 wry as to obecment instruments of coptrote The side sheuld be locted in close proximity to the aree of their expected use. The operater aids stould, wher possible, be protected

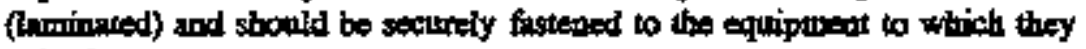
refer."

\section{Use of Onerator Alds}

All peronnal should understand that operatnr sids ase provided as a 


\section{REQUIREMENTS IDENTIEICATION DOCUMENT HIGH LEVEL WASTE STORAGE TANK FARMS \\ Operations \\ Revision 0}

coovenieace. Thoy do not subatibuto for procedures bax, rather provide amplifying information usettl in ortain sintations.

\section{FACILTYY REQUIREMENT SOURCE: DOX5480.19 Chapter XVI, Section C.4}

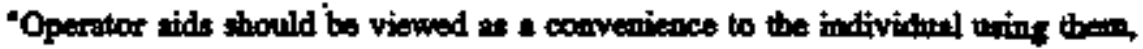

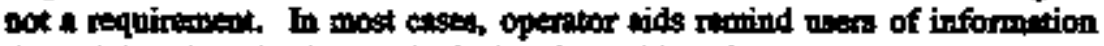
that might otherwise be ovetiocked and previde guidence that is aot procedural in netaro. Operator aids may sopplement approved procectures, but they should not be used in litel of approved procedturiss."

2.175 Dosumentation

Adrmitistretive controls should be develeped to thexire that documbentation of all epertot aids is mpintzined. A list of ell approved gids should be meintrined slong with a file copy of the aid a posted. Maintenares of a

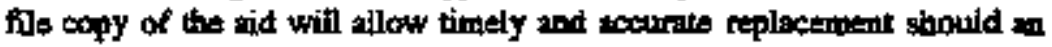
aid bo found missing or darmaged.

\section{FACU,TrY REQUmFMENT SOURCE: DOFS490.19 Chapter XVII, Section C.S}

-A listing of all approved operator aids stould be mainpined along with a copy of each aid posted in the facility. This list should be used duning periodic reviosts of operator aids in order to belp ensure that the posted sids romein carrent, and to provide 2 reference copy should th operator aid bo missing during the review. The list should be kept in the control ares, the operations stupervizor's office, or other mppropriats locetion. Reforducts trom which operator sids were derived, control numbers (inctuding sevioion), and dates of approval stonki be provided."

2.17.6 Review

The Tank Fums operator aid program sbould provicio for a periodic review of all operator aids to ensure conly approved, newserary, und sceurite aidi are

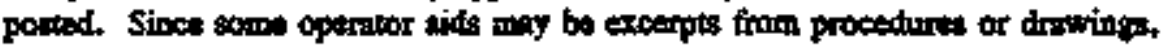

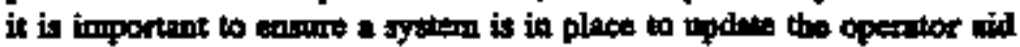
whenever fts source documeot is revised

\section{FACILITY REQUMEMMENT SOURCE: DOESA80.19 Chapter XVI, Seetion C.6}

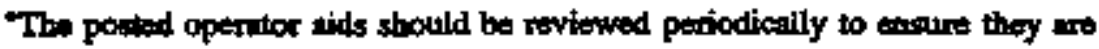
still correct and pecessery. In addition, an operator should andit the control aree listing to enrurs that only currantly poeted tids int rucorded on the listing. Operiont xids oo looger posted shoxuld be removed from the listing, and missing aids should be replaced."

\section{EQUIPMENT AND PIPING LABELING}

A formally implemented and mrintrinod progrem for equipment and piping labeling will heip ensure the persomet ane able to poritively identify equipment they operite. In sddition, equiparent labeling is Inquirud by 


\section{REQUIREMENTS IDENTIFICATION DOCUMENT HIGH LEVEL WASTE STORAGE TANK FARMS \\ Operations \\ Rovicios 0}

Operationel Safety and Hesilth Administration (OSHA) regtlationg. This alement describer the importent aspects of a Labeling Program which fochide dentiffection of equipipant and pipind to be labeled; label informetion;

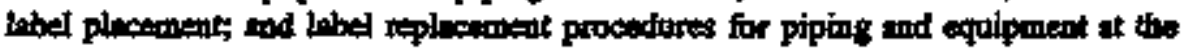

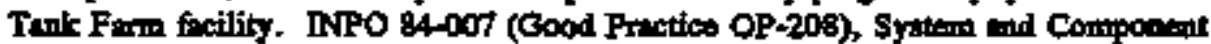

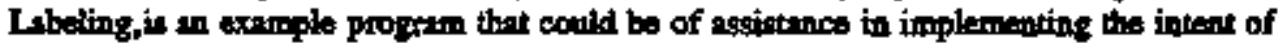
some of the gridelines of this edoment.

\section{Components Requirfing Lahelling}

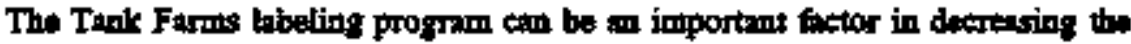
fitretithood of atmotmol events the to operetion of the wrong equipanent. The labeling program should provide an approved list of componetrat types that require labeling. In addition to equipunent, doors, hatches, and weess covers should be lebeled so that personnel carl identify mot only the room or spece beyoud but, if applienble, the equipunent inside.

\section{SITE REQUIREMENT SOURCE: DOE5480.19 Chapter XVII Section C.1 .}

The following components should be totyeled:

2 Vaves;

b. Major equipment (e-g, tents, pumps, and compressors);

c. Switches:

d. Circuit breakers $(4,16 \mathrm{KV}, 480 \mathrm{~V}, 120 \mathrm{VAC} / \mathrm{DC}$, etc.);

- Fuse blocks or fuse locations;

E. Instruments and gauges;

g. Busses and motor control ceaters;

4. Cabinete finctuding internal cormponesta such as relaya, teforinnitis, exc);

i. Room doosat

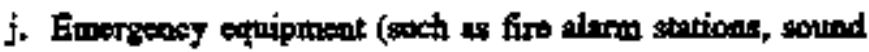
pouvered phoot beedsets, stc.); and

k Firs protection systems."

SIIE REQUIREMENT SOURCE; DOEG430.1A Diviston 13, Section 1301-12.4.11, Paragraph 1

Equipmeat und any parts of that equipment to be uved by personmel thall be identified with sppoptriate labels. Equipment and equipment parts includo, bet art not limited to, system and subsystem eomponent grovpinge, individnal 


\section{REQUIREMENTS IDENIFICATION DOCUMENT \\ HIGH LEVEL WASTE STORAGE TANK FARMS \\ Operations \\ Rerision 0}

components, coutrol positions or modes, display markings, instructions, procedure mopurale, storages spaces, access panete, and tools."

Labei Information

The Tank Farms labeling progrim sbould provide specific guitunce for the information to be included on labels. Alt informotion stoxild be consiatent with the information found on spproved documents such as procectures and

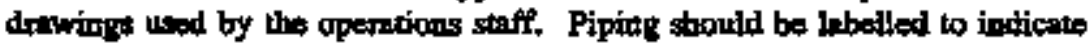
the noxmal difoction of flow and should also indicats the fluid contained. Piping contnining bazardous meterials should be uniquely identified. Is is also important to casuro that the materials latels are mide from are dinnable ard compotible with their applictica.

\section{SITE REQUIREMISNT SOURCE: DOE5480.19 Chapter XVII, Section C.2, Paragraph 1}

Information on labels should be consistent with the information found in faclity procedures, valvo lineop sheets, and piping and instrument dingrams. Abbreviations and nomenclaturo used shonkt bo standardized and should be understood by facility persocant. Labels should be permnent, securely Hehed, and have distinguishable, essy-tortend information. Each compapent bbel should list a unique cortuportent number. The scoompanying component noun namo or description and power supply, if applicable, should also be providect. Labels paly be color ooded for unit, aystem, andior train designation. If solor coding is used, the colors should be applied consistently and beve only soe mesaing per calor or combination."

\section{SITE REQUIREMENT SOURCE; DOE5480.19 Chapter XVII, Section C.2, Paragraph 2}

Piping should be tabeled to indicate the fluid contaired and the mormal flow direction. OSHA color coding for pipes could be used, and pipes eontrining potentially medionctive fluids, toxic fluids, or expiosive gases shouid bo uniquely wited."

\section{SIIE REQUREBANT SOURCE: DOES480.19 Chapter XVII, Section C.2, Paragraph 3}

"I_abels should bo made from mattrials that are compatitits with their particular upplication. For example, chlorido-fres labals shoutd be used on strinless

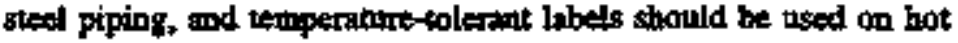
corpoments, Adhesives wed tor label attochment thould also be verified for compatibility."

\section{STrE REQUIREMIENT SOURCE: DOE6430.1A Division 13, Sectien} 1360-12.4.11, Paragraphs 2-5, 8-12

The label shall indicate clearly and concisely the function and purpose of the item being labelod. Unnecessary information (e.z, information used only for mentfacturing purposes) shall not bs included. Hiersichicel 


\section{REQUIREMENTS IDENTTFICATION DOCUMENT HIGH LEVEL WASTE STORAGE TANK FARMS \\ Operations \\ Revision 4}

inbeling also shall be used to facititute component location on ccantrol panels.

The label tuformation stall be tacy to understend. Works, 8ymbols, and

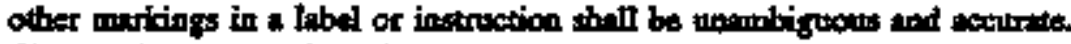
The terminalogy used shall hed commonly wosepted mesning for all users.

Inbel design sall be consiateat. The use of abbreviations and acroinynus shall be minimived.

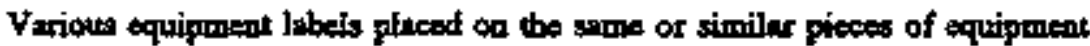
and serving similar fuactions shall use the same materiel, color, font typer ralative lowation to composent, peneral format, and other configuration featumes to prowote simplicity and avoid clutter.

Temporary labols shall bo used only when aeceseary and sthill be controlled adrinistratively. They shall not obsenre ether information or equipmest, and they stall be attected securety. If 2 temporary label is to desipnate a devices that is out of service, the tabel shall be applied so that it prevents the use of that dovica. Other label criteria described in this section sball apply to teroporry labeds.

Labeling stat be legible and conform to tuman visual capabilities and linitations in regerd to physicil charatteristics such as letter and symbol size, contrast, foant simplicity, specing and stroke width.

Properly designed miznic displays shall be used to improve the ksens understending of the system.

Specific gridelines for addressing labeling considentions are contaimed in NUREG 0700, Section 6.6.; and MIL-STD-1472C, Section 5.5. See Section 1040, Identifying Devices."

Label Ptacement

Guidance should be provided for consistent placement of labels to wid

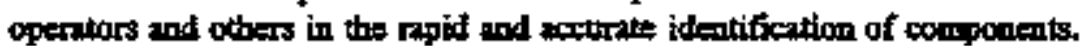
Iebels should generailly by pleced a ciose ax poseible to the component identified. Consideration must also be given to the possibility of obsoaring other equipment stch as slarm intications, or placing labels such that they obstnuct acesss to controis when developing tabel placement guidetines.

\section{SIIE REQUIREMIJNT SOURCE: DOE5480.19 Chapter XVII, Section C.3}

"Labels should be placed on or as near as practicable to the equipmont to be labeled. The label stould be oriented in 2 manner then is easy to xesd and so that he correct compointent is easy to didentify." 


\title{
REQUIREMENTS HENTIICATION DOCUMENT HIGH LEVEL WASTE STORAGE TANK FARMS Operations \\ Rerision
}

\author{
SIIE REQUIREMENT SOURCE: DOE6430.1A Division 13, Section \\ 1300-12.4.11, Pragraphs 6, 7
}

"The terminology used for equipment, procedures, and trimint materinls shell be the samo for ench cusa.

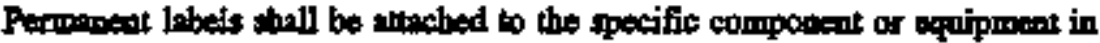

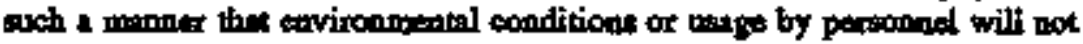
remove or destroy the label.

\section{Renlacing Labels}

The Tank Farm lebeling program should provide for the timely identification

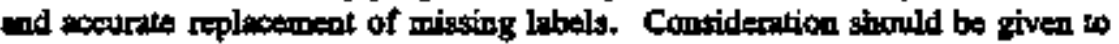

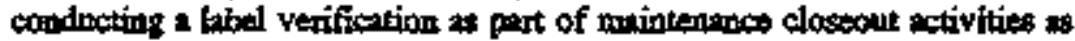
labels tre often lost in the course of mointeanes.

\section{STE REOUIREMENT SOURCE: DOES490.19 Chapter XVII, Section C.4A}

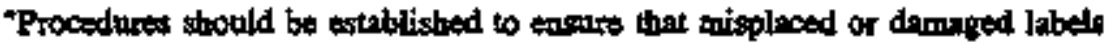
are replaces. Since labeis are ofter missing after minkenance, the postmrinteanance lest could require a chect to ensure that the epproprinte labeis are attachect. Another method that could be used to chact for labels is to add mother coinmen to valve linetip sheets that would require tho operator to verify that labeis ace present, readable, and undamaged."

\section{STIE REQUIREMENT SOURCE: DOES48B.19 Chapter XVII, Section C.4.b}

-A mothod should exist to heip ensure tbe promfr jideotitication and correction of labeling deficimation. A number of ways can be suggested to acoomplish utis: operators could make labels on their own, of operators could fill out forms and forwird thesn to a enared facility to have labels made. In either cesen a termporary label should be attached to the composent until the replecenrent libel can bo mide. The replacement label stoold be approved by

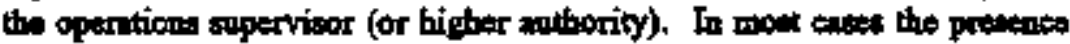
of labeling thentines corsite promotes relabeling."

\section{KEY FROGRAM INIERFACTS}

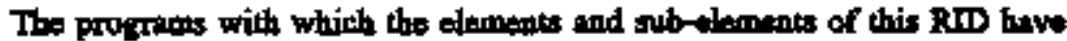
interfeces are tho following to the extent that they are directly reinted to Twok Farms operations. Specific requirament interfaces aro noted at the dement foub-element level in the RID.

\section{CONFIGURATION MANAGEMENT}

Configuration manaptent interfaces with Operations in ensuring that Desigh Basia drawings of Cratical Struchures, Systems, Componeots, Proptrummetic Policies and Procectures, and Operitiona Procedures refleat the chirrent configuration andior operational status. 


\section{REQULREMENTS DENTTICATION DOCUMENT \\ HIGH LEVEL WASTE STORAGE TANK FARMS \\ Operations \\ Rerision 0}

\section{ENGINEERING}

Engipering pasvides Desipan Basis drewings of Critcall Structares, Systems, Components ptus perform reviow of Work Control documents and exteblishes

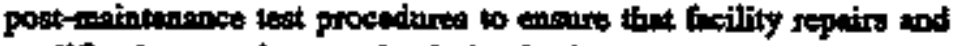
modifiestions conform to the design besis.

\section{EMIERGENCY PREPAREDNESS}

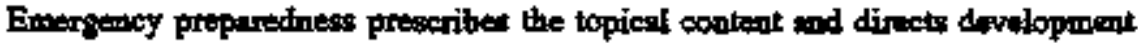
of facility Emergency Plant plus provides emergency mesponse procedures to Operitions.

\section{MAINTENANCE}

Maintenance provides the Wort Control Systern for the conchet of mainteanence on Operations strustures, systems, and components. Procurement for spare parts

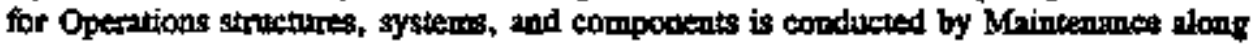
with the warehousing and control of spane pats.

\section{MANAGEMENT SYSTEMS}

Management Systems provides the administrative programs andi procedures for control of operations sach as Tecturicel Operiting Prucedures, docturoentation of operational activities such as operstionsi and serveillanco record tefention and storage. Occurrence Reporting, and operational improvenent procedures such as Corrective Action and Isstre Management.

\section{NUCLEAR SAFETY}

Nuclear Safety provides pafery nalysis of the fuctity desiog batis and develops Operational Safery Requirements for the operation of the Tont Farms inctuding Limiting Conditions of Opertion, Survetilanco Requiremants for Safoty Systesss, and Administrative Controta necessury to maintain the "Safery Envalope' for the tesiltity.

\section{OCCUPATIONAI HEALTH AND SAFETY}

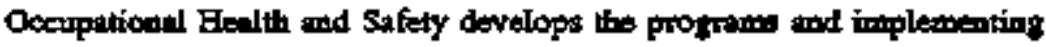
procectures for identification and mitigation of industritl suffecy inchuding cherrical and physiol bezards, indestrial bytiege, and modical evalmation and restroent.

\section{QUALTTY ASSTRANCE}

Quality Assurance develops the Qunlity Assonnes propnm that provides the requiraments to be applied to activities detertwined to be importemt 0 quality as described in the Operations Quality Assurance Plen. Quality Asaurance also provides for the performence of assuranes andits and surveillances of Operations activities plus Quality Control inspectiont to be performed by a Quality Aastrance organization. 


\section{REQUIREMENTS IDENTIFICATION DOCUMENT HIGH LEVEL WASTE STORAGE TANK FARMS \\ Operations \\ Rerision o}

\section{RADIATION PROTECAION}

Rudintion Protoction progenms and procedures atablish the kystems that momitor the rodiation lovela in tho work place and in fucility offluents phos wanitor exposure to porronnel. Redintion Protection also estublistes the

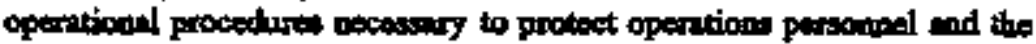

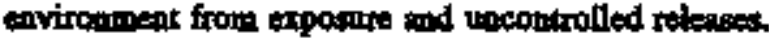

\section{IRAINING AND QUALIFICATION}

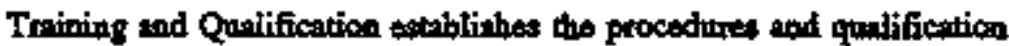
nequintents bat control the training and/or solection of operitionte personel. Training and Qunlification develops training curricull and progtand and provitiod instruttional servited to operitionse.

\section{FIRE PROTECIION}

Fire Protection establiehes the requiruments for survillance of fire protestion equappent such as fire extingrishers, and fire prevention wetivition such it proper storate and hading of flammablo metorialg.

\section{CONSTRUCTON}

The Operations interfece with Constroction involves control of construction wivities in Operations areas in terms of actess control and control of work setivities. Operetions also interfices with Construction in the accepenter testing of new conatruction and modifications.

\section{SELF ASSESSMENT}

Operations develops Peformance Objectives and Criteria and Performance Indicators wo determine the effectiveness of administative control systems such as procedures and facility statis control progroms. Productivity and misstion effectiveness aro also used in assessing Operations performence. An

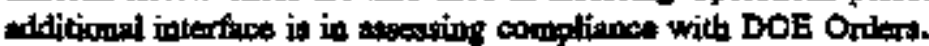

\section{ENVRONMENTAL PROTECHON}

The Operations intorfect with Ervinoumestal Procection invalves the timely notification of Environarental Protection in the event of a spill or release of huardous material to the envicuntent

\section{OCCURRENCE REPORTING}

Opertions intertuces with Occurreace Reporting in the investipation ad disporition of reportable oesurriaces. 